UNIVERSIDADE DE SÃO PAULO

INSTITUTO DE GEOCIEENCIAS

\title{
EVOLUÇÃO TECTÔNICA DOS ORTOGNAISSES DOS COMPLEXOS JUIZ DE FORA E MANTIQUEIRA NA REGIÃO DE JUIZ DE FORA, MG: GEOLOGIA, PETROLOGIA E GEOQUÍMICA
}

\section{Beatriz Paschoal Duarte}

Orientador: Prof. Dr. Mário da Costa Campos Neto

Prof. Dr. Mário Figueiredo (in memorian)

TESE DE DOUTORAMENTO

Programa de Pós-Graduação em Geoquímica e Geotectônica 


\title{
UNIVERSIDADE DE SÃO PAULO \\ INSTITUTO DE GEOCIENNCIAS
}

\section{EVOLUÇÃO TECTÔNICA DOS ORTOGNAISSES DOS COMPLEXOS JUIZ DE FORA E MANTIQUEIRA NA REGIÃO DE JUIZ DE FORA, MG: GEOLOGIA, PETROLOGIA E GEOQUÍMICA}

\author{
BEATRIZ PASCHDAL DUARTE
}

Orientador: Prof. Dr. Mário da Costa Campos Neto

TESE DE DOUTORAMENTO

COMISSÃO JULGADORA

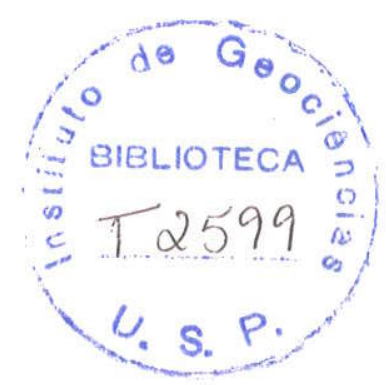

Nome

Presidente:

Examinadores: Prof. Dr. Hans Dirk Ebert

Prof. Dr. Ian McReath

Prof. Dr. Marcos Aurélio F. de Oliveira

Prof Dr $^{\text {a }}$ Maria Angela Fornoni Candia

SÃO PAULO

1998
Assinatura

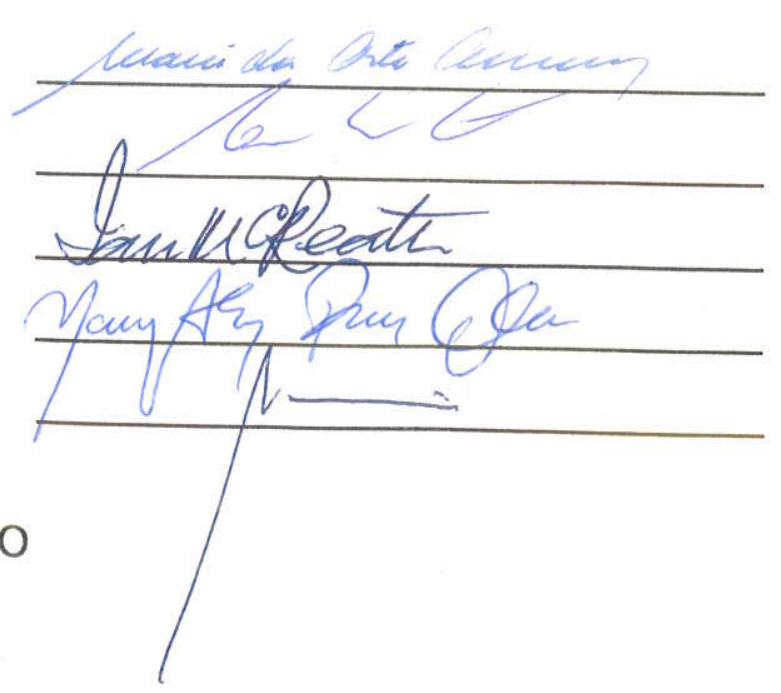




\section{UNIVERSIDADE DE SÃO PAULO INSTITUTO DE GEOCIÊNCIAS}

\section{EVOLUÇÃO TECTÔNICA DOS ORTOGNAISSES DOS COMPLEXOS JUIZ DE FORA E MANTIQUEIRA NA REGIÃO DE JUIZ DE FORA, MG: GEOLOGIA, PETROLOGIA E GEOQUÍMICA}

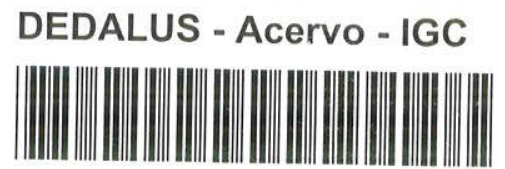

30900004863

Beatriz Paschoal Duarte

Orientador: Prof. Dr. Mário da Costa Campos Neto

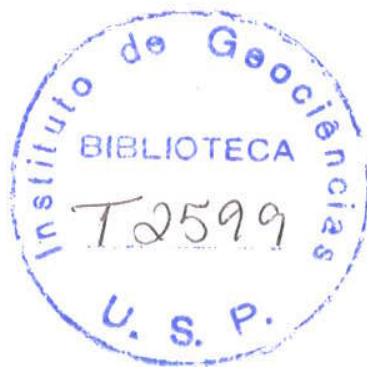

Prof. Dr. Mário C. H. Figueiredo (in memorian)

\section{TESE DE DOUTORAMENTO}

Área de Concentração: Geoquímica e Geotectônica

São Paulo

1998 


\section{AGRADECIMENTOS}

Este trabalho é fruto da colaboração de muitas pessoas e instituições. A todos, meus sinceros agradecimentos. Gostaria de expressar agradecimentos especiais a:

Colega Monica Heilbron, pela oportunidade da realização de um trabalho conjunto em que o resultado parcial é esta tese. Agradeço também, pelo acompanhamento constante do trabalho e pelas importantes discussões e sugestões apresentadas.

Professor orientador Mário Figueiredo (in memorian), por sua orientação e entusiástica dedicação ao tema deste trabalho.

Professor orientador Mário Campos Neto, por sua compreensão em assumir a responsabilidade pela orientação e a atenção dedicada durante a etapa final desta tese.

Amigo Sérgio Valente, pela intensa colaboração oferecida durante a etapa referente ao modelamento petrogenético e pelas significantes discussões e sugestões.

Ao engenheiro Paulo Heilbron, por sua extrema dedicação e colaboração na solução de problemas matemáticos e termodinâmicos relacionados aos cálculos em geotermobarometria.

Colegas Joel Valença, Miguel Tupinambá e José Renato Nogueira, pelas discussões referentes a assuntos pertinentes às várias etapas do trabalho.

Aos colegas do Departamento de Geologia Regional e Geotectônica da UERJ, Claudia Valladares, Claudio Valeriano e Júlio César Almeida, pela amizade e apoio apresentados sempre que necessários.

Aos colegas do setor técnico administrativo, Selma, Sr. Moacyr, Alan, Jorge e Sr. Carlos que, no exercício de suas funções, propiciaram a conclusão satisfatória das várias fases desta pesquisa. 
Ao colega Pedro de Césero, pelas facilidades criadas em meu acesso às dependências e recursos laboratoriais do CENPES e pelas inúmeras sugestões oferecidas em relação a procedimentos de laboratório.

Às amigas Diana Ragatky e Glória Mota, por me receberem com gentileza quando de minha estada em São Paulo e pelos muitos favores prestados durante estes cinco anos.

A Ana Maria Paschoal Duarte, pela paciência e dedicação na revisão de vários textos técnicos em língua inglesa, inclusive o abstract da presente tese.

Aos bosistas de Iniciação Científica, Patrícia Swalf, Pedro Albuquerque, Michel Beringer e Claudio Falcão, pelo acompanhamento das várias etapas da pesquisa.

Aos alunos da UERJ, Alexandre e Adriana, e da UFRRJ, Jorge, Betinho, Eduardo, Marcos, Elisabete e Sebastião, pelo acompanhamento e colaboração durante a etapa de campo e à aluna Olga, pela importante ajuda na compilação dos dados de química mineral.

Às instituições oficiais, UFRRJ, UERJ, CENPES, CNPq e FAPESP, pelo apoio administrativo, laboratorial e financeiro, sem os quais, esta pesquisa não poderia se realizar.

Ao companheiro Rubem Porto Junior, pelo incentivo, dedicação e auxílio fundamentais em todas as fases de elaboração deste trabalho. Inclusive pelas noites mal dormidas em toda a etapa de edição final desta tese.

A meu sobrinho, Frederico Porto Alves, que, com dedicação e paciência, editou várias İguras e prestou inestimável colaboração na etapa final do trabalho.

A todos aqueles que direta ou indiretamente colaboraram com este trabalho e que, eventualmente não tenham sido citados, meus sinceros agradecimentos. 


\section{Agradecimentos}

\section{Resumo}

\section{Abstract}

\section{Lista de Figuras}

\section{Lista de Tabelas}

\section{Parte I - Caracterização da Temática Escolhida}

l. 1) Introdução e objetivos gerias

1.2) Área Estudada: Localização, Apectos Fisográficos e Relações com Unidades 1 Tectônicas

1.3) Geologia Regional e Inserção Tectônica da Área Alvo 5

I.4) Propostas de Compartimentação tectônica para o Precambriano do Sudeste 9 Brasileiro

I.5) Evolução do Conhecimento Sobre Complexos Juiz de Fora e Mantiqueira e a Resposta deste Trabalho

$\begin{array}{ll}\text { 1.5.1) Complexo Juiz de Fora } & 17\end{array}$

1.5.2) Caracterização do Complexo Juiz de Fora (segundo este trabalho) 24

1.5.3) Complexo Mantiqueira 25

1.5.4) Caracterização do Complexo da Mantiqueira (segundo este trabaltıo) 31

I.6) Objetivos Propostos 32

I.7) Método de Trabalho 33

Parte II - Geologia da Região de Juiz de Fora: Apresentação dos Dados

II.1) Compartimentação Tectônica Adotada 39

II.2) Unidades Litológicas do Domínio Tectônico Andrelândia 45

II.2. 1) Complexo Mantiqueira 45

a) Hornblenda Gnaisse Bandado (e migmatítico) 45

b) Biotita Gnaisse Fino 46

c) Rochas Charnoquíticas $\quad 46$ 
d) Hornblenda Gnaisse Maciço 47

e) Anfibólios: bandas, "boudins", lentes e corpos tabulares 47

f) Leucossomas brancos e Corpos Intrusivos de Hornblenda leucognaisse 52

g) Biotita Gnaisse Intrusivo $\quad 52$

h) Biotita Leucognaisse $\quad 54$

i) Injeções Graníticas $\quad 55$

j) Pegmatitos Rochosos 55

II.2.2) Rochas do Cliclo Reposicional Andrelândia

a) Seqüências basal: biotita gnaisse bandado $\quad 57$

b) Seqüência Mista: bt gnaisse; bt-sill-grt gnaisse, quartizito 58

c) Seqüência Topo: Quartizito, bt ganaisses; bt-(sill) gnaisse 59 profiroclástico

II.3) Unidades lotológicas do Domínio Tectônico Juiz de Fora 60

II.3.1) Bt-Grt-Opx gnaisse; bt-sill-grt gnaisse e Quartizito 61

II.3.2) Ortogranulitos do Complexo Juiz de Fora 63

a) Enderbito/Qtz. Norito e Bt ganaisse Associado 64

b) Norito $\quad 67$

c) Migmatitos Estrocromáticos granulíticos 67

d) Charnockitos $\quad 68$

d.1) Bandas e injeções de rochas charnockíticas 68

$\begin{array}{ll}\text { d.2) Charnockito } & 70\end{array}$

d.3) Felsito charnockítico $\quad 71$

$\begin{array}{ll}\text { II.3.3) Ortognaisses (Bt gnaisses e Bt-hbl gnaisses) da Suite Quimino- } & 72\end{array}$ Dorândia

II.3.4) Rochas Metassedimentares e Metabasitos Associados 72

II.3.5) Suite Intrusiva Matias Barbosa 76

a) Biotita Gnaisse fino homogênio $\quad 77$

$\begin{array}{ll}\text { b) Leucogranito rosado } & 79\end{array}$

$\begin{array}{ll}\text { II.3.6) Granada Charnockito } & 80\end{array}$

II.4) Unidades Litológicas do Domínio Tectônico Paraíba do Sul 83

II.4.1) Ortognaisse (bt gnaisses e bt-hbl gnaisse) da Suite Quirino-Dorândia $\quad 84$

II.5) Geologia Estrutural $\quad 86$

II.5.1) Introdução $\quad 86$

II.5.2) Análise Geométrica da Deformação $\quad 87$

$\begin{array}{lr}\text { II.5.3) Análise Cinemática da Deformação } & 108\end{array}$

II.6) Evolução Metamórfica das Rochas da Região Juiz de Fora 118

$\begin{array}{ll}\text { II.6.1) Introdução } & 118\end{array}$

II.6.2) Metamorfismo Contemporâneo à Fase Principal de Deformação: $\quad 119$

Metamorfismo $\mathrm{M}_{1}$

a) Metamorfismo $M_{1}$ no DTAND 120 
b) Metamorfismo $M_{1}$ no DTJF 122

c) Equilibrio no Metamorfismo $M_{1}$ no Domínio Tectônico Juiz de Fora 129

d) Química Mineral e Condições de Pressão e Temperatura do 136

Metamorfismo $M_{1}$ no Domínio Tectônico Juiz de Fora.

II.6.3) Metamorfismo Anterior à Fase Principal de Deformação: $\mathbf{M}_{0} \quad 148$

II.6.4) Integração, Interpretação dos Resultados Geotermobarométricos e $\quad 155$ Discussões Finais

a) Metamorfismo $M_{1}$

b) Metamorfismo $\mathrm{M}_{0}$

II.7) Geoquímica e Modelamento Petrogenético das Rochas dos Complexos Juiz de Fora e Mantiqueira

II.7.1) Condições Juiz de Fora e Mantiqueira

II.7.2) Tratamento dado aos Resultados Analíticos

II.7.3) Estudo Geoquímico-Petrológico dos Litotipos do Complexo Juiz de Fora

a) Trabalhos Anteriores de Cunho Petrológico 166

b) Investigação Geoquímica-Petrológica 167

b. 1) Abordagem com base em Elementos Maiores 167

b. 2) Abordagem com base em Elementos Menores 171

b.3) Abordagem com base em Elementos Terras Raras 175

b.4) Conclusões Gerais $\quad 179$

c) Estudo das Rochas do Grupo Calcioalcalino 179

c. 1) Abordagem com base em ETR 180

d) Modelamento Quantitativo do Processo Petrogenético da Assimilação Simples (Bulk Assossiation)

d. 1) Princípios Básicos, Procedimentos e Resultados 185

$\begin{array}{ll}\text { d.2) Conclusões } & 188\end{array}$

e) Modelamento Quantitativo por Cristalização Fracionada 190

f) Discussões e Conclusões Finais 201

II.7.4) Estudo Geoquímico-Petrológico dos Litotipos do Complexo 204 Mantiqueira

a) Trabalhos Anteriores de Cunho Petrológico 204

b) Investigação Geoquímica-Petrológica 204

b. 1) Abordagem com base nos elementos maiores 204

b.2) Abordagem com base nos elememtos menores 208

b.3) Abordagem com base em Elementos Terras Raras
c) Modelamento Quantitativo do Processo Petrogenético por

Cristalização Fracionada

d) Modelamento por Fração Parcial 223

d. 1) Modelamento da Fonte para as Rochas Ácidas 223

d.2) Modelamento da Fonte para as Rochas Intermediárias 230

e) As Condições Oxidantes do Processo de Fusão Parcial 233

f) Conclusões 236 
II.8) Comparação entre os Complexos Mantiqueura e Juiz de Fora 238

$\begin{array}{ll}\text { II. 8.1) Introdução } & 238\end{array}$

II.8.2) Comparação erntre os Complexos Mantiqueira e Juiz de Fora 239

a) Aspectos de Campo e Petrográficos 2339

b) Aspectos Geoquímicos, Petrológicos e Petrogenéticos 240

$\begin{array}{ll}\text { b. 1) Análise qualitativa } & 240\end{array}$

b.2) Análise quantitativa 243

b.3) Comparação com base no modelamento petrogenético 245

b.4) Discussão 246

\section{Parte III - Discussões e Conclusões}

III.1) Discussão dos resultados isotópicos disponíveis para os Complexos Juiz de Fora e Manqueira

III. 2) Ambiente Geotectônico de formação e evolução dos litotipos dos

Complexos Juiz de Fora e Mantiqueira.

III.2.1) Introdução 252

III.2.2) Ambiente geotectônico de formação das rochas do Complexo da 253 Mantiqueira

a) Ambiente geotectônico dos anfibolitos de afinidade toleítica 253

b) Ambiente geotectônico dos anfibolitos de afinidade alcalina 254

c) Ambiente geotectônico dos gnaisses intermediários à ácidos de afinidade calcialcalina.

III.2.3) Ambiente geotectônico das rochas e Complexo Juiz de Fora 256

a) Ambiente geotectônico dos Noritos 256

b) Ambiente geotectônico dos granulitos enderbíticos à charnockíticos 258

III.3) Integração dos resultados, discussões e modelos geotectônicos para

formação e evolução das rochas dos Complexos Juiz de Fora e Mantiqueira. 260

III.3.1) Processos relacionados à geração e evolução dos protólitos 260

III.3.2) Processos relacionados ao metamorfismo granulítico das rochas do Complexo Juiz de Fora

III.3.3) Correlação Regional das Unidades Metassedimentares 265

\section{Referências Bibliográficas}

\section{Apêndices}

AP - 1) Abreviaturas Utilizadas para Minerais $\quad$ AP $1-1$

AP - 2) Terminologia Petrográfica $\quad$ AP 2-1

AP - 3) Composição Modal das Amostras Selecionadas para Análise Mineral AP 3-1

AP - 4) Especificações das Condições de Análise por Microssonda Eletrônica

Utiliazado, Método Utilizado e Composição Química dos Minerais Analisados $\quad$ AP 4-1 
de Análise Empregadas e Especificações do Tratamento dod Dados Litogeoquímicos

\section{Anexos}

AN - 1) Mapa Geológico e de Pontos da região de Juiz de Fora

$A N$ - 2) Perfis Geológico-Estruturais da Região de Juiz de Fora (MG).

AN - 3) Mapa Estrutural da região de Juiz de Fora 


\section{LISTA DE FIGURAS}

Figura 1 - Localização da Área Alvo no Contexto Geográfico. 3

Figura 2 - Localização da Área Alvo no Contexto Geotectônico. 4

Figura 3 - Mapa Geológico da Região SE de Minas Gerais (Ebert, 1968). 6

Figura 4 - Mapa Geológico do Estado do Rio de Janeiro e Região Limítrofe do Estado de Minas Gerais (Heilbron, 1995).

Figura 5 - Compartimentação da Região SE de Minas Gerais e Região Limítrofe do Estado do Rio de Janeiro (Ebert, 1968).

Figura 6 - Compartimentação Tectônica do Segmento Setentrional da Faixa Ribeira (Campos Neto \& Figueiredo 1990).

Figura 7 - Compartimentação Tectônica da Região Limítrofe dos Estados do Rio de Janeiro e Minas Gerais (Heilbron, 1993).

Figura 8 - Compartimentação Tectônica Proposta para a Região de Juiz de Fora (Área Alvo).

Figura 9 - Perfil Geológico-Estrutural da:

a) Região de Juiz de Fora, segundo esta pesquisa;

b) Transversal Bom Jardim de Minas - Barra do Piraí, segundo Heilbron (1993).

Figura 10 - Hornblenda gnaisse bandado e migmatítico - Complexo Mantiqueira (foto deafloramento). Ponto 516.

Figura 11 - Hornblenda gnaisse maciço - Complexo Mantiqueira. Ponto 564

Figura 12 - Anfibolito:

a) Bandas. Ponto 516

b) Boudins. Ponto 565

c) Corpos Tabulares - Complexo Mantiqueira. Ponto 516.

Figura 13 - Leucossomas brancos e corpos intrusivos de Hornblenda leucognaisse Complexo Mantiqueira. Ponto 564.

Figura 14 - Biotita gnaisse intrusivo - Complexo Mantiqueira. Ponto 577

Figura 15 - Enderbito / Quartzo Norito e Biotita Gnaisse Associado - Complexo Juiz de Fora. Ponto 518

Figura 16 - Norito - Complexo Juiz de Fora. Ponto 518

Figura 17 - Bandas e injeções/leucossoma charnockíticos - Complexo Juiz de Fora. Ponto 32 
Figura 18 - Contato intrusivo da Suite Matias Barbosa com rochas metassedimentares. Folha Mar de Espanha. Ponto307

Figura 19a - Granada Charnockito: enclaves. Paragnaisse. Ponto 37

Figura 19b - Granada Charnockito: enclaves. Ortogranulito. Ponto 37

Figura 20 - Superposição da fase $D_{2}$ sobre a fase $D_{1}$, registrada em boudin de rocha calcisilicática. Ponto 79

Figura 21 - Perfil apertado a isoclinal em dobra $\mathrm{D}_{2}$ em Bt-Sill gnaisse do CDA e Hb-bt gnaisse do CM. AND 1. Pontos 52 e 85

Figura 22 - Estereograma dos planos axiais das dobras $\mathrm{D}_{2}$. AND 1.

Figura 23 - Foliação milonítica $S_{2}$, dada por minerais félsicos recristalizados e/ou estirados. Bt-gnaisse do CM. DTAND. Ponto 564

Figura 24 - Foliação milonítica $\mathrm{S}_{2}$, em bt-(sill) gnaisse porfiroclástico. AND 2 Ponto 49

Figura 25 - Estereograma dos Planos Axiais das dobras $D_{1}, D_{2}$ ou $D_{1}+D_{2}, J F 1$.

Figura 26 - Alternância de bandas dobradas (dobras intrafoliais $\mathrm{D}_{2}$ ) e bandas miloniticas em Ortogranulitos do CJF JF2. Ponto 145

Figura 27 - Textura porfiroclástica em Quartzito do JF2. Ponto 18

Figura 28 - Interdigitação tectônica entre metapelitos e ortogranulitos do Complexo Juiz de Fora (escala métrica). JF 3. Ponto 447

Figura 29 - Estereograma dos planos axiais das dobras $\mathrm{D}_{2} \mathrm{JF} 3$

Figura 30 - Foliação milonitica $S_{2}$ e textura porfiroclástica em bt-gr gnaisse. JF 3. Ponto 176

Figura 31 - Estrutura porfiroclástica tipo sigma em: a) boudin de metabasito do CJF; b) plagioclásio em enderbito do CJF. Pontos 16 e 340

Figura 32 - Estereogramas de Plano Axial (a) e Eixo (b) da fase tardia de deformação, mostrando duas tendências, interpretadas como referentes a $\mathrm{D}_{3} \mathrm{eD}_{4}$.

Figura 33 - Perfil geológico - estrutural, E-W do norte da cidade de Juiz de Fora

Figura 34 - Transposição total da foliação $S_{2}$ para a posição espacial de $S_{4}$. Ponto JF2. Ponto 518

Figura 35 - Indicadores cinemáticos da fase principal de deformação, mostrando movimentação inversa de SSE para NNW: a) DTAND. Ponto 30; b) DTAND. Ponto 27; c) DTJF. Ponto 15 
Figura 36 - Mapa com a distribuição dos indicadores cinemáticos referentes à fase principal de deformação.

Figura 37 - Foliação $S_{1}$ dada por biotita, muscovita e sillimanita em Bt-sill gnaisse do CDA. DTAND. Ponto 54.

Figura 38 - Sillimanita e quartzo estirado na foliação $S_{2}$ em Bt-sill gnaisse do CDA DTAND. Ponto 52. (obs.: lâmina espessa)

Figura 39 - Migmatização em ortognaisse (a) e anfibolito (b) do CM. DTAND. Ponto 564.

Figura 40 - Grãos de hornblenda orientados na foliação principal. Hornblenda gnaisse do CM. DTAND. Ponto 564.

Figura 41 - Sillimanita, biotita e fibrolita na foliação principal em Biotita-sillimanita-granada gnaisse. DTJF. Ponto 286

Figura 42 - Padrão de coloração mosqueada em granada charnockito. DTJF. Ponto 37.

Figura 43 - Hornblenda orientada segundo a foliação principal, formada pelo consumo de piroxênios e plagioclásio. Metabasito do CJF. DTJF. Ponto 15.

Figura 44 - Novos grãos formados pela recristalização das bordas dos minerais da paragênese granulitica de $\mathrm{M}_{0}$. Metabasito do CJF. DTJF. Ponto 42.

Figura 45 - Equilíbrio entre granada ${ }_{1}$, ortopiroxênio, plagioclásio e quartzo em paragnaisse da Unidade Jardim Glória. DTJF. Ponto 36.

Figura 46 - Granada Gobrecrescendo granada $_{1}$. Paragnaisse da Unidade Jardim Glória. DTJF. Ponto 36

Figura 47 - Franja simplectítica no canto superior esquerdo do grão maior de granada. Paragnaisse da Unidade Jardim Glória. DTJF. Ponto 36.

Figura 48 - Condições P-T aproximadas dos pulsos metamórficos $M_{1}$ e $M_{0}$. a) Facies Metamórficas e grade petrogenética para metapelitos; b) $M_{1}$ e $M_{0}$ no DTAND e DTJF.

Figura 49 - Corona de granada em torno de grãos de ortopiroxênio. Metabasito do CJF. DTJF. Ponto 183.

Figura 50 - Hornblenda e granada formadas pelo consumo parcial de piroxênios e plagioclásio. Metabasito do CJF. DTJF. Ponto 15.

Figura 51 - Classificação do ortopiroxênio dos paragnaisses da Unidade Jardim Glória. Estão plotadas composições médias de núcleos e bordas.

Figura 52 - Classificação das granadas (1,2 e 3) do paragnaisse da Unidade Jardim Glória. Estão plotadas composições médias de núcleos, bordas e grãos reduzidos (simplectito). 
Figura 53 - Classificação do plagioclásio do paragnaisse da Unidade Jardim Glória.

Figura 54 - Classificação da biotita do paragnaisse Unid.ade Jardim Glória. Estão plotadas composições médias de núcleos, bordas e grãos reduzidos

Figura 55 - Classificação do ortopiroxênio recristalizado das rochas metabásicas do CJF.

Figura 56 - Classificação do clinopiroxênio recristalizado das rochas metabásicas do CJF.

Figura 57 - Classificação do anfibólio recristalizado das rochas metabásicas do CJF.

Figura 58 - Classificação do anfibólio recristalizado das rochas metabásicas do CJF.

Figura 59 - Classificação do plagioclásio das rochas metabásicas do CJF.

Figura 60 - Classificação da granada das rochas metabásicas do CJF.

Figura 61 - Diagrama discriminante entre ortopiroxênios ígneos e metamórficos (segundo Rietmeijer, 1983).

Figura 62 - Diagrama discriminante entre ortopiroxênios ígneos e metamórficos (segundo Rietmeijer, 1983).

Figura 63a - Arrqanjo granoblástico referente à $\mathrm{M}_{0}$ em Metabasito do CJF. DTJF. Ponto 17.

Figura $63 b$ - Arranjo granoblástico referente à $M_{0}$ e recristalização referente a $M_{1}$ Metabasito do CJF. DTJF. Ponto 42.

Figura 64 - Classificação do ortopiroxênio das rochas metabásicas do CJF.

Figura 65 - Classificação do clinopiroxênio das rochas metabásicas do CJF.

Figura 66 - Classificação do anfibólio das rochas metabásicas do CJF.

Figura 67 - Classificação do anfibólio das rochas metabásicas do CJF.

Figura 68 - Diagrama discriminante entre ortopiroxênios ígneos e metamórficos (segundo Rietmeijer, 1983).

Figura 69 - Diagrama discriminante entre ortopiroxênios ígneos e metamórficos (segundo Rietmeijer, 1983).

Figura 70 - Plote das composições dos anfibólios do Complexo Juiz de Fora

Figura 71 - Diagrama P-T, mostrando o caminho hipotético da evolução de $M_{1}$ para os paragnaisses da Unidade Jardim Glória e ortogranulitos do CJF.

Figura 72 - Diagramas $\mathrm{SiO} 2 \times$ Álcalis para o cojunto das amostras do CJF. Limite dos 
Figura 73 - Diagrama AFM para o conjunto das amostras do CJF. Limite dos campos toleítico e calcioalcalino, segundo Irvine \& Baragar (1971).

Figura 74 - Diagramas de Harker ( elementos maiores) para todo o conjunto das amostras do 169 CJF.

Figura 75 - Diagramas de Harker (elementos traços) para todo o conjunto das amostras do 172 CJF.

Figura 76 - Diagramas ETR normalizados pelo condrito de Boynton para as rochas do CJF

Figura 77 - Diagrama de ETR normalizados pelo condrito de Boynton (1984). Comparação entre o padrão da amostra parental (17A) e aqueles das amostras menos evoluídas do grupo calcioalcalino (99D e 15B).

Figura 78 - Diagrama de ETR com padrões de distribuição normalizados pelo condrito de Boynton (1984). Comparação entre o padrão da amostra parental (17A) e aqueles das amostras menos evoluidas do grupo toleítico (15C e 46P).

Figura 79 - Diagrama classificatório (Middlemost, 1985) para as rochas calcioalcalinas do CJF.

Figura 80 - Diagrama de ETR das amostras do subgrupo 1, com padrões normalizados pelo condrito de Boynton (1984)

Figura 81 - Diagrama de ETR das amostras do subgrupo 2, com padrões normalizados pelo condrito de Boynton (1984).

Figura 82 - Diagrama de ETR das amostras do subgrupo 3, com padrões normalizados pelo condrito de Boynton (1984).

Figura 83 - Diagrama de ETR das amostras dos subgrupos 1e 2, com padrões normalizados pelo condrito de Boynton (1984).

Figura 84 - Diagrama de ETR com padrões normalizados pelo condrito de Boynton (1984).

Figura 85 - Diagrama de ETR com padrões normalizados pelo condrito de Boynton (1984).

Figura 86 - Diagrama de ETR com padrões normalizados pelo condrito de Boynton (1984).

Figura 87 - Diagramas de ETR, com padrões normalizados pelo condrito de Boynton (1984), para modelamento de cristalização fracionada das amostras do subgrupo 1 do CJF.

Figura 88 - Diagramas de ETR, com padrões normalizados pelo condrito de Boynton (1984), para modelamento de cristalização fracionada das amostras dos subgrupos 1 e 2 do CJF. 
Figura 89 - Diagramas de ETR, com padrões normalizados pelo condrito de Boynton (1984) e resultado do modelamento para cristalização fracionada das.

Figura 90 - Esquema simplificado dos processos petrogenéticos em câmara magmática complexa para as rochas calcioalcalinas do CJF.

Figura 91 - Diagramas $\mathrm{SiO} 2$ x Álcalis para o cojunto das amostras do CM. Limite dos campos alcalino e subalcalino, segundo Irvine \& Baragar (1971).

Figura 92 - Diagrama AFM para o conjunto das amostras do CM. Limite dos campos toleítico e calcioalcalino, segundo Irvine \& Baragar (1971).

Figura 93 - Diagramas de Harker (elementos maiores) para todo o conjunto das amostras do CM.

Figura 94 - Diagramas de Harker (elementos traços) para todo o conjunto das amostras do CM.

Figura 95 - Diagrama normativo NE-DI-HY $-\mathrm{OL}$

Figura 96 - Diagramas de ETR normalizados pelo condrito de Boynton (1984) para rochas do CM. A) Rochas Básicas; B) Rochas intermediárias; C e D) Rochas ácidas.

Figura 97 - Diagramas de ETR normalizados pelo condrito de Boynton (1984) para as rocha do $\mathrm{CM}$. Agrupamentos segundo as razões $(\mathrm{La} / \mathrm{Yb})_{\mathrm{N}}$.

Figura 98 - Padrões de ETR para as amostras do CM selecionadas para o modelamento de cristalização fracionada.

Figura 99 - Padrões de ETR para os três termos do modelamento de cristalização fracionada.

Figura 100 - Padrōes de ETR para os três termos do modelamento de cristalização fracionada considerando um fracionamento de $100 \%$ de hornblenda.

Figura 101 - Padrões de ETR para os três termos do modelamento de cristalização fracionada considerando um fracionamento de $100 \%$ de granada.

Figura 102 - Padrões de ETR para amostra de afinidade alcalina transicional e de possível líquido derivativo potencial por cristalização fracionada.

Figura 103 - Resultados obtidos para o modelamento de fusão parcial: de rochas intermediárias do $\mathrm{CM} \operatorname{com}[\mathrm{La} / \mathrm{Yb}] \mathrm{N}$ entre 6 e 9 para rochas ácidas com [La/Yb]N entre 20 e 38 .

Figura 104 - Resultados obtidos para o modelamento de fusão parcial: de rochas intermediárias do $\mathrm{CM}$ com $[\mathrm{La} / \mathrm{Yb}] \mathrm{N}$ entre 20 e 38 para rochas ácidas com $[\mathrm{La} / \mathrm{Yb}] \mathrm{N}>$ 100. 
Figura 105 - Padrões de ETR para modelamento da fonte das rochas intermediárias com $[\mathrm{La} / \mathrm{Yb}] \mathrm{N}$ entre 6 e 9 , por processo de fusão parcial.

Figura 105 - Padrões de ETR para modelamento da fonte das rochas intermediárias com $[\mathrm{La} / \mathrm{Yb}] \mathrm{N}$ entre 20 e 38 , por processo de fusão parcial.

Figura 107 - Diagrama de valores do coeficiente de partição do Eu para diferentes condições de fugacidade de oxigênio (Drake \& Weill, 1975). Área marcada: intervalo de valores de coeficiente de partição de Eu estimados para as rochas do CM.

Figura 108 - Diagrama para assembléias usadas como buffers (Myers \& Eugster, 1983). Área marcada: valores estimados para as rochas do CM.

Figura 109 - Diagrama de classificação das rochas dos Complexos Juiz de Fora e Mantiqueira.

Figura 110 - Diagrama $\mathrm{SiO}_{2} \times \mathrm{Na}_{2} \mathrm{O}+\mathrm{K}_{2} \mathrm{O}$ para rochas dos Complexos Juiz de Fora e Mantiqueira.

Figura 111 - Diagrama AFM para as rochas dos Complexos Juiz de Fora e Mantiqueira.

Figura 112 - Diagrama ETR normalizadas pelo condrito de Boynton para as rochas metabásicas dos Complexos Juiz de Fora e Mantiqueira.

Figura 113 - Diagrama ETR normalizadas pelo condrito de Boynton para as rochas intermediárias dos Complexos Juiz de Fora e Mantiqueira.

Figura 114 - Diagrama ETR normalizadas pelo condrito de Boynton para as rochas intermediárias dos Complexos Juiz de Fora e Mantiqueira.

Figura 15 - Diagrama ETR normalizadas pelo condrito de Boynton para as rochas ácidas dos Complexos Juiz de Fora e Mantiqueira.

Figura 116 - Diagrama ETR normalizadas pelo condrito de Boynton para as rochas ácidas dos Complexos Juiz de Fora e Mantiqueira.

Figura 117 - Diagrama ETR normalizadas pelo condrito de Boynton para as rochas ácidas dos Complexos Juiz de Fora e Mantiqueira.

Figura 118 - Diagrama de variação multi-elementar para os anfibolitos toléticos do Complexo Mantiqueira compradas à basaltos toléticos modernos de ambientes geotectônicos disintos.

Figura 119 - Diagrama de variação multi-elementar para os anfibolitos de afinidade alcalina do Complexo Mantiqueira comprados ao basalto alcalino modernos de ambientes intraplaca.

Figura 120 - Diagrama de distribuição de ETR para as amostras 17A e 17B em comparação com basaltos tipo N-MORB. 
Figura 121 - Diagramas de variação multi-elementar para os noritos toléticos do Complexo Juiz de Fora comparados à basaltos teleíticos d e vários ambientes modernos.

Figura 122 - Plote das rochas enderbíticas à charnockíticas do CJF em comparação com rochas graniticas de arcos vulcânicos e ambientes colisionais modernos. 


\section{LISTA DE TABELAS}

Tabela 1 - Trabalhos Anteriores referentes ao Complexo Juiz de Fora.

Tabela 2 - Trabalhos Anteriores referentes ao Complexo Mantiqueira.

Tabela 3 - Características Lito-Estruturais dos Domínios Tectônicos Propostos por Heilbron $(1993,1995)$.

Tabela 4 - Características Lito-Estruturais dos Domínios Tectônicos Propostos neste Trabalho.

Tabela 5 - Composição Mineralógica, Características Texturais e Classificação dos Litotipos do Complexo Mantiqueira.

Tabela 6 - Composição Mineralógica, Características Texturais e Classificação dos Litotipos da Sequência Basal do Ciclo Deposicional Andrelândia.

Tabela 7 - Composição Mineralógica, Características Texturais e Classificação dos Litotipos da Sequência Mista do Ciclo Deposicional Andrelândia.

Tabela 8 - Composição Mineralógica, Características Texturais e Classificação dos Litotipos da Sequência de Topo do Ciclo Deposicional Andrelândia.

Tabela 9 - Composição Mineralógica, Características Texturais e Classificação dos Litotipos da Unidade Jardim Glória.

Tabela 10 - Composição Mineralógica, Características Texturais e Classificação do BiotitaGranada-Sillimanita Gnaisse e Quartzito.

Tabela 11 - Composição Mineralógica, Características Texturais e Classificação dos Litotipos do Complexo Juiz de Fora.

Tabela 12 - Composição Mineralógica, Características Texturais e Classificação dos Biotita gnaisses bandados e quartzitos.

Tabela 13 - Composição Mineralógica, Características Texturais e Classificação dos BiotitaGranada-Sillimanita Gnaisses e Litotipos Associados.

Tabela 14 - Composição Mineralógica, Características Texturais e Classificação dos 80 Litotipos da Suite Intrusiva Matias Barbosa e Enclaves.

Tabela 15 - Composição Mineralógica, Características Texturais e Classificação do Granada Charnockito.

Tabela 16 - Composição Mineralógica, Características Texturais e Classificação dos Ortognaisses da Suite Quirino-Dorândia.

Tabela 17 - Paragêneses das Rochas Metassedimentares da Região de Juiz de Fora 
Tabela 18 - Equilíbrios minerais para os tipos litológicos investigados

Tabela 19 - Valores de $\mathrm{T}$ calculados para o equilíbrio 1 nos paragnaisses da Unidade Jardim 139 Glória, segundo o geotermômetro de Sen \& Bhattacharya (1984)

Tabela 20 - Valores de $\mathrm{P}$ calculados para equilíbrio 1 da amostra $\mathrm{JG}-108$ da Unidade Jardim Glória, segundo o geobarômetro de Ekert et. Al. (1994), aplicanto a $\mathrm{T}=745^{\circ} \mathrm{C}$.

Tabela 21 - Valores de $\mathrm{T}$ calculados para o equilibrio 2 da amostra $35 \mathrm{~B}$ da Unidade Jardim Glória, segundo os geotermômetros indicados.

Tabela 22 - Valores de T calculados para o equilibrio 2 da amostra $36 \mathrm{~B}$ da Unidade Jardim Glória, segundo os geotermômetros indicados.

Tabela 23 - Valores de T calculados para o equilíbrio 2 da amostra JG-108 da Unidade Jardim Glória, segundo os geotermômetros indicados, aplicados a um P de $7 \mathrm{~Kb}$.

Tabela 24 - Valores de $\mathrm{T}$ calculados para o equilibrio 2 (granada simplectítica e borda de biotita) dos paragnaisses da Unidade Jardim Glória, segundo os geotermômetros indicados, aplicados a um $\mathrm{P}$ de $7 \mathrm{~Kb}$.

Tabela 25 - Valores de T calculados para o equilíbrio 1 das amostras $99 \mathrm{D}$ e $15 \mathrm{~B}$ do conjunto CJF segundo os geotermômetros indicados.

Tabela 26 - Valores de $\mathrm{T}$ para o equilibrio 2 dos ortogranulitos do CJF, segundo os geotermômetros indicados.

Tabela 27 - Valores de $\mathrm{T}$ para o equilibrio 2 dos ortogranulitos do CJF, segundo os 144 geotermômetros indicados (aplicados com as T obtidas do geoctermômetro de Powell, 1985).

Tabela 28 - Valores de $\mathrm{T}$ calculados para o equilibrio 0 entre núcleos de grãos dos ortogranulitos do CJF, segundo os geotermômetros indicados.

Tabela 30 - Valores do quadrado dos coeficientes de regress $\tilde{A}$ o linear (L) e polinomial (P) para as rochas do Complexo Juiz de Fora. As regressões foram feitas para cinco população de amostras diferentes.

Tabela 31 - Coeficientes de regressão polinomial $(P)$ para as rochas do Complexo Juiz de 173 Fora.

Tabela 32 - Valores das razões $\mathrm{Zr} / \mathrm{H}$ e $\mathrm{Zr} / \mathrm{Nd}$ para as rochas do Complexo Juiz de Fora.

Tabela 33 - Coeficientes de partição mineral/líquido $\left(\mathrm{K}_{\mathrm{d}}\right)$ utilizados no modelamento do 193 processo de cristalização gracionada - Fase 1 (15B - 115B).

Tabela 34 - Percentual de volume das fases fracionadas utilizando no modelamento do 193 processo de cristalização fracionada, Modelo 3 (115B - 297B): 53\% de fracionamento.

Tabela 35 - Coeficientes de partição mineral/liquido $\left(\mathrm{K}_{\mathrm{d}}\right)$ utilizados no modelamento do 194 processo de cristalização fracionada, Modelo 1 - Fase 2 (115B - 151B) 
Tabela 36 - Percentual de volume das fases fracionadas utilizado no modelamento do 194 processo de cristalização fracionada, Modelo 1- Fase 2 (115B - 151B): 30\% de fracionamento.

Tabela 37 - Coeficientes de partição mineral/líquido $\left(K_{d}\right)$ utilizados no modelamento do processo de cristalização fracionada, Modelo 1 - Fase 3 (151B - 151A)

Tabela 38 - Percentual de volume das fases fracionadas utilizado no modelamento do processo de cristalização fracionada, Modelo 1 - Fase 3 (151B - 151A): $30 \%$ de fracionamento.

Tabela 39 - Coeficientes de partição mineral/liquido $\left(\mathrm{K}_{\mathrm{d}}\right)$ utilizados no modelamento do processo de cristalização fracionada, Modelo 2 - Fase 1 (297B - 514A).

Tabela 40 - Percentual de volume em fases fracionadas utilizando no modelamento de cristalização fracionada, Modelo 2 - Fase 1: $43 \%$ de fracionamento.

Tabela 41 - Coeficientes de partição mineral/líquido $\left(\mathrm{K}_{\mathrm{d}}\right)$ utilizados no modelamento do processo de cristalização fracionada, Modelo 2 - Fase 2 (514A - 46R).

Tabela 42 - Percentual de volume das fases fracionadas utilizando no modelamento do porcesso de cristalização fracionada - $43 \%$ de fracionamento.

Tabela 43 - Coeficientes de partição mineral/liquido $\left(\mathrm{K}_{\mathrm{d}}\right)$ utilizados no modelamento do 199 processo de cristalização fracionada, no modelo $(115 \mathrm{~B}-297 \mathrm{~B})$.

Tabela 44 - Percentual de volume das fases fracionadas utilizado no modelamento do processo de cristalização fracionada, Modelo $3(115 \mathrm{~B}-297 \mathrm{~B})-43 \%$ de fracionamento.

Tabela 45 .. Valores de $r^{2}$ e nivel de significância para elementos traços dos agrupamentos de rochas do Complexo Mantiqueira

Tabela 46 - Percentual de volume das fases fracionadas utilizando no modelamento do processo de cristalização fracionada $-27 \%$ de fracionamento. Estágio $(577 \mathrm{~B}-564 \mathrm{~F})$.

Tabela 47 - Coeficientes de partição mineral/liquido $\left(\mathrm{K}_{\mathrm{l}}\right)$ utilizados no modelamento do processo de cristalização fracionada - Modelo 1 (577B - 564F).

Tabela 48 - Coeficientes de partição mineral/liquido $\left(K_{d}\right)$ utilizados no modelamento do processo de cristalização fracionada - Modelo 1 (564F - 56).

Tabela 49 - Composição de ETR de fontes potenciais para as rochas ácidas do Complexo da Mantiqueira.

Tabela 50 - Composição média de ETR dos seguintes conjuntos de rochas do Complexo da Mantiqueira: rochas intermediárias $\operatorname{com}[\mathrm{La} / \mathrm{Yb}]_{N} \cong 6-9$; rochas intermediárias com $[\mathrm{La} / \mathrm{Yb}]_{\mathrm{N}} \cong 20-38$; rochas ácidas com $[\mathrm{La} / \mathrm{Yb}]_{\mathrm{N}} \cong 4-65 ;$ e rochas ácidas com $[\mathrm{La} / \mathrm{Yb}]_{\mathrm{N}}>100$.

Tabela 51 - Composição mineralógica das rochas fontes potenciais (rochas intermediárias do Complexo da Mantiqueira). 
Tabela 52 - Composição de ETR da fonte modelada em comparação com a média da fonte potencial Int $1_{M}\left([\mathrm{La} / \mathrm{Yb}]_{\mathrm{N}} \cong 6-9\right)$.

Tabela $\$ 3$ - Composição de ETR da fonte modelada em comparação com a média da fonte potencial $\operatorname{lnt} 2_{M}\left([\mathrm{La} / \mathrm{Yb}]_{N} \equiv 20-38\right)$.

Tabela 54 - Composição de ETR das rochas fontes moldadas em comparação com as composições de Taylor \& Mc Lennan (1981).

Tabela 55 - Composição mineralógica modal do resíduo considerado no modelamento do processo de fusão parcial para a gênese do conjunto de rochas intermediárias com $[\mathrm{La} / \mathrm{Yb}]_{\mathrm{N}}$ entre 6 e 9 .

Tabela 56 - Composição mineralógica modal do resíduo considerado no modelamento do processo de fusão parcial para a gênese do conjunto de rochas intermediárias com $[\mathrm{La} / \mathrm{Yb}]_{\mathrm{N}}$ entre 20 e 38 .

Tabela 57 - Valore calculados em $\mathrm{K}_{\mathrm{d}}$ plagioclásio/líquido para $\mathrm{Eu}$, para cada modelamento de fusão parcial realizado para as rochas calciocalinas do Complexo Mantiqueira. 


\section{ABSTRACT}

The study area (Juiz de Fora region) is located within the central segment of the Late Proterozoic (Brasiliano-Panafrican), NE-SW oriented-Ribeira Belt which lies along the SSE border of the São Francisco Craton. Three NW-directed, thrust-driven tectonic domains with cratonward vergence were identified (from bottom to top): Andrelândia Tectonic Domain; Juiz de Fora Tectonic Domain; and Paraíba do Sul Tectonic Domain.

The Andrelandia Tectonic Domain is characterised by the Medium Proterozoic metassediments of the so-called Andrelândia Depositional Cycle as well as the Archaean to Early Proterozoic basement rocks of the Mantiqueira Complex, a typical high-grade metamorphic terrane. The Juiz de Fora Tectonic Domain includes tectonically bounded metasedimentary rocks (partially correlated to the Andrelândia Depositional Cycle) and Early Proterozoic to Archaean granulitic orthogneisses of the Juiz de fora Complex. The metasedimentary units are intruded by granitoid and charnockitoid rocks. The Paraiba do Sul Domain consists of metasedimentary rocks and orthogneisses of the Paraiba do Sul Complex. Owing to the geographic limits of the study area, this domain was not investigated in detail.

The Andrelândia and huz de fora Tectonic Domains present similar structural and metamorphic evolution. However, their structural styles vary greatly as a result of different crustal levels stacking caused by extreme crustal shortening during the Brasiliano-Panafrican Orogeny. The main phase of deformation $\left(\mathrm{D}_{1}+\mathrm{D}_{2}\right)$ is characterised by: a) structural stacking of tectonic domains; b) tight to isoclinal folding associated to penetrative foliation $\left(S_{2}\right.$ or $S_{1}+$ $\mathrm{S}_{2}$ ); c) shear zones associated to the development of mylonitic rocks; and d) unfrequent mineral lineation. A late phase of deformation $\left(\mathrm{D}_{3}+\mathrm{D}_{4}\right)$ is related to folding and bending of the penetrative foliation as well as normal faulting and ductile-brittle shear zones which locally transpose the $\mathrm{D}_{1}+\mathrm{D}_{2}$ related penetrative foliation.

Two metamorphic events were identified in the study area. The late one $\left(M_{1}\right)$ can be identified in all the studied tectonic domains, being associated to the main phase of deformation. This is characterised by the growth of its mineral paragenesis within the penetrative foliation. $M_{1}$ has evolved under intermediate pressure conditions, reaching thermal 
peak during the development of $\mathrm{D}_{2}$. This metamorphic event evolved differently in each of the aforementioned domains as a result of distinctive temperature and/or fluid pressure conditions. As such, the Andrelândia Tectonic Domain is characterised by amphibolite facies parageneses (sillimanite zone), whereas the Juiz de Fora Tectonic Domain shows evidence for temperature and/or fluid pressure gradients. For instance, the metasedimentary rocks record dehydration reactions whereas retrogressive hydration reactions along the $\mathrm{D}_{2}$ foliation and shear zones appear in the Juiz de Fora Complex granulites. Hardly did the metapelitic gneisses (s.s.) of the Juiz de Fora Tectonic Domain develop metamorphic facies diagnostic parageneses. Nevertheless, the relatively more immature pelitic gneisses show $M_{1}$ orthopyroxene-bearing mineral parageneses and evidence of the evolution of vapor-absent partial melting process. Field, petrographic and geothermobarometric data show that $M_{1}$ evolved under the following conditions: Temperature $>700-750^{\circ} \mathrm{C}$, pressure between 6 and $7 \mathrm{~Kb}$ and gradients of fluid $\left(\mathrm{H}_{2} \mathrm{O}\right)$ pressure. A clockwise P-T-t path is proposed for the evolution of $\mathrm{M}_{1}$ metamorphic event.

The early metamorphic event $\left(\mathrm{M}_{0}\right)$ is recorded on the Juiz de Fora Complex rocks and on some of the Mantiqueira Complex lithotypes. Such rocks show a granoblastic mineral fabric and granulite facies parageneses are clearly prior to the Brasiliano-Panafrican-related penetrative foliation. Granulites occur as strips within the Mantiqueina Complex, wheareas $\mathrm{M}_{0}$ granulitic parageneses are recorded in all of the Juiz de fora lithotypes, including leucossomes and paleossomes of migmatitic gneisses. Thermonetry data indicate $M_{0}$ thermal peak conditions between $\approx 800-895^{\circ} \mathrm{C}$. Chemical composition of granulitic facies amphiboles point to $M_{0}$ low to intermediate (?) pressure conditions. Overall, a $\mathrm{M}_{0}$ passive metamorphic model seems to have resulted from the heat and $\mathrm{CO}_{2}$ fluids released during an extensional event by underplated basic magma. An anti-clockwise P-T-t path of $\mathrm{M}_{0}$ metamorphism is proposed on the basis of those observations.

The Juiz de Fora and Mantiqueira Complexes comprise rocks that can be associated with three different trends: 1) intermediate to acid calc-alkaline rocks; 2) tholeitic basic rocks; and 3) alkaline to transitional basic rocks. Quantitative analysis of hthogeochemical data shows that the petrogenesis of the basic rocks is unrelated to those of the intermediate and acid rocks within both units. Statistical and/or petrological criteria made it possible to define suites and/or 
groups within each one of those units and to constrain petrogenetic models based mostly on their REE data.

The calc-alkaline rocks of the Mantiqueira Complex comprise four petrogenetic different groups which are characterised by limited silica variation. Geochemical modelling suggests that each one of those groups was generated by partial melting of crustal material. Tholeitic basic rocks comprise a heterogeneous group supporting their generation by distinctive source materials as depicted by their E-MORB and intra-continental chondritenormalised REE patterns. The alkaline basic rocks display within plate geochemical chondritenormalised REE patterns and field data point to a continental setting for this group.

A relatively expanded suite of co-genetic rocks was identified among the calc-alkaline group of the Juiz de Fora Complex. It is related to complex magmatic differentiation processes, involving both fractional crystallization and bulk assimilation. Tholeitic basic rocks comprise a heterogeneous petrogenetic group. This heterogeneity seems to be owed to the involvement of distinctive source materials since those tholeites display typical N-MORB and E-MORB as well as intra-continental chondrite-normalised REE patterns. Chondritenormalised REE patterns of the alkaline rocks point to a within-plate (oceanic and/or continental) setting.

The geochemical characteristics of the Juiz de Fora Complex and Mantiqueira Complex rocks and those found in modern tectonic settings are alike. Some of the basic rocks of both units display chemical signatures of extensional tectonic settings whereas intermediate to acid rocks present typical patterns of compressive settings (volcanic and/or magmatic arcs). Some tholeitic basic rocks of the Juiz de Fora Complex seem to be ocean floor basalts. Field data suggest that basic rocks of within plate settings represent a late stage in the evolution of those complexes.

As a result of this research, the Juiz de Fora and Mantiqueira Complexes were defined as distinctive lithological and petrogenetic units. The main geochemical and petrogenetic differences may have largely resulted from differences in their respective tectonic regimes. As such, the Archaean to Early Proterozoic Mantiqueira Complex seems to have been associated with a tectonic setting unable to maintain long-standing magma chambers. This relatively 
instability and dynamic tectonic setting could have resulted from high heat flow and a turbulent regime of mantle convection current patterns. On the other hand, the tectonic setting in which the Archaean (?) to Early Proterozoic rocks of the Juiz de Fora Complex were fomed seems to have been associated to relatively stable tectonic conditions capable of maintaining longstanding magma chambers. This comparatively stable tectonic setting is thought to have resulted from a relatively more uniform and stable mantle convection current patterns (probably established during the Early Proterozoic, under lower heat flow conditions).

Data indicate that the Juiz de Fora Complex evolved from a compressive magmatic arc tectonic setting to an extensional setting where granulite facies metamorphism was caused by magmatic underplating.

Thrusting of the Juiz de Fora Tectonic Domain over the Andrelândia Tectonic Domain occurred during the Brasiliano-Panafrican Orogeny. However, the relative positions of the Juiz de Fora and Mantiqueira Complexes prior to the thrusting event are unknown. 


\section{PARTE I - CARACTERIZACÃO DA TEMÁTICA ESCOLHIDA}

\section{I.1) Introdução e Objetivos Globais}

Os Complexos Juiz de Fora (Oliveira, 1980; Machado et al., 1983) e Mantiqueira (Trouw et al., 1986; Heilbron, 1993, 1995) constituem parte do embasamento pré-1,8 Ga. do segmento central da Faixa Ribeira (Almeida et al., 1973). Esta compreende um cinturão complexo de dobramentos e empurrões ("fold and thrust belt"), gerado no NeoProterozóico/Cambriano durante a Orogênese Brasiliana, na borda sul/sudeste do Cráton do São Francisco (Almeida, 1971, 1977; Cordani et al., 1973). Este segmento do Pré-Cambriano brasileiro registra evidências de evolução complexa e policíclica, o que, associado ao número relativamente pequeno de dados geológicos detalhados já produzidos nesta região, faz com que muitas questões permaneçam em aberto para o esclarecimento da evolução tectônica da Faixa Ribeira. As discussões vão desde: seu limite; constituição; discriminação entre unidades supracrustais, embasamento retrabalhado e rochas intrusivas nas unidades litoestratigráficas ocorrentes (Ciclo Deposicional Andrelândia, Complexos Mantiqueira, Juiz de Fora e Paraíba do Sul); idade de formação, metamorfismo e deformação destes conjuntos litológicos; modelos geotectônicos (Tectônica de Placas x modelos não convencionais de orogênese).

Este trabalho pretende, a partir de uma visão integrada de dados detalhados de campo petrográficos, petrológicos e geoquímicos, contribuir para o conhecimento da constituição, origem e evolução geológica das rochas ortoderivadas que compõem os Complexos Juiz de Fora e Mantiqueira, além das demais unidades litoestrtigráficas que ocorrem na região de Juiz de Fora

\section{2) Área Estudada: Localização, Aspectos Fisiográficos e Relações com Unidades Tectônicas}

A área alvo da presente pesquisa localiza-se no sudeste do Estado de Minas Gerais e engloba grande parte dos municípios de Juiz de Fora, Matias Barbosa, Simão Pereira e Belmiro Braga, abrangendo uma área de aproximadamente $1800 \mathrm{Km}^{2}$, situada entre os meridianos $43^{\circ}$ 
$15^{\prime}$ e $43^{\circ} 30^{\prime} \mathrm{W}$ e entre os paralelos $21^{\circ} 35^{\prime}$ e $22^{\circ} 00^{\prime} \mathrm{S}$ (Fig. 1). O acesso à região é feito pelas seguintes rodovias: BR-040 (Rio - Belo Horizonte); BR - 393 (São Paulo - Três Rios); e BR - 116 (Rio - Bahia).

No contexto geotectônico, a área está inserida na Faixa Ribeira (Almeida et al., 1973) que representa um cinturão de dobramentos e empurrões, gerado no NeoProterozóico/Cambriano, durante a Orogênese Brasiliana, na borda sul/sudeste do Cráton do São Francisco (Almeida, 1971, 1977; Cordani et al., 1967, 1973; Cordani \& Brito Neves, 1982; Teixeira \& Figueiredo, 1991) (Fig.2).

O clima da região é do tipo úmido de verões brandos, com pluviosidade média anual de 1400 a $1500 \mathrm{~mm}$. A estação seca é curta e a temperatura média anual oscila entre $17^{\circ}$ e $19^{\circ}$. O principal curso d'água da região é o Rio Paraibuna que nasce pouco mais a norte, nos contrafortes da Serra da Mantiqueira, e corre para sul, até desembocar no Rio Paraíba do Sul, no município de Três Rios $(\mathrm{RJ})$. A fauna atual da área reflete a atuação antrópica sobre o meio natural, já que pode ser observado amplo domínio de paisagens compostas de pastagens, capoeiras e campos.

A área é dominada por solos antigos, pouco profundos, de textura argilosa e saturados em alumínio e são classificados como latossolos vermelho-amarelos álicos. Secundariamente, ocorrem latossolos vermelhomamarelos distróficos, cambissolos e solos litólicos (pouco desenvolvidos).

As serras e planaltos do sudeste mineiro encontram-se inseridos no Planalto Atlântico do Brasil Sudeste (Ab'Saber, 1972), uma das unidades integrantes do Planalto Brasileiro. Este relevo constitui um planalto cristalino rebaixado que vem sendo afetado de forma intensa por processos morfogenéticos tropicais, predominantemente químicos. Na área alvo, este relevo exibe um pronunciado nivelamento dos diversos interflúvios a cotas variáveis entre 400 e 1000 $\mathrm{m}$, representando resquícios de um prolongado processo de aplainamento correlacionado ao Ciclo Sul-Americano, desenvolvido do Cretáceo Superior ao Terciário Médio (King, 1956). 


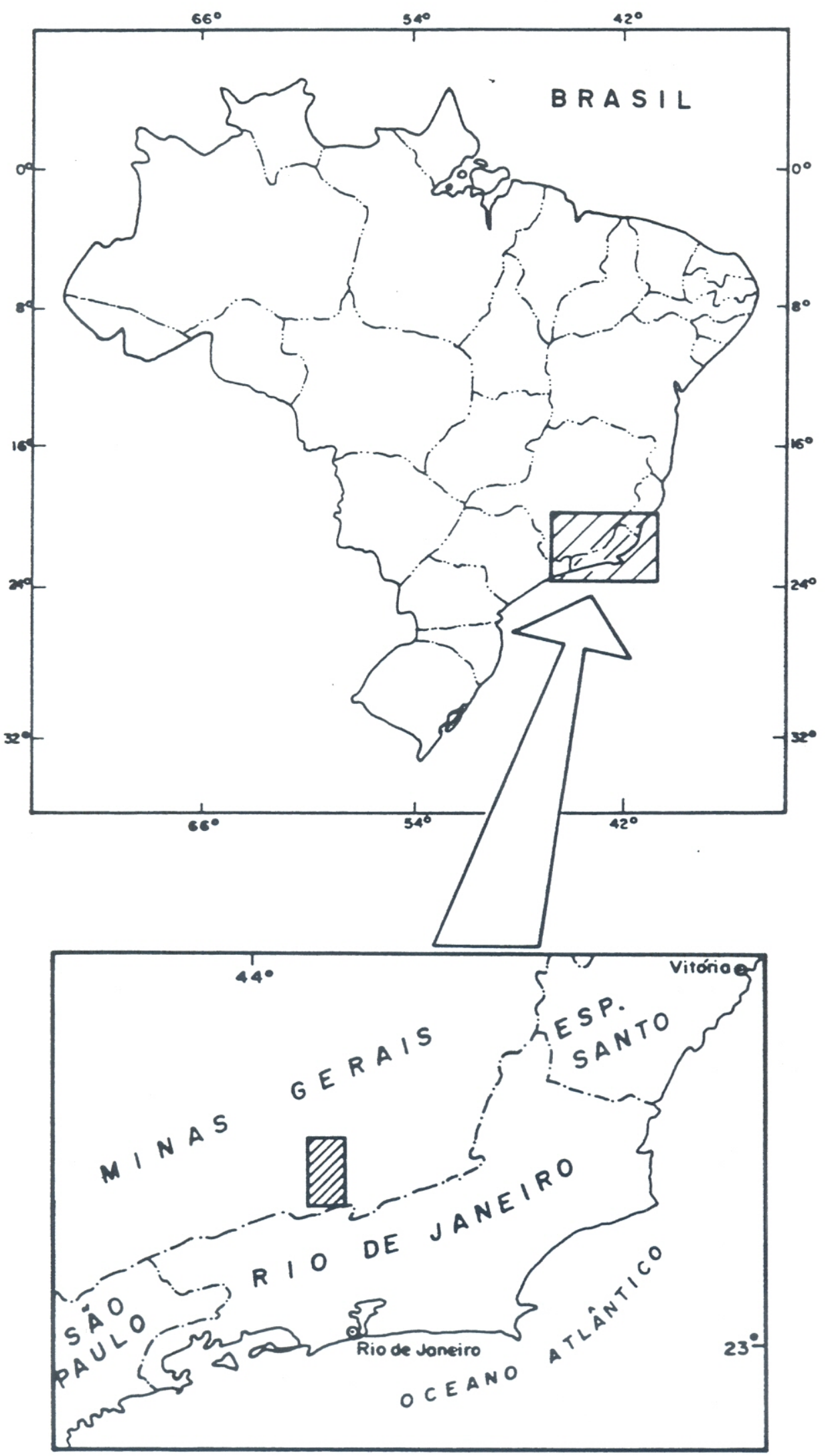

FIGURA 1 - Locolização do Areo Alvo no Contexto Geografico 

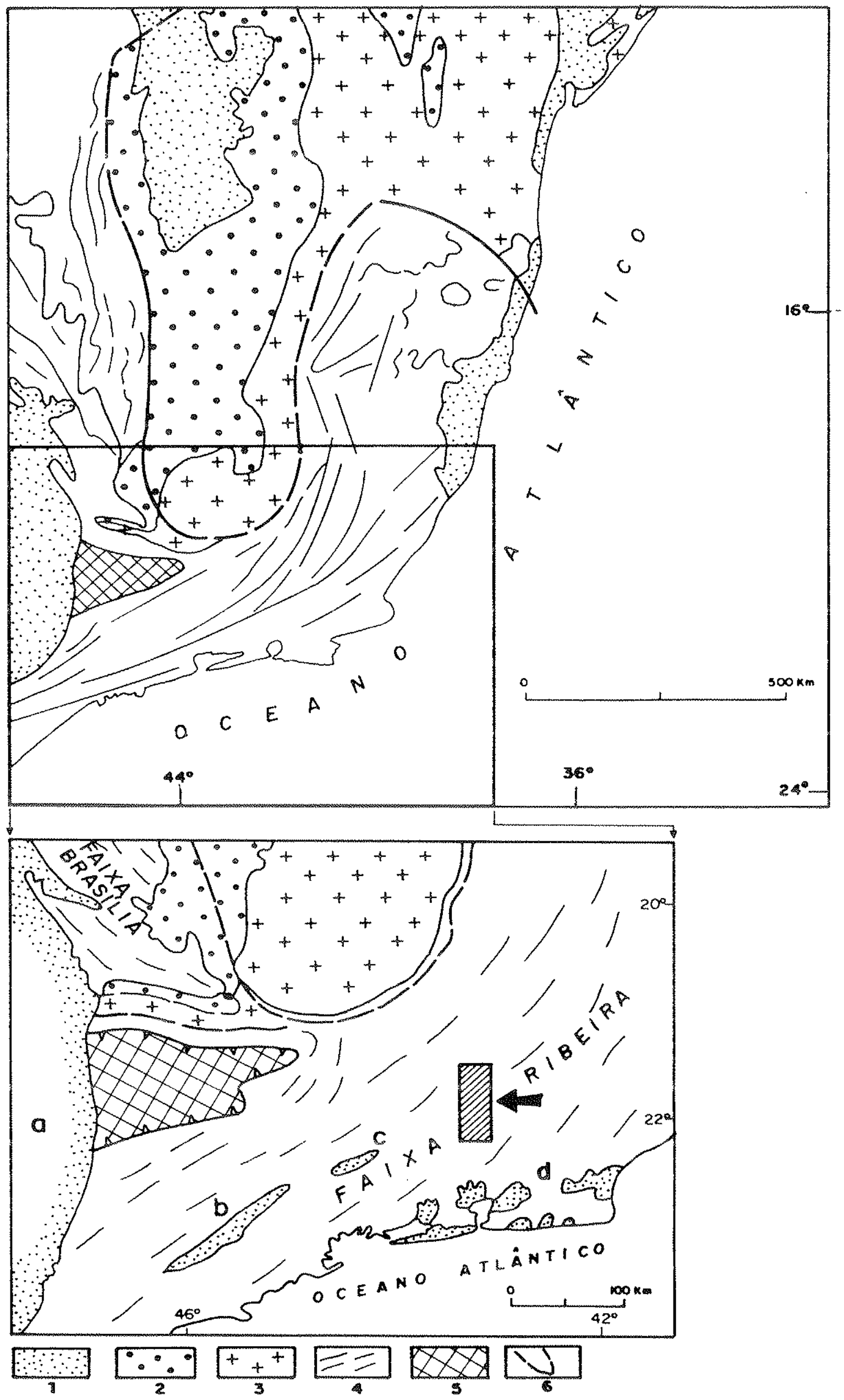

1- Cobertura Fonerozóical a-Bacia do Paraná; b-Bacia de Taubaté; c-Bacia Resende;

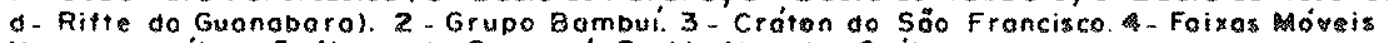
Neoproterazóicas. 5-Noppe de Guazupe'. 6- Limites do Cróton.

FIGURA 2 - Localizaçõo do Áreo Alyo no Contexto Georecrônico 


\section{3) Geologia Regional e Inserção Tectônica da Área Alvo.}

As primeiras subdivisões para o précambriano do sudeste brasileiro foram elaboradas por Barbosa (1954), Ebert (1955, 1956, 1957) e Rosier (1957). Barbosa (op. cit.) identificou dois conjuntos litológicos distintos inseridos nos domínios do ante-país da Orogênese Assíntica. O mais antigo, constituído de rochas metamótficas de alto grau, foi denominado Série Mantiqueira, enquanto que o mais novo, formado por sequência tipo greenstone belt, de baixo grau metamórfico, foi denominado Série Barbacena.

Ebert (op. cit.) definiu as Séries Andrelândia, Juiz de Fora e Paraíba do Sul como unidades paraderivadas correlatas, de idade Assíntica, metamorfoseadas, respectivamente, em níveis crustais médio, inferior sob baixa $P_{\mathrm{F} 20}$ e inferior sob alta $P_{\mathrm{E} 2 \mathrm{O}}$ (Fig.3). Com relação às unidades mais antigas já definidas por Barbosa (op. cit.), Ebert considerou a Série Barbacena como uma associação de facies metamórfica mais baixa do que a das rochas da Série Mantiqueira.

Nas décadas de 70 e 80 programa de mapeamento regional da Folha Rio de Janeiro na escala de 1:1.000.000 foi empreendido por órgãos públicos como DNPM e DRM, por vezes associados a empresas, resultando nas publicações de Fonseca et al. (1979), Machado Filho et al. (1983) e Castro et al. (1984). Estas foram também as décadas das grandes contribuições das universidades públicas no mapeamento detalhado (escalas 1: 50.000 e maiores) de várias partes do Brasil, inclusive da região sudeste, resultando em várias teses e trabalhos publicados em boletins de congressos e outras revistas especializadas.

Ainda na década de 80 , foram realizados trabalhos regionais, de cunho petrológico e geoquímico, no sudeste de Minas Gerais (Oliveira, 1980, 1981, 1982 e 1983) e no Estado do Rio de Janeiro (Barbosa \& Grossi Sad, 1983a, 1983b, 1983c e Grossi Sad \& Barbosa, 1985). Oliveira (op. cit.) realizou estudos sobre as rochas granulíticas aflorantes na região de Juiz de Fora, incluindo também análises de química mineral para a investigação das condições P-T do metamorfismo granulítico. Barbosa \& Grossi Sad (op. cit.) e Grossi Sad \& Barbosa (op.cit.) contribuíram para a caracterização petrológico-geoquímica das rochas do Complexo Juiz de Fora, da Série Paraíba do Sul e do Batólito da Serra dos Órgãos. 

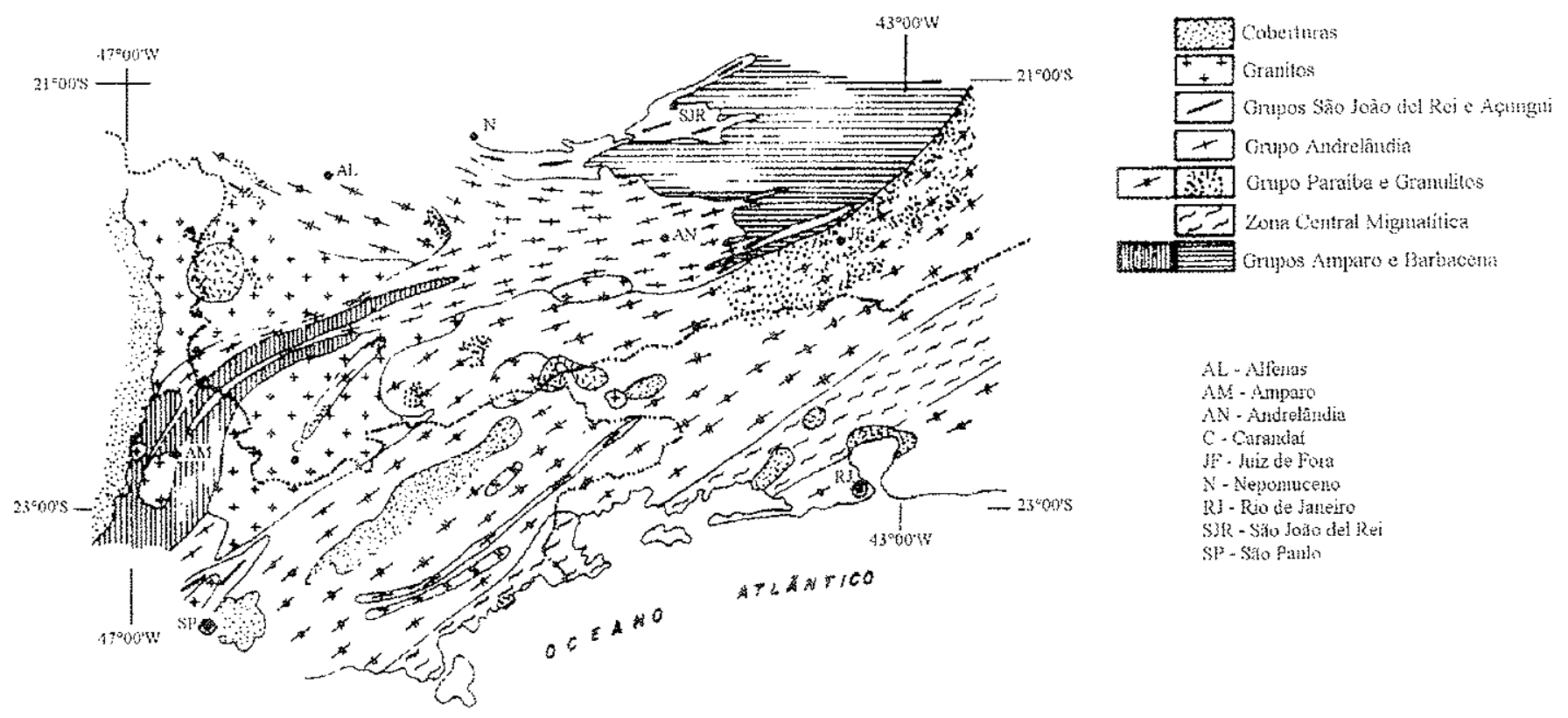

\section{AL- Afferas}

AN- Andreltarndia

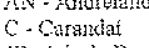

- Neyonucen

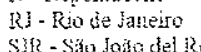

$\mathrm{SP}^{\mathrm{B}}-\mathrm{S}$ \% P Path

Figura 3 - Mapa Geológico da Região Sudeste de Minas Gerais (Ebert, 1968). 
A Série Andrelândia de Ebert (1955) foi redefinida como Grupo Andrelândia a partir de estudos realizados por uma equipe da Universidade Federal do Rio de Janeiro e liderada por Trouw. Desde 1980, vários trabalhos, incluindo sínteses regionais, foram publicados em periódicos nacionais e em boletins de congressos e simpósios (Trouw et al., 1980, 1982, 1983, 1984, 1986; Ribeiro e Heilbron, 1982; Andreis et al., 1989 $1989 b$; e Ribeiro et al., 1990) e várias teses de mestrado (Ribeiro, 1980; Paciullo, 1980; Heilbron, 1984; Valeriano, 1985; Magalhães, 1985; Maciel, 1986; Gonçalves, 1987; Bittar, 1990; Silva, 1991; Chrispin, 1990; Almeida, 1992; e Nummer, 1992) foram defendidas sobre o tema. A abordagem principal destes estudos têm sido a litoestratigrafia e a evolução metamórfico-deformacional dos Grupos Andrelândia e São João del Rei. Andreis et al. (1989a e 1989b), dando continuidade e nova abordagem aos trabalhos até então realizados, redefiniram as sequências supracrustais do sul de Minas Gerais sob a ótica da estratigrafia de sequências, identificando quatro ciclos deposicionais: Ciclo Deposicional Tiradentes; Ciclo Deposicional Lenheiro; Ciclo Deposicional Carandaí, anteriormente englobados no Grupo São João del Rei; e o Ciclo Deposicional Andrelândia. Desta nova proposta resultaram trabalhos de sínteses regionais (Ribeiro et al., 1990; Ribeiro et al., 1995) e teses de doutoramento (Ribeiro, 1997; Paciullo, 1997).

Na década de 90, a CPRM incluiu dentre suas atribuições aquelas referentes ao antigo Serviço Geológico Nacional. Muitas áreas do território nacional foram mapeadas em escala 1:100.000, incluindo várias no SE do Estado de Minas Gerais (Folha Barbacena, Folha Ponte Nova, Folha Rio Espera, Folha Lima Duarte, e Folha Rio Pomba (Pinto et al., 1991 e Viana et al., 1991)).

A década de 90 é também caracterizada por significativa contribuição ao conhecimento da evolução geológica do segmento central da Faixa Ribeira, gerada pela equipe de pesquisadores da Universidade do Estado do Rio de Janeiro, liderada por Heilbron, cujos estudos resultaram em teses de mestrado (Tupinambá, 1992 e Dios, 1995) e doutorado (Heilbron, 1993 e Valladares, 1996) e em várias publicações em boletins e periódicos nacionais, revistas estrangeiras e sínteses regionais (Heilbron et al.,1990, 1991, 1992, 1994a, 1994b, Duarte et al., 1994; Nogueira e Trouw, 1993; Heilbron et al., 1995, 1996; Machado et al., 1996). Dentre os temas abordados, destacam-se a compartimentação tectônica da Faixa Ribeira, sua constituição, evolução metamórfico-deformacional e geocronologia do metamorfismo e da granitogênese desenvolvidos durante a Orogênese Brasiliana (Fig.4). 
Legenda para a figura 4: 1) Embasamento Pré 1,8Ga.: Complexos Barbacena, Mantiqueira e Juiz de

Fora; 2) Suíte Quirino Dorândia; 3) Unidade Rio Negro, Série Inferior ou Costeira; 4) Ciclo Deposicional Lenheiro-Tiradentes; 5) Ciclo Deposicional Carandai; 6) Ciclo Deposicional Andrelândia; 7) Grupo Paraíba do Sul; 8 e 9) Granitóides Brasilianos; 10) Rochas Alcalinas Meso-Cenozóicas; 11) Bacias Cenozóicas e Sedimentação Quaternária; 12, 13, 14 e 15) Empurrões Limitrofes de Domínios Tectônicos; 16 e 17) Falhamentos Normais.

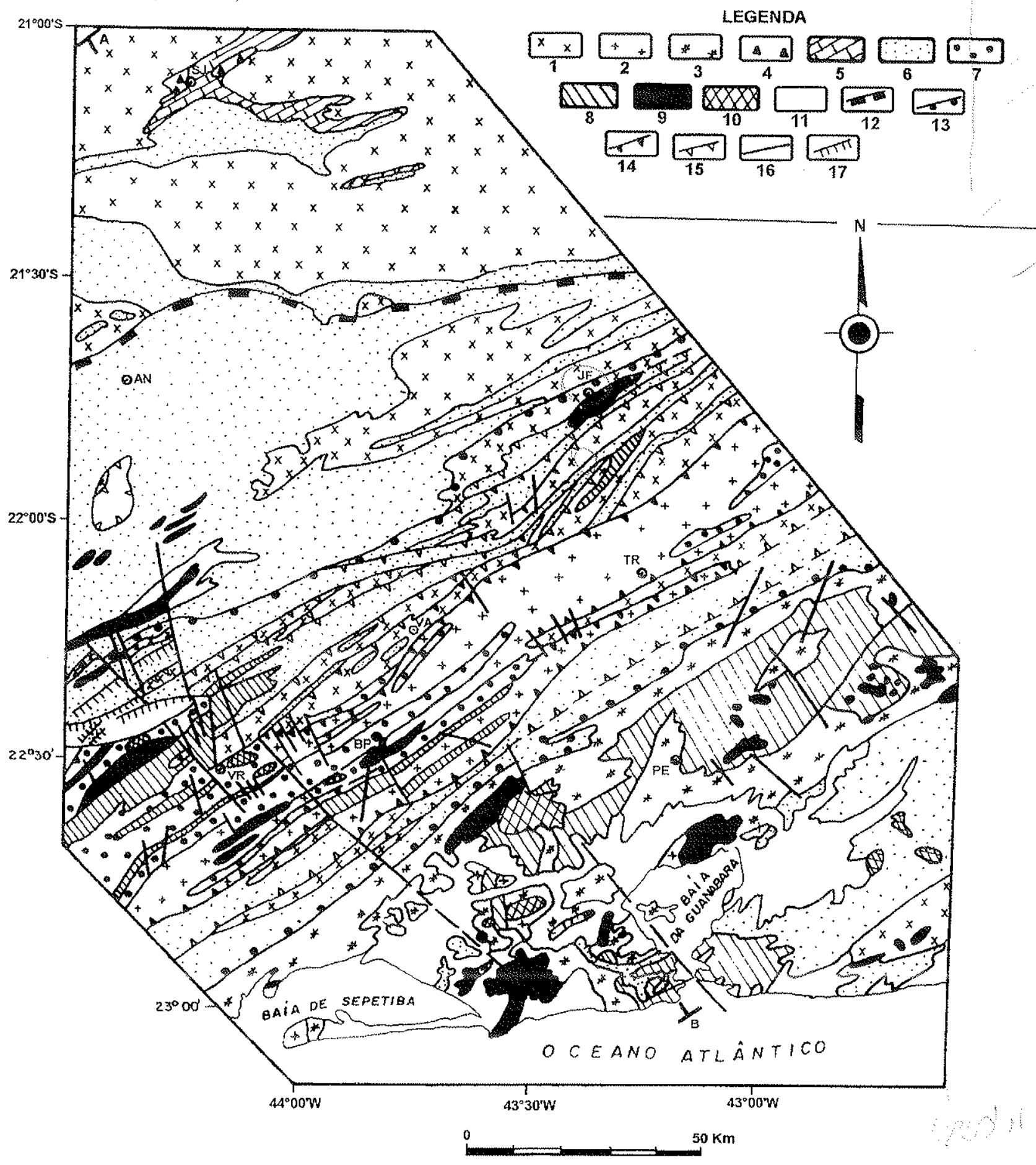

Figura 4 - Mapa Geológico do Estado do Rio de Janeiro e Região limítrofe do Estado de Minas Gerais (Heilbron, 1995). 


\section{1-4) Propostas de Compartimentação Tectônica para o Precambriano do Sudeste Brasileiro.}

Ebert $(1957,1968,1971)$ definiu duas faixas geossinclinais Assínticas, denominadas Araxaides e Paraibides, situadas, respectivamente, a W e SW e a S e SE da área estável (antepaís). Na faixa geossinclinal Paraibides, paralela à costa oriental brasileira e de polaridade voltada para o ante-país, o autor individualizou os Grupos São João del Rei, Andrelândia e Paraíba, interpretados, respectivamente, como correspondentes às zonas externa, de transição e interna da faixa. As rochas granulíticas da Série Juiz de Fora e os granitos e migmatitos da região da Serra dos Órgãos foram interpretadas como representantes da zona axial de divergência desta faixa (Fig. 5).

Trabalhos desenvolvidos a partir de sinteses regionais e datações radiométricas (Cordani et al., 1967; Almeida, 1967,1969; e Cordani et al., 1973) levaram à delimitação do Cráton do São Francisco, então definido como uma entidade tectônica preservada dos efeitos da Orogênese Brasiliana. A sul e sudeste deste terreno, os autores individualizaram um domínio de atuação do Ciclo Brasiliano, primeiramente denominado Cinturão Paraíba do Sul. Posteriormente, este termo passou a designar uma unidade geotectônica Trasamazônica e o termo Cinturão Ribeira foi proposto por Almeida et al. (1973) para representar uma entidade geotectônica Brasiliana sobreposta ao Cinturão Paraíba do Sul. O domínio Uruaçuano, localizado a W do Cráton do São Francisco, foi denominado Faixa Uruaçu, e o Grupo Andrelândia foi reinterpretado como extensão do Grupo Araxá, o que levou à materialização da Faixa Uruaçu no sul de Minas Gerais.

A ocorrência de faixas de rochas granuliticas associadas a paragnaisses com cordierita e sillimanita na costa ESE brasileira levou Fyfe e Leonardos (1974) à definição do Cinturão Atlântico, caracterizado por metamorfismo de baixa Pressão (tipo Abukuma), desenvolvido no Transamazônico sobre rochas mais antigas (Arqueanas).

O termo Faixa de Dobramento, sem qualquer compromisso com teorias de evolução, foi proposto por Hasui et al. (1975) para designar faixas de rochas metamorfizadas e dobradas no Proterozóico Superior, separadas, umas das outras, por extensas porções de rochas mais 


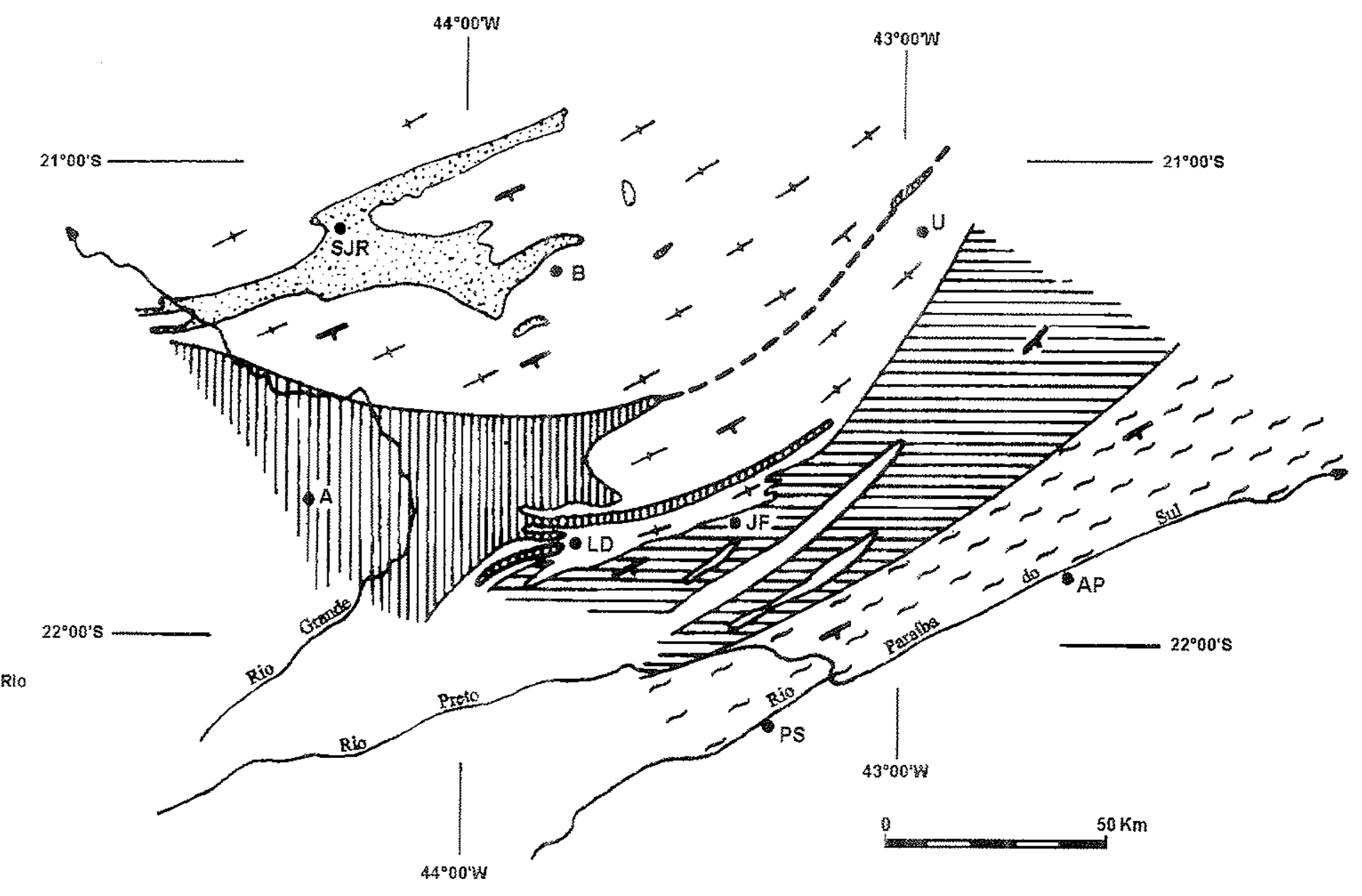

$$
\begin{aligned}
& \text { SJR - São João del Rei } \\
& \text { B - Barbacena } \\
& \text { A - Andrelândia } \\
& \text { LD - Lima Duarte } \\
& \text { JF - Juiz de Fora } \\
& \text { PS - Paraíba do Sul } \\
& \text { AP - Além Paraíba } \\
& \text { U - Ubá } \\
& \\
& \text { Foliação }
\end{aligned}
$$

\section{Neo-Algonquiano}

$\because$ Tiradentes, Carandal, Prados

|[IIIIIIII Série Andrelândia

Série Juiz de Fora

Série Paraiba

\section{Arqueano}

$\mp$ Série Barbacena

Figura 5 - Compartimentação da Região SE de Minas Gerais e Região Limítrofe do Estado do Rio de Janeiro (Ebert, 1968). 
antigas retrabalhadas no Brasiliano (maciços medianos). As pesquisas correntes mostravam que esta associação é característica para os terrenos que bordejam o Cráton do São Francisco e os maciços medianos deveriam representar altos estruturais, afetados de forma não uniforme e não generalizada pelos efeitos termais do Evento Brasiliano. Para os domínios situados a sul e sudeste do cráton, foram definidas as Faixas Apiaí, São Roque e Tijucas, materializadas, respectivamente, pelos Grupos Açungui, São Roque e Brusque. Assim, o Maciço de Joinville foi individualizado entre as Faixas Apiaí e Tijucas. Para a borda ocidental do cráton, a Faixa Uruaçu já havia sido definida por Almeida et al. (1973).

Almeida et al. (1976) estenderam a Faixa Apiaí para os Estados do Rio de Janeiro e Espírito Santo, interpretando estas porções como exposições de níveis crustais inferiores. Mais ao NNE, o Cráton do São Francisco tem, em sua margem leste, a Faixa Araçuaí. Os autores definiram ainda a Faixa Brasilia, como correspondente ao domínio brasiliano que se estende ao longo da borda sudoeste e oeste do Cráton do São Francisco. O Grupo São João del Rei foi considerado extensão do Grupo Bambuí, o que estende para SSE o domínio da Faixa Brasília. Embora Ebert (1957) tenha considerado os Grupos São João del Rei e Andrelândia como contemporâneos, Almeida et al. (1976) consideraram que o segundo seria correlacionável ao Grupo Araxá e, portanto, representaria o prolongamento da Faixa Uruaçu. A este conjunto de faixas de dobramento, maciços medianos e zonas retrabalhadas, Almeida et al. (1976) denominaram Região de Dobramentos Sudeste.

Wernick et al. (1978), a partir da integração de dados regionais, consideraram que a Região de Dobramentos Sudeste tem grande proporção de embasamento pré-brasiliano retrabalhado, sugerindo, então, gênese ensiálica. Sobre este embasamento, houve sedimentação de características marginais, tanto proximais quanto distais. Estes estudos, somados a pesquisas de correlação geológica com o continente africano, levaram os autores a considerar que esta regiäo de dobramentos tem continuidade na margem oeste da África, tendo se desenvolvido entre três áreas estáveis: o Cráton do São Francisco; o Cráton do Congo; e o Cráton do Rio de La Plata.

Segundo Hasui et al. (1978), na Faixa Ribeira predominam gnaisses e migmatitos de infraestrutura, com núcleos frequentes de embasamento (Transamazônico e, em menor grau, Arqueano). As rochas supracrustais correspondentes ao Ciclo Brasiliano são representadas 
pelos sistemas de dobramento Araçuaí e Apiaí. Tais aspectos levaram os autores a considerar esta faixa como do tipo ensiálica, com forte superposição do Brasiliano em faixa também ensiálica denominada Faixa Paraíba do Sul.

Embora a sincronicidade entre os Grupos São João del Rei e Andrelândia venha sendo defendida nos trabalhos mais recentes, existem discussões com relação a sua correlação com outras unidades como já proposto por vários autores (Almeida et al., 1973, 1976). A partir de trabalhos de mapeamento expedito, Cavalcante et al. (1979) advogaram que os Grupos São João del Rei e Andrelândia são separados, respectivamente, dos Grupos Bambuí e Araxá pela Faixa de Cisalhamento Campo do Meio.

Fonseca et al. (1979), a partir de trabalhos de mapeamento reginal em escala 1:1.000.000 da Folha Rio de Janeiro, adotaram uma compartimentação tectônica muito semelhante àquela proposta por Ebert $(1957,1968,1971)$, com vergência estrutural e metamórfica voltada para o ante-país, a nordeste. As propostas destes autores diferem no fato de que Fonseca et al. (op. cit.) definiram uma outra área cratônica (pós-país) assíntica, situada na área litorânea dos estados do Rio de Janeiro e Espírito Santo.

Trabalhos de integração e correlações regionais levaram Almeida et al. (1980) e Lesquer et al. (1981) a proporem uma compartimentação tectônica para o Arqueano da região sudeste brasileira. Foi então individualizado um bloco crustal granito-gnáissico, orlado por duas faixas de rochas de alto grau, denominadas Cinturão Móvel Costeiro e Cinturão Móvel Alfenas. Para a faixa granulítica do litoral ESE brasileiro, foi adotada a denominação de Cinturão Granulítico Atlântico sugerida por Fyfe e Leonardos (1974), enquanto que para a faixa granulítica do SSW de Minas Gerais, Almeida et al. (1980) e Hasui (1982) propuseram o nome de Cinturão Granulítico Rio Grande.

Com base em dados gravimétricos, Haraly e Hasui (1982a, b) propuseram uma compartimentação tectônica em blocos para o Arqueano desta porção brasileira. Foram então definidos, no setor setentrional, os blocos Paraná, São Paulo, Vitória e Brasília, este último correspondente à parte do que se chamou Cráton do Paramirim (denominação já utilizada por Almeida, 198I). Mais a sul, foram individualizados os blocos Piêm e Luís Alves. Para estes autores, os Complexos Varginha e Juiz de Fora ( + Complexo Costeiro) representam, 
respectivamente, porções alçadas dos blocos São Paulo, Luís Alves e Vitória, enquanto que os Complexos Barbacena e Campos Gerais, a porções meridionais do bloco Brasilia.

A partir de trabalhos de mapeamento em escala 1:1.000.000, associados a integrações regionais, Machado Filho et al. (1983) subdividiram a porção sudeste do Estado de Minas Gerais e o Estado do Rio de Janeiro nos seguintes domínios geotectônicos: a) Cráton do Paramirim; b) Faixa de Dobramentos Canastra-Carrancas-Amparo, separadas pelos c) maciços medianos de Guaxupé e Socorro; d) Faixa de Dobramentos Piedade; e) Faixa de Dobramentos Juiz de Fora; e f) Cinturão Móvel Atlântico.

Hasui e Oliveira (1984), a partir de integrações regionais, nas quais trabalhos mais recentes mostravam a falta de continuidade dos Grupos São João del Rei e Andrelândia com os Grupos Bambuí e Araxá, propuseram a adoção de mais uma faixa de dobramentos, representada pelos dois primeiros Grupos. Esta nova faixa, disposta na porção sul/sudeste do Cráton do São Francisco, foi denominada Alto Rio Grande e interpretada como de carater proximal.

Trabalhos de mapeamento e análise estrutural e integração regional levaram Tassinari e Campos Neto (1988) a subdividir a região limítrofe dos Estados de Minas Gerais e São Paulo em cinco domínios: a) Faixa de Dobramentos Alto Rio Grande; b) Nappe Socorro-Guaxupé; c) Domínio São Roque; d) Domínio Embu; e e) Domínio Costeiro.

Andreis et al. (1989a, 1989b), associando mapeamentos geológicomestruturais detalhados à aplicação do conceito de estratigrafia de sequências, reconheceram, no sudeste do Estado de Minas Gerais, quatro ciclos deposicionais Proterozóicos denominados, em ordem estratigráfica, Tiradentes, Lenheiro, Carandaí e Andrelândia. Os dois primeiros ciclos são constituídos predominantemente de quartzitos; o terceiro tem pelitos e calcários em abundância; e o ciclo mais novo é constituído de metarenitos e pelitos. Neste último foram englobadas as rochas dos Grupos Andrelândia e São João del Rei.

Com base em compilações de dados geocronológicos e em estudos da petrogênese e ambiência tectônica de rochas granitóides do segmento setentrional do Cinturão Ribeira, Campos Neto e Figueiredo (1990) identificaram dois domínios tectônicos exóticos: a) 
Domínio Juiz de Fora, interpretado como um domínio infracrustal consolidado no Proterozóico Inferior; e b)Domínio Costeiro e Complexo Paraiba do Sul, com pulsos orogênicos no limite Proterozóico Superior-Cambriano e no Cambriano (Fig 6).

A partir de mapeamento geológico-estrutural em escala de semi-detalhe (1:50.000) da região limítrofe dos estados do Rio de Janeiro e Minas Gerais, Heilbron et al. (1991) individualizaram 4 compartimentos tectônicos, cavalgados para NW, em direção ao Cráton do São Francisco. Da base para o topo, tem-se: a) Domínio Andrelândia Autóctone, que engloba sequências dos Ciclos Deposicionais Lenheiro, Tiradentes, Carandaí e Andrelândia e seu embasamento, representado pelas associações granito-greenstone do Complexo Barbacena; b) Domínio Andrelândia Parautóctone, onde rochas do Ciclo Deposicional Andrelândia ocorrem em contatos normais com seu embasamento, constituído por terrenos granítico-migmatíticogranulíticos, correlacionados ao Grupo Mantiqueira; c) Domínio Juiz de Fora, constituído de uma intercalação tectônica entre rochas ortogranulíticas do Complexo Juiz de Fora e rochas supracrustais metassedimentares correlacionadas ao Ciclo Deposicional Andrelândia; e d) Domínio Paraiba do Sul, representado pelas rochas metassedimentares do Grupo Paraíba do Sul e por corpos granitóides interpretados como intrusivos na sequência metassedimentar e englobados na Suite Intrusiva Quirino-Dorândia. Esta proposta foi aprimorada no trabalho de Heilbron (1993) quando, então, a autora propôs o abandono do termo Faixa Alto Rio Grande, já que esta corresponde aos Domínios Andrelândia Autóctone e Parautóctone do segmento central da Faixa Ribeira (Fig. 7). Segundo os autores supracitados, as associações litológicas e os padrões estruturais observados a norte da zona axial existente nas proximidades da chamada Zona de Cisalhamento do Rio Paraíba do Sul se repetem a sul desta zona, em direção ao litoral. A esta estrutura foi dado o nome de Megassinforma do Rio Paraíba do Sul, o que levou os autores a admitirem a extensão da Faixa Ribeira até a costa do Estado do Rio de Janeiro. O estudo cinemático mostrou vergência para NW, em direção ao Cráton do São Francisco.

Paciullo et al. (1993), dando continuidade aos trabalhos de análise estrutural metamórfica e à aplicação do conceito de estratigrafia de sequências, identificaram 6 associações de litofacies na Bacia Andrelândia, local de sedimentação do ciclo deposicional homônimo. Baseado nesta análise, os autores concluíram que a deposição se iniciou em ambiente continental fluvial, seguido de rifteamento e trasgressão marinha. A deposição deste Ciclo evoluiiu desde ambiente continental até ambiente marinho profundo, envolvendo 


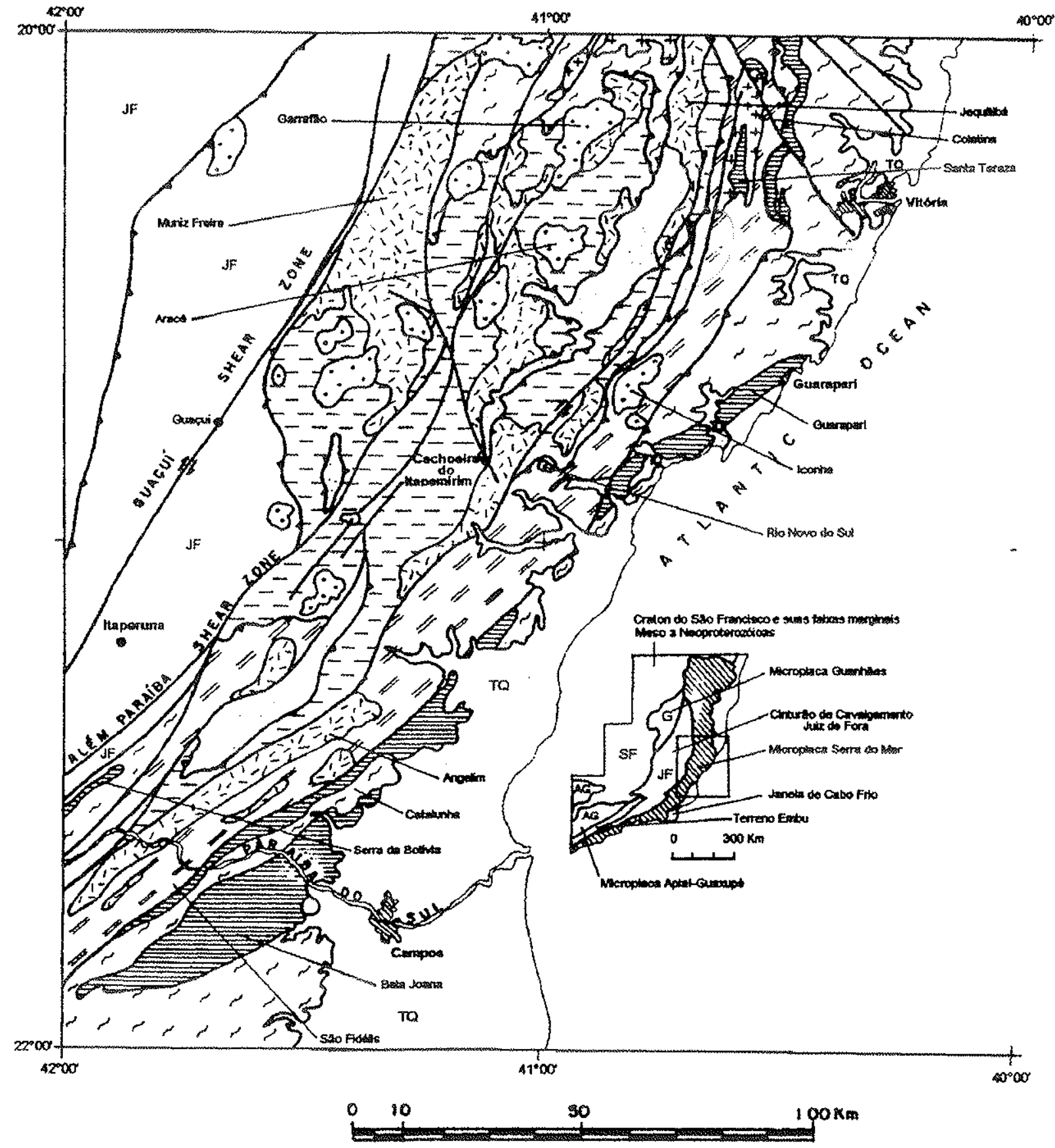

LEGENDA

TQ TercériolQuaternấrio

Dominio Orogenenco Rio Doce

Cantriano Superios - Ordoviciano inferior

$\because \because$ Graritódes pos-colisionais

Carristiano

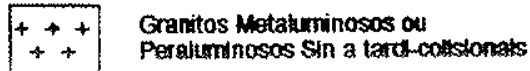

$\sim$; Tereno Gantdito-granitomignatito
Nupoproterozóico III

Rochas Putonicas cakioncalinas pré-cotisionas
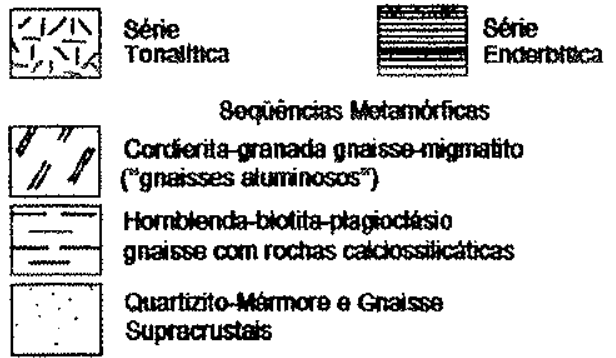

Dominio da Orogenese Brositema

Cinturáo de Empurắo hlocprotercécico Juz de Fora

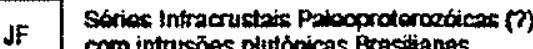
com intrusbos piutónicas Brasitianes

Figura 6-Compartimentação Tectônica do Segmento Setentrional da Faixa Ribeira (Campos Neto \& Figueiredo 1990). 


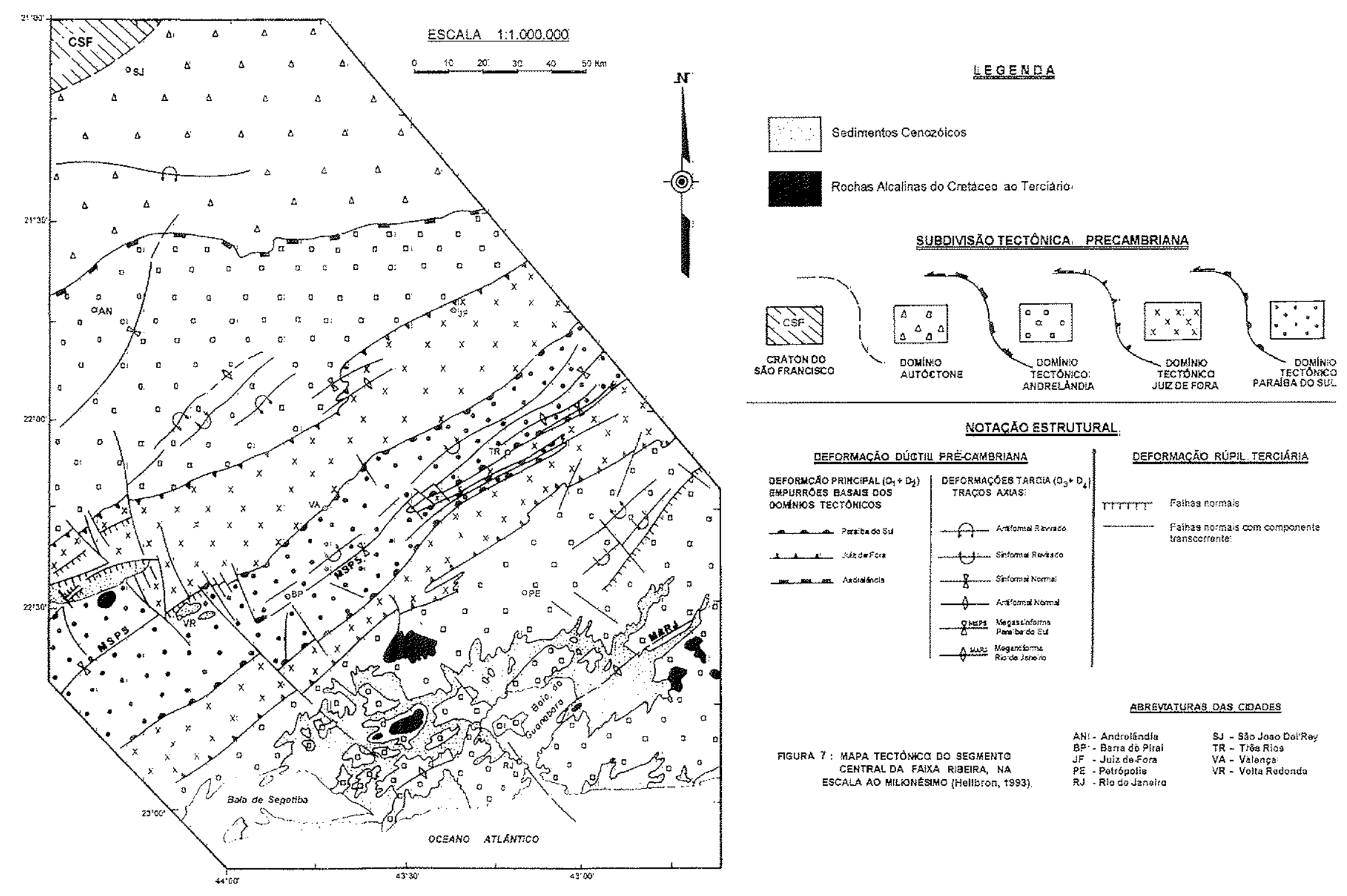


oscilações no nivel do mar, o que levou os autores a conclúrem a favor de uma ambiência de margem passiva para a Bacia Andrelândia. Heilbron et al. (1995), a fim de eliminar confusões e adotar termos sem conotação litoestratigráfica, propuseram a seguinte substituição das denominaçōes propostas em Heilbron et al. (1981) e Heilbron (1993) para os domínios tectônicos do setor central da Faixa Ribeira: a) Domínio Autóctone, correspondente à zona externa da faixa; b) Domínio Inferior; c) Domínio Médio; e d) Domínio Superior. Estes três últimos foram interpretados como constituintes da porção interna da faixa.

Ribeiro et al. (1995), com base na análise de litofacies dos Ciclos Deposicionais Tiradentes, Lenheiro, Carandai e Andrelândia, trouxeram importante contribuição para a reconstrução da evolução geológica do sul do Cráton do São Francisco. Os autores definiram 3 bacias sedimentares proterozóicas denominadas Bacia São João del Rei, Bacia Carandaí e Bacia Andrelândia. As duas primeiras desenvolveram-se em ambiente intracontinental durante o Mesoproterozóico (Ribeiro et al., op. cit.; Ribeiro, 1997), sendo que a Bacia Carandaí foi preenchida pelas litofacies do Ciclo Deposicional Carandaí, enquanto que a Bacia São João del Rei, pelos Ciclos Deposicionais Tiradentes e Lenheiro. A Bacia Andrelândia desenvolveu-se em margem passiva no Neoproterozóico e encerra as litofacies do ciclo deposicional homônimo (Ribeiro et al., op. cit.; Paciullo, 1997).

\section{5) Evolucão do Conhecimento Sobre os Complexos Juiz de Fora e Mantiqueira e a Proposta deste Trabalho.}

Para cada uma destas Unidades será apresentado um breve histórico dos trabalhos realizados, seguido por uma tabela com suas principais idéias. Ao final serão ressaltados os pontos consensuais e principalmente as questões em aberto.

\subsection{1) Complexo Juiz de Fora}

a) Trabalhos Anteriores

As rochas granuliticas que constituem o Complexo Juiz de Fora já foram estudadas por vários autores, tendo como pioneiros Ebert (1955, 1957, 1968), Rosier (1957) e Guimarães 
(1956, 1961) que realizaram pesquisas de cunho regional no sudeste dos Estados de Minas Gerais e Rio de Janeiro.

O final da década de 60 e início da de 70 foi marcado pelos estudos geocronológicos no Precambriano do sudeste brasileiro, destacando-se os trabalhos de Delhal et al. (1969) e Cordani et al. (1973).

Mapeamentos regionais (escala 1:1.000.000) da Folha Rio de Janeiro foram realizados no final da década de 70 e início da de 80 , resultando nos trabalhos de Fonseca et al. (1979) e Machado Filho et al. (1983).

As décadas de 80 e 90 são marcadas por estudos de forte carater petrológico destas rochas, destacando-se os de Oliveira (1980, 1981, 1982 e 1983), Barbosa e Grossi Sad (1983 a, b, c), Grossi Sad e Barbosa (1985), Figueiredo e Campos Neto (1993), Pinto et al. (1991), Viana et al. (1991), Heilbron (1993), Nogueira (1994), Figueiredo e Teixeira (1996) e Heilbron et al. (1996).

Outros trabalhos que também contribuiram para o conhecimento desta unidade nas últimas duas décadas foram Castro et al. (1984), Machado (1984, 1986), Figueiredo e Campos Neto (1990, 1993), Nogueira e Trouw (1994), Heilbron (1995) e Machado et al. (1996).

Uma síntese das principais idéias destes autores é sumarizada na Tabela 1. 
Tabela 1: Trabalhos Anteriores Referentes ao Complexo Juiz de Fora

\begin{tabular}{|c|c|c|c|c|c|c|}
\hline Autores & Denominação & Constituição Litológica & Idade & $\begin{array}{l}\text { Caracteristicas } \\
\text { Geoquimicas }\end{array}$ & \begin{tabular}{|l|} 
Relações \\
Metamorfismo / \\
Deformaçäo
\end{tabular} & $\begin{array}{l}\text { Ambientação } \\
\text { Geotectônica }\end{array}$ \\
\hline Ebert $(1955,1957)$ & $\begin{array}{l}\text { Série Juiz de Fora, } \\
\text { posteriormente Grupo } \\
\text { Paraíba dosul }\end{array}$ & $\begin{array}{l}\text { Rochas da suite } \\
\text { charnockitica, de } \\
\text { origem sedimentar }\end{array}$ & Assintica & & $\begin{array}{l}\text { Metamorísmo carazo- } \\
\text { nal por desidratação } \\
\text { e descalcinação } \\
\text { anterior } \\
\text { milonitização }\end{array}$ & $\begin{array}{l}\text { Porçäo interna do } \\
\text { geosinclinal Assintico } \\
\text { Paraibides }\end{array}$ \\
\hline Rosier $(1957,1965)$ & $\begin{array}{l}\text { Série } \\
\text { Paraiba-Desengano }\end{array}$ & Charnockitos & Assintica & & & $\begin{array}{l}\text { Regiäo profunda de } \\
\text { geossinclinal Assinti- } \\
\text { co,provavelmente } \\
\text { uma } \\
\text { sequência ofiolitica }\end{array}$ \\
\hline $\begin{array}{l}\text { Guimarães } \\
1961 \text { ) }\end{array}$ & & & & & & \\
\hline Ebert (1968) & Grupo Paraiba do Sul & $\begin{array}{l}\text { Granulitos e } \\
\text { paracharnockitos }\end{array}$ & Assintica & & $\begin{array}{l}\text { Milonitização levou à } \\
\text { desidratação e, no } \\
\text { auge do metamorfis- } \\
\text { mo na facies anfibo- } \\
\text { lito, as rochas já } \\
\text { desidratadas deram } \\
\text { origem a granulitos e } \\
\text { charnockitos. }\end{array}$ & $\begin{array}{l}\text { Nappe de } \approx 1 \mathrm{~km} \text { de } \\
\text { espessura, com ver- } \\
\text { gência para o interior } \\
\text { da faixa (NW), asso- } \\
\text { ciada à intensa milo- } \\
\text { nitizaçăo na capa. }\end{array}$ \\
\hline Cordani et al.(1973) & Série Juiz de Fora & $\begin{array}{l}\text { Granulitos de origem } \\
\text { sedimentar }\end{array}$ & $\begin{array}{l}\text { Tranzamazônico, com } \\
\text { indícios de porções } \\
\text { Arqueanas. } \\
\text { Retrabalhamento no } \\
\text { Et Brasiliano. }\end{array}$ & & & \\
\hline $\begin{array}{l}\text { Fyfe \& Leonardos } \\
(1974)\end{array}$ & & Granulitos & $\begin{array}{l}\text { Metamoríismo } \\
\text { granulitico } \\
\text { Transamazônico }\end{array}$ & & $\begin{array}{l}\text { Metamorfismo com } \\
\text { caracterlsticas de } \\
\text { Pressão baixa } \\
\text { (Abukuma) }\end{array}$ & $\begin{array}{l}\text { Pertencentes ao } \\
\text { Cinturão Móvel } \\
\text { Atlântico }\end{array}$ \\
\hline Fonseca et al. (1979) & $\begin{array}{l}\text { Rochas da } \\
\text { Associação } \\
\text { Charnockitica }\end{array}$ & $\begin{array}{l}\text { Charnockitos, migma- } \\
\text { titos, gnaisses facoi- } \\
\text { dais (ortoderivados) }\end{array}$ & $\begin{array}{l}\text { Transamazônico, com } \\
\text { indlcios de núcleos } \\
\text { maisantigos. }\end{array}$ & & & \\
\hline
\end{tabular}


Tabela 1: Trabalhos Anteriores Referentes ao Complexo Juiz de Fora (Cont.)

\begin{tabular}{|c|c|c|c|c|c|c|}
\hline Autor(es) & Denominação & Constituição Litológica & lade & $\begin{array}{l}\text { Características } \\
\text { Geoquimicas }\end{array}$ & $\begin{array}{c}\text { Relaçôes } \\
\text { Metamorfismo/ } \\
\text { Deformação }\end{array}$ & $\begin{array}{l}\text { Ambientação } \\
\text { Geotectônica }\end{array}$ \\
\hline $\begin{array}{l}\text { Machado Filho et al. } \\
(1983)\end{array}$ & $\begin{array}{l}\text { Complexo Juiz de } \\
\text { Fora }\end{array}$ & $\begin{array}{l}\text { Suite Charnockítica } \\
\text { Enderbítica } \\
\text { (ortogranulitos e orto- } \\
\text { granulitos diaftoréicos } \\
\text { com faixas kinzigiti- } \\
\text { cas. }\end{array}$ & $\begin{array}{l}\text { Arqueanas, com retra- } \\
\text { balhamento no } \\
\text { Transamazônico e } \\
\text { em parte, no } \\
\text { Brasiliano. }\end{array}$ & $\begin{array}{l}\text { Rochas ortoderivadas: } \\
\text { trend misto toleitico e } \\
\text { calcioalcalino. } \\
\text { Rochas } \\
\text { paraderivadas: } \\
\text { trend calcioalcalino }\end{array}$ & $\begin{array}{l}\text { Metamorfismo de } \\
\text { facies granulito é } \\
\text { anterior ao de facies } \\
\text { anfibolito. }\end{array}$ & $\begin{array}{l}\text { Rochas da base da } \\
\text { crosta continental ou } \\
\text { basáltica Arqueana. }\end{array}$ \\
\hline $\begin{array}{l}\text { Oliveira (1980, 1981, } \\
1982,1983)\end{array}$ & $\begin{array}{l}\text { Granulitos do Grupo } \\
\text { Paralba do Sul, } \\
\text { posteriormente, } \\
\text { Complexo Juiz de } \\
\text { Fora } \\
\end{array}$ & $\begin{array}{l}\text { Em grande parte, } \\
\text { rochas ortoderivadas } \\
\text { de composiçäo tona - } \\
\text { Iftica a granodioritica. }\end{array}$ & $\begin{array}{l}\text { Metamorfismo } \\
\text { granulitico Arqueano, } \\
\text { com retrabalhamento } \\
\text { noTransamazonico e } \\
\text { no Brasiliano. }\end{array}$ & $\begin{array}{l}\text { Trend linear clacio - } \\
\text { alcalino. Granulitos } \\
\text { podemser restitos } \\
\text { depletados de fusões } \\
\text { crustais. }\end{array}$ & $\begin{array}{l}\text { Condiçóes do meta - } \\
\text { morfismo granulftico: } \\
T: 844^{\circ}-877^{\circ} \\
\mathrm{P}: 6 \sim 7 \mathrm{~Kb}\end{array}$ & $\begin{array}{l}\text { Faixa Juiz de Fora, } \\
\text { posteriormente, Faixa } \\
\text { Paraíba do Sul }\end{array}$ \\
\hline $\begin{array}{l}\text { Barbosa \& Grossi Sad } \\
\text { (1983a, b, c) e Grossi } \\
\text { Sad \& Barbosa (1985) }\end{array}$ & $\begin{array}{l}\text { Complexo Juiz de } \\
\text { Fora: Unidades } \\
\text { Comendador } \\
\text { Venâncio (UCV) e } \\
\text { Raposos (UR); } \\
\text { Unidade ltaperuna } \\
\text { (UI) }\end{array}$ & $\begin{array}{l}\text { UCV -rochas } \\
\text { charnocki- ticas, } \\
\text { básicas aácidas, } \\
\text { quartzitos e bt } \\
\text { gnaisses; } \\
\text { UR - diaftoritos dos } \\
\text { charnockitos da UCV; } \\
\text { Ul - rochas parameta- } \\
\text { mórfi cas e } \\
\text { blastomolini- } \\
\text { ticas da calha do Rio } \\
\text { Paraiba do Sul }\end{array}$ & (1) & $\begin{array}{l}\text { Charnockitos básicos: } \\
\text { toleiitos abissais; } \\
\text { Charnockitos ácidos a } \\
\text { intermediários: série } \\
\text { calcioalcalina. }\end{array}$ & $\begin{array}{l}\text { Granulitização a altas } \\
\text { Te P foi anterior ao } \\
\text { metamorifismo de } \\
\text { facies anfibolito }\end{array}$ & $\begin{array}{l}\text { Substrato mais antigo } \\
\text { alçado tectonicamente } \\
\text { para niveis superiores }\end{array}$ \\
\hline Castro et al. (1984) & $\begin{array}{l}\text { Série Juiz de Fora: } \\
\text { Unidade Juiz de Fora } \\
\text { (UJF); } \\
\text { Unidade Três llhas } \\
\text { (UTI). }\end{array}$ & $\begin{array}{l}\text { UJF: Rochas } \\
\text { charnocki ticas } \\
\text { básicas associadas a } \\
\text { massas irregulares de } \\
\text { enderbitos e } \\
\text { charnocki- tos, com } \\
\text { quartzito subordinado; } \\
\text { UT!: Diartoritos das } \\
\text { rochas charnockiticas, } \\
\text { kinzigitos e quartzitos, } \\
\text { miloníticos a } \\
\text { blastomilo- nitics. }\end{array}$ & & & & \\
\hline Machado $(1984,1986)$ & $\begin{array}{l}\text { Sequência de } \\
\text { Valença, } \\
\text { correlacionável à } \\
\text { Série Juiz de Fora de } \\
\text { Ebert }(1956)\end{array}$ & $\begin{array}{l}\text { Rochas granulfticas } \\
\text { ortoderivadas, } \\
\text { gnaisses } \\
\text { e anfibolitos } \\
\text { associados } \\
\end{array}$ & $\begin{array}{l}\text { Rochas Arqueanas, } \\
\text { granulitizadas no } \\
\text { Transamazônico }\end{array}$ & & $\begin{array}{l}\text { Metamorismo na } \\
\text { facies granulito é } \\
\text { anterior ao de facies } \\
\text { anfibolito }\end{array}$ & $\begin{array}{l}\text { Substrato Arqueano, a } \\
\text { partir do qual } \\
\text { evolufram as rochas } \\
\text { do Grupo Paraíba do } \\
\text { Sul }\end{array}$ \\
\hline
\end{tabular}


Tabela 1: Trabalhos Anteriores Referentes ao Complexo Juiz de Fora (Cont.)

\begin{tabular}{|c|c|c|c|c|c|c|}
\hline Autor(es) & Denominação & Constituição Litológica & lade & $\begin{array}{l}\text { Características } \\
\text { Geoquímicas }\end{array}$ & $\begin{array}{c}\text { Relações } \\
\text { Metamorfismo/ } \\
\text { Deformação }\end{array}$ & $\begin{array}{l}\text { Ambientação } \\
\text { Geotectônica }\end{array}$ \\
\hline $\begin{array}{l}\text { Figueiredo \& Cmpos } \\
\text { Neto (1989, 1990, } \\
\text { 1993) }\end{array}$ & $\begin{array}{l}\text { Complexo Juiz de } \\
\text { Fora * } \\
\text { * área investigada: } \\
\text { norte fluminense }\end{array}$ & $\begin{array}{l}\text { Ortogranulitos mig- } \\
\text { matíticos e gnaisses e } \\
\text { migmatitos cinzentos } \\
\text { subordinados; } \\
\text { Diatexitos graníticos } \\
\text { peraluminosos (tipo S) }\end{array}$ & $\begin{array}{l}\text { Proterozóico Inferior } \\
\text { com retrabalhamento } \\
\text { e granulitização no } \\
\text { Proterozóico Médio - } \\
\text { Superior }\end{array}$ & $\begin{array}{l}\text { Ortogranulitos: } \\
\text { Série Calcioalcalina } \\
\text { de baixo K: } \\
\text { Série Calcioalcalina } \\
\text { de médio a alto K, } \\
\text { enriquecida em LILE. }\end{array}$ & $\begin{array}{l}\text { Metamorfismo na } \\
\text { facies granulito foi } \\
\text { sintectônico è follação } \\
\text { regional }\end{array}$ & $\begin{array}{l}\text { Correspondem a } \\
\text { unidades infraclustais } \\
\text { que cavalgam para } \\
\text { oeste os terrenos do } \\
\text { Cráton do São } \\
\text { Francisco }\end{array}$ \\
\hline Pinto et al. (1991) & $\begin{array}{l}\text { Complexo Juuiz de } \\
\text { Fora: Unidade } \\
\text { Migmatitica (UMg); } \\
\text { Unidade Metassedi- } \\
\text { mentar (UMs). }\end{array}$ & $\begin{array}{l}\text { Umg: gnaisses e mig- } \\
\text { matitos com paleosso- } \\
\text { mas básicos e } \\
\text { enderbi- } \\
\text { ticos; } \\
\text { Ums: kinzigitos, } \\
\text { quartitos e gnaisses } \\
\text { aluminosos. }\end{array}$ & $\begin{array}{l}\text { Arqueano com retra } \\
\text { balhamento no } \\
\text { Transamazônico e no } \\
\text { Brasiliano }\end{array}$ & $\begin{array}{l}\text { UMg } \\
\text { Noritos, enderbitos e } \\
\text { charnoenderbitos: } \\
\text { toleiftos de baixo } \mathrm{K} \text {; } \\
\text { Outros: trend misto } \\
\text { toleítico e calcioalca- } \\
\text { lino; } \\
\text { Granitoides granulitin } \\
\text { cos: alto } \mathrm{Al}_{2} \mathrm{O}_{3}\end{array}$ & $\begin{array}{l}\text { Metamorfismo } \\
\text { granulitico, promovido } \\
\text { por metassomatismo } \\
\text { carbônico, anterior ao } \\
\text { de facies anfibolito. }\end{array}$ & $\begin{array}{l}\text { Granulitos básicos: } \\
\text { basaltos de arcos de } \\
\text { ilha ou de bacias de } \\
\text { retro-arco; } \\
\text { Granulitos ácidos a } \\
\text { intermediarios: grani- } \\
\text { tos de arco vulcânico } \\
\text { (não conclusivo) }\end{array}$ \\
\hline $\begin{array}{l}\text { Heilbron et al. (1989) } \\
\text { e } \\
\text { Heilbron (1993, 1995) }\end{array}$ & $\begin{array}{l}\text { Complexo Juiz de } \\
\text { Fora }\end{array}$ & $\begin{array}{l}\text { Rochas granulíticas } \\
\text { ortoderivadas, básicas } \\
\text { a acidas } € \\
\text { ortognaisses } \\
\text { miloniticos a blasto } \\
\text { miloníticos. }\end{array}$ & $\begin{array}{l}\text { Transamazônico, em } \\
\text { parte, Arqueano; } \\
\text { retrabalhado no } \\
\text { Brasiliano. }\end{array}$ & $\begin{array}{l}4 \text { Séries Magmáticas: } \\
\text { Série Alcalina: rochas } \\
\text { básicas; } \\
\text { Série Toleiítica: } \\
\text { rochasbásicas; } \\
\text { Série Calcioalcalina: } \\
\text { rochas intermediaria a } \\
\text { ácidas: } \\
\text { Série Calcioalcalina } \\
\text { de alto K: rochas in- } \\
\text { termediárias a ácidas. }\end{array}$ & $\begin{array}{l}\text { Metamorfismo } \\
\text { granulitico é anterior à } \\
\text { fase principal da } \\
\left.\text { deformação( } D_{1}+D_{2}\right) \\
\text { Metamorfismo na } \\
\text { facies anfibolito é } \\
\text { contemporâneo à fase } \\
D_{1}+D_{2} \text {. }\end{array}$ & $\begin{array}{l}\text { Segmento de corsta } \\
\text { profunda, provavel. } \\
\text { mente raiz de arco } \\
\text { magmático, incorpora- } \\
\text { do e intensamente } \\
\text { retrabalhado durante } \\
\text { colisäo continental } \\
\text { oblíqua. Duplex da } \\
\text { corsta continental na } \\
\text { zona interna da Faixa } \\
\text { Ribeira. }\end{array}$ \\
\hline $\begin{array}{l}\text { Nogueira (1994)e } \\
\text { Nogueira \& Trouw } \\
\text { (1994) }\end{array}$ & $\begin{array}{l}\text { Complexo Mantiqueira } \\
\text { (CM) e Complexo } \\
\text { Juiz de Fora (CJF) }\end{array}$ & $\begin{array}{l}\text { CJF - rochas granulíti- } \\
\text { cas, desde básicas a } \\
\text { acidas, ortoderivadas; } \\
\text { CM - ortognaisses }\end{array}$ & $\begin{array}{l}\text { Metamorfismo } \\
\text { granulitico é anterior à } \\
1^{a} \text { fase de deforma - } \\
\text { ção, provavelmente } \\
\text { contemporâneo à } \\
\text { formaçäo da bacia } \\
\text { Andrelândia. }\end{array}$ & $\begin{array}{l}\text { Inclusões Fluidas: } \\
\text { fluido de alta } \\
\text { densidade, rico em } \\
\mathrm{CO}_{2}\end{array}$ & $\begin{array}{l}\text { Metamorfismogranu - } \\
\text { litico promovido por } \\
\text { fluidos ricos em } \mathrm{CO}_{2} \text {, } \\
\text { em regime crustal } \\
\text { extensional. } \\
\text { Caminho P-T-t } 18 \mathrm{C} \text { : } \\
\text { T: } 750-800^{\circ} \mathrm{C} \text {; } \\
\text { P: } 4-6 \mathrm{~Kb} \text {. }\end{array}$ & $\begin{array}{l}\text { Base da crosta onde } \\
\text { depositaram-se os } \\
\text { sedimentos Anorelan - } \\
\text { dia }\end{array}$ \\
\hline
\end{tabular}


Tabela 1: Trabalhos Anteriores Referentes ao Complexo Juiz de Fora (Cont.)

\begin{tabular}{|c|c|c|c|c|c|c|}
\hline Autor(es) & Denominação & $\begin{array}{l}\text { Constituição } \\
\text { Litológica }\end{array}$ & Idade & $\begin{array}{l}\text { Carcterísticas } \\
\text { Geoquímicas }\end{array}$ & $\begin{array}{c}\text { Relações } \\
\text { Metamorfismo/ } \\
\text { Deformação }\end{array}$ & $\begin{array}{l}\text { Ambientação } \\
\text { Geotectónica }\end{array}$ \\
\hline $\begin{array}{l}\text { Figueiredo \& Teixeira } \\
(1996)\end{array}$ & Complexo Juiz de Fora & $\begin{array}{l}\text { Ortogranulitos mig- } \\
\text { matiticos e gnaisses } \\
\text { e } \\
\text { migmatitos cinzentos } \\
\text { subordinados: } \\
\text { Diatexitos graniticos } \\
\text { peraluminosos (tipo } \\
\text { s) }\end{array}$ & $\begin{array}{l}\text { Transamazônico, com } \\
\text { retrabalhamento na } \\
\text { Orogênese Rio Doce }\end{array}$ & $\begin{array}{l}\text { Ortogranulitos: } \\
\text { Série Calcioalcalina de } \\
\text { baixo Ki } \\
\text { Série Calcioalcalina de } \\
\text { médio a alto K, } \\
\text { enriquecida em LILE. }\end{array}$ & & $\begin{array}{l}\text { Arco magmático madu- } \\
\text { ro Transamazônico, em } \\
\text { margem continental ati- } \\
\text { va, com retrabalhamen- } \\
\text { to de crosta Arqueana; } \\
\text { terreno cavalgado para } \\
\text { oeste sobre os terrenos } \\
\text { do Cráton do São Fran- } \\
\text { cisco. }\end{array}$ \\
\hline
\end{tabular}


b) Análise Geral Sobre o Estágio Atual do Conhecimento.

Com base na análise da Tabela 1 , podemse concluir que existem poucos pontos de concordância dentre os vários autores que estudaram o "Complexo Juiz de Fora", como segue:

i) Para a maioria dos autores, o metamorfismo granulítico é de idade transamazônica, embora os protólitos possam ser arqueanos;

ii) Os contatos superior e inferior do "Complexo Juiz de Fora" com as demais Unidades são tectônicos;

iii) O "Complexo Juiz de Fora" é constituído predominantemente de enderbitos de provável origem magmática, com intercalaçöes metassedimentares subordinadas. No entanto, não existe consenso quanto à relação entre os metassedimentos e os granulitos de origem ígnea;

iv) Para a maioria dos autores o metamorfismo de facies granulito é anterior ao de facies anfibolito, sendo que para alguns desses autores as reações metamórficas retrógradas foram, localmente, generalizadas;

v) Para alguns autores, o metamorfismo granulítico antecedeu o episódio tectônico que gerou os empurröes e a milonitização. No entanto, para Ebert (1968), a milonitização é anterior ao evento metamórfico que, tendo atuado sobre rochas hidratadas e rochas desidratadas, promoveu o desenvolvimento de paragêneses correspondentes às facies anfibolito e granulito, respectivamente;

vi) Os autores que realizaram estudos geoquímicos parecem concordar que os tipos granulíticos básicos mostram afinidade toleítica, enquanto que os intermediários à ácidos apresentam tendência calcio-alcalina.

vii) Não há consenso quanto à constituição litológica do "Complexo Juiz de Fora" e do "Complexo Paraiba do Sul" nem quanto aos limites destas Unidades; 
vii) Não há consenso quanto às relações existentes entre os granulitos do "Complexo Juiz de Fora" e as Unidades metassedimentares dos "Grupos São Jöao del Rei e Andrelândia e do Complexo Paraíba do Sul";

ix) Os aspectos expostos nos ítens vii e viii indicam que estas generalizações podem estar longe da melhor hipótese.

Pode-se concluir que ainda persistem dúvidas a serem esclarecidas por trabalhos detalhados de campo e, somente a partir de um bom controle dos dados então obtidos, podese avançar em direção à investigação litogeoquímica para que, posteriormente, possa ser elaborado um modêlo geotectônico adequado.

\section{I.5.2) Caracterização do Complexo Juiz de Fora (segundo este trabalho)}

O termo Juiz de Fora foi pioneiramente utilizado por Ebert (Série Juiz de Fora, definida em 1955) para englobar paragnaisses com paragêneses diagnósticas para a facies granulito que ocorrem na porção centro-oeste da cidade de Juiz de fora e cercanias.

Posteriormente, a identificação da ocorrência de ortognaisses granulíticos associados levou vários autores a englobar também estas rochas sob a denominação Juiz de Fora (Série ou Complexo Juiz de Fora; Cordani et al., 1973; Fonseca et al., 1979; Oliveira, 1980, 1981, 1982, 1983; Machado Filho et al., 1983; Barbosa \& Grossi Sad, 1983a, 1983b, 1983c; Grossi Sad \& Barbosa, 1985; Pinto et al. 1991).

A constatação, em vários segmentos da Faixa Ribeira, de que somente rochas ortoderivadas tinham paragêneses diagnósticas para a facies granulito induziu alguns autores a utilizarem o termo Juiz de Fora para agrupar tais rochas (Figueiredo et al., 1989; Campos Neto \& Figueiredo, 1990; Figueiredo \& Campos Neto, 1993; Teixeira \& Figueiredo, 1991; Heilbron, 1993, 1995; Nogueira, 1994; Nogueira \& Trouw, 1993; Heilbron et al., 1995, 1996; Machado et al., 1996). 
Assim, a utilização prática do termo Juiz de Fora, ao longo das últimas duas ou três décadas, foi gradativamente se afastando da definição original, o que levou à forte associação do termo aos gnaisses ortoderivados com paragêneses da facies granulito.

O mapeamento geológico realizado na presente pesquisa permitiu a identificação do conjunto metassedimentar granulítico que Ebert (1955) englobou em sua Série Juiz de Fora. Este conjunto tem ampla distribuição nas porções centromoeste e centro sudoeste da cidade de Juiz de Fora, abrangendo os bairros Salvaterra, Salvaterra de Cima, Independência, Jardim Glória e a porção oeste do centro comercial. Sua rocha tipo, um biotita-granada-ortopiroxênio gnaisse granoblástico, sustenta o mais alto morro da cidade, conhecido informalmete como Morro da Torre ou Morro do Cristo Redentor. No entanto, com base no exposto anteriormente, uma proposta de retornar à utilização original do termo Juiz de Fora, ainda que justificada, é entendida como negativa, uma vez que geraria mais confusão do que esclarecimentos. Assim, com a intenção de minimizar prováveis confusões, a presente pesquisa adotou o termo Complexo Juiz de Fora para englobar um conjunto de ortoganaisses, ora migmatíticos, e metabasitos com paragêneses diagnósticas para a facies granulito, o que vai ao encontro do que hoje os autores identificam a partir do termo Juiz de Fora. Ao conjunto litológico que engloba as rochs metassedimentares na facies granulito foi dado o nome informal de Unidade Jardim Glória, por ser este o nome de um bairro da cidade que encerra vários bons afloramentos destas rochas.

\subsection{3) Complexo Mantiqueira}

a) Trabalhos Anteriores

Ao conjunto de gnaisses e migmatitos da Serra da Mantiqueira, Barbosa (1954) deu o nome de Série Mantiqueira, entendendo que correspondiam a rochas distintas e mais velhas do que aquelas da Série Barbacena.

Ainda na década de 50 , trabalhos realizados por Ebert $(1955,1958)$ reconheceram dois conjuntos distintos: um ortoderivado, de idada Arqueana e retrabalhado na Orogênese 
Assíntica, o qual ele relacionou a uma facies mais metamórfica da Fm Barbacena; e outro metassedimentar, ao qual denominou Gnaisse Piedade.

$\mathrm{Na}$ década de 70 destacam-se estudos geocronológicos (Cordani et al. 1973) e trabalhos de mapeamento geológico (Silva et al., 1978; Fonseca et al., 1979) que contribuíram com maior conhecimento desta unidade.

A década de 80 é também caracterizada por trabalhos de mapeamento geológico (Oliveira, 1980; Machado Filho et al., 1983; Oliveira \& Hasui, 1984; e Trouw et al., 1986) que levaram a um maior detalhamento das características lito-estruturais do então denominado Gnaisse Piedade ou Complexo Barbacena ou Grupo Mantiqueira. Nesta década teve também inicio a abordagem petrológica destas unidades como o trabalho de Machado Filho et al. (1983)

Trabalhos de mapeamento geológico em distintas escalas, uma abordagem petrológicogeoquímica mais apurada e investigações geocronológicas caracterizam a abordagem destas unidades na década de 90 (Pinto et al., 1991; Viana et al., 1991; Figueiredo et al., 1991; Heilbron, 1993, 1995; Nogueira, 1994; Nogueira \& Trouw, 1993; e Figueiredo \& Teixeira, 1996).

As contribuiçōes ao estudo do Complexo Mantiqueira existentes até a presente data estão apresentadas na tabela 2 . 
Tabela 2: Trabalhos Anteriores Referentes ao Complexo Mantiqueira

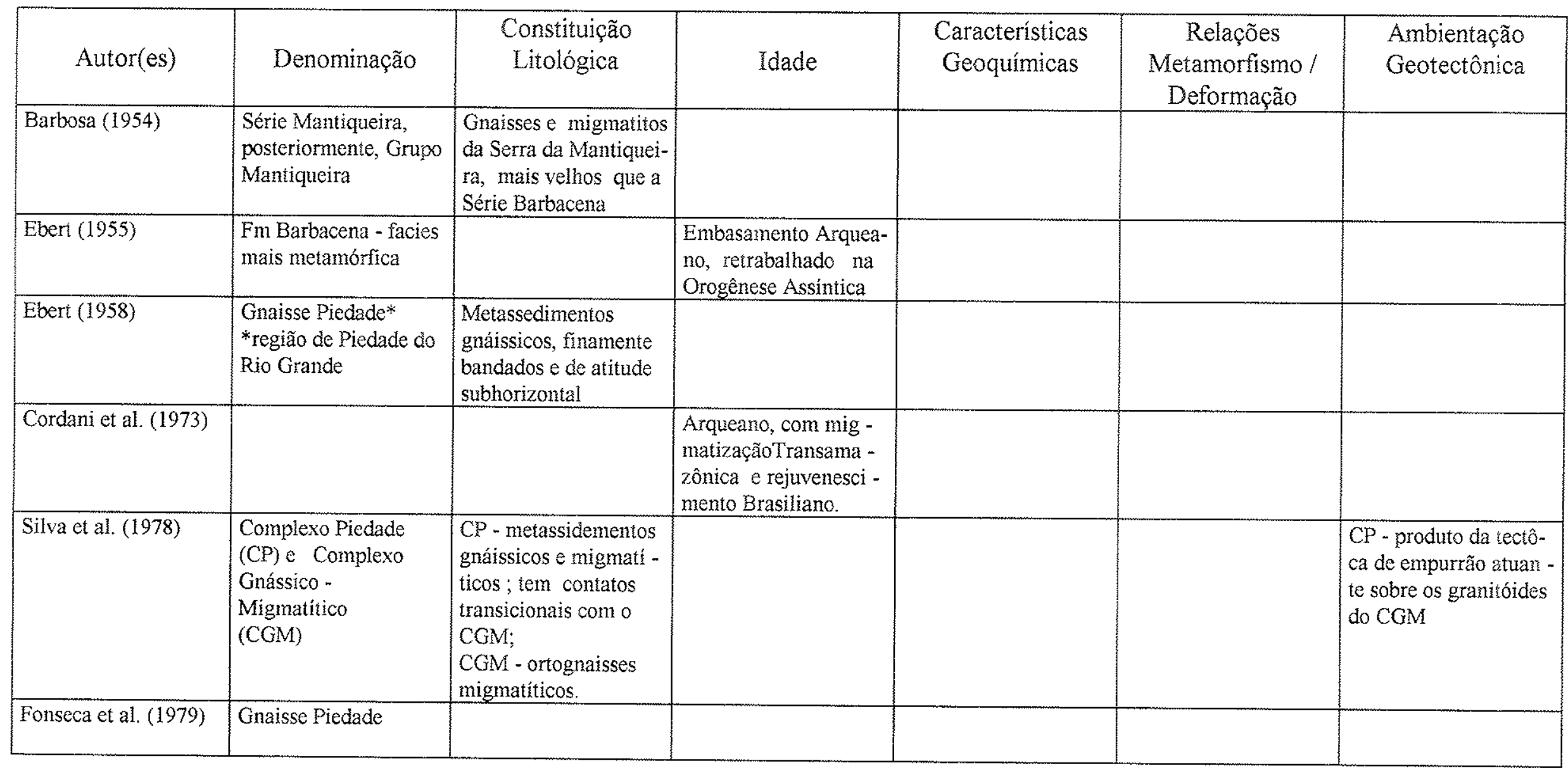


Tabela 2: Trabalhos Anteriores Referentes ao Complexo Mantiqueira (Cont.)

\begin{tabular}{|c|c|c|c|c|c|c|}
\hline Autor(es) & Denominação & $\begin{array}{c}\text { Constituição } \\
\text { Litológica }\end{array}$ & Idade & $\begin{array}{l}\text { Características } \\
\text { Geoquímicas }\end{array}$ & $\begin{array}{c}\text { Relações } \\
\text { Metamorfismo / } \\
\text { Deformação }\end{array}$ & $\begin{array}{l}\text { Ambientação } \\
\text { Geotectônica }\end{array}$ \\
\hline $\begin{array}{l}\text { Pinto et al. (1991) e } \\
\text { Viana et al. (1991) }\end{array}$ & $\begin{array}{l}\text { Complexo } \\
\text { Mantiqueira }\end{array}$ & $\begin{array}{l}\text { Gnaisses bandados, to- } \\
\text { naliticos a trondhjemí- } \\
\text { ticos e granítico-gra - } \\
\text { nodioriticos, com } \\
\text { metauitrabasitos, cal - } \\
\text { cissilicáticas,metaga - } \\
\text { bros e quartzitos su - } \\
\text { bordinados }\end{array}$ & & $\begin{array}{l}\text { Gnaisses bandados: } \\
\text { metandesitos calcioal- } \\
\text { calinos; } \\
\text { Metabasitos: } \\
\text { metatoleiitos - restitos } \\
\text { de fusão; } \\
\text { Granulitos: vulcanitos } \\
\text { intermediários conta- } \\
\text { minados por sedimen- } \\
\text { tos carbonáceos; } \\
\text { Bt gnaisses: } \\
\text { sedimentos } \\
\text { aluninosos, margosos } \\
\text { e granitos crustais; } \\
\text { Calcissilicática / Meta- } \\
\text { diorito: marga / diorito }\end{array}$ & & $\begin{array}{l}\text { Rochas granitóides in- } \\
\text { trusivas ou remanes- } \\
\text { centes do embasamen- } \\
\text { to e rochas granitóides } \\
\text { crustais geradas por } \\
\text { fusão parcial de se - } \\
\text { quências metassedi - } \\
\text { mentares. }\end{array}$ \\
\hline
\end{tabular}


Tabela 2: Trabalhos Anteriores Referentes ao Complexo Mantiqueira (Cont.)

\begin{tabular}{|c|c|c|c|c|c|c|}
\hline Autor(es) & Denominação & $\begin{array}{l}\text { Constituição } \\
\text { Litológica }\end{array}$ & Idade & $\begin{array}{l}\text { Características } \\
\text { Geoquímicas }\end{array}$ & $\begin{array}{c}\text { Relações } \\
\text { Metamorfismo } \\
\text { Deformação }\end{array}$ & $\begin{array}{l}\text { Ambientação } \\
\text { Geotectônica }\end{array}$ \\
\hline $\begin{array}{l}\text { Figueiredo et al. } \\
\text { (1992) }\end{array}$ & Gnaisses Mantiqueira & $\begin{array}{l}\mathrm{Hb} \text {-bo gnaisses, local - } \\
\text { mente migmatizados }\end{array}$ & Eoproterozóica & $\begin{array}{l}\text { Duas Sequências: } \\
\text { Calcioalcalina de bai - } \\
\text { xo } \mathrm{K} \text {, ou TTG, enri - } \\
\text { que cida em Mg, Ca, } \\
\text { Al e Cr; } \\
\text { Calcioalcalina } \\
\text { enriquecida em LLE, } \\
\text { álcalis,Ti, Fe, P, Rb, } \\
\mathrm{Zr}, \mathrm{Nb} \text {, eY. } \\
\end{array}$ & $\begin{array}{l}\text { Rochas mais antigas, } \\
\text { retrabalhadas no Tran- } \\
\text { samazônico; } \\
\text { Granitogênese tardia, } \\
\text { pós-tectônica ao Tran- } \\
\text { samazônico; } \\
\text { Retrabalhamento no } \\
\text { Brasiliano. }\end{array}$ & \\
\hline Heilbron $(1993,1995)$ & $\begin{array}{l}\text { Grupo Mantiqueira, } \\
\text { posteriormente, Com- } \\
\text { plexo Mantiqueira }\end{array}$ & $\begin{array}{l}\text { Ortognaisses } \\
\text { bandados, } \\
\text { migmatíticos, com en - } \\
\text { claves e/ou lentes de } \\
\text { metabásicas e faixas li- } \\
\text { neares granulíticas; } \\
\text { Lentes de gnaisse gra - } \\
\text { nodiorítico invadem o } \\
\text { conjunto; } \\
\text { Aplitos graníticos, cin- } \\
\text { zentos e rosados, com- } \\
\text { pletam o conjunto. } \\
\end{array}$ & $\begin{array}{l}\text { Arqueana a Protero - } \\
\text { zóica Inferior, retra - } \\
\text { balhado no ETt Bras- } \\
\text { illano }\end{array}$ & $\begin{array}{l}\text { Leucognaisses intrusi - } \\
\text { vos: granitos a grano - } \\
\text { dioritos calcioalcalinos } \\
\text { de alto K. } \\
\text { Semelhanças } \\
\text { com a Série Calcioal - } \\
\text { calina de alto K do } \\
\text { Complexo Juiz de } \\
\text { Fora. }\end{array}$ & $\begin{array}{l}\text { Metamorfismo Transa- } \\
\text { mazonico: facies anfi- } \\
\text { bolito/facies granulito; } \\
\text { Metamorfismo Brasili- } \\
\text { ano: } \\
M_{1} \text { - facies anfibolito } \\
\text { superior (Alta } T, P \\
\text { média); } \\
M_{2} \text { - facies anfibolito } \\
\text { (alta } T \text {, baixa } P \text { ) }\end{array}$ & $\begin{array}{l}\text { Embasamento das ro- } \\
\text { chas do Ciclo Deposi- } \\
\text { cional Andrelândia. }\end{array}$ \\
\hline \multicolumn{7}{|l|}{$\begin{array}{l}\text { Nogeuira (1994) e } \\
\text { Nogueira \& Trouw } \\
(1994) \\
\end{array}$} \\
\hline $\begin{array}{l}\text { Figueiredo \& Teixeira } \\
\text { (no 1996) }\end{array}$ & $\begin{array}{l}\text { Complexo (Metamórifi- } \\
\text { co) Mantiquera }\end{array}$ & $\begin{array}{l}\text { Bt-hb gnaisses e mig- } \\
\text { matitos, tonalíticos - } \\
\text { granodioríticos-graní - } \\
\text { ticos, com rochas má - } \\
\text { ficas, metassedimentos } \\
\text { subordinados e intru - } \\
\text { sões granitóides. }\end{array}$ & $\begin{array}{l}\text { Paleoproterozóica,com } \\
\text { sugestão de porçôes } \\
\text { mais antigas Arquanas }\end{array}$ & $\begin{array}{l}2 \text { Séries Calcioalcali - } \\
\text { nas: } \\
\text { Baixo K (rochas bási - } \\
\text { cas a ácidas); } \\
\text { Alto K, enriquecida } \\
\text { em } \\
\text { LILE. }\end{array}$ & & $\begin{array}{l}\text { Cinturão Paleoprotero- } \\
\text { zóico - Arco magmáti- } \\
\text { co maduro Transama - } \\
\text { zônico, em margem } \\
\text { continental ativa, com } \\
\text { retrabalhamento de } \\
\text { crosta Arqueana. }\end{array}$ \\
\hline
\end{tabular}


b) Análise Geral Sobre o Estágio Atual do Conhecimento

Com base no exposto na tabela 2, pode-se verificar que são poucos os pontos de consenso dentre os vários autores e, a partir desta análise, faz-se as seguintes considerações:

i) A denominação, formal ou informal, varia bastante de um autor para outro, mas isto, além de ser consequência de diferentes regiões enfocadas, é, em grande parte, função de se considerar um litotipo específico ou um conjunto litológico. Neste segundo caso, acrescenta-se ainda o fato de alguns autores terem formalizado uma unidade constituida somente de rochas ortoderivadas, enquanto outros incluíram também rochas paradervadas;

ii) Como já adiantado no ítem anterior, um ponto muito polêmico é o da constituição do "Complexo Mantiqueira". Para muitos autores, esta unidade é composta de um conjunto de rochas ortoderivadas, principalmente gnaisses, anfibolitos e corpos granulíticaos subordinados, que corresponde ao embasamento das rochas metassedimentares que ocorrem associadas. No entanto, também é grande o número de autores que incluem paragnaisses e granitóides tipo $\mathrm{S}$ neste conjunto, demonstrando a dificuldade na definição do tipo de relação existente entre rochas orto e paraderivadas;

iii) O único ponto de consenso se refere ao da idade destas rochas. Para todos os autores, esta unidade é constituída de rochas antigas formadas e/ou retrabalhadas no Transamazônico. No entanto, restam algumas dúvidas no que diz respeito à existência ou não de porções de idade Arqueana e de retrabalhamento durante o Brasiliano. A consideração ou não de retrabalhamento generalizado durante o Neoproterozóico-Paleozóico Inferior é função da área e/ou compartimento tectônico investigado;

iv) Com relação à litogeoquímica destas rochas, soma-se, a todos os fatores supracitados, o fato dos dados serem ainda em pequeno número e muito dispersos. No entanto, deve-se considerar que, para muitos autores, os dados litogeoquímicos indicam semelhanças entre o "Complexo Mantiqueira" e o "Complexo Juiz de Fora";

v) Para vários autores, "Complexo Mantiqueira" corresponde ao embasamento (Arqueano e/ou Proterozóico Inferior) das supracrustais pós -Transamazônicas, sendo considerado parte 
de um arco magmático maduro, associado à granitogênese tardia Transamazônica, com retrabalhamento de crosta Arqueana;

vi) Enquanto que para a maioria dos autores esta é uma unidade litológicamente individualizada, para Silva et al (1978) e Machado Filho et al. (1983), o "Complexo Mantiqueira" é produto de cisalhamento (Transamazônico?), atuante sobre rochas Arqueanas (Complexo Barbacena, Supergrupo Rio das Velhas e Complexo Gnássico-Migmatítico);

vii) Embora sejam ainda pouco relevantes os estudos desenvolvidos sobre as lentes e enclaves de rochas básicas desta unidade, os autores oscilam entre a hipótese dos mesmos representarem restitos de fusão parcial e porções preservadas de toleítos de arco de ilha.

\subsection{4) Caracterização do Complexo Mantiqueira (segundo este trabalho)}

O histórico da evolução da utilização do termo Mantiqueira mostrou que há uma forte tendência dos trabalhos mais recentes associarem este nome a um conjunto ou conjuntos de ortognaisses, com metabasitos e ortogranulitos subordinados (Trouw et al., 1986; Figueiredo et al., 1992; Heilbron, 1993, 1995; Nogueira, 1994; Nogueira \& Trouw, 1993; Figueiredo \& Teixeira, 1996), o que encontra respaldo na denominação original de Série Mantiqueira proposta por Barbosa (1954). A presente pesquisa segue esta tendência e define o Complexo Mantiqueira como um conjunto de ortognaisses tonalíticos a graníticos, bandados e migmatíticos, com lentes de metabasito associadas. Ortogranulitos enderbíticos ocorrem em corpos lineares subordinados. Aplitos graníticos cinzentos e rosados invadem o conjunto. Assim, a presente definição se aproxima muito daquelas utilizadas por Trouw et al. (1986) e por Heilbron (1993, 1995), o que é, com certeza, consequência destes autores terem investigado regiões adjacentes à área alvo desta pesquisa. 


\section{6) Detalhamento dos Objetivos Propostos.}

Com base na análise da literatura disponível pretende-se contribuir para esclarecer as seguintes lacunas:

i) Mapeamento geológico-estrutural de semi-detalhe (1:50.000) da região de Juiz de Fora, sudeste de Minas Gerais;

ii) Caracterização e definição das unidades litológicas da área alvo;

iii) Caracterização dos litotipos e/ou associações litológicas que constituem os Complexos Mantiqueira e Juiz de Fora;

iv) Caracterização dos litotipos e/ou associações litológicas que constituem as unidades supracrustais metamorfizadas e deformadas no Neo-Proterozóico/Cambriano;

v) Caracterização litológica das rochas granitóides intrusivas e/ou anatéticas, formadas no Neoproterozóico/Cambriano;

vi) Estudo petrográfico-petrológico dos litotipos e associações litológicas dos Complexos Juiz de Fora e Mantiqueira;

vii) Estudo geoquímico dos litotipos dos Complexos Juiz de Fora e Mantiqueira, visando a caracterização de diferentes conjuntos magmáticos e, se possivel, sua ambiência geotectônica;

viii) Comparação dos resultados obtidos com dados já publicados na literatura;

ix) Estudo geotermométrico e geobarométrico das paragêneses granulíticas e retrógradas das rochas do Complexo Juiz de Fora, a fim de obter as condições P. T do metamorfismo granulítico e do retrógrado na facies anfibolito; 
x) Estudo geotermométrico e geobarométrico das paragêneses metamórficas dos paragnaisses da Unidade Jardim Glória, a fim de obter as condições P-T do metamorfismo granulítico mais novo, desenvolvido durante a Orogênese Brasiliana.

xi) Integração dos resultados e elaboração de um modelo evolutivo para a região.

\section{l.7) Método de Trabalho}

O trabalho se desenvolveu, basicamente, ao longo de seis etapas, como discriminado a seguir:

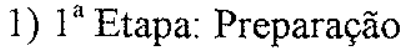

Foram realizados o levantamento e a análise do material bibliográfico disponível sobre os temas afins às abordagens da pesquisa. Como temas principais e imprescindiveis, tem-se: a) revisão bibliográfica sobre os Complexos Juiz de Fora e Mantiqueira; b) revisão bibliográfica sobre a Faixa Ribeira e a compartimentação tectônica do Precambriano do sudeste brasileiro; e c) levantamento e análise bibliográfica sobre rochas granulíticas, incluindo nomenclatura, aspectos petrográficos, petrológicos e geoquímicos, condições do metamorfismo granulítico, petrogênese, idade e ambiência geotectônica destas rochas.

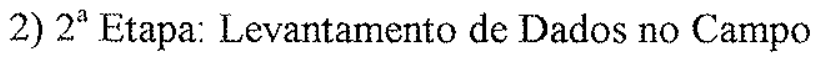

Com base na análise bibliográfica realizada, os objetivos da pesquisa foram melhor delineados e partiu-se então para a etapa de campo, com o desenvolvimento de trabalhos de mapeamento geológico-estrutural da área alvo. Este mapeamento foi realizado tendo como base folhas topográficas na escala 1:50.000 (Folha IBGE Matias Barbosa e metade sul da Folha IBGE Juiz de Fora), sempre monitorado pela análise e interpretação de fotografias aéreas na escala $1: 60.000$ da região. Os dados coletados nesta etapa foram integralizados a escala $1: 100.000$.

A área alvo da presente pesquisa insere-se em um contexto de terrenos de alto grau metamórfico, onde a associação entre os valores de Pressão e altas Temperaturas leva à alta plasticidade, intensa recristalização, fusão parcial e a um alto grau de transposição das estruturas mais antigas e de obliteração de contatos e outras relações primárias. Assim, a 
metodologia de mapeamento adotada baseou-se no conceito de unidades lito-tectônicas, associado à discriminação entre unidades orto e paraderivadas. As unidades de mapeamento foram então definidas, tendo-se a preocupação de somente agrupar litotipos com o mesmo significado tectônico (em relação ao Evento Termo-tectônico Brasiliano) e de derivações semelhantes. Para as unidades do embasamento pré-1,8 Ga., os trabalhos desenvolvidos visaram a definição de associações litológicas, além da investigação das relações originais entre os protólitos.

A abordagem dos afloramentos rochosos visou o reconhecimento do litotipo e/ou da associação litológica exposta, bem como a identificação de pistas das relações originais e tipos de contatos entre os protólitos. Em acompanhamento a esta análise litológica, foram também coletados dados de elementos estruturais (planos de foliações, lineações, planos axiais e eixos de dobras, estilos de dobramento, clivagens em geral, planos de falhas, fraturas, etc), além da análise dos indicadores cinemáticos eventualmente presentes. Todas estas feições, quando bem visiveis, foram registradas em filmes fotográficos.

Visando o recobrimento de toda a área alvo, foram visitados mais de cinco centenas de afloramentos, distribuídos segundo o Anexo 1. Além disso, foram também realizados perfis regionais que elevaram a qualidade das informações coletadas na área. Foram coletadas amostras representativas das várias unidades definidas, para posterior análise petrográfica e petroquímica.

\section{3) $3^{a}$ Etapa: Petrografia}

Visando a boa caracterização das unidades de mapeamento e seus litotipos, foram confeccionadas cerca de 300 lâminas delgadas. A partir da análise petrográfica destas lâminas, detalhou-se a composição dos litotipos individuais e das associações litológicas das diferentes unidades. Durante esta etapa foram também realizadas análises modais (contagem por ponto) dos litotipos representativos de cada unidade, visando melhorar a qualidade da informação petrográfica até então obtida e possibilitando a classificação das mesmas, a partir da utilização de diagramas apropriados. 
4) $4^{\mathrm{a}}$ Etapa: Geoquímica

Com base nos dados de campo e petrográficos, foram selecionadas amostras representativas para proceder à análise química. Foram analisadas 60 amostras dos litotipos dos Complexos Juiz de Fora e Mantiqueira. As análises foram efetuadas nos laboratórios ACTLABS, no Canadá, para elementos maiores e traços (incluindo os elementos terras raras), empregando as técnicas de análise por ICP e INAA.

Para o estoque e a manipulação dos resultados analíticos for utilizado o programa NEWPET que permite ampla aplicação e qualificação destes dados. Considerando a grande dificuldade que os terrenos de alto grau impõem ao reconhecimento das relações litológicas originais, a correta análise e avaliação dos dados litogeoquímicos vêm auxiliar e ampliar a qualidade da informação litológica, permitindo, inclusive, a definição do tipo de fonte e do ambiente de formação das rochas ortoderivadas. Prosseguiu-se então à análise destes resultados em comparação com dados de outros autores que já trabalharam com a química destas rochas e/ou com a de unidades semelhantes existentes em outras partes do Brasil e do mundo.

A análise dos dados litoquímicos foi quantitativa e incluiu uma etapa de modelamento petrogenético, o que possibilitou um entendimento mais qualificado dos dados e uma interpretação menos especulativa sobre a origem das rochas dos Complexos Mantiqueira e Juiz de Fora.

A partir destes dados, nunca prescindindo do controle de campo e petrográfico, foi possível trazer nova contribuição acerca da constituição, petrogênese e ambiência geotectônica das rochas dos Complexos Juiz de Fora e Mantiqueira.

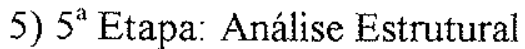

A partir da coleta de elementos estruturais realizada durante a etapa de campo, foi possivel construit um mapa estrutural, onde podem ser definidos domínios estruturais caracterizados, principalmente, pela atitude da foliação principal e sua relação com a lineação mineral e/ou de estiramento e pelo estilo da deformação. Foram então construídos estereogramas com foliações, lineações, eixos e planos axiais de dobras para cada domínio. 
Perfis geológicos transversais à foliação principal das unidades forneceram informações quanto à forma, vergência e natureza do empilhamento lito-tectônico observado na área. O estudo microtectônico de lâminas confeccionadas a partir de amostras orientadas forneceu resultados relevantes acerca da cinemática da deformação atuante na área.

\section{6) $6^{a}$ Etapa: Geotermobarometria}

Com o objetivo de definir as condições de Pressão (P) e Temperatura (T) do metamorfismo granulítico (Transamazônico?) das rochas do Complexo Juiz de Fora e do metamorfismo retrógrado para a facies anfibolito superior (Brasiliano), análisou-se pares ou paragêneses minerais adequadas. Para tal, foram selecionadas 5 amostras, cujas associações minerais, além de serem sensíveis às variações de $\mathrm{P}$ ou $\mathrm{T}$, mostravam clara relação de equilibrio. Através da análise petrográfica das lâminas delgadas correspondentes às amostras selecionadas, pode-se verificar que os minerais a serem analisados não mostravam-se visivelmente zonados. A metodologia então seguida consistiu da sondagem de 3 pontos nas bordas e 3 no núcleo de cada grão de interesse, tendo sido analisados 4 grãos de um mesmo mineral por lâmina. Este número aparentemente excessivo de análises se deve à necessidade de um rigoroso controle das composições minerais, já que se pretende usá-las como padrões para o estudo geotermobarométrico.

Em uma primeira etapa foram sondados 373 pontos, tendo sido analisados ortopiroxênio, clinopiroxênio, granada, hornblenda, biotita e ilmenita. Na segunda etapa, foram realizadas as análises dos plagioclásios que, em geral, não mostraram-se zonados. Os dados analíticos obtidos foram então trabalhados como segue: a) a organização e estocagem dos dados; b) o cálculo da média aritmética dos pontos obtidos para cada núcleo, para cada borda e, finalmente, para cada amostra; c) a projeção dos valores das médias em diagrama de classificação mineral e em outros diagramas apropriados; e d) o cálculo das temperaturas ou pressões dos processos metamórficos (facies granulito e facies anfibolito superior) a partir das análises obtidas.

Para a organização, estocagem, cálculo das médias e plote dos resultados em diagramas apropriados foi utilizado o programa MINPET (Versão 2.02). Os valores de P e T obtidos foram utilizados para a construção de diagramas indicativos do caminho P-T-t das rochas investigadas. 
Com base nestes dados e na análise petrográfica, foram construídos diagramas petrogenéticos e mapas metamórficos da região.

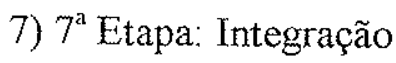

Nesta última etapa foi realizada a integração dos resultados obtidos nas etapas precedentes, o que permitiu a construção de um modelo de evolução genética e geotectônica das rochas estudadas. Foi ainda elaborado o documento da tese, utilizando-se a tecnologia corrente, qual seja, editores de texto e gráficos e softwares para a digitalização de imagens. 


\section{PARTE II = GEOLOGIA DA REGIÃO DE JUIZ DE FORA: APRESENTACÃO DOS DADOS}

\section{II-1) Compartimentação Tectônica Adotada}

A integração dos dados obtidos a partir do mapeamento geológico de semi-detalhe (1:50.000) da região de Juiz de Fora (Anexo 1) adicionou elementos em favor da proposta de Heilbron $(1993,1995)$ para a compartimentação tectônica do segmento central da Faixa Ribeira. Segundo este modelo, quatro escamas de empurrão, imbricadas de SSE para NNW, cavalgam o Domínio Tectônico Autóctone (DTA). Da escama inferior para a superior, os seguintes domínios foram individualizados por Heilbron (op. cit.): Domínio Tectônico Inferior (DTl) ou Dominio Tectônico Andrelândia (DTAND); Domínio Tectônico Médio (DTM) ou Domínio Tectônico Juiz de Fora (DTJF); e Domínio Tectônico Superior (DTS) ou Domínio Tectônico Paraíba do Sul (DTPS). Esta proposta procurou agrupar terrenos com características litológicas definidas e evoluções tectono-metamórficas semelhantes. Os quatro domínios alóctones propostos são separados por importantes descontinuidades estruturais que integram um sistema de falhas de empurrão, desenvolvidas em regime dúctil, com transporte tectônico para NNW, direcionado para o Cráton do São Francisco. A tabela seguinte (Tab. 3) apresenta as características lito-estruturais de cada um destes domínios.

\section{Tabela 3 - Caracteristicas Lito-Estruturais dos Domínios Tectônicos Propostos} por Heilbron $(1993,1995)$

\begin{tabular}{|c|c|c|c|c|}
\hline $\begin{array}{l}\text { Dominios } \\
\text { Tectônicos }\end{array}$ & $\begin{array}{l}\text { Unidades Litológicas } \\
\text { da Cobertura }\end{array}$ & $\begin{array}{l}\text { Unidades Litológicas } \\
\text { pré-1,8 Ga. }\end{array}$ & $\begin{array}{l}\text { Caracteristicas } \\
\text { Estruturais }\end{array}$ & $\begin{array}{l}\text { Características } \\
\text { Essenciais }\end{array}$ \\
\hline DTA & $\begin{array}{l}\text { Litotipos dos Ciclos } \\
\text { Deposicionais, Lenhei- } \\
\text { ros, Tiradentes, Carandaí e } \\
\text { Andrelândia }\end{array}$ & $\begin{array}{l}\text { Terrenos granito-green- } \\
\text { stone (Comp. Barbacena) } \\
\text { e gnássico-migmatíticos } \\
\text { (Complexo Mantiqueira) }\end{array}$ & $\begin{array}{l}\text { Nítida polaridade defor - } \\
\text { ma cional e metamórfica, } \\
\text { que diminui de intensida- } \\
\text { de em direção ao Cráton } \\
\text { do São Francisco }\end{array}$ & $\begin{array}{l}\text { Ocorrem relaçöes de } \\
\text { contato claras entre } \\
\text { embasamento e cober- } \\
\text { tura metassedimentar }\end{array}$ \\
\hline DTAND & $\begin{array}{l}\text { Litotipos do Ciclo } \\
\text { Deposicional Andrelân- } \\
\text { dia }\end{array}$ & $\begin{array}{l}\text { Gnaisses tonalíticos a } \\
\text { granodioríticos com } \\
\text { lentes anfiboliticas do } \\
\text { Complexo Mantiqueira }\end{array}$ & $\begin{array}{l}\text { Dobras apertadas, aber- } \\
\text { tas a reviradas.Foliação } \\
\text { principal é clivagem ou } \\
\text { xistosidade de crenulação. }\end{array}$ & $\begin{array}{l}\text { Limitado por falhas de } \\
\text { empurrão. Contatos } \\
\text { normais entre cobertura } \\
\text { e embasamento }\end{array}$ \\
\hline DTJF & $\begin{array}{l}\text { Litotipos do Ciclo } \\
\text { Deposicional Andrelân- } \\
\text { dia }\end{array}$ & $\begin{array}{l}\text { Granulitos ortoderi- vados } \\
\text { do Complexo Juiz de Fora } \\
\text { e gnaisses tonalíticos do } \\
\text { Complexo Mantiqueira }\end{array}$ & $\begin{array}{l}\text { Intensa deformação } \\
\text { (milonitização e trunca- } \\
\text { mento lateral de cama das) }\end{array}$ & $\begin{array}{l}\text { Interdigitação tectônica } \\
\text { entre rochas pré } 1.8 \mathrm{Ga} \text {. } \\
\text { e rochas metassedi- } \\
\text { mentares pós- } 1,8 \mathrm{Ga} \text {. }\end{array}$ \\
\hline DTPS & $\begin{array}{l}\text { Rochas Quartzo-Felds- } \\
\text { páticas, Metapelitos e } \\
\text { Mármo res do Grupo } \\
\text { Paraiba do Sul }\end{array}$ & $\begin{array}{l}\text { Bt (Hb) granitóides defor- } \\
\text { mados, com encla ves má- } \\
\text { ficos e lentes de rochas } \\
\text { calcissilicáticas (Suite } \\
\text { QuirinomDorândia) }\end{array}$ & $\begin{array}{l}\text { Deformação pouco inten- } \\
\text { sa, com exceção das zo - } \\
\text { nas mais próximas de seu } \\
\text { contato basal. }\end{array}$ & $\begin{array}{l}\text { Relaçōes de contato } \\
\text { duvidosas entre co- } \\
\text { bertura e unidade } \\
\text { pré-1,8 Ga. }\end{array}$ \\
\hline
\end{tabular}


Os objetivos da presente pesquisa levaram ao estudo detalhado de dois destes Dominios: Dominio Tectônico Inferior (ou DTAND) e Domínio Tectônico Médio (ou DTJF), já que o Domínio Superior (ou DTPS) ocorre de maneira muito restrita na área.

O presente trabalho deu preferência à terminologia DTAND, DTJF e DTPS por esta dar maior ênfase à constituição litológica e, por conseguinte, à caracterização de diferentes níveis crustais. A terminologia DTI, DTM e DTS é mais específica, com significado estritamente estrutural. As características lito-estruturais observadas na área alvo levaram a sua compartimentação segundo os mesmos dominios de Heilbron e, portanto, sua denominação foi mantida.

Com base no acima exposto, propõe-se a seguinte compartimentação tectônica para a região de Juiz de Fora, que, da escama inferior para a superior, pode ser assim descrita: DTAND; DTJF; e DTPS. Todos estes domínios são separados por importantes falhas de empurrão desenvolvidas durante a Orogênese Brasiliana, com transporte para NNW, em direção ao Craton do São Francisco, como já proposto por vários autores (Ebert, 1955, 1957, 1968), Heilbron, 1993 e 1995).

A figura 8 e os Anexos 1,2 e 3 mostram a compartimentação tectônica proposta para a região de Juiz de Fora. A tabela 4 resume as principais características de cada um destes domínios e a figura 9 mostra um perfil da região estudada (Fig. 9a) em comparação aos perfis propostos por Heilbron (1993) (Fig. 9b).

No item seguinte, as características litológicas e metamótficas de cada Domínio serão apresentadas e somente no capítulo procedente, será feita uma abordagem estrutural destes domínios. 


\section{Tabela 4 - Características lito-estruturais dos Domínios Tectônicos propostos} neste trabalho.

\begin{tabular}{|c|c|c|c|c|}
\hline Domínio Tectônico & $\begin{array}{l}\text { Unidades Litológicas } \\
\text { da Cobertura }\end{array}$ & $\begin{array}{l}\text { Unidades Litológicas } \\
\text { pré-1,8 Ga. }\end{array}$ & $\begin{array}{l}\text { Rochas Granitóides } \\
\text { Intrusivas }\end{array}$ & $\begin{array}{l}\text { Caracterísitcas } \\
\text { Estruturais }\end{array}$ \\
\hline DTAND & $\begin{array}{l}\text { Litotipos do Ciclo } \\
\text { Deposicional Andrelân. } \\
\text { dia. }\end{array}$ & $\begin{array}{l}\text { Gnaisses tonalíticos a } \\
\text { granodioriticos e lentes } \\
\text { e/ou corpos anfibolíticos } \\
\text { do Complexo Manti- } \\
\text { queira. }\end{array}$ & $\begin{array}{l}\text { Não ocorre na área } \\
\text { estudada. }\end{array}$ & $\begin{array}{l}\text { Ocorrem relações de } \\
\text { contato claras entre } \\
\text { embasamento e cobertu- } \\
\text { ra. Ocorrem dobras em } \\
\text { várias escalas. A } \\
\text { oliação principal é ulna } \\
\text { xistosidade grossa e/ou } \\
\text { descontinua. Lineação } \\
\text { mineral down dip ou } \\
\text { obliqua é comum Próxi- } \\
\text { mo a seu contato de } \\
\text { topo, a foliação predo- } \\
\text { minante é milonitica, de } \\
\text { baixo angulo. lineação } \\
\text { mineral down dip ou } \\
\text { obliqua é comum }\end{array}$ \\
\hline DTJF & $\begin{array}{l}\text { Paragnaisses e rochas } \\
\text { associadas da Unidade } \\
\text { Jardim Glória. (?) } \\
\text { Metapsamitos, metapeli. } \\
\text { tos e quartzitos correla - } \\
\text { tos ao CDA }\end{array}$ & $\begin{array}{l}\text { Granulitos ortoderivados } \\
\text { do Complexo Juiz de } \\
\text { Fora. } \\
\text { Paragnaisses e rochas } \\
\text { associadas da Unidade } \\
\text { Jardim Gloria. (?) } \\
\text { Ortognaisses da Suite } \\
\text { Quirino-Dorândia }\end{array}$ & $\begin{array}{l}\text { Granada chamockito } \\
\text { Leucogranito }\end{array}$ & $\begin{array}{l}\text { Interdigitação tectônica } \\
\text { entre unidades pré-1,8 } \\
\text { Ga. e unidades pósul, } 8 \\
\text { Ga. É comum a } \\
\text { alternância de bandas } \\
\text { dobradas e bandas } \\
\text { milonitizadas. A foliação } \\
\text { e uma xistosidade } \\
\text { grossa, a norte e milo- } \\
\text { nitica, a sul. } \\
\text { Lineação mineral é rara, } \\
\text { a norte e mais pene- } \\
\text { trativa, a sul. A deform } \\
\text { mação diminui de } \\
\text { sul/sudeste para norte / } \\
\text { moroeste. }\end{array}$ \\
\hline DTPS & $\begin{array}{l}\text { Biotita gnaisse bandado } \\
\text { (Complexo Paraíba do } \\
\text { Sul) }\end{array}$ & $\begin{array}{l}\text { Ortognaisses da Suite } \\
\text { Quirino-Dorândia } \\
\text { (Complexo Paraiba do } \\
\text { Sul) }\end{array}$ & $\begin{array}{l}\text { Não ocorre na área } \\
\text { estudada }\end{array}$ & $\begin{array}{l}\text { No contato con o D'TJi, } \\
\text { a foliação é milonitica. }\end{array}$ \\
\hline
\end{tabular}




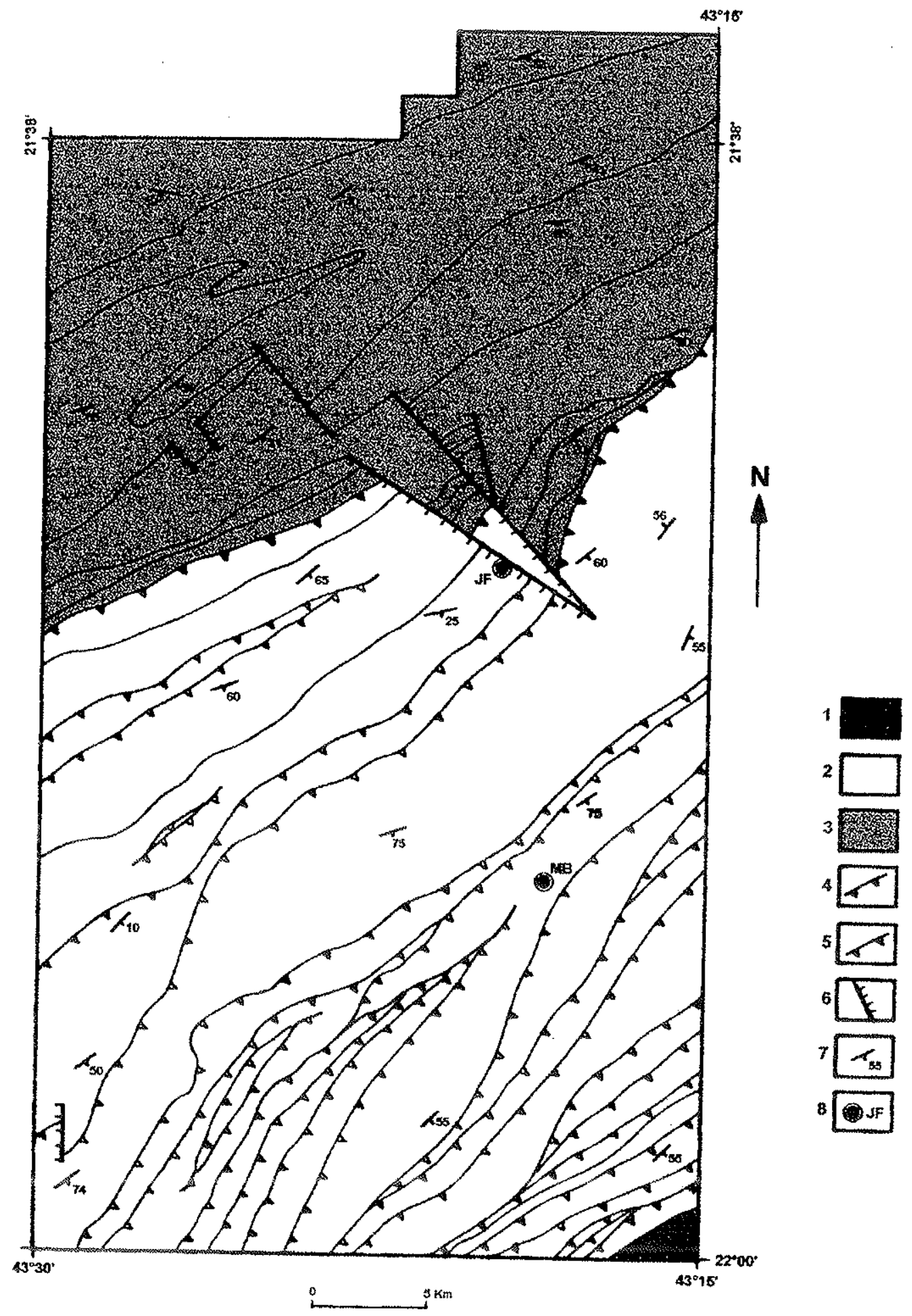

Figura 8 - Compartimentação Tectônica da Região de Juiz de Fora (MG). 1 - Dominio Tectônico Paraíba do Sul; 2 - Domínio Tectônico Juiz de Fora; 3 - Domínio Tectônico Andrelândia; 4 - Empurrão e Limite dos Domínios Tectônicos; 5 - Empurrão Subordinado; 6 - Zona de Cisalhamento Dúctil-Rúptil; 7 - Foliação Principal; e 8 - Zona Urbana: Juiz de Fora (JF); Matias Barbosa (MB). 


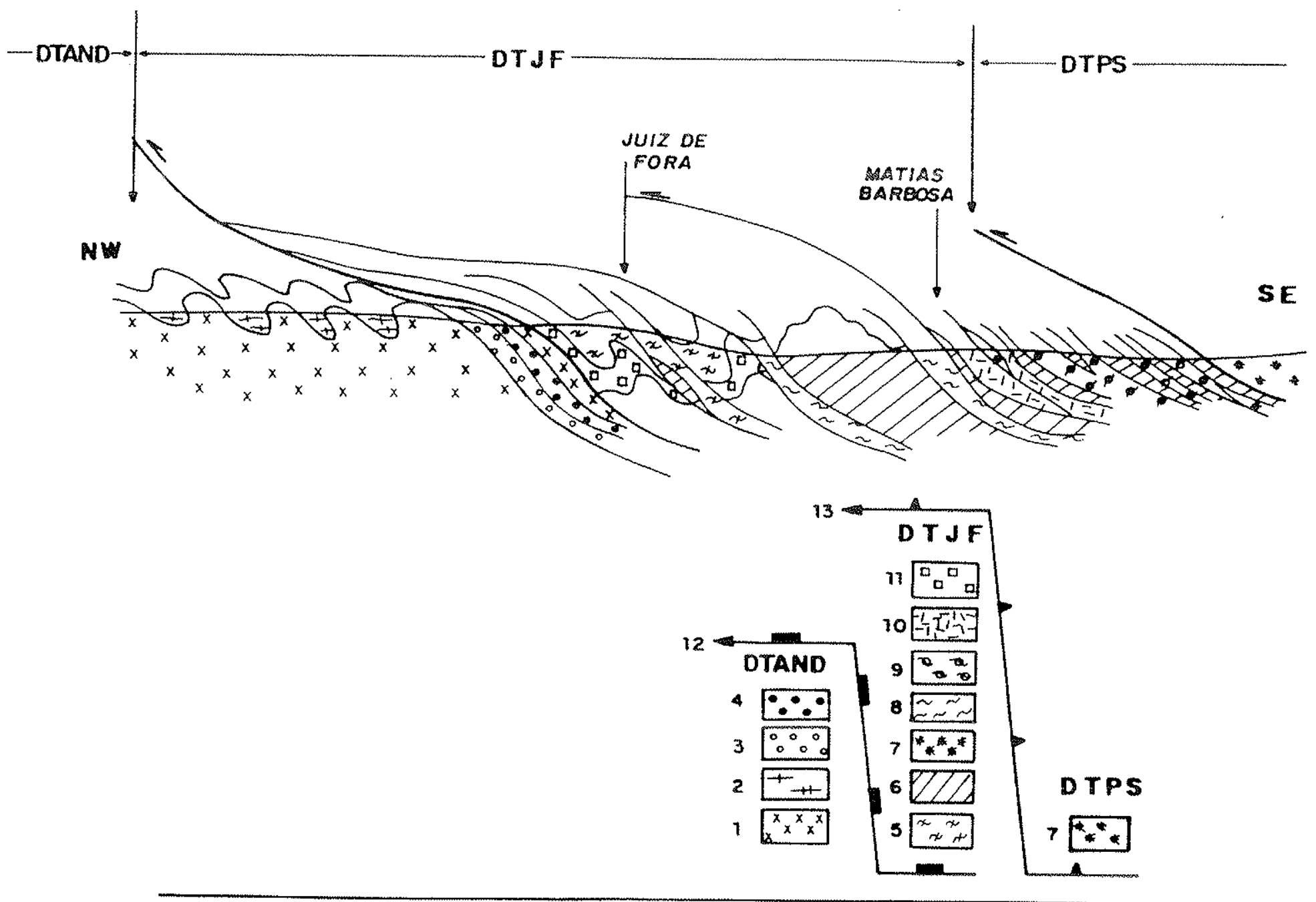

1 - ORTOGNAISSES E METABASITOS ASSOCIADOS (COMPLEXO MANTIQUEIRA)

2 BIOTITA-RGANADA)-(SILLIMANITA) GNAISSES (CICLO DEPOSICIONAL ANORELANOIA)

3 - SILLIMANITA QUARTZITO FELDSPÁtICO E BIOTITA GNAISSE QUARTZOSOICICLO DEPOSICIONAL ANDRELANNDIA)

4 - BIOTITA- (SILLIMANITA) GNAISSE PORFIROCLASTICO (CICLO DEPOSICIONAL ANORELANDIA)

5 - BIOTITA-GRANADA-(SILLIMANITA)-ORTOPIROXÉNIO (UNIDADE JARDIM GLÓRIA)

6 - ortognaISSES gRANULíticos E METABASITOS ASSOCIADOS ICOMPLEXO JUIZ DE FORA)

7 - ORTOGNAISSES E PARAGNAISSES (COMPLEXO PARAIB́ DO SUL)

8 - BIOTITA GNAISSE COM LENTES DE OUARTZITO

9 - BIOTITA-GRANADA- (SILLUMANITA) GNAISSE

10 - ORTOGNAISSE E LEUCOGRANITO (SUITE INTRUSIVA MATIAS BARBOSA)

11 - GRANADA CHARNOCKITO

12 - EMPURRĂO LIMITE DOS DOMINIOS TECTÓNICOS ANDRELANDIA E JUIZ DE FORA

13 . EMPURRÃO LIMITE DOS DOMINIOS TECTONICOS JUIZ DE FORA E PARAIBA DO SUL.

FIgura 9A - Perfil Esquemático do Regiöo de Juiz de foro 


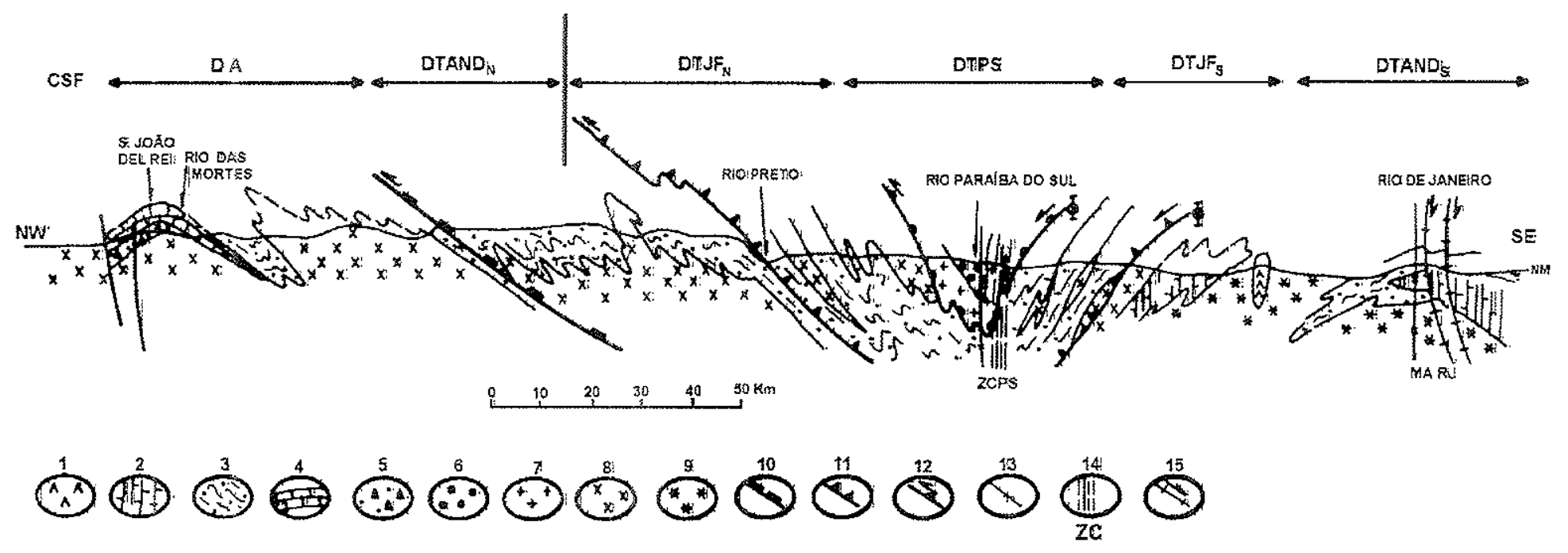

Legenda para a figura 9b: 1) Embasamento Pré 1,8Ga.: Complexos Barbacena, Mantiqueira e Juiz de Fora; 2) Suíte Quirino Dorândia; 3) Unidade Rio Negro, Série Inferior ou Costeira; 4) Ciclo Deposicional Lenheiro-Tiradentes; 5) Ciclo Deposicional Carandaí; 6) Ciclo Deposicional Andrelândia; 7) Grupo Paraiba do Sul; 8 e 9) Granitóides Brasilianos; 10) Rochas Alcalinas Meso-Cenozóicas; 11) Bacias Cenozóicas e Sedimentação Quaternária; 12, 13, 14 e 15) Empurrões Limitrofes de Dominios Tectônicos; 16 e 17) Falhamentos Normais.

Figura 9b - Perfil Geológico-Estrutural da Transversal Bom Jardim de Minas - Barra do Piraí, segundo Heilbron (1993). 


\section{II.2) Unidades Litológicas do Domínio Tectônico Andrelândia}

Este Domínio compreende dois conjuntos litológicos distintos: a) conjunto metassedimentar correlacionado ao Ciclo Deposicional Andrelândia (CDA) (Andreis et al., 1989) com rochas metabasiticas que datam do Proterozóico Médio/Superior; e b) o embasamento constituído de ortognaisses do Complexo Mantiqueira (CM), cuja história remonta ao Arqueano. Cada uma destas unidades será abordada em detalhe a seguir.

\section{II.2.1) Complexo Mantiqueira}

Esta unidade é constituída principalmente de biotita-hornblenda gnaisses cinzentos, bandados, por vezes migmatíticos, de composição tonalítica a granodiorítica, com bandas, enclaves e/ou lentes centimétricas a métricas de rochas metabásicas. O conjunto apresenta comumente estruturas migmatíticas (estromática, agmatítica, schollen schlieren), cujos leucossomas são caracterizados pela presença de cristais grossos de hornblenda. Ortognaisses intrusivos, graníticos e granodioríticos, associados a pegmatitos e aplitos, completam o quadro desta unidade. As paragêneses minerais, texturas e estruturas encontradas indicam condições metamórficas da facies anfibolito superior, com anatexia e formação de migmatitos. As rochas do Complexo Mantiqueira ocorrem em boas exposições, principalmente em cortes de rodovias federais e estaduais e em várias pedreiras, abandonadas ou ainda em exploração, no município de Juiz de Fora. A seguir serão apresentadas as relações de campo e as características petrográficas dos litotipos que constituem esta unidade.

\section{a) Hornblenda Gnaisse Bandado (e migmatítico)}

Este litotipo ocorre em todo o Domínio Inferior, no entanto predomina na porção norte da área estudada, sugerindo ser esta a unidade basal do Complexo Mantiqueira. A rocha é caracterizada por bandamento gnáissico dado pela alternância de níveis milimétricos a centimétricos félsicos e máficos. Frequentemente apresenta feições migmatíticas principalmente do tipo estromática, cujos leucossomas brancos têm hornblendas grossas (até 1 $\mathrm{cm}$ de diâmetro), schlierens máficos (ricos em $\mathrm{Hb}$ ) e xenocristais de hornblenda (Fig. 10). O gnaisse inclui bandas e/ou boudins e, localmente, corpos irregulares, sigmóidais de anfibolitos, formando estruturas tipo shollen e agmática. Níveis leucossomáticos rosados de composição 
granítica ocorrem injetados em todo o conjunto. Subordinadamente, ocorrem bandas centimétricas de biotita gnaisse fino de cor cinza clara.

Possui granulometria fina à média, textura granoblástica, localmente protomilonítica, estrutura foliada e bandada. Os porfiroclastos são de plagioclásio, quartzo e ortoclásio, cujas bordas registram feições resultantes de processo de recristalização incipiente. Hornblenda e biotita são as fases máficas predominantes e ocorrem em grãos orientados em meio à matriz fina composta por mosaico poligonal de minerais félsicos recristalizados. Clinopiroxênio é fase máfica subordinada, de ocorrência esparsa, mas não incomum. Titanita é o mineral acessório mais abundante, além de minerais opacos, apatita e zircão.

\section{b) Biotita Gnaisse Fino}

Esta rocha tem cor cinza clara, granulomentria fina e foliação marcante sem, no entanto, apresentar o bandamento característico da maioria dos gnaisses da área. Ocorre em bandas centimétricas no $\mathrm{Hb}$ gnaisse bandado, tendo então maior expressão na porção norte deste Domínio. Localmente, apresenta estrutura estromática, indicando processo de migmatização. A textura é granoblástica, sendo que eventualmente mostra feições relacionadas a processo de milonitização. A observação ao microscópio mostra que a rocha apresenta bandamento dado pela alternância de bandas félsicas mais e menos enriquecidas em fases máficas, principalmente biotita. Plagioclásio, quartzo, biotita e hornblenda são os principais constituintes e, assim como as demais rochas deste conjunto, a titanita é comum e ocorre em grãos isolados ou coroando mineral opaco. Outras fases acessórias importantes são apatita e zircão.

\section{c) Rochas Charnockiticas}

Em dois cortes da rodovia que liga as cidades de Juiz de Fora e Coronel Pacheco, na porção NNE da área mapeada, foi observada a ocorrência de uma associação litológica incomum para o Complexo Mantiqueira na área: rochas verdes com paragêneses diagnósticas para a facies granulito, com ou sem granada, associadas a hornblenda gnaisses migmatíticos estromáticos de cor cinzenta. Dois tipos de rochas verdes foram identificadas e serão descritas a seguir. 


\section{c.1) Enderbito Bandado}

Esta rocha tem cor verde, granulometria fina à média e estrutura bandada, sendo que cada banda apresenta aspecto maciço. A textura varia de granoblástica a protomilonítica, quando então os porfiroclastos são de plagioclásio, ortoclásio, quartzo, ortopiroxênio e clinopiroxênio. Hornblenda e biotita ocorrem na matriz fina recristalizada e as relações texturais sugerem que estes minerais formaram-se pelo consumo de piroxênios. Como fases acessórias ocorrem apatita, zircão e mineral opaco.

\section{c.2) Charnoenderbito}

Ėste litotipo tem também cor verde e aparência maciça. A análise petrográfica mostrou que esta rocha tem granulometria fina e textura granoblástica à milonítica. Os principais constituintes são plagioclásio, ortoclásio, quartzo, ortopiroxênio, clinopiroxênio, hornblenda, granada e biotita. Mineral opaco, apatita e zircão são fases acessórias.

\section{d) Hornblenda Gnaisse Maciço}

Esta rocha ocorre na porção SSW do Domínio Inferior e é caracterizada por sua cor cinza clara e aspecto maciço (Fig. 11). Quando observada mais de perto, percebe-se uma fraca foliação, marcada pela orientação de fases máficas. A granulometria é fina e a textura é granoblástica, localmente poligonal. Seus constituintes principais são plagioclásio, hornblenda, quartzo, biotita e ortoclásio e como acessórios ocorrem minerais opacos, apatita e zircão.

\section{e) Anfibolitos: Bandas, Boudins, Lentes e Corpos Tabulares}

Os anfibolitos ocorrem tanto como corpos pequenos sob a forma de bandas, boudins ou lentes, quanto como corpos maiores tabulares (Fig. 12a,b,c).

As bandas, boudins e lentes apresentam espessura centimétrica e ocorrem associadas a todos os gnaisses do Complexo Mantiqueira. Têm cor negra, granulomentria fina à média e aspecto ora maciço ora foliado. A análise da relação cronológica que estes corpos mostram com os demais litotipos são diferentes nos diversos afloramentos visitados. Em vários locais, estes anfibolitos são injetados por leucossomas com hornblenda grossa. No entanto, é comum também apresentarem bordos mais básicos e recristalizados, sugerindo processo de assimilação parcial, neste caso, promovida pelo magma que gerou os bt gnaisses que serão abordados 


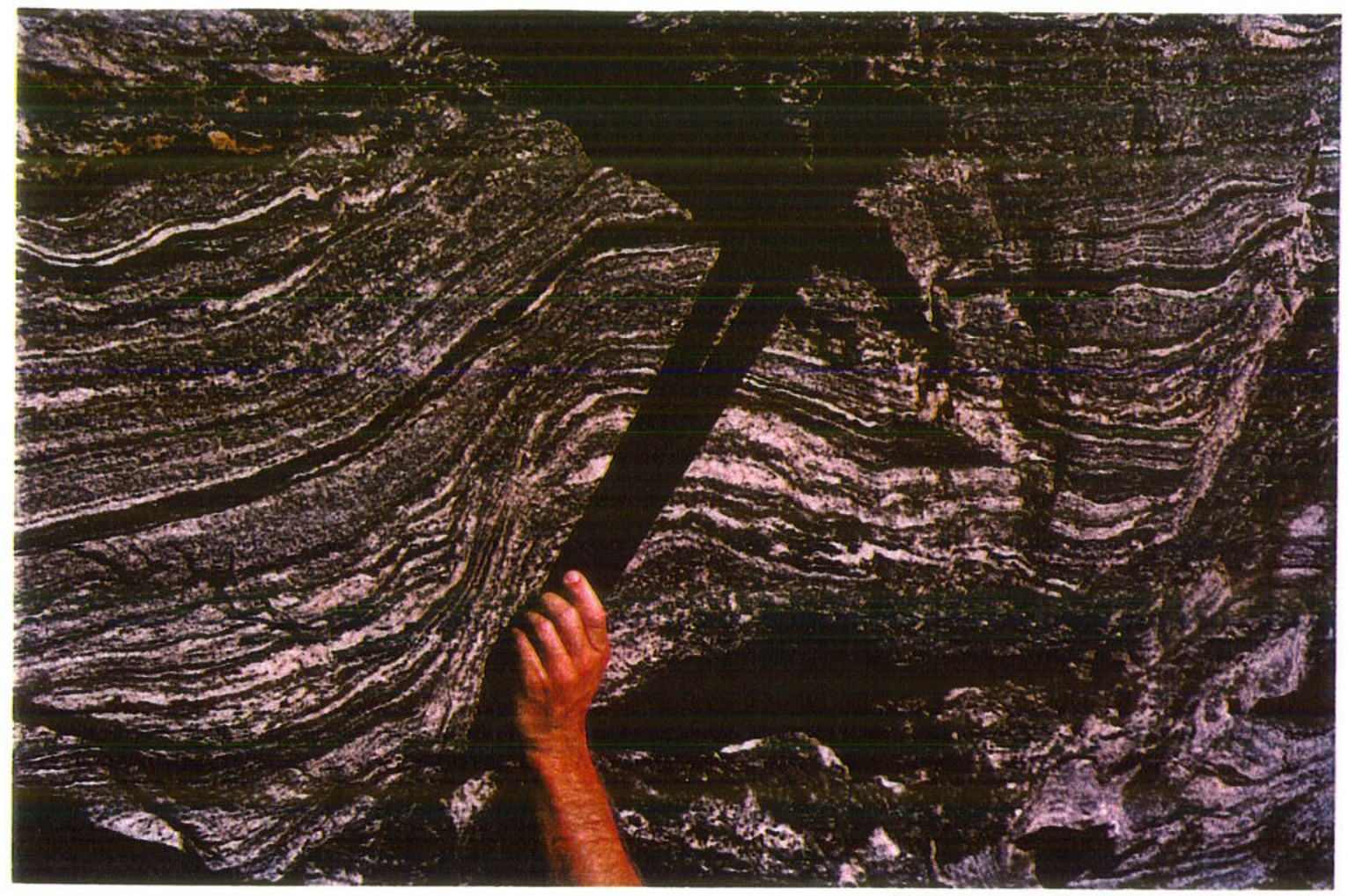

Figura 10 - Hornblenda gnaisse bandado e migmatítico - Complexo Mantiqueira. Ponto 516

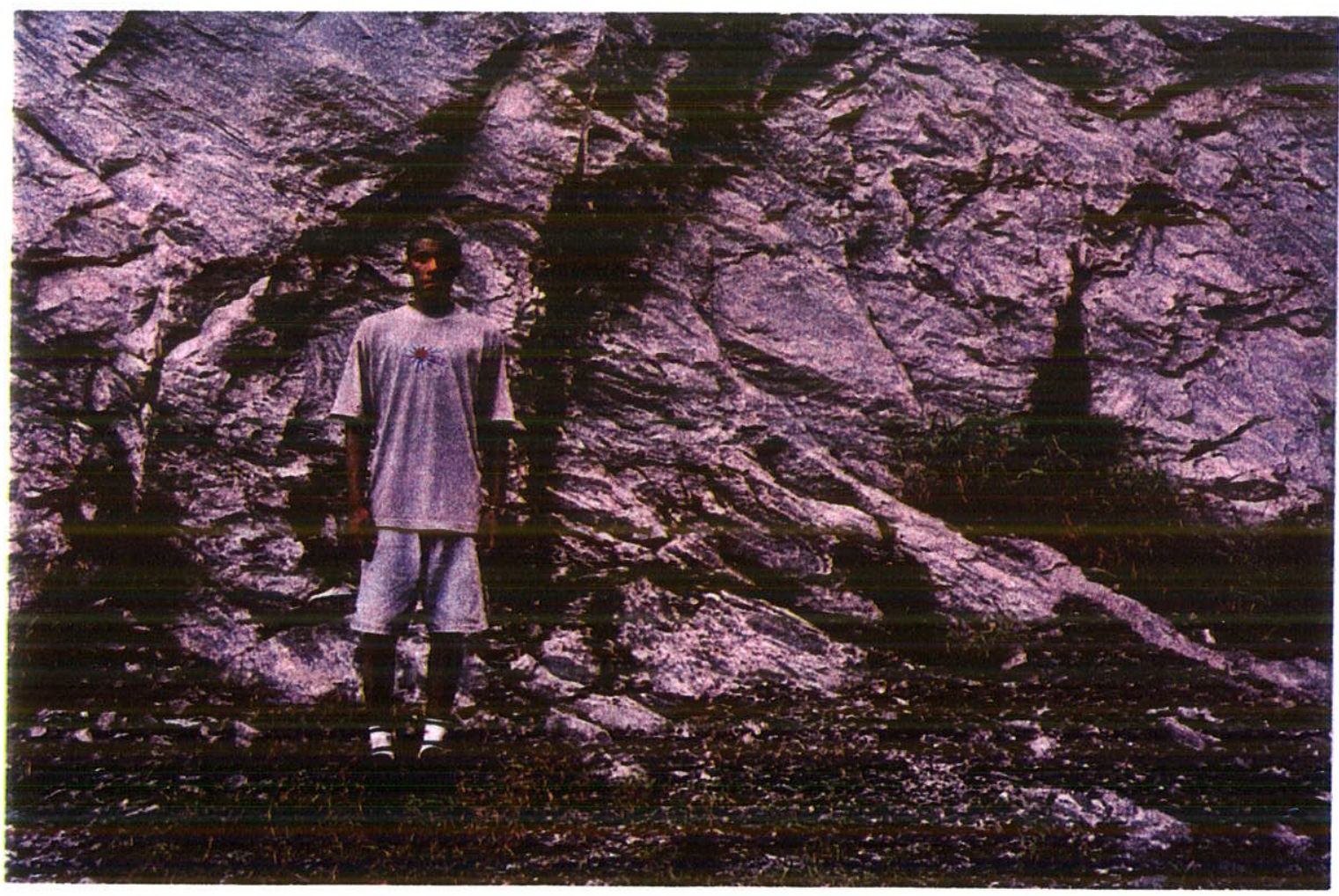

Figura 11 - Hornblenda gnaisse maciço - Complexo Mantiqueira. Ponto 564 


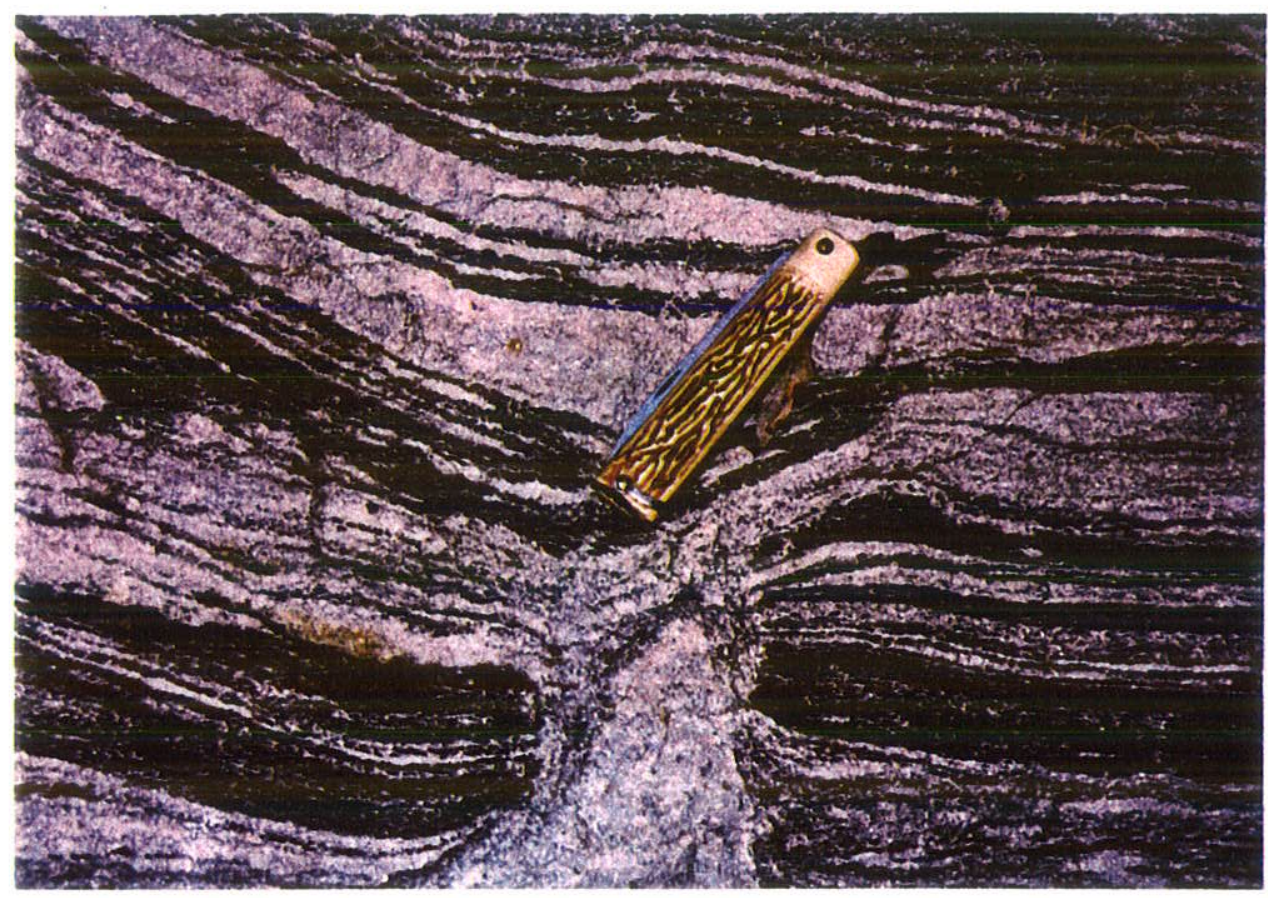

Figura 12a - Anfibolito: Bandas, ponto 516. Complexo Mantiqueira.

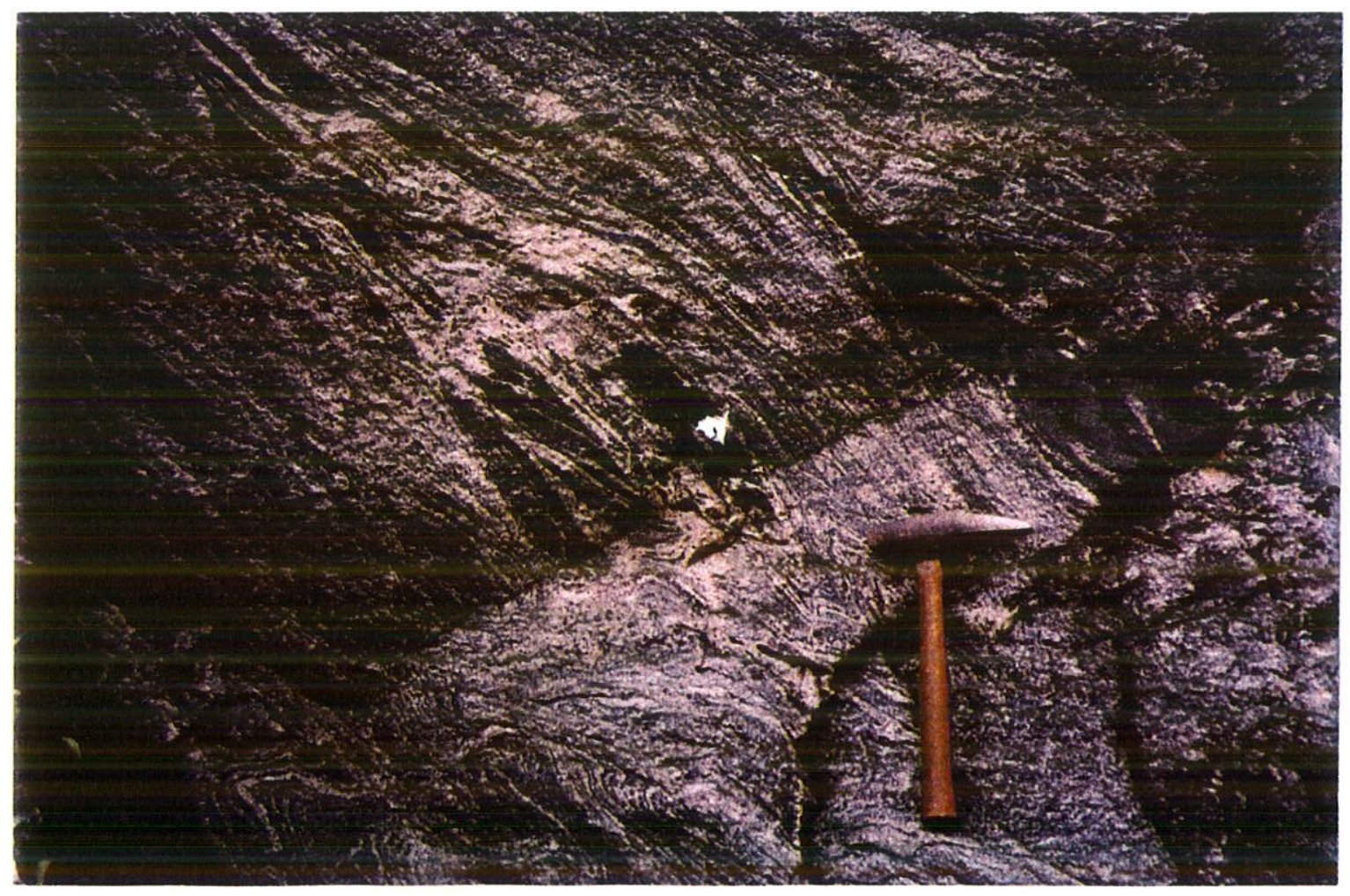

Figura 12b) Anfibolito:" boudins". Ponto 565. Complexo Mantiqueira. 


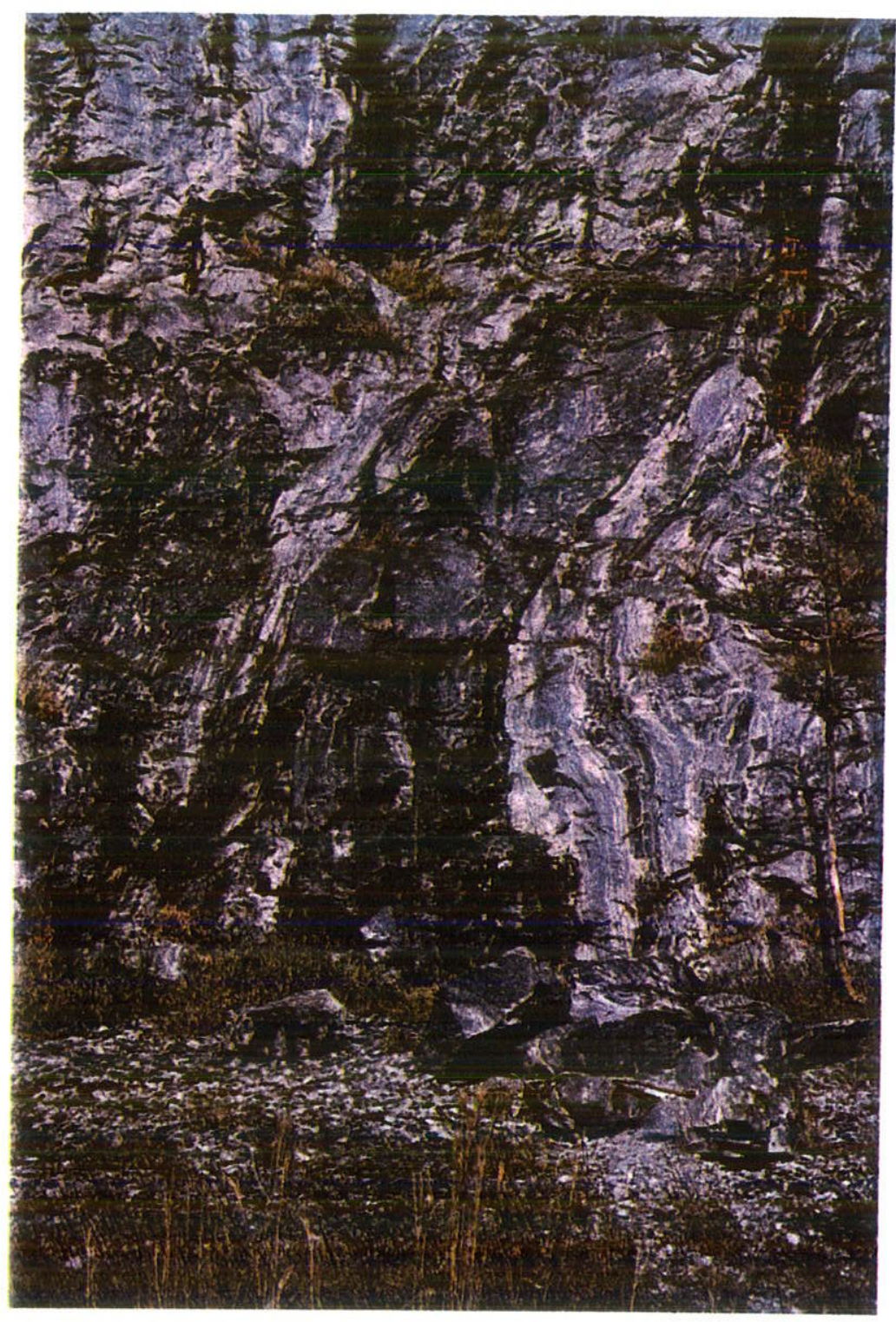

Figura 12 c) Anfibolito: corpos tabulares. Ponto516 - Complexo Mantiqueira. 
adiante. Muitas vezes ocorrem bandados com hornblenda leucognaisses, gerando estruturas sugestivas de representarem restitos de fusão parcial de ortognaisses.

Estes anfibolitos apresentam foliação fraca a moderada. A textura é ora granoblástica, localmente poligonal, a protomilonítica, ora nematoblástica. Quando protomilonítica, os porfiroclastos são de plagioclásio, clinopiroxênio e, talvez, hornblenda. A matriz incipiente é fina e constituída de plagioclásio recristalizado, hornblenda e biotita orientadas, além de minerais acessórios (titanita, apatita, minerais opacos e zircão(?)). Os principais constituintes são plagioclásio e hornblenda. Raros grãos de clinopiroxênio ocorrem como cristais relictos e são rodeados por grãos de hornblenda. Intercrescimento simplectítico entre hornblenda e plagioclásio é comum nestas zonas de borda do clinopiroxênio. Titanita é um mineral comum e ocorre tanto em cristais isolados como coroando grãos de mineral opaco. Ocorrem também quartzo e ortoclásio.

Os corpos tabulares de anfibolito apresentam espessuras da ordem de 1 metro e são, localmente, lenticulares. É comum ocorrerem como corpos blocosos, aparentemente discontínuos, mas que, no conjunto, distribuem-se de uma forma tabular. Em algun locais, como no ponto 516 (Pedreira abandonada, bairro Benfica - Juiz de Fora), esta estrutura tabular mostra-se discordante em relação à foliação dos hb gnaisses associados. Estas características sugerem fortemente que estes anfibolitos representam diques intrusivos nos $\mathrm{hb}$ gnaisses (bandados ou maciços), deformados pela tectônica Brasiliana. Assim como os anfibolitos decritos anteriormente, estas rochas são claramente injetadas por leucossomas com hornblendas grossas e apresentam, localmente, feições indicativas de processo de assimilação parcial. Com exceção da forma de ocorrência, estes anfibolitos não diferem em nada daqueles descritos no item $e$ e, portanto, parece bastante possivel que as bandas, boudins e lentes representem estágios de maior deformação destes mesmos diques.

A análise petrográfica destes anfibolitos revelou as mesmas características texturais e composicionais que aquelas das demais ocorrências de anfibolito (bandas, lentes e boudins), sendo, então, desnecessário descrever repetidamente tais feições 


\section{f) Leucossomas Brancos e Corpos Intrusivos de Hornblenda Leucognaisse}

Os leucossomas brancos são aqueles portadores de hornblendas grossas já descritos como associados a vários litotipos deste conjunto (Fig. 13). Transicionam para corpos intrusivos de proporções volumétricas relativamente grandes, quando então encerram vários corpos métricos de anfibolito. Localmente há uma transição entre os leucossomas brancos e injeções de leucogranito rosado descritas mais adiante. Ambos têm granulometria grossa, textura granoblástica, localmente poligonal, e estrutura foliada (foliação comumente fraca). Plagioclásio é seu principal constituinte, seguido de hornblenda e biotita verde. Estas rochas também apresentam textura milonítica, com porfiroclastos de plagioclásio, ortoclásio e quartzo, além de fitas de quartzo estiradas segundo a foliação. As fases acessórias são microclina, titanita e minerais opacos.

\section{g) Biotita Gnaisse Intrusivo}

Este biotita gnaisse tem cor cinza, granulomentria média à grossa e estrutura foliada. Localmente apresenta-se bandado, com injeções graníticas rosadas (subconcordantes e discordantes) e com megacristais tipo augen de K-feldspato, formados, provavelmente, a partir de interações entre a rocha e as injeções graniticas rosadas (Fig. 14). Possui enclaves de anfibolito e dois tipos de interações podem ser observados: a) os enclaves apresentam uma borda mais negra, empobrecida em fases félsicas, o que sugere processo de assimilação parcial do anfibolito pelo biotita gnaisse; e b) leucossomas brancos com hornblendas grossas formamse nos contatos entre estes dois litotipos, sugerindo, talvez, que o calor da intrusão do magma que gerou o biotita gnaisse induziu fusão parcial nos enclaves de anfibolito. Foram observados vários outros tipos de rocha em associação a este biotita gnaisse: hb gnaisse cinza escuro maciço; hb gnaisse cinza escuro grosso, maciço; e bt gnaisse fino leucocrático cinza claro e foliado. Muito embora as relações não sejam muito claras, todos os tipos parecem também enclaves no biotita gnaisse. Estes gnaisses são também injetados por leucogranito rosado e composicionalmente variam de tipos tonalíticos a graníticos.

O biotita gnaisse intrusivo tem textura granoblástica, localmente poligonal, a milonítica e, neste caso, a porção porfiroclástica é constituída de microclina, quartzo e plagioclásio e a matriz é fina, formada pela recristalização destes mesmos minerais e biotita. A estrutura é foliada, localmente anastomosada devido à presença de megacristais de K-feldspato. A 


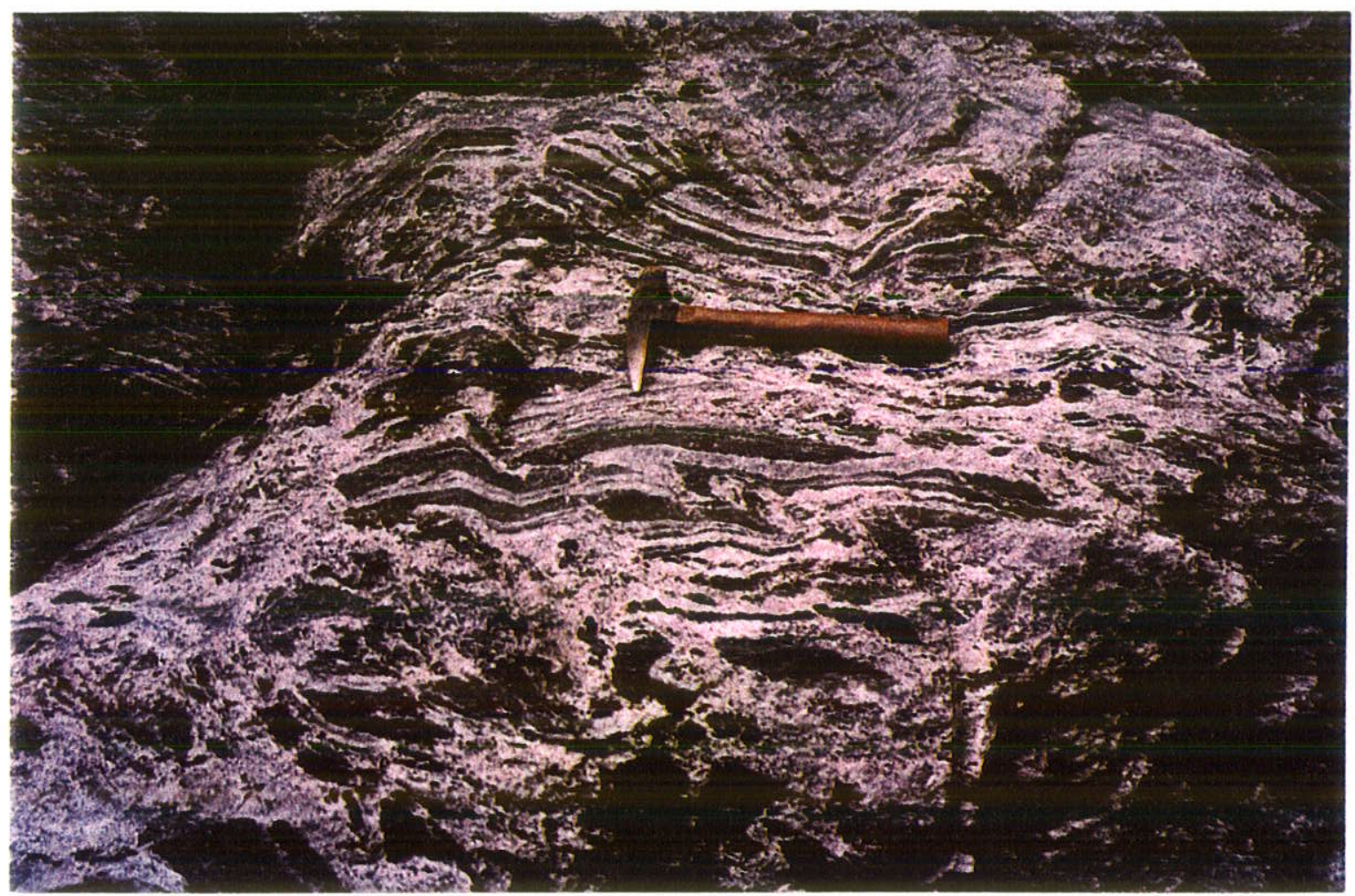

Figura 13 - Leucossomas brancos e corpos intrusivos de Hornblenda leucognaisse. Complexo Mantiqueira. Ponto 564

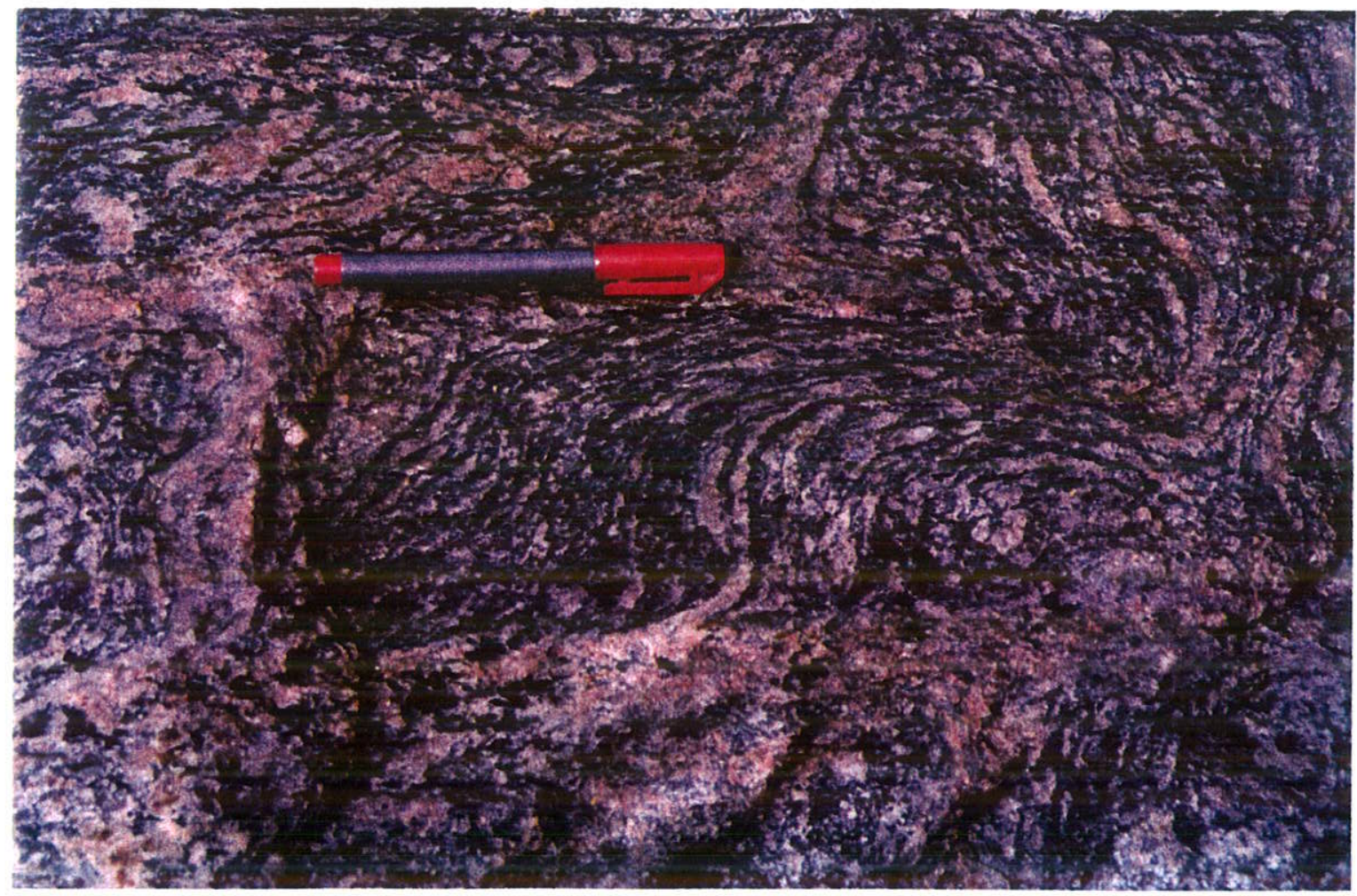

Figura 14 - Biotita gnaisse intrusivo - Complexo Mantiqueira. Ponto 577. 
composição da rocha é dada por microclina, plagioclásio, quartzo, ortoclásio, biotita, minerais opacos, titanita, apatita e zircão.

O biotita gnaisse fino leucocrático tem textura granoblástica à milonítica e estrutura foliada. Tem microclina, quartzo, ortoclásio, plagioclásio e biotita como minerais essenciais, além de minerais opacos e zircão como fases acessórias. O hornblenda gnaisse fino tem textura granoblástica e apresenta foliação anastomosada. É formado por plagioclásio, hornblenda, quartzo, biotita, titanita, apatita, minerais opacos, ortoclásio e zircão. O hornblenda gnaisse grosso tem textura granoblástica, localmente poligonal, e estrutura foliada. É constituído de plagioclásio, quartzo, ortoclásio, hornblenda, biotita, titanita, apatita, minerais opacos e zircão.

\section{h) Biotita Leucognaisse}

É uma rocha de cor branca, leucocrática a hololeucocrática, foliada e localmente bandada. Ocorre em bandas associadas aos demais gnaisses do Complexo Juiz de Fora. As relações originais são em geral bastante obiteradas por tectônica complexa que afetou o conjunto. A granulomentria varia de fina à média e a textura é granoblástica, localmente milonítica, com arranjo poligonal na matriz. A estrutura foliada é marcada pela orientação de plaquetas de biotita. Um leve bandamento é também observado, onde níveis leucocráticos com e sem biotita ocorrem intercalados, porém, na maioria das vezes, o bandamento é resultante de variações granulométricas entre bandas mais e menos recristalizadas.

A composição mineralógica desta rocha é dada por plagioclásio, ortoclásio, microclina, quartzo e biotita, além de titanita, mineral opaco, apatita e zircão como fases acessórias. Quando milonítica, a fração de porfiroclastos é formada por plagioclásio, ortoclásio e quartzo, enquanto que a matriz é constituída de um mosaico recristalizado de plagioclásio, microclina e quartzo, além de biotita em plaquetas orientadas. Fitas de quartzo também ocorrem na matriz. É comum a presença de intercrescimento mirmequítico nas interfaces plagioclásio / ortoclásio. Uma característica conspícua desta rocha é a cor esverdeada da biotita, feição esta não obsevada nos demais litotipos do conjunto. Titanita é a fase acessória mais abundante e ocorre em cristais isolados e/ou coroando grãos de mineral opaco. Zircão é relativamente raro neste litotipo. 


\section{i) Injeções Graníticas Tardias}

Ocorrem principalmente sob a forma de corpos tabulares, dispostos em planos subparalelos à foliação principal das rochas gnáissicas, sendo apenas localmente discordantes. As injeções graníticas têm coloração rosada, granulometria média à grossa e têm textura granoblástica a milonítica, na qual microclina, plagioclásio e quartzo constituem a porção porfiroclástica, enquanto que a matriz, granoblástica-poligonal, é formada por um mosaico fino destes mesmos minerais recristalizados, além de biotita e minerais acessórios. A rocha é ligeiramente foliada, marcada pelo maior comprimento de alguns grãos félsicos e pela orientação de plaquetas de biotita. Ocorrem também ortoclásio, hornblenda, biotita e, como acessórios, titanita, zircão, minerais opacos e apatita.

\section{j) Pegmatitos Rosados}

Estes corpos têm composição mineralógica semelhante às injeções rosadas. Ocorrem principalmente ao longo de fraturas, sendo discordantes em relação à estrutura das rochas encaixantes. A granulometria é grossa, a textura é granular e a estrutura é maciça. São constituídos de microclina, quartzo, plagioclásio, biotita, minerais opacos e zircão. Localmente, há continuidade entre as bandas rosadas subconcordantes e os pegmatitos discordantes. Estes corpos pegmatíticos são frequentemento observados no bt gnaisse intrusivo.

A tabela 5 apresenta os resultados da análise petrográfica dos litotipos do Complexo Mantiqueira. 
Tabela 5 - Composição Mineralógica, Características Texturais e Classificação dos Litotipos do Complexo Mantiqueira.

\begin{tabular}{|c|c|c|c|c|}
\hline Litotipo & $\begin{array}{l}\text { Minerais (em ordem } \\
\text { decrescente de } \% \text { vol) }\end{array}$ & Granulometria & Textura / Estrutura & Classificação \\
\hline Hb gnaisse bandado & $\begin{array}{l}\text { plg, hb, bt, cpx, } \mathrm{qz} \text {, ort, tit, ap, } \\
\text { op, zc }\end{array}$ & fina à média & $\begin{array}{l}\text { granoblástica a protomilinítica a milonítica } \\
\text { / foliada, bandada e migmatitica }\end{array}$ & tonalito \\
\hline Bt gnaisse cinza claro & $\mathrm{plg}, \mathrm{qz}$, ort, bt, hb, op, ap, zc & fina & $\begin{array}{l}\text { granoblástica a milonítica; } \\
\text { bandada e foliada }\end{array}$ & granodiorito \\
\hline Enderbito bandado & $\begin{array}{l}\text { plg, qz, hb, bt, cpx, opx, ort, ap, } \\
z c, \text { op }\end{array}$ & fnaà média & $\begin{array}{l}\text { granoblástica a protomilo- } \\
\text { nítica; maciça }\end{array}$ & enderbito \\
\hline Charnoenderbito & $\mathrm{plg}, \mathrm{qz}, \mathrm{bt}$, ort $, \mathrm{gr}, \mathrm{op}, \mathrm{zc}$, ap & fina & $\begin{array}{l}\text { granoblástica a milonitica; } \\
\text { foliação fraca a moderada }\end{array}$ & charnoenderbito \\
\hline Hb gnaisse maciço & $\mathrm{plg}, \mathrm{hb}, \mathrm{qz}, \mathrm{bt}$, tit, op, ap, ort, $\mathrm{zc}$ & $\sin a$ & $\begin{array}{l}\text { granoblástica; } \\
\text { folią̧ão fraca }\end{array}$ & tonalito \\
\hline $\begin{array}{l}\text { Anfibolitos: Bandas e Corpos } \\
\text { Tabulares }\end{array}$ & $\begin{array}{l}\text { plg, hb, cpx, bt, tit, ap, qz, ort, } \\
\text { op, zc }\end{array}$ & fina à média & $\begin{array}{l}\text { granoblástica, grano-nematoblástica a } \\
\text { protomilonitica / fraca a moderadamente } \\
\text { foliada }\end{array}$ & gabro \\
\hline $\begin{array}{l}\text { Leacossoma branco con } \\
\text { hornblenda grossa }\end{array}$ & $\begin{array}{l}\text { plg, hb, qz, bt, ort, tit, mi, ap, op, } \\
z c,\end{array}$ & grossa & $\begin{array}{l}\text { granoblástica, localmente poligonal, a } \\
\text { milonítica / maciça a bandada e fracanente } \\
\text { foliada }\end{array}$ & tonalito a granodiorito \\
\hline $\mathrm{Bt}$ gnaisse & $\begin{array}{l}\text { mi, plg, az, bt, ort, op, ti, ap, zc, } \\
\text { hb }\end{array}$ & média à grossa & $\begin{array}{l}\text { granoblástica-milonítica } \\
\text { foliada e bandada }\end{array}$ & granodiorito a granito \\
\hline bt leucognaisse & plg, ort, $q \mathrm{z}, \mathrm{bt}, \mathrm{zc}, \mathrm{op}$ & fina à média & $\begin{array}{l}\text { granoblástica, localmente poligonal; } \\
\text { bandada e foliada }\end{array}$ & granodiorito a granito \\
\hline Injeções graníticas rosadas & mi, qz, plg, ort, bt, hb, op, ap, zc, & média à grossa & granoblástica-milonítica;fracamente foliada & granito \\
\hline Pegmatito rosado & $\mathrm{mi}, \mathrm{qz}, \mathrm{plg}, \mathrm{bt}, \mathrm{op}, \mathrm{zc}$ & grossa & granular; maciça & granito \\
\hline
\end{tabular}




\section{II.2.2) Rochas do Ciclo Deposicional Andrelândia}

Foram individualizados três diferentes litotipos ou conjuntos litológicos no CDA que serão descritos a seguir.

\section{a) Sequência Basal: Biotita Gnaisse Bandado}

Esta rocha constitui a base da sequência Andrelândia na área e ocorre entre Paula Lima e Dias Tavares. É caracterizada pela presença de bandamento marcante que pode ser observado mesmo quando bastante intemperizada, o que é seu estado mais comum na área. $O$ bandamento é dado pela alternância entre níveis félsicos e níveis biotíticos (bandamento gnáissico) e também pela presença de bandas centimétricas de quartzito e de rocha anfibolítica. Ocorrem também leucossomas graníticos, normalmente em forma de bolsões ou de veios múltiplos. Localmente, há um aumento gradual na quantidade e na espessura das bandas quartzíticas até que o gnaisse dá lugar a um quartzito com pouco feldspato. A rocha tem textura granoblástica, localmente protomilonítica, e a estrutura bandada ocorre também a nível milimétrico. Os minerais constituintes são plagioclásio, biotita, quartzo, K-feldspato, granada, apatita, zircão e mineral opaco (Tab 6). É interessante ressaltar que a granada, mineral não observado em afloramento, é comumente observada em lâmina, em grãos milimétricos e dispersos. O quartzito tem granulometria variando de média à grossa, textura granoblástica a poligonal. Quando mais deformado, os grãos de quartzo formam fitas alongadas segundo a foliação. Quartzo é o mineral largamente predominante, ocorrendo também feldspato, muscovita, zircão e mineral opaco.

Tabela 6 - Composição Mineralógica, Caracteristicas Texturais e Classificação dos Litotipos da Sequência Basal do Ciclo Deposicional Andrelândia.

\begin{tabular}{|l|l|c|c|}
\hline \multicolumn{1}{|c|}{ Litotipo } & $\begin{array}{l}\text { Minerais (em ordem } \\
\text { decrescente de vol) }\end{array}$ & Granulometria & Textura / Estrutura \\
\hline Bt Gnaisse Bandado & $\begin{array}{l}\text { plg, bt, qz, ort, gr, op, ap, } \\
\mathrm{zc}\end{array}$ & fina à média & $\begin{array}{l}\text { Granoblástica a Protomi - } \\
\text { lonítica, Bandada }\end{array}$ \\
\hline Quartzito & qz, plg, um, zc, op & média à grossa & $\begin{array}{l}\text { Granoblástica-Poligonal; } \\
\text { Foliada. }\end{array}$ \\
\hline
\end{tabular}




\section{b) Sequência Mista: Biotita gnaisse bandado, biotita-sillimanita-granada gnaisse, quartzito}

Esta sequência é caracterizada pela interestratificação de vários litotipos que ocorrem em forma de lentes. As variações faciológicas ocorrem tanto na vertical quanto na horizontal.

O biotita gnaisse bandado predomina na base da Sequência Mista, onde ocorre interestratificado com camadas centimétricas a decamétricas de quartzito. Esta rocha é bastante semelhante aquela descrita anteriormente para a porção basal do CDA na área, residindo a diferença na maior abundância e espessura de camadas de quartzito e menor proporção de bandas anfibolíticas. Leucossomas quartzo-feldspáticos, graníticos, brancos ou rosados, são comuns.

O biotita gnaisse tem granulometria fina à média, textura granoblástica e bandamento dado pela alternância de níveis félsicos com diferentes proporçôes de biotita. plagioclásio, quartzo, biotita e K-feldspato são os principais constituintes e como acessórios ocorrem zircão, apatita, mineral opaco e turmalina.

Em direção ao topo desta sequência, há um aumento na quantidade e espessura das camadas de quartzito e começam a ocorrer lentes de metapelitos, representados por biotitasillimanita-granada gnaisse que parece predominar nesta porção da sequência, embora ocorra ainda intercalada ao biotita gnaisse bandado. Quando alterada a rocha metapelítica assemelhase a um xisto. Mesmo quando fresca, observa-se uma alternância de níveis de granulometria mais fina, mais pelíticos e níveis mais grossos onde verifica-se a ocorrência de leucossomas peraluminosos com granada e biotita. Localmente ocorrem níveis de sillimanitito. O biotiasillimanita-granada gnaisse tem granulometria fina à média, textura granoblástica, localmente protomilonítica, e é constituído de plagioclásio, quartzo, biotita, sillimanita, fibrolita, granada, ortoclásio e, como fases acessórias, tem mineral opaco, apatita, zircão e rutilo. Lentes e/ou boudins centimétricos de rochas calcissilicáticas ocorrem associadas a estes metapelitos. Os constituintes minerais desta rochas são plagioclásio, quartzo, hornblenda, granada, clinopiroxênio, apatita, titanita e mineral opaco.

As camadas de quartzito, como descrito anteriormente, ocorrem tanto interestratificadas com o biotita gnaisse quanto com o metapelito, sendo também mais 
abundantes e possantes em direção ao topo da sequência. O quartzito tem granulomentria média à grossa (localmente tipo sal grosso), textura granoblástica poligonal e é constituído predominantemente de quartzo, ocorrendo também plagioclásio, muscovita, sillimanita, turmalina, zircão, rutilo e mineral opaco.

Tabela 7 - Composição Mineralógica, Características Texturais e Classificação dos Litotipos da Sequência Mista do Ciclo Deposicional Andrelândia.

\begin{tabular}{|l|l|c|l|}
\hline \multicolumn{1}{|c|}{ Litotipo } & $\begin{array}{l}\text { Minerais (em ordem } \\
\text { decrescente de vol) }\end{array}$ & Granulometria & \multicolumn{1}{|c|}{ Textura / Estrutura } \\
\hline Bt Gnaisse Bandado & $\begin{array}{l}\mathrm{plg}, \mathrm{bt}, \mathrm{qz}, \text { ort, } \mathrm{gr}, \mathrm{op}, \mathrm{ap}, \\
\mathrm{zc}\end{array}$ & fina à média & $\begin{array}{l}\text { Granoblástica a Protomi - } \\
\text { lonítica; Bandada }\end{array}$ \\
\hline Quartzito & $\mathrm{qz}, \mathrm{plg}, \mathrm{mu}, \mathrm{sll}, \mathrm{tur}, \mathrm{zc}, \mathrm{op}$ & média à grossa & $\begin{array}{l}\text { Granoblástica-Poligonal; } \\
\text { Foliada. }\end{array}$ \\
\hline Bt-Sill-Gr Gnaisse & $\begin{array}{l}\mathrm{plg}, \mathrm{qz}, \mathrm{bt}, \mathrm{sll}, \mathrm{fbr}, \mathrm{gr}, \text { ort, } \\
\mathrm{op}, \mathrm{ap}, \mathrm{zc}, \mathrm{rt}\end{array}$ & fina à média & $\begin{array}{l}\text { Granoblástica a Protomi - } \\
\text { lonítica; Bandada }\end{array}$ \\
\hline Rocha Calcissilicática & $\mathrm{plg}, \mathrm{hb}, \mathrm{gr}, \mathrm{cpx}, \mathrm{ap}, \mathrm{ti}, \mathrm{op}$ & fina à média & $\begin{array}{l}\text { Granoblástica-Poligonal; } \\
\text { Maciça. }\end{array}$ \\
\hline
\end{tabular}

\section{c) Sequência de Topo: Quartzito, biotita gnaisses quartzosos, biotita-} (sillimanita) gnaisse porfiroclástico

Quartzito forma a base desta sequência e ocorre comumente intercalado com biotita gnaisses quartzosos e níveis pelíticos pouco espessos. As camadas de quartzito variam de centimétricas a métricas, o mesmo ocorrendo com o biotita gnaisse. Este conjunto litológico é bastante explorado para saibro na área, dada a boa mistura entre materiais psamíticos e pelíticos. Tanto o quartzito quanto o biotita gnaisse tem granulometria que varia de fina à grossa e, comumente, o conjunto apresenta-se milonítico.

O quartzito tem composição variável, desde termos mais puros até composições mais feldspáticas. A composição mineralógica é dada por quartzo, plagioclásio, muscovita, sillimanita, turmalina, zircão e mineral opaco. O biotita gnaisse também varia de termos mais e menos quartzosos e seus constituintes principais são plagioclásio, K-feldspato (?), quartzo e biotita. Como minerais acessórios ocorrem muscovita, zircão, turmalina e mineral opaco. Localmente esta rocha apresenta granada e, raramente, sillimanita. 
No topo desta sequência, em contatos aparentemente não gradacionais com as unidades sotopostas, ocorre um gnaisse fino porfiroclástico, cuja matriz tem coloração escura. Esta rocha apresenta-se, invariavelmente, milonítica, feição esta bem visível dado o contraste granulométrico entre porfiroclastos (plagioclásio) e matriz. É comum o quartzo apresentar-se azulado. Porfiroblastos de K-feldspato e muscovita ocorrem localmente sobrecrescendo matriz e porfiroclastos. São também observados leucossomas quartzo-feldspáticos. Este gnaisse tem estrutura bandada, melhor observada quando alterada e ao microscópio. Bandas milimétricas félsicas e biotíticas alternam-se, conferindo bandamento à rocha. Ocorrem também níveis quartzosos de espessura milimétrica. O conjunto de porfiroclastos é formado plagioclásio e ortoclásio (?), enquanto que biotita, sillimanita e minerais félsicos constituem a matriz recristalizada. Como acessórios ocorrem apatita, mineral opaco, zircão e turmalina. Muscovita e microclina são secundários, provavelmente formados por metamorfismo retrógrado. A muscovita ocorre ao longo da foliação, formando sombras de pressão em torno do plagioclásio e, principalmente, sobrecrescendo a foliação em uma direção quase perpendicular.

Tabela 8 - Composição Mineralógica, Características Texturais e Classificação dos Litotipos da Sequência de Topo do Ciclo Deposicional Andrelândia.

\begin{tabular}{|c|c|c|c|}
\hline Litotipo & $\begin{array}{l}\text { Minerais (em ordem } \\
\text { decrescente de \% vol) }\end{array}$ & Granulometria & Textura / Estrutura \\
\hline Quartzito & $\begin{array}{l}\mathrm{q}, \mathrm{plg}, \mathrm{um}, \mathrm{sll}, \mathrm{tur}, \mathrm{zc}, \\
\text { op }\end{array}$ & fina à grossa & Milonítica; Foliada \\
\hline Bt-Qz Gnaisse & $\begin{array}{l}\text { plg, ort, } \mathrm{qz}, \mathrm{bt}, \mathrm{sll}, \mathrm{gr} \\
\text { op, zc, tur }\end{array}$ & finaà grossa & Milonítica; Foliada \\
\hline $\begin{array}{l}\mathrm{Bt} \cdots(\text { Sill }) \quad \text { Gnaisse } \\
\text { Porfiroclástico }\end{array}$ & $\begin{array}{l}\text { plg, ort, } \mathrm{qz}, \mathrm{bt}, \mathrm{sll}, \mathrm{ap}, \\
\text { op, zc, tur, } \mathrm{mu}^{*}, \mathrm{mi}^{*}\end{array}$ & fina & Milonitica; Foliada \\
\hline
\end{tabular}

* fase mineral tardia

\section{II.3) Unidades Litológicas do Domínio Tectônico Juiz de Fora}

Quatro associações litológicas compõem este Domínio: a) biotita-granadaortopiroxênio gnaisse com lentes de quartzito e de rocha calcissilicática; b) ortognaisses e metabasitos na facies granulito do Complexo Juiz de Fora (CJF); c) rochas metassedimentares 
(correlatas ao Ciclo Deposicional Andrelândia) e metabasitos associados; e d) ortognaisses da Suite Quirino-Dorândia. Duas rochas granitóides intrusivas ocorrem: a) biotita ganisses da Suite Intrusiva Matias Barbosa; e b) granada charnockito. Com exceção de sua porção noroeste, onde predominam contatos normais entre as unidades, a grande maioria dos contatos neste Dominio são tectônicos, configurando uma interdigitação entre escamas de rochas ortogranulíticas e escamas de rochas metassedimentares.

\section{II.3.1) Biotita-Granada-Ortopiroxênio Gnaisse, Biotita-Sillimanita-Granada Gnaisse e Quartzito}

O biotita-granada-ortopiroxênio gnaisse unidade aflora a oeste da cidade de Juiz de Fora e constitui o litotipo que sustenta os morros próximos ao centro desta cidade, normalmente referidos como Morro da Torre e Morro do Cristo Redentor. Foi exatamente nestes morros que Ebert (1955) definiu a Série Juiz de Fora como constituida de paragnaisses na facies granulito, sendo a rocha-tipo um biotita-granada gnaisse com ortopiroxênio.

Esta rocha é normalmente escura de tonalidade esverdeada ou azulada, foliada e de estrutura bandada com alternância de níveis mais e menos escuros. Granada e biotita podem ser obsevadas em todos os afloramentos, no entanto, a identificação de ortopiroxênio é mais dificil. A granada pode chegar a ter dimensões centimétricas. É muito comum apresentar estruturas migmatíticas, nebulítica e/ou estromática, quando então torna-se mais clara. Os leucossomas são brancos a esverdeados/azulados e têm granada, quartzo azul e ortopiroxênio. Localmente, estes leucossomas apresentam schlierens de biotita e granada. Veios de quartzo também ocorrem e, tanto estes quanto os leucossomas, apresentam raramente grafita. Lentes e/ou boudins centimétricos de rocha calcissilicática associam-se a este conjunto, ocorrendo em proporções bastante reduzidas. Poucas bandas centimétricas de anfibolito são observadas, sempre em estágio avançado de alteração. É muito comum a presença de pegmatitos com biotita, discordantes ou concordantes em relação à foliação do paragnaisse.

Próximo aos contatos com a escama tectônica de ortogranulitos do Complexo Juiz de Fora, o paragnaisse adquire textura milonítica, onde porfroclastos de granada, feldspatos e ortopiroxênio ocorrem em uma matriz fina recristalizada com fitas de quartzo. $\mathrm{O}$ 
paragnaisse, é bem visível em lâminas delgadas. Possui granulometria fina à média e textura granoblástica, localmente poligonal, tornando-se milonítica próximo aos contatos com as diferentes escamas tectônicas. A análise petrográfica ao microscópio mostrou que esta rocha é muito rica em plagioclásio e relativamente pobre em quartzo. Os principais constituintes, além do plagioclásio, são biotita, granada, ortopiroxênio e clinopiroxênio. Sillimanita foi encontrada em apenas 1 afloramento. Como minerais acessórios são comuns apatita, por vezes em grandes quantidades, e mineral opaco. Por outro lado, os leucossomas são constituídos de ortoclásio micropertítico, plagioclásio, quartzo, granada, ortopiroxênio, biotita, zircão e apatita.

As rochas calcissilicáticas têm coloração clara, esverdeada, textura granoblástica poligonal e estrutura maciça. Os minerais constituintes são plagioclásio, clinopiroxênio, granada, ortopiroxênio, biotita e apatita. Os altos teores de plagioclásio e, por vezes, também de apatita do paragnaisse sugerem protólito cálcico. Esta sugestão é também apoiada pelo fato desta associação ser relativamente pobre em $\mathrm{K} \mathrm{e} \mathrm{Al}$, elementos estes só enriquecidos nos níveis pelíticos. É possível, então, que esta sequência represente um depósito de origem mista, em parte pelítico, em parte químico, provavelmente uma sequência de fundo marinho, constituída de margas e cherts.

\section{Tabela 9 - Composição Mineralógica, Características Texturais e Classificação dos Litotipos da Unidade Jardim Glória.}

\begin{tabular}{|l|l|l|l|}
\hline \multicolumn{1}{|c|}{ Litotipo } & $\begin{array}{l}\text { Minerais (em ordem } \\
\text { decrescente de vol) }\end{array}$ & Granulometria & Textura / Estrutura \\
\hline Paragnaisse & $\begin{array}{l}\text { plg, opx, gr, bt, cpx, qz, } \\
\text { ort, op, sll (rara), ap }\end{array}$ & fina à média & $\begin{array}{l}\text { Granoblástica - poligonal, } \\
\text { Grano-porfiroblástica, Milonitica; } \\
\text { Bandada, Foliada, Migmatítica. }\end{array}$ \\
\hline Leucossomas & $\begin{array}{l}\text { ort, plg, qz, bt, gr, opx, } \\
\text { op, zc, ap }\end{array}$ & fina à média & $\begin{array}{l}\text { Granoblástica; } \\
\text { Maciça a Foliada. }\end{array}$ \\
\hline Rocha Calcissilicática & plg, cpx, gr, bt, op, ap & fina à média & $\begin{array}{l}\text { Granoblástica - poligonal; } \\
\text { Maciça. }\end{array}$ \\
\hline
\end{tabular}

O biotita-sillimanita-granada gnaisse apresenta cor cinza clara, é rico em sillimanita e não é portador de ortopiroxênio. Ocorre sob a forma de lentes e camadas dentro do biotitagranada-ortopiroxênio gnaisse. Localmente, ocorrem níveis extremamente ricos em sillimanita, 
formando sillimanititos. Lentes e/ou camadas centimétricas de quartzito ocorrem intercaladas a esta unidade. O quartzito pode ser puro ou feldspático e poucas lentes apresentam granada, abrindo a possibilidade de, pelo menos, parte das lentes de quartzito serem gonditos e, portanto, terem protólito de origem química (chert impuro). O quartzito apresenta localmente sulfetos, hematita especular, grafita e é, comumente, percolado por óxidos e/ou hidróxidos de Mn ao longo da foliação, clivagens e fraturas.

O biotita-sillimanita-granada gnaisse tem granulometria fina, textura variando entre os termos granoblástico, nemato-granoblástico e pórfiro-granoblástico. Próximo aos contatos, é comum o desenvolvimento de foliação milonítica, onde minerais félsicos e granada compõem a fração porfiroclástica e a matriz é fina, recristalizada e inclui também biotita e sillimanita, ambos em cristais orientados. Os principais minerais constituintes são plagioclásio, ortoclásio, quartzo, sillimanita, granada e biotita. Como acessórios ocorrem mineral opaco, zircão e apatita.

Tabela 10 - Composição Mineralógica, Características Texturais Classificação do Bt-Gr-Sill Gnaisse e Quartzito da Unidade Jardim Glória.

\begin{tabular}{|l|l|c|l|}
\hline \multicolumn{1}{|c|}{ Litotipo } & $\begin{array}{l}\text { Minerais (em ordem } \\
\text { decrescente de \% vol) }\end{array}$ & Granulometria & Textura / Estrutura \\
\hline Bt-Sill-Gr Gnaisse & $\begin{array}{l}\text { plg, ort, qz, sll, bt, gr, op, } \\
\mathrm{zc}, \mathrm{ap}\end{array}$ & fina & $\begin{array}{l}\text { Granoblástica, Nemato-blás- } \\
\text { tica, Pórfiro-Granoblástica, } \\
\text { Milonitica; Foliada. }\end{array}$ \\
\hline Quartzito & $\mathrm{qz}, \mathrm{plg}, \mathrm{gr}, \mathrm{hm}, \mathrm{sf}, \mathrm{gf}$ & fina & $\begin{array}{l}\text { Granoblástica a Milonítica; } \\
\text { Foliada }\end{array}$ \\
\hline
\end{tabular}

\section{II.3.2) Ortogranulitos do Complexo Juiz de Fora}

Sob a denominação de Complexo Juiz de Fora, foram englobadas rochas metamórficas ortoderivadas, cujas paragêneses são diagnósticas para a facies granulito. Este conjunto dispõe-se em escamas tectônicas interdigitadas com escamas de rochas supracrustais metassedimentares, mostrando alto grau de obliteração de texturas, estruturas originais. Com base nas relações de campo, fica claro que estes ortogranulitos não são intrusivos em rochas 
metassedimentares, já que não contêm enclaves nem nenhum tipo associação metassedimentar. No entanto, dada a complexidade estrutural deste Domínio, restam importantes dúvidas sobre as relações originais entre os dois conjuntos orto e para derivados: se os ortogranulitos são o embasamento das rochas metassedimentares; ou se cada conjunto representa um terreno distinto, exótico, que, pelos efeitos de intenso tectonismo, foram dispostos lado a lado.

Além dos resultados advindos da recorrência de eventos deformacionais, a individualização de litotipos do Complexo Juiz de Fora constitui-se em uma tarefa árdua, visto que o metamorfismo na facies granulito, em especial, leva as rochas a adquirirem uma tonalidade esverdeada, o que diminui o grau de contraste entre as fases minerais. Na área estudada existem excelentes exposições das rochas deste Complexo, principalmente em pedreiras (abandonadas ou ativas) e em cortes da BR - 040 e da Estrada de Ferro Central do Brasil. Todas estas exposições foram estudadas detalhadamente, o que, juntamente com a análise petrográfica ao microscópio, levou à identificação de seis diferentes litotipos ou associações litológicas: a) enderbitos e quartzo noritos; b) noritos; c) charnockitos cor de carne; d) leucossomas charnockíticos; e) charnockitos intrusivos; e f) felsitos charnockíticos.

\section{a) Enderbito / Quartzo Norito e Bt Gnaisse Associado}

Estas rochas têm cor esverdeada e bandamento centimétrico, dado pela alternância de níveis mais félsicos centimétricos (cor caramelo) e menos félsicos milimétricos (cor verde) (Fig. 15). A foliação não é claramente percebida, a não ser pela orientação de grãos dispostos em níveis máficos milimétricos ou quando a rocha encontra-se parcialmente alterada. Associados a estas rochas, ocorrem noritos sob a forma de bandas e/ou boudins de espessuras que variam de centimétricas a 1 metro. Bandas leucocráticas, de composição charnockítica e cor caramelo rosado, alternam-se com os demais litotipos citados e, eventualmente, mostram contatos intrusivos com as rochas enderbíticas. O contato entre as diferentes bandas é regular e bem definido. Boudins centimétricos a decamétricos de uma rocha maciça, de cor cinza azulada, ocorrem localmente, mais especificamente, na Pedreira do ponto 518 (porção Leste da área mapeada). Localmente, este conjunto apresenta-se migmatítico, com estrutura estromática, cujos leucossomas são esverdeados, com grãos grossos de opx e hornblenda. Em zonas de cisalhamento o enderbito / quartzo norito é afetado por metamorfismo retrógrado e material leucogranítico róseo preenche os planos de cisalhamento. Forma-se então um biotita 
gnaisse bandado e migmatítico e as injeções róseas, estiradas e boudinadas, enriquecem o gnaisse em megacristais de K-feldspato, gerando, localmente, estrutura tipo augen.

O enderbito / quartzo norito é uma rocha de granulometria fina à média, textura que varia de granoblástica a protomilonítica, com foliação fraca a forte. Foliação milonítica formase localmente, gerando porfiroclastos constituídos de plagioclásio, ortoclásio, quartzo e ortopiroxênio, e matriz fina, formada pelas porções recristalizadas dos porfiroclastos, além de biotita, mineral opaco e hornblenda. Esta estrutura é melhor desenvolvida próximo aos contatos tectônicos (zonas de cisalhamentos), onde, em função da percolação de fluidos, a rocha adquire coloração cinza, indicando, provavelmente, processo retrometamórfico. $\mathrm{O}$ plagioclásio, principal constituinte, encerra várias feições interessantes como antipertitas, intercrescimento gráfico com quartzo; inclusões arredondadas de quartzo e inclusões retas, orientadas, de finas agulhas de mineral opaco. O ortoclásio não é pertítico e é comum a ocorrência de mirmequita em algumas interfaces ortoclásio / plagioclásio. O ortopiroxênio tem também inclusões de mineral opaco ao longo de suas clivagens e apresenta-se, por vezes, geminado. Hornblenda e biotita ocorrem na matriz, nas bordas de ortopiroxênio. A rocha é relativamente rica em zircão e fases acessórias também comuns são mineral opaco e apatita.

O biotita gnaisse é uma rocha de textura granoblástica, localmente poligonal e inequigranular (ou porfiróide?). Ortoclásio micropertítico e plagioclásio ocorrem em grãos maiores (finos a médios) em matriz fina constituída de microclina, quartzo, biotita e relativamente, muita titanita. Outros minerais acessórios são apatita, mineral opaco e zircão. Como minerais secundários ocorrem muscovita, sericita, clorita e carbonato.

A rocha azulada tem textura granoblástica e estrutura maciça. Os minerais constituintes são plagioclásio, clinopiroxênio, mineral opaco, titanita, biotita e zircão.

Poucos corpos pegmatíticos ocorrem associados a estes granulitos. São rochas intrusivas, discordantes, de coloração cinza e 1 metro de espessura. A composição mineralógica é dada por quartzo, K-feldspato, plagioclásio, biotita e magnetita. Próximo ao contato com este pegmatito, em uma zona muito restrita, os ortogranulitos sofrem processo de retrometamorfismo, levando à formação de hornblenda gnaisse mesocrático, de composição tonalítica, e de hornblenda gnaisse leucocrático, granítico a granodiorítico. 


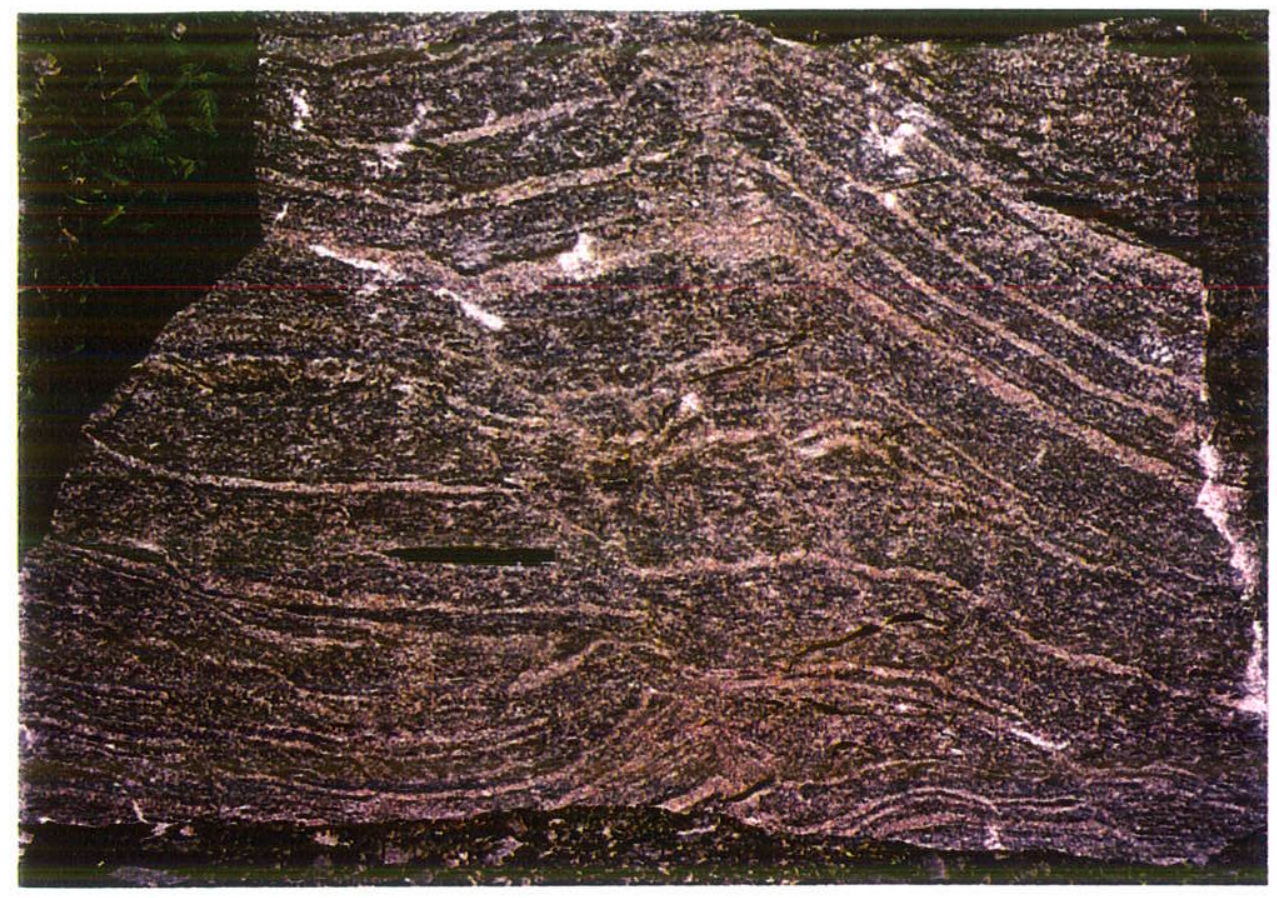

Figura 15 - Enderbito / Quartzo Norito e Biotita Gnaisse Associado. Complexo Juiz de Fora. Ponto 518

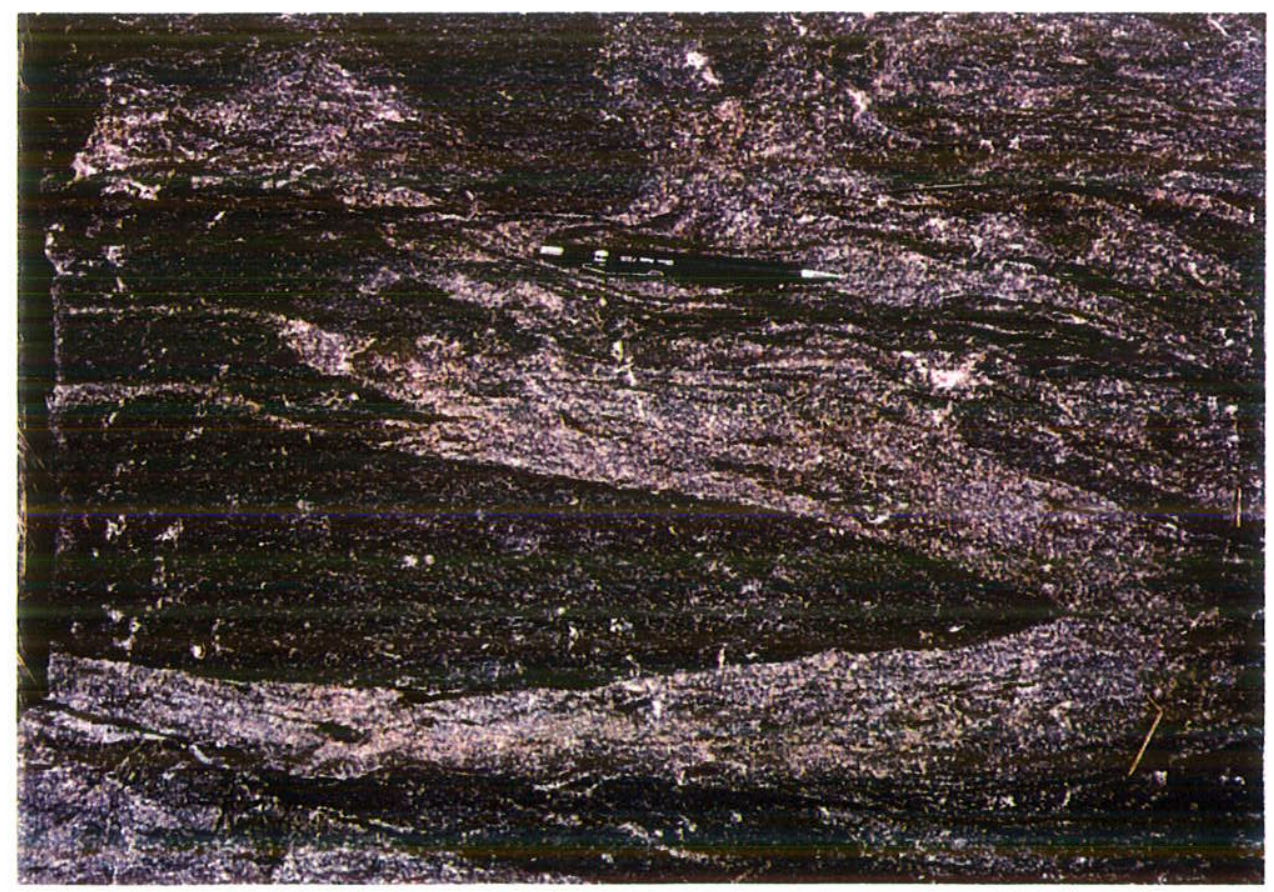

Figura 16 - Norito - Complexo Juiz de Fora (foto de afloramento). Ponto 518 


\section{b) Norito}

Ocorre sob a forma de bandas e/ou boudins de espessura centimétrica a 1 metro, hospedados em granulitos quartzo noríticos a charnockíticos (Fig. 16). Esta rocha tem composição gabróica, granulometria fina à média, textura granoblástica a protomilonítica e estrutura maciça a fracamente foliada. Quando protomilonítica, plagioclásio, clinopiroxênio, ortopiroxênio, hornblenda e, subordinadamente, mineral opaco constituem a fração porfiroclástica. Em seus bordos, estes minerais foram afetados por um processo de recristalização incipiente, levando à formação de restrita matriz fina e poligonizada. Fazem parte desta matriz, biotita, mineral opaco, granada, quartzo, apatita e uma segunda geração de hornblenda. Esta forma-se nas bordas e ao longo de clivagens de piroxênios, enquanto que a biotita forma-se preferencialmente nas bordas de hornblenda da primeira geração. É muito comum a ocorrência de mineral opaco acicular em clivagens de hornblenda da primeira geração e, menos frequentemente, em piroxênios. Granada ocorre nas bordas de ortopiroxênio e mineral opaco. Textura coronítica de granada em ortopiroxênio, clinopiroxênio ou plagioclásio é comum. A formação da granada está, em parte, associada à formação de biotita e da segunda geração de hornblenda.

\section{c) Migmatitos Estromáticos Granulíticos}

É comum o conjunto formado por enderbito / quartzo norito e norito apresentar texturas migmatíticas reliquiares. Nestes locais, pode-se verificar que tanto paleossomas quanto melano e leucossomas são verdes e têm ortopiroxênio, o que sugere fortemente que a anatexia in situ precedeu a granulitização destas rochas. Muito embora os migmatitos não constituam um tipo litológico distinto e sim uma disposição estrutural conspícua, eles são aqui tratados separadamente por uma questão de clareza, dada sua complexidade.

Os migmatitos são caracterizados por uma alternância de mesossomas enderbíticos e leucossomas charnockíticos, ambos com ortopiroxênio. Em zonas de cisalhamento paralelas à foliação principal ocorre o retrometamorfismo destas rochas, transformando-as em migmatitos a hornblenda. Ainda nestas mesmas zonas de cisalhamento ocorrem leucossomas com granada e biotita.

O Mesossoma Enderbítico apresenta fraca foliação, textura granoblástica a protomilonítica e foliação fraca a milonítica. Seus constituintes minerais são plagioclásio (não 
anti-pertítico), ortoclásio (não pertítico), quartzo, ortopiroxênio, hornblenda, biotita, mineral opaco, titanita, apatita e zircão. Tem, como característica mais marcante, a ocorrência de estrutura simplectítica entre hornblenda e plagioclásio e/ou hornblenda e mineral opaco (provavelmente ilmenita), desenvolvida nos bordos ou nas proximidades de grãos de ortopiroxênio. Mirmequita é comum nas interfaces ortoclásio / plagioclásio.

O leucossoma charnockítico tem textura granoblástica a protomilonítica e uma fraca foliação. A presença de estrutura simplectítica é também comum neste litotipo, sendo aqui formada pelo intercrescimento entre biotita e plagioclásio, que se desenvolve nas proximidades dos grãos de ortopiroxênio. O ortoclásio micropertítico é o constituinte de maior percentual em volume desta rocha que tem também quartzo, plagioclásio (não antipertítico), ortopiroxênio, hornblenda, granada (pequeno volume), mineral opaco, apatita, titanita e zircão. Intercrescimento mirmequítico é também comum nas interfaces ortoclásio / plagioclásio.

Localmente, os leucossomas transicionam para diatexitos charnockíticos, leucocráticos, com schlierens ricos em biotita, como na Pedreira Santa Monica (a SE do centro de Juiz de Fora; ponto 151 no Anexo 1), onde também apresentam rara granada. Tanto os migmatitos quanto os diatexitos são verdes e têm ortopiroxênio.

\section{d) Charnockitos}

Além dos leucossomas charnockíticos, três tipos de charnockitos ocorrem no Complexo Juiz de Fora: bandas e injeções de rocha charnockítica; charnockito intrusivo; e felsito charnockítico intrusivo. Cada uma destas rochas será descrita a seguir.

\section{d.4) Bandas e Injeções de Rocha Charnockítica}

As bandas e injeções de rocha charnockítica constituem corpos centimétricos, de cor caramelo-rosada e ocorrem hospedadas em enderbitos e quartzo noritos (Fig 17a), com os quais localmente mostram contatos intrusivos (Fig. 17b). A análise petrográfica revelou que estas bandas têm composição enderbítica / charno-enderbítica a charnockítica, sendo esta última a predominante. A rocha tem granulometria fina à média, textura granoblástica a protomilonítica e estrutura maciça. Nos termos enderbíticos/charno-enderbíticos, o 

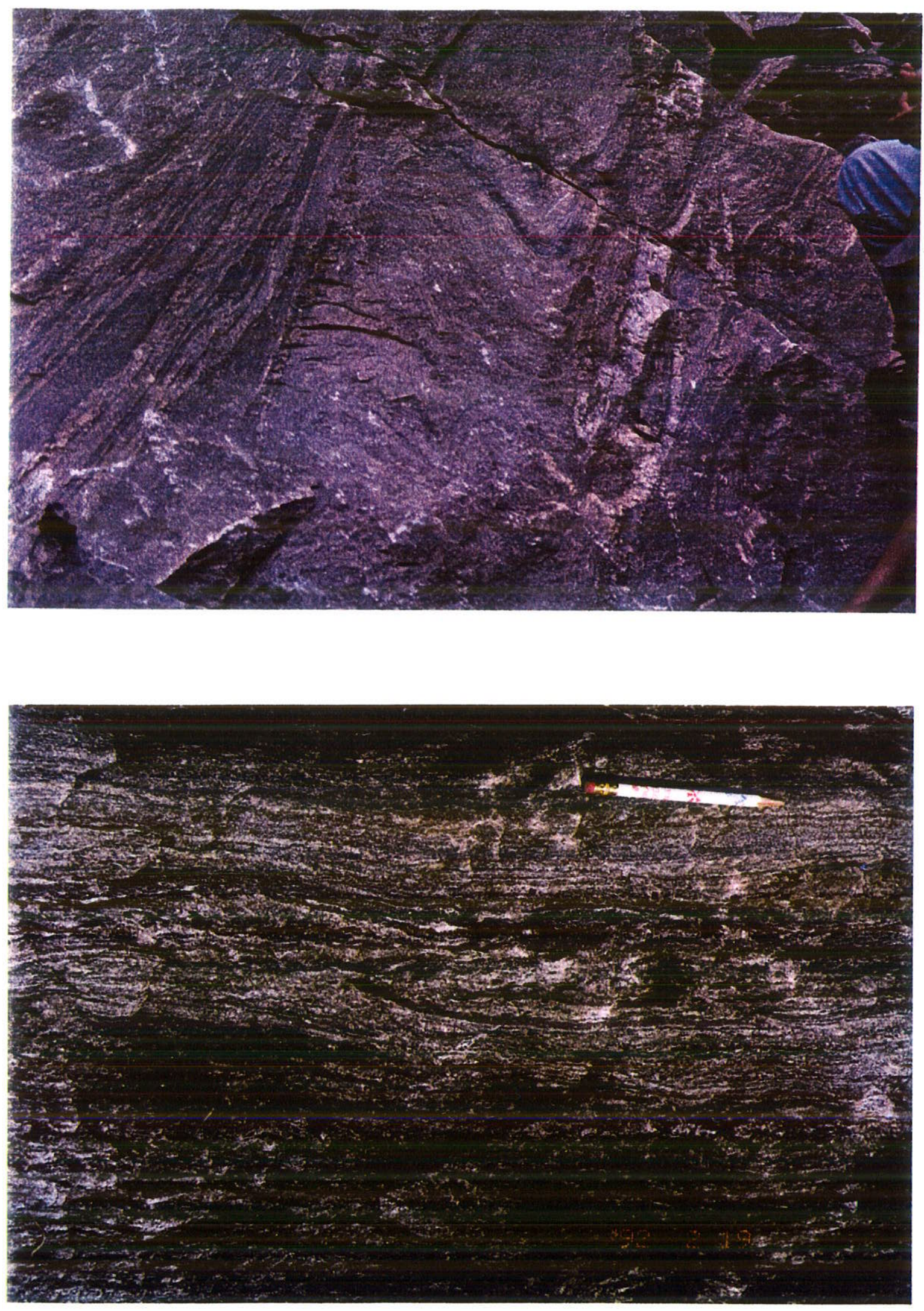

Figura 17a e b - Bandas e injeções/leucossoma charnochíticos. Complexo Juiz de Fora. Ponto32 
plagioclásio é micro-antipertítico e tem inclusões gráficas de quartzo, enquanto que nos termos charnockíticos, o ortoclásio é micropertítico. Plagioclásio, ortoclásio, quartzo e ortopiroxênio constituem os porfiroclastos das porções protomiloníticas e apresentam bordos recristalizados que, juntamente com biotita e mineral opaco, formam a matriz da rocha. Além do mineral opaco, apatita e zircão são fases acessórias comuns.

\section{d.2) Charnockito}

Intrusivo em todo o conjunto, ocorre um corpo de rocha félsica, hololeucocrática a leucocrática, isotrópica, com poucos a raros grãos grossos de ortopiroxênio. Localmente, talvez em zonas de borda, a rocha mostra-se pintada de grãos de allanita. O charnockito intrusivo tem estrutura predominantemente maciça a fracamente foliada, adquirindo, localmente, foliação milonítica. Em alguns locais, como na Pedreira Santa Mônica, pode-se observar uma continuidade entre este corpo intrusivo e os leucossomas verdes dos migmatitos granulíticos já abordados.

O charnockito intrusivo tem granulometria média à grossa e, quando maciça, a textura é granoblástica. A textura protomilonítica a milonítica é formada por porfiroclastos de plagioclásio, ortoclásio, agregados policristalinos de quartzo, ortopiroxênio e mineral opaco (?) em matriz fina, onde as porções recristalizadas dos porfiroclastos se juntam à biotita que ocorre em plaquetas orientadas. O conjunto dá origem a uma foliação milonitica anastomosada. O ortoclásio é seu principal constituinte e mostra-se invariavelmente micropertítico. Quartzo e plagioclásio (às vezes, antipertítico) também ocorrem em quantidades apreciáveis e é abundante a presença de intercrescimento mirmequítico nas interfaces ortocláio / plagioclásio. Os minerais máficos presentes são raros cristais de ortopiroxênio, biotita, rara hornblenda, rara granada e, localmente, poucos grãos de allanita. As fases acessórias são, além da allanita, mineral opaco, zircão e apatita. Uma característica interessante é a presença de textura simplectítica entre biotita e feldspato (ortoclásio e/ou plagioclásio) e/ou quartzo, provavelmente resultante de reação que levou ao consumo de ortopiroxênio (restos deste mineral são observados próximo ao simplectito). Raros grãos de hornblenda são consumidos para gerar biotita. 
Os leucossomas verdes têm composição charnockítica, textura granoblástica a protomilonítica e foliação fraca. Seu principal constituinte é o K-feldspato (ortoclásio micropertítico como porfiroclasto e microclina em arranjo poligonal na matriz). Ortopiroxênio, hornblenda, plagioclásio e quartzo ocorrem como porfiroclastos com bordos recristalizados. Plaquetas orientadas de biotita ocorrem na matriz, próximo a ortopiroxênio e hornblenda. Granada é rara e mineral opaco, apatita e zircão compõem o conjunto das fases acessórias.

\section{d.3) Felsito Charnockítico}

É uma rocha de cor clara, ligeiramente esverdeada, de granulometria grossa, carater isotrópico e com blastos centimétricos de ortopiroxênio. Apresenta contatos intrusivos com granulitos de composição enderbítica e tem enclaves de rochas granulíticas básicas. Localmente, forma porções pegmatóides com longos (centimétricos) cristais de anfibólio (hornblenda?, tremolita?). A rocha tem textura granoblástica, estrutura maciça e granulometria grossa. Seu principal constituinte é o quartzo que apresentamse com extinção ondulante e contatos arredondados tipo "embayed". Finas plaquetas orientadas de biotita, formadas próximo aos grãos de ortopiroxênio, conferem fraca foliação à rocha. Os feldspatos, se presentes, são de dificil identificação. Em diagrama QAP normativo, (Le Maitre, 1989), a rocha plota no campo 1A. As fases acessórias são apatita e zircão.

Tabela 11 - Composição Mineralógica, Características Texturais e Classificação dos Litotipos do Complexo Juiz de Fora.

\begin{tabular}{|l|l|c|c|}
\hline \multicolumn{1}{|c|}{ Litotipo } & $\begin{array}{l}\text { Minerais (em ordem } \\
\text { decrescente de \% vol) }\end{array}$ & Granulometria & Textura/Estrutura \\
\hline $\begin{array}{l}\text { Enderbito } \\
\text { QuartzoNorito }\end{array}$ & $\begin{array}{l}\mathrm{plg}, \mathrm{opx}, \mathrm{hb}, \mathrm{ort}, \mathrm{bt}, \mathrm{op}, \mathrm{ap}, \\
\mathrm{zc}\end{array}$ & fina à média & $\begin{array}{l}\text { Granoblástica a Proto-milo- } \\
\text { nítica; Maciça a Foliada. }\end{array}$ \\
\hline Norito & $\begin{array}{l}\mathrm{plg}, \mathrm{cpx}, \mathrm{hb}, \mathrm{opx}, \mathrm{op}, \mathrm{gr}, \\
\mathrm{ort}, \mathrm{qz}, \mathrm{bt}, \mathrm{ap}, \mathrm{ti}, \mathrm{zc}\end{array}$ & fina à média & $\begin{array}{l}\text { Granoblástica a Proto-milo- } \\
\text { nítica; Maciça. }\end{array}$ \\
\hline Migmatito Granulítico & $\begin{array}{l}\mathrm{plg}, \mathrm{ort}, \mathrm{hb}, \mathrm{qz}, \mathrm{bt}, \mathrm{opx}, \mathrm{op}, \\
\mathrm{gr}, \mathrm{ap}, \mathrm{zc}\end{array}$ & fina à média & $\begin{array}{l}\text { Granoblástica a Proto-milo- } \\
\text { nítica; Estromática. }\end{array}$ \\
\hline $\begin{array}{l}\text { Bandas e Injeçôes de } \\
\text { Rocha Charnockítica }\end{array}$ & $\begin{array}{l}\mathrm{plg}, \mathrm{q} \mathrm{z}, \mathrm{ort}, \mathrm{opx}, \mathrm{bt}, \mathrm{op}, \mathrm{ap}, \\
\mathrm{zc}\end{array}$ & fina à média & $\begin{array}{l}\text { Granoblástica a Proto-milo- } \\
\text { nítica; Maciça. }\end{array}$ \\
\hline $\begin{array}{l}\text { Chatnockito Intrusivo } \\
\text { e Leucossomas }\end{array}$ & $\begin{array}{l}\text { ort, } \mathrm{qz}, \mathrm{plg}, \mathrm{opx}, \mathrm{all}, \mathrm{op}, \\
\mathrm{zc}, \mathrm{ap}\end{array}$ & média a grossa & $\begin{array}{l}\text { Granoblastica a Milonítica; } \\
\text { Maciça a Foliada. }\end{array}$ \\
\hline $\begin{array}{l}\text { Felsito Charnockítico } \\
\text { Intrusivo }\end{array}$ & $\begin{array}{l}\mathrm{qz}, \mathrm{opx}, \mathrm{bt}, \mathrm{ap}, \mathrm{zc}, \mathrm{plg}(?) \\
\text { ort }(?)\end{array}$ & grossa & $\begin{array}{l}\text { Granular/Granoblástica; } \\
\text { Maciça }\end{array}$ \\
\hline
\end{tabular}




\section{II.3.3) Ortognaisses (Biotita gnaisses e Biotita-Hornblenda gnaisses) da Suite Quirino-Dorândia}

Estes gnaisses são descritos mais adiante, uma vez que constituem uma associação litológica característica do Domínio Tectônico Paraíba do Sul.

\section{II.3.4) Rochas Metassedimentares e Metabasitos Associados}

Neste Domínio duas associações distintas de rochas metassedimentares, ambas associadas a metabasitos, puderam ser individualizadas: 1) biotita gnaisse homogêneo associado a quartzitos; e 2) biotita-granada-sillimanita gnaisses associados a quartzitos e rochas calcissilicáticas.

\section{\# Biotita Gnaisses Bandados, Quartzitos e Metabasitos Associados}

O biotita gnaisse homogêneo é o litotipo mais suscetível ao intemperismo na área. As melhores exposições desta rocha são encontradas em cortes de estradas, já em estágio avançado de alteração. Ocorre ao longo de duas escamas tectônicas e forma a base deste Domínio. Considerando todo o pacote sedimentar, o biotita gnaisse homogêneo ocorre estruturalmente na base. Este gnaisse apresenta-se foliado, no entanto, o bandamento é fino, com altenância de níveis milimétricos claros (félsicos) e escuros (biotíticos). Localmente ocorrem estruturas migmatíticas que indicam processos de anatexia in situ, e o conjunto tornase mais grosso, com o desenvolvimento de leucossomas graníticos, configurando estruturas do tipo estromáticas e/ou bolsões de material fundido. A granulometria desta rocha varia de fina à grossa, mantendo, entretanto, seu carater homogêneo. Próximo aos contatos com outras escamas tectônicas, a rocha adquire textura milonítica, com porfiroclastos de feldspatos (raramente granada) e matriz fina recrstalizada com biotita. $O$ gnaisse apresenta composição mineralógica monótona e pouco variável, dada por plagioclásio, ortoclásio quartzo, biotita e rara granada, o que parece explicar o caracter homogêneo desta rocha.

Associado a este gnaisse ocorre um grande número de camadas centimétricas a métricas de quartzito, cuja granulometria varia de fina à média. As camadas de quartzito possuem granulometria grossa e, muitas vezes, são as únicas expressões desta associação em superficie. O quartzito apresenta uma clivagem espaçada, ao longo da qual ocorrem plaquetas orientadas de muscovita. É comum a presença de uma lineação mineral, dada pelo estiramento 
de grãos de quartzo e também pela orientação de grãos de muscovita e turmalina. Próximo aos contatos tectônicos, o quartzito também apresenta-se milonítico, quando, então, destacam-se porfiroclastos de plagioclásio. Os minerais constituintes são quartzo, plagioclásio, muscovita, sillimanita e raramente biotita e/ou granada. Como fases acessórias ocorrem zircão, turmalina e mineral opaco.

Bandas e/ou boudins de anfibolito e/ou rocha calcissilicática ocorrem associados a este conjunto, porém em pequenas proporções. Ocorrem normalmente muito intemperizados, constituindo-se em material argiloso de coloração ocre.

Tabela 12 - Composição Mineralógica, Características Texturais e Classificação dos Biotita gnaisses bandados e quartzitos.

\begin{tabular}{|l|l|c|l|}
\hline \multicolumn{1}{|c|}{ Litotipo } & $\begin{array}{l}\text { Minerais (em ordem } \\
\text { decrescente de \% vol) }\end{array}$ & Granulometria & \multicolumn{1}{|c|}{ Textura/Estrutura } \\
\hline Bt Gnaisse Bandado & $\begin{array}{l}\text { plg, ort, qz, bt, gr (rara), } \\
\text { ap, op, zc }\end{array}$ & fina à grossa & $\begin{array}{l}\text { Granoblástica a Milonítica; } \\
\text { Bandada, Foliada, Migmatí- } \\
\text { tica. }\end{array}$ \\
\hline Quartzito & $\begin{array}{l}\text { qz, plg, um, sll, bt, gr, } \\
\text { zc, tur, op }\end{array}$ & $\begin{array}{l}\text { fina à média, } \\
\text { localmente, grossa }\end{array}$ & $\begin{array}{l}\text { Granoblástica a Milonítica; } \\
\text { Foliada. }\end{array}$ \\
\hline
\end{tabular}

\section{2) Biotita-Granada-(Sillimanita) Gnaisses, Biotita Gnaisses Homogêneos e Bandados, Quartzitos, Rochas Calcissilicáticas, Granada Quartzito e Metabasitos Associados}

Esta associação litológica ocorre estruturalmente acima da descrita anteriormente. Está distribuída ao longo de oito escamas tectônicas principais e outras cinco de menor tamanho, que interdigitam-se com ortogranulitos do CJF e ocupam a porção sudeste da área estudada.

O litotipo predominante é um biotita-granada-sillimanita gnaisse de granulometria média à grossa, foliação marcante e bandamento gnáissico normalmente presente. Estruturas migmatíticas, principalmente estromáticas, são comumente observadas, evidenciando o desenvolvimento de anatexia in situ. Os leucossomas gerados têm a composição de granitos 
peraluminosos que, além de quartzo e feldspatos, apresentam granada e biotita. Na escama superior, houve desenvolvimento de leucogranito branco com granada e cordierita, devendo-se ressaltar que este último mineral não é encontrado nos gnaisses que encaixam e que deram origem ao leucogranito. Por ocorrerem em escamas de espessura relativamente reduzida, é comum estes gnaisses apresentarem textura milonítica, onde porfiroclastos de feldspatos e granada ocorrem em uma matriz mais fina, recristalizada, e minerais como biotita e sillimanita orientam-se ao longo da foliação milonítica. A paragênese da rocha e as evidências de anatexia indicam condições de metamorfismo de alto grau, porém não são diagnósticas de facies metamórfica, sendo estáveis tanto na facies anfibolito superior quanto na facies granulito. Entretanto, os gnaisses apresentam comumente coloração acinzentada, resultante da alternância de bandas claras (brancas) e escuras (pretas), cores estas típicas de ambientes metamórficos com $\mathrm{P}_{\mathrm{H} 2 \mathrm{O}}=\mathrm{P}_{\text {carga, }}$ característico da facies anfibolito. Localmente, a rocha adquire coloração esverdeada, sugerindo ambiente metamórfico anidro, típico da facies granulito. Camadas e/ou lentes de biotita gnaisses homogêneos e quartzitos ocorrem intercaladas a estes gnaisses. Bandas, lentes e/ou boudins de rocha calcissilicática e granada quartzito também associam-se ao conjunto. Anfibolito ocorre também sob a forma de bandas e/ou boudins. É comum a presença de pegmatitos de composição granítica, principalmente discordantes em relação à foliação das rochas.

O biotita-granada-sillimanita gnaisse apresenta uma variedade de tipos texturais, como granoblásticos, grano-porfiroblásticos, nematoblásticos, protomiloníticos e miloníticos. Em contraste com os biotita gnaisses homogêneos, esta rocha tem uma composição mineralógica bem variada, dada por plagioclásio, ortoclásio, quartzo, biotia, granada, sillimanita e/ou fibrolita e, como acessórios, mineral opaco, zircão, rutilo, apatita e hercinita (rara). Localmente, há desenvolvimento de ortopiroxênio nos gnaisses de coloração esverdeada, diagnosticando condições metamórficas da facies granulito. Quando milonítica, os minerais encontrados como porfiroclastos são plagioclásio, ortoclásio micropertítico, granada, quartzo, ortopiroxênio, mineral opaco e sillimanita (?). Na matriz recristalizada, além dos minerais félsicos, ocorrem plaquetas de biotita e prismas de sillimanita e fibrolita orientados segunda a foliação. Muscovita, sericita, carbonato e clorita são fases secundárias formadas pela alteração de feldspatos e biotita. 
Biotita gnaisses homogêneos, muito semelhantes aos descritos no item anterior, ocorrem interdigitados aos biotita-granada-sillimanita gnaisses nas escamas estruturalmente inferiores. Em direção ao topo estrutural, a presença dos gnaisses homogêneos torna-se gradativamente menos expressiva até a total ausência. É comum a presença de biotita gnaisses homogêneos estar associada à presença de quartzitos.

Camadas e lentes centimétricas a métricas de quartzito associam-se com frequência a este conjunto e, como dito anteriormente, parecem guardar uma relação estreita com os biotita gnaisses homogêneos. No entanto, ocorrem também intercaladas com camadas de biotitagranada-sillimanita gnaisse.

Assim como ocorre para os gnaisses homogêneos, as camadas de quartzito são também mais frequentes nas escamas inferiores, sendo que nas três escamas superiores não foram encontrados quartzitos. Da mesma forma que os gnaisses homogêneos, os quartzitos são bastante semelhantes aos descritos no item anterior, apresentando as mesmas feições estruturais e a mesma composição mineralógica, embora sejam mais enriquecidos em muscovita e sillimanita.

Bandas, lentes e/ou boudins de rocha calcissilicática e, subordinadamente, de granada quartzito ocorrem associados aos biotita-granada-sillimanita gnaisses, sendo mais abundantes na escama 5 (a mais espessa). A rocha calcissilicática tem coloração verde clara, aspecto maciço, granulometria fina à média, textura granoblástica a poligonal e é constituída de plagiocásio, clinopiroxênio, biotita, mineral opaco, quartzo e granada.

O granada quartzito tem coloração acastanhada e estrutura maciça a bandada, com alternância de níveis félsicos brancos e níveis félsicos com granada castanhos. A rocha tem granulometria média à grossa e é constituída de quartzo, granada vermelha-alaranjada e mineral opaco. Óxidos e/ou hidróxidos de Mn podem estar presentes nos espaços intergranulares.

Bandas e/ou boudins de anfibolito ocorrem normalmente paralelos ao bandamento e à foliação da rocha hospedeira. 
Tabela 13 “ Composição Mineralógica, Características Texturais e Classificação dos Biotita-Granadan(Sillimanita) Gnaisses e Litotipos Associados.

\begin{tabular}{|c|c|c|c|}
\hline Litotipo & $\begin{array}{l}\text { Minerais (em ordem } \\
\text { decrescente de \% vol) }\end{array}$ & Granulometria & Textura/Estrutura \\
\hline Bt-Gr-(Sill) Gnaisse & $\begin{array}{l}\text { plg, ort, qz, bt, gr, sll, } \\
\text { fbr, op, zc, rt, ap, hc } \\
\text { (rara), opx (raro) }\end{array}$ & média à grossa & $\begin{array}{l}\text { Granoblástica a Milonítica; } \\
\text { Foliada, Bandada, Migma- } \\
\text { títica. }\end{array}$ \\
\hline $\begin{array}{l}\text { Leucossomas } \\
\text { Peraluminosos }\end{array}$ & plg, ort, $\mathrm{q} z, \mathrm{gr}, \mathrm{bt},(\mathrm{crd})$ & média à grossa & $\begin{array}{l}\text { Granoblástica a Milonítica; } \\
\text { Maciça à Foliada. }\end{array}$ \\
\hline Bt Gnaisse Bandado & $\begin{array}{l}\text { plg, ort, qz, bt, gr (rara), } \\
a p, o p, z c\end{array}$ & fina à grossa & $\begin{array}{l}\text { Granoblástica a Milonítica; } \\
\text { Bandada, Foliada, Migmati- } \\
\text { tica. }\end{array}$ \\
\hline Quartzito & $\begin{array}{l}\mathrm{qz}, \mathrm{plg}, \mathrm{um}, \text { sll, bt, gr, } \\
z c, \text { tur, op }\end{array}$ & $\begin{array}{c}\text { fina à média, } \\
\text { localmente, grossa }\end{array}$ & $\begin{array}{l}\text { Granoblástica a Milonítica; } \\
\text { Foliada. }\end{array}$ \\
\hline Rocha Calcissilicática & $\begin{array}{l}\text { plg, cpx, bt, op, qz, gr, } \\
\text { ap, ti }\end{array}$ & fina à média & $\begin{array}{l}\text { Granoblástica - Poligonal; } \\
\text { Maciça. }\end{array}$ \\
\hline Granada Quartzito & $q z, g r, o p$ & média à grossa & $\begin{array}{l}\text { Granoblástica - Poligonal; } \\
\text { Maciça a Bandada. }\end{array}$ \\
\hline
\end{tabular}

\section{II.3.5) Suite Intrusiva Matias Barbosa}

Dois tipos litológicos compõem esta suite intrusiva: a) biotita gnaisse homogêneo fino; e b) Leucogranito rosado. Estas rochas compõem um corpo ígneo de forma alongada numa direção paralela à foliação regional, constituindo o substrato geológico da cidade de Matias Barbosa. As rochas frequentemente apresentam foliação interna paralela àquelas dos demais litotipos. Em geral, as relações de contato com as demais rochas deste Domínio Tectônico não são muito claras. No entanto, na porção a nordeste da área estudada, foi observado contato claramente intrusivo deste biotita gnaisse homogêneo fino com biotita-granada-sillimanitaortopiroxênio gnaisse (Fig. 18) da associação descrita anteriormente. Além disso, é comum a ocorrência de enclaves de rochas calcissilicáticas, representando provavelmente xenólitos das rochas encaixantes. Três diferentes associações litológicas (ortogranulitos do Complexo Juiz de Fora, biotita gnaisse bandado e biotita-granada-sillimanita gnaisse) deste Domínio formam contatos tríplices em locais onde há desenvolvimento de texturas miloníticas. Estas relações sugerem fortemente que, pelo menos em parte, as rochas da suite intrusiva Matias Barbosa 


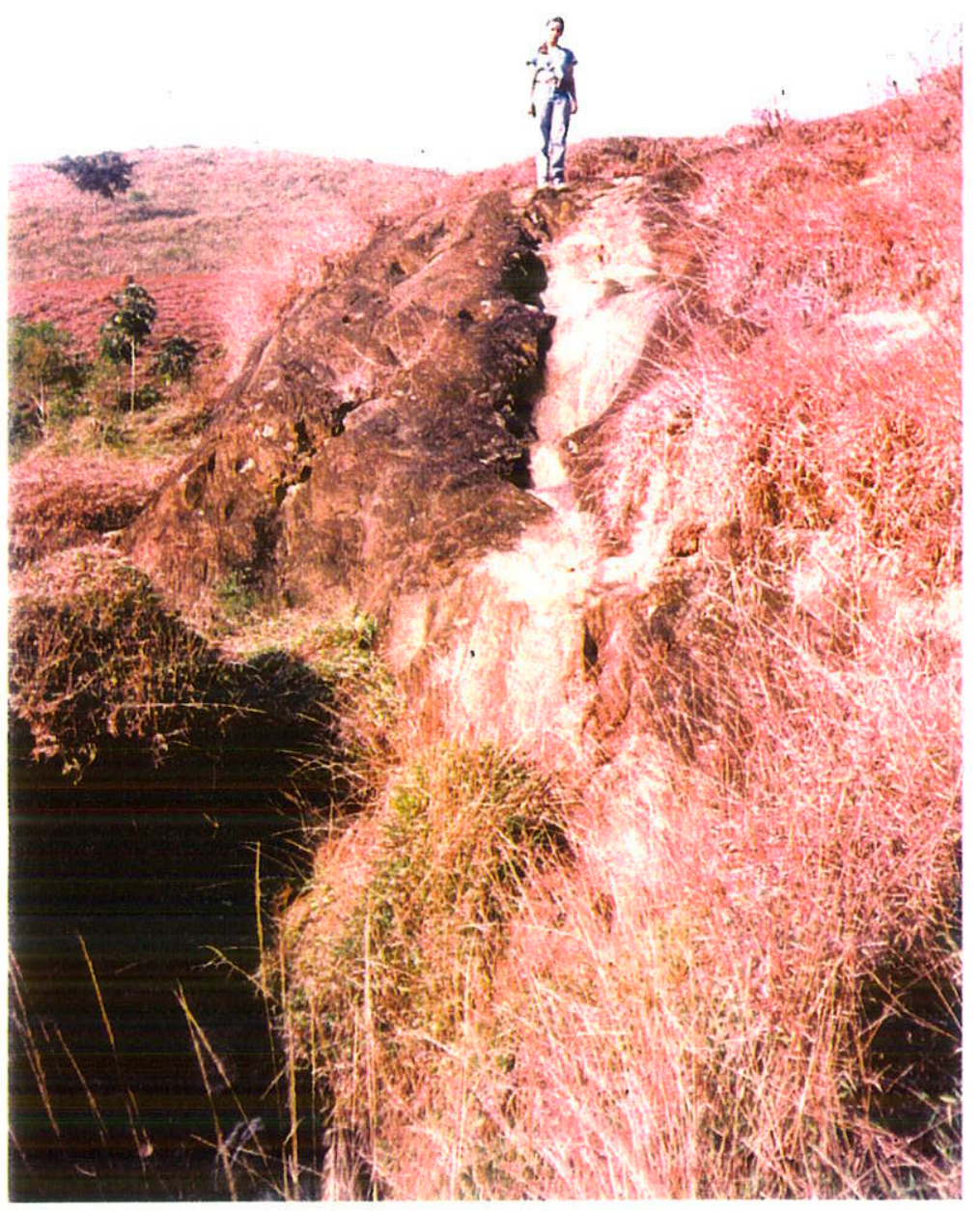

Figura 18 - Contato intrusivo da Suite Matias Barbosa com rochas metassedimentares. Folha Mar de Espanha. Ponto307. 
foram envolvidas na tectônica responsável pela interdigitação de escamas. A seguir será descrito cada um dos litotipos que compõem esta suite.

\section{a) Biotita Gnaisse Fino Homogêneo}

Este é o litotipo predominante da associação. A rocha tem coloração cinza escura e aspecto homogêneo e isotrópico quando observada a certa distância. De perto, a foliação é bem marcante e é comum a presença de grãos grossos de hornblenda esparsamente distribuídos. A granulometria da rocha é predominantemente fina, podendo chegar à média. Leucossomas irregulares, discordantes e concordantes, também com cristais grossos de hornblenda ocorrem eventualmente e de maneira esparsa, não alterando o carater homogêneo da rocha. Tem schlierens e pãezinhos máficos próximos aos níveis leucossomáticos. Tanto a rocha quanto os leucossomas estão dobrados (dobras fechadas intrafoliais), indicando que este conjunto foi afetado pela fase de deformação principal desenvolvida na área. Localmente, esta rocha torna-se porfiróide, com megacristais (milimétricos a centimétricos) euedrais de $\mathrm{K}$ feldspato que se dispõem em parte paralelos e em parte oblíquos à foliação da matriz. A passagem da facies homogênea para a porfiróide é gradacional. Próximo aos contatos com outras unidades, este biotita gnaisse homogêneo apresenta-se milonitico, com porfiroclastos simétricos a assimétricos de feldspato. Embora a rocha tenha uma cor relativamente escura, sua composição varia de granodiorítica a granítica e seu índice de cor, de mesocrático a leucocrático. É comum a presença de enclaves de rocha calcissilicática, sugerindo representarem xenólitos da rocha encaixante. Além disso, na folha Mar de Espanha (a Este da área estudada), foi observado contato intrusivo deste litotipo em biotita-granada-sillimanita gnaisse.

O biotita gnaisse fino homogêneo tem textura ora grano-lepidoblástica, ora protomilonítica a milonítica, com recristalização das bordas dos minerais féisicos. Os minerais essenciais são plagioclásio, ortoclásio, quartzo, microclina, biotita, hornblenda e clinopiroxênio. Como acessórios ocorrem escapolita, titanita, zircão, apatita, mineral opaco e granada. Quando milonítica, os porfiroclastos são de plagioclásio e, menos comumente, de ortoclásio micropertítico, quartzo e clinopiroxênio. Estes grãos apresentam extinção ondulante, geminações deformadas e recristalização das bordas. É comum ocorrer intercrescimento mirmequítico nas interfaces plagioclásio/ortoclásio. Microclina, em grãos 
poligonizados, ocorre na matriz recristalizada, juntamente com os demais minerais félsicos, formando bandas claras que intercalam-se com bandas onde há concentração de biotita. Biotita e hornblenda ocorrem orientadas na matriz e algumas feições sugerem que estes dois minerais formaram-se, em parte, pelo consumo de clinopiroxênio. Biotita parece formar-se também a partir de hornblenda.

Os grãos de titanita têm inclusões de mineral opaco e localmente são bordejados por um filme de mineral opaco. As bandas com concentração de microclina pertencem à facies mais grossa e tardia. Muscovita é secundária e forma-se pela alterção de biotita, enquanto que sericita forma-se pela alteração de plagioclásio e ortoclásio. Microclina não mostra-se alterada. Ainda como fases secundárias ocorrem também carbonato e clorita.

\section{b) Leucogranito Rosado}

Esta rocha está intimamente associada ao biotita gnaisse fino homogêneo, com o qual tem contatos bruscos, localmente de carater intrusivo. O leucogranito rosado ocorre sob a forma de bandas (milimétricas até 15-20 cm), bolsões ou leucossomas de granulometria grossa ou média, coloração rosada, ricos em K-feldspato. Leucossomas e bandas são paralelas à foliação do biotita gnaisse fino homogêneo. Injeções pegmatíticas, comumente subconcordantes, são também comuns.

Esta facies rosada tem microclina, quartzo, ortoclásio, plagioclásio, biotita (rara) e apatita, sendo sua textura normalmente granoblástica. A microclina é, as vezes, micropertítica e ocorre tanto em grãos grossos (porfiroclastos) quanto na matriz, também félsica, da rocha. Intercrescimento mirmequítico é comum nas bordas deste mineral. Quartzo, plagioclásio e microclina podem estar estirados, mesmo na matriz e os porfiroclastos apresentam extinção ondulante, geminação deformada e bordos recristalizados.

A matriz é normalmente granoblástica poligonal e os raros grãos de biotita ocorrem orientados ao longo da foliação da rocha. Estas feições indicam que mesmo esta faciologia tardia sofreu alguns efeitos da deformação regional. Este fato é também corroborado pela observação local de foliação milonítica grossa, acompanhada da redução da matriz à 
granulometria fina. Muscovita, sericita e carbonato são produtos secundários da alteração dos feldspatos.

Tabela 14 - Composição Mineralógica, Características Texturais e Classificação dos Litotipos da Suite Intrusiva Matias Barbosa e Enclaves.

\begin{tabular}{|c|c|c|c|}
\hline Litotipo & $\begin{array}{l}\text { Minerais (em ordem } \\
\text { decrescente de } \% \text { vol) }\end{array}$ & Granulometria & Textura / Estrutura \\
\hline Biotita Gnaisse Homogêneo & $\begin{array}{l}\mathrm{plg}, \text { ort, bt, } \mathrm{qz}, \mathrm{mi}, \mathrm{hb} \\
\mathrm{scp}, \mathrm{cpx}, \mathrm{p}, \mathrm{ti}, \mathrm{zc}, \mathrm{ap}, \mathrm{gr} \\
\text { (rara) }\end{array}$ & fina & $\begin{array}{l}\text { Grano-lepidoblástica; } \\
\text { Protomilonítica a Milo- } \\
\text { nítica.Foliada. }\end{array}$ \\
\hline Biotia Gnaisse Porfiróide & $\begin{array}{l}\text { mi, plg, } \mathrm{qz} \text {, ort, bt, hb, } \\
\text { scp, op, ti, zc, ap }\end{array}$ & $\begin{array}{l}\text { fina, com megacristais } \\
\text { mms a cms de K- } \\
\text { feldspato. }\end{array}$ & $\begin{array}{l}\text { Porfiróide a milonítica; } \\
\text { Foliada. }\end{array}$ \\
\hline Leucogranito Rosado & $\mathrm{mi}, \mathrm{q}$, ort, plg, bt, ap & média à grossa & $\begin{array}{l}\text { Granoblástica - poligonal, } \\
\text { Milonítica; } \\
\text { Maciça a Foliada. }\end{array}$ \\
\hline Rocha Calcissilicática & $\begin{array}{l}\text { plg, di, gr, scp, hb, qz, } \\
\text { bt, ti, op }\end{array}$ & fina & Granoblástica \\
\hline
\end{tabular}

\section{II.3.6) Granada Charnockito}

O granada charnockito é um corpo que localmente mostra feições intrusivas em relação ao biotita-granada-ortopiroxênio gnaisse. Assim, em diversos afloramentos as telações de contato sugerem origem a partir de fusão parcial in situ. Isto porque próximo ao granada charnockito, o paragnaisse torna-se migmatítico, muito enriquecido em leucossomas, cuja composição é muito semelhante àquela do granada charnockito. Assim, muitas vezes os contatos entre este charnockito e o paragnaisse parecem gradacionais, partindo do gnaisse, passando por metatexito, diatexito e corpo intrusivo. Feições de carater tipicamente intrusivo (stoping) não são observadas.

O granada charnockito tem granulometria média à grossa e textura granoblástica a grano-porfiroblástica. Estruturalmente é bastante isotrópico, com schlierens orientados ao longo de uma foliação fraca e paralela à foliação regional, muitas vezes assemelhando-se a estruturas "fantasmas", herdadas de gnaisses pré-existentes. Além do carater isotrópico, esta 
rocha é caracterizada por apresentar diferenças de tonalidade, ora esverdeada (tonalidade predominante), ora branca acinzentada, e por ser salpicada de granada. Esta variação de tonalidade sugere processos ígneos, envolvendo distribuição heterogênea de fluidos, incluindo porções anidras (esverdeadas) e porções "hidratadas". Outra hipótese é que esta variação seja função de variações na composição da fase fluida, sugerindo que as porções esverdeadas representem fluidos pobres em $\mathrm{H}_{2} \mathrm{O}$ e aquelas acinzentadas, fluidos ricos em $\mathrm{H}_{2} \mathrm{O}$. Outra característica bastante conspícua é a presença de inúmeros enclaves de paragnaisse (Fig. 19a), rochas calcissilicáticas e ortogranulitos semelhantes aqueles do CJF (Fig. 19b), que podem ser tanto interpretados como xenólitos ou como restitos.

Próximo às escamas tectônicas de ortogranulitos, o granada charnockito também adquire textura milonítica, mostrando que esta rocha é mais antiga do que a tectônica de empurrões que atingiu este Domínio.

O granada charnockito é constituído de plagioclásio, ortoclásio, quartzo, biotita, granada e ortopiroxênio. Como minerais acessórios ocorrem zircão, mineral opaco e apatita. A textura é granoblástica ou grano-porfiroblástica, sendo que os minerais félsicos podem apresentar feições como extinção ondulante e formação de subgrãos em suas bordasnas bordas. Quando protomilonítico ou milonítico, os porfiroclastos são de ortopiroxênio, granada e minerais félsicos e a matriz é formada pela recristalização dos minerais félsicos, biotita e mineral opaco. Nas interfaces ortoclásio/plagioclásio ocorre frequentemente intercrescimento mirmequítico. A granada ocorre em grãos médios a grossos, muitas vezes cheios de inclusões de quartzo, plagioclásio, biotita e mineral opaco. Feição também conspícua é a presença de franjas em torno dos grãos de granada, constituídas de intercrescimento simplectítico entre granada e mineral opaco e/ou granada e mineral félsico (quartzo e/ou feldspatos). É comum o ortopiroxênio apresentar-se parcial a totalmente transformado para um material fino, fibroso e/ou micáceo, de coloração amarronada, provavelmente um mineral de argila. Como este material forma-se pseudomorficamente a partir do ortopiroxênio, é possível definir a préexistência deste mineral, mesmo quando já totalmente transformado. A biotita ocorre tanto ao longo da foliação quanto nas bordas de granada e de ortopiroxênio, transformado ou não, sugerindo que a biotita é mais nova que estes minerais e também mais nova do que o material que substituiu o ortopiroxênio. $\mathrm{O}$ zircão ocorre normalmente incluso em plagioclásio, 


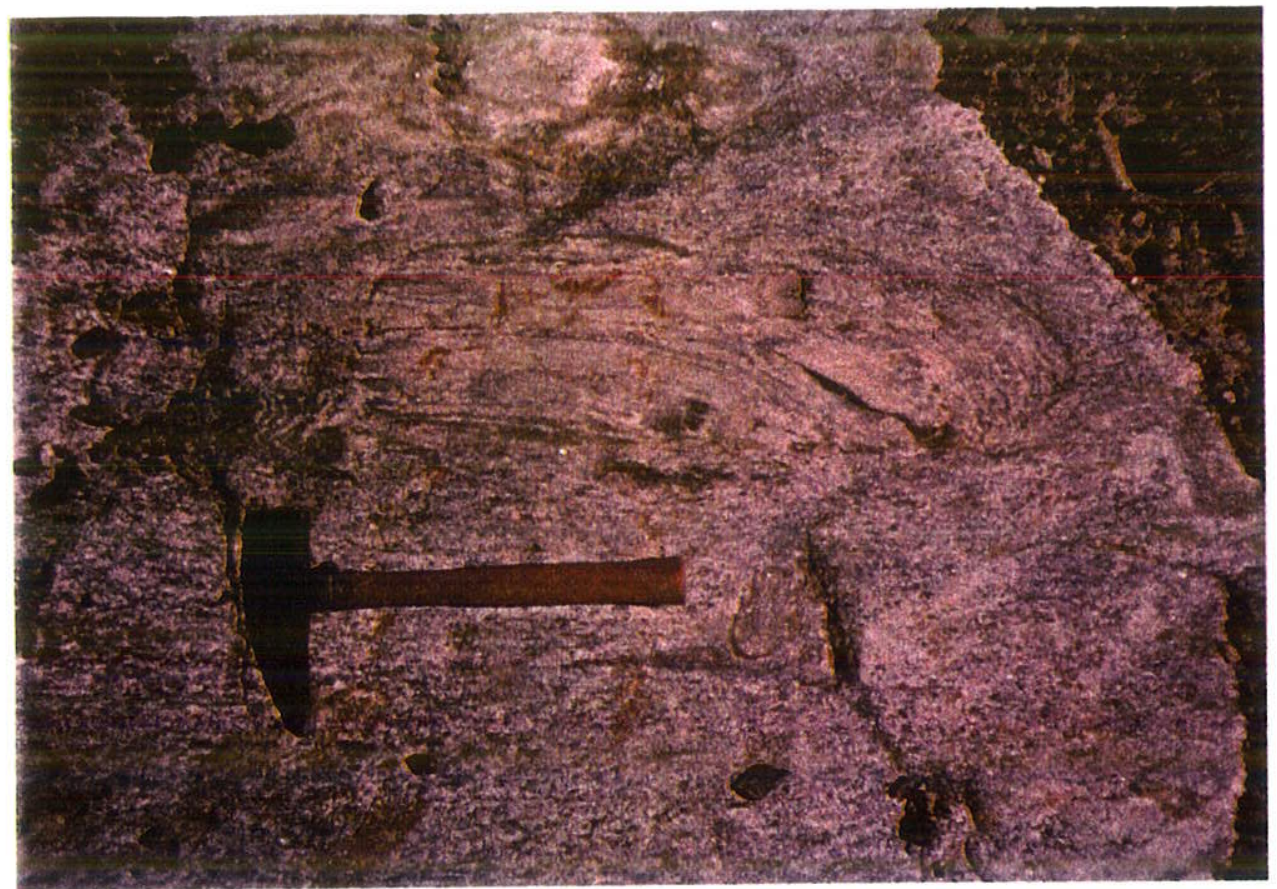

Figura 19a - Granada Charnockito apresentando enclave de paragnaisse. Ponto 37

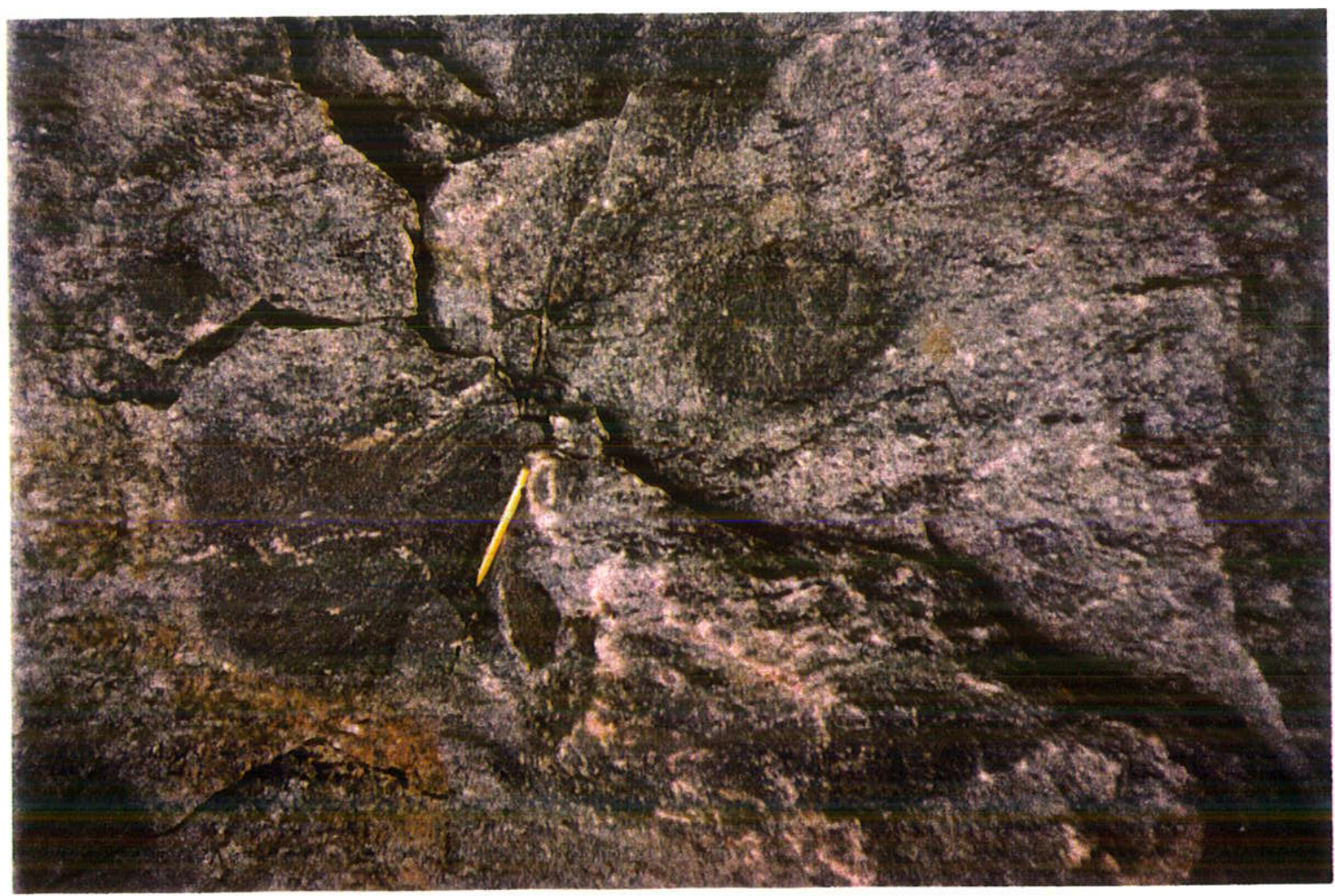

Figura 19b - Granada Charnockito apresentando enclave de ortogranulito. Ponto 37 
ortopiroxênio e biotita. Muscovita, sericita, carbonato, clorita e epidoto (?) são minerais secundários, formados pela alteração de feldspatos, biotita e ontopiroxênio.

Os enclaves de paragnaisse e rochas calcissilicáticas têm as mesmas características apresentadas pelas rochas já descritas no ítem anterior referente ao paragnaisse e, portanto, não serão abordadas novamente. Com relação aos enclaves de ortogranulito, por apresentarem a mesma composição e outras feições do que aqueles descritos para o CJF mais adiante, não serão abordados neste item.

Tabela 15 - Composição Mineralógica, Características Texturais e Classificação do Granada Charnockito.

\begin{tabular}{|l|l|l|l|}
\hline Litotipo & $\begin{array}{l}\text { Minerais (em ordem } \\
\text { decrescente de \% vol) }\end{array}$ & Granulometria & \multicolumn{1}{|c|}{ Textura / Lstrutura } \\
\hline Granada Charnockito & $\begin{array}{l}\mathrm{plg}, \mathrm{g} \%, \text { ort, bt, gr, opx, } \\
\text { op, zc, ap }\end{array}$ & $\begin{array}{l}\text { fina à média; } \\
\text { localmente, grossa. }\end{array}$ & $\begin{array}{l}\text { Granoblástica a Grano- } \\
\text { porfiroblástica; Milonítica. } \\
\text { Maciça a Foliada. }\end{array}$ \\
\hline
\end{tabular}

\section{Il.4) Unidades Litológicas do Dominio Tectônico Paraiba do Sul}

Em face aos limites geográficos da área alvo deste trabalho, o Dominio Tectônico Paraiba do Sul tem expressão areal bastante reduzida, não sendo possivel seu detalhamento, seja com relação à constituição litológica ou a sua característica estrutural. Este Domínio Tectônico na área é constituído de duas associações distintas de rochas englobadas no Complexo Paraíba do Sul. São elas: a) ortognaisses da Suite Quirino-Dorândia, com as mesmas características já descritas para estas rochas no Domínio Tectônico Juiz de Fora; e b) biotita gnaisse bandado milonitico, provavelmente de origem sedimentar. A seguir são apresentadas as características de campo e petrográficas dos ortognaisses da Suite QuirinoDorândia. O biotita gnaisse bandado milonítico, em função de sua restrita ocorrência e de apresentar-se intensamente intemperizado, não será abordado em detalhe nesta seção. 


\section{II.4.1) Ortognaisses (Biotita gnaisses e Biotita-Hornblenda gnaisses) da Suite Quirino-Dorândia}

Na extremidade sul da área, próximo ao contato com o Domínio Tectônico Superior, ocorre uma escama tectônica de pequena espessura e constituída de ortognaisses muito semelhantes aqueles da Suite Quirino-Dorândia (Heilbron, 1993; Valladares, 1996). Ocorre um bt-hb gnaisse claro, de granulometria média à grossa, sem bandamento, porém marcadamente foliado. Tanto nesta escama quanto no Domínio Tectônico Superior, esta rocha apresenta foliação protomilonítica a milonítica. Localmente, estes ortognaisses adquirem feições indicativas de migmatização, com formação de leucossomas brancos com schlierens máficos e cristais grossos de hornblenda, desenvolvendo estruturas estromáticas. Associados a estes gnaisses, ocorrem com bandas e/ou boudins de rocha máfica, ultramáfica e de rocha calcissilicática de coloração verde clara.

Estes gnaisses têm composição tonalítica e textura protomilonítica a milonítica, cujos porfiroclastos são plagioclásio, quartzo, ortoclásio e pseudomorfos de tremolita e hornblenda sobre piroxênio. Plaquetas orientadas de biotita e o maior comprimento dos minerais félsicos conferem marcante foliação à rocha. Como minerais acessórios ocorrem apatita, mineral opaco e zircão.

Os leucossomas têm composição granítica, dada por ortoclásio, microclina, plagioclásio, quartzo, hornblenda e biotita. Ortoclásio, plagioclásio e quartzo ocorrem como porfiroclastos e recristalizados na matriz que também é formada de microclina, hornblenda e biotita. As fases acessórias são mineral opaco, apatita e zircão.

As bandas básicas têm composição norítica a quartzo norítica. Opx, cpx e plagioclásio são seus principais constituintes. Tremolita forma-se, pseudomorficamente, sobre opx e cpx. Hornblenda e biotita ocorrem nos bordos ou nas proximidades dos piroxênios. Quartzo e ortoclásio ocorrem em quantidade muito reduzida e as fases acessórias identificadas são mineral opaco, apatita e zircão. 
Tabela 16 - Composição Mineralógica, Características Texturais e Classificação dos Ortognaisses da Suite Quirino-Dorândia.

\begin{tabular}{|l|l|c|l|}
\hline \multicolumn{1}{|c|}{ Litotipo } & $\begin{array}{l}\text { Minerais (em ordem } \\
\text { decrescente de \% vol) }\end{array}$ & Granulometria & \multicolumn{1}{|c|}{ Textura/Estrutura } \\
\hline Bt Gnaisse e Bt-Hb Gnaisse & $\begin{array}{l}\mathrm{plg}, \mathrm{qz}, \mathrm{ort}, \mathrm{hb}, \mathrm{tm}, \mathrm{cpx}, \\
\mathrm{bt}, \mathrm{ap}, \mathrm{op}, \mathrm{zc}\end{array}$ & média à grossa & $\begin{array}{l}\text { Protomilonítica a Milonítica; } \\
\text { Foliada. }\end{array}$ \\
\hline Bandas Básicas & $\begin{array}{l}\mathrm{plg}, \mathrm{opx}, \mathrm{cpx}, \mathrm{hb}, \mathrm{bt}, \mathrm{tm}, \\
\mathrm{qz}, \mathrm{ort}, \mathrm{op}, \mathrm{ap}, \mathrm{zc}\end{array}$ & fina à média & Granoblástica; Foliada \\
\hline Leucossoma & $\begin{array}{l}\mathrm{ort}, \mathrm{mi}, \mathrm{plg}, \mathrm{qz}, \mathrm{hb}, \mathrm{bt}, \mathrm{op}, \\
\mathrm{ap}, \mathrm{zc}\end{array}$ & média à grossa & $\begin{array}{l}\text { Granoblástica a Protomilo- } \\
\text { nítica; Foliada }\end{array}$ \\
\hline Rocha Calcissilicática & $\begin{array}{l}\mathrm{plg}, \mathrm{cpx}, \mathrm{gr}, \mathrm{hb}, \mathrm{scp}, \mathrm{bt}, \\
\mathrm{qz}, \mathrm{ti}, \mathrm{ap}, \mathrm{op}\end{array}$ & fina à média & $\begin{array}{l}\text { Granoblástica-Poligonal; } \\
\text { Maciça. }\end{array}$ \\
\hline
\end{tabular}




\section{II.5 - Geologia Estrutural}

\section{II.5.1) Introdução}

A partir da análise geométrica das estruturas pré-cambrianas observadas na área de estudo, foi possivel identificar duas fases de deformação: a) fase da deformação principal $\left(\mathrm{D}_{\mathrm{n}}\right)$; e b) fases de deformação tardias $\left(D_{n+1}\right.$ e $\left.D_{n+2}\right)$. Este estudo teve como principais abordagens a cronologia relativa de geração de foliação e a relação entre a formação de estruturas e minerais dos conjuntos litológicos ocorrentes. Como não foram observadas feições de superposição entre as duas fases tardias, é possível que estas sejam contemporâneas.

De um total de 570 afloramentos visitados, em 433 foram coletados dados (medidas) das várias estruturas identificadas: 590 medidas de foliação, 93 de lineações minerais, além de medidas de planos axiais (36), eixos de dobras (76) e de superficies de cisalhamento, referentes à fase principal de deformação; com relação à fase tardia, foram coletados dados de 31 planos axiais, e 54 foliações, incluindo zonas de cisalhamento. Estes dados estão apresentados em diagramas estereográficos e em mapa estrutural (Anexo 3). Com base nos diferentes estilos de deformação observados no campo, a área alvo foi subdividida em domínios estruturais, como mostrado no Anexo 3. A análise estrutural, envolvendo o estudo das relações entre os vários elementos estruturais e a maior ou menor intensidade de uma ou outra fase de deformação, possibilitou a comparação entre os vários domínios e a confirmação da subdivisão gerada ainda na etapa dos trabalhos de campo. Assim, a análise geométrica da deformação foi realizada para cada Domínio Estrutural e o estilo de cada um destes domínios está apresentado em perfis geológico-estruturais (Anexo 2) e no mapa estrutural (Anexo 3). A análise destes resultados, integrada à análise de indicadores cinemáticos, permitiu a elaboração de um modelo cinemático de deformação Pré cambriana para esta área.

A fase principal de deformação, que será abordada com maior detalhe em item procedente, foi responsável pela geração da foliação principal (milonítica ou não), pelo intenso imbricamento de contatos tectônicos e pelo empilhamento estrutural dos Domínios Tectônicos. Para cada Domínio Tectônico, esta fase de deformação desenvolveu características específicas, o que será também abordado adiante. A fase de deformação tardia foi responsável pelo dobramento e arqueamento da foliação principal e dos contatos tectônicos. Localmente, zonas 
de cisalhamento geradas nesta fase giram ou, até mesmo, transpõem a foliação gerada na fase $\mathrm{D}_{\mathrm{n}}$. Ainda associados a esta fase tardia, ocorrem zonas de cisalhamento e falhamentos dúcteis rúpteis, com pequeno rejeito. A descrição e a análise dos elementos estruturais gerados nesta fase serão abordadas no ítem II.5.2. A fase principal teve sua evolução sincrônica ao auge metamórfico, sob condições da facies anfibolito superior à facies granulito, enquanto que a fase tardia se desenvolveu sob condições de P e T pós-auge do metamorfismo.

O item II.5.3, que finaliza este capítulo, se dedica à integração dos dados e resultados obtidos e à análise cinemática da evolução deformacional do Pré-cambriano da área alvo

\subsection{2 - Análise Geométrica da Deformação}

\section{Fase Principal da Deformação}

Como já foi exposto anteriormente, a fase principal de deformação apresenta características específicas nos diferentes Domínios Estruturais. Assim sendo, esta deformação será analisada separadamente em cada um destes Domínios, com exceção do Domínio Estrutural Paraíba do Sul (coincidente com o Domínio Tectônico homônimo) que, por ocupar uma porção muito reduzida da área estudada, não apresenta dados e medidas em número suficiente para proceder à análise. Os Domínios Tectônicos Andrelândia e Juiz de Fora foram subdivididos, respectivamente, em dois e três Domínios Estruturais (AND 1, AND 2, JF 1, JF 2, JF 3), tendo como principais critérios a intensidade de deformação associada à transposição de estruturas mais antigas, e predomínio de foliação milonítica sobre uma foliação gnáissica ou uma xistosidade (Anexo 3).

A seguir, são descritas as características geométricas dos elementos estruturais gerados na deformação principal para cada um dos Domínios Estruturais supracitados.

\section{\#AND 1}

No AND 1, a fase principal de deformação é caracterizada, dentre outros, por duas gerações de dobramentos aqui relacionados, respectivamente, a $D_{1}$ e $D_{2}$, muito embora seja muito reduzido o número de dobras $\mathrm{D}_{1}$ observadas. Isto é provavelmente decorrente do fato das dobras $\mathrm{D}_{1}$ e $\mathrm{D}_{2}$ apresentarem estilo e orientação muito semelhantes, como já verificado por outros autores que investigaram áreas adjacentes (Heilbron, 1993 e Pacciulo, 1997), o que 
torna dificil a identificação das dobras $D_{1}$, a não ser em afloramentos onde haja a superposição de $\mathrm{D}_{2}$ sobre $\mathrm{D}_{1}$. Além disso, não é frequente a associação de $\mathrm{D}_{2}$ com a formação de uma xistosidade de crenulação, outro fator que vem dificultar o diagnóstico de estruturas $\mathrm{D}_{1}$. $\mathrm{A}$ observação de superposição destas duas fases ocorre normalmente em corpos litológicos mais competentes (camadas, lentes e/ou "boudins" de quartzo, calssilicáticas, gondito, anfibolito, etc), onde a transposição das estruturas mais antigas não tenha sido total. Os padrões resultantes desta superposição são do tipo dobra dobrada (Fig.20). As dobras $\mathrm{D}_{1}$ são observadas principalmente em escala de afloramento e têm perfil isoclinal a apertado. Como foi adiantado, para o que se está denominando fase principal de deformação, tanto as dobras $\mathrm{D}_{1}$ quanto as $\mathrm{D}_{2}$ desenvolveram-se sob condições de $\mathrm{P}$ e $\mathrm{T}$ correspondentes ao auge do metamorfismo (facies anfibolito superior) que afetou tanto o embasamento quanto rochas supracrustais. Este aspecto, associado ao fato das dobras $D_{1}$ e $D_{2}$ serem geometricamente muito semelhantes, sugerem que $\mathrm{D}_{1}$ e $\mathrm{D}_{2}$ tenham sido fases de deformação progressiva como já proposto por Heilbron $(1993,1995)$ para o setor central da Faixa Ribeira. Sendo assim, a fase principal de deformação é redefinida como composta por duas fases progressivas $D_{1}$ e $D_{2}$, podendo ser simbolizada por $\mathrm{D}_{1}+\mathrm{D}_{2}$.

\section{\# Foliação $S_{X}$}

A foliação $S_{1}$ é uma xistosidade que, localmente, pode ser definida como subparalela ao acamamento sedimentar e também paralela ao plano axial de $D_{1}$. No AND $1, S_{1}$ apresenta-se comumente transposta para a direção de $\mathrm{S}_{2}$. $\mathrm{O}$ arranjo planar de minerais micáceos ou tabular de minerais prismáticos definem esta foliação. Além disso, veios leucossomáticos de origem anatética também se dispõem ao longo de $S_{1}$, levando à formação de um bandamento composicional.

\section{\# Dobras $\mathrm{D}_{2}$}

Dobras relacionadas à fase de deformação $\mathrm{D}_{2}$ têm perfil apertado a isoclinal e ocorrem em qualquer escala de observação (Anexos 2 e 3 e Fig.21a e b). A atitude dos planos axiais destas dobras varia de subhorizontal a inclinada, sendo estas estruturas comumente paralelas à foliação penetrativa $S_{2}$. Tais superficies mergulham predominantemente para $\mathrm{SE}$, com máximo em 132/27 (Fig.22) eixos têm rumo variando de SW a NE, com caimento subhorizontal a inclinado (estereograma no Anexo 3). Assim, as dobras $\mathrm{D}_{2}$ variam de recumbentes a reclinadas. 
N

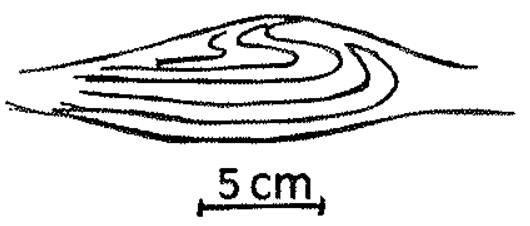

Figura 20 - Superposição da fase $\mathrm{D}_{2}$ sobre a fase $\mathrm{D}_{1}$, registrada em boudin de rocha calcissilicática. Ponto 79
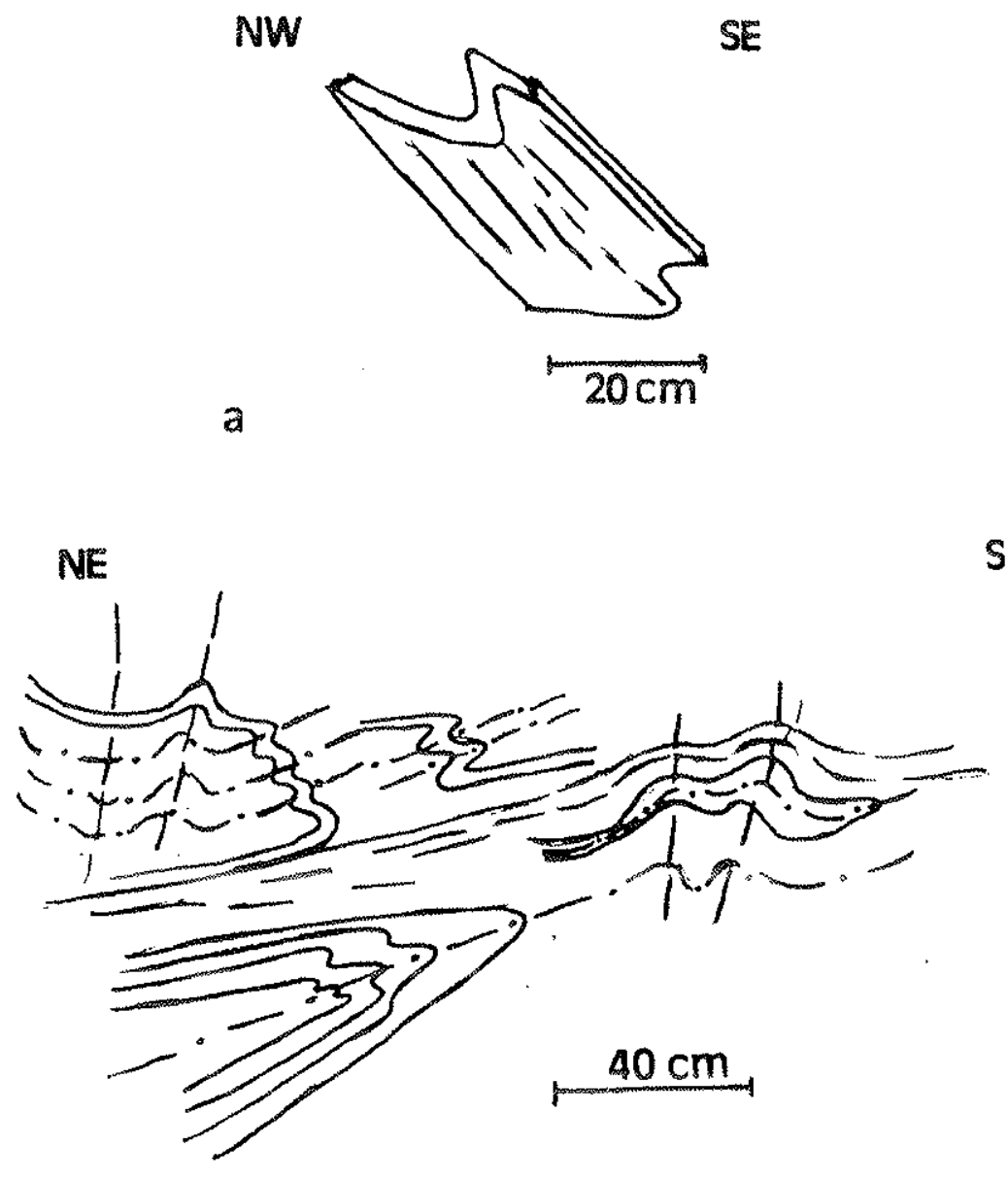

b

Figura 21 - Perfil apertado a isoclinal em dobra $\mathrm{D}_{2}$ em Biot-Sill gnaisse do CDA (a) e $\mathrm{Hb}$-bt gnaisse do CM (b). AND 1. Pontos 52 e 85 


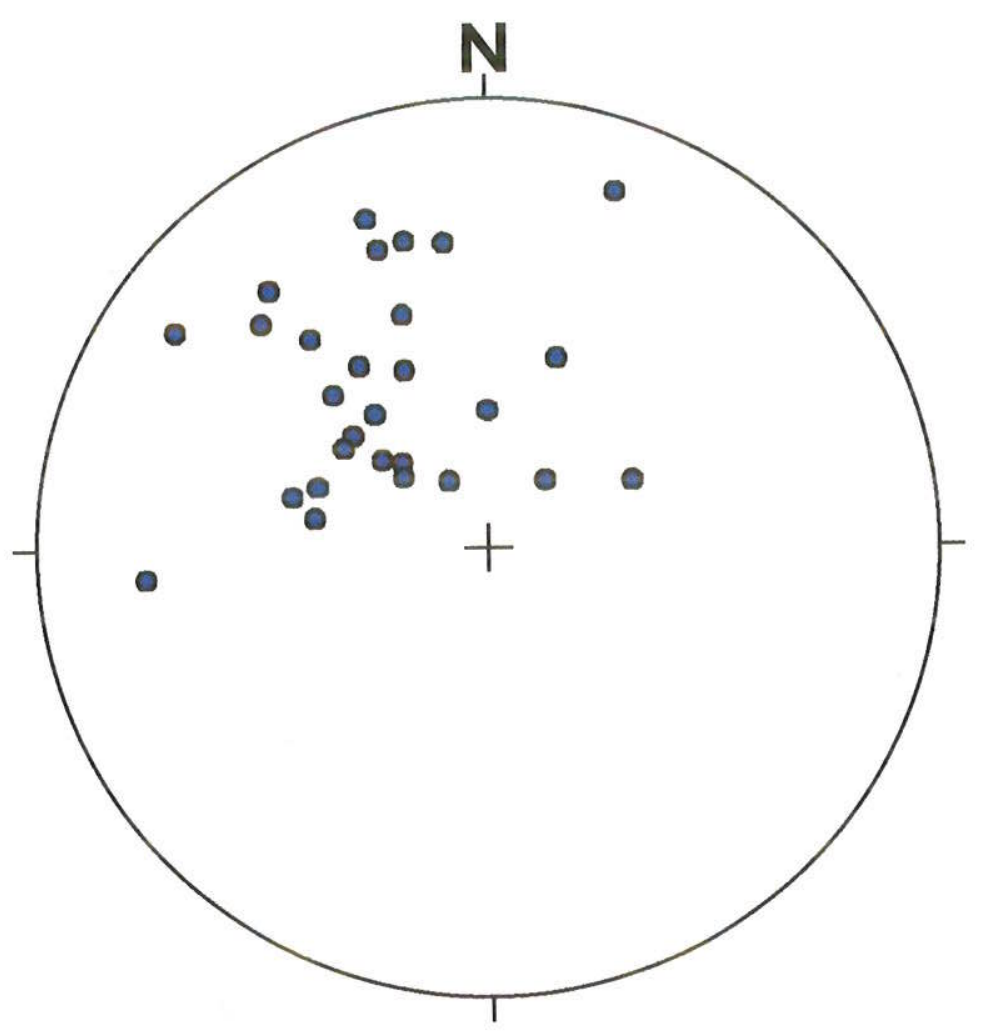

Figura 22 - Estereograma dos planos axiais das dobras $\mathrm{D}_{2}$. AND1. $\mathrm{N}=28$ pontos. Máximo $=132^{\circ} / 27^{\circ}$ 
O caráter acilíndrico das dobras $D_{2}$ pode ser verificado dada a variação na atitude de seus eixos e planos axiais, mesmo em áreas não afetadas pela deformação tardia. Localmente, a variação de atitude dos eixos causa o embainhamento das dobras $\mathrm{D}_{2}$. No entanto, não se pode descartar que parte da acilindricidade do dobramento possa ser decorrente de superposição de $\mathrm{D}_{2}$ sobre $\mathrm{D}_{1}$.

\section{\# Foliação $S_{2}$}

A paralelização e a transposição quase total de $S_{1}$ para $S_{2}$ são características frequentes e importantes no AND 1. A transposição se dá por recristalização dinâmica, em graus variados, de todos os minerais, que se reorientam na posição espacial de $S_{2}$. Estes aspectos traduzem a intensidade da deformação $\mathrm{D}_{2}$ que se desenvolveu durante o ápice térmico do metamorfismo. Tanto macro quanto microscopicamente, a foliação $\mathrm{S}_{2}$ mostra-se como uma xistosidade grossa, definida pelo paralelismo de minerais micáceos, prismáticos e tabulares. Em litotipos mais micáceos (gnaisse pelítico) ou em porções melanossomáticas de rocha gnáissica, observa-se, localmente, o desenvolvimento de uma xistosidade de crenulação $\mathrm{S}_{2}$. Em lâmina delgada, é comum esta crenulação ser representada pela formação de arcos poligonais em biotita e sillimanita, principalmente nos gnaisses pelíticos.

Em rochas mais competentes, a foliação $S_{2}$ mostra-se como uma xistosidade espaçada, disjuntiva, semelhante a fraturas. Ao microscópio, é definida por grãos de quartzo alongados, cujos contornos escuros (filme de material opaco) e irregulares sugerem ter ocorrido processo de dissolução por pressão.

A atitude de $S_{2}$ (ou $S_{1}+S_{2}$ ) é apresentada em estereograma do Anexo 3, sendo seu máximo registrado em $155 / 44$.

\section{\# Zonas de Cisalhamento $\mathrm{D}_{2}$}

Zonas de Cisalhamento $\mathrm{D}_{2}$ são observadas em vários afloramentos no AND 1 e são responsáveis pelo desenvolvimento de uma foliação $S_{2}$ milonítica (Fig. 23). Esta estrutura é caracterizada por proporções variadas entre porfiroclastos e matriz. Dependendo do litotipo, os porfiroclastos podem ser feldspatos, granadas, hornblenda ou clinopiroxênio, enquanto que a matriz é fina, formada por subgrãos e fitas de quartzo e feldspato, além de minerais micáceos e/ ou prismáticos orientados (recristalização dinâmica). É comum o desenvolvimento posterior 
de recristalização estática, gerando agregados granoblásticos poligonais. Franjas de recristalização do tipo sigma são eventualmente observadas.

$\mathrm{O}$ mergulho de $\mathrm{S}_{2}$ (milonitica) é predominantemente para $\mathrm{SE}$, sendo paralela à atitude da foliação principal $S_{1}+S_{2}$ deste domínio.

\section{\# Lineação de Interseç̧ão $L i_{2}$ e de crenulação $L c_{2}$.}

No AND 1 a lineação $L_{i}$ se desenvolve pela intersecção das superficies $S_{1}$ e $S_{2}$ e é observada em litotipos mais competentes, principalmente nas camadas quartzíticas. Poucas medidas foram coletadas para esta estrutura e sua atitude mostra paralelismo com os eixos das dobras $\mathrm{D}_{2}$.

A lineação de crenulação $\mathrm{Lc}_{2}$, também paralela aos eixos das dobras $\mathrm{D}_{2}$, só é observada em litotipos peliticos (bt-sill-gr gnaisses) ou em melanossomas de litotipos pelíticos e qtzfeldspáticos do AND 1. Como sua ocorrência é muito restrita, seus dados não foram plotados em estereogramas.

\section{\# Lineação mineral (Lm)}

A lineação mineral é muito comum no AND 1 e é principalmente associada à foliação principal $S_{1}, S_{2}$ ou $S_{1}+S_{2}$. A orientação preferencial de grãos minerais (quartzo, feldspatos, micas, anfibólios) e/ou agregados minerais definem esta estrutura. A relação angular entre Lm e os eixos das dobras D2 é muito variável, desde subparalela à quase perpendicular (Estereograma $\mathrm{Lm}_{2}$ no Anexo 3). Em muitos casos, como por exemplo, quando quartzo e/ou feldspatos materializam Lm, esta estrutura é nitidamente resultado de estiramento.

\section{\#AND 2}

Este Domínio é caracterizado por intensa transposição das estruturas relacionadas a $\mathrm{D}_{1}$ para a posição das estruturas $\mathrm{D}_{2}$. A principal estrutura é uma foliação milonítica $\mathrm{S}_{2}$; nem dobras $D_{1}$ nem foliação $S_{1}$ puderam ser verificados neste Domínio.

\section{\# Dobras $\mathrm{D}_{2}$}


Poucas dobras $\mathrm{D}_{2}$ foram observadas neste Domínio. Ocorrem em escala de afloramento e são intra-foliação milonítica $S_{2}$. Têm perfil fechado a isoclinal, podendo ser, a maioria, classificada como similar.

\section{\# Foliação Milonítica $\mathbb{S}_{2}$}

No AND 2, a única foliação observada é a milonitica, relacionada à transposição promovida por $\mathrm{D}_{2}$. Esta foliação é caracterizada por proporções variadas entre porfiroclastos e matriz e, dependendo do litotipo, os porfiroclastos podem ser feldspatos, granadas, hornblenda ou clinopiroxênio, enquanto que a matriz é fina, formada pela recristalização dinâmica de quartzo e feldspato (subgrãos e fitas), além de minerais micáceos e/ ou prismáticos orientados (Fig.24). Agregados granoblásticos poligonais são comumente observados, indicando o desenvolvimento posterior de recristalização estática. Franjas de recristalização do tipo sigma, principalmente em feldspatos, são eventualmente observadas.

$\mathrm{O}$ mergulho de $\mathrm{S}_{2}$ é predominantemente para $\mathrm{SE}$, com máximo em 169/26, sendo caracteristicamente de menor ângulo (25-30 ) quando comparado ao AND 1 (Estereograma no Anexo 3).

\section{\# Lineações de Intersecção $\left(L i_{2}\right)$ e de Crenulação $\left(L c_{2}\right)$}

Como no AND 2 a foliação $S_{1}$ está totalmente transposta, tanto $L i_{2}$ quanto $L c_{2}$ não são observadas.

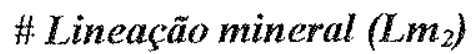

Semelhantemente ao ANo 1, a foliação milonítica $S_{2}$ é intimamente associada a uma lineação mineral $\mathrm{Lm}_{2}$ e, como no AND 2 esta foliação tem baixo mergulho, $\mathrm{Lm}_{2}$ neste domínio tem um "plunge" muito menor do que no AND 1 (Anexo 3). A lineação $\mathrm{Lm}_{2}$ é formada pela orientação preferencial de quartzo, feldspatos, micas e anfibólios, dependendo do litotipo em que é observada. Assim como para o AND 1, quando quartzo e/ou feldspatos materializam $\mathrm{Lm}_{2}$, verifica-se que esta é claramente uma lineação de estiramento. Em um afloramento do AND 2 foi observado o giro da $L m$ contida na $S_{2}$ milonítica, o que, associado à provável acilindricidade das dobras $\mathrm{D}_{2}$ (em analogia ao que é observado no AND 1), levam à formação de dobras em bainha. 


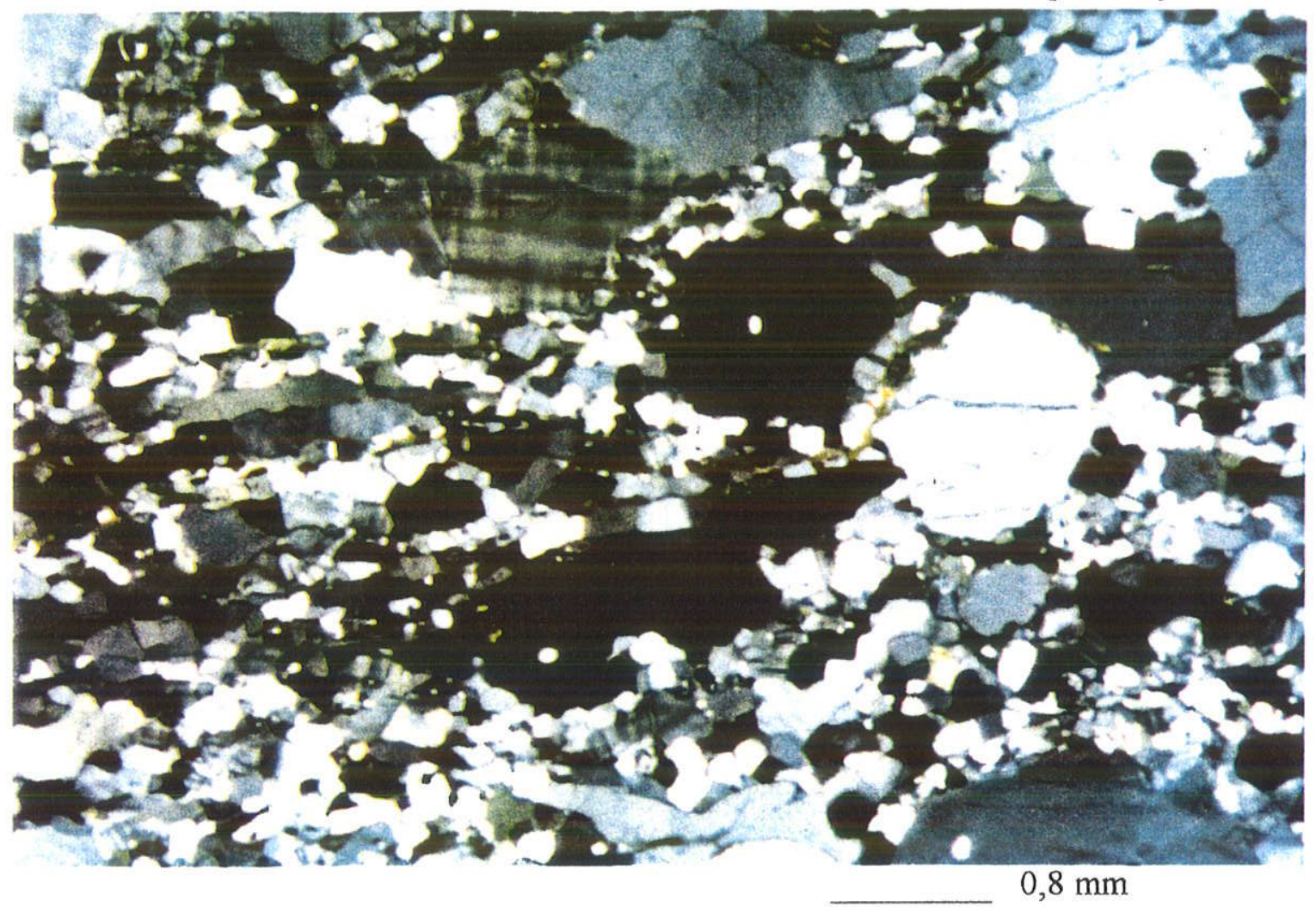

Figura 23 - Foliação milonítica $\mathrm{S}_{2}$, dada por minerais félsicos recristalizados e/ou estirados em bt-gnaisse do CM. DTAND. Ponto 564.

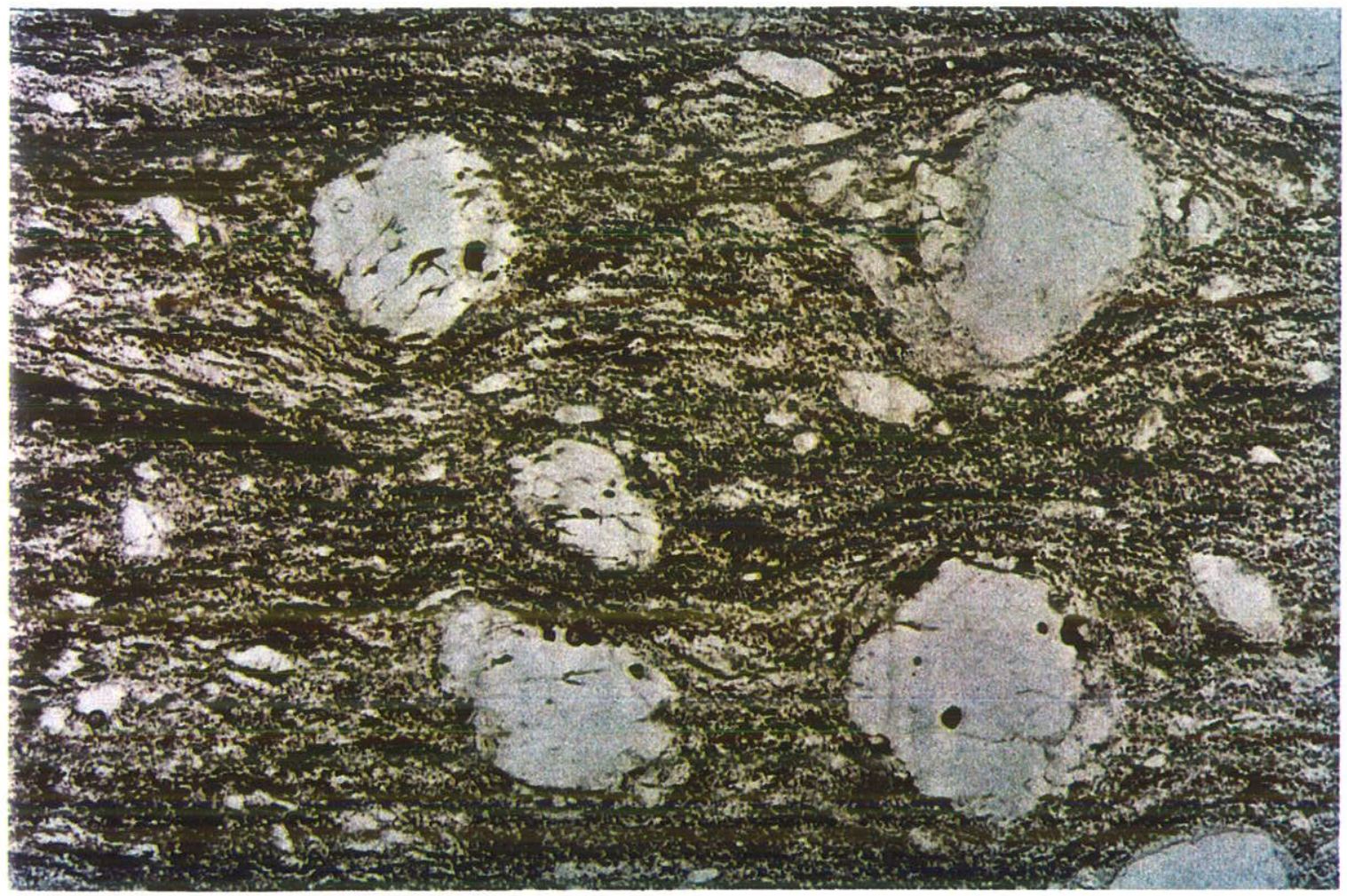

$0,8 \mathrm{~mm}$

Figura 24 - Foliação milonítica $S_{2}$, em bt-(sill) gnaisse porfiroclástico. AND 2. Ponto 49 


\section{\# JFI}

O JF1 apresenta carcterístícas bastante conspícuas. Sinformais e antiformais relacionados a $\mathrm{D}_{2}$ são as principais expressões da fase principal de deformação (Anexos 2 e 3 ) e estas estruturas, de escala de mapa, delineiam um grande sinformal, já caracterizado por Ebert (1956). Dobras $\mathrm{D}_{1}$ não foram identificadas com certeza, já que não foram observadas estruturas de superposição de $\mathrm{D}_{2}$ sobre $\mathrm{D}_{1}$. Esta ausência de estruturas de superposição deve estar relacionada aos tipos litológicos que predominam neste domínio: gnaisses migmatíticos e corpos charnockíticos/graníticos (Fig. 25).

\section{\# Foliação Principal $S_{1}, S_{2}$ ou $S_{1}+S_{2}$}

A foliação principal deste domínio mostra-se diferente para cada tipo litológico. Os btgr-(opx) gnaisses migmatíticos e os corpos charnockíticos tem uma xistosidade grossa, definida pela orientação de biotitas e feldspatos. Ainda nos bt-gr-(opx) gnaisses, leucossomas qtz-feldspáticos e melanossomas estão orientados na posição espacial da foliação principal, gerando migmatitos estromáticos. Com exceção dos locais onde há superposição de $\mathrm{S}_{2}$ sobre $\mathrm{S}_{1}$, ou em locais de ocorrência de dobras $\mathrm{D}_{2}$, é muito dificil identificar se a foliação principal é $\mathrm{S}_{1}$ ou $\mathrm{S}_{2}$. Em litotipos mais competentes (quartzitos e rochas calcisilicáticas), é comum a preservação de $S_{1}$, no entanto já dobrada por $D_{2}$. Em zonas de cisalhamento $D_{2}$, ocorre transposição quase total de $S_{1}$ para a posição espacial de $S_{2}$. Neste caso, $S_{2}$ é uma foliação milonítica, onde porfiroclastos são constituidos de feldspato, granada, ortopiroxênio e a matriz é fina e constituída de minerais félsicos e biotita. Nos gnaisses mais pelíticos (bt-gr-sill gnaisse), é mais fácil distinguir $S_{1}$ de $S_{2}$, já que comumente $S_{1}$ está crenulada e $S_{2}$ é uma xistosidade de crenulação. Entretanto, é também mais clara a transposição quase total de $S_{1}$ para a posição de $S_{2}$. A xistosidade $S_{1}$ é definida pela orientação de biotitas e feldspatos, enquanto que $\mathrm{S}_{2}$, além daqueles minerais tem também sillimanita. Quando milonítica, em zonas de cisalhamento $\mathrm{D}_{2}, \mathrm{~S} 2$ mostra porfiroclastos de feldspatos e granadas e matriz fina constituída de minerais félsicos recristalizados dinamicamente, biotita e sillimanita. Nos quartzitos ocorre uma xistosidade grossa e espaçada $\left(\mathrm{S}_{1}\right)$ e outra espaçada disjuntiva $\left(\mathrm{S}_{2}\right)$.

Nos ortognaisses granulíticos deste domínio não foram claramente observadas estruturas geradas pela superposição de $D_{2}$ sobre $D_{1}$, o que torna dificil a correlação da foliação principal destas rochas com $\mathrm{S}_{1}$ ou $\mathrm{S}_{2}$. Esta estrutura se traduz em uma xistosidade grossa, geralmente milonítica, cujos porfiroclastos são de feldspatos e piroxênios (opx e/ou 


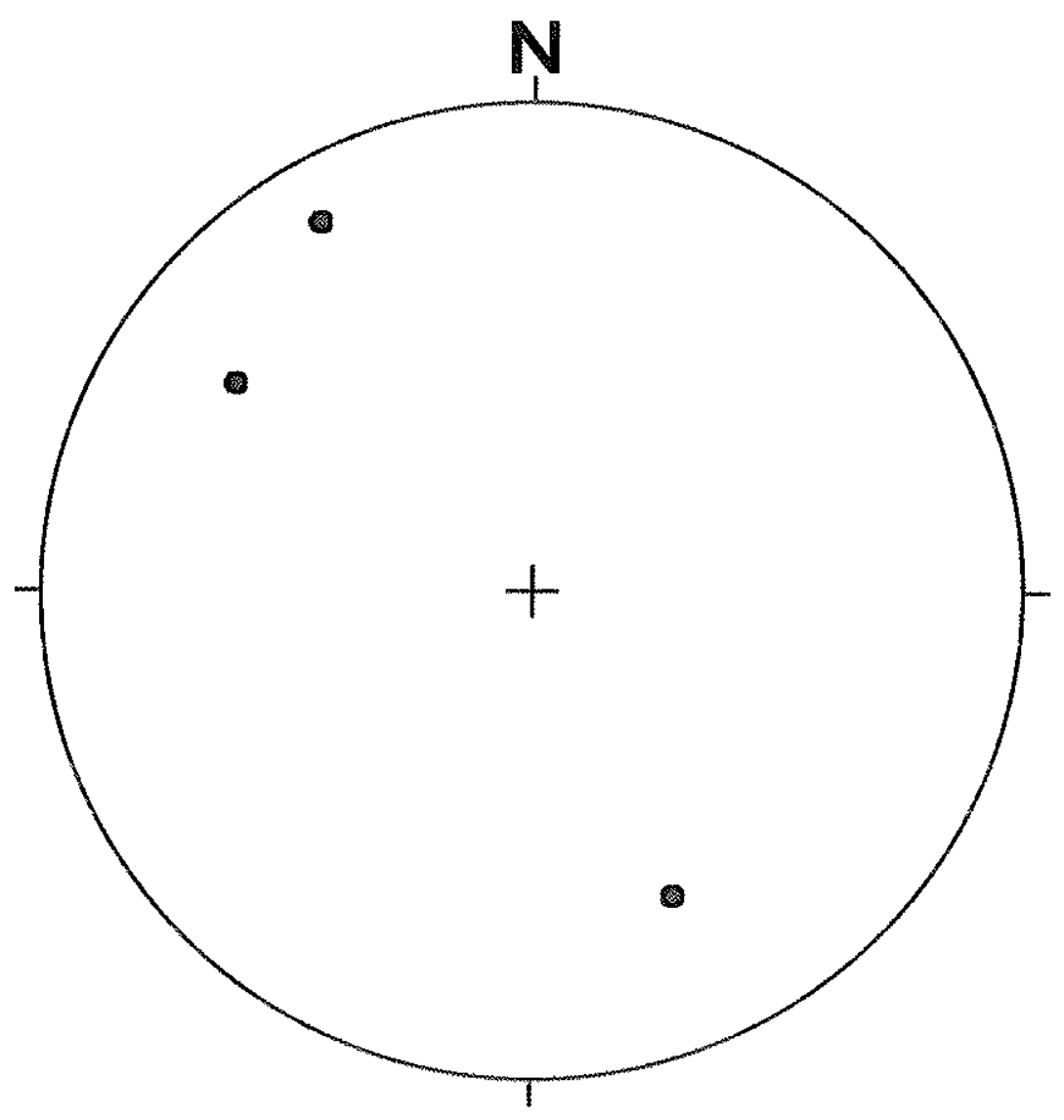

Fig. 25 - Estereograma dos Planos Axiais das dobras $\mathrm{D}_{1}, \mathrm{D}_{2}$, ou $\mathrm{D}_{1}+\mathrm{D}_{2}$, JF1. 
cpx, além de homblenda) e a matriz é composta pela recristalização dinâmica de minerais félsicos e máficos (piroxênios, biotita e hornblenda). Veios leucossomáticos esverdeados também se orientam ao longo da foliação principal, gerando bandamento composicional e migmatitos estromáticos.

Em estereograma (Anexo 3), a foliação principal, provavelmente $S_{1}$, mostra duas concentrações, NW (337/40) e SE (153/53), como resultado do dobramento $\mathrm{D}_{2}$, gerando um grande sinformal, cujo Plano Axial tem mergulho alto para NW e o Eixo, mergulho baixo para $\mathrm{SW}$. Assim, esta grande dobra $\mathrm{D}_{2}$ pode ser classificada como inclinada, segundo proposta de Turner e Weiss (1963). As dobras $\mathrm{D}_{2}$ têm perfil aberto a fechado, variando desde horizontal normal a inclinado. Os eixos destas dobras têm atitudes, em geral, subhorizontais, cujo máximo concentra-se em 58/10. Os planos axiais têm atitudes subverticais, mergulhando ora para NW ora para SE (Fig.25). Em zonas de cisalhamento $\mathrm{D}_{2}$, onde a relação $\mathrm{S}_{1^{-}} \mathrm{S}_{2}$ é clara, verifica-se o paralelismo de $\mathrm{S}_{2}$ com $\mathrm{PA}_{2}$.

\section{\# Lineações de Intersecção Li e de Crenulação Lcr}

Em bandas quartzíticas, pode ser observada uma lineação de intersecção, definida pela relação de $S_{1}$ com $S_{2}$, lineação esta paralela aos eixos das dobras $D_{2}$.

No caso dos gnaisses pelíticos, é comum a ocorrência de uma lineação de crenulação, resultante da superposição de $\mathrm{D}_{2}$ sobre $\mathrm{D}_{1}$. Esta lineação é paralela aos eixos das dobras $\mathrm{D}_{2}$.

\section{\# Lineação Mineral}

Neste domínio não foi observada lineação mineral relacionada à fase principal de deformação. Isto pode ser função dos tipos litológicos (bt-gr gnaisse, charnockito, ortogranulito) mostrarem-se muito migmatíticos e/ou isotrópicos. Os bt-gr sill gnaisses, talvez por serem muito micáceos, também năo desenvolveram lineações minerais. Outra explicação pode estar no tipo de "stress" que afetou estas rochas, muito embora, a autora entenda que esta hipótese é extremamente desfavorecida, ao fazer analogias com os demais domínios.

\section{\# JF2}

Este Dominio é formado por três escamas tectônicas, sendo duas constituídas de rochas metassedimentares (biotita gnaisses bandados, quartzitos e biotitangranada gnaisses) 
correlatas ao CDA e uma constituida de ortognaisses granulíticos do Complexo Juiz de Fora (Anexos 1, 2 e 3). Em termos de grandes estruturas, este Domínio é semelhante ao JF1, já que, em escala de mapa, verifica-se o delineamento de dobras $\mathrm{D}_{2}$ (Anexo 3 ).

\# Dobras $\mathrm{D}_{1}$

Assim como ocorre para o JF1, dobras $D_{1}$ não são identificadas com certeza no JF 2 .

\section{\# Foliaçấo $S_{1}$}

Também neste Domínio, a foliação $\mathrm{S}_{1}$ só é reconhecida nos locais menos deformados, onde há sobreposição de $\mathrm{D}_{2}$ sobre $\mathrm{D}_{1}$. $\mathrm{S}_{1}$ consiste de uma xistosidade grossa tanto nos ortogranulitos quanto nos biotita gnaisses bandados e biotita-granada gnaisses e de uma xistosidade espaçada nas camadas de quartzito.

\section{Hobras $\mathrm{D}_{2}$}

A característica mais conspícua do JF2 é a alternância entre porções menos deformadas, com dobras $\mathrm{D}_{2}$ intrafoliais, e porções onde a única estrutura visível é uma foliação milonítica (Fig. 26), feição esta que mostra a heterogeneidade e partição da deformação $\mathrm{D}_{2}$.

As dobras $\mathrm{D}_{2}$ têm padrão motfológico assimétrico, do tipo similar, sendo também comuns dobras simétricas. A relação entre Eixo (máximo em 52/07; Anexo 3) e Plano Axial (em geral de mergulho subvertical) gera padrão do tipo horizontal normal a inclinada, segundo Turner \& Weiss (1963). As dobras normalmente tem perfil apertado.

\section{\# Foliação $\boldsymbol{S}_{2}$}

No JF 2 , a foliação $\mathrm{S}_{2}$ é milonítica, formada pela transposição quase total de $\mathrm{S}_{1} \mathrm{em}$ regiões de maior deformação (zonas de cisalhamento $\mathrm{D}_{2}$ ). É definida pelo arranjo planar de minerais tabulares, prismáticos e/ou micáceos em uma matriz fina a média constituída de grãos dinamicamente recristalizados e variadas proporções entre porfiroclastos e matriz ocorrem. Bandas leucossomáticas e melanossomáticas também orientammse paralelamente a esta estrutura, dando origem a um bandamento composicional tectônico. Embora as estruturas $\mathrm{S}_{0} \mathrm{e}$ $S_{1}$ tenham sido quase totalmente transpostas, verifica-se que tanto a foliação $S_{2}$ quanto o bandamento composicional $S_{2}$ mostram-se paralelos àquelas estruturas. A atitude da foliação 
principal $S_{1}, S_{2}$ ou $S_{1}+S_{2}$ é mostrada em estereograma no Anexo 3 e pode-se verificar seu máximo em 315/54 e submáximo em 120/50 (Estereograma - Anexo 3).

Em escala microscópica, a heterogeneidade da deformação pode também ser verificada, dada a alternância de níveis de granulomentria mais fina e mais grossa, ou seja, de níveis mais e menos deformados, mostrando que a foliação $S_{2}$ forma-se pela redução na granulomentria da rocha, como consequência de recristalização dinâmica.

A análise petrográfica mostrou serem os porfiroclastos constituídos de piroxênio (opx e/ou cpx), hornblenda e plagioclásio nos ortogranulitos e de feldspatos e, menos comumente, granada, nas rochas metassedimentares. A matriz é constituída de grãos recristalizados dos minerais que formam os porfiroclastos, além de quartzo e biotita (Fig.27). Extinção ondulante, bandas e/ou lamelas de deformação e formação de subgrãos são feições comumente observadas nos porfiroclatos, enquanto que a matriz é granoblástica, formada por novos grãos e fitas de quartzo.

Franjas de recristalização, tanto em escala de afloramento quanto em escala microscópica são observadas estruturas do tipo sigma que normalmente ocorrem ao redor dos porfiroclastos ou em "boudins" formados por litotipos mais competentes (quartzito, calcissilicáticas, anfibolito e ortogranulitos básicos). Estes "boudins" mostram, muitas vezes, foliação interna que, associada à morfologia da franja, indica o sentido do transporte tectônico

Foliações S e C são estruturas eventualmente observadas no JF 2 , tanto em escala microscópica quanto mesoscópica.

\section{\# Lineação Mineral $\mathrm{Lm}_{2}$}

A lineação mineral $\mathrm{Lm}_{2}$ tem características variáveis, dependendo do litotipo em que é desenvolvida. Nos litotipos metassedimentares (gnaisses quartzo-feldspáticos, quartzitos e gnaisses pelíticos), a lineação mineral $\mathrm{Lm}_{2}$ é mais visivel, sempre associada à foliação milonítica $\mathrm{S}_{2}$. Diferentemente das rochas metassedimentares, nos ortogranulitos do Complexo Juiz de Fora esta lineação é dificilmente observada, mesmo nas superficie miloníticas. 


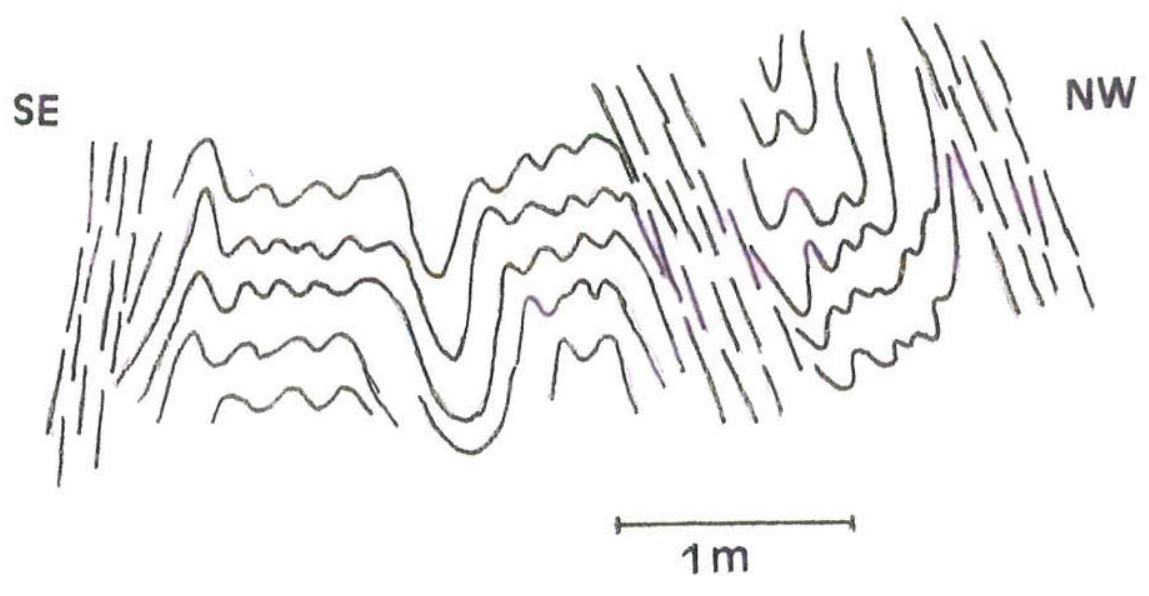

Figura 26 - Alternância de bandas dobradas (dobras intrafoliais $\mathrm{D}_{2}$ ) e bandas miloníticas em ortogranulitos do CJF. JF2. Ponto 145

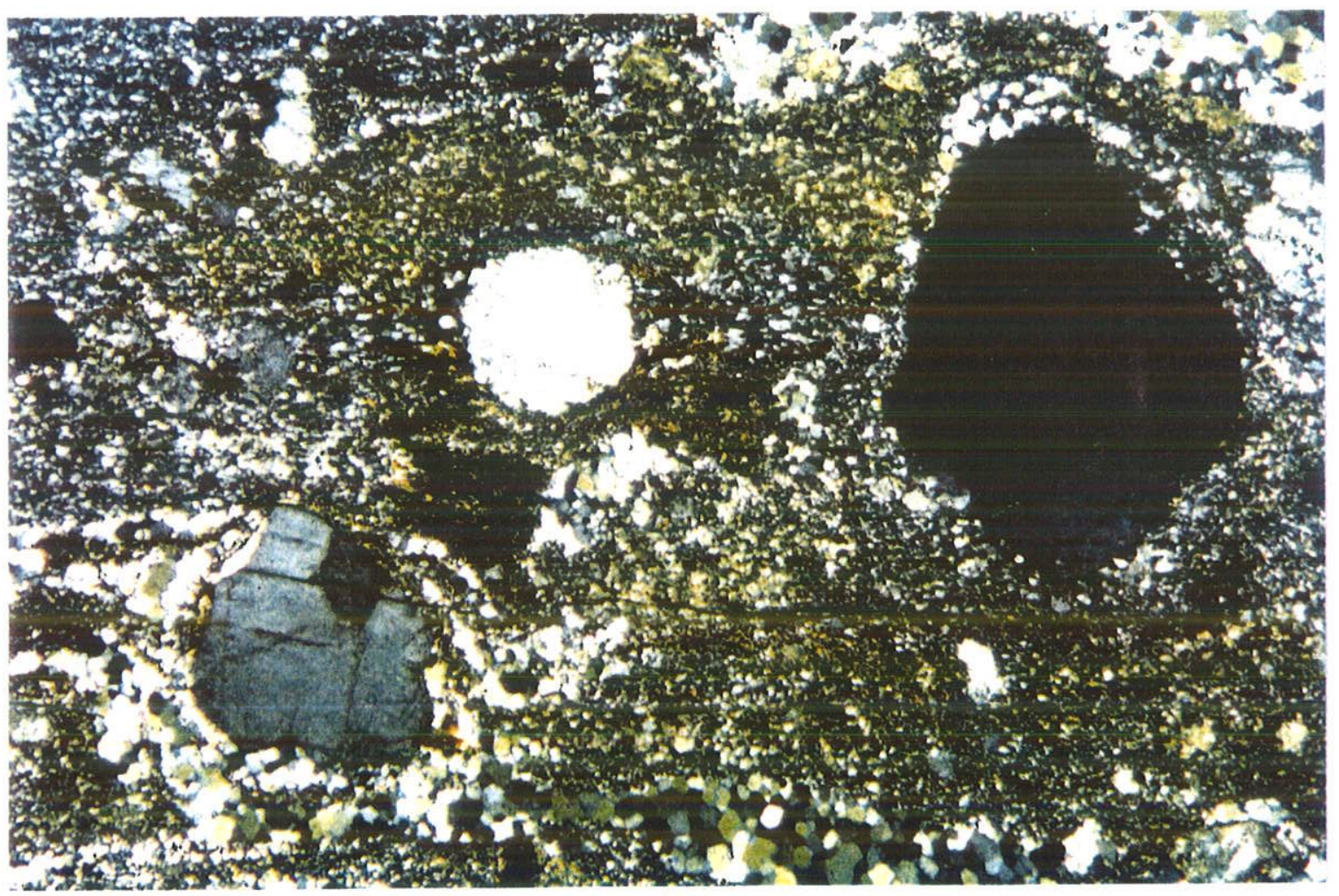

$0,8 \mathrm{~mm}$

Figura 27 - Textura porfiroclástica em Quartzito do JF2. Ponto 18. 
$\mathrm{Lm}_{2}$ é definida pela orientação preferencial de minerais como quartzo, hornblenda, piroxênios e biotita ou estiramento de agregados, de acordo com o litotipo. Sua atitude, comumente paralela a subparalela aos eixos das dobras $D_{2}$, tem dois máximos: $55 / 29$ e 302/70.

\section{\# JF3}

Este domínio é caracterizado por intensa interdigitação tectônica com imbricamento de contatos, entre rochas metassedimentares (biotita-granada-(sillimanita) gnaisses, biotita gnaisses, quartzitos, rochas calcissilicáticas e granada quartzito (correlatos ao CDA) e ortogranulitos do Complexo Juiz de Fora. Esta interdigitação tectônica é observada tanto em escala de mapa, onde as escamas tem formas amendoadas e se estendem na direção NE-SW (Anexos 1, 2, e 3), quanto em escala de afloramento, com escamas variando então de centimétricas a métricas (Fig. 28). Quando comparado ao JF 2, este Domínio apresenta escamas muito menos espessas, a transposição de $S_{1}$ para a posição de $S_{2}$ é total e o número de lentes tectônicas e contatos tríplices é muito maior (Anexos 1,2 e 3 ).

No JF 3 não são observadas com frequência dobras da fase principal de deformação e a foliação principal é uma xistosidade milonítica, associada a bandamento composicional e a uma lineação mineral. Em poucos afloramentos, observam-se dobramentos de uma foliação antiga, apertados a isoclinais intrafoliais e transpostos pela xistosidade milonítica, então considerada $\mathrm{S}_{2}$.

\section{\#Dobras D2}

No JF 3 a estrutura principal consiste de uma alternância entre bandas dobradas, onde a foliação principal é uma xistosidade grossa $\left(S_{1}\right)$, e bandas miloníticas, onde a foliação principal é milonítica $\left(S_{2}\right)$ e transpõe a foliação $S_{1}$. No entanto, neste Domínio, a razão entre a porção milonítica e a porção dobrada é alta, bem maior do que para o JF 2. Este "bandamento estrutural" mostra a heterogeneidade e partição da deformação principal.

No JF3, as dobras $\mathrm{D}_{2}$ são ainda mais apertadas e são comuns dobras com perfil isoclinal. Diferentemente do JF 2 , as dobras são simétricas, sendo seu padrão do tipo dobras similares. Os planos axiais têm mergulhos íngremes para SE (Fig. 29), e os eixos, ora para NE, ora para SW. 


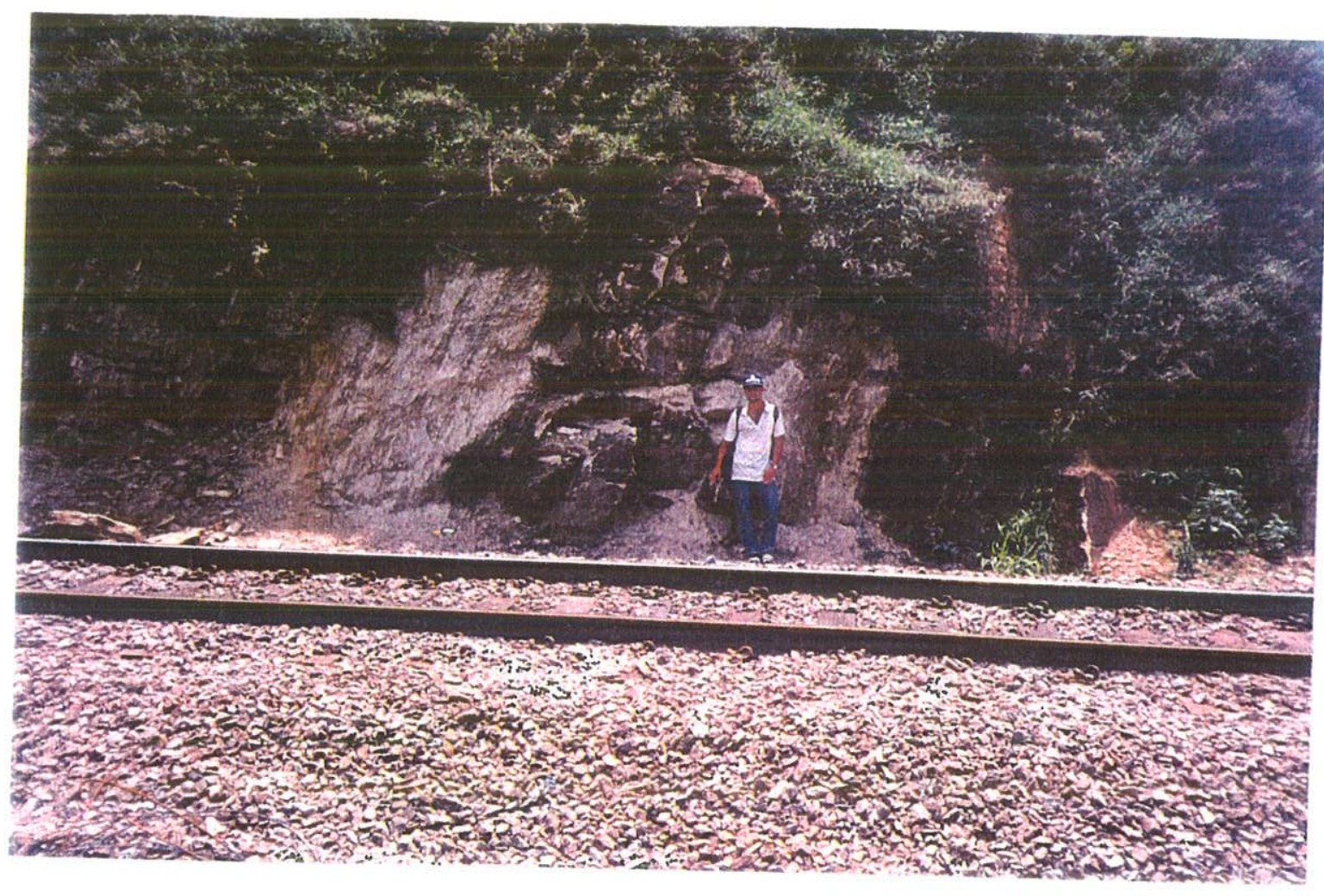

Figura 28 - Interdigitação tectônica entre metapelitos e ortogranulitos do Complexo Juiz de Fora (escala métrica). JF 3. Ponto 447

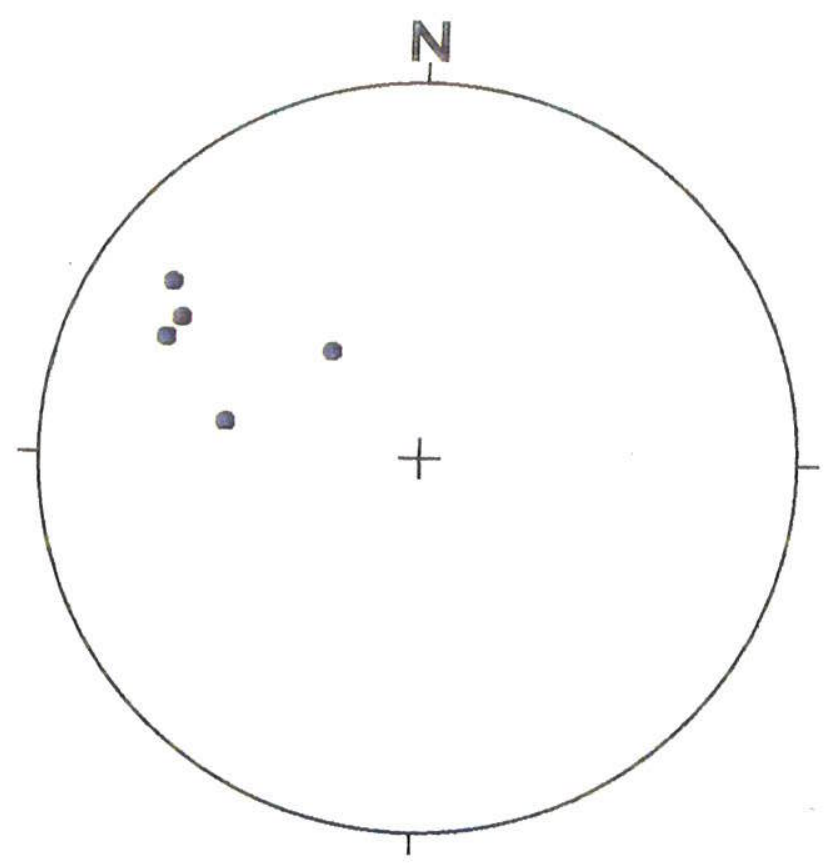

Figura 29 - Estereograma dos planos axiais das dobras $\mathrm{D}_{2}$. JF3 


\section{\# Foliação $S_{2}$}

No JF2, a estrutura $S_{2}$ é uma foliação milonítica, definida pelo arranjo planar de minerais tabulares, prismáticos e micáceos em uma matriz fina a média que eventualmente isola profiriclastos de minerais mais refratários à recristalização dinâmica. Além desta orientação mineral, observa-se forte paralelismo de veios leucossomáticos e de melanossomas a esta estrutura, gerando um bandamento composicional de origem tectônica. Embora as estruturas $S_{0}$ e $S_{1}$ tenham sido quase totalmente transpostas, verifica-se que a foliação $S_{2}$ e bandamento composicional $\mathrm{S}_{2}$ guardam paralelismo àquelas estruturas. $\mathrm{A}$ atitude de $\mathrm{S}_{2}$ pode ser observada em estereograma (Anexo 3), cujo máximo está em 132/52.

A foliação milonítica $S_{2}$ é resultado de um processo de recristalização dinâmica, levando à redução no tamenho dos grãos da rocha. Principalmente em escala microscópica, pode-se verificar mais uma vez a heterogeneidade da deformação, já que as rochas mostram alternância de níveis mais finos e mais grossos, ou seja, mais e menos deformados, respectivamente.

A análise petrográfica desta estrutura permitiu a identificação e carcterização de $S_{2}$. Ocorrem profiroclastos de piroxênio (opx e/ou cpx), hornblenda, plagioclásio e granada, dependendo do tipo litológico, e a matrix, de granulometria variável, é constituída de grãos recristalizados dos minerais que formam os porfiroclastos, além de quartzo e biotita (Fig.30). Além de recristalizados nas bordas, os porfiroclastos mostram outros efeitos da deformação, como extinção ondulante, bandas e/ou lamelas de deformação e formação de subgrãos. Por outro lado, a matriz é granoblástica, apresentando novos grãos e fitas de quartzo.

Franjas de recristalização, constituindo estruturas em sigma são observadas tanto em escala de afloramento, quanto em escala microscópica (Fig. 31). Normalmente ocorrem ao redor dos porfiroclastos ou em "boudins"formados por litotipos mais competentes (quartzito, calcisilicáticas, gondito, anfibolito). Estes "boudins" mostram, muitas vezes, foliação interna, cuja orientação, associada à morfologia da franja, indica a cinemática do transporte tectônico.

Outros importantes indicadores cinemáticos observados desde escala microscópica até métrica, são foliações $\mathrm{S}$ e $\mathrm{C}$ e duplexes de foliação $\mathrm{S}_{2}$. 


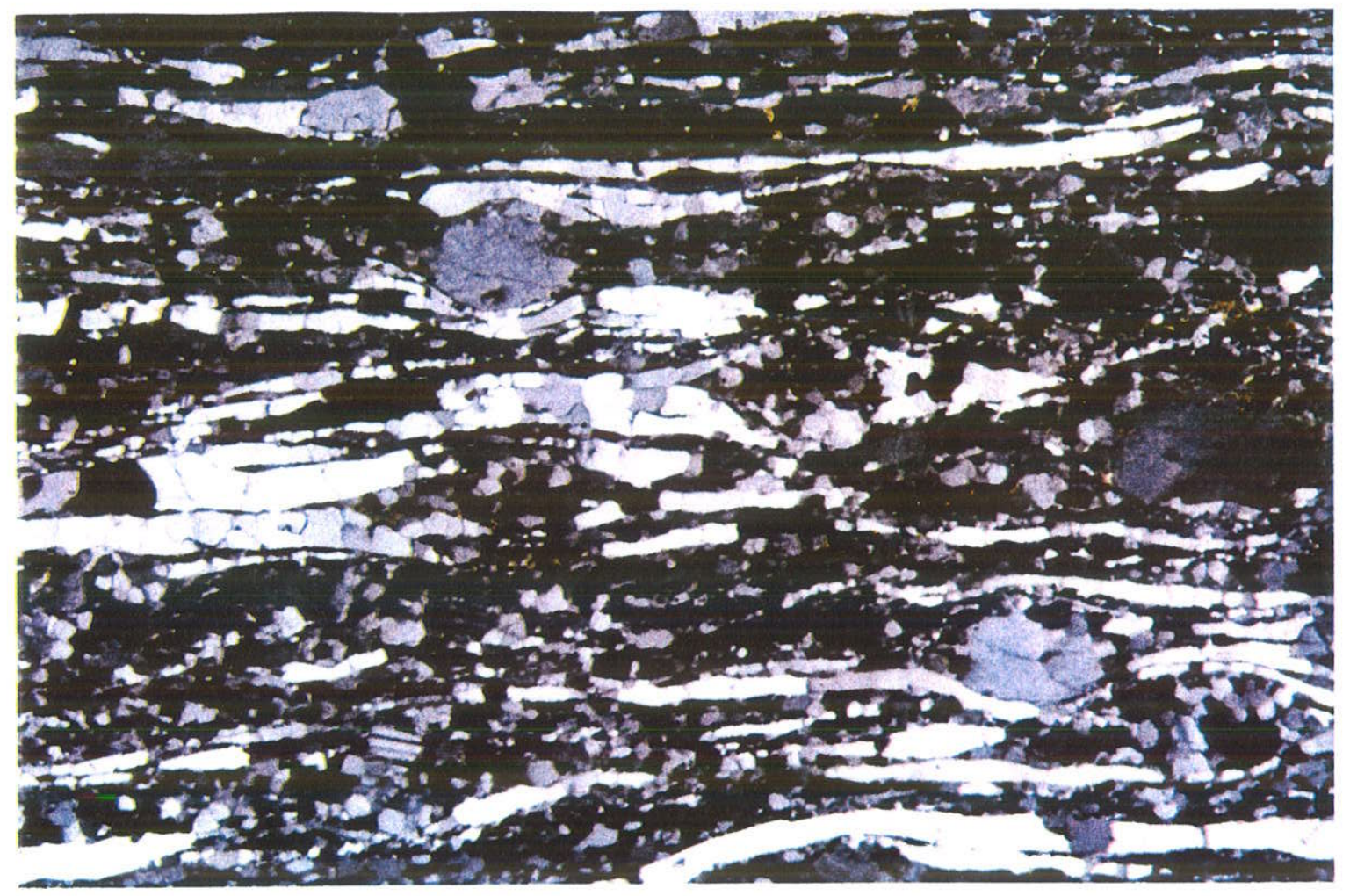

$0,8 \mathrm{~mm}$

Figura 30 - Foliação milonítica $S_{2}$ e textura porfiroclástica em bt-gr gnaisse. JF 3. Ponto 176

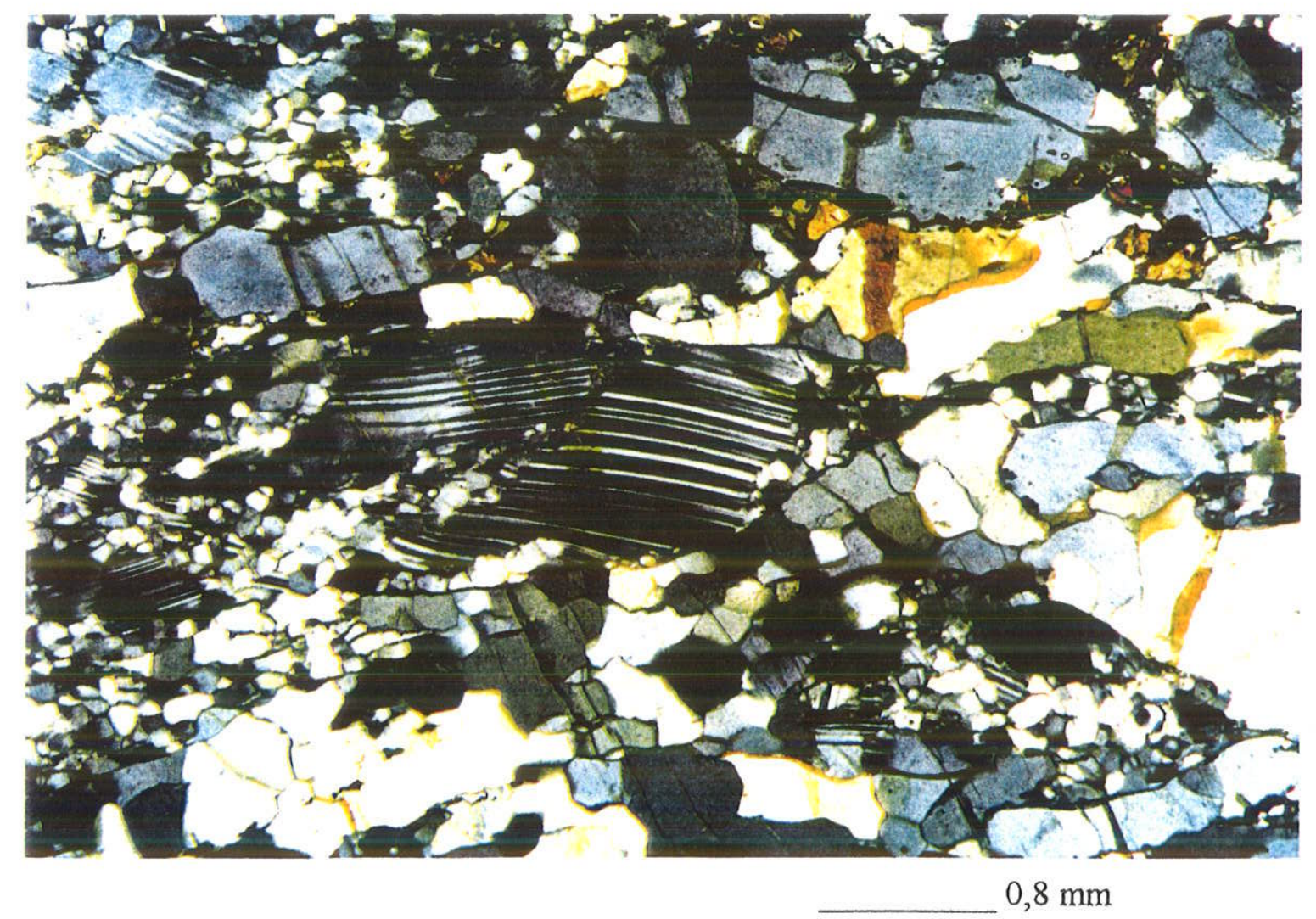

Figura 31 - Estrutura porfiroclástica tipo sigma em plagioclásio enderbito do CJF. JF3. Ponto 340 


\section{\# Lineação mineral $\mathrm{Lm}_{2}$}

A lineação mineral $\mathrm{L}_{2}$ é mais ou menos visivel, de acordo com o litotipo em que é desenvolvida. Nas rochas metassedimentares (gnaisse qtz-feldspático, gnaisses pelíticos e quartzitos), esta estrutura é observada com frequência, sempre associada à foliação milonítica $\mathrm{S}_{2}$. O granitóide Matias Barbosa também se mostra uma rocha propicia ao desenvolvimento de $\mathrm{Lm}_{2}$. Por outro lado, nas superficies miloníticas dos ortogranulitos do Complexo Juiz de Fora, esta lineação é dificilmente observada, sendo, no entanto, mais comum do que no JF2.

A orientação preferencial de minerais como quartzo, hornblenda, piroxênios e biotita ou estiramento de agregados, de acordo com o litotipo, definem esta estrutura. Sua atitude, comumente paralela a subparalela aos eixos das dobras $\mathrm{D}_{2}$, varia desde $\mathrm{NE}$ a $\mathrm{SW}$, tendo máximo em 49/19.

\section{\# Fase de Deformação Tardia}

Duas (ou uma) fases de deformação tardia, $\mathrm{D}_{3}$ e $\mathrm{D}_{4}$, redobram a xistosidade principal e podem ser reconhecidas nos cinco domínios tectônicos estudados (AND 1, AND 2, JF 1, JF 2 e JF3). A intensidade de deformação é diferente entre estas duas fases, sendo as estruturas relacionadas a $\mathrm{D}_{4}$ muito mais frequentes, embora esta seja mais particionada. Entretanto, esta fase não desenvolve xistosidade plano axial, a não ser em zonas de cisalhamento a ela relacionadas. Este aspecto sugere que $\mathrm{D}_{3}$ e $\mathrm{D}_{4}$ se desenvolveram em níveis crustais mais rasos e, muito embora tenham características de deformação dúctil e dúctil-rúptil, respectivamente, as evidências mostram que sua evolução se deu sob condições mais frias do que as da fase principal de deformação e, portanto, após o auge do metamorfismo.

\section{\# Dobras $D_{3}$}

Poucos exemplos de dobras $\mathrm{D}_{3}$ foram observados em escala de afloramento e, quase sempre, estavam associados a zonas de cisalhamento. A morfologia das dobras $D_{3}$ é muito variável, predominando as reclinadas e inclinadas.

De acordo com o litotipo ou com a proximidade às zonas de cisalhamento $\mathrm{D}_{3}$, as dobras desta fase têm perfil que varia de aberto a apertado. Além disso, nos ortognaisses migmatíticos do Complexo Mantiqueira, as dobras são, em geral, simétricas, enquanto que nas rochas metassedimentares, a assimetria é mais característica. 
As dobras $\mathrm{D}_{3}$ têm Plano Axial com mergulhos altos a médios para SE ou NW e eixos com caimentos suaves para SW (Fig. $32 \mathrm{a}$ e b). A assimetria também tem variação, ora é em "Z", ora em "S", em perfis NW-SE.

Segundo a classificação de Ramsay (1967), os padrões de interferência gerados pela superposição de $D_{3}$ sobre $D_{1}+D_{2}$ variam desde tipo 2 (cogumelo) até o tipo 3 (dobra dobrada), o que mostra as relações entre os eixos $D_{1}+D_{2}$ e $D_{3}$, perpendiculares no tipo 2 e oblíquas no tipo 3.

A acilindricidade das dobras D3 também foi verificada em vários afloramentos, com a variação na atitude do eixo em uma mesma zona de charneira.

\section{\# Zona de Cisalhamento $D_{3}$ existosidade milonítica $S_{3}$}

A alternância local de zonas de cisalhamento $\mathrm{D}_{3}$ com zonas de dobramentos $\mathrm{D}_{3}$ evidencia o caráter heterogêneo desta fase de deformação. Nas zonas de cisalhamento $D_{3}$, a xistosidade principal $\left(\mathrm{S}_{1}, \mathrm{~S}_{2}\right.$ ou $\left.\mathrm{S}_{1}+\mathrm{S}_{2}\right)$ sofre transposição total, o que dá origem a uma foliação $\mathrm{S}_{3}$ milonítica. Próximo a estas zonas de cisalhamento, as dobras $\mathrm{D}_{3}$ tornam-se mais apertadas. A movimentação é dextral, tanto normal quanto inversa.

\section{\# Clivagem de Fratura}

Nos quartzitos de todos os Domínios Estruturais, é frequente a ocorrência de uma clivagem de fratura $S_{3}$, paralela ao plano axial das dobras $D_{3}$. Esta clivagem mostra-se como uma estrutura espaçada, disjuntiva, semelhante a uma fratura e tem um arranjo em leque com relação às dobras $\mathrm{D}_{3}$.

\section{\# Lineação de Intersecção $L i_{3}$}

Em função da interseção entre a xistosidade principal $S_{1}, S_{2}$ ou $S_{1}+S_{2}$ e a clivagem de fratura $S_{3}$, é formada uma lineação de interseção $L_{3}$, paralela ao eixo das dobras $D_{3}$.

\section{\# Dobras, Falhas e Zonas de Cisalhamento $D_{4}$}

A deformação $\mathrm{D}_{4}$ gerou zonas de cisalhamento de caráter dúctil/rúptil, falhas e dobras abertas a suaves. As duas primeiras estruturas e os planos axiais das dobras $\mathrm{D}_{4}$ guardam uma relação de paralelismo, tendo direção variando de N30W a N30E e mergulhos médios a altos, 


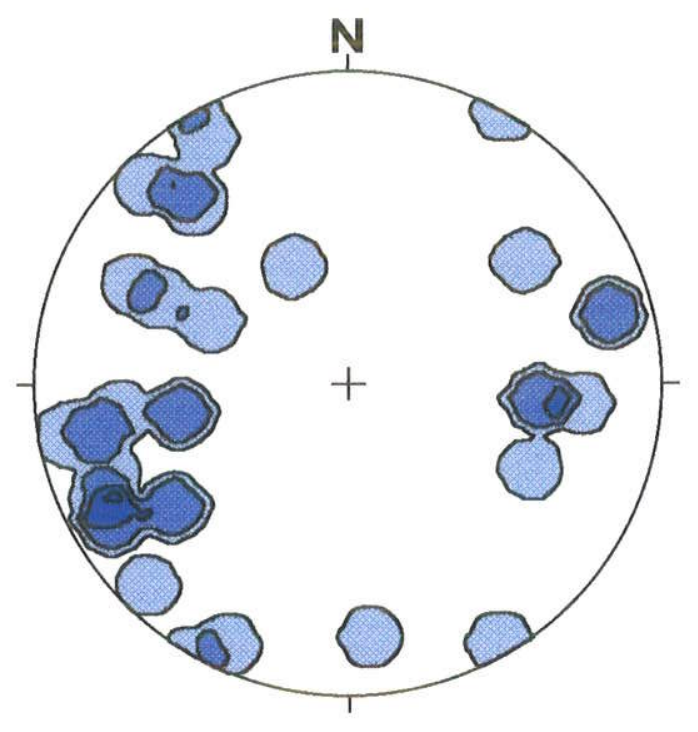

a

Número de pontos: 31

Linhas: $1-3 \%$

$2-6 \%$

$3-9 \%$

$4-12 \%$

b

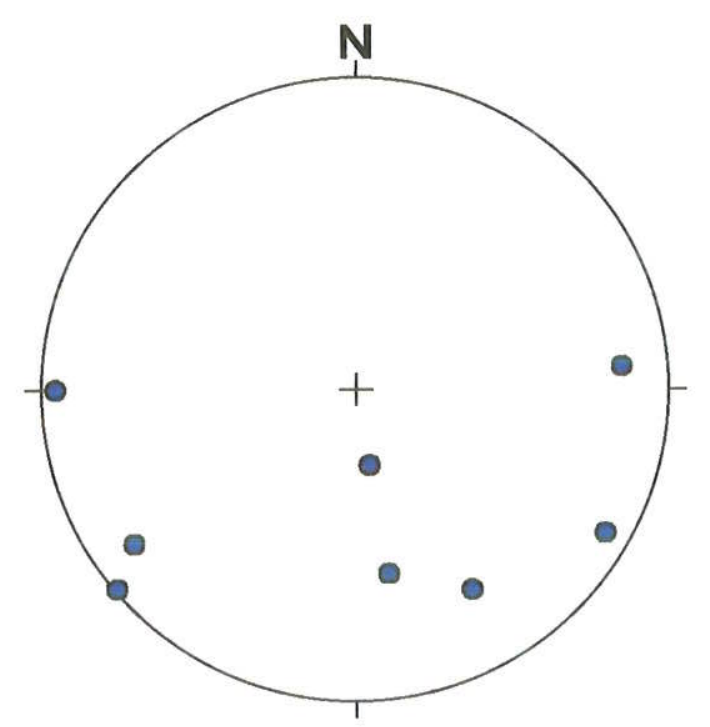

Figura 107 - Estereograma do Plano Axial (a) e Eixo(b) da fase de deformação, mostrando duas tendências, interpretadas como referentes a $D_{3}$ e $D_{4}$. 
comumente para ENE, com máximos em $81 / 54$ e 64/72, respectivamente (Fig 32a e b). Ao longo das zonas de cisalhamento e das falhas, caracteriza-se uma movimentação preferencialmente normal sinistrógira, com pequeno componente de rejeito vertical. $O$ bordo oeste é frequentemente abatido (Fig. 33), no entanto, subordinadamente foi também verificado o abatimento do bloco leste (Anexos 1, 2 e 3).

$\mathrm{O}$ carater dúctil da deformação $\mathrm{D}_{4}$ pode ser verificado, em escala megascópica, pelo arrasto que esta fase provoca na foliação principal (Anexos 1, 2 e 3) e, em escala de afloramento, pelo arrasto e transposição quase total desta mesma foliação em zonas de cisalhamento $\mathrm{D}_{4}$ (Fig. 34).

\section{II.5.3 Análise Cinemática da Deformação}

\section{Fase Principal de Deformacão}

\section{\# Indicadores Cinemáticos}

Vários indicadores cinemáticos da foliação principal $\left(S_{1}, S_{2}\right.$ ou $\left.S_{1}+S_{2}\right)$ foram observados nos diversos Domínios Tectônicos investigados. Sombras de pressão, assimetria de dobras, foliações $\mathrm{S}$ x C, foliação interna e externa em boudins, estruturas tipo sigma e/ou delta em porfiroclastos e boudins e outros indicadores de giro foram analisados sempre quando associados à lineação mineral de estiramento $\mathrm{Lm}_{2}$. A figura 35 apresenta estas estruturas e verifica-se que, independente do Domínio Tectônico, a movimentação relacionada à fase principal de deformação se deu por cavalgamento de SE para NW. Nas zonas de cisalhamento $\mathrm{D}_{1}+\mathrm{D}_{2}$, incluindo os limites entre os Domínios Tectônicos, indicadores cinemáticos também apontam para uma movimentação inversa, de SE para NW (Fig.36). Em poucos casos, onde estas zonas de cisalhamento são mais íngrimes, as estruturas assimétricas indicam, além de movimentação inversa, também componentes direcionais predominantemente dextrógiros, mostrando a ocorrência de movimentos transcorrentes (Fig. 36).

\section{\# Interpretação da Cinemática}

A fase principal de deformação $\left(D_{1}+D_{2}\right)$ foi responsável pela compartimentação tectônica da área estudada, promovendo o empilhamento estrutural de seis escamas que, da base para o topo, são: DTAND, DTJF e DTPS. Os limites entre os diferentes Domínios são 


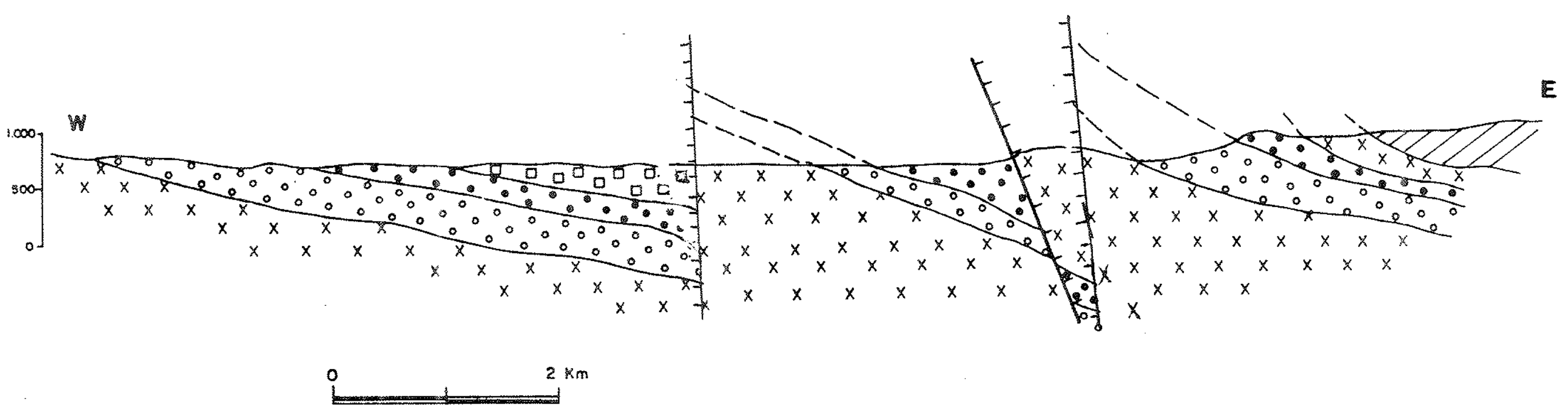

27 ortogranulitos do cag

DD GRANADA CHARNOCKITO

BIOTITA-ISILLIMANITA) GNAISSE PORFIROCLÁSTICO

10.0] QUARTZITO 2 BIOTITA GNAISSE DO CDA

[X $x_{x}$ ORTOGNAISSES DO CH

7 falhas $E$ zonas oe cisalhamento $D_{4}$ 

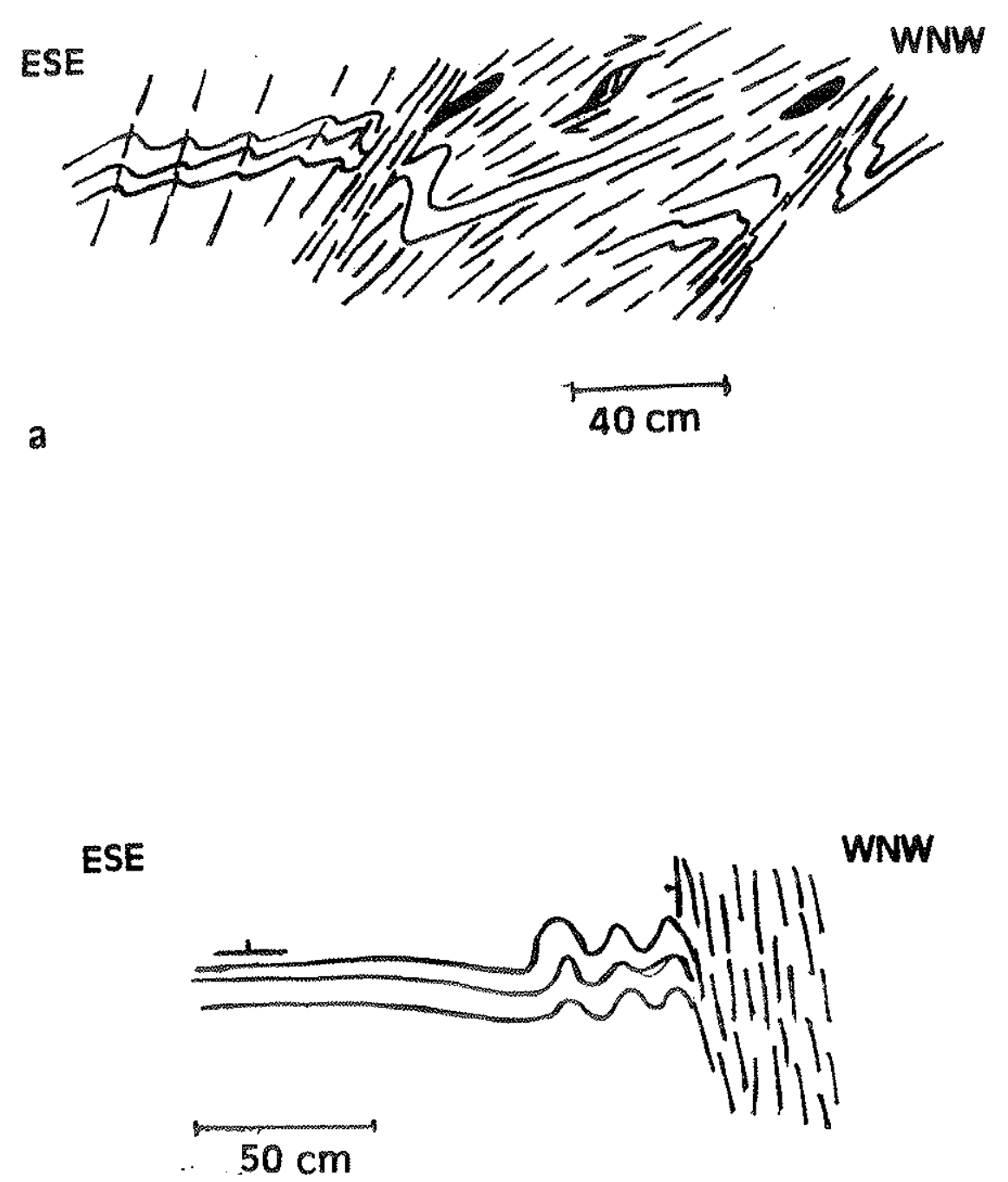

b

Figura 34 - Transposição total da foliação $S_{2}$ para a posição espacial de $S_{4}$. JF2.

a) Ponto 373 ; b) Ponto 518 
$N$

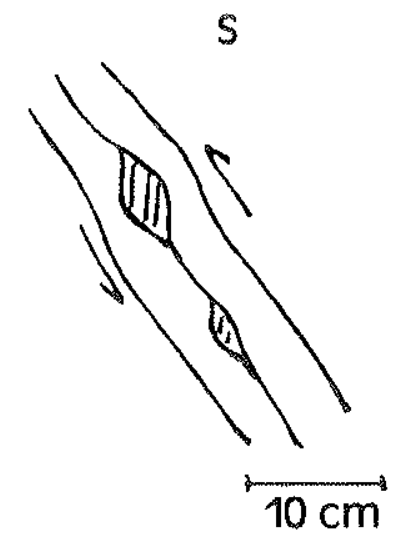

a

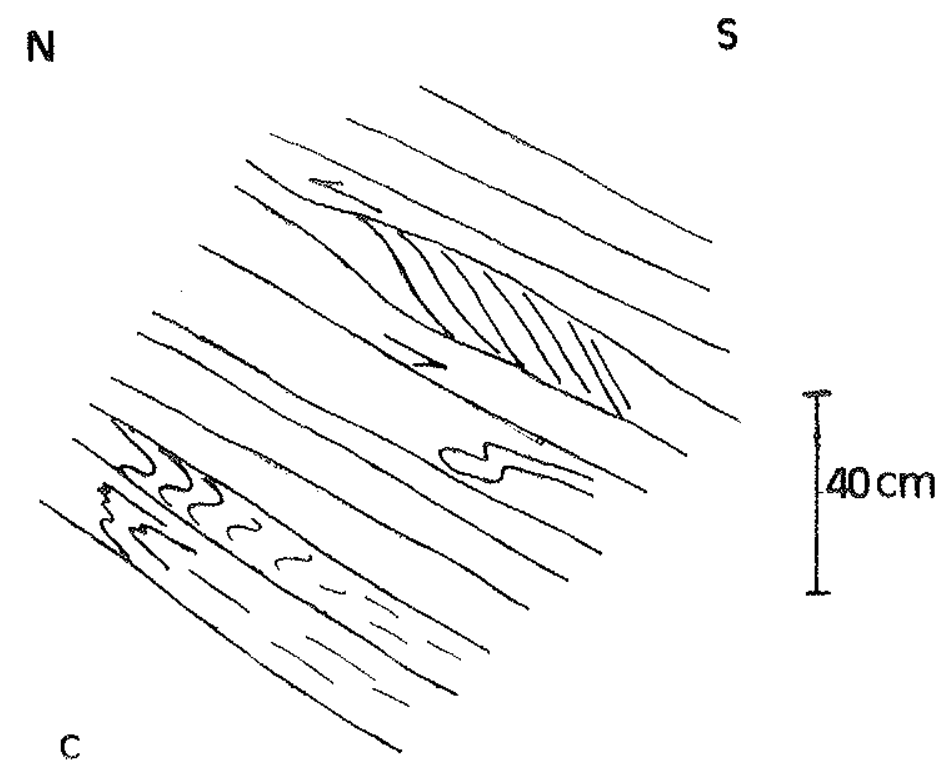

$\mathrm{b}$

S

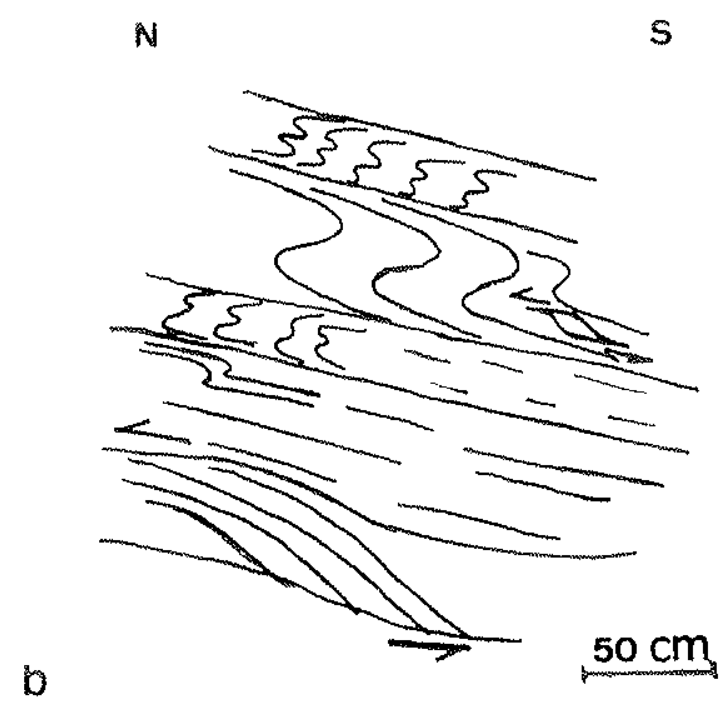

Figura 35 - Indicadores cinemáticos da fase principal de deformação, mostrando movimentação inversa de SSE para NNW: a) DTAND. ponto 30;

b) DTAND, ponto 27, c) DTJF ponto 15 . 


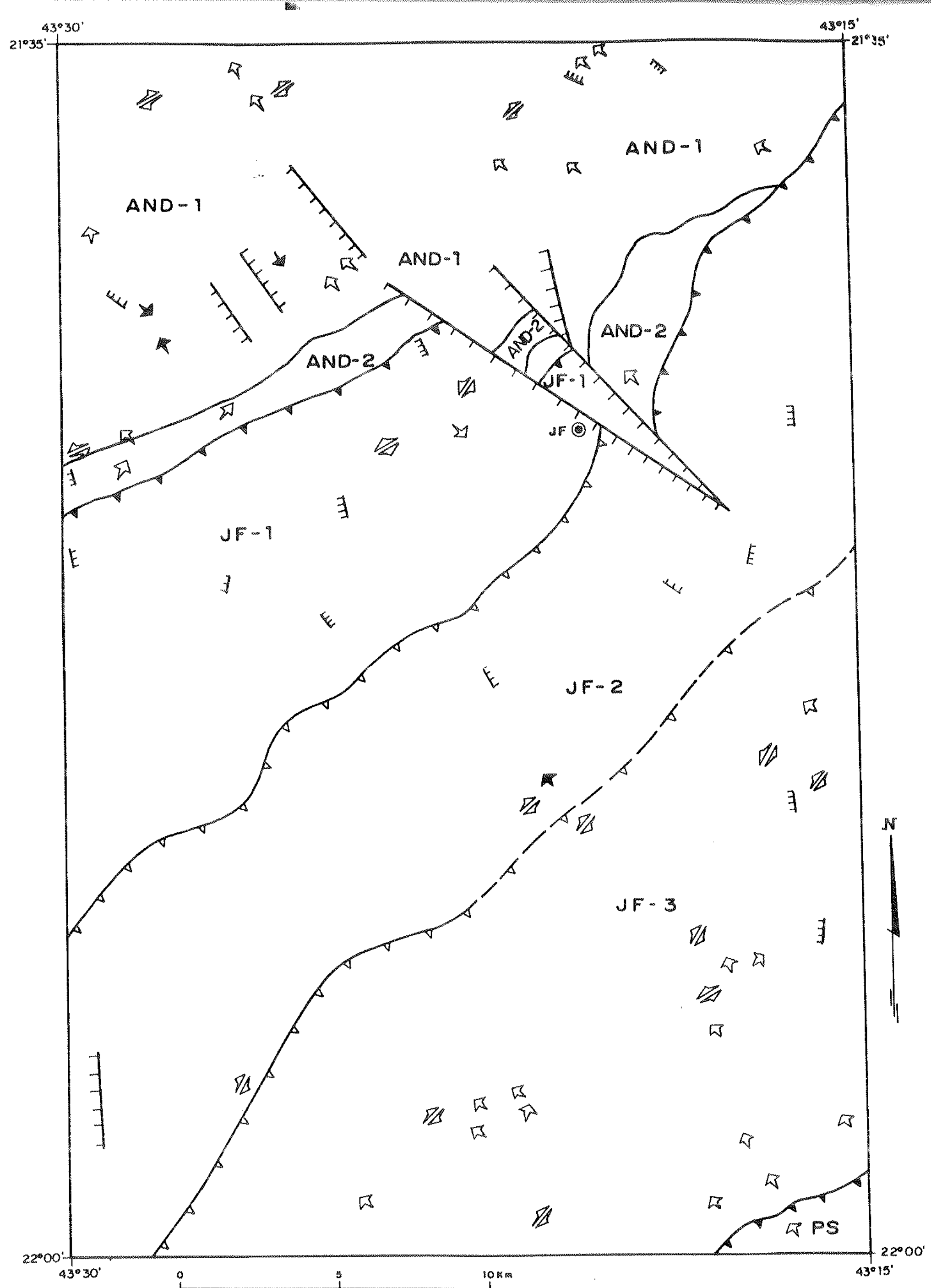

\section{LEGENDA}

EMPURRÄO DA DEFORMACAO PRINCIPAL E LIMITE DOS EOMINIOS TECTÓMICOS

EMPURRÄO DA DEFORMAGĂO PRINCIPAL E LIMITE DOS DOMINIOS ESTRUTURAIS

ZONA DE CISALHAMENTO E FALHAS SURVERTCAIS COM COMPONENTE DE MOVIMENTACÄO NORMAL IDEFORMAG\&O TARDIA)

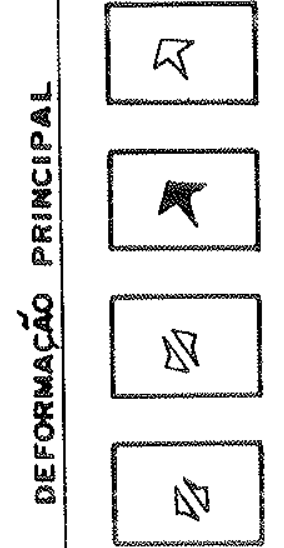

INDICADOR DE CAVALGAMENTO

INDICADOR DE MOVIMENTAGĂO EXTENSIONAL DÚCTL

INDICADOR SINISTRÓGIRO

INDICADOR DEXYROGIRO

JF 0

AND - I

AND- 2

$J F=1$

$J F \cdot 2$

$J F-3$

PS

FIGURA 36. Mapa dos indicadores do senfido do cisalhamenro para os Dominios Estrururais identificados 
representados por descontinuidades estruturais onde a deformação é intensa, resultando no desenvolvimento de zonas de cisalhamento dúcteis de baixo a médio ângulo, associadas invariavelmente à formação de rochas miloníticas.

Estruturas relacionadas a $\mathrm{D}_{1}+\mathrm{D}_{2}$ como dobras fechadas a isoclinais, dobras inclinadas ou reclinadas a recumbentes, dobras acilíndricas; zonas de cisalhamento dúcteis de componente principal inverso (ou inverso a transcorrente em alguns casos); e lineação mineral de estiramento (desenvolvida de maneira seletiva dentre os vários Domínios) podem ser encontradas em todos os Domínios investigados e são interpretadas como resultante de uma tectônica compressiva que promoveu intenso encurtamento crustal em regime dúctil.

Embora os efeitos da deformação principal possam ser verificados em todos os Domínios Tectônicos estudados, cada Domínio mostra especificidades estruturais que são provavelmente resultantes da atuação de um ou mais dos seguintes fatores: temperatura e pressão reinantes durante a atuação de $\mathrm{D}_{1}+\mathrm{D}_{2}$, responsáveis pela caracterização dúctil e/ou rúptil de um ambiente e, consequentemente, pela geração de diferentes estilos de deformação; caráter heterogêneo da deformação principal que, em função de diferenças na intensidade da deformação de uma área para outra (um Domínio para outro ou até dentro de um mesmo Domínio), resulta no desenvolvimento de estruturas de estilos variados; e mudanças dos vetores responsáveis pelo transporte tectônico durante a atuação da fase principal de deformação.

Poucos dados foram coletados para o DTPS dada a restrita ocorrência areal deste domínio na área estudada. No entanto, Heilbron (1993), com base em análise geométrica, concluiu que as estruturas observadas (dobras $\mathrm{D}_{2}$ menos apertadas, mais cilíndricas e menos abundantes; raras zonas de cisalhamento com milonitos associados) são compatíveis com nível crustal mais raso, quando comparado aos demais domínios então identificados (DTAND e DTJF). Segundo Heilbron (op. cit.), as características estruturais do DTAND (xistosidade $\mathrm{S}_{2}$ bem desenvolvida; frequentes dobras apertadas a isoclinais, geralmente assimétricas, observadas em todas as escalas e onde é ainda possível identificar a xistosidade $S_{1}$ e o acamamento $\mathrm{S}_{0}$; acilindricidade do dobramento; e a ocorrência de dobras em bainha e tubulares) indicam um nível crustal intermediário. O DTJF, caracterizado por deformação mais intensa (frequente desenvolvimento de foliação milonítica associada a dobras intrafoliais sem 
raiz; zonas de cisalhamento com ultramilonitos; interdigitação tectônica de rochas supracrustais e embasamento; e lineação de estiramento muito penetrativa), foi ralcionado pela autora, a uma megazona de cisalhamento dúctil, de proporções crustais.

A partir do presente trabalho, foi possivel agregar as seguintes características metamórfico-estruturais para o AND1: constituído de para e ortognaisses migmatíticos na facies anfibolito superior; dobras $\mathrm{D}_{1}+\mathrm{D}_{2}$ abertas a fechadas, assimétricas, observadas desde a escala de afloramento até a escala de mapa; transposição local de $S_{1}$ e formação da xistosidade de crenulação $S_{2}$ ou, menos comumente de foliação milonítica $S_{2}$; lineação mineral penetrativa, observaçào de superimposição de estrutura $D_{2}$ sobre estrutura $D_{1}$; clara definição do embasamento e da cobertura. Todas estas características permitem correlacionar o AND1 a um ambiente crustal intermediário, o que vai de encontro à interpretação de Heilbron (1993) para seu DTAND.

Os dados caracterizados para o AND2 (xistosidade milonítica $\mathrm{S}_{2}$, transposição quase total da xistosidade $S_{1}$, dobras $D_{1}+D_{2}$ apertadas a isoclinais intrafoliação $S_{2}$, somente observadas em escala de afloramento, para ortognaisses na facies anfibolito suprior permitem correlacionar este domínio a uma zona de cisalhamento dúctil, relacionada à fase principal de deformação $\mathrm{D}_{1}+\mathrm{D}_{2}$, instalada também em nível crustal intermediário. Esta zona de cisalhamento foi gerada provavelmente como consequência do cavalgamento de JFl sobre DTAND, ou seja, o AND2 não parece um dominio alóctone para o AND1 e sim mostra-se como o AND1 muito deformado.

As características metamórfico-estruturais do JFl - para os ortognaisses na facies granulito (e anfibolito superior); charnockitos ígneos isotrópicos a foliados; dobras abertas $D_{2}$ abertas a fechadas, desde a escala de afloramento até a escala de mapa; xistosidade grossa $\mathrm{S}_{1}$; intarfoliação local de $S_{1}$ e formação de xistosidade $S_{2}$; milonitização local; contatos ora tectônicos; migmatitos com leucossoma verde com opx - permitem correlacioná-lo a um nível crustal mais profundo, quando comparado aos AND1 e AND2. A inversão metamórfica (rocha granulítica sobre rocha na facies anfibolito) então verificada corrobora a interpretação de tectônica de empurrão feita com base na análise geométrica e cinemática da área. O JF1 não ocorre na área estudada por Heilbron (op. cit.), o que indica que este domínio forma uma 
grande escama que se fecha para SW e também para NE, no canto da cidade de Juiz de Fora (Anexo 2), quando é truncada pelo cavalgamento do JF2.

O JF2 tem como principal característica um bandamento estrutural, no qual zonas de dobras $D_{2}$ alternam-se com zonas de cisalhamento $D_{2}$ onde a foliação milonítica $S_{2}$ e um bandamento composicional $\mathrm{S}_{2}$ são as únicas estruturas visíveis. Estas características associadas ao fato deste domínio ser constituído por escamas tectônicas, ora constituídas de ortogranulitos, ora por paragnaisses e quartzitos com paragênese não diagnóstica, sugerem que o JF2 representa um nível crustal semelhante ou ainda de características mais dúcteis do que o do JF1. O fato do JF1 apresentar menor número ou volume de zonas de cisalhamentos $\mathrm{D}_{2}$ pode ser decorrente de tipos litológicos menos suscetíveis à deformação. Não se descarta também a possibilidade do JF1 ser representante de um nível crustal mais profundo do que o JF2, já que no primeiro existem evidências de anatexia ter ocorrido sob condições anídricas (leucossomas verdes com opx e presença de granada charnockito).

O empurrão relacionado à escama do JF2 é claramente posterior (teve percurso mais longo de cavalgamento) aquele do JF1, já que ocorre truncamento, primeiro do JF1, quando, então, o JF2 ocorre cavalgado sobre o AND2. No entanto, o empurrão trunca também este domínio e o JF2 cavalga o AND1.

Na área investigada por Heilbron (1993) só ocorrem as escamas de paragnaisses deste domínio, que constituem a base do DTJF então definido.

O JF3, que cavalga o JF2, é caracterizado por uma interdigitação tectônica entre ortognaisse na facies granulito e metapelitos em geral com paragêneses não diagnósticas para a facies metamórfica, mas, localmente, com opx. São vários os contatos tríplices observados, mostrando o "overlapping" de uma escama sobre a outra. A xistosidade milonítica $\mathrm{S}_{2}$, dobras apertadas intrafoliais sem raiz e lineação mineral e de estiramento são as principais estruturas observadas, tanto nos contatos entre as diferentes escamas, quanto dentro das mesmas. Este domínio tem forma amendoada, com grande variação de sua espessura em mapa, desde $15 \mathrm{Km}$ na porção central da amêndoa, a $2 \mathrm{Km}$ a SW em direção à Valença $(\mathrm{RJ})$. À medida que a amêndoa vai se tornando mais estreita, a intercalação passa da escala de dezenas de metros para escala métrica até de poucos centímetros. Todas estas características associadas sugerem 
fortemente que o JF3 seja uma megazona de cisalhamento, desenvolvida durante a fase principal de deformaçăo como sugerido por Heilbron (1993) para o DTJF. Para o JF3, os indicadores cinemáticos mostram uma movimentação inversa para NNW e NNE que varia para uma movimentação com componente principal transcorrente. Para os demais domínios (AND1, AND2 e JF2), os dados indicam movimentação inversa ou oblíqua para NNW. Isto sugere que os vetores sofreram variação na direção durante a evolução da deformação principal $\mathrm{D}_{1}+\mathrm{D}_{2}$. Inicialmente a compressão foi mais frontal, gerando cavalgamento de baixo ângulo para NNW. Transicionou para uma compressão com cavalgamento de médioa alto ângulo para NNW e NNE (JF2) e, durante a última etapa (tardi $-\mathrm{D}_{2}$ ), a movimentação principal foi direcional, com transcorrência dextrógira.

Os dados aqui apresentados corroboram o modelo de colisão oblíqua proposta por Heilbron (1993) para o setor central da Faixa Ribeira.

\section{\# Deformacão Tardia}

A estruturas geradas durante a fase principal de deformação foram posteriormente dobradas ou giradas por fases tardias de deformação, aqui denominadas de $\mathrm{D}_{3}$ e $\mathrm{D}_{4}$.

A fase de deformação $\mathrm{D}_{3}$ teve um desenvolvimento restrito na área estudada e gerou dobras abertas, assimétricas, associadas a uma foliação plano-axial do tipo xistosidade disjuntiva. Poucas zonas de cisalhamento podem ser relacionadas a esta fase que não gerou estruturas penetrativas em nenhum dos dominios investigados. Isto sugere que a deformação $\mathrm{D}_{3}$ evoluiu sob condições crustais mais rasas do que aqelas da deformação $\mathrm{D}_{1}+\mathrm{D}_{2}$, embora esteja associada à formação de paragêneses minerais compatíveis com a facies anfibolito superior.

Estruturas relacionadas à fase de deformação $\mathrm{D}_{4}$ são mais comuns na área estudada. São observadas desde escala de afloramento até escala de mapa. Dobras abertas a apertadas, zonas de cisalhamento dúcteis-rúpteis e falhas são as principais estruturas relacionadas a $\mathrm{D}_{4}$. $\mathrm{Na}$ área estudada, as estruturas $\mathrm{D}_{4}$ mais evidentes são as falhas e zonas de cisalhamento de direção N-S ou NW-SE no centro e arredores da cidade de Juiz de Fora. Aí verifica-se claramente que estas estruturas superpõem-se indiscriminadamente a vários dominios 
tectônicos e/ou estruturais (AND1, AND2, JF1 e JF2). É também possível verificar que $\mathrm{D}_{4}$ promoveu o arrasto da xistosidade principal (S1, S2 ou S1+2) e está, em geral, associada a uma movimentação sinistrógira normal, onde o bloco oeste é normalmente abatido. Localmente, nas zonas de cisalhamento $\mathrm{D}_{4}$ ocorre a transposição da xistosidade principal, mostrando o caráter dúctil dessa fase de deformação que, embora tenha ocorrido em níveis mais rasos do que a fase princiapal, não foi desenvolvida sob condições muito frias. 


\section{6) Evolução Metamórfica das Rochas da Região de Juiz de Fora}

\section{II.6.1) Introdução}

O estudo da evolução metamórfica da área alvo foi realizado com base nos resultados da investigação de cerca de 300 lâminas. As seguintes abordagens foram efetuadas neste estudo: a) análise petrográfico-petrológica, incluindo a determinação das paragêneses minerais e relações entre as várias fases; b) análise microtectônica, a fim de estabelecer as relações entre crescimento e/ou recristalização mineral e fases de deformação; c) análise geotermobarométrica com base na composição química das fases de interesse, visando o aprimoramento da caracterização petrológica das rochas e a determinação das condições de Pressão (P) e Temperatura $(\mathrm{T})$ do(s) pulso(s) metamórficos identificados. Somente o Domínio Tectônico Juiz de Fora foi alvo desta última abordagem. Finalmente, com a integração dos resultados obtidos nestas diferentes abordagens, elaborou-se o modelo para a evolução tectono-metamórfica da área.

Dois pulsos metamórficos foram identificados na área alvo. $O$ mais novo $\left(\mathrm{M}_{1}\right)_{2}$ impresso em todos os Domínios Tectônicos estudados, se desenvolveu contemporaneamente à fase principal de deformação, o que é bem caracterizado pela materialização de sua paragênese na foliação principal S1, S2 ou S1+S2, gerada durante a Orogênese Brasiliana (Machado et al. 1996; Valladares, 1996). Para cada domínio, este metamorfismo mostrou ter evoluido sob condições específicas de $\mathrm{P}, \mathrm{T}$ e/ou $\mathrm{P}_{\text {fluidoss. }}$. Até mesmo dentro de um único domínio, como é o caso do DTJF, são registradas evidências de que existiam gradientes de T e $P_{\text {fluidos }}$ durante a evolução metamórfica contemporânea à fase principal de deformação.

O pulso metamórfico mais antigo é somente registrado nas rochas do Complexo Juiz de Fora e em alguns litotipos do Complexo Mantiqueira, nos quais uma paragênese granoblástica diagnóstica para a facies granulito é claramente anterior ao desenvolvimento da follação principal brasiliana e às paragêneses metamórficas a ela associadas. 
Este capítulo tem como objetivo apresentar a evolução metamórfica da área alvo e, com a intenção de torná-lo mais didático, está subdividido em duas partes. A primeira irá tratar da evolução do metamorfismo contemporâneo à fase principal de deformação e será subdividida em: 1) evolução metamórfica nos diversos litotipos para cada Domínio Tectônico investigado, onde serão apresentadas as paragêneses minerais, relações texturais e possíveis reações metamórficas; 2) investigação petrológica, incluindo as condições P-T do metamorfismo, com base em química mineral. Os litotipos alvos são os ortogranulitos do Complexo Juiz de Fora (DTJF) e o Bt—Gr-Opx gnaisse da Unidade Jardim Glória (DTJF); e 3) integração dos resultados e proposta de um modelo metamórfico para a área estudada, com ênfase no DTJF:

A segunda parte deste capítulo abordará a caracterização e evolução do metamorfismo anterior à fase principal de deformação, também subdividida como segue: 1) caracterização do metamorfismo nos Domínios Tectônicos em que é registrado (DTAND e, principalmente, DTJF); 2) investigação petrológica, incluindo as condições P-T do metamorfismo, com base em química mineral, da qual foram alvos os ortogranulitos do Complexo Juiz de Fora (DTJF); e 3) integração dos resultados e proposta de um modelo metamórfico para a área estudada, com ênfase no DTJF.

\subsection{2) Metamorfismo Contemporâneo à Fase Principal de Deformação: Metamorfismo $M_{1}$}

$O$ metamorfismo $M_{1}$ é registrado em todos os litotipos da área, independente do Domínio Tectônico. Seu ápice termal foi contemporâneo ao desenvolvimento da fase principal de deformação, o que é evidenciado pelo crescimento e/ou recristalização de minerais que materializam a foliação principal $S_{1}, S_{2}$ ou $S_{1}+S_{2}$. As condições de $P, T$ e $P_{\text {fluidos }}$ deste evento variaram entre os diferentes Domínios Tectônicos e até dentro de um mesmo Domínio. No DTAND, são registradas paragêneses diagnósticas de facies anfibolito superior, já no limite com a facies granulito, dada a ausência de muscovita nas rochas metapelíticas e à ocorrência de anatexia em todos os litotipos deste domínio. No DTJF, a evolução de $M_{1}$ mostra-se mais complexa e são registradas tanto paragêneses diagnósticas para a facies granulito quanto para a facies anfibolito superior, mostrando a existência de gradientes (locais) de $\mathrm{T}$ e $\mathrm{P}_{\text {fluidos }}$ durante o 
processo metamórfico. Paragêneses não diagnósticas também ocorrem neste domínio, o que torna complexa a interpretação e integração dos dados. $M_{1}$ foi também responsável pela geração de corpos granitóides/charnockitóides tipo $\mathrm{S}$, de dimensões batolíticas, como o Granada Charnockito, formado pela anatexia das rochas metassedimentares do DTJF. Leucossomas paralelos à foliação principal ocorrem em todos os litotipos, orto e paraderivados, de todos os domínios, com exceção dos ortogranulitos do Complexo Juiz de Fora.

A Suite Intrusiva Matias Barbosa corresponde a um corpo batolítico, cujos contatos com as demais unidades são de dificil caracterização, por estarem bastante tectonizados. Esta suite tem enclaves de rochas calcissilicáticas e, em um afloramento a leste da área de estudo, foi observado contato intrusivo com biotita-granada gnaisses que tem continuidade fisica com aqueles do presente trabalho (Fig. 18). As rochas que constituem esta suite intrusiva tem a foliação principal, quase sempre $\mathrm{S}_{2}$ o que mostra que a intrusão se deu em um período pré a cedo-deformação principal.

A seguir serão apresentadas as características de $\mathrm{M}_{1}$ para cada Domínio Tectônico.

\section{a) Metamorfismo $M_{1}$ no DTAND}

A evolução metamórfica das rochas do Ciclo Deposicional Andrelândia vem sendo estudada por vários autores (Heilbron, 1993; Trouw, 1992; Trouw et al., 1994; Trouw et al., 1996) tanto no Domínio Autóctone (Domínio ou Faixa Alto Rio Grande) quanto no Domínio Alóctone (DTAND). Grande parte destes estudos levaram à elaboração de um esquema de facies tipo Barrowiano para esta área, desde a zona da clorita, próximo ao domínio cratônico, passando pelas zonas da biotita, granada, cianita, sillimanita e K-feldspato. O intenso imbricamento tectônico que se desenvolveu durante a fase principal de deformação foi responsável pela repetição de algumas zonas e isógradas numa direção nororeste-sudeste e pelo padrão inverso do metamorfismo, onde escamas estruturalmente superiores registram condições metamórficas mais altas do que as que thes são sotopostas (Heilbron, 1993). O nível atual de erosão expõe a transição desde a zona da clorita até a zona da sillimanita no Domínio Autóctone, enquanto que no Domínio Alóctone (DTAND de Heilbron, 1993) ocorrem pulos metamórficos devido aos cavalgamentos e somente próximo a seu limite superior é registrada a isógrada do K-feldspato in. Entretanto, Trouw et al. (1994), Trouw e 
Castro (1996) e Trouw et al. (1998) verificaram a ocorrência no Dominio Alto Rio Grande, de metapelitos do Ciclo Deposicional Andrelândia com paragêneses para facies granulito de alta pressão (cianita + K-feldspato) e de retroeclogitos (Hoppe et al., 1985; Tronw, 1992). Além da análise estrutural, estas observações levaram os autores a interpretar este domínio como uma zona de interferência entre a Faixa Brasília (facies granulito de alta $\mathrm{P}$ - campo de estabilidade da cianita) e a Faixa Ribeira (facies granulito de média P - campo de estabilidade da sillimanita).

As paragêneses minerais, sin-fase principal de deformação, registradas nos litotipos do DTAND na área estudada são:

\section{Complexo Mantiqueira}

a) plagioclásio + ortoclásio \pm microclina + quartzo + hornblenda + biotita \pm clinopiroxênio + titanita + apatita + mineral opaco + zircão (gnaisses tonalíticos a graníticos - Hb gnaisse bandado, Hb gnaisse maciço, Bt gnaisse, Bt leucognaisse, Leucossomas brancos, Injeções rosadas e Pegmatitos);

b) plagioclásio + ortoclásio + quartzo + hornblenda \pm clinopiroxênio + biotita + mineral opaco + titanita + apatita + zircão (anfibolitos); e

c) plagioclásio + ortoclásio + quartzo t hornblenda + biotita \pm granada + mineral opaco + zircão + apatita (granulitos enderbíticos e charnockíticos retrógrados).

\section{Ciclo Deposicional Andrelândia}

a) plagioclásio $+\mathrm{K}$-feldspato + quartzo + biotita \pm granada \pm muscovita \pm sillimanita + zircão + apatita + mineral opaco \pm turmalina (Bt gnaisse bandado, Bt gnaisse quartzoso e Bt gnaisse porfiroclástico);

b) plagioclásio + ortoclásio + quartzo + biotita + granada \pm sillimanita + mineral opaco + apatita + zircão + rutilo (Bt-gr-(sill) gnaisse);

c) plagioclásio + quartzo + muscovita \pm sillimanita + turmalina + zircão + rutilo + mineral opaco (quartzitos); 
d) plagioclásio + quartzo + clinopiroxênio + granada + titanita + apatita + mineral opaco + biotita (rocha calcissilicática).

A presença de K-feldspato e ausência de muscovita nas rochas metapelíticas (s.s.) indicam que $M_{1}$ atingiu condições da facies anfibolito superior - zona do K-feldspato, o que está de acordo com os dados dos autores apresentados anteriormente. A contemporaneidade entre o metamorfismo $M_{1}$ e a fase principal de deformação é evidenciada pelo equilíbrio dentre as fases e pela materialização de minerais como biotita, muscovita e sillimanita nas foliações $S_{1}$ (Fig. 37). Arcos poligonais em biotitas e sillimanitas e biotita, sillimanita e fitas de quartzo na foliação milonítica $S_{2}$ (Fig. 38) mostram o crescimento e/ou recristalização sin- a tardi- $D_{2}$. Tanto as rochas metapelíticas quanto as metapsamíticas apresentam comumente estruturas migmatíticas e os leucossomas ocupam a posição espacial da foliação principal.

As rochas do Complexo Mantiqueira também apresentam paragêneses da facies anfibolito superior e são muitas as evidências de migmatização, tanto dos ortognaisses quanto dos anfibolitos (Fig. 39). Os minerais máficos (hornblenda, biotita e clinopiroxênio) ocorrem comumente alongados na foliação principal (Fig. 40) e, quando protomilonítica a milonítica, fitas de quartzo e até feldspatos materializam a foliação milonítica $S_{2}$.

Localmente, o Complexo Mantiqueira mostra registros de um evento metamórfico mais antigo, anterior à fase principal de deformação, com paragêneses diagnósticas para a facies granulito. As fases minerais presentes dispõem-se em um arranjo granoblástico e mostram-se parcialmente consumidas pelos novos minerais formados durante o desenvolvimento de $M_{1}$. Este tema será tratado com maior profundidade mais adiante.

\section{b) Metamorfismo $M_{1}$ no DTJF}

As rochas orto e paraderivadas do DTJF registram grande complexidade na evolução do metamorfismo $M_{1}$, já que na foliação principal são encontradas ora paragêneses diagnósticas para a facies granulito ora paragêneses típicas da facies anfibolito superior e, até mesmo, paragênses não diagnósticas para uma destas facies. 


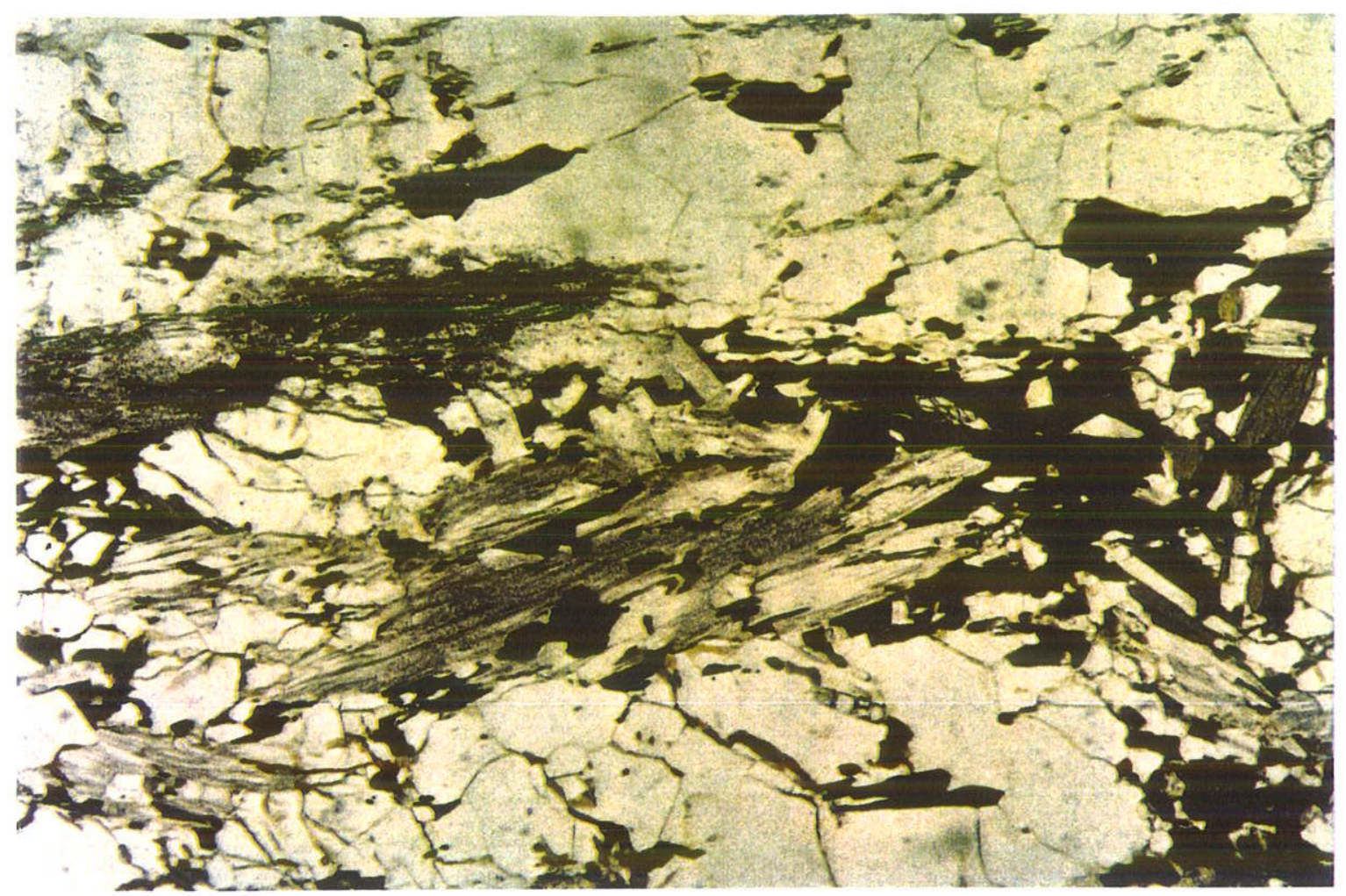

$0,8 \mathrm{~mm}$

Figura 37 - Foliação $S_{1}$ dada por biotita, muscovita e sillimanita em Bt-sill gnaisse do CDA. DTAND. Ponto 54.

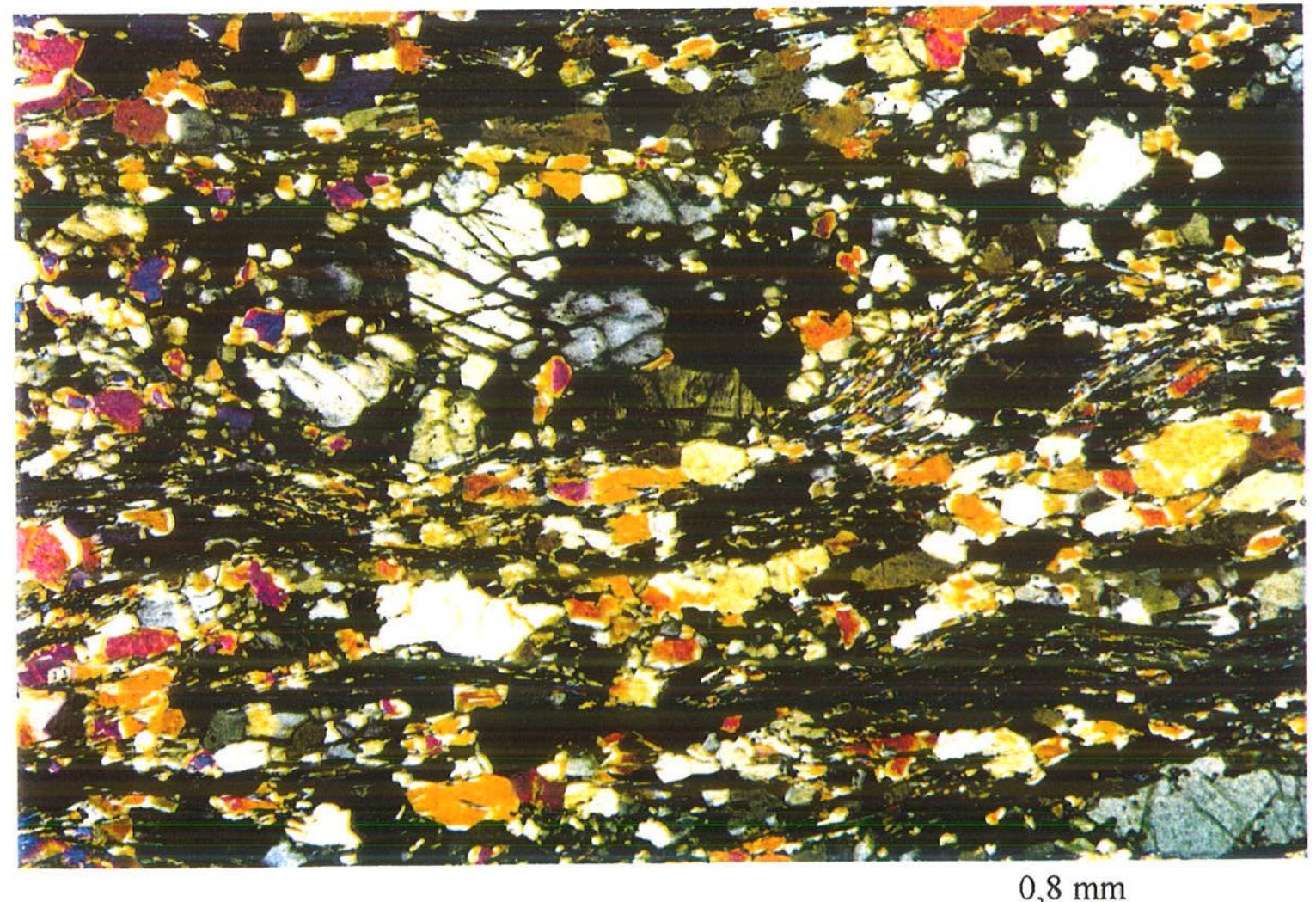

Figura 38 - Sillimanita e quartzo estirado na foliação $\mathrm{S}_{2}$ em Bt-sill gnaisse do CDA. DTAND. Ponto 52. (obs.: lâmina espessa) 


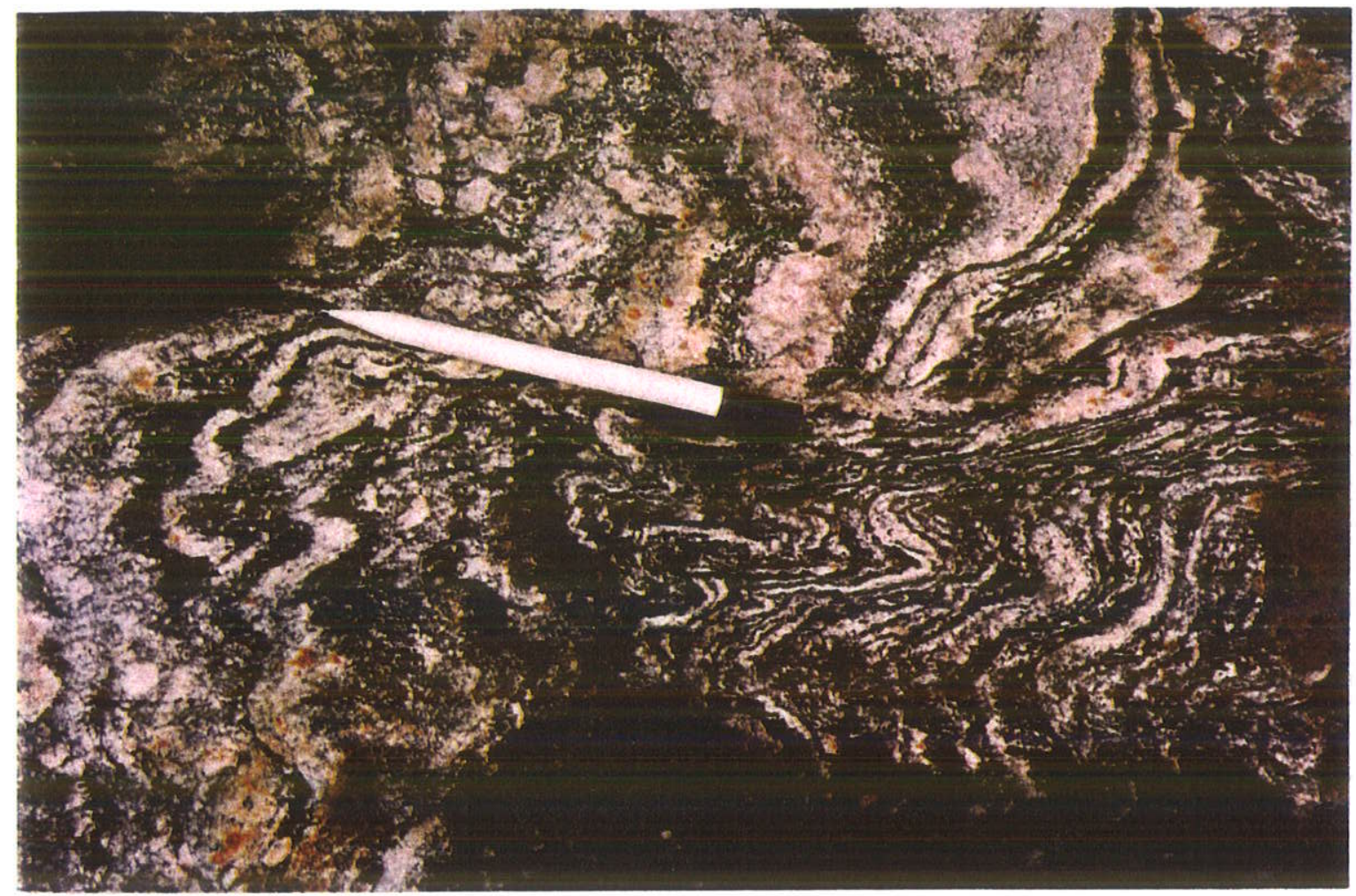

a

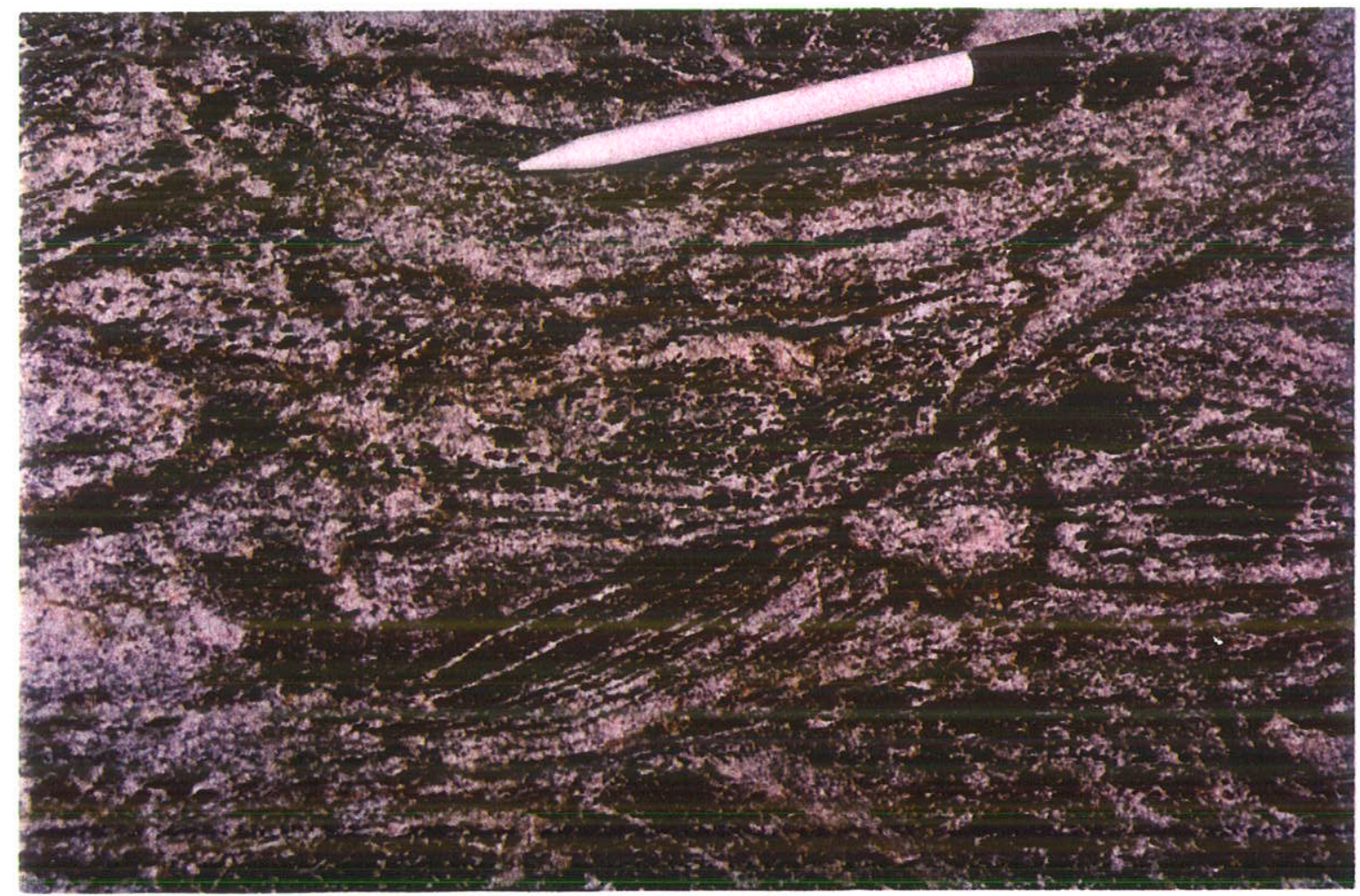

b

Figura 39 - Migmatização em ortognaisse (a) e anfibolito (b) do CM. DTAND. Ponto 564. 
Para maior clareza da abordagem petrológica, as unidades metassedimentares foram agrupadas em: metapelitos; meta-semipelitos e metapsamitos; quartzitos; e rochas calcissilicáticas. A tabela 17 mostra as paragêneses de $M_{1}$ encontradas para cada um destes grupos e também para o Granada Charnockito e leucossomas das rochas gnáissicas.

Tabela 17 - Paragêneses das Rochas Metassedimentares da Região de Juiz de Fora

\begin{tabular}{|l|l|}
\hline Rochas Metassedimentares & \multicolumn{1}{|c|}{ Paragêneses Minerais de Ml } \\
\hline Metapelitos & $\begin{array}{l}\text { ortoclásio + plagioclásio + granada + biotita }+ \text { sillimanita } \pm \\
\text { fibrolita }+ \text { quartzo }+\mathrm{m} . \text { opaco } \pm \text { hercinita }\end{array}$ \\
\hline Meta-semipelitos & $\begin{array}{l}\text { ortoclásio + plagioclásio + granada + biotita }+ \text { quartzo } \pm \\
\text { ortopiroxênio } \pm \text { sillimanita } \pm \text { fibrolita }+\mathrm{m} . \text { opaco } \pm \text { hercinita }\end{array}$ \\
\hline Metapsamitos & $\begin{array}{l}\text { ortoclásio }+ \text { plagioclásio }+ \text { quartzo }+ \text { biotita } \pm \text { granada }+\mathrm{m} . \\
\text { opaco }\end{array}$ \\
\hline Quartzitos & $\begin{array}{l}\text { quartzo } \pm \text { ortoclásio + plagioclásio }+ \text { biotita } \pm \text { sillimanita } \pm \\
\text { fibrolita }+\mathrm{m} . \text { opaco } \pm \text { turmalina }\end{array}$ \\
\hline Rochas calcissilicáticas & $\begin{array}{l}\text { plagioclásio }+ \text { clinopiroxênio }+ \text { hornblenda }+ \text { granada }+ \text { biotita }+ \\
\text { quartzo }+\mathrm{m} . \text { opaco }\end{array}$ \\
\hline
\end{tabular}

As rochas metapelíticas, os quartzitos e as rochas calcissilicáticas não apresentam paragêneses diagnósticas para facies metamórfica, sendo as associações estáveis tanto na facies anfibolito superior (zona do Kufeldspato) quanto na facies granulito. Ainda assim, estas rochas, em especial as metapelíticas, registram o auge do metamorfismo $\mathrm{M}_{1}$, com crescimento de biotita, fibrolita e sillimanita na foliação principal, $S_{1}$ ou $S_{2}$ (Fig. 41), além de granadas sintectônicas. Indícios de cristalização e/ou recristalização pós- $\mathrm{D}_{1} /$ pré-- $\mathrm{D}_{2}$ podem ser resgatados nas relações foliação interna (trilhas de inclusões em granadas) x foliação externa. Arcos poligonais em biotitas e sillimanitas testemunham uma recristalização tardi- $\mathrm{D}_{2}$. Associados às rochas metapelíticas, ocorrem pequenos volumes de leucossomas, cujas paragêneses sugerem processo de formação com envolvimento de quebra de biotita e sillimanita (e/ou fibrolita) e geração de granada, minerais félsicos e, eventualmente, ortopiroxênio.

Coloração esverdeada, forte carater migmatítico e a presença de paragêneses com ortopiroxênio são feições comuns nos meta-semipelitos e metapsamitos do DTJF e também nos leucossomas de origem anatética. Estas são evidências de um processo de desidratação, 


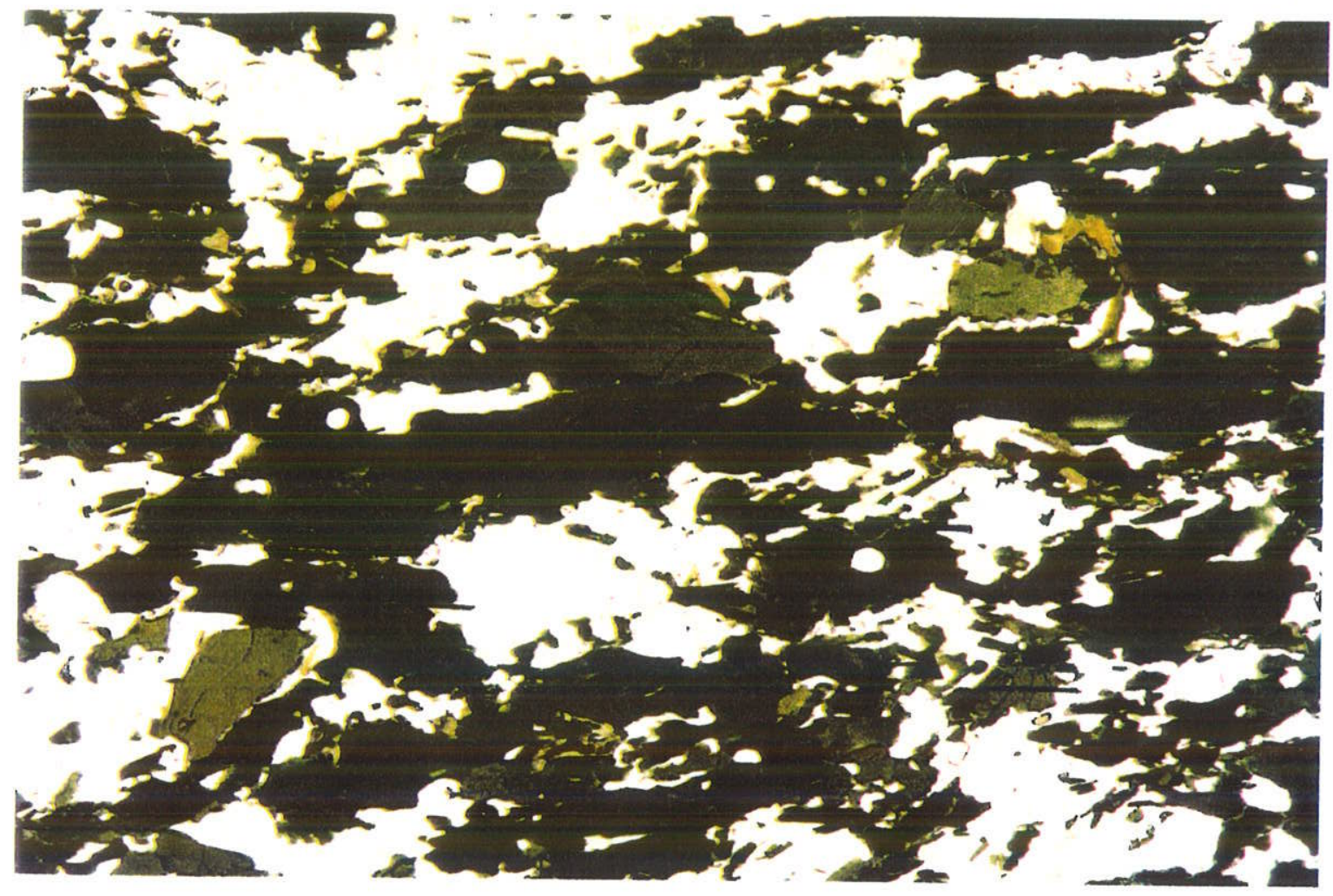

$0,8 \mathrm{~mm}$

Figura 40 - Grãos de hornblenda orientados na foliação principal. Hornblenda gnaisse do CM. DTAND. Ponto 564.

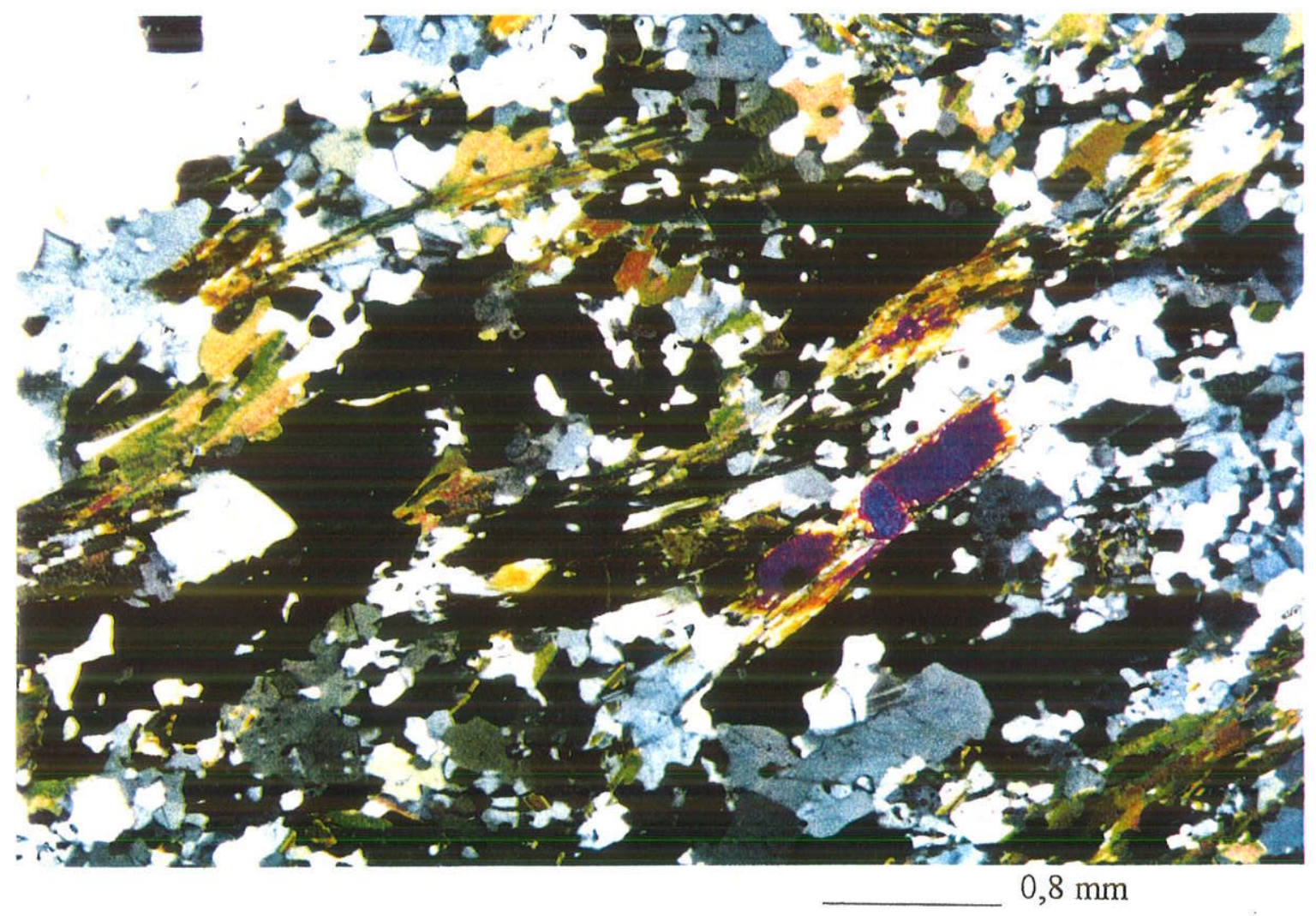

Figura 41 - Sillimanita, biotita e fibrolita na foliação principal em Bt-sill-gr gnaisse. DTJF. Ponto 286. 
envolvendo a quebra de minerais como biotita e a formação de um residuo mais seco e também de fusões inicialmente com $a_{k 20}$ baixo, como será abordado mais adiante. Os minerais presentes na foliação principal, $S_{1}$ ou $S_{2}$, são biotita (em equilibrio com opx) e, eventualmente, ortopiroxênio. Granada $\sin -\mathrm{D}_{2}$ completa o quadro do minerais máficos sin-fase principal de deformação para estas rochas.

O corpo, de dimensões batolíticas, denominado Granada Charnockito é fruto do processo anatético das rochas meta-semipelíticas, o que é evidenciado por contatos extremamente migmatizados com estas rochas. Na transição dos gnaisses smipelíticos para o Granada Cahrnockito, as seguintes estruturas podem ser reconhecidas: estromática, nebulítica, corpo channockítico individualizado, de características isotrópicas a levemente anisotrópicas. Variações en $P_{\text {fluidos }}$ são também verificadas no Granada Charnockito que apresenta um padrão de coloração mosqueado, ora esverdeado, com ortopiroxênio estável, ora esbranquiçado, sem ortopiroxênio ou com ortopiroxênio instável (Fig. 42). Este padrão pode representar diferenças na $P_{12 z o}$, ora alta ora baixa. Estes dados indicam que inicialmente a fusão se desenvolveu sob condições de baixa $a_{\mathrm{H} z o}$, capaz de estabilizar o ortopiroxênio, tendo, posteriormente, adquirido atro mais altas.

Para os ortognaisses e metabasitos granuliticos do Complexo Juz de Fora, o metamotismo $M_{1}$ teve carater claramente retrógrado, evidenciado pelo consumo e/ou recristalizaçăo de um arranjo granoblástico entre ortopiroxênio, clinopiroxênio, hornblenda e plagioclásio e formação de biotita, hornblenda, plagioclásio e, mais raramente, granada (Fig.43). Outra feição relativamente comum é a ocorrência de recristalização das bordas dos minerais da paragênese granulitica mais antiga, sugerindo que $M_{1}$ teve, em parte, um carater de baixa $a_{120}$ nestas rochas. Os novos minerais ocorrem nas bordas dos antigos (e/ou de suas porções recristalizadas) e na matriz recrstalizada que materializa a foliação principal, em parte $S_{1}$ e, quando milonítica, $S_{2}$ (Figs. 44). Estas relaçōes indicam que durante a fase principal de deformação, as rochas do CJF foram afetadas inicialmente e de maneira restrita por metamorfismo $M_{1}$ sob baixa $P_{k z o}$. Em uma segunda etapa, um processo de hidratação, provavelmente canalizado ao longo das zonas de cisalhamento $D_{1}+D_{2}$ e das foliações $S_{1}$ e $S_{2}$ promoveu a destruição parcial das paragêneses com ortopiroxênio estável. É interessante ressaltar a complexidade do processo metamórfico $\mathrm{M}_{1}$ que, enquanto levou à desidratação das 


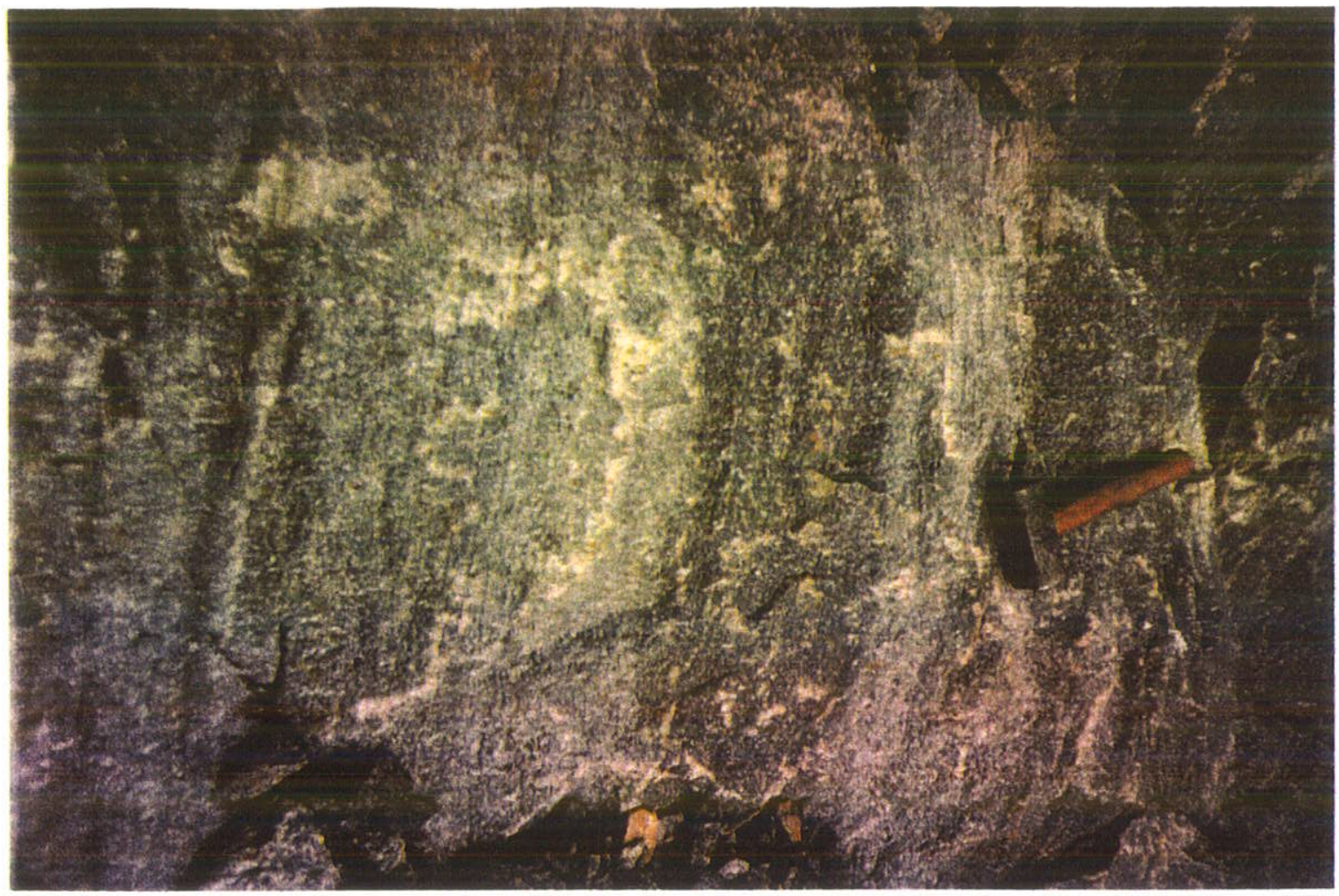

Figura 42 - Padrão de coloração mosqueada em granada charnockito. DTJF. Ponto 37.

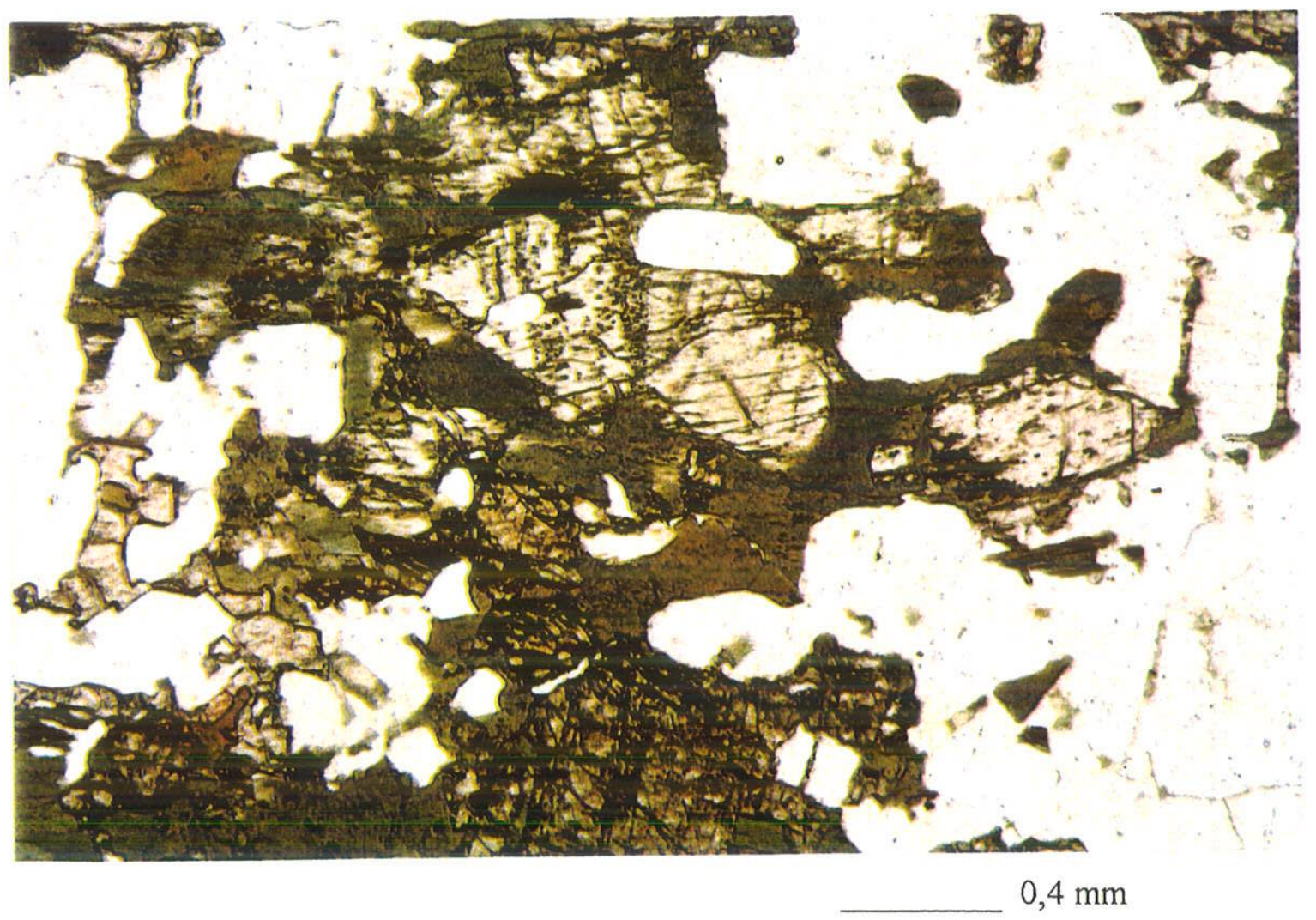

Figura 43 - Hornblenda orientada segundo a foliação principal, formada pelo consumo de piroxênios e plagioclásio. Metabasito do CJF. DTJF. Ponto 15. 
rochas meta-semipelíticas e metapsamíticas, promoveu a hidratação das rochas granulíticas do CJF.

\section{c) Equilibrio no Metamorfismo $M_{1}$ no Dominio Tectônico Juiz de Fora}

A identificação da existência de equilíbrio dentre as fases minerais se baseou na análise petrográfica e microtectônica de mais de 2 centenas de lâminas, com ênfase nos litotipos do CJF e nas unidades metassedimentares e leucossomas correspondentes. Para a abordagem de química mineral, somente foram alvos os gnaisses semipelíticos do noroeste do DTJF (Gnaisses da Unidade Jardim Glória), seus leucossomas, o Granada Charnockito e os litotipos básicos do Complexo Juiz de Fora. As seguintes relações de equilíbrio, estável ou metaestável, foram identificadas (o índice no mineral identifica distintas etapas de formação dos mesmos):

Gnaisses Semipelíticos

$$
\begin{aligned}
& \text { (1) } \mathrm{Gr}_{1}+\mathrm{Opx}+\mathrm{Plg}+\mathrm{Qz}+\mathrm{Op}_{1}( \pm \mathrm{Bt} \text { ?) } \\
& \text { (2) } \mathrm{Gr}_{2}+(\mathrm{Opx} ?)+\mathrm{Plg}+\mathrm{Qz}+\mathrm{Bt}+\mathrm{Op}_{1} \\
& \text { (3) } \mathrm{Gr}_{3}+\mathrm{Plg}+\mathrm{Qz}+\mathrm{Bt}+\mathrm{Op}_{2}
\end{aligned}
$$

O equilibrio (1) (Fig. 45) corresponde ao ápice térmico do metamorfismo $M_{1}$ nos gnaisses semipeliticos e, portanto, seus minerais foram analisados quimicamente a fim de serem utilizados para o cálculo dos valores de $\mathrm{T}$ e $\mathrm{P}$ correspondentes ao auge de $\mathrm{M}_{1}$. Foram utilizados geotermômetros e geobarômetros Gr-Opx-Plg-Qz.

Os equilíbrios (2) e (3) (Figs.46 e 47) săo interpretados como a volta do metamorfismo M1. Os pares Gr-Opx e Bt-Gr (geotermômetros) foram utilizados para obter as condições da volta de M1 na etapa do equilíbrio (2). Para o equilíbrio (3), o par Bt-Gr foi utilizado como geotermômetro.

Leucossomas em Gnaisses Semipelíticos e Granada Charnockito
(1) Bt (instável?) $+\mathrm{Gr}_{1}+\mathrm{Opx}\left(\right.$ estável) $+\mathrm{Plg}_{1}+\mathrm{Ort}+\mathrm{Qz}+\mathrm{Op}$
(2) $\mathrm{Bt}+\mathrm{Gr}_{2}+\mathrm{Opx}$ (instável) $+\mathrm{Plg}_{2}+\mathrm{Ort}+\mathrm{Qz}+\mathrm{Op}$
(3) $\mathrm{Bt}+\mathrm{Gr}+\mathrm{Plg}+\mathrm{Ort}+\mathrm{Qz}+\mathrm{Op}$ 


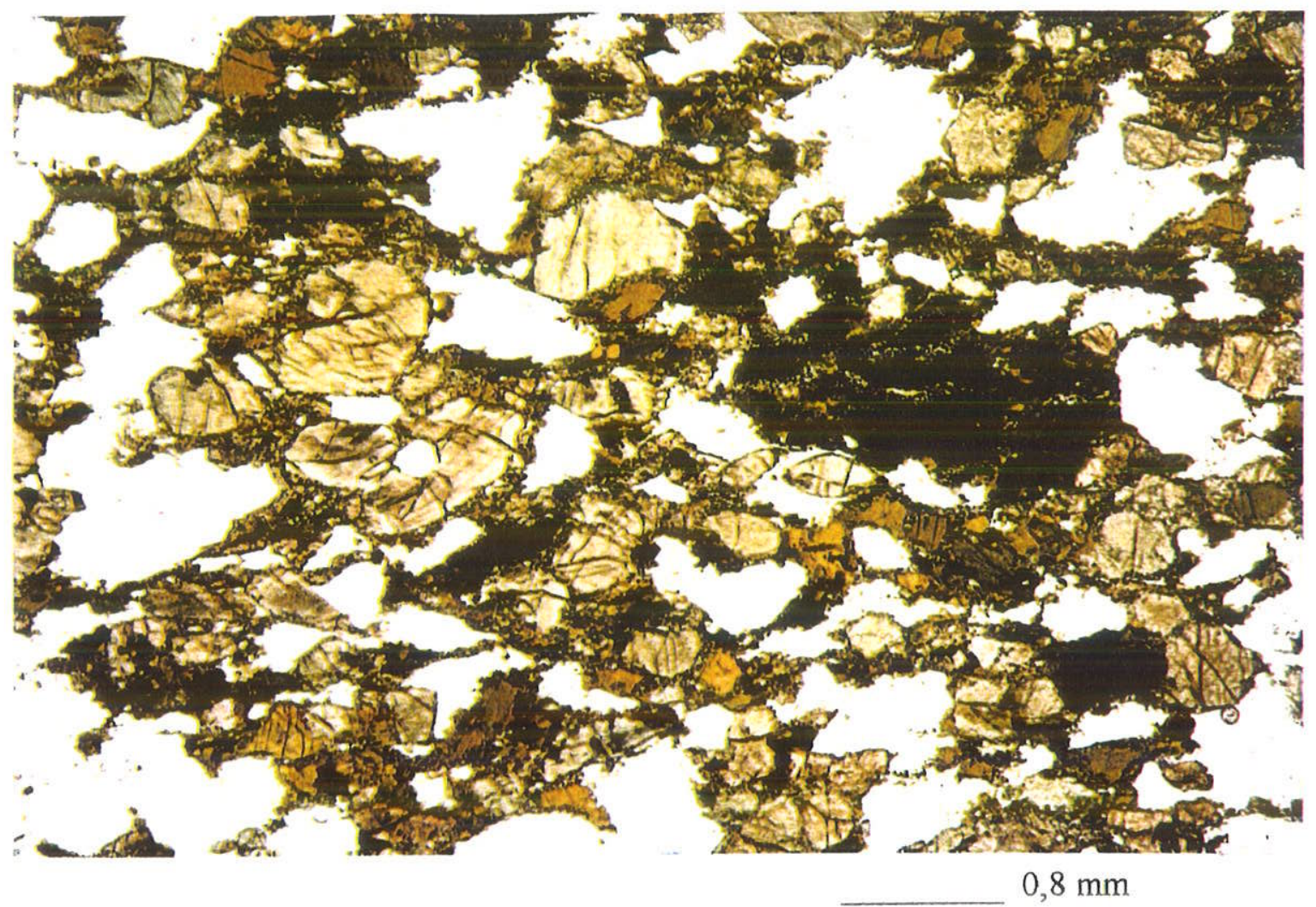

Figura 44 - Novos grãos formados pela recristalização das bordas dos minerais da paragênese granulitica de $\mathrm{M}_{0}$. Metabasito do CJF. DTJF. Ponto 42.

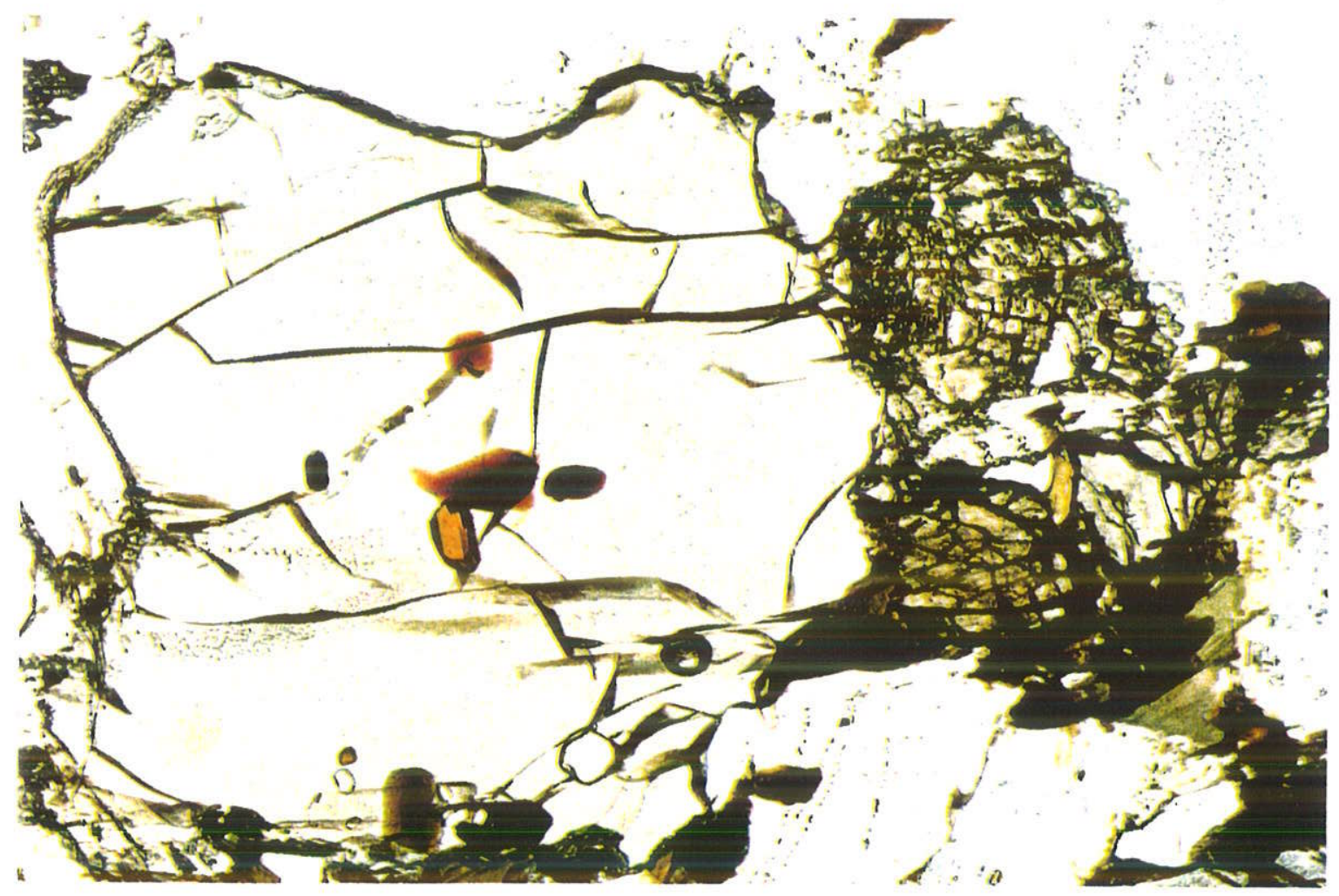

$0,2 \mathrm{~mm}$

Figura 45 - Equilíbrio entre granada ${ }_{1}$, ortopiroxênio, plagioclásio e quartzo em paragnaisse da Unidade Jardim Glória. DTJF. Ponto 36. 


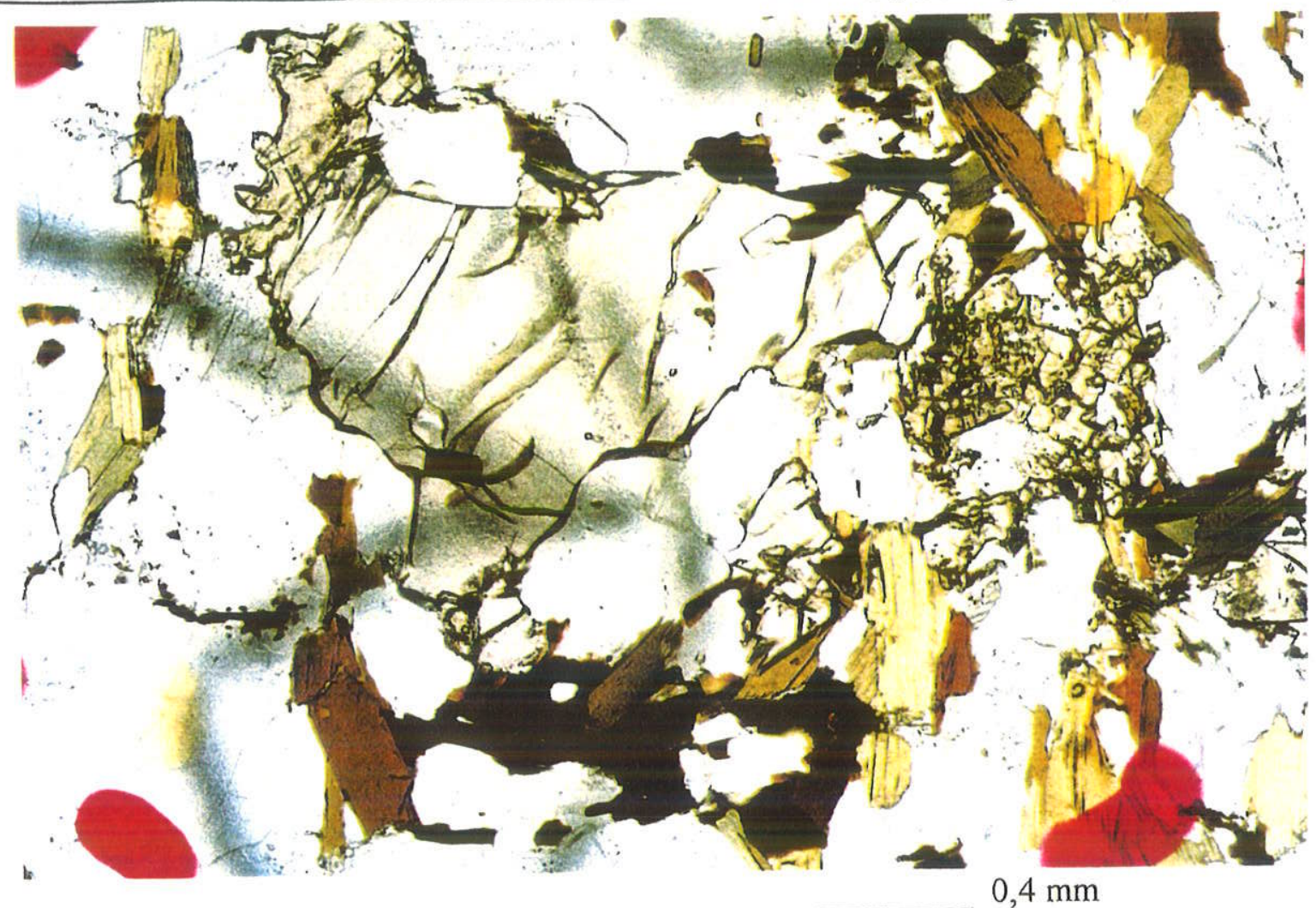

Figura 46 - Granada 2 sobrecrescendo granada 1 . Paragnaisse da Unidade Jardim Glória. DTJF. Ponto 36.

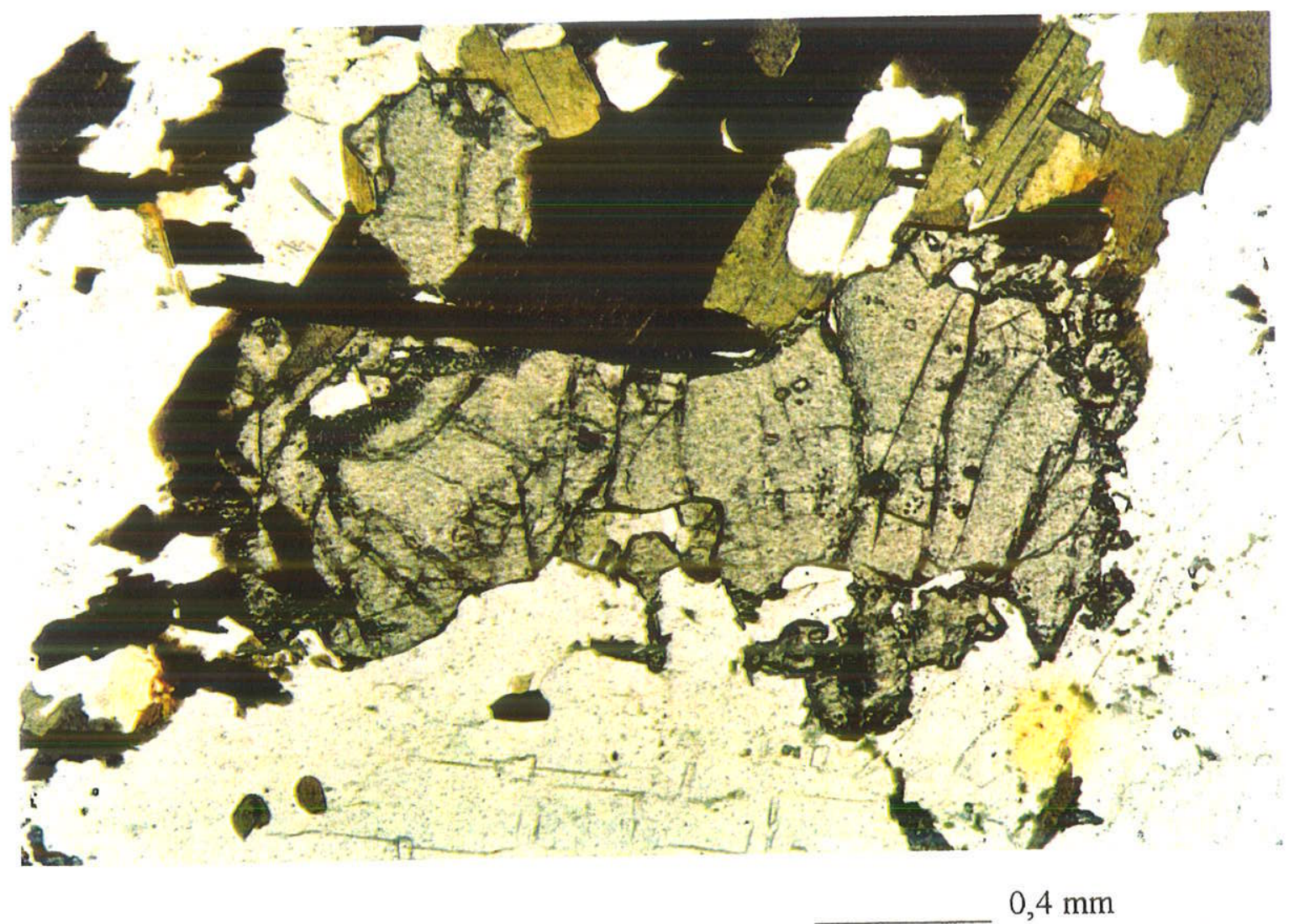

Figura 47 - Franja simplectítica no canto superior esquerdo do grão maior de granada. Paragnaisse da Unidade Jardim Glória. DTJF. Ponto 36. 
Indícios de um processo que leva ao consumo de ortopiroxênio e formação de biotita, sendo a granada estável durante todas as etapas, também são identificados nos leucossomas e no Granada channockito, demonstrando que o processo de anatexia que atingiu os gnaisses semipelíticos foi contemporâneo a $M_{1}$. Da mesma forma que para estes gnaisses, o equilíbrio 1 é interpretado como o auge térmico de $M_{1}$, enquanto que os demais equilíbrios são vistos como registros da volta de $\mathrm{M}_{1}$.

A presença de estruturas migmatíticas típicas de processo de fusão parcial in situ, cuja porção leucossomática tem, com frequência, ortopiroxênio, indica que a anatexia procedeu sob condições de ausência de uma fase fluida. As seguintes reações são sugeridas para o desenvolvimento deste processo:

Nos metapelitos: biotita + sillimanita + plagioclásio + quartzo $=$ granada $+\mathrm{K}$-feldspato + fusão Nos meta semipelitos e nos metpasamitos: biotita + plagioclásio + quartzo $=$ ortopiroxênio + K- feldspato + fusão

Este processo de fusão parcial levou à geração de um grande corpo ígneo denominado Granada Charnockito. Isto sugere que tenham sido geradas grandes quantidades de fusão. Clemens \& Vielzeuf (1987) mostraram que a quebra de biotita pode gerar até $50 \%$ de volume de fusão granítica. Assim, o envolvimento de biotita na reação pode ser suficiente para a produção de plútons graníticos a partir da fusão parcial de gnaisses pelíticos. Estas duas reações são mostradas no gráfico P-T da figura 48, donde se conclui que seu desenvolvimento se dá a $\mathrm{T}>700^{\circ} \mathrm{C}$ dentro do campo de estabilidade da sillimanita.

Metabasitos granulíticos do CJF

(0) $\mathrm{Opx}_{1}+\mathrm{Cpx}_{1}+\mathrm{Plg}_{1}+\mathrm{Hbl}_{1}+\mathrm{Op}_{1}+\mathrm{Ort}+\mathrm{Qz}$ (paragênese pré-M1)

(1) $\mathrm{Opx}_{1}$ (instável) $+\mathrm{Cpx}_{1}$ (instável) $+\mathrm{Opx}_{2}+\mathrm{Cpx}_{2}+\mathrm{Plg}_{2}+\mathrm{Cbl}_{2}+\mathrm{Op}_{2}+\mathrm{Ort}$ $+\mathrm{Qz}$

(2) Opx (instável) $+\mathrm{Cpx}$ (instável) $+\mathrm{Hbl}_{3} \pm \mathrm{Bt} \pm \mathrm{Gr}+\mathrm{Op}_{3}+\mathrm{Plg}_{3}+\mathrm{Ort}+\mathrm{Qz}$

(3) $\mathrm{Hbl}_{3}+\mathrm{Plg}_{3} \pm \mathrm{Bt} \pm \mathrm{Gr}+$ Ort (instável) $+\mathrm{Mcr}+\mathrm{Qz}+\mathrm{Op}$ 
a)

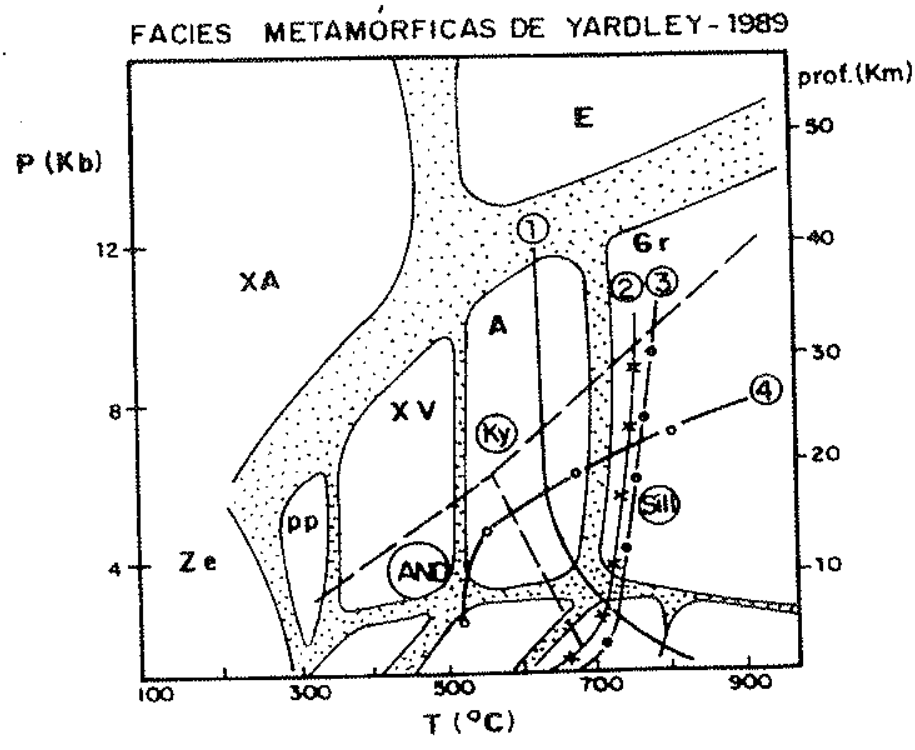

b)

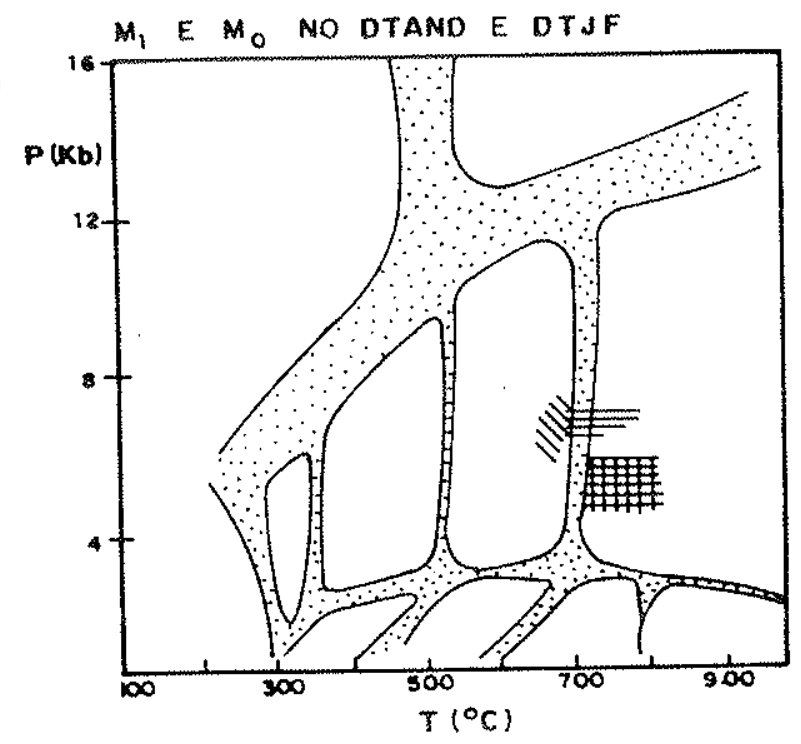

ABREVIATURAS PARA FACIES METAMÓRFICAS

$$
\begin{aligned}
& \text { XA - XISTO AZUL E - ECLOGITO ZE - ZEÓLITA } \\
& \text { XV - XISTO VERDE A - ANFIBOLITO Gr - GRANULITO } \\
& \text { CURVAS EXTRAIDAS DE BARKER(1990), WINKLER(1977), LE BRETON \& THOMPSON (1987) } \\
& \text { E CLEMMENS \& WALL (1981) }
\end{aligned}
$$
(1) $\mathrm{Ab}+\mathrm{Ki}+\mathrm{Q} \mathrm{Z}$ - FUSÃO GRANÍTICA NA PRESENÇA DE $\mathrm{H}_{2} \mathrm{O}$
(2) $B t+S i l l+P I Q+Q z-G r+K f+F U S A \tilde{O}$
(3) $B t+P l g+Q z-O p x+K++F U S A ̃ O$
(4) CORDIERITA IN
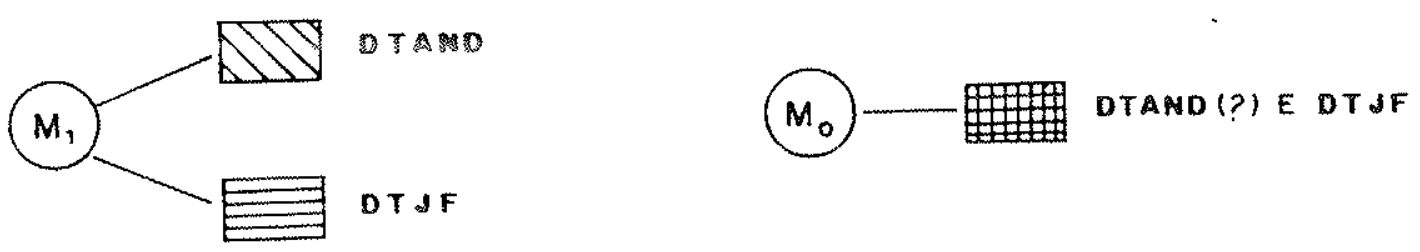

FIGURA 48 - Condiçóes P-T aproximadas dos pulsos metamórficos $\mathrm{M}_{1}$ Mo

a) - Facies metamórficas e grade perrogenérica para metopelitos. b) $M_{1}$ M $M_{0}$ no DTAND e DTJF 
O equilíbrio (0) é claramente anterior à formação da foliação S1 nas rochas da área e, portanto, é interpretado como resquício de um evento metamórfico mais antigo, estabilizado sob condições da facies granulito. Este evento será abordado mais adiante.

Por outro lado, os equilíbrios de (1) a (3) (Figs.44, 49 e 50) correspondem a processos metamórficos que evoluíram durante a fase principal de deformação e, portanto, correspondem a $M_{1}$. O equilibrio (1) é interpretado como o ápice térmico de $M_{k}$, porém são grandes as possibilidades de ter tido duração extremamente efêmera, dada a restrita distribuição de suas fases e o fato de que as mesmas são quase sempre vistas já em processo de consumo por parte das fases do equilíbrio (2). Assim, os equilíbrios (1) e (2) são vistos como terem se desenvolvido durante a fase principal de deformação e, portanto, ambos são interpretados como o ápice térmico de $\mathrm{M}_{1}$. $\mathrm{O}$ equilíbrio (3) representa o consumo total da paragênese mais antiga em facies granulito e é possível que tenha também se desenvolvido durante o auge de $\mathrm{M}_{1}$. Este equilibrio é mais comum em gnaisses granulíticos de composição intermediária à félsica do CJF. Para o cálculo da $\mathrm{T}$ de $\mathrm{M}_{1}$ nestas rochas foram utilizados os pares Opx-Cpx do equilíbrio (1) e Hbl-Plg, Cpx-Gr e Opx-Gr do equilíbrio (2). Nestas rochas não foram encontradas relações que pudessem indicar o equilíbrio entre Bt e Gr. Como geobarômetro, foi utilizada a paragêsese gr-cpx-plg-qz. A tabela 18 sintetiza os equilíbrios metamórficos encontrados para todas as unidades, para $M_{0}$ e $M_{1}$. A figura 48 mostra as condições P.T aproximadas do pulso metamórfico $\mathrm{M}_{1}$ no DTAND e DTJF.

Tabela 18 - Equilíbios minerais para os tipos litológicos investigados.

\begin{tabular}{|c|c|c|c|c|}
\hline Litotipo & Equilibrio 0 (M0) & Equilibrio 1 & Equilibrio 2 & Equilibrio 3 \\
\hline $\begin{array}{l}\text { Gnaisses Semipeliticos } \\
\text { (Unidade Jardim } \\
\text { Glória) }\end{array}$ & Não observado & $\begin{array}{l}\mathrm{Gr}_{1}+\mathrm{Opx}+\mathrm{Plg}+ \\
\mathrm{Qz}+\mathrm{Op}_{1}( \pm \mathrm{Bt} ?)\end{array}$ & $\begin{array}{l}\mathrm{Gr}_{2}+(\mathrm{Opx} ?)+\mathrm{Plg} \\
+\mathrm{Qz}+\mathrm{Bt}+\mathrm{Op}_{1}\end{array}$ & $\begin{array}{l}\mathrm{Gr}_{3}+\mathrm{Plg}+\mathrm{Qz}+ \\
\mathrm{Bt}+\mathrm{Op}_{2}\end{array}$ \\
\hline $\begin{array}{l}\text { Leucossomas em } \\
\text { Gnaisses Semipelíticos } \\
\text { e Granada } \\
\text { Charnockito }\end{array}$ & Não Observado & $\begin{array}{l}\mathrm{Bt} \text { (instável?) }+\mathrm{Gr}_{1} \\
+\mathrm{Opx} \text { (estável) }+ \\
\mathrm{Plg}_{\mathrm{l}}+\mathrm{Ort}+\mathrm{Qz}+ \\
\mathrm{Op}\end{array}$ & $\begin{array}{l}\mathrm{Bt}_{2}+\mathrm{Gr}_{2}+\mathrm{Opx} \\
\text { (instável) }+\mathrm{Plg}_{2}+ \\
\text { Ort }+\mathrm{Qz}+\mathrm{Op}\end{array}$ & $\begin{array}{l}\mathrm{Bt}+\mathrm{Gr}+\mathrm{Plg}+\mathrm{Ort} \\
+\mathrm{Qz}+\mathrm{Op}\end{array}$ \\
\hline $\begin{array}{l}\text { Metabasitos } \\
\text { granuliticos do CJF }\end{array}$ & $\begin{array}{l}\mathrm{Opx}_{1}+\mathrm{Cpx}_{1}+\mathrm{Plg}_{1} \\
+\mathrm{Hbl}_{1}+\mathrm{Op}_{1}+\mathrm{Ort} \\
+\mathrm{Qz}\end{array}$ & $\begin{array}{l}\mathrm{Opx}_{1} \text { (instável) }+ \\
\mathrm{Cpx}_{3} \text { (instável) }+ \\
\mathrm{Opx}_{2}+\mathrm{Cpx}_{2}+\mathrm{Plg}_{2} \\
+\mathrm{Hbl}_{2}+\mathrm{Op}_{2}+\mathrm{Ort} \\
+\mathrm{Qz}\end{array}$ & $\begin{array}{l}\mathrm{Opx} \text { (instável) }+ \\
\mathrm{Cpx} \text { (instável) }+ \\
\mathrm{Hbl}_{3} \pm \mathrm{Bt} \pm \mathrm{Gr}+ \\
\mathrm{Op}_{3}+\mathrm{Plg}_{3}+\mathrm{Ort}+ \\
\mathrm{Qz}\end{array}$ & $\begin{array}{l}\mathrm{Hbl}_{3}+\mathrm{Plg}_{3} \pm \mathrm{Bt} \pm \\
\mathrm{Gr}+\mathrm{Ort} \text { (instável) } \\
+\mathrm{Mcr}+\mathrm{Qz}+\mathrm{Op}\end{array}$ \\
\hline
\end{tabular}




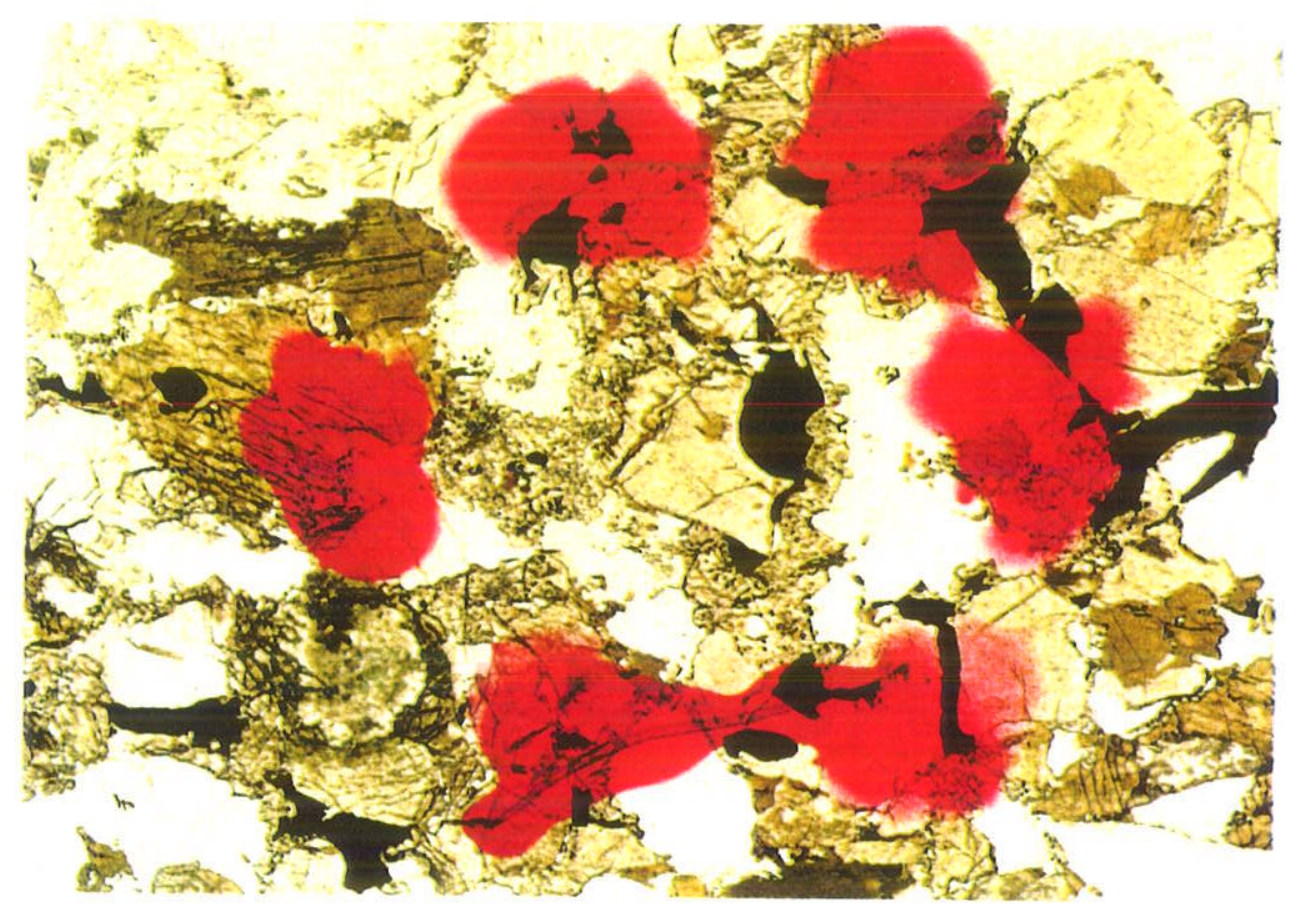

$0,8 \mathrm{~mm}$

Figura 49 - Corona de granada em torno de grãos de ortopiroxênio. Metabasito do CJF. DTJF. Ponto 183.

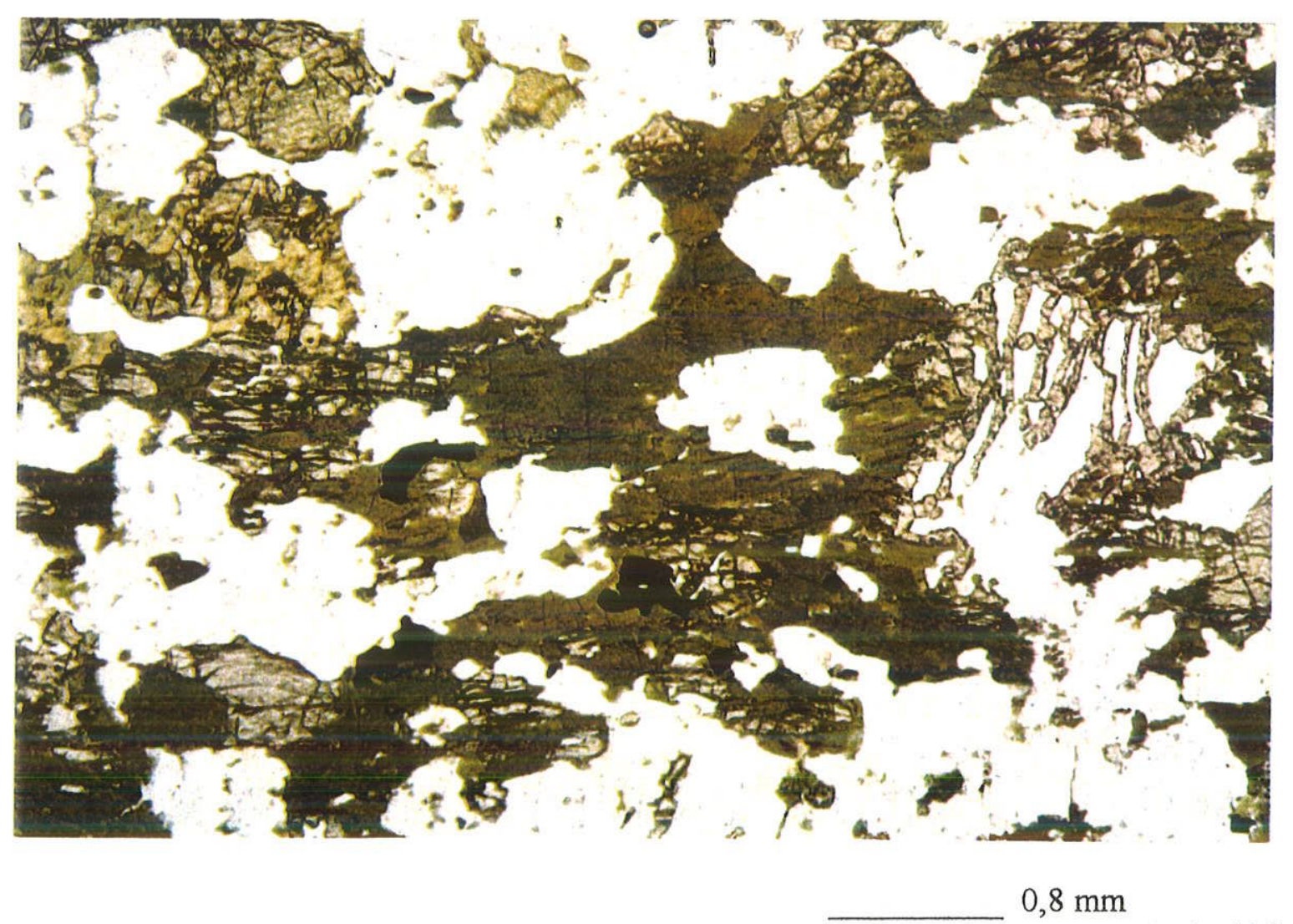

Figura 50 - Hornblenda e granada formadas pelo consumo parcial de piroxênios e plagioclásio. Metabasito do CJF. DTJF. Ponto 15. 


\section{d) Quimica Mineral Condições de Pressão Temperatura do Metamonismo $M_{1}$ no Dominio Tectônico Juiz de Fora}

Com base no estudo petrográfico e na identificação dos três equilíbrios descritos anteriormente para os gnaisses semipelíticos, três amostras de Bt-Gr-(Opx) gnaisse da Unidade Jardim Glória $(35 \mathrm{~B}, 36 \mathrm{~B}$ e JG-108) foram selecionadas para proceder à análise química de mineral o procedimento realizado para a obtenção destes dados e sua utilização encontra-se descrito na seção Método de Trabalho da presente tese. Foram analisados ortopiroxênio, granadas 1,2 e 3, plagioclásio e biotita, quando possivel seus núcleos e bordas. Os diagramas das figuras 51 a 54 mostram a classificação destas fases e as variações entre núcleos e bordas. O ortopiroxênio é do tipo Fe-hiperstênio - hiperstênio, sendo que as bordas são sempre ligeiramente mais magnesianas do que os núcleos (Fig. 51). Todas as granadas, 1, 2 e 3 , podem ser classificadas como almandinas (Fig.52). Não foram verificadas variações significativas ou sistemáticas entre núcleo e borda de granada 1 . No entanto, as granadas 2 e 3 têm composições pouco mais cálcicas do que as granadas 1 (Fig. 52). Isto indica que as granadas 2 e 3 foram formadas pelo consumo de mais componente cálcico do que as mais antigas. Neste grau metamórfico, o componente cálcico é provavelmente o componente anortita do plagioclásio. O plagioclásio tem composição de andesina, com bordas ligeiramente mais cálcicas do que os núcleos (Fig.53). O fato das bordas de plagioclásio terem maior quantidade do componente anortita do que os núcleos sugere crescimento e não consumo desta fase mineral. Dessa forma, sugere-se aqui que, embora as bordas do plagioclásio tenham formecido parte de seu componente anortita para a formação das granadas de $2^{a}$ e $3^{a}$ gerações, ainda assim, manteve-se com bordas mais cálcicas do que seus núcleos. A biotita tem razão $\mathrm{Mg} / \mathrm{Fe}$ que varia de 1,2 a 1,0 , podendo, no entanto, ser ainda classificada como biotita (Fig. 54).

Para os metabasitos do Complexo Juiz de Fora, três amostras (15B, 99D e 183A) foram utilizadas para a análise química mineral. Em duas destas $(990$ e $183 \mathrm{~A})$, foi testado, como geotermômetro, o par Opx-Cpx, referente ao equilibrio (2). As amostras $15 \mathrm{~B}$ e $183 \mathrm{~A}$ foram utilizadas para a obtenção de valores de T através dos pares Opx-Gr, Cpx-Gr e Hbl-Plg correspondentes ao equilíbrio (3). Para o cálculo dos valores de $\mathrm{P}$, foram utilizados o seguinte geobarômetro: Gr-Cpx-Plg-Qz. 


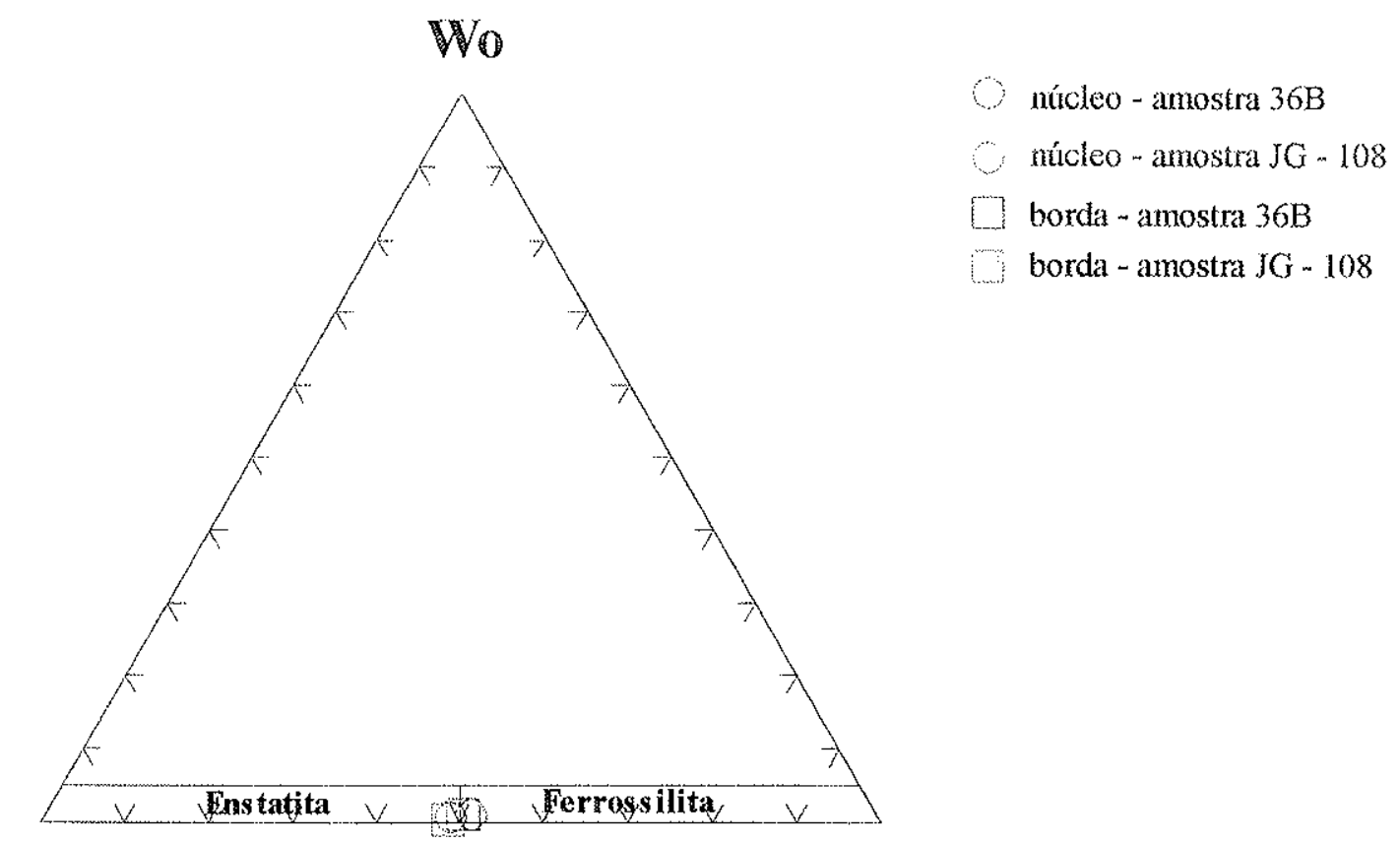

\section{En}

\section{Fs}

Figura 51 - Classificação do ortopiroxênio dos paragnaisse da Unidade Jardim Glória Estão plotadas apenas as médias de núcleos e bordas.

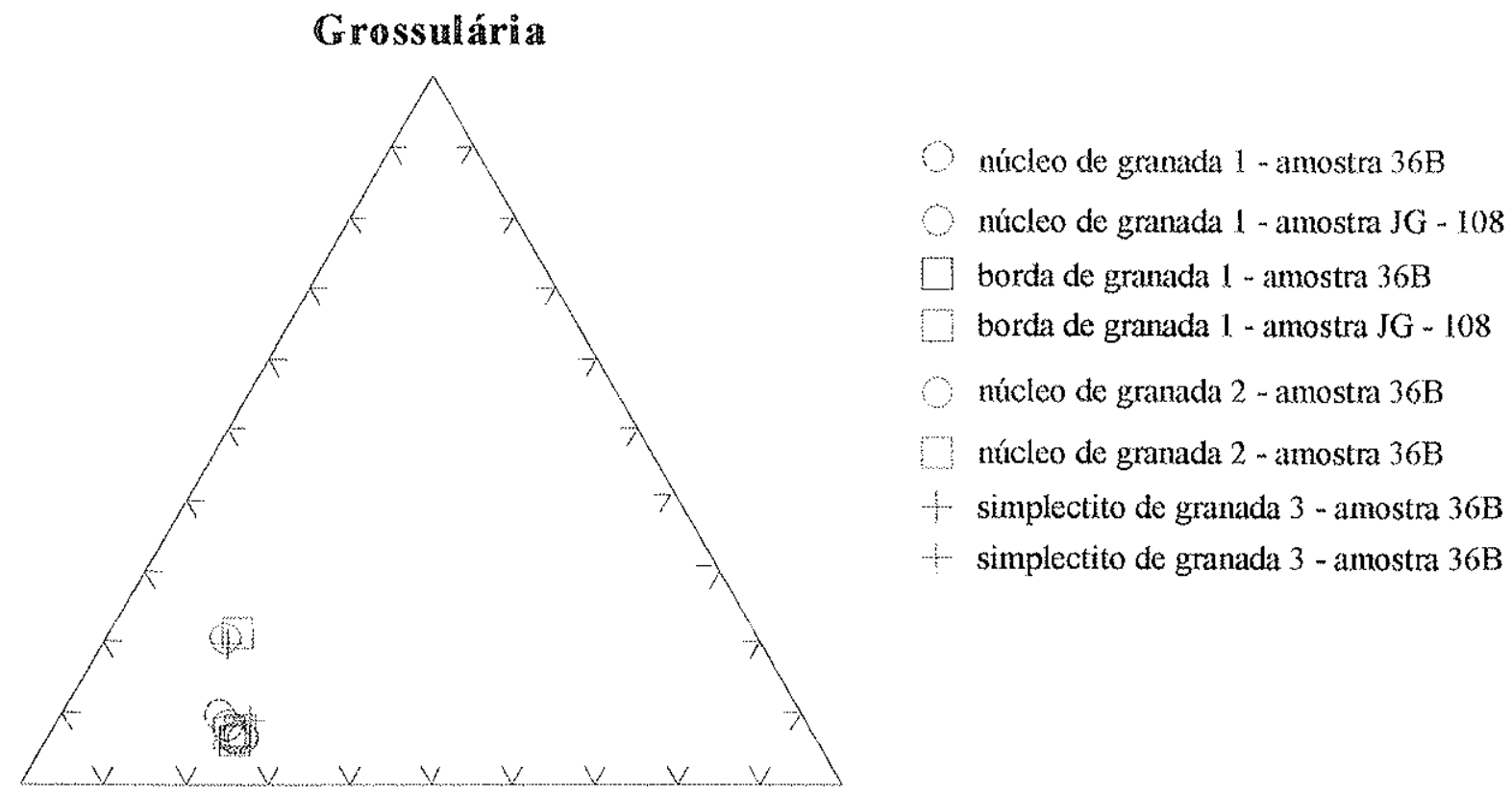

\section{Almandina}

\section{Piropo}

Figura 52 - Classificação das granadas dos paragnaisse da Unidade Jardim Glória. Estão plotadas apenas as médias de núcleos, bordas ou grão reduzidos (simplectito). 


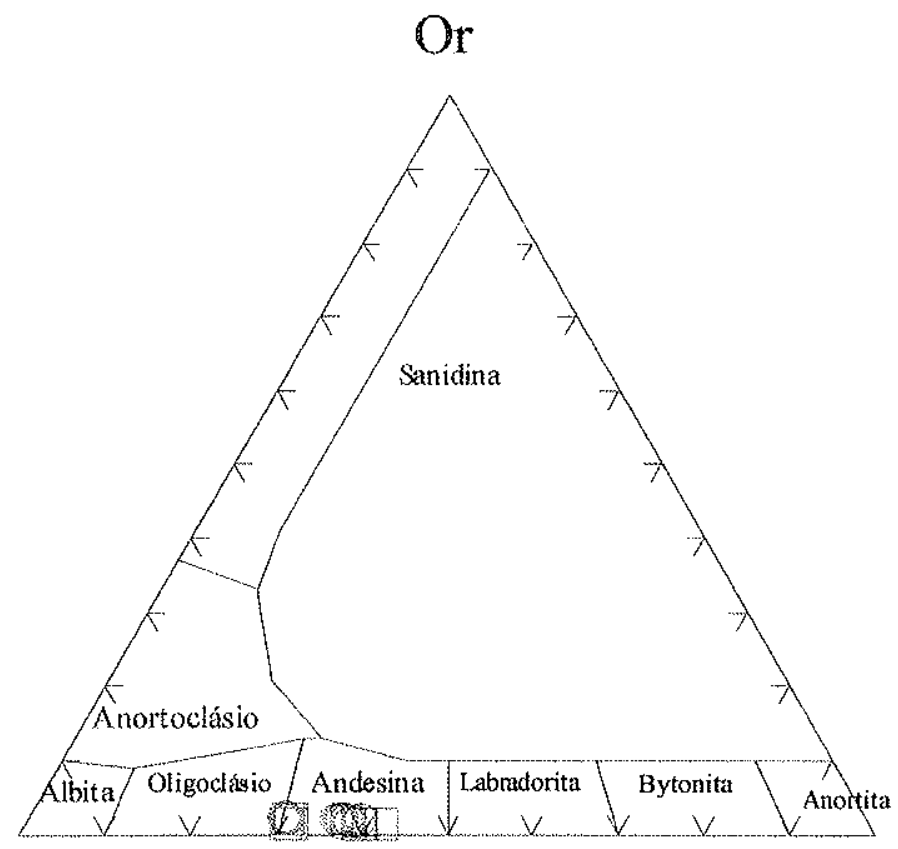

$\mathrm{Ab}$

An

Figura 53 - Classificação do plagioclásio dos paragnaisses da Unidade Jardim Glória.
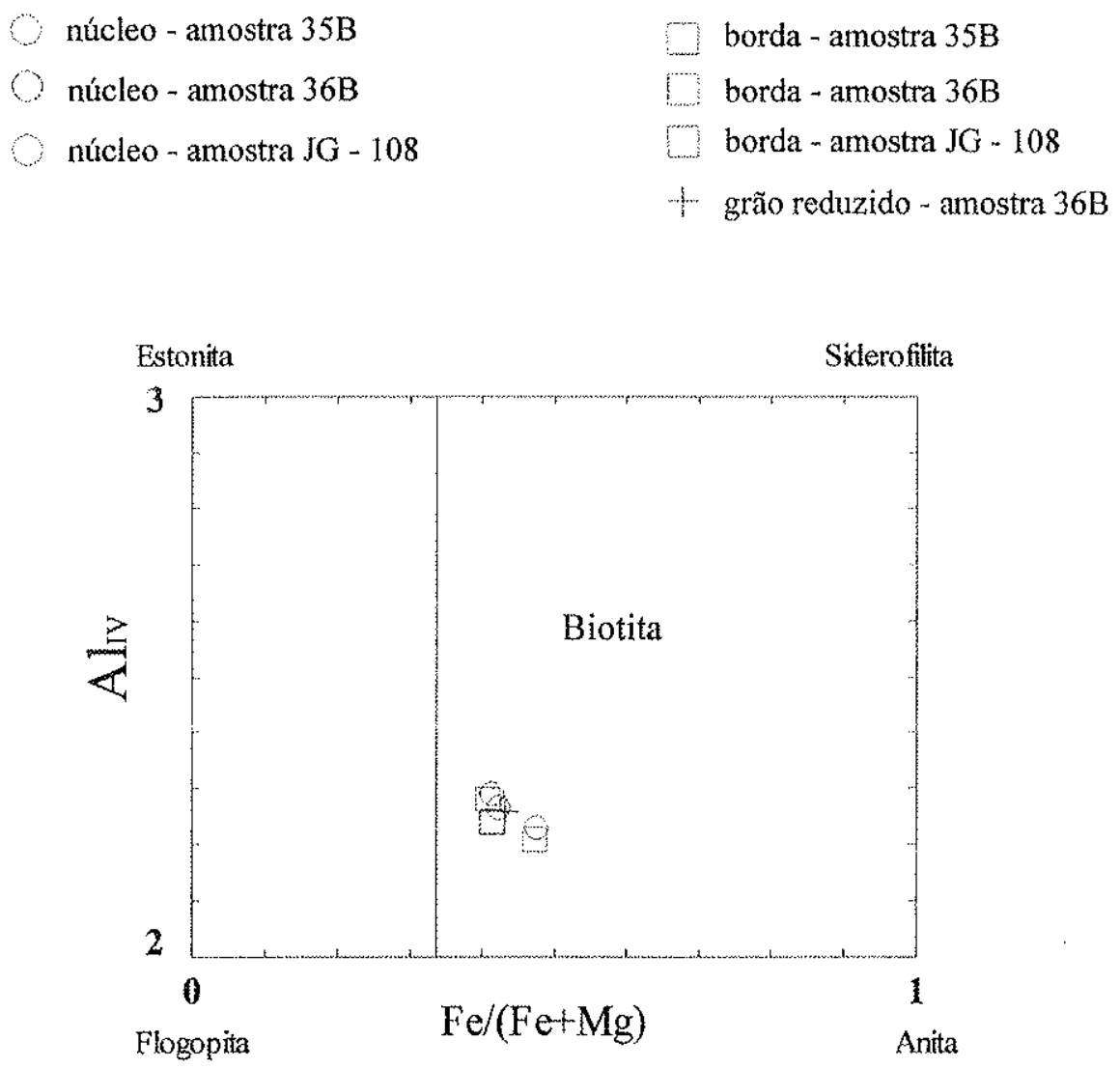

Figura 54 - Classificação da biotita dos paragnaisses da Unidade Jardim Glória. Estão plotadas apenas as médias de núcleos, bordas e grãos reduzidos. 
A composição química das fases analisadas encontra-se no Apêndice 4 e os diagramas das figuras 55 a 60 apresentam a classificação das mesmas.

As tabelas 19 a 27 mostram os valores de $\mathrm{T}$ e $\mathrm{P}$ calculados a partir da química dos equilíbrios de fases analisados com base no estudo e na interpretação das paragêneses descritas anteriormente.

Tabela19 - Valores de T calculados para o equilibrio 1 nos paragnaisses da Unidade Jardim Glória, segundo o geotermômetro de Sen \& Bhattacharya (1984).

\begin{tabular}{|l|c|c|}
\hline Amostra & $\begin{array}{c}\mathrm{T}\left({ }^{\circ} \mathrm{C}\right) \text { - nícleo de } \mathrm{gr}_{1} \mathrm{e} \\
\text { núcleo de opx }\end{array}$ & $\begin{array}{c}\mathrm{T}\left({ }^{\circ} \mathrm{C}\right) \text { - borda de } \mathrm{gr}_{\mathrm{i}} \mathrm{e} \\
\text { borda de opx }\end{array}$ \\
\hline $36 \mathrm{~B}$ & $673 \pm 30$ & $640 \pm 30$ \\
\hline JG -108 & $677 \pm 30$ & $649 \pm 30$ \\
\hline Média & $675 \pm 30$ & $645 \pm 30$ \\
\hline
\end{tabular}

Tabela 20 - Valores de P calculados para o equilibrio 1 da amostra JG - 108 da Unidade Jardim Glória, segundo o geobarômetro de Ekert et al. (1994), aplicado a $T=$ $745^{\circ} \mathrm{C}$.

\begin{tabular}{|l|c|c|}
\hline Amostra & $\begin{array}{c}\mathrm{P}(\mathrm{Kb}) \text { - nícleo de gr } 1 \mathrm{e} \\
\text { núcleo de opx }\end{array}$ & $\begin{array}{c}\mathrm{P}(\mathrm{Kb})-\text { borda de } \mathrm{gr}_{1} \mathrm{e} \\
\text { borda de opx }\end{array}$ \\
\hline $\mathrm{JG}-108$ & $6,45 \pm 1,55$ & $5,94 \pm 1,55$ \\
\hline
\end{tabular}

Tabela 21 - Valores de $T$ calculados para o equilíbrio 2 da amostra $35 B$ da Unidade Jardim Glória, segundo os geotermômetros indicados.

\begin{tabular}{|l|c|}
\hline Geotermômetro & $\begin{array}{c}\mathrm{T}\left({ }^{\circ} \mathrm{C}\right) \text { - borda de } \\
\mathrm{gr} \text { e núcleo bt }\end{array}$ \\
\hline Ferry \& Spear (1978) & $616 \pm 50$ \\
\hline Perchuk (1981) & 600 \\
\hline Hoinkes (1986) & $694 \pm 30$ \\
\hline Indares \& Martignole (1985) & $510 \pm 50$ \\
\hline Thompson (1976) & 603 \\
\hline Média & 604 \\
\hline
\end{tabular}




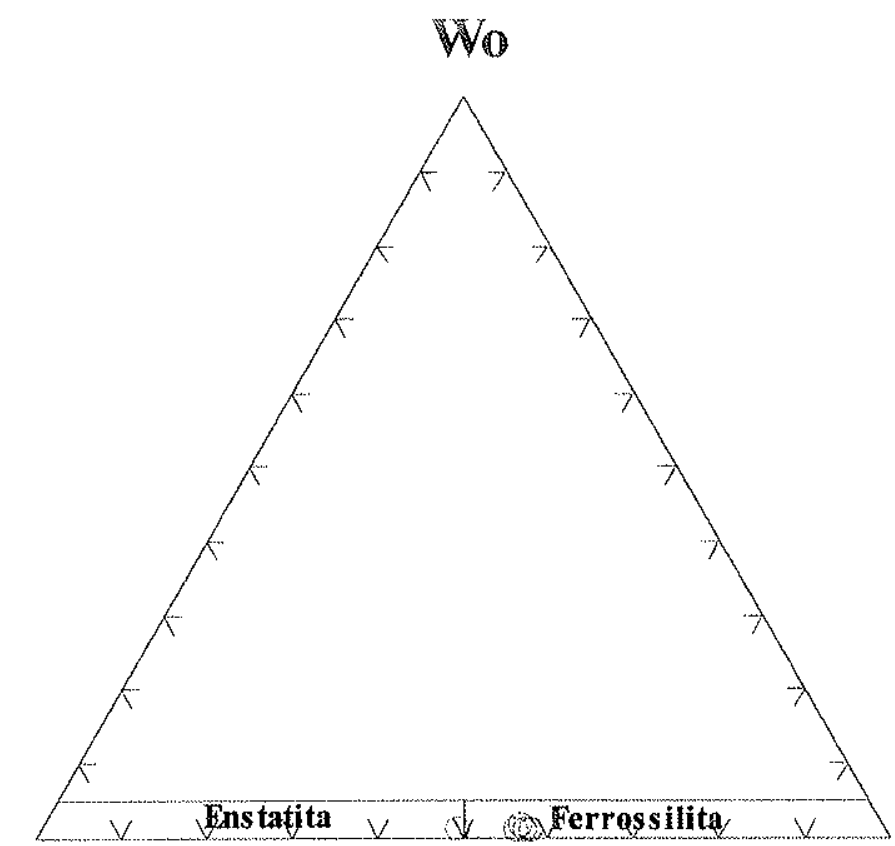

En

Fs

Figura 55 - Classificação do ortopiroxênio recristalizado das rochas metabásicas do CJF.

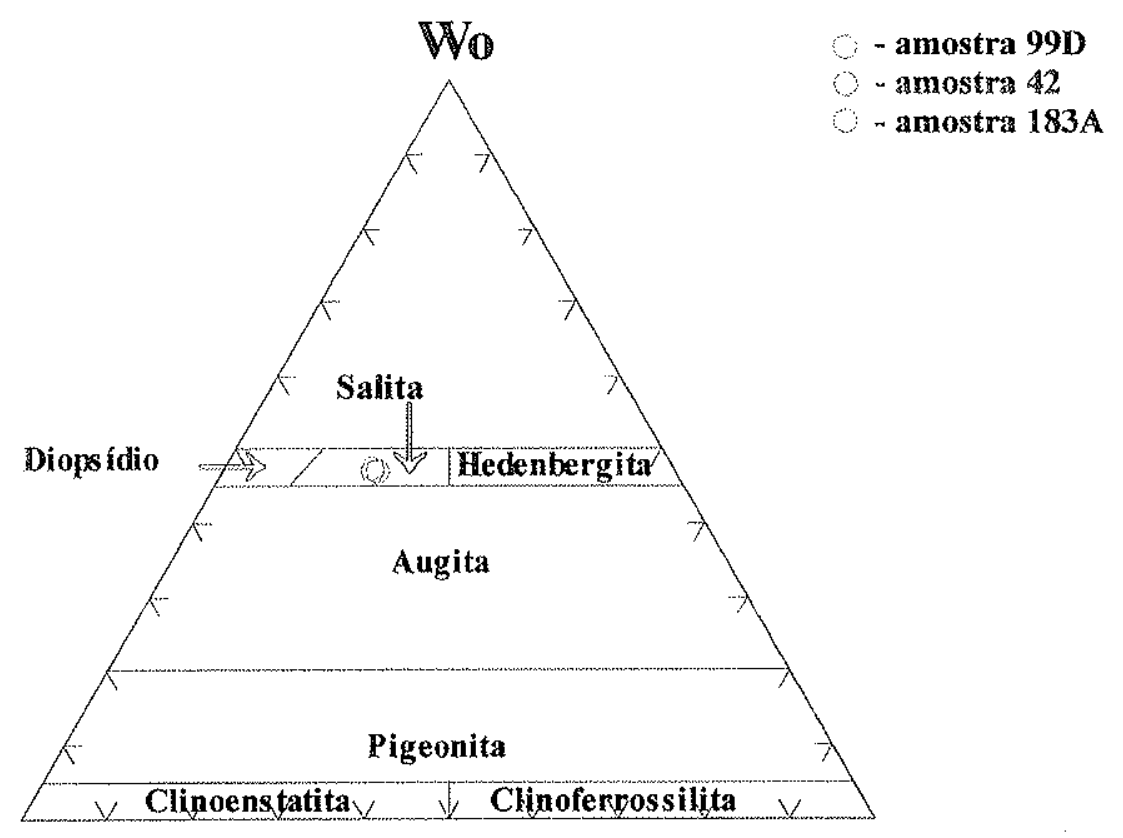

En

Fs

Figura 56 - Classificação do clinopiroxênio recristalizado das rochas metabásicas do CJF. 


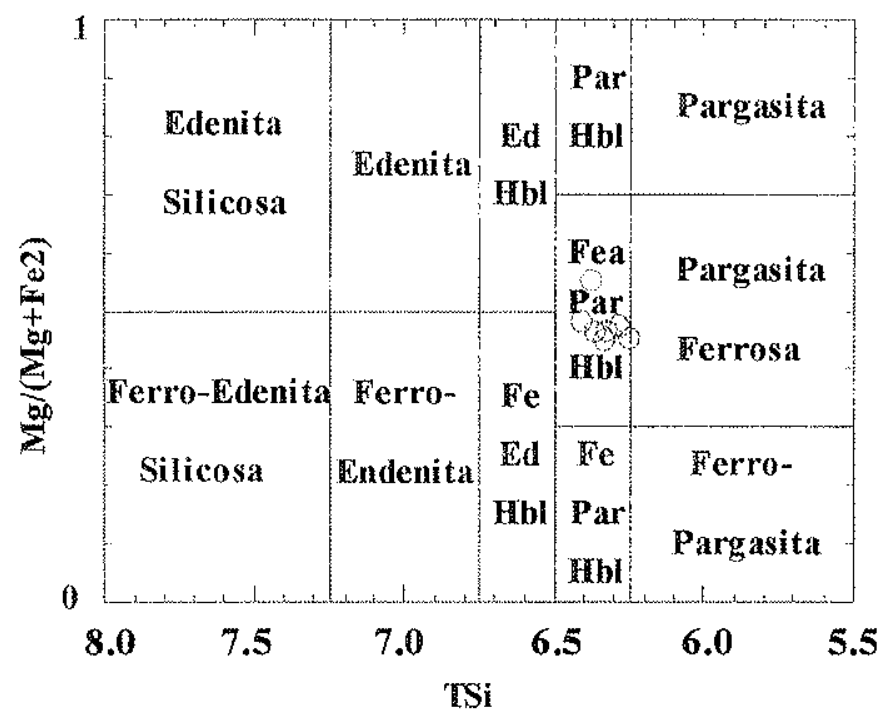

Figura 57 - Classificação do anfibólio recristalizado das rochas metabásicas do CJF.
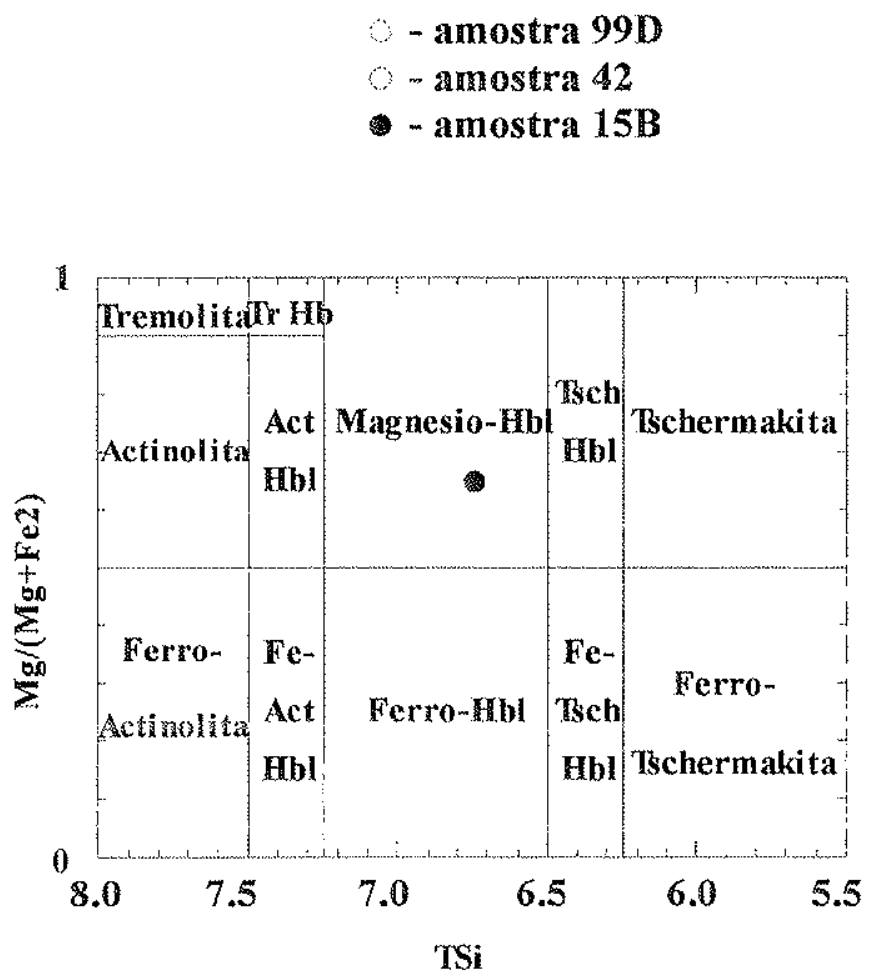

Figura 58 - Classificação do anfibólio recristalizado das rochas metabásicas do CJF. 


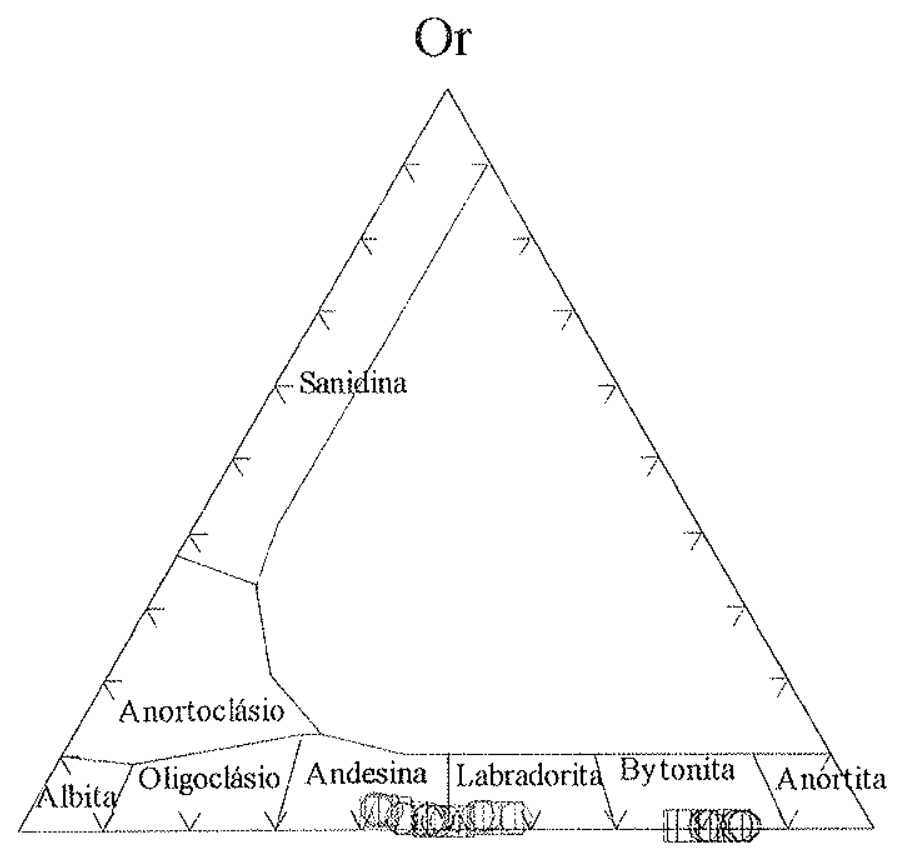

$\mathrm{Ab}$

An

Figura 59 - Classificação do plagioclásio das rochas metabásicas do CJF.
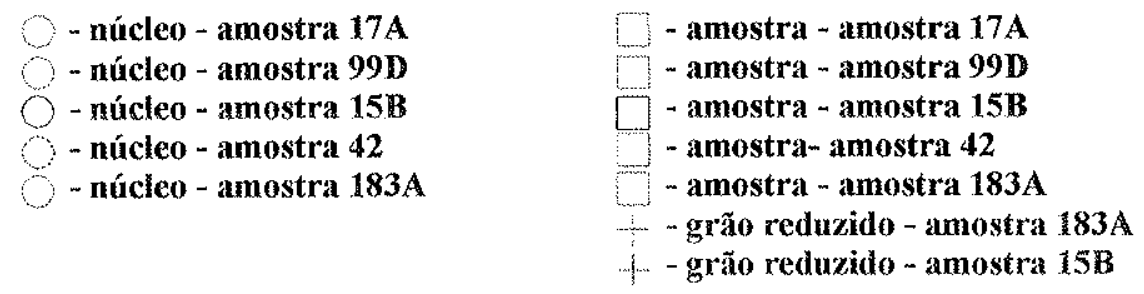

\section{Grossulária}

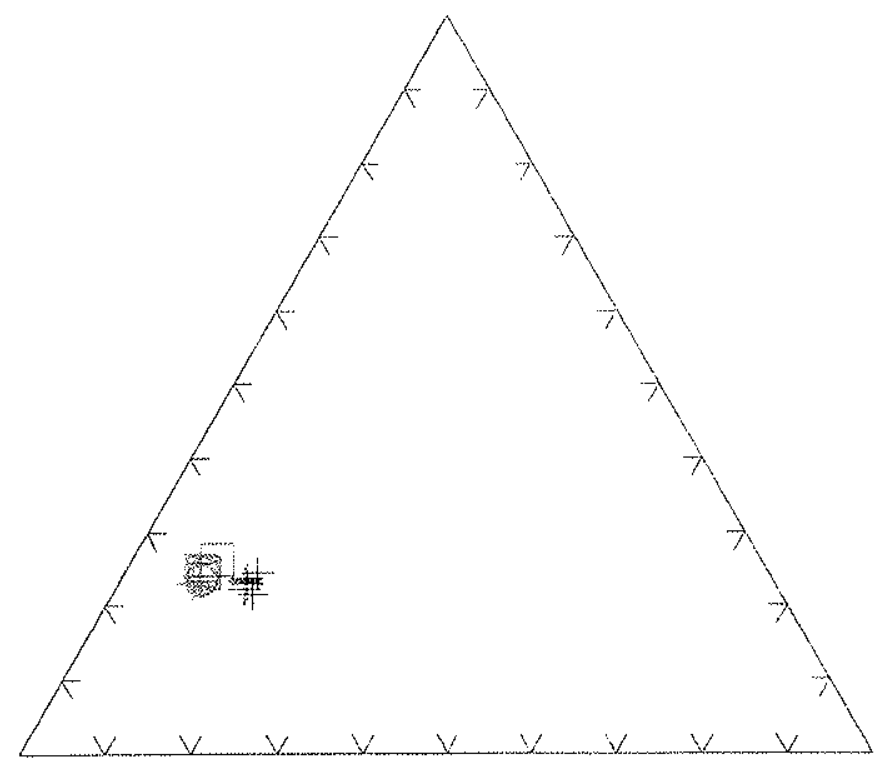

Almandina

Figura 60 - Classificação da granada das rochas metabásicas do CJF. 
Tabela 22 - Valores de $\mathrm{T}$ calculados para o equilíbrio 3 da amostra $36 \mathrm{~B}$ da Unidade Jardim Glória, segundo os geotermômetros indicados.

\begin{tabular}{|l|c|c|c|}
\hline Geotermômetro & $\begin{array}{c}\mathrm{T}\left({ }^{\circ} \mathrm{C}\right)-\text { borda de } \\
\mathrm{gr}_{1} \text { e núcleo bt }\end{array}$ & $\begin{array}{c}\mathrm{T}\left({ }^{\circ} \mathrm{C}\right)-\text { núcleo de } \\
\mathrm{gr}_{2} \text { e núcleo bt }\end{array}$ & $\begin{array}{c}\mathrm{T}\left({ }^{\circ} \mathrm{C}\right)-\text { borda de } \\
\mathrm{gr}_{2} \text { e borda de bt }\end{array}$ \\
\hline Ferry \& Spear (1978) & $669 \pm 50$ & $575 \pm 50$ & $604 \pm 50$ \\
\hline Perchuk (1981) & 628 & 577 & 593 \\
\hline Hoinkes (1986) & $774 \pm 30$ & $718 \pm 30$ & $758 \pm 30$ \\
\hline Indares \& Martignole (1985) & $583 \pm 50$ & $568 \pm 50$ & $614 \pm 50$ \\
\hline Thompson (1976) & 641 & 572 & 593 \\
\hline Média & 659 & 602 & 632 \\
\hline
\end{tabular}

Tabela 23 - Valores de $T$ calculados para o equilíbrio 3 da amostra JG - 108 da Unidade Jardim Glória, segundo os geotermômetros indicados, aplicados a uma $\mathrm{P}$ de $7 \mathrm{~Kb}$.

\begin{tabular}{|l|c|c|c|}
\hline Geotermômetro & $\begin{array}{c}\mathrm{T}\left({ }^{\circ} \mathrm{C}\right) \cdots \text { borda de } \\
\mathrm{gr}_{1} \text { e núcleo bt }\end{array}$ & $\begin{array}{c}\mathrm{T}\left({ }^{\circ} \mathrm{C}\right)-\text { núcleo de } \\
\mathrm{gr}_{2} \text { e núcleo bt }\end{array}$ & $\begin{array}{c}\mathrm{T}\left({ }^{\circ} \mathrm{C}\right)-\text { borda de } \\
\mathrm{gr}_{2} \text { e borda de bt }\end{array}$ \\
\hline Ferry \& Spear (1978) & $625 \pm 50$ & $655 \pm 50$ & $645 \pm 50$ \\
\hline Perchuk (1981) & 605 & 621 & 616 \\
\hline Hoinkes (1986) & $701 \pm 30$ & $725 \pm 30$ & $715 \pm 30$ \\
\hline Indares \& Martignole (1985) & $515 \pm 50$ & $572 \pm 50$ & $565 \pm 50$ \\
\hline Thompson (1976) & 610 & 631 & 624 \\
\hline Média & 612 & 641 & 633 \\
\hline
\end{tabular}

Tabela 24 - Valores de $T$ calculados para o equilibrio 2 (granada simplectítica e borda de biotita) dos paragnaisses da Unidade Jardim Glória, segundo os geotermômetros indicados, aplicados a $P=7 \mathrm{~Kb}$.

\begin{tabular}{|l|c|c|c|}
\hline Geotermômetro & $\begin{array}{c}\mathrm{T}\left({ }^{\circ} \mathrm{C}\right)-\mathrm{gr}_{3} \mathrm{e} \\
\text { borda de bt (35B) }\end{array}$ & $\begin{array}{c}\mathrm{T}\left({ }^{\circ} \mathrm{C}\right)-\mathrm{gr}_{3} \mathrm{e} \\
\text { borda de bt }(36 \mathrm{~B})\end{array}$ & $\begin{array}{c}\mathrm{T}\left({ }^{\circ} \mathrm{C}\right)-\mathrm{gr}_{3} \mathrm{e} \\
\text { borda de bt }(\mathrm{JG}-108)\end{array}$ \\
\hline Ferry \& Spear (1978) & $698 \pm 50$ & $635 \pm 50$ & $655 \pm 50$ \\
\hline Perchuk (1981) & 618 & 595 & 606 \\
\hline Hoinkes (1986) & $785 \pm 30$ & $793 \pm 30$ & $777 \pm 30$ \\
\hline Indares \& Martignole (1985) & $761 \pm 50$ & $647 \pm 50$ & $604 \pm 50$ \\
\hline Thompson (1976) & 586 & 544 & 557 \\
\hline Média & 690 & 643 & 640 \\
\hline
\end{tabular}


Tabela 25 - Valor de T calculados para o equilibrio 1 das amostra $99 \mathrm{D}$ e $15 \mathrm{~B}$ do conjunto do CJF, segundo os geotermômetros indicados.

\begin{tabular}{|l|c|c|}
\hline Geotermômetro & $\begin{array}{c}\mathrm{T}\left({ }^{\circ} \mathrm{C}\right)-\mathrm{opx}_{2} \text { e } \mathrm{cpx}_{2} \\
\text { amostra 99D }\end{array}$ & $\begin{array}{c}\mathrm{T}\left({ }^{\circ} \mathrm{C}\right)-\mathrm{hbl} l_{2} \text { e borda } \\
\text { de plg }- \text { amostra 15B }\end{array}$ \\
\hline Wood \& Banno (1973) & $742 \pm 70$ & \\
\hline Wells (1977) & $747 \pm 70$ & \\
\hline Blundy \& Holland (1990) & & $713 \pm 75$ \\
\hline Média & $745 \pm 70$ & \\
\hline
\end{tabular}

Tabela 26 - Valor de T calculados para o equilíbrio 2 dos ortogranulitos do CJF, segundo os geotermômetros indicados.

\begin{tabular}{|l|c|c|c|}
\hline Amostra & $\begin{array}{c}\mathrm{T}\left({ }^{\circ} \mathrm{C}\right)-\text { borda de opx } \\
\text { núcleo de } \mathrm{gr}-\mathrm{Sen} \& \\
\text { Bhattacharya }(1984)\end{array}$ & $\begin{array}{c}\mathrm{T}\left({ }^{\circ} \mathrm{C}\right) \text { - borda de } \mathrm{cpx}_{1} \mathrm{e} \\
\text { núcleo de } \mathrm{gr} \\
\text { Powell }(1985)\end{array}$ & $\begin{array}{c}\mathrm{T}\left({ }^{\circ} \mathrm{C}\right)-\text { borda de } \mathrm{cpx}_{1} \mathrm{e} \\
\text { núcleo de gr } \\
\text { Ellis \& Green (1979) }\end{array}$ \\
\hline $15 \mathrm{~B}$ & $664 \pm 30$ & & $519 \pm 25$ \\
\hline 183A & $623 \pm 30$ & 643 & \\
\hline Média & $644 \pm 30$ & & \\
\hline
\end{tabular}

Tabela 27 - Valores de P calculados para o equilibrio 2 dos ortogranulitos do CJF, segundo os geobatometros indicados (aplicados com as T obtidas do geotermômetro de Powell, 1985).

\begin{tabular}{|l|c|c|}
\hline Amostra & $\begin{array}{c}\mathrm{P}(\mathrm{Kb}) \text { borda de } \mathrm{cpx}_{1}, \text { borda de } \\
\text { plgi e núcleo de gr Ekert et al. (1989) }\end{array}$ & $\begin{array}{c}\mathrm{p}(\mathrm{Kb}) \text { borda de cpx } \\
\text { núcleo de grda de } \mathrm{plg}_{1} \mathrm{e}\end{array}$ \\
\hline $183 \mathrm{~A}$ & $6,96 \pm 1,9$ & $4,93 \pm 0,5$ \\
\hline $183 \mathrm{~A}$ & $7,08 \pm 1,9$ & $5,05 \pm 0,5$ \\
\hline
\end{tabular}

No caso dos metassedimentares da Unidade Jardim Glória, as condições de T e P do metamorfismo $M_{1}$ para o equilíbrio 1 foram claculadas a partir de: termômetros gr-opx (Sen \& Bhattacharya, 1984) e barômetro gr-opx-plg-qu (Ekert et al., 1990), como indicado abaixo.

Cálculo de T: núcleo de granada 1 e núcleo de opx borda de granada 1 e borda de opx

Cálculo de P: núcleo de granada 1, núcleo de opx e núcleo de plagioclásio

A tabela 19 mostra os resultados obtidos para o par opx-granada, podendo-se afirmar que as composições do núcleo forneceram uma $\mathrm{T}$ média $(\mathrm{Tm})$ de $\approx 675 \pm 30^{\circ} \mathrm{C}$, enquanto 
que as da borda forneceram $\mathrm{Tm}$ de $\approx 645 \pm 30^{\circ} \mathrm{C}$. Ambos os valores de $\mathrm{T}$ são muito baixos, considerando que estas rochas passaram pelo processo de fusão parcial descrito anteriormente, a partir de reações que se desenvolvem sob condições termais mais altas do que $700^{\circ} \mathrm{C}$. Assim, sugere-se que as temperaturas encontradas resultam do fato das trocas cationicas Fe-Mg entre granada e ortopiroxênio terem continuado a T mais baixas que o pico termal de M1.

As valores de pressão (Tab. 20) obtidos foram de $6,45 \pm 1,55 \mathrm{~Kb}$ e $5,94 \pm 1,55 \mathrm{~Kb}$ para o equilibrio entre núcleos e bordas, respectivamente.

A partir do equilíbrio 2 das rochas metassedimentares, foram considerados os resultados dos seguintes pares ou paragêneses:

Cálculo de T: borda de granada 1 e núcleo de biotita núcleo de granada 2 e núcleo de biotita borda de granada 2 e borda de biotita

Para estes cálculos foram utilizados os termômetros gr-opx (Sen \& Bhattacharya, 1984) (Tab. 20) e gr-bt (segundo várias calibrações; ver tabelas 21 a 24). Dada a inexistência de feições texturais que comprovassem o equilíbrio entre granada 2 e ortopiroxênio, valores de P não puderam ser calculados.

Os valores para o par granada 2 - biotita são mostrados nas tabelas 22 e 23 . Verifica-se uma variação desde 572 até 670 nos resultados obtidos. Esta gama de variações nos valores de T é provavelmente consequência da utilização de diferentes calibrações.

A inexistência de equilíbrios sensíveis às variações de $\mathrm{P}$ não permitiram o cálculo das condições de pressão desta etapa do metamorfismo $M_{i}$.

A partir do equilíbrio 3, podem ser calculados valores de $\mathrm{T}$ com base no par borda simplectítica de granada - borda de biotita. Os valores obtidos encontram-se na tabela 24, onde verifica-se uma variação desde 544 até $698^{\circ} \mathrm{C}$.

Para o caso dos ortogranulitos do CJF, o equilíbrio 0, como já foi citado, corresponde ao metamorfismo $M_{0}$ que teve desenvolvimento anterior à fase principal de deformação, 
provavelmente durante um evento tectono-termal anterior à Orogênese Brasiliana. Este metamorfismo será tratado mais adiante, ainda neste capitulo.

As condições de $\mathrm{T}$ de formação do equilíbrio 1 destes ortogranulitos foram estimadas a partir dos pares opx2 - cpx2 (estas fases representam bordas recristalizadas dos minerais da pargênese granoblástica referente a $M_{0}(o p x 1$ e cpx1). Esta recristalização é interpretada como resultante do cisalhamento promovido pelo cavalgamento ocorrido durante a fase principal de deformação da Orogênese Brasiliana na área. As figuras 61 e 62 mostram que os ortopiroxênios 2 do CJF plotam no campo das rochas metamórficas, confirmando sua origem a partir de metamorfismo regional. Este diagrama foi proposto por Rietmeijer (1983) para ortopiroxênios coexistindo com clinopiroxênio, como é o caso dos ortogranulitos do CJF.

Os termômetros utilizados foram o par opx-cpx (Wood \& Banno, 1973; Wells, 1977) e anf-plg (Blundy \& Holland, 1990). Somente a partir da amostra 990 foi possivel calcular valores de T para o par opx-cpx, cuja Tm é de $745 \pm 70^{\circ} \mathrm{C}$ (Tab. 25). Para o par hbl-plg, a T obtida, a partir da amostra 15B, foi de $713 \pm 75$.

O equilíbrio 2 nos ortogranulitos do CJF permitiu o cálculo de T e P, a partir de: termômetros gr-opx (Sen \& Bhattacharya, 1984) e gr-cpx (Powell, 1985; Ellis \& Green, 1979); barômetro gr-cpx-plg-qz (Newton \& Perkins, 1982; Ekert et al., 1989). Foram considerados os seguintes equilibrios:

Cálculo de T: borda de opxl - núcleo de granada* borda de cpx1 (ou cpx2) - núcleo de granada* borda de plgl - núcleo de hbl3*

Cálculo de P: borda de opx1 - borda de plg1 - núcleo de granada*

* (ou grão indiviso, no caso de ser muito reduzido)

A tabela 26 mostra os resultados de T para o para opx - granada que forneceu uma Tm de $\approx 644 \pm 30^{\circ} \mathrm{C}$. O par cpx - granada só foi avaliado para a amostra 183 A e forneceu valor de 643 e $519^{\circ} \mathrm{C}$, dependendo da calibração. 


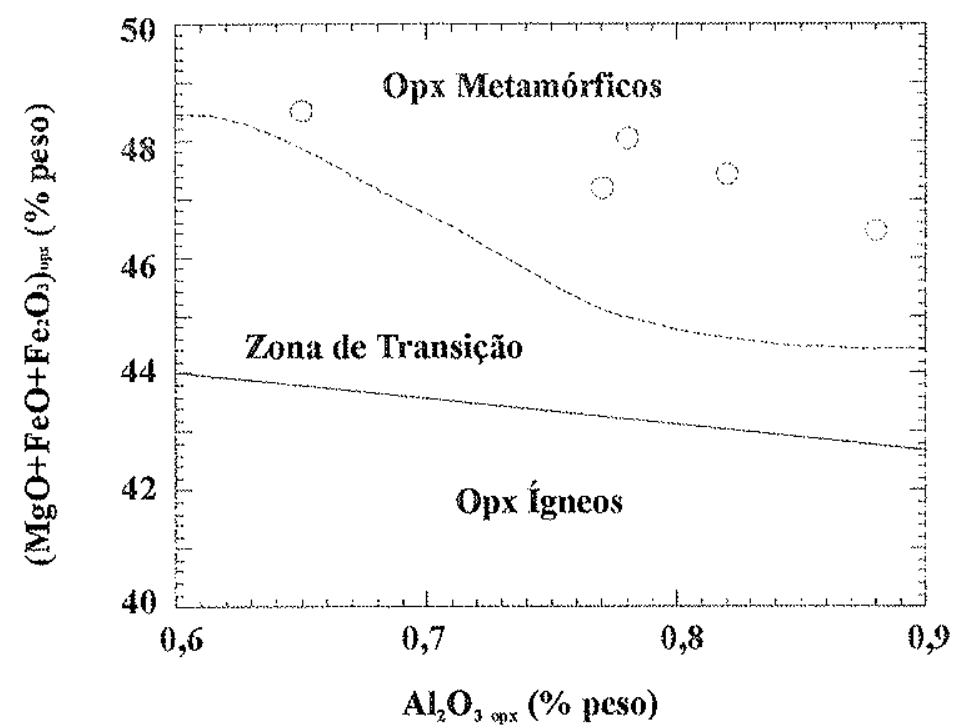

Figura 61 - Diagrama discriminante entre ortopiroxênios ígneos e metamórficos (segundo Rietmeijer, 1983).

- amostra 99D

- amostra 42

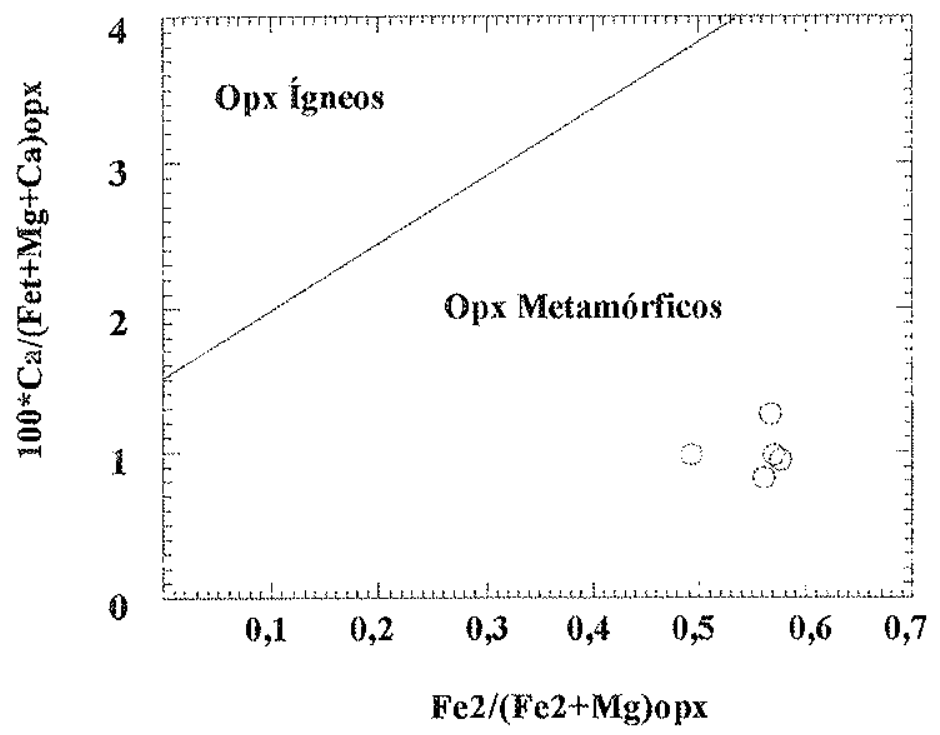

Figura 62 - Diagrama discriminante entre ortopiroxênios ígneos e metamórficos (segundo Rietmeijer, 1983). 
Com as temperaturas encontradas para o geotermômetro cpx-granada, foram calculados os valores de $\mathrm{P}$, como mostrado na tabela 27 . Foram então obtidos valores de $\approx 4,9$ a 5,1 Kb (calibração de Newton \& Perkins, 1982) e de 6,9 Kb a 7,1 Kb (calibração de Ekert et al., 1989).

\subsection{3) Metamorfismo Anterior à Fase Principal de Deformação: $M_{0}$}

Os registros encontrados para o evento metamórfico $M_{0}$ correspondem a um arranjo granoblástico de uma paragênese mineral diagnóstica para a facies granulito, mais antiga do que a foliação principal da área $\left(S_{1}, S_{2}\right.$ ou $\left.S_{1}+S_{2}\right)$ (Fig. 63a). Esta é uma feição amplamente registrada nas rochas do Complexo Juiz de Fora, mas também pode ser observada nos litotipos granulíticos do Complexo Mantiqueira. Como as características de $\mathrm{M}_{0}$ apresentam-se de maneira idêntica nos dois domínios tectônicos estudados (DTAND e DTJF), ambos os domínios serão tratados em conjunto no presente capítulo, embora todos os cálculos tenham sido realizados nos metabasitos do CJF. O arranjo granoblástico, tipo recrsitalização estática, da paragênese de $\mathrm{M}_{0}$ mantém com a foliação principal uma relação de não contemporaneidade, sendo o primeiro claramente mais antigo do que a segunda

O metamorfismo $M_{0}$ distribui-se de maneira distinta, dependendo do Domínio Tectônico enfocado. No DTAND, ocorrem faixas de pequena espessura e extensão de rochas granulíticas nos gnaisses do Complexo Mantiqueira. Por outro lado, no DTJF, as paragêneses de $M_{0}$ são registradas em todos os litotipos do Complexo Juiz de Fora. Tanto rochas enderbíticas, em parte mais antigas e encaixantes de intrusões ácidas e básicas mais jovens, quanto estas últimas têm tonalidades esverdeadas a carameladas e registram paragêneses diagnósticas para a facies granulito. $\mathrm{O}$ arranjo granoblástico dos minerais sugere metamorfismo ou recristalização sob condições estáticas de deformação. Dados $\mathrm{Rb} / \mathrm{Sr}$ e U/Pb indicam idades mais velhas que 1,8 Ga. (Evento tectono-termal Transamazônico) para o metamorfismo e/ou protólitos das rochas do CJF e sugerem a ocorrência de litotipos mais antigos (Arqueanos) retrabalhados no Transamazônico (Delhal et al., 1969; Cordani et al., 1973; Machado et al., 1996). Entretanto, estas idades foram efetuadas para rochas paraderivadas da antiga Série Juiz de Fora (Ebert, 1955), tendo sido analisada somente uma amostra de granulito ortoderivado, considerado pelo presente trabalho como Complexo Juiz de Fora. Machado et al. (1996), a partir de dados $\mathrm{U} / \mathrm{Pb}$, encontraram idade de 2,1 Ga. para um ortogranulito charnockítico, cujas 
feições intrusivas sugerem que represente o litotipo mais novo do CJF. Os autores interpretaram esta idade como a época da granulitização das rochas do CJF.

\section{a) Equilibrio no Metamorfismo $M_{0}$}

Por apresentarem bons pares minerais para o estudo geotermométrico do metamorfismo $\mathrm{M}_{0}$, somente os metabasitos granulíticos do Complexo Juiz de Fora foram selecionados para a realização de análise química mineral. $O$ seguinte equilíbrio referente a $M_{0}$ foi identificado nestas rochas:

(0) $\mathrm{Opx}+\mathrm{Cpx} \pm \mathrm{Hbl}+\mathrm{Plg}+\mathrm{Qz}+\mathrm{Op}$

Esta paragênese forma um arranjo granoblástico quando a rocha tem estrutura maciça e constituem a porção porfiroclástica da rocha quando foliada, indicando corresponderem a fases antigas e, até certo ponto, resistentes aos efeitos da deformação e das novas condições P-T de $M_{1}$ (Figs. 63b). É possível, porém pouco provável, que o equilíbrio (0) represente o ápice termal de $\mathrm{M}_{0}$, já que a temperatura de fechamento para a troca cationica é comumente mais baixa do que o ápice metamórfico. A maior probabilidade de se chegar a obter a $\mathrm{T}$ do auge metamórfico é através do equilibrio entre os núcleos dos pares minerais apropriados. Foram selecionadas 5 amostras (15B, 17A, 42,99D e 183A) e utilizados os pares opx-cpx (Wood \& Banno, 1973; Wells, 1977) e hbl-plg (Blundy \& Holland, 1990), núcleos e bordas, para a obtenção dos valores de T. Equilíbrios indicadores de valores de $\mathrm{P}$ não foram gerados por $\mathrm{M}_{0}$ nestas rochas.

\section{b) Quimica Mineral e Condições de P e T do Metamorfismo Mo no DTJF}

A composição química dos minerais analisados está apresentada no Apêndice 4 e para a classificação dos mesmos foram utilizados os diagramas das figuras 59 e 64 a 67 . O ortopiroxênio de algumas amostras é classificado como Fe-hiperstênio e, em outras, como hiperstênio (Fig. 64). Não foram detectadas variações significantes entre núcleos e bordas, o que pode ser consequência de um de dois fatores: não houve trocas catiônicas a $\mathrm{T}$ mais baixas do que aquelas do ápice metamórfico; ou o reequilibrio a $\mathrm{T}$ mais baixas se deu por completo, atingindo todo o grão. O clinopiroxênio mostra uma variação desde núcleos augíticos até 


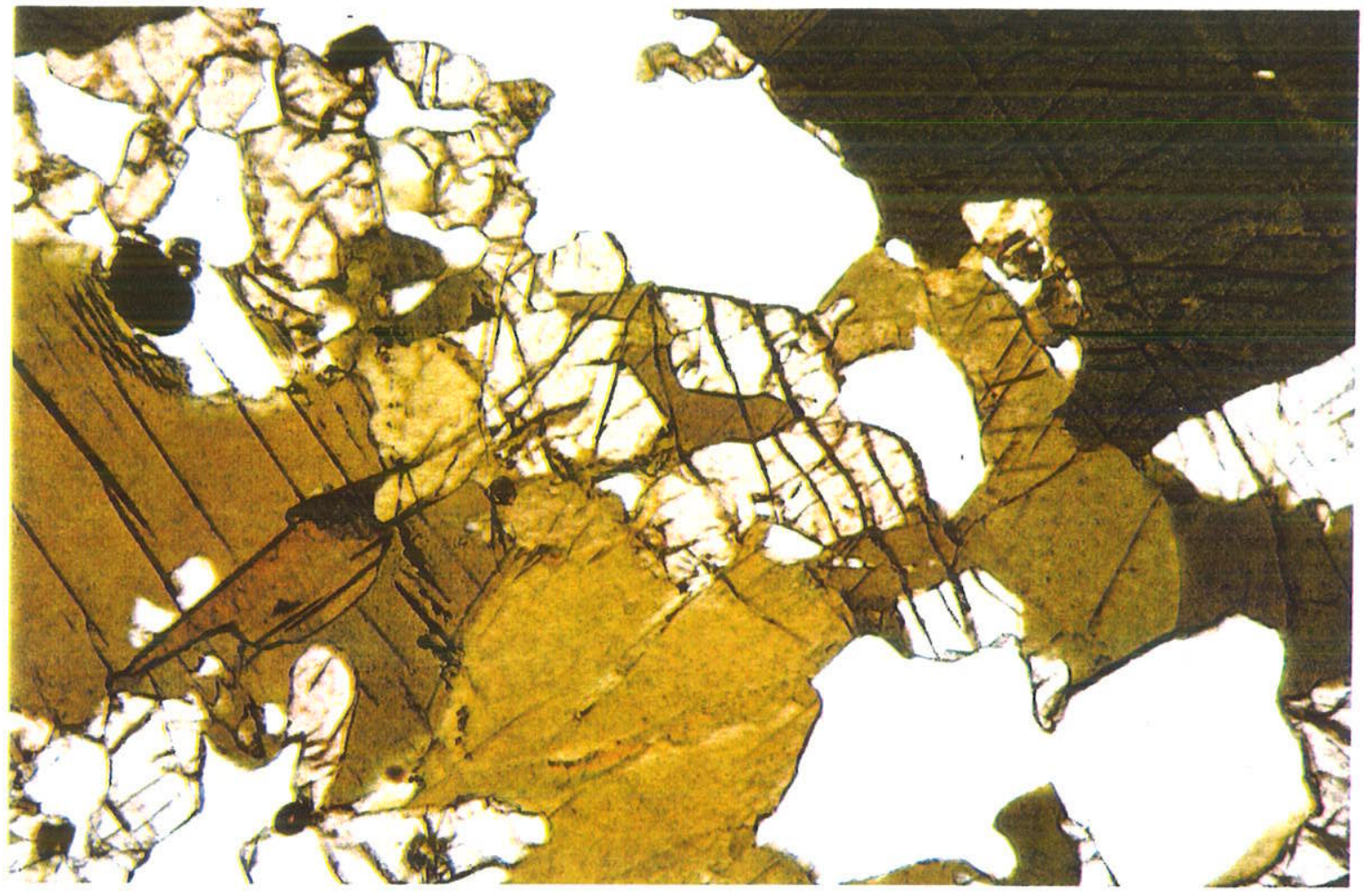

$0,4 \mathrm{~mm}$

Figura 63a - Arranjo granoblástico referente à $\mathrm{M}_{0}$ em Metabasito do CJF. DTJF. Ponto 17.

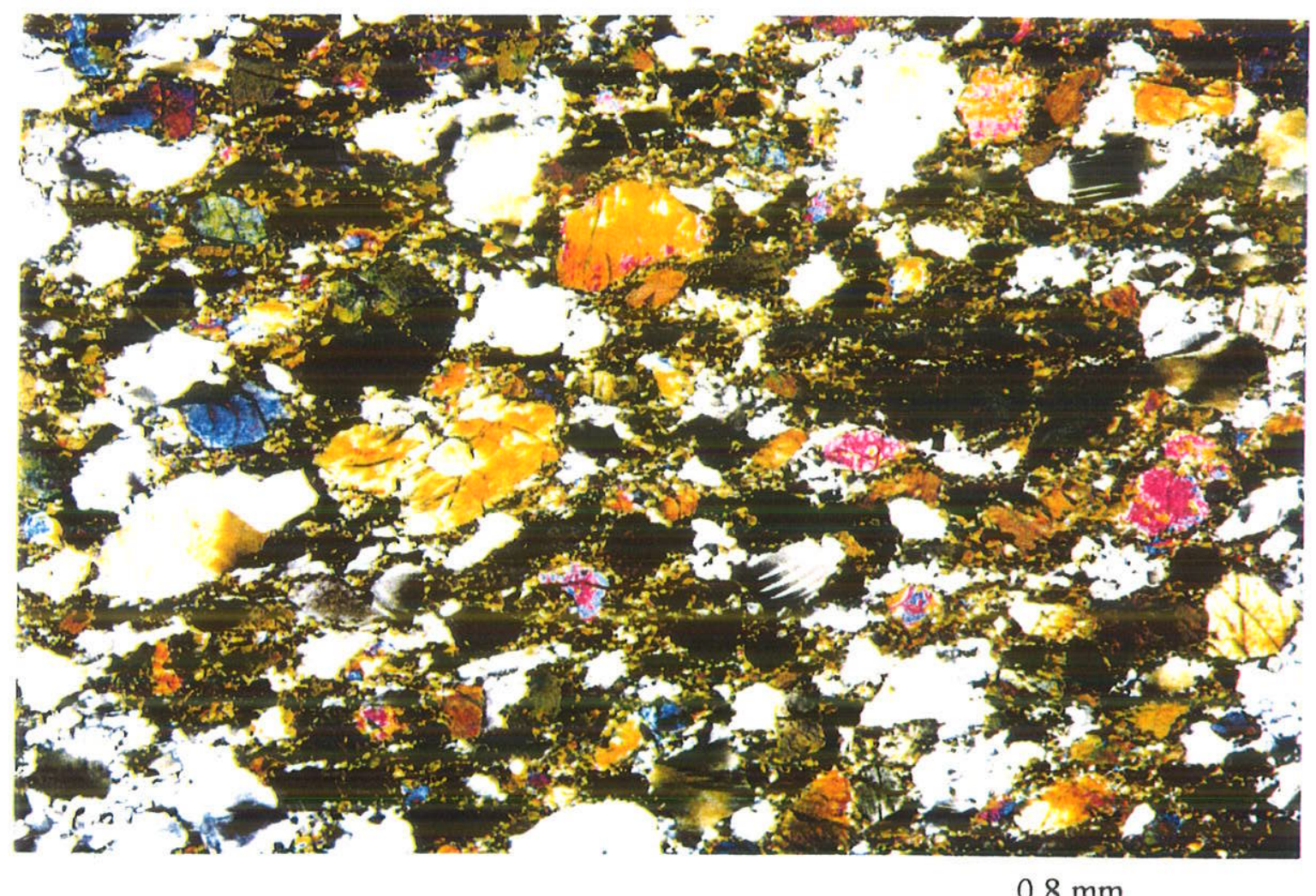

Figura 63 b - Arranjo granoblástico de $\mathrm{M}_{0}$ e recristalização referente a M1. Metabasito do CJJ. DTJF. Ponto 42. 


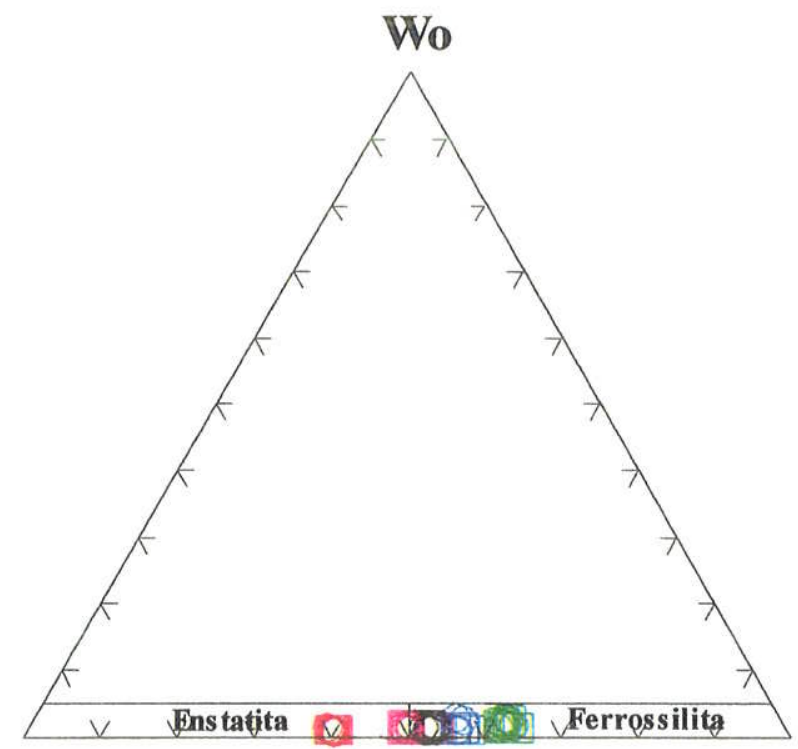

En

Fs

Figura 64 - Classificação do ortopiroxênio das rochas metabásicas do CJF.
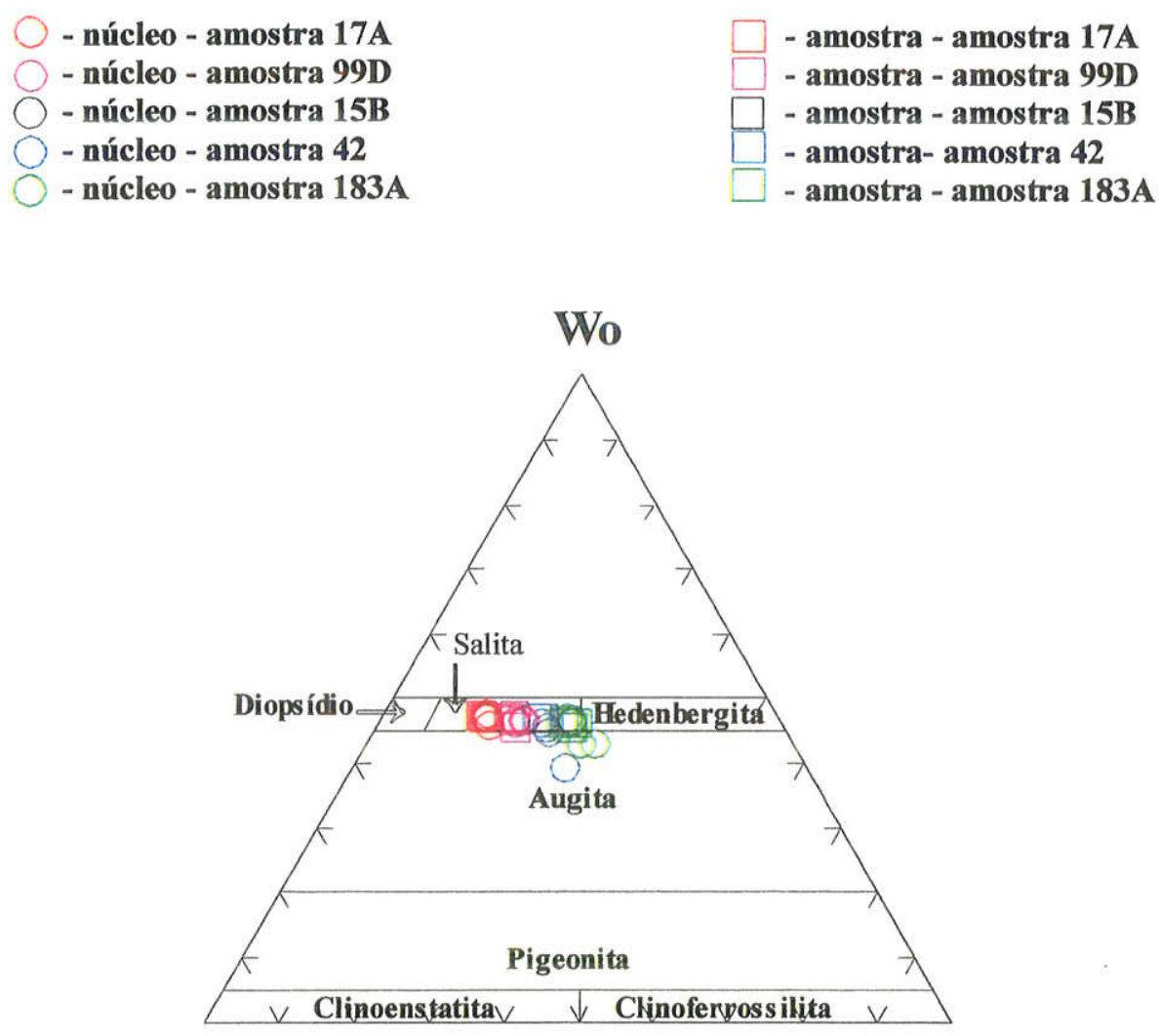

En

Fs

Figura 65 - Classificação do clinopiroxênio das rochas metabásicas do CJF. 
bordas salíticas em algumas amostras, enquanto que para outras, núcleos e bordas têm a mesma composição (Fig. 65). As hornblendas referentes ao equilíbrio de $M_{0}$ são do tipo pargassitico e ocorrem pequenas diferenças entre núcleos e bordas (Figss. 66 e 67).

Utilizando-se os diagramas propostos por Rietmeijer (1983), citados anteriormente, verifica-se que os ortopiroxênios da paragênese $M_{0}$ plotam no campo dos ortopiroxênios das rochas metamórficas (Figs. 68 e 69).

Apenas o equilíbrio opx $+\mathrm{cpx}+\mathrm{hbl}+\mathrm{plg}+\mathrm{q} z+$ op é observado como correspondente à evolução de $\mathrm{M}_{0}$ na área. O único mineral opaco identificado, tanto a partir da análise petrográfica quanto da análise química, é ilmenita. Assim, a paragênese mais antiga e granoblástica do CJF fornece dois pares (opx-cpx e hbl-plg) geotermômetros e nenhum equilíbrio na paragênese apresentada pode ser utilizado como geobarômetro. Dessa forma, apenas valores de $T$ foram calculados para o metamorfismo $\mathbf{M}_{0}$, como pode ser observado nas tabelas 28 e 29. Foram utilizados: núcleo de opx - núcleo de cpx; borda de opx - borda de cpx; núcleo de hbl - núcleo de plg; borda de hbl - borda de plg. Para cada uma das calibrações utilizadas, os valores de Tm para os equilibrios dos núcleos de opx e cpx foram de $804^{\circ} \mathrm{C}$ (Wood \& Banno, 1973) e $838^{\circ} \mathrm{C}$ (Wells, 1977). Para os núcleos de hbl e plg foi obtida uma Tm de $744^{\circ} \mathrm{C}$ (Blundy \& Holland, 1990). Para os equilibrios das bordas destes mesmos pares, foram obtidas $\mathrm{Tm}$ de $779^{\circ} \mathrm{C}, 802^{\circ} \mathrm{C}$ e $751^{\circ} \mathrm{C}$, respectivamente. Pode-se verificar que os valores das bordas, embora sejam sistematicamente menores do que aqueles dos núcleos, são da mesma ordem de grandeza.

Tabela 28 - Valores de T calculados para o equilíbrio 0 entre núcleos de grãos dos ortogranulitos do CJF, segundo os geotermômetros indicados.

\begin{tabular}{|c|c|c|c|}
\hline Amostra & $\begin{array}{c}\mathrm{T}\left({ }^{\circ} \mathrm{C}\right) \text { - núcleo de } \\
\text { opx } \text { e núcleo de } \mathrm{cpx}_{\mathrm{I}} \\
(\text { Wood \& Banno, } \\
\text { 1973) }\end{array}$ & $\begin{array}{c}\mathrm{T}\left({ }^{\circ} \mathrm{C}\right) \text { - núcleo de } \\
\mathrm{opx}_{1} \text { e núcleo de } \mathrm{cpx}_{1} \\
(\text { Wells, 1977) }\end{array}$ & $\begin{array}{l}\mathrm{T}\left({ }^{\circ} \mathrm{C}\right) \text { - núcleo de hbl } \\
\text { e núcleo de plg } \\
\text { (Blundy \& Holland, } \\
1990)\end{array}$ \\
\hline $17 \mathrm{~A}$ & $815 \pm 70$ & $821 \pm 70$ & $745 \pm 75$ \\
\hline 42 & $831 \pm 70$ & $894 \pm 70$ & $752 \pm 75$ \\
\hline $99 \mathrm{D}$ & $781 \pm 70$ & $802 \pm 70$ & $738 \pm 75$ \\
\hline $183 \mathrm{~A}$ & $788 \pm 70$ & $834 \pm 70$ & $740 \pm 75$ \\
\hline Média & $804 \pm 70$ & $838 \pm 70$ & $744 \pm 75$ \\
\hline
\end{tabular}




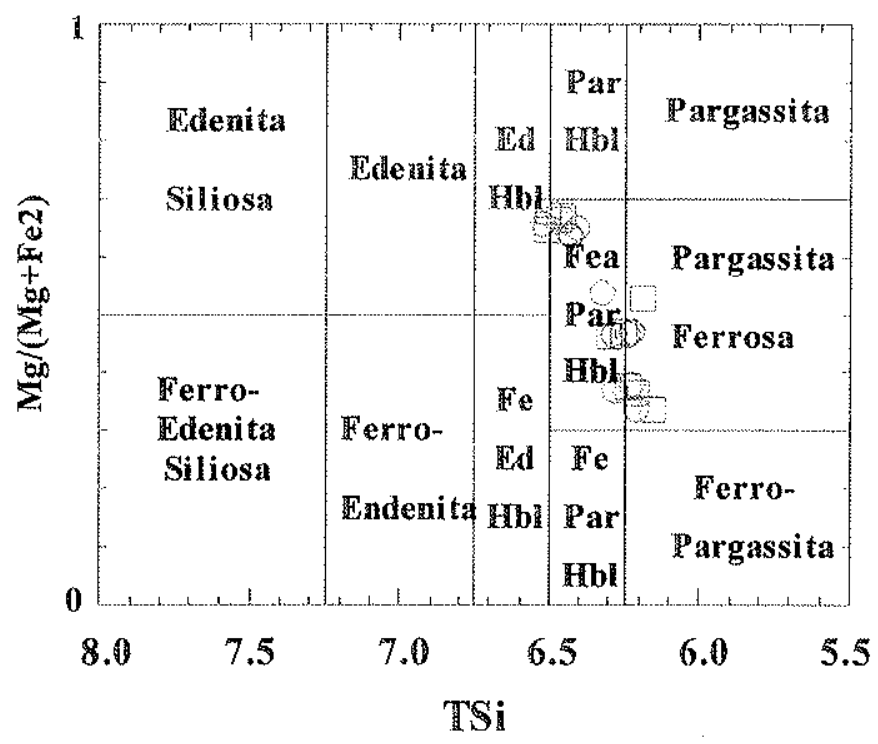

Figura 66 - Classificação do anfibólio das rochas metabásicas do CJF.

- núcleo - amostra 17A

- núcleo - amostra 99D

- núcleo - amostra 15B

- núcleo - amostra 42

- núcleo-amostra $183 \mathrm{~A}$
- amostra - amostra 17A

- amostra - amostra 99D

- amostra - amostra 15B

- amostra- amostra 42

- amostra - amostra 183A

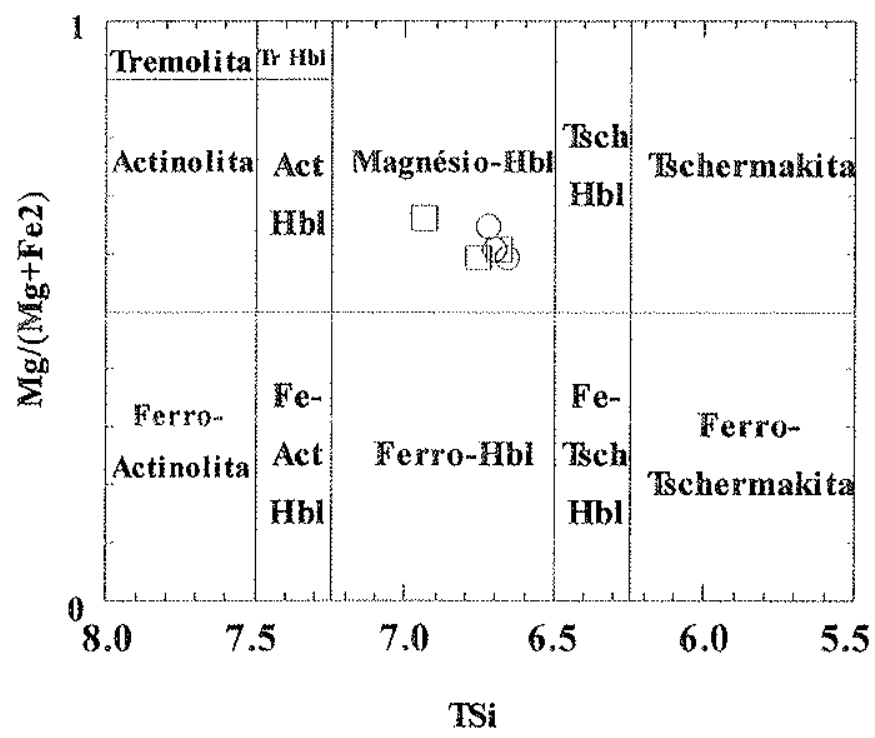

Figura 67 - Classificação do anfibólio dos metabásicos do CJF. 


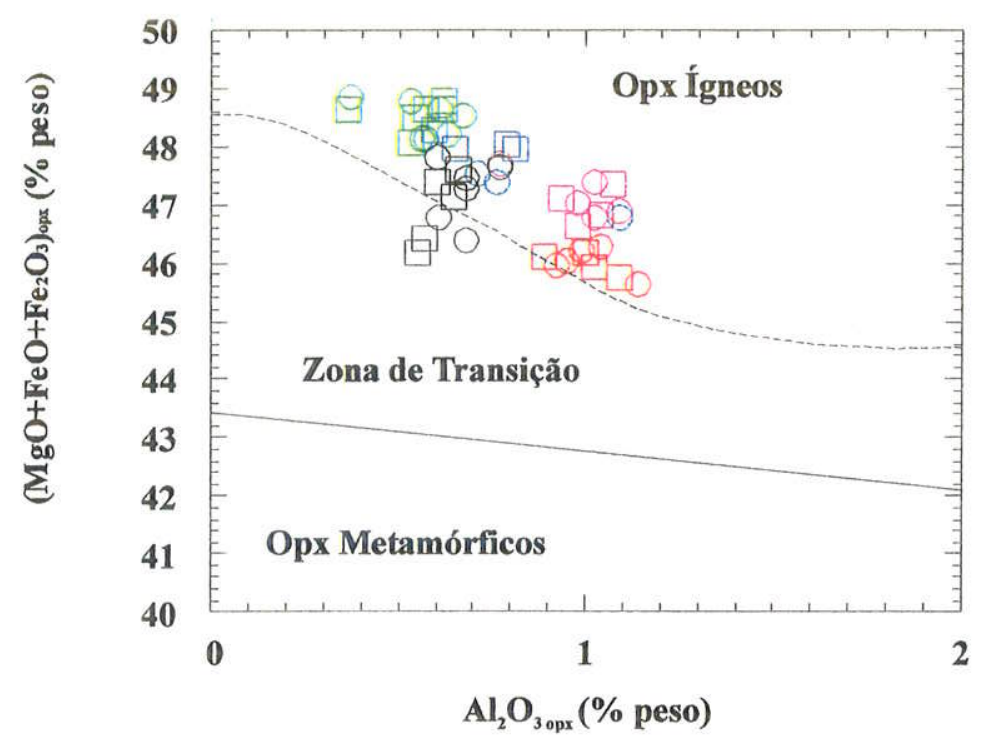

Figura 68 - Diagrama discriminante entre ortopiroxênios ígneos e metamórficos (segundo Rietmeijer, 1983).
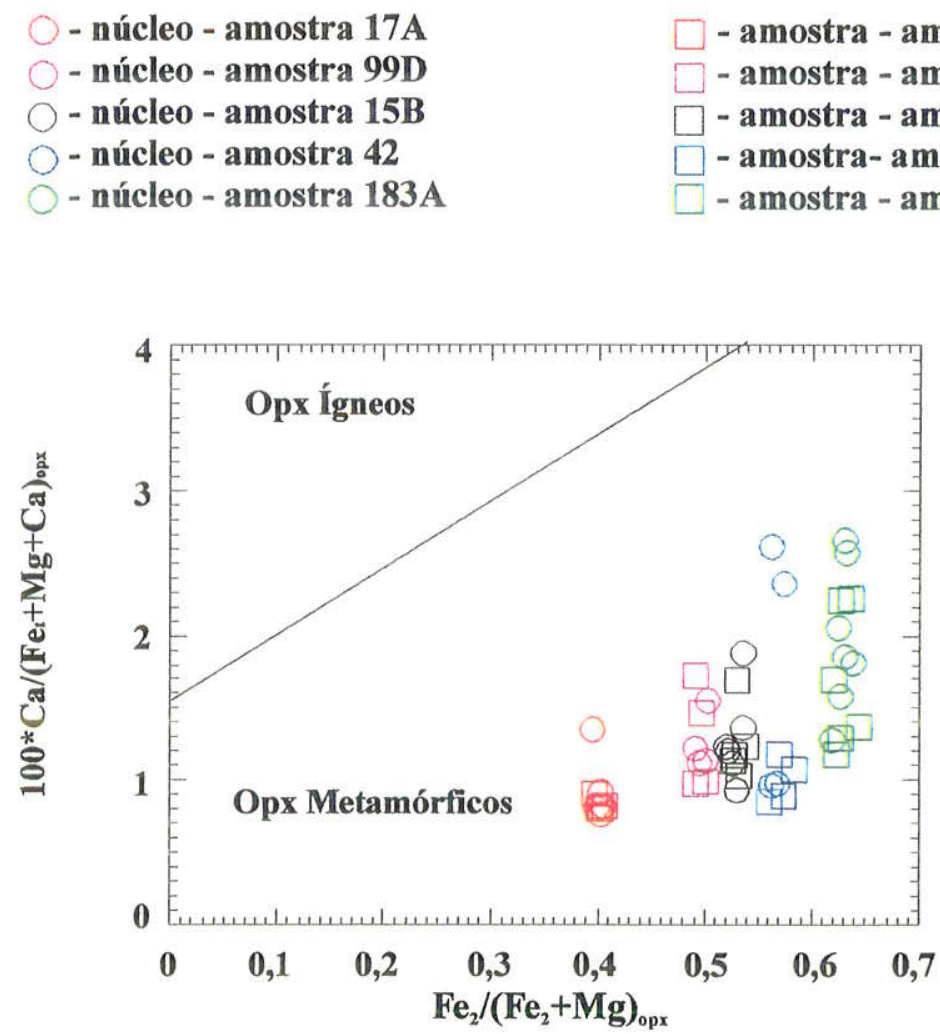

Figura 69 - Diagrama discriminante entre ortopiroxênios ígneos e metamórficos (segundo Rietmeijer, 1983). 
Tabela 29 - Valores de $T$ calculados para o equilibrio 0 entre bordas de grãos dos ortograntitos do CJF, segundo os geotermômetros indicados.

\begin{tabular}{|c|c|c|c|}
\hline Amostra & $\begin{array}{l}T(\mathrm{C}) \text { - borda de opx } \mathrm{x}_{1} \mathrm{e} \\
\text { borda de } \mathrm{cpx}_{1} \\
(\text { Wood \& Bamo, 1973) }\end{array}$ & $\begin{array}{c}\text { T }(\mathrm{C}) \text { - borda de opx } \mathrm{e} \\
\text { borda de } \mathrm{cpx}_{1} \\
(\text { Wells, 1977) }\end{array}$ & $\begin{array}{c}\mathrm{T}\left({ }^{\circ} \mathrm{C}\right) \text { - borda de hbl, e } \\
\text { borda de plg (Blundy \& } \\
\text { Holland, 1990) }\end{array}$ \\
\hline $17 \mathrm{~A}$ & $797 \pm 70$ & $799 \pm 70$ & $738 \pm 75$ \\
\hline 42 & $758 \pm 70$ & $784 \pm 70$ & $737 \pm 75$ \\
\hline 990 & $791 \pm 70$ & $819+70$ & $763+75$ \\
\hline $183 \mathrm{~A}$ & $771+70$ & $805 \div 70$ & $766 \pm 75$ \\
\hline Média & $779 \pm 70$ & $802 \pm 70$ & $751 \pm 75$ \\
\hline
\end{tabular}

A ausência de geobarômetros nesta paragênese faz com que se dê maior ênfáse a outros dados que, em conjunto com a análise petrográfica, podem ser utilizados como monitores das condições de $\mathrm{P}$ do metamorfismo $\mathrm{M}_{0}$. Laird \& Albee (1981) mostratam que a composição química dos anfibólios varia com o tipo bárico do metamorfismo. A partir de diagramas que envolvem a cristaloquimica destes minerais, os autores definiram campos de metamorfismo de alta, média e baixa pressão. Plotando-se a composição química dos anfibólios da área alvo nestes diagramas, verificause que os mesmos ocupam o campo dos anfibólios gerados por metamorfismo de baixa P, tipo Abukuma ou Buchan (Fig. 70). Os anfibólios da amostra $15 \mathrm{~B}$ se adequam tanto ao campo de baixa quanto ao campo de média $\mathrm{P}$. No presente trabaho, estes anfibólios (da amostra 15B) são interpretados como gerados durante o desenvolvimento da foliação principal da rocha, ou seja, durante o evento $M_{1}$ que regionalmente mostra claras cracterísticas de metamorfismo de $\mathrm{P}$ intermediária do tipo Barrowiano. A figura 48 mostra as condiçoes P.T do pulso metamórfico $\mathrm{M}_{0}$, com base nas paragêneses metamórficas decritas e na composição química da hornblenda.

\section{II.6.4) Integração, Interpretação dos Resultados Geotermobarométricos a Discussōes Finais}

\section{a) Metamorfismo $M_{1}$}

Os valores de temperatura obtidos a partir do equilíbrio 1 nos paragnaisses da Unidade Jardim Glória coincidem com aqueles do equilibrio 3 dos ortogranulitos do CJF. Esta analogia 

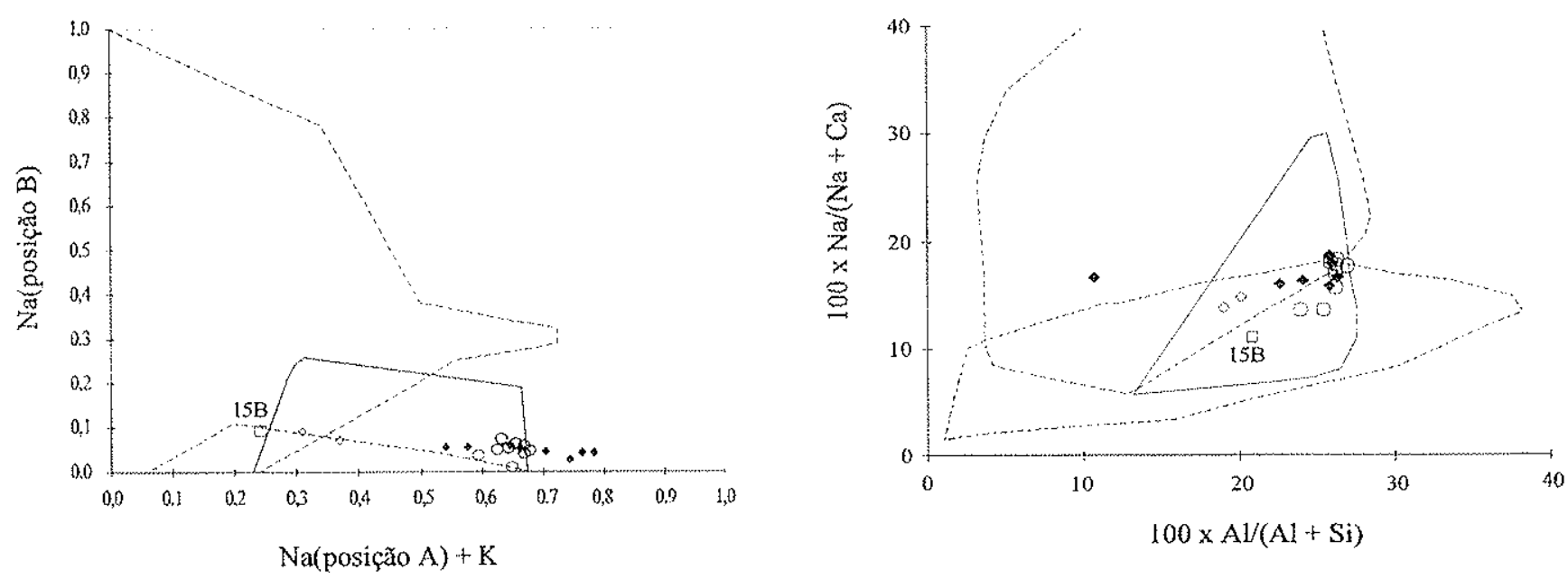

- Anfibólios 1 (facies granulito) do CJF

- Anfibólios 2 (facies anfibolito superior) do CJF

- Bordas recristalizadas de anfibólios 1 do CJF

Bordas recristalizadas de anfibólios 2 do CJF

Campo dos anfibólios de facies metamórfica de alta $\mathrm{P}$ Terrenos Sanbagawa, Japão e Franciscano, Califórnia. Campo dos anfibólios de facies metamórfica de média $\mathrm{P}$ Terrenos Dalradian, Escócia e Kaast River, N. Zelândia. Campo dos anfibólios de facies metamórfica de baixa $\mathrm{P}$ Terreno Abukuma, Japão
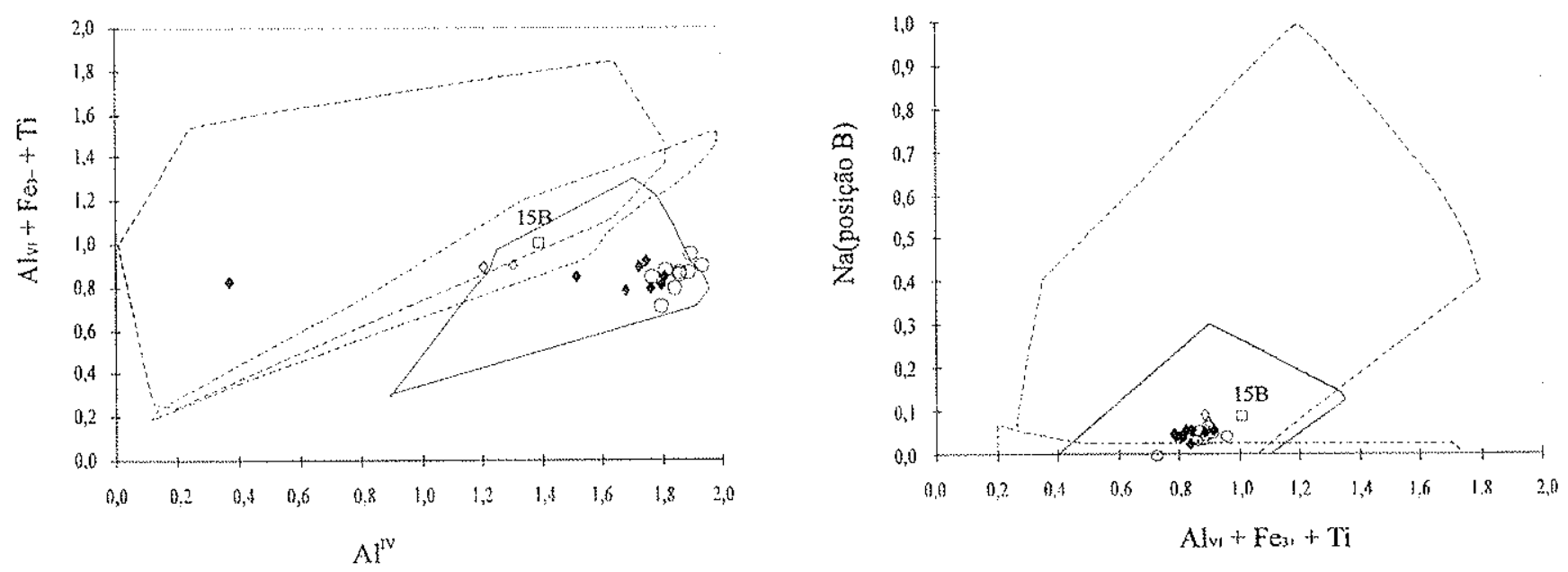

Figura 70 - Plote das composições de anfibólios do Complexo Juiz de Fora.

Campos de diferentes posiçôes de P definidos por Laird \& Albee (1981). 
é extremamente consistente com a análise petrográfica realizada. No entanto, com base na evidência de processo de anatexia a vapor ausente, as temperaturas do auge de $\mathrm{M}_{1}$ deveriam ser $>700^{\circ} \mathrm{C}$. Os baixos valores encontrados mostram que granada e ortopiroxênio e granada e clinopiroxênio nestas rochas continuaram a se reequilibrar durante o resfriamento a partir do auge térmico de $\mathrm{M}_{1}$. Assim, é provável que os valores entre 640 e $645^{\circ} \mathrm{C}$ representem as temperaturas de fechamento deste sistema de trocas catiônicas. O termômetro gr-cpx nas calibrações de Ellis \& Green (1979) fornece T muito baixas. Dada a consistência entre petrografia e resultados para dois conjuntos distintos de rocha (metassedimentares e ortogranulitos) a partir de outras calibrações, é razoável supor que a calibração de Ellis \& Green (op.cit.) não é, por algum motivo, adequada às rochas em questão.

Os valores de temperatura obtidos a partir do equilibrio 2 das rochas metassedimentares, calculados com base em termômetros grubt, fornecem valores baixos. Embora evidências petrográficas indiquem que este equilibrio não represente as condições auge de $M_{1}$, ainda assim, os baixos valores de $T$ são provavelmente resultantes de trocas cationicas que continuaram a ocorrer durante o resfriamento da rocha, no caminho de volta do metamorfismo $\mathrm{M}_{1}$

É possivel que o equilíbrio 1 das rochas ortogranulíticas do CJF represente as condições termais do auge de $M_{1}$, uma vez que é constituído de novos grãos formados pela recristalização da paragênese de $M_{0}$ durante o cavalgamento contemporâneo a $M_{1}$. Para este equilíbrio foram encontradas temperaturas entre 713 e $747^{\circ} \mathrm{C}$ que são consistentes com as observações de campo e petrográficas da participação de quebra de biotita no processo de anatexia dos paragnaisses da Unidade Jardim Glória. Para o cálculo das condições báricas de $\mathrm{M}_{1}$ foi utilizado um valor de $\mathrm{T}=745^{\circ} \mathrm{C}$, que representa a média dos valores encontrados para o par opx-cpx do equilíbrio 1 nos ortogranulitos do CJF. O barômetro gr-cpx $-p l g \sim q z$ de Newton \& Perkins (1982) forneceu valores de $\approx 2 \mathrm{~Kb}$ mais baixos do aquele de Ekert et al. (1989). Estes últimos autores implementaram ajustes ao sistema GADS (gr-cpx-plg $-\mathrm{qz}$ ) que sistematicamente mostrava resultados de $\approx 2 \mathrm{~Kb}$ mais baixos que o sistema GAPES (gr-opxplg-qz) em granulitos a dois piroxênios. Sendo assim, o presente trabalho dá preferência aos valores de $\mathrm{P}$ obtidos a partir do termômetro gr-cpx-plg-qz com os ajustes empregados por Ekert et al (1989). Além disso, a partir dos paragnaisses, o termômetro gr-opx-plg-qz (Ekert 
et al., 1990), com refinamentos mais apurados para a calibração, forneceu resultados semelhantes àqueles produzidos pelo termômetro gr-opx-plg-qz de Ekert et al. (1989). Os resultados obtidos variam de $\approx 6 \mathrm{a} 7 \mathrm{Kab}$, o que comprova que $\mathrm{Ml}$ se desenvolveu sob condições de pressão intermediária. Como estes barômetros envolvem reações de troca multicatiônica entre fases minerais estruturalmente distintas, os resultados gerados expressam as condições báricas mais altas atingidas durante $\mathrm{M}_{\mathrm{l}}$.

A figura 71 mostra o caminho P-T -t para os dois conjuntos de rocha (paragnaisses da Unidade Jardim Glória e ortogranulitos do CJF) durante o desenvolvimento do metamorfismo $\mathrm{M}_{1}$. A etapa progressiva deste metamorfismo foi construida com base em dados regionais, observações de campo e estudo petrográfico-petrológico.

As seguintes etapas podem ser descritas para a evolução dos paragnaisses da Unidade Jardim Glória durante $\mathrm{M}_{1}$ :

Etapa 1 - Uma porção crustal (grande parte do DTJF e o DTPS) provavelmente muito espessa $(\approx 20-25 \mathrm{Km})$ cavalga estes paragnaisses. Nesta etapa é possível que tenha ocorrido um grande aumento de pressão sem variações significantes de temperatura (isothermal loading);

Etapa 2 - Com o cavalgamento de uma porção crustal quente (ortogranulitos do CJF) sobre rochas mais frias (paragnaisses da Unidade Jardim Glória), começa a ocorrer transferência de calor da escama superior para a inferior. Os paragnaisses sofrem aquecimento isobárico, perdem $\mathrm{H}_{2} \mathrm{O}$ intergranular e chegam a gerar paragêneses com granada e ortopiroxênio, além de anatexia a vapor ausente (vapour absent dehydration melting), envolvendo, provavelmente, a reação:

$$
\text { Biotia + Quartzo } \rightarrow \text { Ortopiroxênio + Fusão }
$$

Esta etapa corresponde ao auge térmico do metamorfismo $M_{1}$ para estas rochas.

Etapa 3 - Declínio de $\mathrm{P}$ devido à erosão e isostasia. Como a pressão responde mais rapidamente do que a temperatura às variações de profundidade e/ou esforços tectônicos, durante esta etapa é possível que a temperatura tenha sido mantida (descompressão isotérmica); 


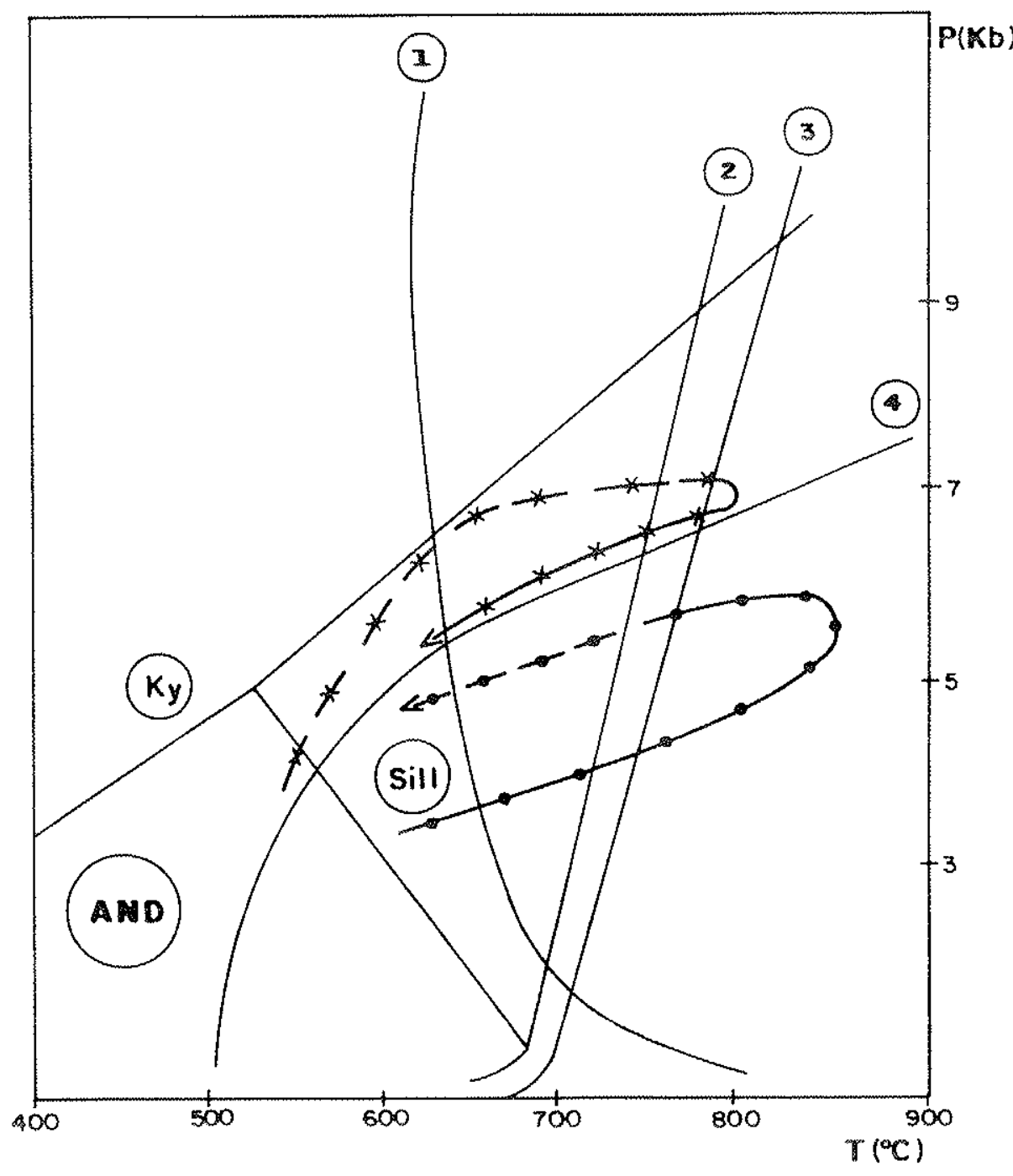

(1) $A D+K i+O_{2} \longrightarrow$ FUSÄO gRANÍticA SATURADA EM $\mathrm{H}_{2} \mathrm{O}$

(2) $\mathrm{Bi}+\mathrm{Sill}+\mathrm{PIg}+\mathrm{Qz} \longrightarrow \mathrm{Gr}+\mathrm{K}+\mathrm{F}+\mathrm{F}$ ÃO (Le Breton \& Thompson, 1987)

(3) $\mathrm{Bt}+\mathrm{Plg}+\mathrm{Oz} \rightarrow \mathrm{Opx}+\mathrm{K}+\mathrm{FuSÄO}$ (Clemmens 8 Wolls, 1981 )

(4) Cordierita IN

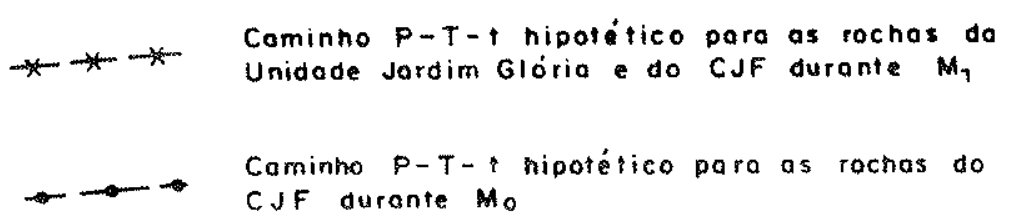

FIGURA 71 - Grófico P-T exiraido de Yardley (1989) e Winkler (1977), indicondo os caminhos $P-T-\uparrow$ hipotéticos de $M_{1}$ e $M_{0}$ para as rochas do DTJF 
Etapa 4 - Isostasia atinge o equilíbrio e $\mathrm{T}$ começa a cair (resfriamento isobárico).

As seguintes etapas podem ser descritas para a evolução dos ortogranulitos do Complexo Juiz de Fora durante $M_{1}$ :

Etapa 1 - Estas rochas foram aparentemente alçadas a niveis mais rasos. Entretanto, como é provável que quase ao mesmo tempo as mesmas tenham sido cavalgadas por porção correspondente, pelo menos, à crosta superior (DTPS), é possível que inicialmente não tenha havido variações significantes de $\mathrm{P}$ ou $\mathrm{T}$ e a paragênese granulítica sofreu recristalização. Através das superficies de cisalhamento, os ortogranulitos ganhavam $\mathrm{H}_{2} \mathrm{O}$ e sua paragênese era hidratada, ou seja, piroxênios e plagioclásio eram consumidos para gerar hornblenda e/ou biotita. Nesta etapa parece haver gradientes de PH2O em espaços restritos. É possível, porém não certo, que a temperatura estivesse em declínio.

Etapa 2 - Os metabasitos granulíticos começaram a gerar coronas de granada em tormo de piroxênios e hornblenda de $2^{\text {a }}$ geração. Esta reação indica aumento de pressão, embora não seja definitiva quanto às condições termais;

Etapa 3 - Com o tempo, ocorre declínio da temperatura, uma vez que estas rochas transferiam calor para os metassedimentos sotopostos. No entanto, havia também ganho de calor promovido pelos efeitos da deformação que estava em franco desenvolvimento. É dificil avaliar se nesta etapa houve variações significantes de $T$ ou $P$;

Etapa 4 - Erosão e isostasia promovem o decínio de P. T inicialmente fica constante (descompressão isotérmica);

Etapa 5 - $\mathrm{T}$ abaixa e $\mathrm{P}$ se mantém constante com o equilíbrio isostático (resfriamento isobárico).

Pode-se verificar que para ambas as unidades, o caminho da evolução metamórfica é do tipo dextrógiro (regra da mão direita) ou clockwise. Camihos P.T-t deste tipo têm sido associados a faixas móveis geradas por colisão continental, envolvendo importante tectônica de empurrões e metamorfísmo inverso (Tauern Window nos Alpes Orientais, Áustria; Cadeia 
dos Himalayas, Sul da Ásia) (Spear, 1993). As características estruturais e metamórficas descritas para o segmento central da Faixa Ribeira (onde se incluem os DTAND, DTJF e DTPS) indicam evolução muito semelhante aos orógenos citados acima; ou seja, importante tectônica de empurrões promovida por esforços compressivos e que produziram um modelo de metamorfismo inverso, onde isógradas minerais que representam condições termais mais altas ocorrem acima daquelas que expressam condições mais baixas. Isto pode ser observado dentro de cada domínio tectônico: no DTAND (Gonçalves, 1987; Heilbron, 1993); no DTJF (Heilbron, 1993; este trabalho); é observado também na relação entre estes dois domínios tectônicos: rochas de paragênese granulítica (DTJF) por cima de rochas de paragênese típica da facies anfibolito superior (DTAND) (Heilbron, 1993; este trabalho).

Este modelo de colisão continental é bastante consistente com os resultados obtidos a partir das observações de campo, da análise petrográfico-petrológica e da aplicação de termobarômetros. Além disso, a partir de estudos de inclusões fluidas, tanto nas rochas metassedimentares (aqui denominadas Unidade Jardim Glória) quanto nos ortogranulitos do CJF, Nogueira (1994) encontrou evidencias de caminho ITD para o metamorfismo Brasiliano $\left(\mathrm{M}_{1}\right)$.

\section{b) Metamonismo $M_{0}$}

Os valores de $\mathrm{T}\left(\approx 780-840^{\circ} \mathrm{C}\right)$ obtidos a partir do equilíbrio 1 entre os núcleos de opx e cpx dos ortogranulitos do CJF são interpretados como o pico do metamorfismo $\mathrm{M}_{0}$. Verifica-se que os resultados do termômetro opx-cpx são bastante consistentes para todas as amostras. Os resultados obtidos a partir do equilibrio entre núcleos de hbl e plg fornecem valores mais baixos. Isto deve ser decorrente de óbvias diferenças de calibrações, mas também pode indicar equilíbrio atingido a $\mathrm{T}$ mais baixas do que aqueles do auge metamórfico de $\mathrm{M}_{0}$.

Considerando cada uma das calibrações utilizadas em cada amostra, verifica-se que os valores de $\mathrm{T}$ obtidos com as bordas dos grãos são sistematicamente mais baixos do que aqueles do núcleo (exceção às amostras 990 para opx-cpx e $183 \mathrm{~A}$ para hbl-plg). Esta variação sistemática pode estar expressando o resfriamento de $\mathrm{M}_{0}$. 
As condições báricas deste metamorfismo não puderam ser calculadas dada a ausênica de barômetros neste equilíbrio. Oliveira $(1980,1982)$ encontrou valores de 6 a $7 \mathrm{~Kb}$, o que, no presente trabalho, são interpretados como referentes a $\mathrm{M}_{1}$. A utilização da composição química dos núcleos dos anfibólios indica metamorfismo de baixa pressão (Fig.70).

A definição de caminhos $\mathrm{P}-\mathrm{T}-\mathrm{t}$ para rochas que foram metamorfisadas na facies granulito é uma tarefa árdua, dados a frequente obliteração total das evidências do caminho progressivo e os comuns reajustes advindos do caminho retrogressivo (Bohlen, 1987; Harley, 1989; Spear, 1993). Dois tipos de caminhos são reconhecidos para rochas granulíticas: 1) caminho caracterizado por um período de descompressão quase isotérmica (ITD); 2) caminho caracterizado por um periodo de resfriamento quase isobárico (IBC). Harley (1989) fez uma compilação dos caminhos P-T de terrenos granulíticos no mundo e concluiu que existe um número grosseiramente igual de caminhos ITD e IBC.

Muito embora existam vários problemas relacionados aos resultados produzidos pela análise geotermobarométrica e suas interpretações, respostas à questão do porquê da existência destes dois tipos de caminhos em terrenos granulíticos têm sido objeto de várias pesquisas. A distinção entre caminhos ITD e IBC é importante já que diferentes caminhos implicam em diferentes ambientes tectônicos. Caminhos ITD têm sido relacionados ao espessamento tectônico da crosta seguido de exumação dominada por erosão ou por tectonismo.

Caminhos IBC são mais dificeis de serem interpretados a não ser que pelo menos uma parte da evolução progressiva possa ser deduzida. São necessariamente uma consequência da elevação do gradiente geotérmico, o que é normalmente relacionado à acreção magmática na base da crosta (underplating) (Bohlen, 1987). Tanto processos de erosão quanto exumação tectônica geram caminhos que podem produzir um período de resfriamento isobárico.

As condições de alta $\mathrm{T}$ e baixa $\mathrm{P}$ deduzidas para o metamorfismo $\mathrm{M}_{0}$ sugerem que a granulitização pré-Orogênese Brasiliana pode ter sido resultante da infiltração de $\mathrm{CO}_{2}$ proveniente de underplating magmático na base da crosta. A acreção magmática por underplating associada à geração de metamorfismo de alta $\mathrm{T}$ e baixa $\mathrm{P}$ na porção crustal sobreposta é frequentemente associada a um período de extensão crustal, durante o qual 
podem ter se desenvolvido bacias sedimentares. No segmento central da Faixa Ribeira existem registros de rifteamento no Meso-Proterozóico (1,8 a 1,0 Ga; Valeriano, 1985; Ribeiro et al, 1990; Ribeiro, 1992) quando da formação das bacias preenchidas pelos sedimentos dos Ciclos Deposicionais Tiradentes, Lenheiro, Carandaí e Andrelândia.

A Bacia Andrelândia, geograficamente mais próxima aos ortogranulitos do CJF, é a que apresenta os registros mais jovens. Ortoanfibolitos interpretados como diques intrusivos nas rochas do Ciclo Deposicional Andrelândia, forneceram idades $\mathrm{T}_{\mathrm{DM}}$ entre 1184 e $1053 \mathrm{Ma}$. Entretanto, dado que o metamorfismo granulítico do CJF ocorreu em 2,1 Ga. (Machado et al., 1996), a extensão a ele associada deve ser mais antiga e, portanto, desvinculada do desenvolvimento da Bacia Andrelândia. Por outro lado, é possível que esta idade de 2,1 Ga. represente a idade mínima de formação do protólito das rochas ortogranulíticas do CJF e, dessa forma, sua granulitização poderia ter ocorrido em um período pós-2,1Ga.

Esta hipótese da associação da granulitização do CJF a underplating magmático e processos extensionais, levando à abertura da Bacia Andrelândia já foi sugerido por Nogueira (comunicação verbal). Outra possibilidade é que este período extensional esteja associado à formação da "Bacia Paraíba do Sul", cuja idade é desconhecida.

Dados de campo sugerem que seus litotipos sejam pré-2,1Ga., uma vez que são vistos invadidos por rochas da Suite Quirino-Dorândia (Tupinambá, comunicação verbal) de idade 2,1 Ga. (Machado et al., 1996; Valladares, 1996). Esta suite de rochas graníticas e granodioríticas contem xenólitos de rochas calcissilicáticas, metapelitos, além de ortognaisses esverdeados a ortopiroxênio (Heilbron, 1993; Valladares, 1996).

Caminho IBC para o metamorfismo granulítico das rochas do CJF, aqui denominado

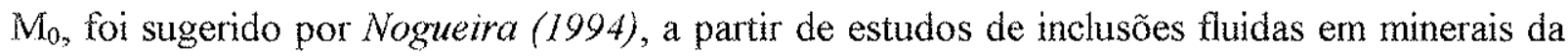
paragênese correspondente.

A granulitização associada a períodos extensionais e underplating apresenta-se como uma modelo bastante consistente com os dados de campo e petrográficos apresentados, uma vez que as evidências abaixo relacionadas sugerem que o processo metamórfico foi passivo. 
a) o arranjo da paragênese granulítica dos litotipos do CIF é granoblástico, sem evidências de recristalizą̧ão dinâmica;

b) todas as rochas do CJF, independente de composição ou estrutura, apresentam paragêneses com ortopiroxênio, o que sugere processo de desidratação associado à infiltração de um fluido rico em $\mathrm{CO}_{2}$ e expulsão ou diluição de $\mathrm{H}_{2} \mathrm{O}$ no sistema;

c) litotipos migmatíticos têm tanto leucossomas quanto paleossomas esverdeados, com ortopiroxênio, sugerindo que a migmatização, processo obviamente dinâmico, foi anterior à granulitização; e

d) os dados sugerem que a granulitização ocorreu em um período posterior à migmatização e anterior ao desenvolvimento da foliação principal gerada durante a Orogênese Brasiliana. 


\section{7) Geoquímica e Modelamento Petrogenético das Rochas dos Complexos Juiz de Fora e Mantiqueira}

\subsection{1) Condições Analíticas}

Trinta e sete amostras do Complexo Juiz de Fora foram selecionadas para as análises químicas. Grande parte das análises (29) foi realizada no Activation Laboratories Ltd (ACTLABS), Canadá, tendo sido analisados os elementos maiores e vários traços, incluindo as terras raras. As oito análises restantes foram realizadas no Laboratório de Geoquímica da Queen's University Belfast (Irlanda do Norte).

Trinta e uma amostras do Complexo Mantiqueira foram selecionadas para proceder à análise química. Todas as análises, para elementos maiores e traços, incluive terras raras, foram realizadas no ACTLABS.

Os resultados analíticos para ambas as unidades litológicas e um resumo das técnicas analíticas empregadas são apresentados no Apêndice 5.

O controle direto do processo analítico não era um objetivo da tese. Mesmo assim, amostras foram utilizadas como monitores toda a vez que um lote de amostras era enviado ao ACTLABS ou ao Laboratório da Queen's University. Os resultados analíticos obtidos para os monitores de diferentes lotes foram sempre semelhantes.

O exame preliminar dos resultados permitiu identificar eventuais irregularidades ou discrepâncias. Por exemplo, a soma dos óxidos de 15 amostras do CJF e 17 do CM é baixa (entre 96 e 99\% peso). No entanto, não foi possível identificar qualquer incoerência ou resultado sistemático que pudesse explicar os baixos valores do somatório dos óxidos. Sendo assim, optou-se por trabalhar estas amostras em base anídrica, distribuindo-se a diferença de maneira homogênea por todos os óxidos. Este procedimento não altera os resultados relativos e permite a análise qualitativa e quantitativa dos dados de modo satisfatório. 


\section{II.7.2 - Tratamento dado aos Resultados Analíticos}

Os dados químicos de rocha total podem ser tratados, quantitativa ou qualitativamente, com base em dois critérios distintos: critérios estatísticos e critérios petrogenéticos. Ambos os critérios foram utilizados sempre que adequado e possível, considerando-se o número e as características dos dados adquiridos.

Dada a complexidade tectono-estrutural da área alvo e, mais especificamente, das unidades litológicas em consideração (ortognaisses e metabasitos de alto grau metamórfico facies granulito para o CJF e anfibolito superior para o CM - e complexa evolução policíclica), como apresentado em capítulos anteriores, o procedimento utilizado partiu da premissa de que não existiam claras evidências da presença de agrupamentos distintos dentro destas unidades. Portanto, todas as amostras, do CJF de um lado e do CM de outro, foram inicialmente tratadas como se pertencentes a um único grupo.

\section{II.7.3) Estudo Geoquímico-Petrológico dos Litotipos do Complexo Juiz de Fora}

\section{a) Trabalhos Anteriores de Cunho Petrológico}

Oliveira $(1980,1982)$ foi pioneiro na abordagem geoquímica das rochas do Complexo Juiz de Fora, verificando que as rochas básicas apresentavam carater toleítico, enquanto que as intermediárias a ácidas eram calcioalcalinas, depletadas em elementos incompatíveis, o que levou o autor a concluir que estes granulitos são restitos de fusões crustais. Machado Filho et al. (1983) sugeriram que os granulitos toleiticos e calcioalcalinos do CIF representavam parte da base da crosta continental Arqueana ou da crosta basáltica. Barbosa \& Grossi Sad (1983) c) chegaram às mesmas conclusões ao estudarem as rochas granulíticas do Estado do Rio de Janeiro e leste do Estado de Minas Gerais. Pinto et al. (199l) sugeriram que os ortogranulitos (granulitos básicos e dioríticos) eram toleítos de baixo $\mathrm{K}$, provalvemente de arco de itha ou bacia de retro-arco, enquanto que os granulitos enderbíticos eram rochas calcioalcalinas. Heilbron (1993), para a região entre Barra do Piraí e Valença (RJ), propôs que o CJF era constituído de quatro séries magmáticas distintas: a) série toleítica de tendência alcalina (granulitos básicos); b) série toleítica (granulitos básicos); c) série calcioalcalina (granulitos 
intermediários a ácidos); e d) série calcioalcalina de alto $\mathrm{K}$ (granulitos intermediários a ácidos). Figueiredo \& Teixeira (1996), estudando uma área ao norte da cidade de Juiz de Fora, concluiram que os ortogranulitos do CJF constituiam duas séries magmáticas: a) série calcioalcalina de baixo $\mathrm{K}$; e b) série calcioalcalina de médio a alto $\mathrm{K}$.

\section{b) Investigação Geoquímico-Petrológica}

\section{b.1) Abordagem com base em Elementos Maiores}

Inicialmente, todas as amostras foram plotadas em diagrama $\mathrm{SiO}_{2} \times$ Álcalis (Fig. 72) e AFM (Fig. 73). Os gráficos apontam para a existência de dois grupos subalcalinos distintos: um grupo disposto ao longo de um trend toleítico; e outro, em um trend calcioalcalino. Estes grupos são separados por um gap que se estende de $50 \mathrm{a} \approx 55 \% \mathrm{SiO}_{2}$. Duas amostras $(17 \mathrm{~A}$ e 17B), cujos valores de $\mathrm{MgO}$ são os mais altos (8,85 e 8,93, respectivamente), têm um posicionamento no gráfico AFM que levanta dúvidas sobre suas relações parentais com os membros mais evoluidos dos dois trends. Assim, a partir desta primeira abordagem formulouse as seguintes hipóteses:

1) As amostras do CJF representam de fato dois conjuntos distintos? e

2) As rochas com mais alto $\mathrm{MgO}$ são parentais para algum daqueles dois possíveis grupos?

Partiu-se, então, para um tratamento estatístico dos dados obtidos para elementos maiores. As amostras foram plotadas em diagramas de Harker (Fig. 74) e os padrốes de distribuição foram analisados com base na construção de curvas de regressão e no cálculo dos respectivos coeficientes de correlação (r). Os valores de $\mathrm{r}$ indicam os níveis de significância da correlação testada para uma determinada população n. A abordagem estatística utilizada é apresentada no Apêndice 5 (Métodos de Regressão). Os resultados são apresentados na tabela 30. 


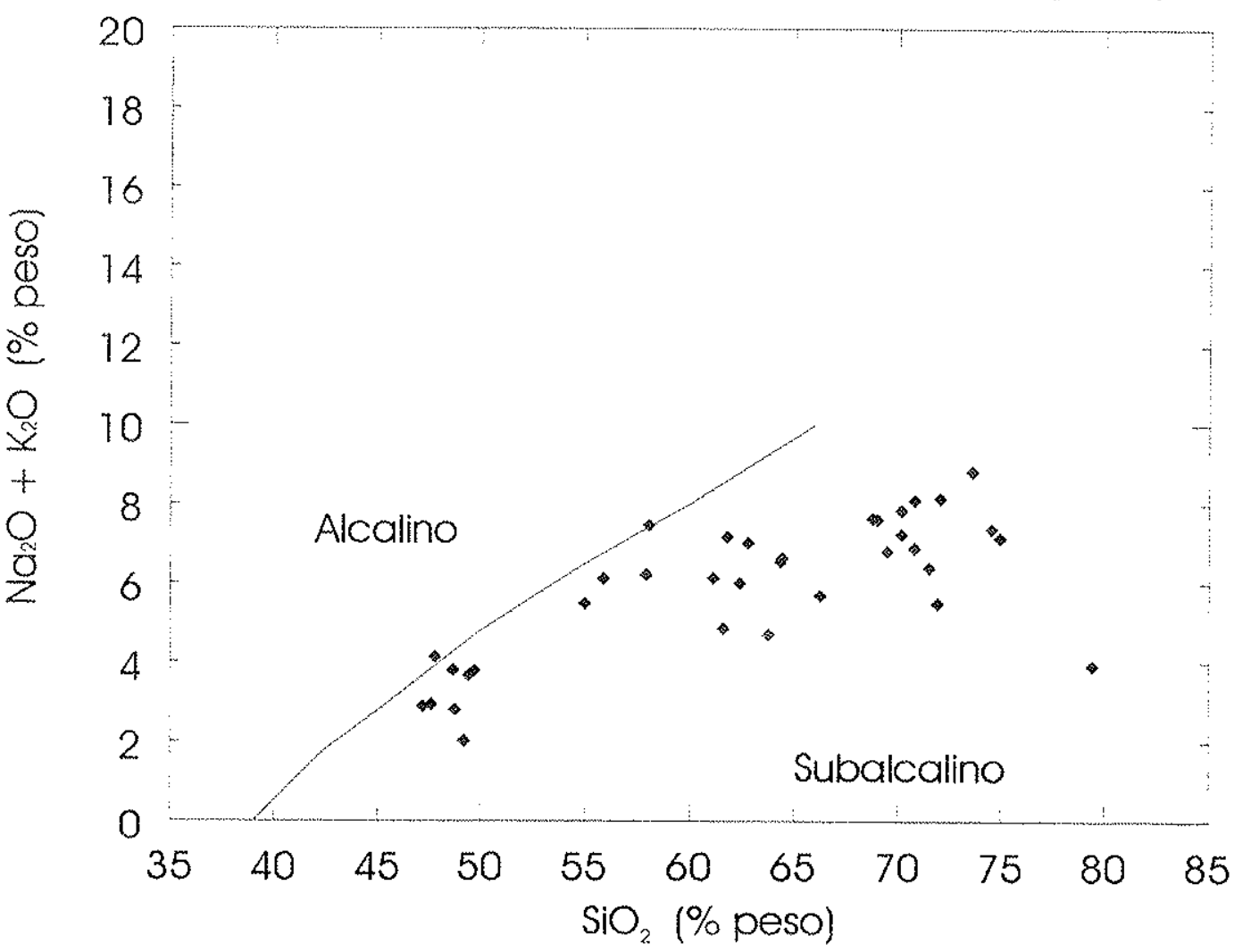

Figura 72 - Diagramas $\mathrm{SiO}_{2}$ x Álcalis para o cojunto das amostras do CJF. Limite dos campos alcalino e subalcalino, segundo Irvine \& Baragar (1971).

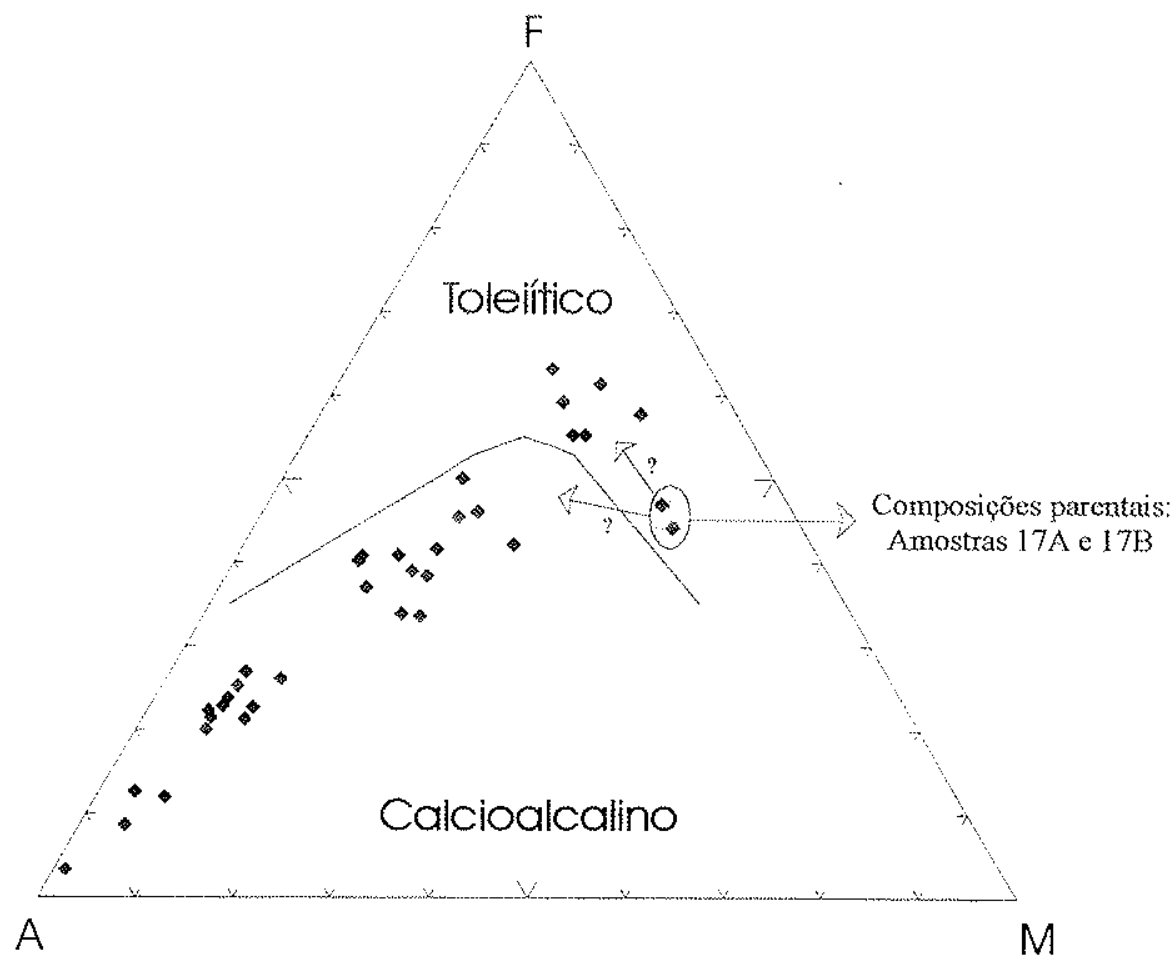

Figura 73 - Diagrama AFM para o conjunto das amostras do CJF. Limite dos campos tolético e calcioalcalino, segundo Irvine \& Baragar (1971).

$\mathrm{A}=\mathrm{K}_{2} \mathrm{O}+\mathrm{Na}_{2} \mathrm{O} ; \mathrm{F}=\mathrm{FeO}+0,8998 \mathrm{Fe}_{2} \mathrm{O}_{3} ;$ e $\mathrm{M}=\mathrm{MgO}$ 

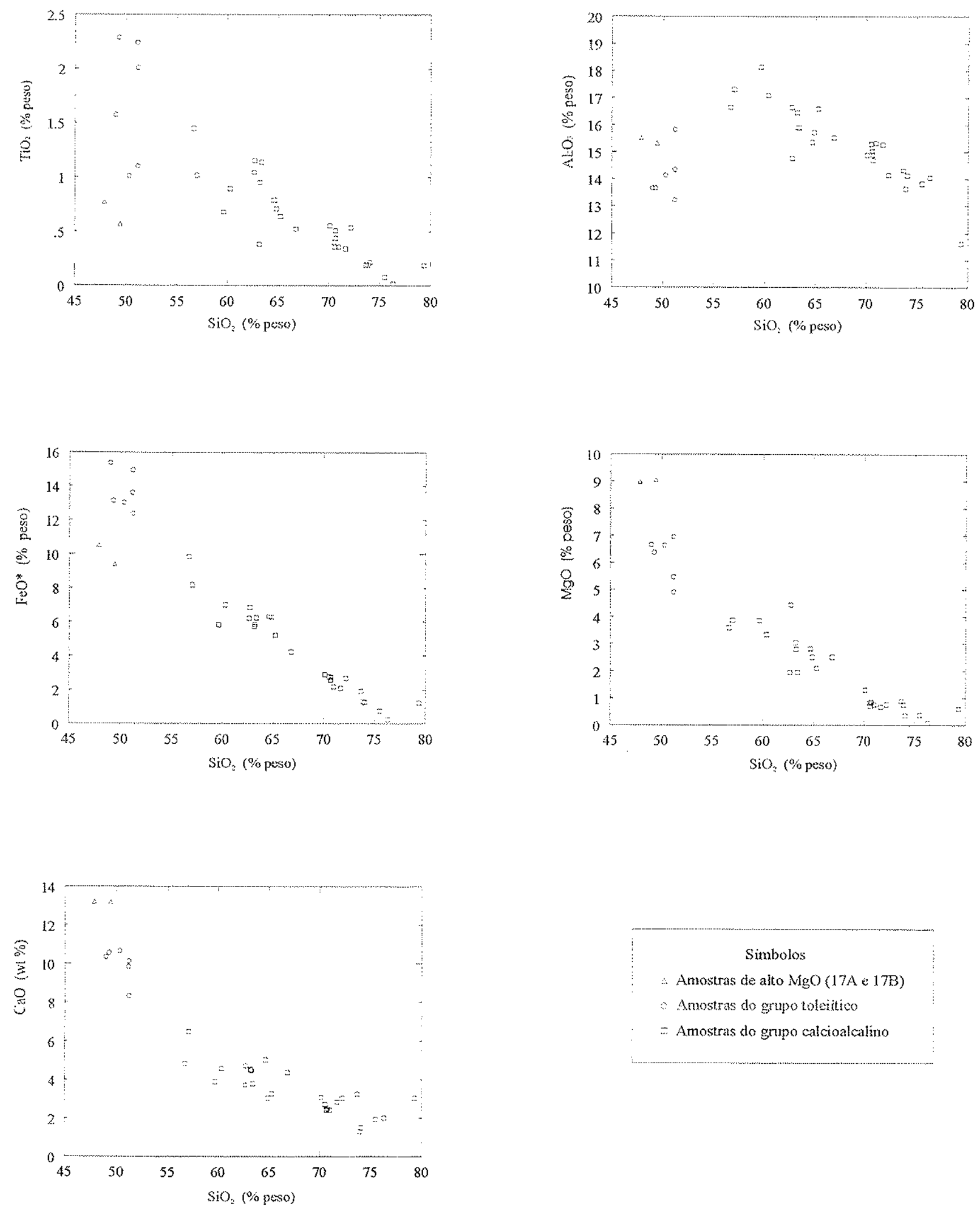

\section{Simbolos}

$\therefore$ Amostras de aito $\mathrm{MgO}(17 \mathrm{~A}$ e 17B)

a Amostras do grupo toleitico

- Amostras do grupo calcioalcalino

Figura 74 - Diagramas de Harker ( elementos maiores) para todo o conjunto das amostras do CJF. 
Tabela 30 - Valores do quadrado dos coeficientes de regressão linear (L) e polinominal (P) para as rochas do Complexo Juiz de Fora. As regressões foram feitas para sinco diferentes populaçôes de amostras.

\begin{tabular}{|l|c|c|c|c|c|c|c|c|c|c|}
\hline Óxido & $1 \mathrm{~L}$ & $1 \mathrm{P}$ & $2 \mathrm{~L}$ & $2 \mathrm{P}$ & $3 \mathrm{~L}$ & $3 \mathrm{P}$ & $4 \mathrm{~L}$ & $4 \mathrm{P}$ & $5 \mathrm{~L}$ & $5 \mathrm{P}$ \\
\hline $\mathrm{TiO} 2$ & 0,6196 & 0,6215 & 0,7266 & 0,7271 & 0,0062 & 0,1663 & 0,0012 & 0,5382 & 0,4965 & 0,6400 \\
\hline $\mathrm{Al} 2 \mathrm{O} 3$ & 0,0312 & 0,6522 & 0,7707 & 0,8096 & 0,0243 & 0,0340 & 0,0572 & 0,4237 & 0,4986 & 0,7908 \\
\hline $\mathrm{FeO}$ & 0,9184 & 0,9257 & 0,8931 & 0,8970 & 0,022 & 0,0439 & 0,0607 & 0,3642 & 0,9146 & 0,9163 \\
\hline & & & & & & & & & & \\
$\mathrm{MgO}$ & 0,8719 & 0,9032 & 0,8188 & 0,8291 & 0,2899 & 0,3091 & 0,3377 & 0,4915 & 0,8287 & 0,9239 \\
\hline $\mathrm{CaO}$ & 0,8134 & 0,9201 & 0,6607 & 0,6977 & 0,2994 & 0,3035 & 0,3601 & 0,3879 & 0,6884 & 0,8977 \\
\hline
\end{tabular}

1 - Toda a população de amostras analisadas $(n=36)$;

2 - Grupo calcioalcalino isolado $(n=28)$;

3 - Grupo toleítico isolado $(n=8)$;

4 - Grupo toleítico excluídas as amostras ricas em $\mathrm{MgO}(17 \mathrm{~A}$ e 17B) $(\mathrm{n}=6) ; \mathfrak{e}$

5 - Grupo calcioalcalino incluídas as amostras $17 \mathrm{~A}$ e $17 \mathrm{~B}(\mathrm{n}=30)$.

Para os diagramas de Harker da figura 74 foram construidas curvas de regressão para as seguintes populações: 1 - todas as amostras analisadas; 2 - o grupo calcioalcalino isoladamente; 3 - o grupo toleítico isoladamente (incluindo-se aqui as rochas com alto $\mathrm{MgO}$ ); 4 - o grupo toleítico, (subtraido das amostras com alto $\mathrm{MgO}$ ); e 5 -. o grupo calcioalcalino adicionado das amostras com alto $\mathrm{MgO}$. Curvas de regressão linear e polinomial e os respectivos quadrados dos coeficientes de correlação $\left(\mathrm{r}^{2}\right)$ foram obtidos para cada um dos cinco casos. A tabela 6 mostra os valores de $\mathrm{r}^{2}$ obtidos para alguns óxidos. É possível verificar que, para todos os casos, os valores de $\mathrm{r}^{2}$ são melhores para as regressões polinominais do que para as lineares. Isto elimina o processo de mistura magmática e suporta processos de cristalização fracionada na petrogênese das rochas do CJF. Considerando-se somente as regressões polinominais tem-se:

1) Valores de $\mathrm{r}^{2}$ para toda a população de amostras do CJF $(\mathrm{n}=36)$ são significantes acima de 99,9\% para todos os óxidos considerados;

2) $O$ isolamento das amostras do grupo calcioalcalino $(n=28)$ produz regressões com valores de $\mathrm{r}^{2}$ que são mais elevados do que aqueles em 1 somente para $\mathrm{TiO}_{2}$ e $\mathrm{Al}_{2} \mathrm{O}_{3}$. No entanto, mesmo os valores de $\mathrm{t}^{2}$ mais baixos do que aqueles em 1 são significantes acima de $99,9 \%$; e 
3) O isolamento das amostras do grupo toleiítico produz valores de $r^{2}$ menores do que aqueles vistos em 1 e significantes abaixo de $80 \%$ para $\mathrm{TiO}_{2}, \mathrm{Al}_{2} \mathrm{O}_{3}$ e $\mathrm{Fe}_{2} \mathrm{O}_{3}{ }^{\mathrm{t}}$ e entre $80 \%$ e $90 \%$ para $\mathrm{MgO}$ e $\mathrm{CaO}$.

Em conclusão, a análise estatística simples apresentada acima indica que é improvável que as rochas do grupo toleítico formem uma única suite. Além disso, esta análise é dúbia na discriminação de uma suite calcioalcalina isolada (como indicado pelo item 2 acima) e não responde conclusivamente à primeira hipótese formulada nesta seção.

A segunda hipótese levantada, i. e. se as amostras de alto $\mathrm{MgO}$ (17A e 17B) são parentais para algum dos dois grupos discriminados na figura 73, pode também ser testada pela análise da tabela 30. Assim, verifica-se que:

1) Os valores de $\mathrm{r}^{2}$ para o grupo toleiítico aumentam substancialmente quando as amostras de alto $\mathrm{MgO}$ não são incluídas na correlação. Excluídas as amostras de alto $\mathrm{MgO}$, os valores de $\mathrm{r}^{2}$ tornam-se significantes entre $90 \%$ e $95 \%$ para $\mathrm{TiO}_{2}$, entre $80 \%$ e $90 \%$ para $\mathrm{Al}_{2} \mathrm{O}_{3}$, embora mantenham valores semelhantes de significância para $\mathrm{FeO}^{*}, \mathrm{MgO}$ e $\mathrm{CaO}$; e

2) Os valores de $\mathrm{r}^{2}$ para o grupo calcioalcalino aumentam para $\mathrm{Al}_{2} \mathrm{O}_{3}, \mathrm{FeO}^{*}, \mathrm{MgO}$ e $\mathrm{CaO}$, incluidas as amostras de alto $\mathrm{MgO}$. Além disso, mesmo para $\mathrm{TiO}_{2}$, a correlação é significante acima de $99,9 \%$.

Em conclusão, muito embora as amostras de alto $\mathrm{MgO}$ plotem no campo toleítico (Fig. 73), a análise estatística dos dados indica que é mais provável que estas rochas representem magmas parentais para os termos mais evoluídos do trend calcioalcalino. Esta hipótese será testada no item seguinte.

\section{b.2) Abordagem com base em Elementos Traços}

Para dar prosseguimento ao teste da parentalidade das amostras de alto $\mathrm{MgO}$ para o grupo calcioalcalino, foram selecionados elementos traços com as seguintes características: 2 elementos compativeis ( $\mathrm{Ni}$ e $\mathrm{V}$ ); 2 elementos incompatíveis imóveis ( $\mathrm{Zr}$ e Y); e 2 elementos incompatíveis móveis ( $\mathrm{Ba}$ e $\mathrm{Sr}$ ). As amostras foram plotadas em diagramas de Harker para estes elementos como mostra a figura 75. Utilizando-se o mesmo método de regressão polinomial apresentado na seção anterior, foram obtidos valores de $r^{2}$ (Tab. 31). 
Amostras de alto $\mathrm{MgO}$ (17A e 178)

- Amostras do grupo toleítico

$?$ Amostras do grupo calcioalcalino
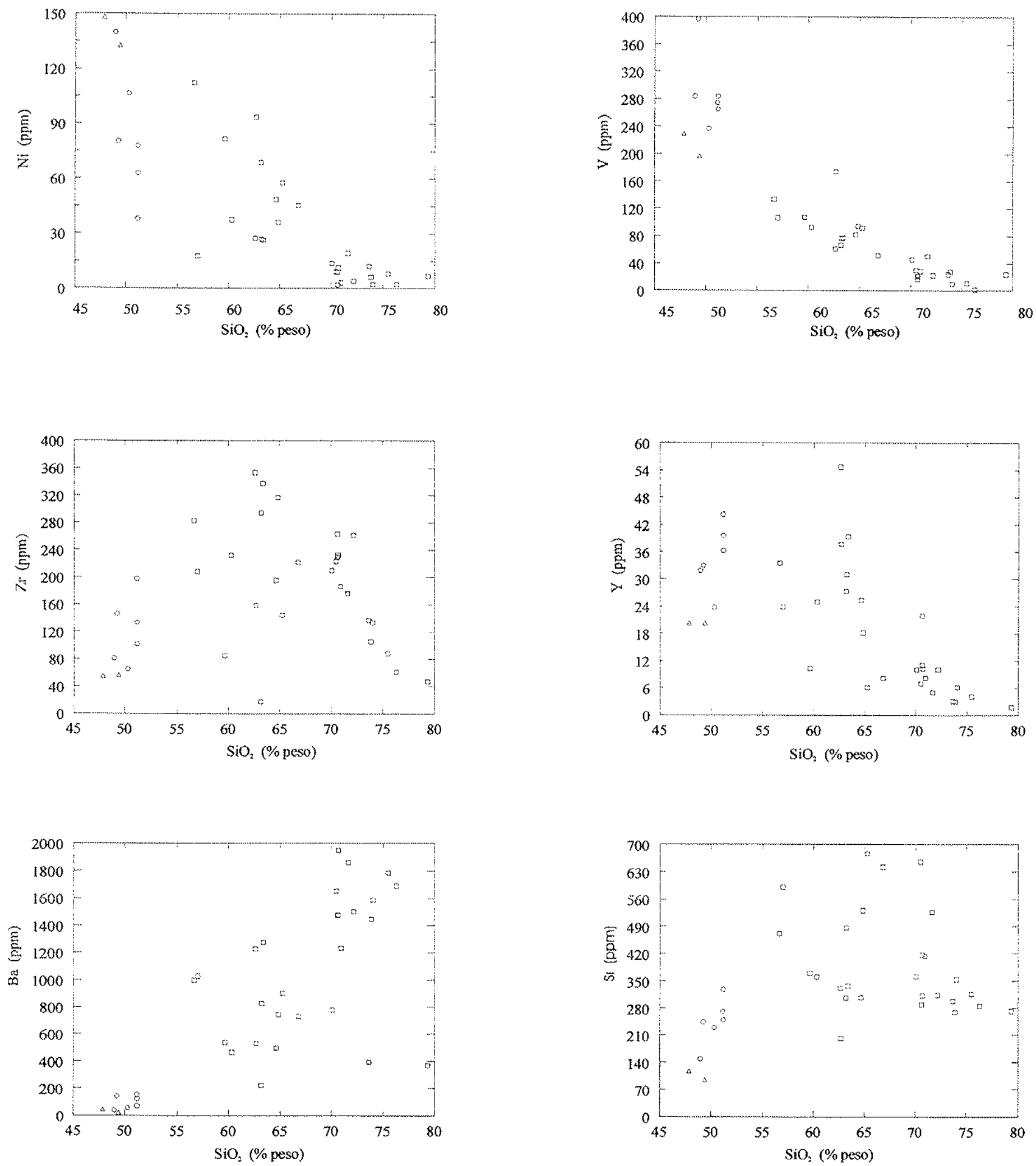

Figura 75 - Diagramas de Harker (elementos traços) para todo o conjunto das amostras do CJF. 
Tabela 31 . Coeficientes de regressão polinomial (P) para as rochas do Complexo Juiz de Fora.

\begin{tabular}{|c|c|c|}
\hline Elementos & $2 \mathrm{P}$ & $5 \mathrm{P}$ \\
\hline $\mathrm{Ni}$ & 0,4986 & 0,7351 \\
\hline $\mathrm{V}$ & 0,6947 & 0,8415 \\
\hline $\mathrm{Zr}$ & 0,2749 & 0,3759 \\
\hline $\mathrm{Y}$ & 0,4651 & 0,4502 \\
\hline $\mathrm{Ba}$ & 0,2106 & 0,3853 \\
\hline $\mathrm{Sr}$ & 0,0961 & 0,2851 \\
\hline
\end{tabular}

2- Grupo calcioalcalino isolado $(\mathrm{n}=28)$;

5 - Grupo calcioalcalino incluidas as amostras com alto $\mathrm{MgO}(17 \mathrm{~A}$ e $17 \mathrm{~B})(\mathrm{n}=30)$.

A partir deste tratamento estatístico, verifica-se que os valores de $r^{2}$ são melhores quando considera-se as amostras de alto $\mathrm{MgO}$ como parte do grupo das calcioalcalinas, sendo todos significantes até ou acima de 99,9\%. Note-se a melhora substancial do nível de significância mesmo para os elementos incompatíveis móveis (Ba e Sr). Disto conclui-se que as amostras de alto $\mathrm{MgO}$ podem, de fato, ser parentais para o grupo calcioalcalino, conforme sugerido pela análise dos elementos maiores. Em outras palavras, as rochas calcioalcalinas mais evoluídas $\left(\mathrm{SiO}_{2}>54 \%\right.$ peso) do CJF podem ter sido geradas pela cristalização fracionada de magmas parentais representados pelas composições ticas em MgO (17A e 17B) encontradas na área.

Para garantir a imparcialidade no procedimento adotado, optou-se por dar prosseguimento ao teste desta hipótese, agora com base em critérios petrogenéticos. Vários autores consideram que as razões entre elementos incompativeis não variam substancialmente em processos de cristalização fracionada (p. ex., Cox et al., 1979). Variações nas razões de elementos incompatíveis em cerca de 1,5 vezes não esperadas dentre rochas cogenéticas. Com base nisto, foram então selecionadas duas destas razões: $\mathrm{Zr} / \mathrm{Hf}$ e $\mathrm{Zr} / \mathrm{Nd}$. Os resultados expostos na tabela 32 permitem verificar que somente $20 \%$ ( 3 ou 4 amostras) das amostras do grupo calcioalcalino apresentam razões similares àquelas das rochas com alto $\mathrm{MgO}$. 
Tabela 32 - Valores das razões Zr/Hf e Zr/Nd para as rochas do Complexo Juiz de Fora.

\begin{tabular}{|l|c|c|}
\hline Amostra & $\mathrm{Zr} / \mathrm{Nd}$ & $\mathrm{Zr} / \mathrm{Hf}$ \\
\hline$M B-17 A$ & 10,8 & 67,5 \\
\hline$M B-42$ & 8,8 & 39,5 \\
\hline$M B-514 C$ & 7,7 & 36,4 \\
\hline$M B-46 \mathrm{P}$ & 7,0 & 35,0 \\
\hline$M B-17 B$ & 11,2 & 70,0 \\
\hline$M B-15 C$ & 9,8 & 61,2 \\
\hline$M B-183 A$ & 6,5 & 39,1 \\
\hline$M B-514 B$ & 6,8 & 37,7 \\
\hline$M B-99 D$ & 6,1 & 29,1 \\
\hline$M B-43 C$ & & \\
\hline$M B-15 B$ & 4,6 & 49,6 \\
\hline$M B-46 C$ & & \\
\hline$M B-19$ & 5,6 & 38,5 \\
\hline$M B-46 A$ & & \\
\hline$M B-32 A$ & 7,9 & 42,0 \\
\hline$M B-46 T$ & 0,6 & 24,3 \\
\hline$M B-32 D$ & 5,0 & 36,7 \\
\hline$M B-145 B$ & 8,4 & 38,6 \\
\hline$M B-297 D$ & 11,8 & 32,1 \\
\hline$M B-297 B$ & 6,0 & 37,5 \\
\hline$M B-115 B$ & 6,7 & 45,8 \\
\hline$M B-32 C$ & 18,8 & 43,5 \\
\hline$M B-241 A$ & 4,4 & 27,0 \\
\hline$M B-48 A$ & & \\
\hline$M B-514 E$ & 4,4 & 40,4 \\
\hline$M B-151 B$ & 10,5 & 55,7 \\
\hline$M B-514 A$ & 16,1 & 39,5 \\
\hline$M B-32 B$ & 7,7 & 39,7 \\
\hline$M B-37(1)$ & 16,2 & 41,8 \\
\hline$M B-46 R$ & 13,4 & 39,4 \\
\hline$M B-151 A$ & 6,5 & 35,1 \\
\hline$M B-43 B$ & & \\
\hline$M B-46 B$ & & \\
\hline$M B-46 U$ & 7,5 & 30,0 \\
\hline$M B-43 A$ & & \\
\hline$M B-17 H$ & 48,6 & 39,8 \\
\hline
\end{tabular}


Conclui-se, então, que, muito embora o critério estatístico tenha apontado para uma cogeneticidade entre as rochas do grupo calcioalcalino e aquelas com alto MgO, o critério petrogenético descarta a hipótese destes dois conjuntos serem correlacionados por processos de cristalização fracionada.

Como pode ser verificado a partir da tabela 32, o critério petrogenético adotado também descarta a hipótese das amostras de alto $\mathrm{MgO}$ serem parentais para o grupo toleítico, conforme já discutido em itens anteriores. Concluindo, é improvável que as rochas ricas em $\mathrm{MgO}$ encontradas na área sejam parentais para os termos mais evoluídos tanto do trend toleítico quanto do trend calcioalcalino do CJF.

\section{b.3) Abordagem com base nos Elementos Terras Raras}

Os diagramas das figuras 76,77 e 78 mostram padrões de distribuição de elementos terras raras (ETR) para alguns grupos de rochas do CJF, normalizados pelo condrito de Boynton (1984). Os seguintes grupos são representados: grupo toleiítico (incluindo as amostras com alto $\mathrm{MgO}$ ); e dois conjuntos de rochas de composição intermediária do grupo calcioalcalino, cujos padrões de ETR são distintos. O diagrama para as rochas do grupo toleiítico (Fig. 76) mostra padrões muito variados. Isto corrobora a ausência de cogeneticidade entre todas as rochas do grupo. Esta conclusão está de acordo com os resultados obtidos anteriormente, tanto a partir de critérios estatísticos para elementos maiores e menores, quanto a partir do critério petrogenético adotado para elementos traços.

Para testar a hipótese das amostras de alto $\mathrm{MgO}$ poderem ser parentais para um dos dois grupos, foram construídos os diagramas das figuras 77 e 78 . Neles foram plotadas, para cada padrão de ETR identificado, as amostras menos evoluídas, acrescidas daquele da amostra 17A, com alto $\mathrm{MgO}$. A partir do exame destas figuras e dos valores de $(\mathrm{La} / \mathrm{Yb})_{\mathrm{N}}$ também apresentados, conclui-se que:

1) É improvável que os padrões de ETR das amostras $99 \mathrm{D}$ e $15 \mathrm{~B}$ sejam produzidos pela cristalização fracionada de qualquer assembléia ( $\mathrm{Hbl} \pm \mathrm{Grt} \pm \mathrm{Cpx} \pm \mathrm{Plg}$ ), a qualquer $\mathrm{P}$ ou $P_{\mathrm{F} z \mathrm{O}}$, a partir do líquido representado pela amostra 17A;

2) As amostras $99 \mathrm{D}$ e $15 \mathrm{~B}$ têm razões $(\mathrm{La} / \mathrm{Yb})_{\mathrm{N}}$ muito distintas e, portanto, é extremamente improvável que sejam cogenéticas. 


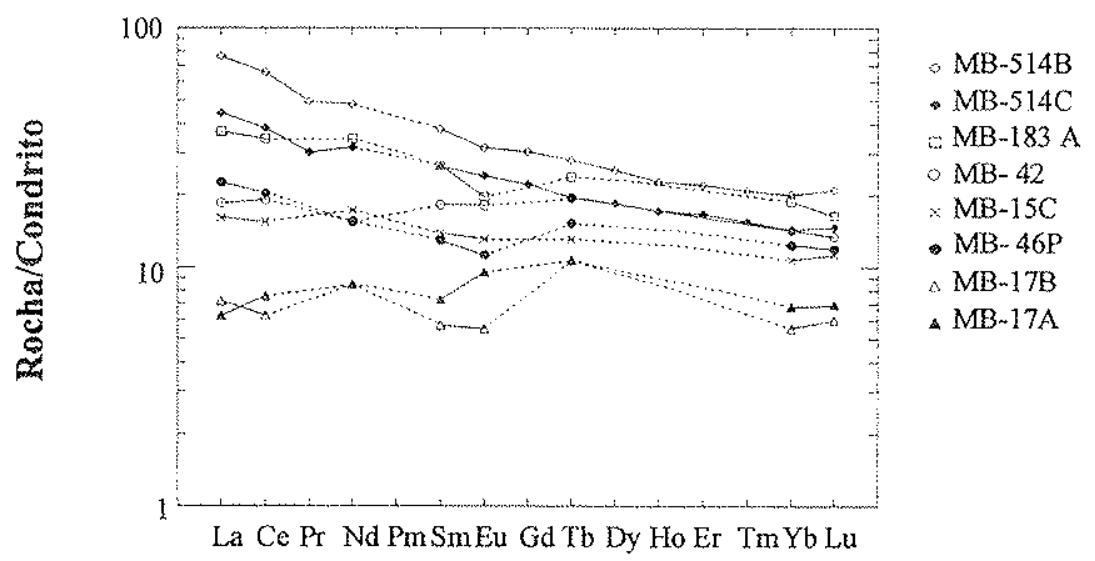

Figura 76a - Diagrama de ETR normalizados pelo condrito de Boynton (1984). Estão plotadas as amostras com alto $\mathrm{MgO}(17 \mathrm{~A}$ e 17B) e as do grupo toleíitico.

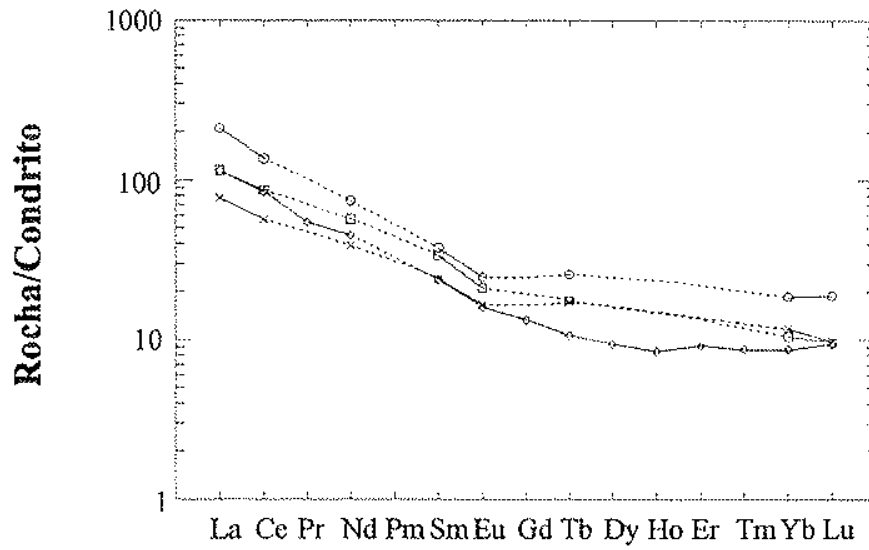

- MB- 32A

- MB- 99D

$\times \mathrm{MB}-145 \mathrm{~B}$

MB- 297D

Figura 76b - Diagrama de ETR normalizados pelo condrito de Boynton (1984). Estão plotadas as amostras menos fracionadas de composição intermediária do grupo calcioalcalino.

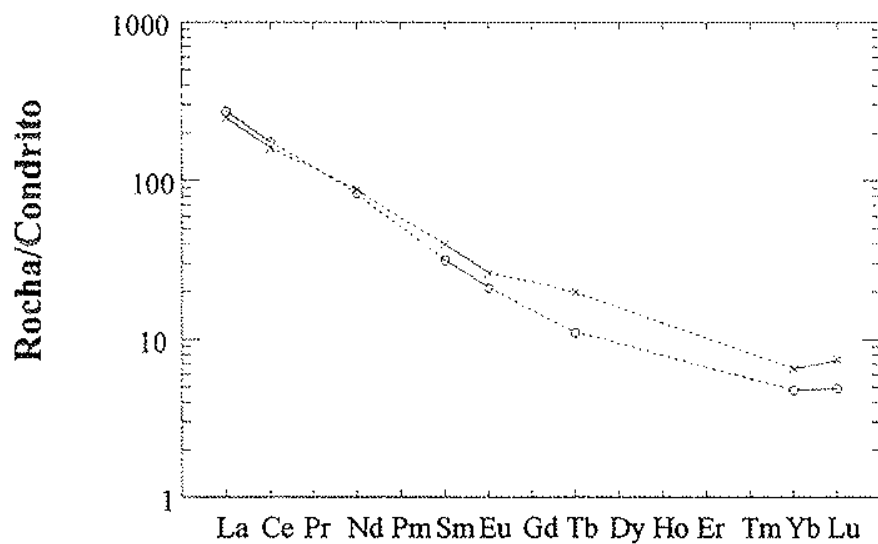

MB $15 B$

* MB-19

Figura 76c - Diagrama de ETR normalizados pelo condrito de Boynton (1984).

Estão plotadas as amostras mais fracionadas de composição intermediária do grupo calcioalcalino. 


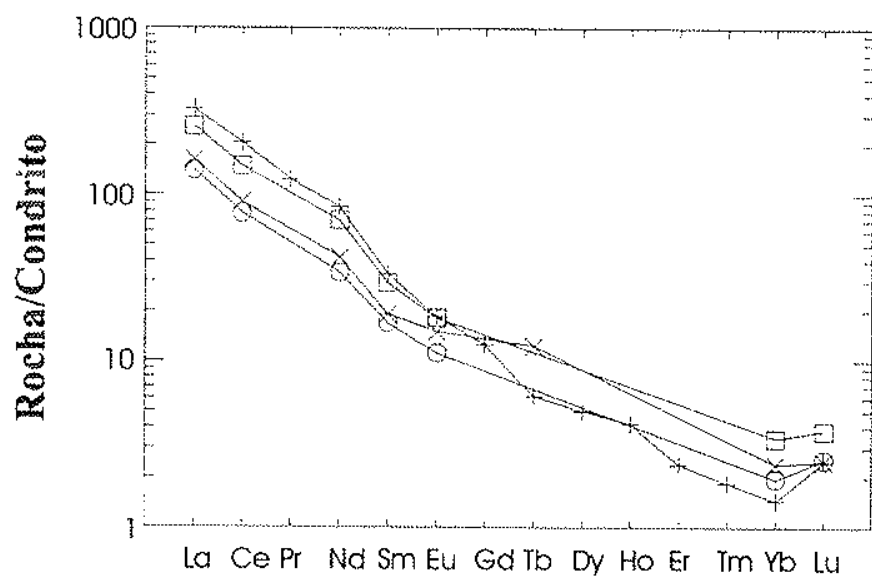

oxdem crescente de [laMb]N

MB - $151 B$

$M B-15\} A$

$\mathrm{MB}-241 \mathrm{~A}$

MB - 514E

Figura 76d - Diagrama de ETR normalizados pelo condrito de Boynton (1984). Estão plotadas as amostras mais fracionadas de composição ácida do grupo calcioalcalino.

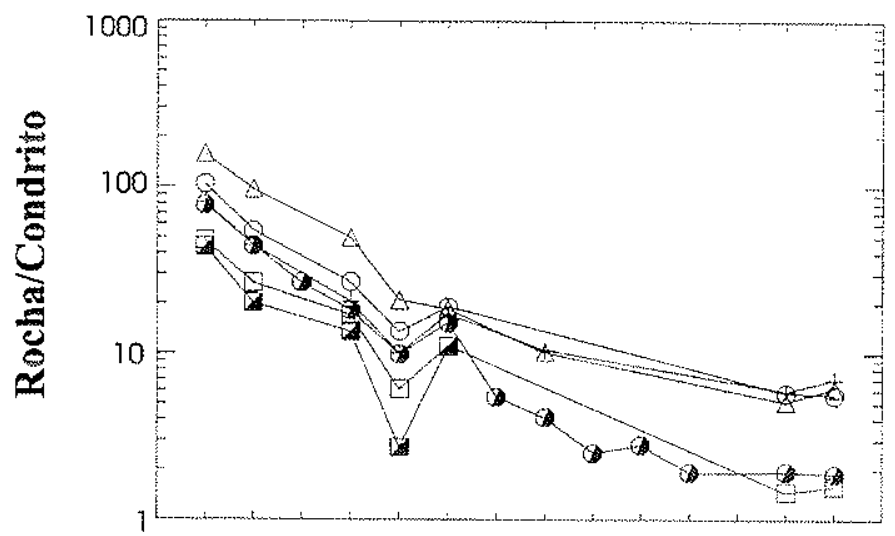

Orclem crescente de [laMb]N

$\mathrm{MB}-32 \mathrm{C}$

$\mathrm{MB}-37(1)$

$\mathrm{MB}-328$

- $M B-514 A$

c $M B-46 R$

$\Rightarrow \mathrm{MB}-46 \mathrm{U}$

La Ce Pr Nd Sm Eu Gdib Dy Ho Er Tm Vo Lu

Figura 76e - Diagrama de ETR normalizados pelo condrito de Boynton (1984). Estão plotadas as amostras menos fracionadas de composição ácida do grupo calcioalcalino.

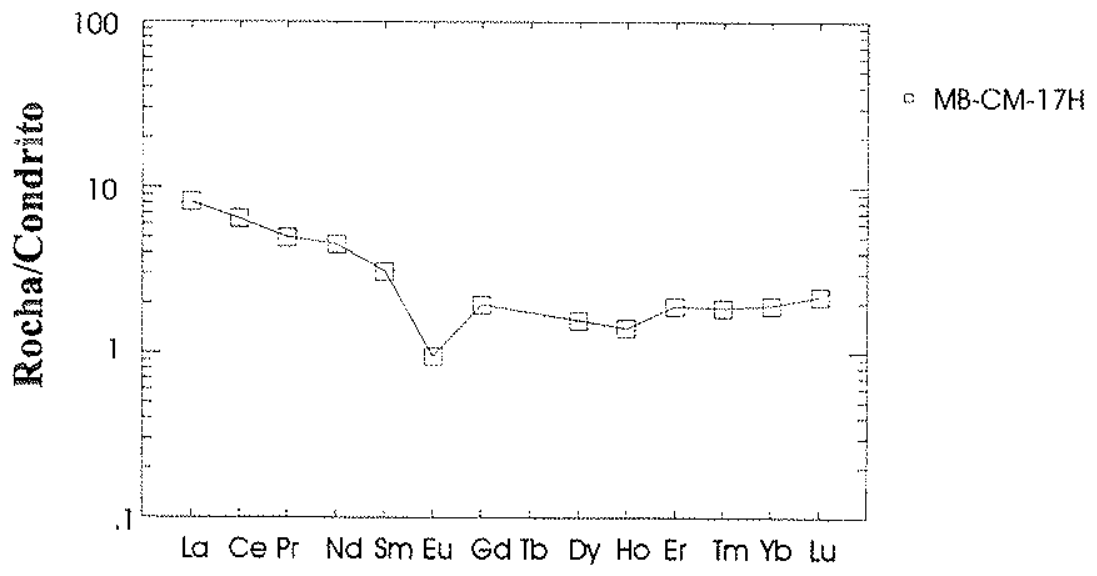

Figura 76f - Diagrama de ETR normalizados pelo condrito de Boynton (1984). Está plotada a amostra $17 \mathrm{H}$ de composição ácida do grupo calcioalcalino. 


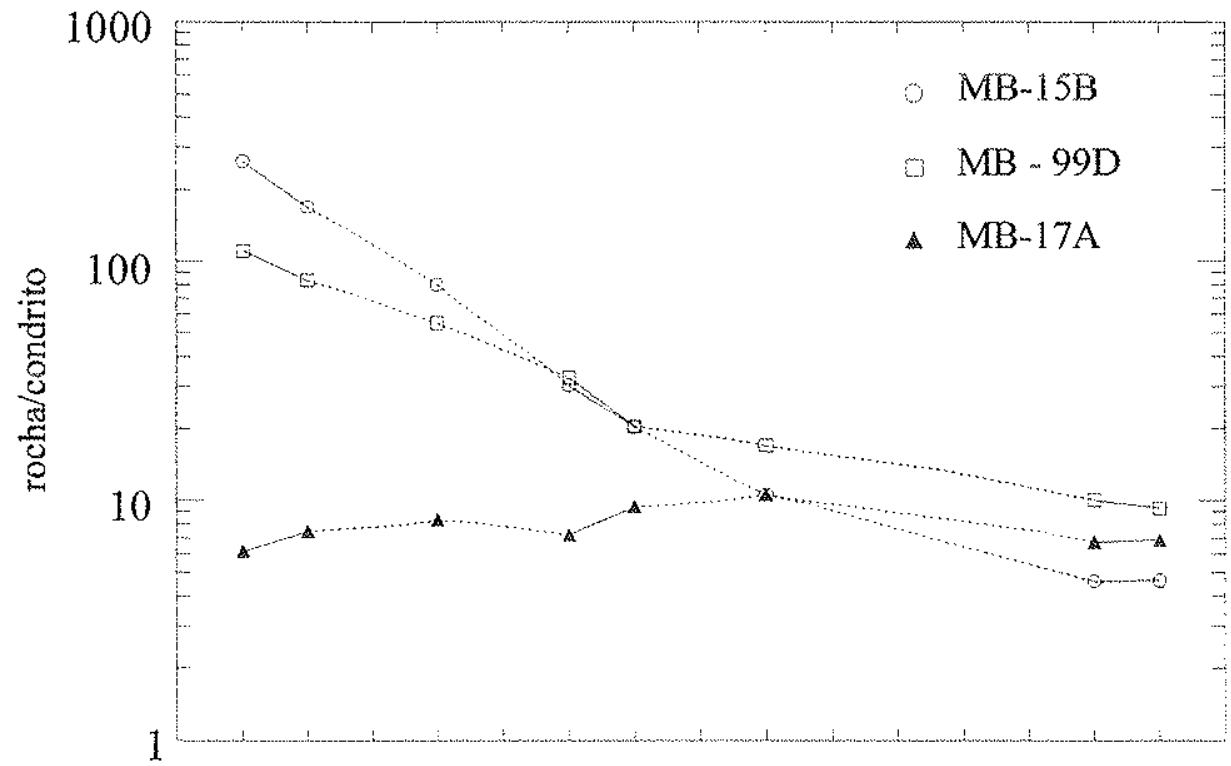

\begin{tabular}{|lcc|}
\hline Amostra & $\left(\mathrm{La} / \mathrm{Xb}_{1}\right.$ & $\% \mathrm{MgO}$ \\
$15 \mathrm{~B}$ & 57,24 & 3,22 \\
$99 \mathrm{D}$ & 11,01 & 3,74 \\
$17 \mathrm{~A}$ & 0,91 & 8,85 \\
N-morb & 0,82 & \\
E-morb & 2,66 & \\
OrB & 17,13 & \\
\hline
\end{tabular}

La Ce Pr Nd PmSmEu Gd Tb Dy Ho Er Tm Yb Lu

Figura 77 - Diagrama de ETR normalizados pelo condrito de Boynton (1984). Comparação entre o padrão da amostra parental (17A) e aqueles das amostras menos evoluídas do grupo calcioalcalino (99D e 15B). São apresentados também os valores de $(\mathrm{La} / \mathrm{Yb})_{\mathrm{N}}$ e de $\% \mathrm{MgO}$ para estas amostras. Os valores $\left(\mathrm{La} / \mathrm{Yb}\right.$ ) ${ }_{\mathrm{N}}$, de N-MORB, E-MORB e OIB (Sun \& McDonough,1991) são apresentados para comparação.

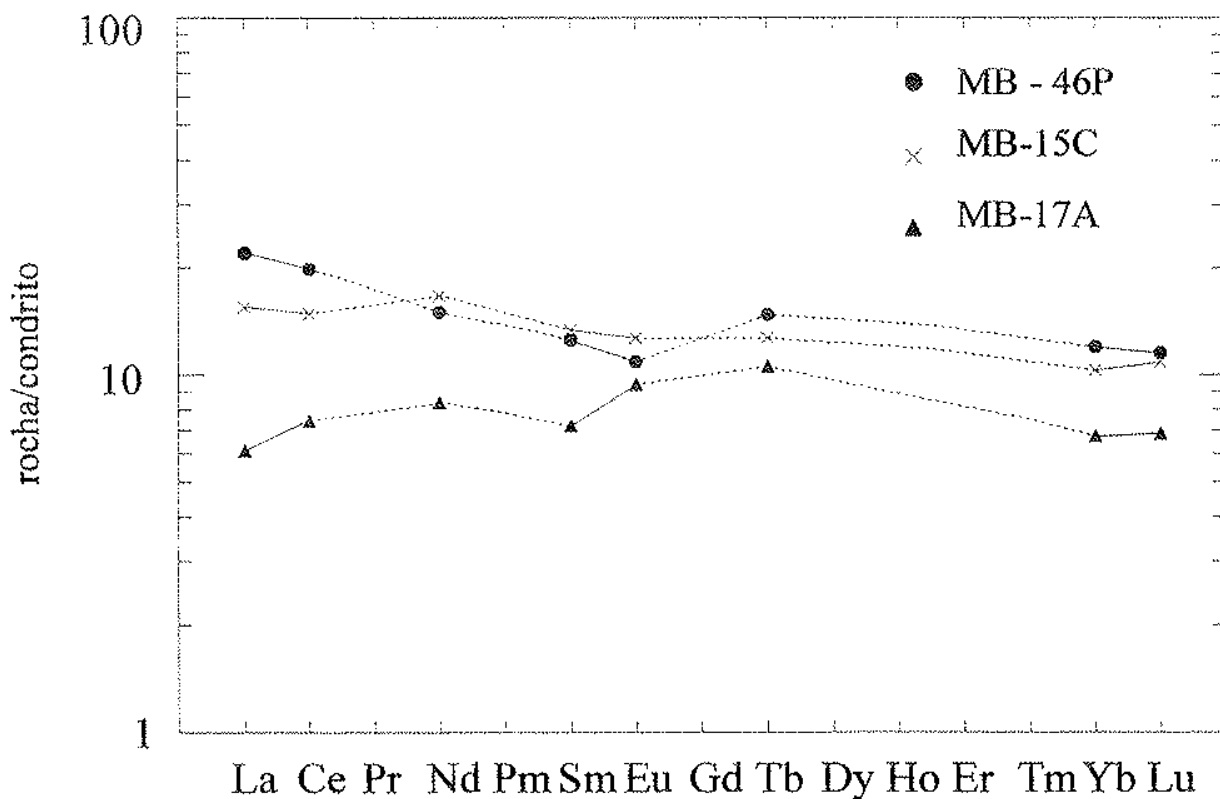

\begin{tabular}{|lcc|}
\hline Amostra & $(\mathrm{La} / \mathrm{Yb})$ & $\% \mathrm{MgO}$ \\
$46 \mathrm{P}$ & 1,83 & 6,43 \\
$15 \mathrm{C}$ & 1,51 & 6,68 \\
$\mathrm{I7A}$ & 0,91 & 8,85 \\
N-morb & 0,82 & \\
E-morb & 2,66 & \\
OHB & 17,13 & \\
\hline
\end{tabular}

Figura 78 - Diagrama de ETR com padrões de distribuição normalizados pelo condrito de Boynton (1984). Comparação entre o padrão da amostra parental (17A) e aqueles das amostras menos evoluídas do grupo toleítico (15C e 46P). São apresentados também os valores de $(\mathrm{La} / \mathrm{Yb})_{\mathrm{N}}$ e de $\% \mathrm{MgO}$ para estas amostras. Os valores de $(\mathrm{La} / \mathrm{Yb})_{\mathrm{N}}$ de N-MORB, E-MORB e OIB (Sun \& Mc Donough, 1991) são apresentados para comparação. 
3) A fonte mantélica para a amostra 17A é do tipo N-MORB; e

4) As amostras $15 \mathrm{C}$ e $46 \mathrm{P}$ são provavelmente cogenéticas e sua fonte é do tipo E-MORB.

Portanto, a amostra de alto $\mathrm{MgO}, 17 \mathrm{~A}$, não é parental para nenhum dos dois grupos, toleiítico ou calcioalcalino. As rochas toleiíticas menos evoluídas parecem estar relacionadas a fontes distintas (N-MORB e E-MORB). É possivel que haja mais que um suite calcioalcalina no CJF.

\section{b.4) Conclusões Gerais}

O CJF engloba rochas toleiticas e calcioalcalinas. No entanto, deve haver mais do que uma suite dentro destas duas séries de rochas no CJF. Qualquer que seja o número de suites, o processo petrogenético mais provável para a evolução magmática das rochas do CJF é o de cristalização fracionada. Dentre as amostras máficas, existem duas (17A e 17B) que são parentais em potencial (i.e., têm alto $\mathrm{MgO}$ ). Entretanto, dados de elementos maiores e traços (incluindo ETR) indicam que estas rochas não podem ser parentais para possiveis suites em ambas as séries identificadas no CJF. Além disso, as rochas toleiiticas devem estar relacionadas a diferentes fontes mantélicas. A amostra $17 \mathrm{~A}$ parece relacionada a uma fonte mantélica do tipo N-MORB $\left([\mathrm{La} / \mathrm{Yb}]_{\mathrm{N}}=0,91\right)$. A amostra $17 \mathrm{~B}$ tem valor $[\mathrm{La} / \mathrm{Yb}]_{\mathrm{N}}$ igual a 1,3 e deve, portanto, estar relacionada a uma fonte do tipo E.MORB.

\section{c) Estudo das Rochas do Grupo Calcioalcalino}

Nos itens precedentes, a análise quantitativa e qualitativa para elementos maiores e traços (excluindo-se os ETR) mostrou que é possível que as rochas do grupo calcioalcalino constituam uma única suite, cuja evolução se deu através de processo de cristalização fracionada. Entretanto, a análise, ainda superficial, para ETR revelou padrões muito distintos, sugerindo a existência de amostras não cogenéticas no grupo. Este item tem como objetivo avaliar qualitativamente, com base em critérios petrogenéticos mais sensiveis, as relações de cogeneticidade existentes e identificar possiveis suites. Os primeiros critérios a serem utilizados são os padrões de distribuição dos ETR, com base nas razões $[\mathrm{La} / \mathrm{Yb}]_{\mathrm{N}}$. 


\section{c.1) Abordagem com base em ETR}

Como procedimento inicial, foram selecionadas as amostras menos evoluídas do grupo calcioalcalino (99D e 15B) por representarem magmas parentais potenciais. A figura 79 mostra que ambas as amostras plotam no campo dos quartzo monzodioritos e que seus teores em sílica diferem de somente $\approx 2 \%$. Outro dado complementar é a diferença de apenas $0,5 \%$ no teor de $\mathrm{MgO}$ das duas amostras (Apêndice 5). Por outro lado, os valores das razões [La/Yb]N são muito distintos, da ordem de 11 para a amostra 99D e de 57 para a 15B (Figs. 80 e 82). É improvável que qualquer processo de diferenciação magmática possa ser responsável por tão ampla variação no fracionamente de ETR sem uma variação também significante em $\mathrm{SiO}_{2}$ e $\mathrm{MgO}$. Com base nestes dados, ambas as amostras foram mantidas como magmas parentais potenciais e procedeu-se à identificação, dentre as demais amostras do grupo calcioalcalino, de padrões de ETR semelhantes a uma ou a outra para a identificação de possíveis suites. Foi então possível identificar outras amostras com valores $[\mathrm{La} / \mathrm{Yb}]_{\mathrm{N}}$ semelhantes àqueles das amostras 99D e 15B (Figs. 80 e 82). As amostras que não se encaixaram, a princípio, em nenhum dos dois grupos, têm valores $[\mathrm{La} / \mathrm{Yb}]_{\mathrm{N}}$ entre 30 e 40 e, portanto, foram agrupadas em um único conjunto (Fig. 81). Esta análise possibilitou a identificação de três diferentes ordens de valores $[\mathrm{La} / \mathrm{Yb}]_{\mathrm{N}}$ e o agrupamento das amostras em subgrupos 1,2 e 3 (Figs. 80, 81 e 82), cujas características encontram-se expostas a seguir:

1) O subgrupo 1 tem os padrões ETR mais fracionados, com $[\mathrm{La} / \mathrm{Yb}]_{\mathrm{N}}$ variando em torno de uma média de 65,04 $\pm 6,61$. Anomalias de Eu são, em geral, ausentes e, quando presentes, são ora positivas ora negativas.

2) O subgrupo 2 apresenta fracionamento moderado, com média para as razões $[\mathrm{La} / \mathrm{Yb}]_{\mathrm{N}}$ de $35,39 \pm 3,92$. Anomalias de Eu são levemente negativas ou marcadamente positivas nos temos mais ácidos.

3) O subgrupo 3 mostra os padrões de ETR menos fracionados, estando a média da razão $[\mathrm{La} / \mathrm{Yb}]_{N}$ em $13,08 \pm 2,39$, com anomalias de Eu variando de negativas nos termos menos ácidos a positivas nos mais ácidos.

De uma maneira geral, para todos os três agrupamentos, oas abundâncias de ETR diminuem com o aumento no teor de $\mathrm{SiO}_{2}$. Entretanto, uma análise mais detalhada mostra que dentro do subgrupo 3 (Fig. 82) não existe uma correlação evolutiva simples entre os teores de 


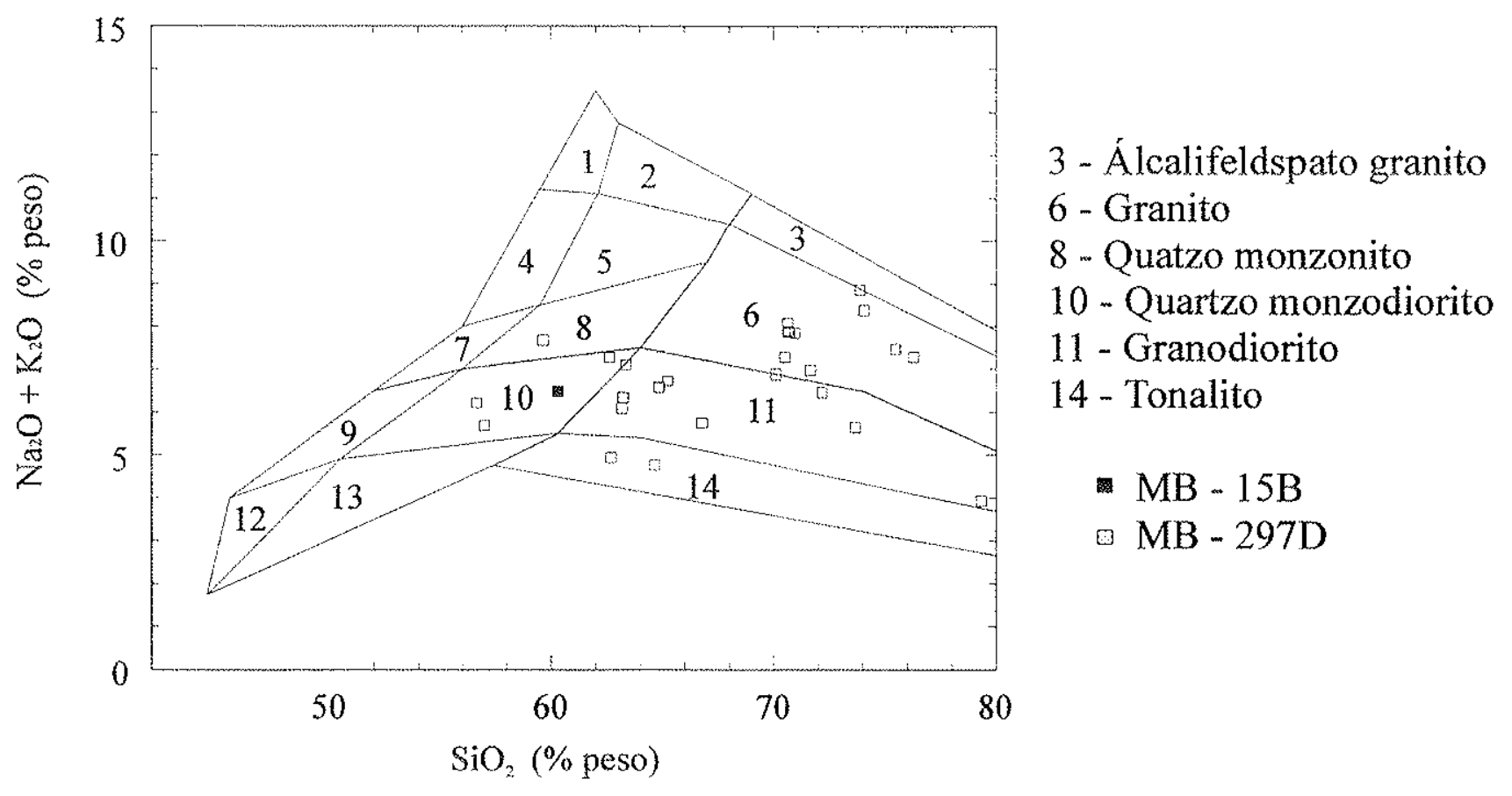

Figura 79 - Diagrama classificatório (Middlemost, 1985) para as rochas calcioalcalinas do Complexo Juiz de Fora. 


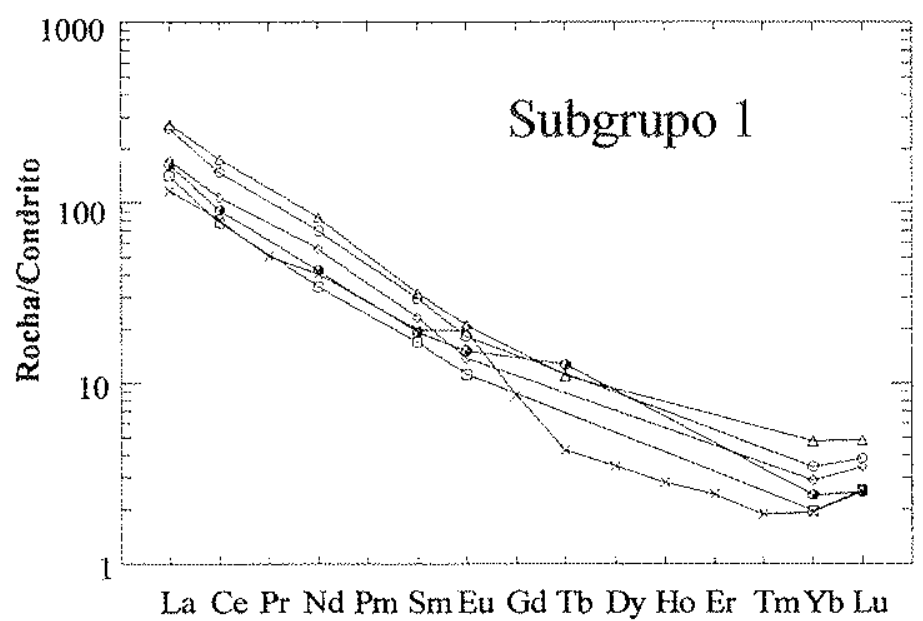

\begin{tabular}{|llccc}
\hline & Amostra & {$\left[\mathrm{La} / \mathrm{Yb}_{\mathrm{N}}\right.$} & $\mathrm{SiO}_{2}$ & $\mathrm{MgO}$ \\
$\Delta$ & $\mathrm{JF}-15 \mathrm{BB}$ & 57,24 & 57,95 & 3,22 \\
$\times$ & $\mathrm{MB}-297 \mathrm{~B}$ & 60,17 & 64,44 & 2,09 \\
$\mathrm{MB}-115 \mathrm{~B}$ & 59,22 & 66,24 & 2,50 \\
$\mathrm{MB}-241 \mathrm{~A}$ & 75,03 & 69,00 & 0,75 \\
$\mathrm{MB}-151 \mathrm{~B}$ & 67,29 & 70,18 & 0,84 \\
$\mathrm{MB}-151 \mathrm{~A}$ & 71,30 & 72,05 & 0,35 \\
\hline
\end{tabular}

Figura 80 - Diagrama de ETR das amostras do subgrupo 1, com padrões normalizados pelo condrito de Boynton (1984)

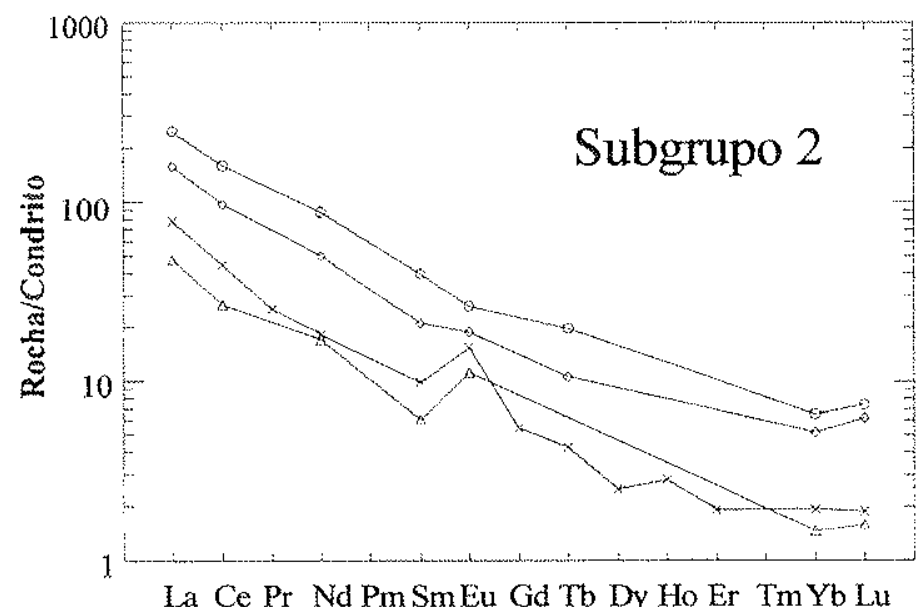

\begin{tabular}{|c|c|c|c|c|}
\hline & Amostra & {$[\mathrm{L} a / Y b]_{N}$} & $\mathrm{SiO}_{2}$ & $\mathrm{MgO}$ \\
\hline o & MB-19 & 38,05 & 61,12 & 2,71 \\
\hline$x$ & $\mathrm{MB}-514 \mathrm{~A}$ & 40,28 & 70,79 & 0,67 \\
\hline 0 & $M B-32 B$ & 30,65 & 70,82 & 0,71 \\
\hline$\Delta$ & $M B-46 R$ & 32,59 & 71,92 & 0,88 \\
\hline
\end{tabular}

Figura 81 - Diagrama de ETR das amostras do subgrupo 2, com padrões normalizados pelo condrito de Boynton (1984). 


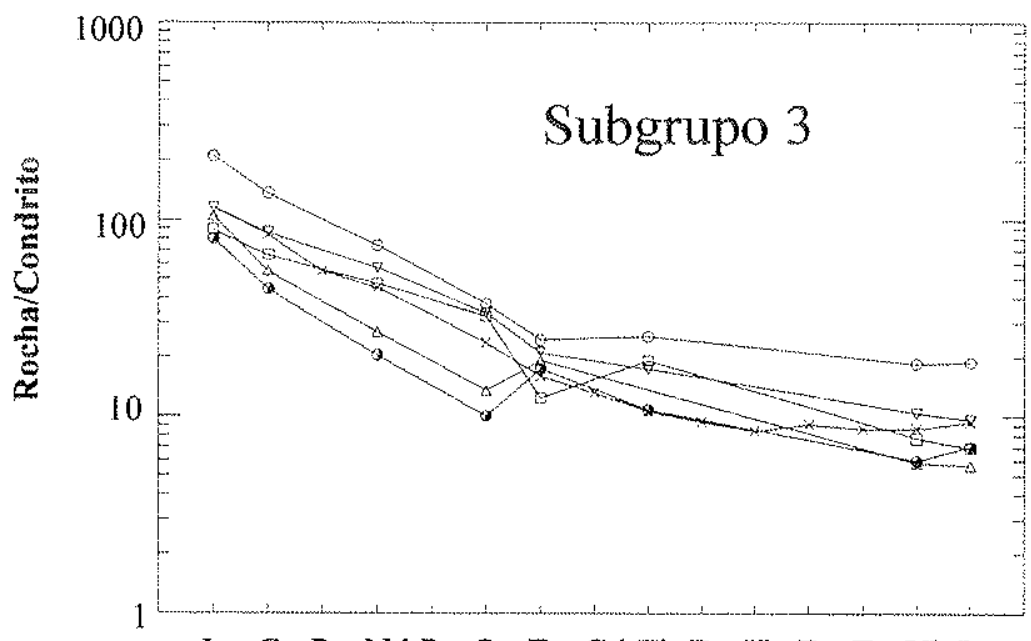

\begin{tabular}{|lllll} 
& Amostra & {$[\mathrm{La} / \mathrm{Yb}]_{\mathrm{N}}$} & $\mathrm{SiO}_{2}$ & $\mathrm{MgO}$ \\
& $\mathrm{MB}-99 \mathrm{D}$ & 11,01 & 54,99 & 3,74 \\
$\mathrm{MB}-32 \mathrm{~A}$ & 11,32 & 61,80 & 1,94 \\
$\mathrm{M}$ & $\mathrm{MB}-46 \mathrm{~T}$ & 11,46 & 62,40 & 3,01 \\
$\times$ & $\mathrm{MB}-297 \mathrm{D}$ & 13,22 & 64,35 & 2,50 \\
$\mathrm{MB}-32 \mathrm{C}$ & 13,48 & 68,77 & 0,84 \\
$\mathrm{MB}-31(1)$ & 17,98 & 71,50 & 0,77
\end{tabular}

La Ce Pr Nd Pm SmEu Gd Tb Dy Ho Er Tm Yb Lu

Figura 82 - Diagrama de ETR das amostras do subgrupo 3, com padrões normalizados pelo condrito de Boynton (1984).

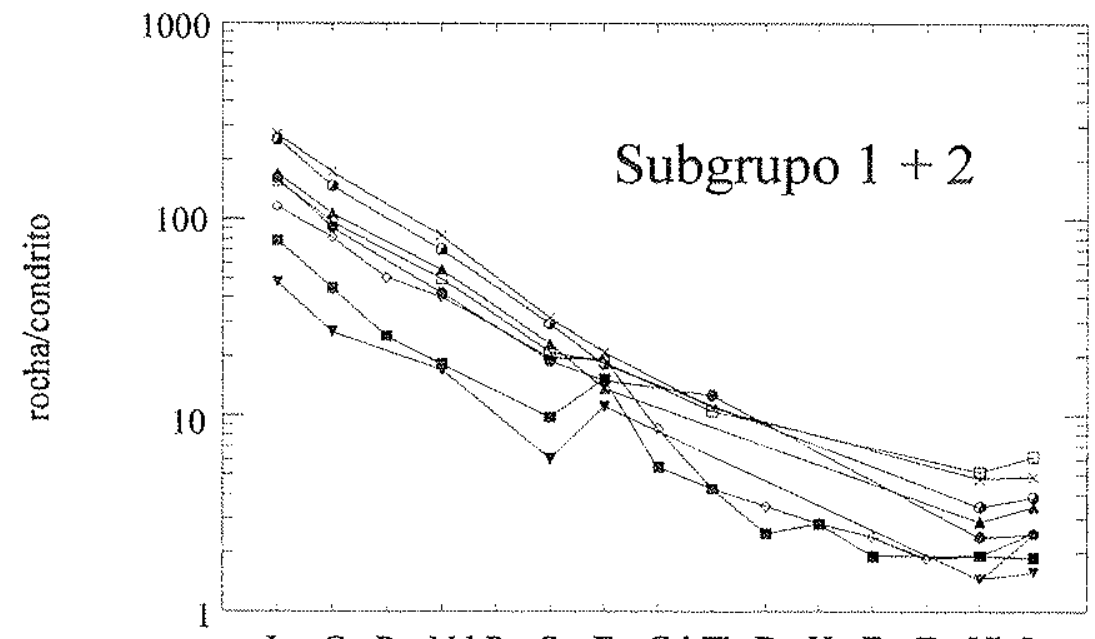

$\begin{array}{|lllll|}\text { Amostra } & {[\mathrm{La} / \mathrm{Yb}] ;} & \mathrm{SiO}, & \mathrm{MgO} \\ \times & \mathrm{MB}-15 \mathrm{~B} & 57,24 & 57,95 & 3,22 \\ \mathrm{MB}-297 \mathrm{~B} & 60,17 & 64,44 & 2,09 \\ \mathrm{MB}-115 \mathrm{~B} & 59,22 & 66,24 & 2,50 \\ \mathrm{MB}-241 \mathrm{~A} & 75,03 & 69,00 & 0,75 \\ \mathrm{MB}-151 \mathrm{~B} & 67,29 & 70,18 & 0,84 \\ \mathrm{MB}-514 \mathrm{~A} & 40,28 & 70,79 & 0,67 \\ \mathrm{MB}-32 \mathrm{~B} & 30,65 & 70,82 & 0,71 \\ \mathrm{MB}-46 \mathrm{R} & 32,59 & 71,92 & 0,88 \\ \end{array}$

Figura 83 - Diagrama de ETR das amostras dos subgrupos 1e 2, com padrões normalizados pelo condrito de Boynton (1984). 
$\mathrm{SiO}_{2}$ e os valores de $[\mathrm{La} / \mathrm{Yb}]_{\mathrm{N}}$. Isto mostra a impossibilidade das amostras deste subgrupo serem relacionadas por processos de cristalização fracionada.

Outro problema que advem nova subdivisão é a inexistência de candidatos a magmas parentais no subgrupo 2 , já que a amioreia das amostras é relativamente evoluída, com $\mathrm{SiO}_{2}>$ 70\% (Fig. 81). Plotando-se os padrões de ETR das amostras do subgrupo 2 em conjunto com aqueles das amostras do subgrupo 1, verifica-se que é possível que ambos os subgrupos formem uma única suite relacionada por processos de cristalização fracionada, desde que haja uma mudança na assembléia fracionante em um intervalo de $\approx 67-70 \% \mathrm{SiO}_{2}$ (Fig. 83). É interessante notar que esta mudança nos valores de $[\mathrm{La} / \mathrm{Yb}]_{\mathrm{N}}$ coincide com inflexões nos diagramas de Harker a $\mathrm{SiO}_{2} \approx 70 \%$ peso (Figs. 74 e 75), suportando a hipótese de mudanças na assembléia fracionante.

Evidências de campo mostram que algumas das amostras do subgrupo 3 (32A e 46T) são rochas encaixantes para rochas mais ácidas dos subgrupos 2 e 3 . Isto abre a possibilidade das amostras do subgrupo 2 representarem magmas contaminados. Como as amostras deste subgrupo têm valores de $[\mathrm{La} / \mathrm{Yb}]_{\mathrm{N}}$ intermediários entre aqueles dos demais subgrupos, seria possível que as mesmas fossem resultantes da contaminação de magmas representados no subgrupo 1 por rochas encaixantes representadas no subgrupo 3.

Com base no exposto, foram formuladas as seguintes hipóteses:

1) Haveria, no subgrupo 3 , representantes potenciais para materiais contaminantes e magmas contaminados?

2) Seriam as amostras do subgrupo 2 magmas do subgrupo 1 contaminados por rochas do subgrupo 3 ?

Para tentar responder estas questões passou-se ao modelamento quantitativo apresentado no item seguinte. 


\section{d) Modelamento Quantitativo do Processo Petrogenético de Assimilação Simples (Bulk Contamination)}

\section{d.1) Principios Básicos, Procedimentos e Resultados}

O processo de assimilação simples resulta da mistura de materiais (magma e rocha) com diferentes composições químicas. A mistura resultante tem composição química que pode ser traduzida por meio de modelos simples de mistura binária. Por exemplo, a mistura entre dois componentes $\mathrm{A}$ e $\mathrm{B}$ em proporções distintas pode ser especificada por um parâmetro $f$ definido por:

$$
f=A / A+B
$$

onde $\mathrm{A}$ e $\mathrm{B}$ são os membros finais na mistura considerada. A concentração de qualquer elemento na mistura é:

$$
X_{M}=X_{A}+X_{B}(l-f)
$$

onde $X_{A}$ e $X_{B}$ são as concentrações do elemento $X$ nos componentes $A$ e $B$, respectivamente, expresso em unidades de peso. Como $X_{A}$ e $X_{B}$ são constantes para qualquer conjunto de amostras formadas pela mistura de $\mathrm{A}$ e $\mathrm{B}$ em diferentes proporções, $X_{M}$ é uma função linear de $f$ :

$$
X_{M}=f\left(X_{A}-X_{B}\right)+X_{B}
$$

Desta forma, o valor do parâmetro $f$ pode ser calculado a partir da concentração de qualquer elemento $X$ em uma mistura de dois componentes, desde que as concentrações de $X$ nos membros extremos $\left(X_{A}\right.$ e $\left.X_{B}\right)$ sejam conhecidas.

Considerando-se a concentração de dois elementos $\mathrm{X}$ e $\mathrm{Y}$ na mistura $\left(\mathrm{X}_{\mathrm{M}}\right.$ e $\left.\mathrm{Y}_{\mathrm{M}}\right)$ entre $A$ e $B$, cujas concentrações podem ser expressas por $X_{A}, Y_{A}$ e $X_{B}, Y_{B}$, respectivamente, tem-se a seguinte equação pela eliminação do parâmetro $f$ :

$$
Y_{M}=X_{M_{A}\left(Y_{A}-Y_{B}\right)}+\frac{\left(Y_{B} X_{A}-Y_{A} X_{B}\right)}{\left(X_{A}-X_{B}\right)}
$$


Esta é a equação de uma reta de coordenadas $\mathrm{X}_{\mathrm{M}}$ e $\mathrm{Y}_{\mathrm{M}}$, na qual ocorrem todos os pontos que representam misturas entre $A$ e $B$ em diferentes proporções, incluindo os componentes puros.

O processo de assimilação simples pode ocorrer nas paredes de uma câmara magmática, quando a temperatura do solidus das rochas encaixantes é excedida; ou quando blocos de rochas encaixantes são arrancados e englobados pelo magma durante sua ascensão. Em ambos os casos, o magma deve ter energia termal suficiente para levar à fusão parcial ou completa das rochas encaixantes. A cessão do calor leva ao resfriamento do magma que, então, pode começar a cristalizar. Como raramente os magmas são superaquecidos, é improvável que este processo seja extensivo. As quantidades máximas irão raramente exceder 10 - 20\% (Wilson, 1989, Cap. 4, pg 91). Segundo De Paolo (1981), o processo de assimilação em câmaras magmáticas está comumente associado à cristalização fracionada simultânea. A quantidade de assimilação vai depender da energia termal do magma. No entanto, outros fatores como fluxo turbulento e/ou volume de magma podem promover uma interação magma/rocha encaixante mais extensiva. Um bom exemplo do processo de assimilação modelado com base em elementos traços incompatíveis (incluindo ETR) é apresentado em Wilson (1989; Cap. 4, pg. 94-95).

O modelamento quantitativo com base em ETR foi utilizado a seguir para testar as hipóteses levantadas na seção 7.1 .

Em uma primeira abordagem, a hipótese 1 da seção anterior foi testada. Verificou-se, por exemplo, se as amostras do subgrupo $3 \mathrm{com}[\mathrm{L} / \mathrm{Yb}]_{\mathrm{N}} \mathrm{de} \approx 13$ poderiam ser resultantes do processo de assimilação simples de materiais com $[\mathrm{La} / \mathrm{Yb}]_{\mathrm{N}}$ de $\approx 11$ (também do subgrupo 3) por magmas do subgrupo 1 , com $[\mathrm{La} / \mathrm{Yb}]_{\mathrm{N}}$ entre 57 e 67 . Com base nos dados de campo, a amostra $32 \mathrm{~A}$ foi escolhida como provável material contaminante, enquanto que a amostra $32 \mathrm{C}$, intrusiva na $32 \mathrm{~A}$, foi selecionada como material contaminado. Em função de suas características parentais potenciais, a amostra $15 \mathrm{~B}$ foi selecionada como magma não contaminado. $\mathrm{O}$ modelamento então realizado $(15 \mathrm{~B}+32 \mathrm{~A}=32 \mathrm{C})$ forneceu quantidades elevadas de assimilação ( $>80 \%$ de assimilação) por respresentar uma quantidade excessiva de assimilação, como discutido anteriormente. É interessante notar que a substituição do magma 
não contaminado, então de composição intermediária, por outro de composição mais ácida $(151 \mathrm{~B}+32 \mathrm{~A}=32 \mathrm{C})$. forneceu resultados semelhantes $(>80 \%)$.

Os modelos de assimilação foram concebidos, em geral, para magmas quentes, basálticos (p. ex.: Huppert \& Sparks 1985; Campbell 1985). Com relação a magmas intermediários e ácidos, existem muito menos informações. É possível que o papel dos fluidos, no caso dos magmas intermediários e ácidos, seja tão importante quanto o da temperatura nos magmas básicos. No entanto, é dificil avaliar a influência relativados vários parâmetros envolvidos no processo de assimilação. Em geral, consegue-se apenas eleger magmas não contaminados e, principalmente, rochas contaminantes potenciais como foi feito nesta seção. De qualquer modo, mesmo na incerteza de como todos estes parâmetros se integram, os valores de assimilação indicados pelo modelamento quantitativo $>80 \%$ ) são muito altos para serem considerados prováveis.

Para testar a hipótese 2, i. e.; se as amostras do subgrupo 2 podem ser magmas do subgrupo 1 contaminados por materiais do subgrupo 3 , foram selecionadas as seguintes amostras: 15B (subgrupo 1), magma parental potencial não contaminado; 32A (subgrupo 3), material encaixante contaminante; e 19, amostra menos evoluída do subgrupo 2, como possível magma contaminado. O modelatnento forneceu valores de assimilação bastante inferiores (14 $16 \%$ ) àqueles obtidos anteriormente $(>80 \%)$. Em bases termais, valores de aproximadamente $15 \%$ de assimilação são considerados bastante razoáveis em processos de assimilação simpoes (p. ex.: Wilson, 1993). No entanto, o modelo de assimilação simples é incapaz de gerar as anomalias positivas de Eu que caracterizam as outras amostras do subgrupo 2, mantendo-se os mestnos membros finais (i.e., $15 \mathrm{~B}$ e $32 \mathrm{~A}$ ).

Para testar a possibilidade das amostras do subgrupo 2 com anomalia positiva de Eu representarem magmas contaminados envolvendo outros membros finais, elegeu-se as seguintes amostras: $151 \mathrm{~B}$ como magma não contaminado (por ser a amostra mais evoluída do subgrupo 1); 37(1) como material contaminante (por apresntar anomalia positiva de Eu); e 514A, como magma contaminado, por apresentar teor em sílica intermediário entre aqueles dois magmas finais. Os resultados deste modelamento $(151 \mathrm{~B}+37(1)=514 \mathrm{~A})$ mostram que para se chegar à razão $[\mathrm{La} / \mathrm{Yb}]_{\mathrm{N}}$ da amostra $514 \mathrm{~A}$ seriam necessários $34 \%$ de assimilação. No entanto, as abundâncias de ETR são mais elevadas que aquelas da amostra 514A (Fig. 84). Isto 
era esperado já que a amostra 514A tem $\Sigma E T R$ mais baixo do que os membros finais potenciais (151B e 37(1)). Estes dados indicam que é improvável que as amostras com anomalia positiva de Eu do subgrupo 2 sejam resultado de processos de assimilação simples.

Ainda como uma forma de avaliar o processo petrogenético das amostras evoluidas com anomalia positiva de Eu, foi considerada a contaminação simples entre dois membros finais (magmas e contaminantes) também com esta anomalia. O resultado obtido pode ser visualizado na figura 85. A abundância de ETR, especialmente os pesados, dos possíveis candidatos a materiais contaminantes $\left(32 \mathrm{C}\right.$ e $\left.37(1)-[\mathrm{La} / \mathrm{Yb}]_{\mathrm{N}} \approx 13\right)$, é demasiadamente elevada para suportar o processo de assimilação simples, considerados os magmas iniciais e finais.

No subgrupo $2\left([\mathrm{La} / \mathrm{Yb}]_{\mathrm{N}} \approx 30-40\right)$, a amostra de rocha evoluida com menor anomalia positiva de Eu é a MB - 32B. A possibilidade desta amostra representar um produto de processo de assimilação simples foi testada $(151 \mathrm{~B}+32 \mathrm{~A}=32 \mathrm{~B})$. A amostra $151 \mathrm{~B}$ foi eleita como magma não contaminado, enquanto que a $32 \mathrm{~A}$ foi selecionada para representar o material contaminante. Os resultados deste modelamento são apresentados na figura 86 , onde verifica-se uma boa concordância entre o padrão ETR do modelo e aquele esperado (i.e., o da amostra $32 \mathrm{~B}$ ) para $15 \%$ de assimilação. Embora o modelamento indique um teor de sílica $2 \%$ menor do que aquele da amostra 32B, o procedimento adotado foi capaz de explicar uma variação de mais de 2 vezes no teor de ETR a partir de uma quantidade razoável $(15 \%)$ de assimilação. Além disso, cabe ressaltar que os dados de campo suportam esta hipótese, já que a rocha representada pela amostra $32 \mathrm{~B}$ é intrusiva naquela representada pela amostra $32 \mathrm{~A}$.

\section{d.2) Conclusões}

A partir do modelamento realizado, conclui-se que:

1) O subgrupo 3 não encerra ambos os materiais contaminantes e contaminados. As amostras do subgrupo 3 (com $[\mathrm{La} / \mathrm{Yb}]_{\mathrm{N}}$ entre 11 e 13) devem, outrossim, constituir um conjunto encaixante para as demais rochas calcioalcalinas do $\mathrm{CJF}$. As razões $[\mathrm{La} / \mathrm{Yb}]_{\mathrm{N}}$ semelhantes dentro do subgrupo 3 (entre 11 e 13) e a diferença com os restantes torna esta hipótese viável; 


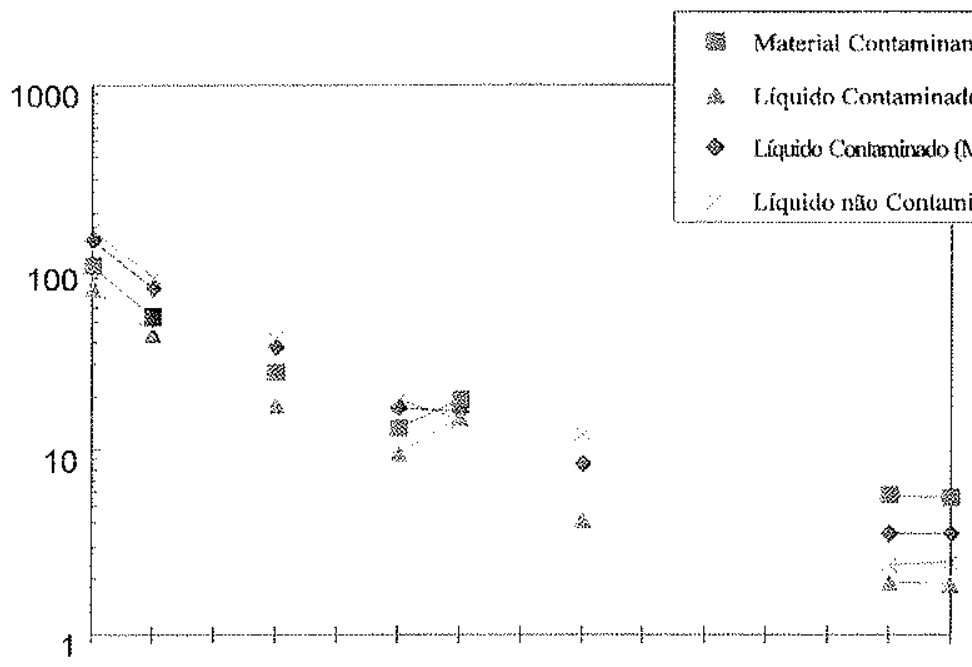

La Ce Pr Nd Pm Sm Eu Gd Tb Dy Ho Er Tm Yb Lu

Figura 84 - Diagrama de ETR com padrões normalizados pelo condrito de Boynton (1984).

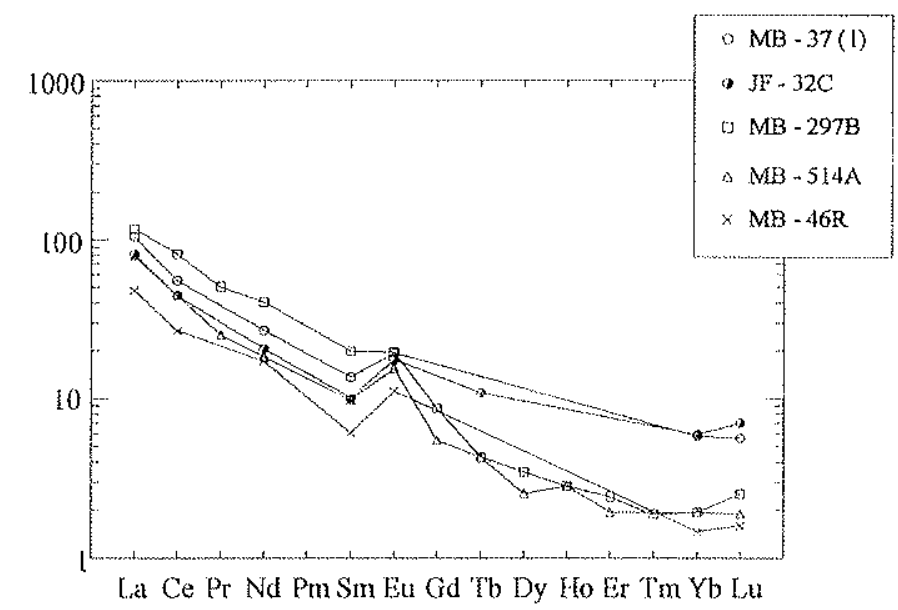

Figura 85 - Diagrama de ETR com padrões normalizados pelo condrito de Boynton (1984).

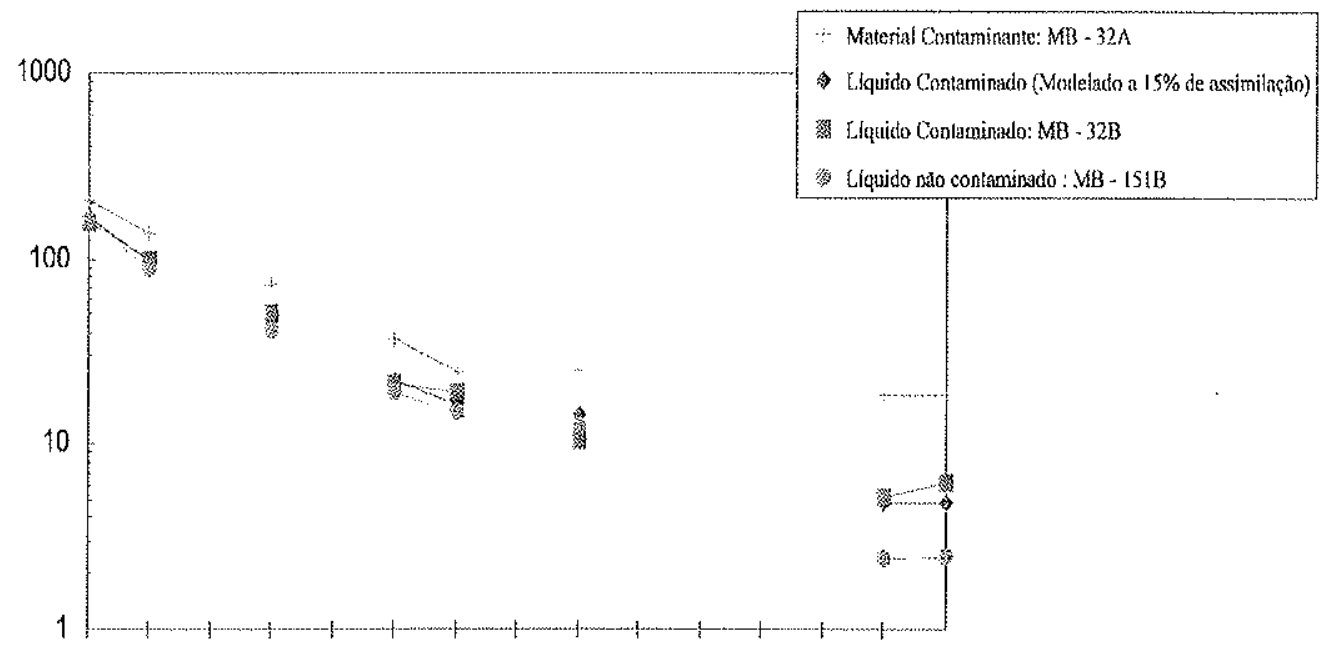

La Ce Pr Nd Pm Sm Eu Gd Tb Dy Ho Er Tm Yb Lu

Figura 86 - Diagrama de ETR com padrões normalizados pelo condrito de Boynton (1984). 
2) Dentro deste conjunto (subgrupo 3 ), as amostras de $[\mathrm{La} / \mathrm{Yb}]_{\mathrm{N}}$ de $\approx 11$ são possíveis contaminantes para magmas graníticos do subgrupo 1, como, por exemplo, o $151 \mathrm{~B}$. Quantidades razoáveis de assimilação simples (aproximadamente 15\%, Fig. 85) envolvendo estes magmas e contaminantes conseguem explicar os padrões de ETR de algumas rochas relativamente mais evoluídas com pequenas anomalias positivas de Eu dentro do grupo calcioalcalino e representadas no subgrupo 2. Quantidades semelhantes de assimilação simples (14 - 16\% envolvendo o mesmo contaminante, também explicam a geração de magmas menos evoluidos e sem anomalias positivas de Eu do subgrupo 2 a partir dos magmas mais parentais dentro do subgrupo 1.

O método de modelamento adotado teve como base os ETR e deveria ser quantitativamente testado por outros critérios, i.e., elementos maiores e dados isotópicos. Entretanto, isto está além do escopo desta tese. Os resultados obtidos pelo modelamento realizado foram capazes de explicar adequadamente a variação de $>1,5$ vezes no valor das razões $[\mathrm{La} / \mathrm{Yb}]_{\mathbb{N}}$ dentre os subgrupos identificados no CJF. Não existe a pretensão de esclarecer todas as variações químicas a partir desse modelo de assimilação simples. A diferença de $2 \%$ no teor de sílica para a amostra $32 \mathrm{~B}$, por exemplo, (que tem $70,82 \%$ quando se esperaria $\approx 69 \%$ pelo modelamento) pode ser atribuída a outros fatores, como o processo metamórfico e/ou erros analíticos, como já discutido no início deste capítulo. Uma hipótese alternativa é que o processo petrogenético pode ter sido mais complexo e envolvido AFC (assimilação e cristalização fracionada) ou AEC (assimilação e cristalização em equilíbrio), por exemplo.

Ainda com base nos ETR, algumas questões podem ser levantadas e testadas, principalmente no que se refere às amostras mais ácidas com anomalias positivas de Eu (para as quais o modelo de assimilação simples não se aplica). Assim, formula-se a seguinte hipótese: Poderiam algumas amostras do subgrupo 1 estar relacionadas entre si ou àquelas do subgrupo 2 por algum processo petrogenético como cristalização fracionada (Figs. 80 e 83)?

\section{e) Modelamento Quantitativo por Cristalizaçäo Fracionada}

Dois tipos de cristalização magmática são normalmente considerados como processo petrogenético importante: cristalização em equilíbrio (equilíbrio completo entre todos os 
sólidos e o líquido) e cristalização fracionada (ou de Rayleigh), onde os cristais são efetivamente separados do liquido.

Destes dois processos, a cristalização fracionada é a que melhor descreve o processo de cristalização magmática, já que envolve a remoção efetiva dos cristais no instante em que são formados. A distribuiçăo resultante de elementos traços traduz um processo caracterizado pela ausência de equilíbrio sólido/líquido.

A equação para o fracionamento de Rayleigh é dada por:

$$
C_{L} / C_{0}=F^{(D-1)}
$$

onde $\mathrm{C}_{0}$ é a concentração inicial de um elemento traço no magma parental; $\mathrm{C}_{\mathrm{L}}$ é a concentração do elemento traço no líquido derivativo; F é a fração de líquido residual; e D é o coeficiente de partição total da assembléia fracionante (i. e., é o somatório dos coeficientes de partição $\left(\mathrm{K}_{d}\right)$ do elemento para a quantidade em volume de fracionamento de cada fase envolvida).

No presente trabalho, as hipóteses formuladas na seção anterior serão testadas quantitativamente, utilizando-se o fracionamento de Rayleigh.

Dentre o magma parental potencial (amostra 15B) e as demais amostras do subgrupo 1 (297B e $115 \mathrm{~B}$ ) existe um gap no intervalo de $58 \mathrm{a} \approx 65 \% \mathrm{SiO}_{2}$. No entanto, as três amostras têm razões $[\mathrm{La} / \mathrm{Xb}]_{\mathrm{N}}$ semelhantes, entre 57 e 60 . Isto significa que estas amostras podem estar relacionadas por processo de cristalização fracionada, implicando que 0 intervalo $58<\mathrm{SiO}_{2}<64 \%$ pode não ter sido representado na amostragem.

Considerando-se os subgrupos 1 (Fig. 80) e 2 (Fig. 81), isoladamente ou em conjunto, verifica-se que a abundância de ETR diminui com o teor em $\mathrm{MgO}$, i. e., com a diferenciação magmática.

Em detalhe, a análise do diagrama apresentado na figura 83 permite identificar que: 
a) Existe um grupo com padrões ETR paralelos $\mathrm{e} \mathrm{SiO}_{2}$ variando de $\approx 57$ a $72 \%$ (amostras $15 \mathrm{~B}, 115 \mathrm{~B}, 151 \mathrm{~B}$ e $151 \mathrm{~A})$;

b) Existe um outro conjunto constituido por amostras (297B, 514A e 46R) cujos teores em $\mathrm{SiO}_{2}$ variam de $\approx 64$ a $72 \%$, sendo, portanto, englobado pelo intervalo de $\mathrm{SiO}_{2}$ mostrado pelo outro grupo; estas amostras têm padrões de ETRleves e teores muito semelhantes de ETRpesados.

Com base no exposto, formulou se as seguintes hipóteses:

1) Seriam as amostras de cada grupo correlacionadas isoladamente por processo de cristalização fracionada?;

2) Seriam as amostras de um grupo correlacionadas com aquelas do outro grupo por processo de cristalização fracionada?

Para testar estas hipóteses, procedeu-se inicialmente ao modelamento quantitativo de cristalização fracionada para cada grupo isoladamente: a) $15 \mathrm{~B}-115 \mathrm{~B}-151 \mathrm{~B}-151 \mathrm{~A}$; e b) 297B - 514A - 46R.

As amostras do CJi foram afetadas por metamorfismo na facies granulito e, posteriormente, por processo retrógrado na facies anfibolito superior. Isto dificulta a escolha de assembléias fracionantes a serem utilizadas no modelamento geoquímico. Alternativamente, optou-se por uma assembléia típica de quartzo monzodiorito, cujo litotipo corresponde àquele da amostra parental potencial (15B) do grupo 15B - 151A acima (Fig. 79). Assim sendo, para o primeiro modelamento, as fases hornblenda, plagioclásio, minerais opacos (magnetita, ilmenita), titanita, apatita e, talvez, biotita podem ser incluídas numa assembléia fracionante potencial. Foram, então, selecionados valores de coeficientes de partição mineral/líquido $\left(\mathrm{K}_{\mathrm{d}}\right)$ disponiveis na literatura para estas fases minerais, considerando-se a composição química dos magmas parentais de cada fase evolutiva. Muito embora o líquido $15 \mathrm{~B}$ tenha composição quartzo monzodiorítica, os valores de $\mathrm{K}_{\mathrm{d}}$ utilizados para biotita são relativos a líquidos dacíticos e riolíticos (Tab. 32), dada a ausência destes valores para rochas de composição intermediária à básica. 
O modelamento dos líquidos derivativos $115 \mathrm{~B}, 151 \mathrm{~B}$ e $151 \mathrm{~A}$ a partir da cristalização fracionada gerou bons resultados com a seguinte assembléia: hornblenda, plagioclásio, magnetita e biotita. Os valores de $\mathrm{K}_{d}$ utilizados e o percentual de volume dos minerais considerados no fracionamento em cada fase são apresentados nas tabelas 33 a 38 .

Tabela 33 - Coeficientes de partição mineral/líquido $\left(\mathrm{K}_{\mathrm{d}}\right)$ utilizados no modelamento do processo de cristalização fracionada, Modelo 1 - Fase 1 (15B - 115B)

\begin{tabular}{|l|c|c|c|c|c|c|c|c|c|}
\hline $\mathrm{K}_{d}$ & $\mathrm{La}$ & $\mathrm{Ce}$ & $\mathrm{Nd}$ & $\mathrm{Sm}$ & $\mathrm{Eu}$ & $\mathrm{Gd}$ & $\mathrm{Tb}$ & $\mathrm{Yb}$ & $\mathrm{Lu}$ \\
\hline Hornblenda & $0,5442^{1}$ & $0,8430^{1}$ & $1,3395^{1}$ & $1,8035^{1}$ & $1,5565^{1}$ & $2,0165^{1}$ & $1,3000^{2}$ & $2,1000^{3}$ & $1,5625^{1}$ \\
\hline Plagioclásio & $0,3020^{4}$ & $0,2210^{4}$ & $0,0551^{1}$ & $0,0394^{1}$ & $1,1255^{1}$ & $0,0710^{4}$ & $0,0700^{10}$ & $0,0670^{5}$ & $0,0600^{5}$ \\
\hline Magnetita & $3,0000^{6}$ & $3,0000^{6}$ & $3,0000^{6}$ & $2,2000^{6}$ & $1,5000^{6}$ & $0,9000^{11}$ & $2,0000^{6}$ & $1,8000^{6}$ & $1,8000^{6}$ \\
\hline Biotita & $3,1800^{7}$ & $2,8030^{7}$ & $2,5600^{8}$ & $2,1170^{8}$ & $2,0200^{8}$ & $0,2800^{9}$ & $1,9570^{8}$ & $1,4730^{8}$ & $1,6170^{8}$ \\
\hline
\end{tabular}

1 - média de dois líquidos andesito basálticos $\mathrm{SiO}_{2}=55$ e $57 \%$ (Fujimaki et al, 1984);

2 - líquido andesito basáltico (Dostal et al, 1983);

3 - liquido andesitico (Green \& Pearson 1985): interpolado da figura 3;

4 - líquido andesítico (Fujikami et al. 1984);

5 - líquido andesito basáltico compilação de Arth (1976);

6 - líquido andesito basáltico; Lu assume o mesmo valor que $\mathrm{Yb}$ (Schock 1979);

7 - líquidos riolíticos de alta sílica (Mahood \& Hildreth 1983);

8 - líquidos riolíticos (Nash \& Crecraf 1985);

9 - liquidos riolíticos (Arth 1976);

10 - não há valores disponíveis. Alternativamente, foi usado o valor 0,0700 que é da mesma ordem de grandeza do que o valor para $\mathrm{Gd}$.

Tabela 34 - Percentual de volume das fases fracionadas utilizado no modelamento do processo de cristalização fracionada, Modelo 1 - Fase 1 (15B - 115B): 53\% de fracionamento.

\begin{tabular}{|l|c|}
\hline Fases minerais fracionadas & $\begin{array}{c}\text { Percentual de } \\
\text { volume }\end{array}$ \\
\hline Hornblenda & $35 \%$ \\
\hline Plagioclásio & $25 \%$ \\
\hline Magnetita & $20 \%$ \\
\hline Biotita & $20 \%$ \\
\hline Total & $100 \%$ \\
\hline
\end{tabular}


Tabela 35 - Coeficientes de partição mineral/liquido $\left(K_{d}\right)$ utilizados no modelamento do processo de cristalização iracionada, Modeio 1 .. Fase 2 (115B - 151B).

\begin{tabular}{|l|c|c|c|c|c|c|c|c|c|}
\hline $\mathrm{K}_{\mathrm{d}}$ & $\mathrm{La}$ & $\mathrm{Ce}$ & $\mathrm{Nd}$ & $\mathrm{Sm}$ & $\mathrm{Ea}$ & $\mathrm{Gd}$ & $\mathrm{Tb}$ & $\mathrm{Yb}$ & $\mathrm{La}$ \\
\hline Hornblenda & $0.8990^{1}$ & $0.8990^{1}$ & $2.8900^{1}$ & $3.9900^{1}$ & $1.2000^{1}$ & $5.4800^{1}$ & $1.3000^{5}$ & $4.8900^{1}$ & $4.5300^{1}$ \\
\hline Plagioclásio & $0.3800^{2}$ & $0.2670^{2}$ & $0.2030^{2}$ & $0.1650^{2}$ & 0.0790 & $0.1250^{2}$ & $0.0700^{5}$ & $0.0900^{2}$ & $0.0920^{2}$ \\
\hline Magnetita & $1.5000^{3}$ & $2.5500^{3}$ & $1,0000^{3}$ & $1.1000^{3}$ & $0.6000^{3}$ & $0.9000^{3}$ & $2.0000^{3}$ & $0.9000^{3}$ & $0.9000^{3}$ \\
\hline Biotita & $3.1800^{1}$ & $2.8030^{1}$ & $2.2330^{1}$ & $0.2600^{4}$ & $0.8670^{1}$ & & $1.0530^{1}$ & $0.5370^{1}$ & $0.6130^{1}$ \\
\hline
\end{tabular}

1 - líquidos dacíticos (Arth 1976);

2- liquidos riolíticos (Nash \& Crecraft 1985);

3 - líquidos andesito basálticos (Shock 1979);

4- líquidos riolíticos (Mahood \& Hilfreth 1983);

5 - não há valores disponiveis. Alternativamente: foi mantido o valor de Tb utilizado na fase precedente; e foi utilizado valor de liquido andesítico-basálticos para Tb (Dostal et al., 1983)

Tabela 36 - Percentual de volume das fases fracionadas utilizado no modelamento do processo de cristalização fracionada, Modelo 1- Fase $2(115 \mathrm{~B}-151 \mathrm{~B}): 30 \%$ de fracionamento.

\begin{tabular}{|l|c|}
\hline Fases minerais fracionadas & Percentual de volume \\
\hline Hormblenda & $35 \%$ \\
\hline Plagioclásio & $25 \%$ \\
\hline Magnetita & $20 \%$ \\
\hline Biotita & $20 \%$ \\
\hline Total & $100 \%$ \\
\hline
\end{tabular}

Tabela 37 - Coeficientes de partição mineral/líquido $\left(K_{d}\right)$ utilizados no modelamento do processo de cristalização fracionada, Modelo 1 - Fase $3(151 \mathrm{~B}$ - 151A)

\begin{tabular}{|l|c|c|c|c|c|c|c|c|c|}
\hline $\mathrm{K}_{\mathrm{d}}$ & $\mathrm{La}$ & $\mathrm{Ce}$ & $\mathrm{Nd}$ & $\mathrm{Sm}$ & $\mathrm{Eu}$ & $\mathrm{Gd}$ & $\mathrm{Tb}$ & $\mathrm{Yb}$ & $\mathrm{Lu}$ \\
\hline Hornblenda & $1.5200^{1}$ & $1.5200^{1}$ & $4.2600^{1}$ & $7.7700^{1}$ & $5.1400^{1}$ & $10.0000^{1}$ & & $8.3800^{1}$ & $5.5000^{1}$ \\
\hline Plagioclásio & $0.3800^{2}$ & $0.2670^{2}$ & $0.2030^{2}$ & $0.1650^{2}$ & $2.1500^{3}$ & $0.1250^{2}$ & $0.0700^{7}$ & $0.0900^{2}$ & $0.0920^{2}$ \\
\hline Magnetita & $1.5000^{4}$ & $1.3000^{4}$ & $1.0000^{4}$ & $1.1000^{4}$ & $0.6000^{4}$ & $0.9000^{4}$ & $2.0000^{4}$ & $1.8000^{4}$ & $1.8000^{4}$ \\
\hline Biotita & $3.1800^{5}$ & $2.8030^{5}$ & $2.5600^{6}$ & $1.5500^{5}$ & $0.8670^{5}$ & & $1.0530^{5}$ & $0.5370^{5}$ & $0.6130^{5}$ \\
\hline
\end{tabular}

1 - líquidos daciticos (Arth 1976);

2 - líquidos andesito basálticos (Shock 1979);

3 - líquidos riolíticos (Arth 1976);

4 - líquidos andesito basálticos (Shock 1979);

5 - líquidos riolíticos (Mahood \& Hildreth 1983);

6 - liquidos riolíticos (Nash \& Crecraft 1985);

7 - não há valores disponíveis. Alternativamente, foi mantico o valor de Tb utilizado nas fases precedentes. 
Tabela 38 - Percentual de volume das fases fracionadas utilizado no modelamento do processo de cristalizą̧ão fracionada, Modelo 1- Fase $3(1510-151 \mathrm{~A}): 30 \%$ de fracionamento.

\begin{tabular}{|l|c|}
\hline Fases minerais fracionadas & Percentual de volume \\
\hline Hornblenda & $6 \%$ \\
\hline Plagioclásio & $28 \%$ \\
\hline Magnetita & $32 \%$ \\
\hline Biotita & $34 \%$ \\
\hline Total & $100 \%$ \\
\hline
\end{tabular}

Verifica-se que, embora o líquido (amostra 115B) agora tenha composição granodioritica (i.e., composição ácida), os valores de $\mathrm{K}_{\mathrm{d}}$ utilizados para magnetita são aqueles correspondentes a líquidos andesito-basálticos. Esta opção se deu pelo fato de que estes são os dados disponíveis na literatura e, portanto, foram utilizados também para a fase $151 \mathrm{~B}-151 \mathrm{~A}$. A figura 87 mostra os líquidos derivativos modelados em cada uma das fases, em comparação com os líquidos derivativos para o grupo 15B - 151A. Como todos os números envolvidos neste procedimento, sejam de $\mathrm{K}_{\mathrm{d}}$, de \% em volume das fases fracionantes como também da percentagem de fracionamento, são bastante pertinentes, conclui-se que estas amostras devem ser cogenéticas e podem ser correlacionadas pelo processo de cristalização fracionada ora descrito.

O modelamento quantitativo com base nos ETR indicou que: 1) a primeira fase de evolução (15B - 115B) envolveu uma quantidade relativamente maior de cristalização fracionada $(53 \%)$ do que as duas fases subsequentes $(30 \%$ cada); 2) a variação das abundâncias de ETR para todo o grupo pode ser explicada pelo fracionamento cristalino de uma única assembléia que inclui hornblenda, plagioclásio, magnetita e biotita; 3) a contribuição relativa das fases fracionantes manteve-se bastante constante ao longo do processo. No entanto, magnetita e biotita devem ter contribuído mais para o processo de cristalização fracionada, em detrimento de hornblenda, na fases finais de evolução magmática. 

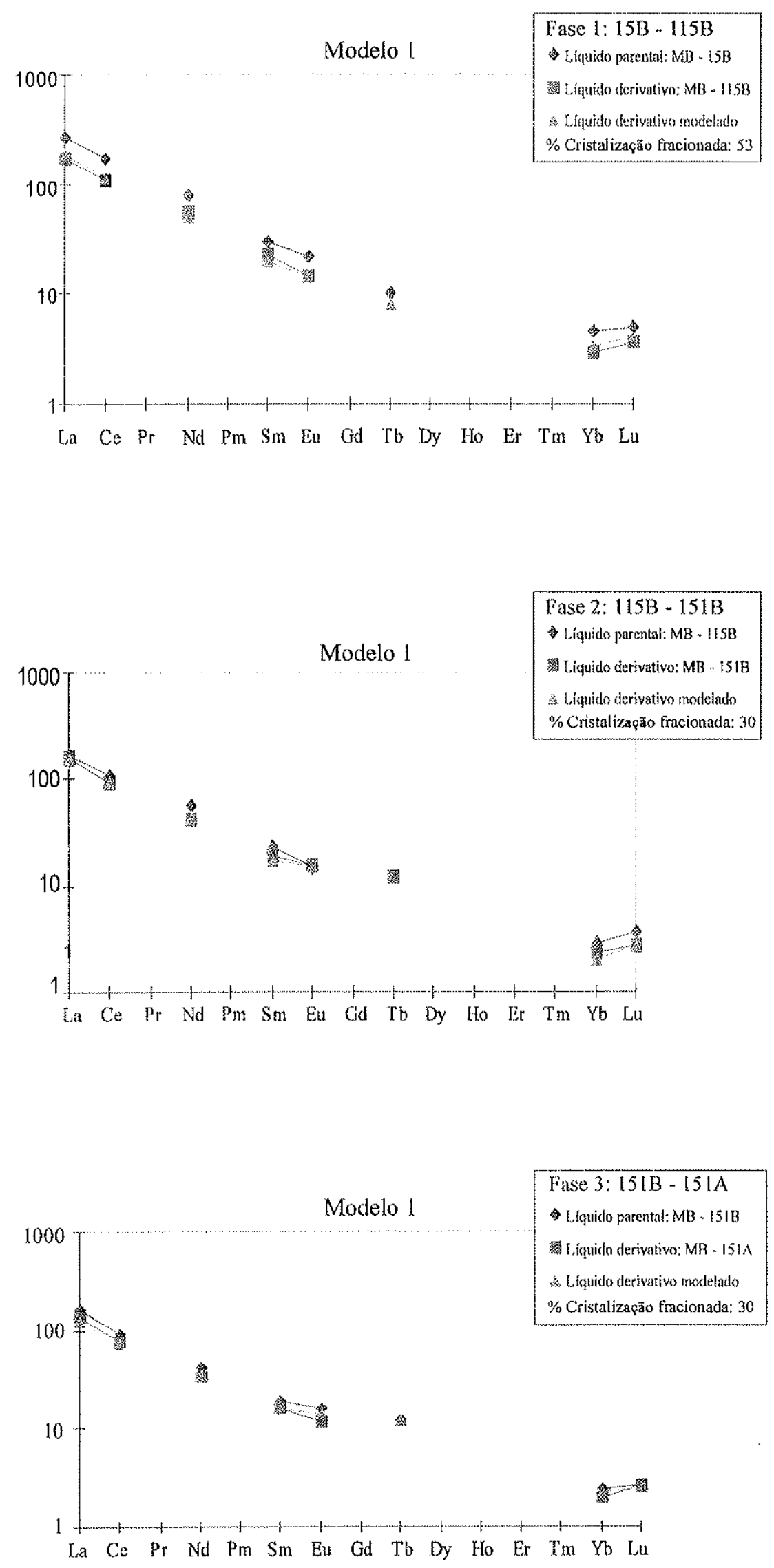

Figura 87 - Diagramas de ETR, com padrões normalizados pelo condrito de Boynton (1984), para modelamento de cristalização fracionada das amostras do subgrupo 1 do CJF. 
O mesmo procedimento foi adotado para modelar o processo de cristalização fracionada das amostras com anomalia positiva de Eu (2978 - 514A - 46R). As fases fracionantes consideradas foram as mesmas (hornblenda, plagioclásio, magnetita e biotita), embora em proporções distintas, já que o líquido parental potencial (2978) é mais ácido, de composição quartzo monzonítica (Fig.79). As tabelas 39 a 42 apresentam os valores de $K_{d}$ utilizados no modelamento e as percentagens de volume das fases fracionantes. Para a magnetita, foram utilizados valores de $K_{d}$ relativos a líquidos andesito-basálticos devido a escassez de dados na literatura para rochas mais ácidas.

Tabela 39 - Coeficientes de partição mineral/liquido $\left(K_{d}\right)$ utilizados no modelamento do processo de cristalização fracionada - Modelo 2 - Fase 1 (297B - 514A).

\begin{tabular}{|l|c|c|c|c|c|c|c|c|c|}
\hline $\mathrm{K}_{\mathrm{d}}$ & $\mathrm{La}$ & $\mathrm{Ce}$ & $\mathrm{Nd}$ & $\mathrm{Sm}$ & $\mathrm{Eu}$ & $\mathrm{Gd}$ & $\mathrm{Tb}$ & $\mathrm{Yb}$ & $\mathrm{Lu}$ \\
\hline $\mathrm{Hbl}$ & $1,5200^{1}$ & $1,5200^{1}$ & $4,2600^{1}$ & $7,7700^{1}$ & $3,4400^{2}$ & $10,000^{1}$ & $1,3000^{7}$ & $8,3800^{1}$ & $5,5000^{3}$ \\
\hline $\mathrm{Plg}$ & $0,3800^{3}$ & $0,2670^{3}$ & $0,2030^{3}$ & $0,1650^{3}$ & $0,2150^{1}$ & $0,1250^{3}$ & $0,0700^{7}$ & $0,0900^{3}$ & $0,0920^{3}$ \\
\hline $\mathrm{Mgt}$ & $1,5000^{4}$ & $3,0000^{4}$ & $3,0000^{4}$ & $2,2000^{4}$ & $0,2500^{5}$ & $0,9000^{4}$ & $2,0000^{4}$ & $0,9000^{4}$ & $1,8000^{4}$ \\
\hline $\mathrm{Bt}$ & $3,1800^{6}$ & $2,8030^{6}$ & $2,5600^{6}$ & $2,1170^{6}$ & $0,8670^{6}$ & $0,2800^{7}$ & $1,0530^{6}$ & $0,5370^{6}$ & $0,6130^{6}$ \\
\hline
\end{tabular}

1 - liquidos rioliticos (Arth 1976);

2- liquidos dacíticos (Arth 1976);

3 - líqulos riolíticos (Nash \& Crecraft 1985);

4 - líquido andesito basáltico; Lu assume o mesmo valor que Yb (Schock 1979);

5- líquidos andesiticos (Gill 1981);

6 - riolitos de alta sílica - $\mathrm{SiO}_{2} 75-77,5 \%$ (Mahood \& Fildreth 1983);

7 - não há valores disponiveis. Alternativamente, foi mantido o valor de Tb utilizado nas fases precedentes.

Tabela 40 - Percentual de volume das fases fracionadas utilizado no modelamento do processo de cristalização fracionada, Modelo 2 - Fase 1 (297B - 514A): 43\% de fracionamento.

\begin{tabular}{|l|c|}
\hline Fases minerais fracionadas & $\begin{array}{c}\text { Percentual em } \\
\text { Volume }\end{array}$ \\
\hline Homblenda & $7 \%$ \\
\hline Plagioclásio & $28 \%$ \\
\hline Magnetita & $30 \%$ \\
\hline Biotita & $35 \%$ \\
\hline Total & $100 \%$ \\
\hline
\end{tabular}


Tabela 41 - Coeficientes de partição mineral/íquido $\left(K_{d}\right)$ utilizados no modelamento do processo de cristalização fracionada, Modelo 2 - Fase 2 (514A - 46R)

\begin{tabular}{|l|c|c|c|c|c|c|c|c|c|}
\hline $\mathrm{K}_{\mathrm{d}}$ & $\mathrm{La}$ & $\mathrm{Ce}$ & $\mathrm{Nd}$ & $\mathrm{Sm}$ & $\mathrm{Eu}$ & $\mathrm{Gd}$ & $\mathrm{Tb}$ & $\mathrm{Yb}$ & $\mathrm{Lu}$ \\
\hline $\mathrm{Hbl}$ & $1,5200^{1}$ & $1,5200^{1}$ & $4,2600^{1}$ & $7,7700^{3}$ & $3,4400^{2}$ & $10,000^{1}$ & $1,3000^{6}$ & $8,3800^{1}$ & $5,5000^{1}$ \\
\hline $\mathrm{Plg}$ & $0,3800^{3}$ & $0,2670^{3}$ & $0,2030^{3}$ & $0,1650^{3}$ & $0,2150^{1}$ & $0,1250^{3}$ & $0,0700^{6}$ & $0,0900^{3}$ & $0,0920^{3}$ \\
\hline $\mathrm{Mgt}$ & $2,3500^{4}$ & $3,0000^{4}$ & $1,0000^{4}$ & $2,2000^{4}$ & $0,6000^{4}$ & $0,9000^{4}$ & $2,0000^{4}$ & $1,8000^{4}$ & $1,8000^{4}$ \\
\hline $\mathrm{Bt}$ & $3,1800^{5}$ & $2,8030^{5}$ & $2,2330^{5}$ & $2,1170^{3}$ & $0,8670^{5}$ & $0,2800^{1}$ & $1,0530^{5}$ & $0,5370^{5}$ & $0,6130^{5}$ \\
\hline
\end{tabular}

1 - líquidos rioliticos (Arth 1976);

2 - liquidos dacíticos (Arth 1976);

3 - liqudos riolíticos (Nash \& Crecraft 1985);

4 - liquido andesito basáltico; Lu assume o mesmo valor que Yb (Schock 1979);

5 liquidos riolíticos (Mahood \& Hildreth 1983);

6 - não há valores disponíveis. Alternativamente: foi mantido o valor de tb atilizado nas fases precedentes; foi utilizado valor de líquido andesítico-basálticos para To (Dostal et al., 1983)

Tabela 42 - Percentual em volume das fases fracionadas utilizado no modelamento do processo de cristalização fracionada, Modelo 2 - Fase 2 (514A - 46R): 43\% de fracionamento.

\begin{tabular}{|l|c|}
\hline Fases minerais fracionadas & $\begin{array}{c}\text { Percentual em } \\
\text { Volume }\end{array}$ \\
\hline Hornblenda & $7 \%$ \\
\hline Plagioclásio & $33 \%$ \\
\hline Magnetita & $30 \%$ \\
\hline Biotita & $30 \%$ \\
\hline Total & $100 \%$ \\
\hline
\end{tabular}

A figura 88 apresenta, para cada fase evolutiva, o padrão ETR do líquido derivativo modelado em comparação ao liquido derivativo. A análise dos diagramas desta figura e de todos os números utilizados (valores de $\mathrm{K}_{\mathrm{d}}$, percentagem de volume das fases fracionantes $\mathrm{e}$ quantidades de fracionamento) mostram que é provável que estas rochas sejam cogenéticas, relacionadas por processo de cristalização fracionada. Os resultados deste modelamento indicam que: 1) o percentual de cristalização fracionada (43\%) manteve-se constante por todo o processo; 2) uma única assembléia mineralógica é capaz de explicar as variações nas abundâncias de ETR existentes dentre as rochas envolvidas (297B, 514A e 46R); e 3) a contribuição relativa das fases fracionantes manteve-se bastante constante ao longo do 
processo. Apenas pequenas diferenças foram observadas: a diminuição no percentual de biotita da fase evolutiva 1 para a 2 e aumento no plagioclásio. quantidades relativas dos minerais ocorreram da fase evolutiva 1 (biotita é o mineral de maior percentual de fracionamento) para a 2 (plagioclásio passa a ser o mineral mais fracionado).

O fato do processo de cristalização fracionada explicar de modo satisfatório as variações de ETR nos dois grupos considerados isoladamente, nos remete ao teste da segunda hipótese: seriam as amostras de ambos os grupos cogenéticas e relacionadas por processo de cristalização fracionada? Esta hipótese implica em encontrar-se no grupo 15B - 151A um candidato parental à amostra 297B do grupo 297B - 46R. O candidato óbvio, a considerar-se os teores de $\mathrm{MgO}$, por exemplo (Fig. 83), é a amostra 115B.

A mesma assembléia fracionante foi considerada no modelamento e os valores de $\mathrm{K}_{\mathrm{d}}$ utilizados bem como os percentuais de volume são mostrados nas tabelas 42 e 43 . A figura 89 mostra diagramaticamente os resultados obtidos neste modelamento, que podem ser considerados bastante razoáveis.

Tabela 43 - Coeficientes de partição mineral/líquido $\left(K_{d}\right)$ utilizados no modelamento do processo de cristalização fracionada, Modelo 3 (115B-297B).

\begin{tabular}{|l|c|c|c|c|c|c|c|c|}
\hline $\mathrm{K}_{\mathrm{d}}$ & $\mathrm{La}$ & $\mathrm{Ce}$ & $\mathrm{Nd}$ & $\mathrm{Sm}$ & $\mathrm{Eu}$ & $\mathrm{Tb}$ & $\mathrm{Yb}$ & $\mathrm{Lu}$ \\
\hline Hornblenda & $0,8990^{1}$ & $0,8990^{1}$ & $2,8900^{1}$ & $3,9900^{1}$ & $1,2000^{2}$ & $1,3000^{8}$ & $4,8900^{1}$ & $4,5300^{1}$ \\
\hline Plagioclásio & $0,3800^{3}$ & $0,2670^{3}$ & $0,2030^{3}$ & $0,1650^{3}$ & $0,0130^{4}$ & $0,0700^{8}$ & $0,0900^{3}$ & $0,0920^{3}$ \\
\hline Magnetita & $3,0000^{5}$ & $3,0000^{5}$ & $1,0000^{5}$ & $1,1000^{5}$ & $0,2500^{6}$ & $2,0000^{5}$ & $0,9000^{5}$ & $0,9000^{5}$ \\
\hline Biotita & $3,1800^{7}$ & $2,8030^{7}$ & $2,2330^{7}$ & $0,2600^{4}$ & $0,1450^{1}$ & $1,0530^{7}$ & $0,5370^{7}$ & $0,6130^{7}$ \\
\hline
\end{tabular}

1 - liquidos dacíticos (Arth 1976);

2. líquidos andesito basálticos (Dostal et al, 1983);

3 - liqudos riolíticos (Nash \& Crecraft 1985);

4 - liquidos riolíticos (Arth 1976);

5 - liquido andesito basáltico; L u assume o mesmo valor que Yb (Schock 1979);

6 - liquidos andesíticos (Gill 1981);

7 - riolitos de alta silica (Mahood \& Hildreth 1983).

8 - não há valores disponiveis. Alternativamente, foi mantido o valor de Tb utilizado nas fases precedentes. 


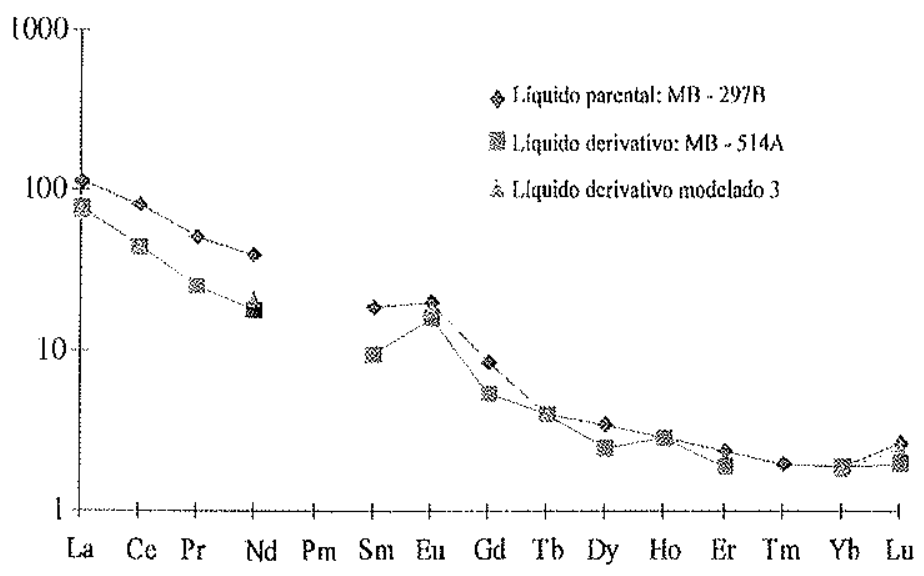

Figura 88 - Diagramas de ETR, com padrões normalizados pelo condrito de Boynton (1984), para modelamento de cristalização fracionada das amostras dos subgrupos 1 e 2 do CJF.

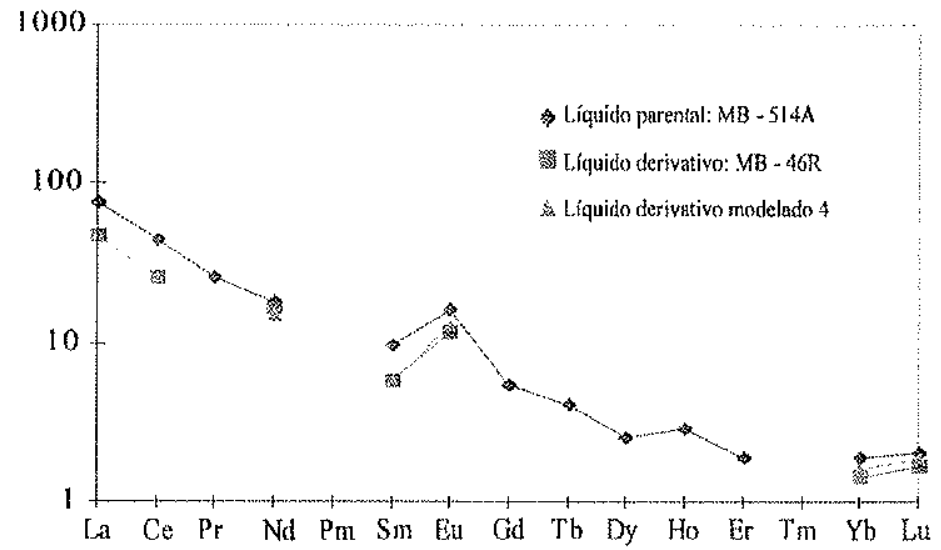

- Liquido parental: $M B$ - ILjB

Líguido derivalivo: $M B-297 B$

क. L.quide derivalivo modelado 2

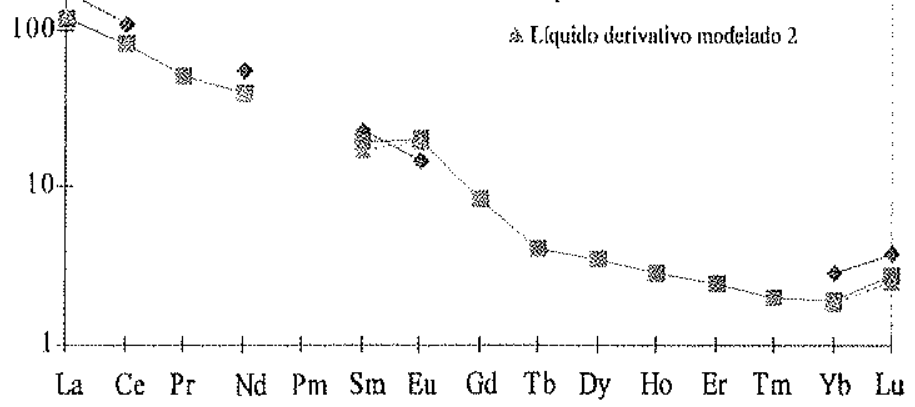

Figura 89 - Diagramas de ETR, com padrões normalizados pelo condrito de Boynton (1984) e resultado do modelamento para cristalização fracionada das. 
Tabela 44 - Percentual de volume das fases fracionadas utilizado no modelamento do processo de cristalização fracionada, Modelo $3(1158-2978) \cdot 43 \%$ de fracionamento.

\begin{tabular}{|l|c|}
\hline Fases minerais fracionadas & $\begin{array}{c}\text { Percentual de } \\
\text { volume }\end{array}$ \\
\hline Hornblenda & $30 \%$ \\
\hline Plagioclásio & $30 \%$ \\
\hline Magnetita & $20 \%$ \\
\hline Biotita & $20 \%$ \\
\hline Total & $100 \%$ \\
\hline
\end{tabular}

\section{f) Discussões e Conclusões Finais}

Os resultados do modelamento quantitativo (com base nas variações de ETR) apresentados nesta seção indicam que cristalização fracionada deve ter sido um processo petrogenético muito importante na evolução magmática das rochas calcioalcalinas do CJF. Isto corrobora as conclusões feitas nas seções b.1 e b. 2 onde abordou-se as variações de elementos maiores e traços (à exceção de ETR) para estas rochas. No entanto, os reseultados dos modelamentos quantitativos aqui apresentados também demonstram que o processo de cristalização fracionada deve ter sido complexo. É ambíguo, por exemplo, o fato de que o mesmo processo petrogenético sirva para explicar variações de ETR para subgrupos isolados (hipótese 1) e em conjunto (hipótese 2). Este fato parece remeter a condições bastante peculiares dentro da câmara magmática em que a cristalização fracionada ocorreu. Aparentemente, houve uma bifurcação do trend evolutvo (tendo a amostra $115 \mathrm{~B}$ como ponto comum) num ambiente complexo e dinâmico dentro da câmara magmática. (Fig. 90). É possível que em diferentes porções de uma mesma câmara magmática estivesse sendo desenvolvido o mesmo processo petrogenético (cristalização fracionada), porém com características distintas. Diferenças físicas, envolvendo processos mecânicos comparativamente distintos, poderiam ser responsáveis pelo desenvolvimento de dois trends de evolução magmática.

Sendo assim, considera-se a possibilidade da câmara magmática ser heterogênea em termos de características mecânicas, fazendo com que o processo petrogenético considerado (cristalização fracionada) tenha desenvolvimento também complexo. Propõe-se que diferenças 


\section{$297 \mathrm{~B} \longrightarrow 514 \mathrm{~A} \longrightarrow 46 \mathrm{R}$}

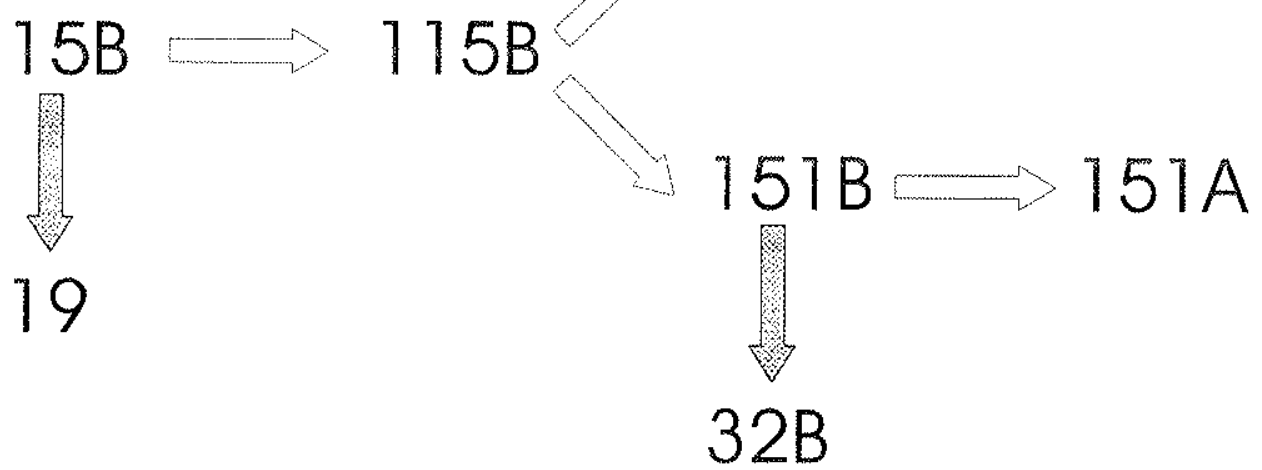

Cristalização Fracionada

Assimilação Simples

Figura 90 - Esquema simplificado dos processos petrogenéticos em câmara magmática complexa para as rochas calcioalcalinas do CJF. 
no comportamento do magma resultantes da presença de correntes de convecção mais ou menos efetivas sejam as responsáveis pela complexidade supracitada. Sob condições mais calmas, quando as correntes de convecção são pouco atuantes, o processo de fracionamento de cristais é mais efetivo (linha evolutiva 1 na figura 90). Por outro lado, em presença de corrente de convecção relativamente forte, o processo de cristalização fracionada é constantemente perturbado e pode dar lugar, localmente, a processos de assimilação simples (seção II.7.3.d e linha evolutiva 2 na figura 90). Da mesma forma, magmas relativamente mais quentes, situados na vase da câmara magmática, são potencialmente mais aptos a assimilar rochas encaixantes (15B - 19). Magmas relativamente mais evoluídos e frios, porém situados em porções mais convectivas da câmara, também são potencialmente capazes de assimilar localmente as rocnas encaixantes. A maior quantidade de fluidos nestes magmas mais evoluídos também servem à redução do eutético das rochas encaixantes, propiciando a assimilação simples.

Conclui-se então que é provável que, com exceção das amostras com $[\mathrm{La} / \mathrm{Yb}]_{\mathrm{N}}$ entre 11 e 18, todas as demais amostras do grupo calcioalcalino sejam cogenéticas, formando uma suite magmática que evoluiu principalmente por processo de cristalização fracionada. $O$ ambiente de câmara magmática parece ter sido bastante dinâmico, levando à bifurcação de trends evolutivos, bem como à atuação de processos de assimilação simples localizada. 


\section{II.7.4) Esudo Geoquímico ..Petrológico dos litotipos do complexo Mantiqueira.}

\section{a) Trabalhos Anteriores de Cunho Petrológico}

A abordagem geoquímico-petrológica dos gnaisses do Complexo Mantiqueira teve início na década de 1980, quando Machado Filho et al. (1983) identificaram um trend misto toleiítico-calcioalcalino para as rochas ortoderivadas da Unidade Migmatítica do Gnaisse Piedade. A partir de estudos geoquímicos em rochas do Complexo Mantiqueira, Pinto et al. (1991) e Viana et al. (1991) concluíram que: a) os gnaisses bandados são metandesitos calcioalcalinos, enquanto que os metabasitos são restitos de fusão; b) as rochas granulíticas correspondem a vulcanitos intermediários contaminados por sedimentos carbonáceos; c) os biotita gnaisses, associados a rochas calcissilicáticas, são, em grande parte, metassedimentos aluminosos e margosos e, por vezes, são granitos crustais gnaissificados. Figueiredo et al. (1992) identificaram duas sequências distintas dentre os hb-bt gnaisses do que denominaram Gnaisses Mantiqueira: a) sequência calcioalcalina de baixo $K$, ou TTG; e b) sequência calcioalcalina enriquecida em LILE. Posteriormente, para a região de Juiz de Fora, Figueiredo e Teixeira (1996) definiram os mesmos agrupamentos químicos, agora classificados como série, no então denominado Complexo (Metamórfico) Mantiqueira, como segue: a) série calcioalcalina de baixo $\mathrm{K}$, incluindo rochas básicas a ácidas, interpretadas como retrabalhamento de crosta Arqueana; e b) série calcioalcalina de alto $\mathrm{K}$ enriquecida em LILE, dada por associações de rochas intermediárias a ácidas, integrantes de arco magmático maduro Transamazônico.

\section{b) Investigação Geoquímica - Petrológica}

\section{b.1) Abordagem com base nos Elemento Maiores}

A partir do plote das amostras do Complexo Mantiqueira (CM) em diagrama $\mathrm{SiO}_{2} \mathrm{x}$ Álcalis (Fig. 91), verifica-se que existe um gap considerável (de $\approx 53 \%$ a $\approx 63 \%$ ), separando os termos básicos dos termos intermediários e ácidos do grupo. Pode-se verificar ainda que as rochas básicas plotam tanto no campo alcalino quanto no subalcalino, mostrando, assim, um trend similar aquele de basaltos transicionais. Por outro lado, as rochas intermediárias a ácidas plotam francamente no campo subalcalino. 


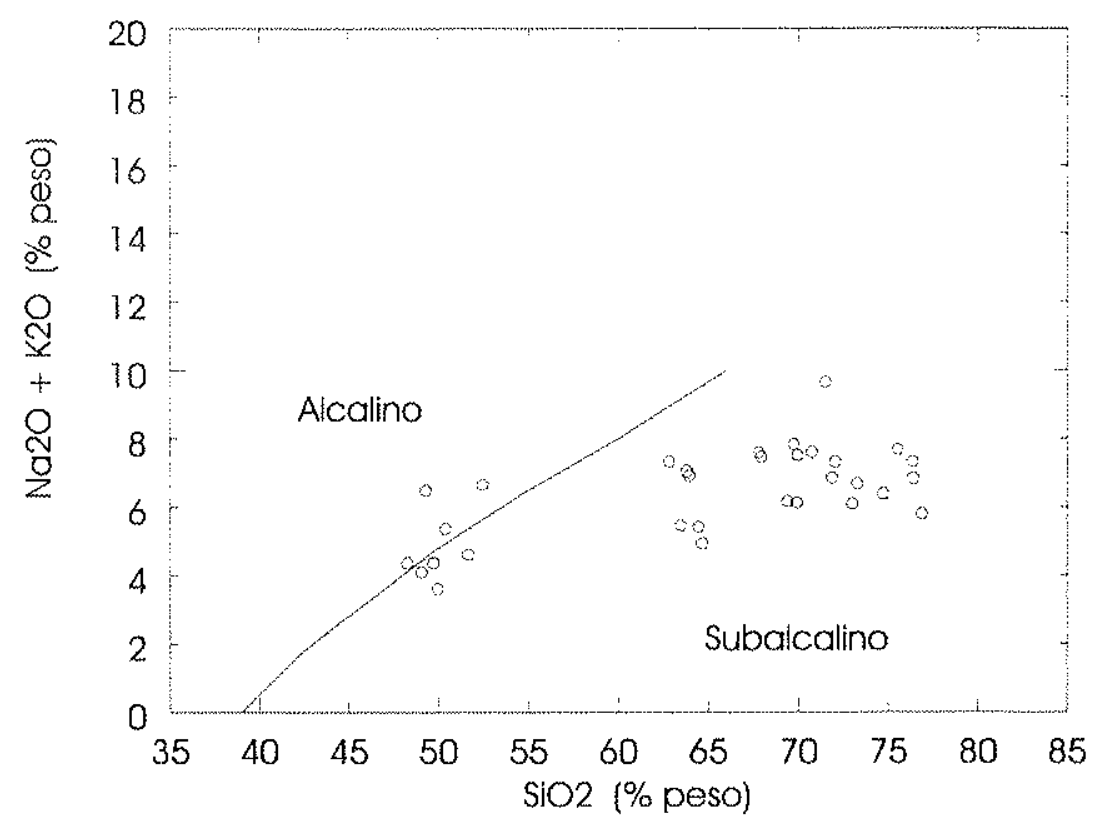

Figura 91 - Diagramas $\mathrm{SiO}_{2}$ x Álcalis para o cojunto das amostras do CM. Limite dos campos alcalino e subalcalino, segundo Irvine \& Baragar (1971).

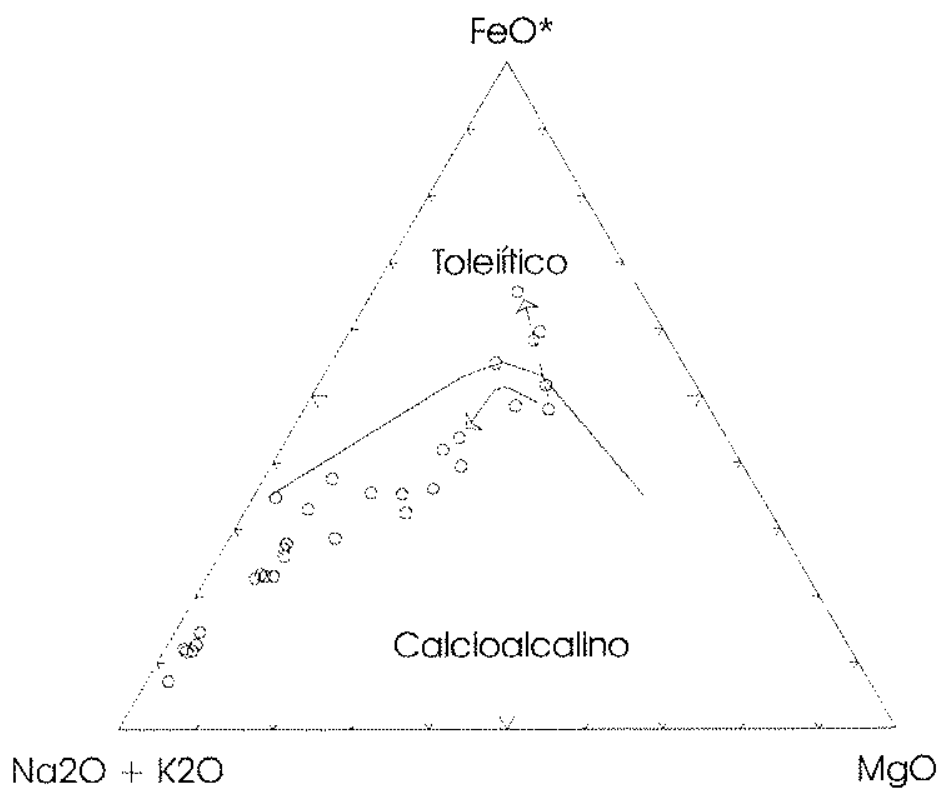

Figura 92 - Diagrama AFM para o conjunto das amostras do CM. Limite dos campos toleítico e calcioalcalino, segundo Irvine \& Baragar (1971). $\mathrm{A}=\mathrm{K}_{2} \mathrm{O}+\mathrm{Na}_{2} \mathrm{O} ; \mathrm{F}=\mathrm{FeO}+0,8998 \mathrm{Fe}_{2} \mathrm{O}_{3} ; \mathrm{e} \mathrm{M}=\mathrm{MgO}$ 
Em diagrama AFM (Fig. 92), as rochas básicas distribuem-se ao longo de dois trends: um francamente toleítico e outro com pequeno enriquecimento em ferro, semelhante a trend alcalino ou calcioalcalino. As demais amostras, de composição intermediária à ácida apresentam-se dispostas ao longo de trend calcioalcalino.

Com base no exposto, foram formuladas as seguintes hipóteses: 1) Toda a população de amostras do CM constitui uma única suite; 2) As rochas básicas, de um lado, e as intermediárias a ácidas, do outro, constituem suites isoladas. Passou-se ao tratamento estatístico dos dados, a fim de testar as hipóteses então formuladas. Primeiramente, as amostras do CM foram plotadas em diagramas de Harker para os elementos maiores (Fig. 93). Foram então construídas curvas de regressão, lineares e polinominais (para os elementos maiores menos móveis), para cada um dos seguintes casos: 1) Toda a população de amostras; 2) o grupo de rochas básicas transicionais isolado; e 3) o grupo de rochas intermediárias e ácidas calcioalcalinas isolado.

A tabela 44 mostra os valores do coeficiente de regressão $\mathrm{r}^{2}$ da correlação $\mathrm{SiO}_{2} \mathrm{x}$ elementos maiores menos móveis para cada um dos casos considerados. A partir deste tratamento estatístico, é possível verificar que:

a) Os valores de $r^{2}$ obtidos para as regressões polinominais representam maior nivel de significância do que aqueles obtidos para as regressões lineares, para qualquer um dos casos considerados. Correlações deste tipo são esperadas quando do envolvimento de processos petrogenéticos como cristalização fracionada e/ou fusão parcial; a mistura magmática que gera trends lineares em diagramas de Harker pode ser descartada como processo petrogenético para as rochas do $\mathrm{CM}$.

b) Os casos 1 (toda a população) e 3 (grupo calcioalcalino) apresentam correlação significante acima de $99,9 \%$ para $\mathrm{TiO}_{2}, \mathrm{Fe}_{2} \mathrm{O}_{3},{ }^{t} \mathrm{MgO}$ e $\mathrm{CaO}$ e acima de $99 \%$ para $\mathrm{Al}_{2} \mathrm{O}_{3}$. Ou seja, ambos os casos apresentam igual nível de significância nestas correlações.

c) $\mathrm{O}$ grupo das rochas básicas apresenta correlação significante acima de $99 \%$ para $\mathrm{Al}_{2} \mathrm{O}_{3}$, acima de $95 \%$ para $\mathrm{Fe}_{2} \mathrm{O}_{3}{ }^{\mathrm{t}}$, acima de $80 \%$ para $\mathrm{TiO}_{2}$ e abaixo de $80 \%$ para $\mathrm{MgO}$ e $\mathrm{CaO}$. Podese considerar que o nível de significância para estas rochas é baixo. 

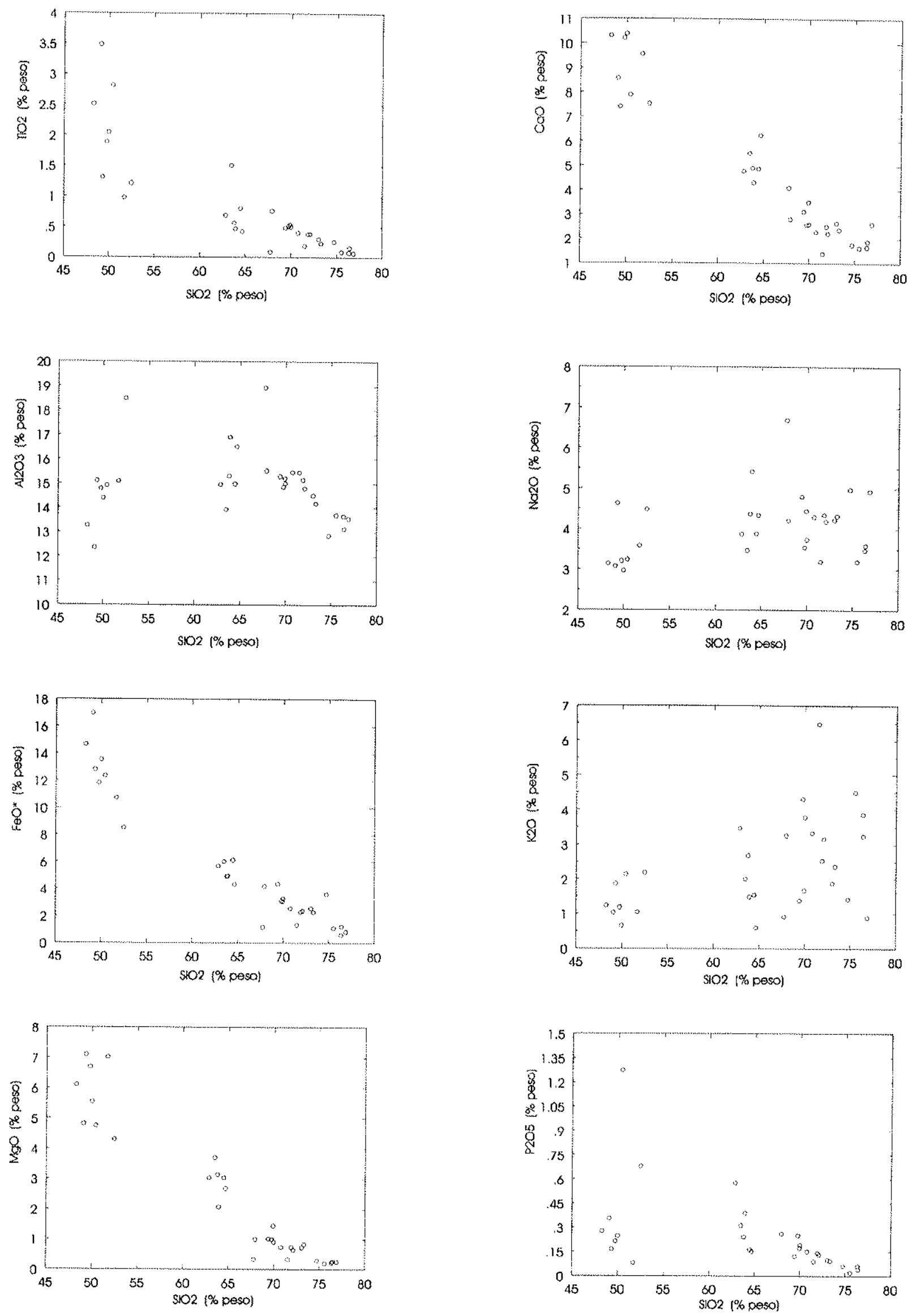

Figura 93 - Diagramas de Harker ( elementos maiores) para todo o conjunto das amostras do CM. 
trends lineares em diagramas de Harker pode ser descartada como processo petrogenético para as rochas do $\mathrm{CM}$.

b) Os casos 1 (toda a população) e 3 (grupo calcioalcalino) apresentam correlação significante acima de $99,9 \%$ para $\mathrm{TiO}_{2}, \mathrm{Fe}_{2} \mathrm{O}_{3},{ }^{\mathrm{t}} \mathrm{MgO}$ e $\mathrm{CaO}$ e acima de $99 \%$ para $\mathrm{Al}_{2} \mathrm{O}_{3}$. Ou seja, ambos os casos apresentam igual nível de significância nestas correlações.

c) $\mathrm{O}$ grupo das rochas básicas apresenta correlação significante acima de $99 \%$ para $\mathrm{Al}_{2} \mathrm{O}_{3}$, acima de $95 \%$ para $\mathrm{Fe}_{2} \mathrm{O}_{3}{ }^{\mathrm{t}}$, acima de $80 \%$ para $\mathrm{TiO}_{2}$ e abaixo de $80 \%$ para $\mathrm{MgO}$ e CaO . Podese considerar que o nível de significância para estas rochas é baixo.

A partir do exposto, conclui-se que:

1) O tratamento estatístico com abordagem nos elementos maiores descarta a possibilidade das rochas básicas serem termos de uma única suite magmática. Esta característica já havia sido sugerida pelo diagrama AFM, no qual as rochas básicas parecem estar dispostas ao longo de dois trends: um com enriquecimento forte em ferro (toleítico) e outro com enriquecimento moderado em ferro (alcalino e/ou calcioalcalino).

2) O tratamento estatístico até então desenvolvido não foi capaz de discriminar os casos 1 e 3 que representam hipóteses claramente alternativas.

3) As duas conclusões anteriores, em conjunto, indicam que é pouco provável que o caso 1 seja verdadeiro, muito embora os critérios estatísticos sejam concordantes, já que o caso 2 não é. Isto sugere que é grande a possibilidade das rochas do grupo calcioalcalino formarem uma única suite magmática.

4) Seja qual for o agrupamento considerado, os processos petrogenéticos que melhor explicam as correlações encontradas são cristalização fracionada e fusão parcial.

\section{b.2) Abordagem com base nos elementos traços}

Critérios estatísticos foram também utilizados na investigação do comportamento dos elementos traços nos três casos anteriormente definidos. Foram selecionados os seguintes elementos traços: Ni e V (elementos compativeis); Zr e Hf (elementos incompatíveis imóveis); e Ba e Sr (elementos incompatíveis móveis). A partir do plote das amostras em diagramas de 
Harker (Fig. 94), foram construídas curvas de correlação para cada um destes elementos. A tabela 45 mostra os valores de $r^{2}$ obtidos e os níveis de significância correspondentes para os três casos considerados.

Tabela 45 - Valores de $r^{2}$ e nível de significância para elementos traços dos agrupamentos de rochas do Complexo Mantiqueira.

\begin{tabular}{|l|c|c|c|c|c|c|}
\hline Elementos & IP & $\%$ sign & 2P & \% sign & 3P & $\%$ sign \\
\hline $\mathrm{Ni}$ & 0,5739 & $>99,9$ & 0,0049 & $<<80$ & 0,7853 & $>99,9$ \\
\hline $\mathrm{V}$ & 0,8012 & $>99,9$ & 0,2964 & $<80$ & 0,7733 & $>99,9$ \\
\hline $\mathrm{Zr}$ & 0,1067 & $<80$ & 0,0196 & $<<80$ & 0,1985 & $<80$ \\
\hline $\mathrm{Hf}$ & 0,0928 & $<80$ & 0,0373 & $<<80$ & 0,1699 & $<80$ \\
\hline $\mathrm{Ba}$ & 0,1905 & $<80$ & 0,1389 & $<80$ & 0,0818 & $<<80$ \\
\hline $\mathrm{Sr}$ & 0,2199 & $<80$ & 0,3556 & $<80$ & 0,1253 & $<80$ \\
\hline
\end{tabular}

1 - Toda a população de amostras;

2 - Grupo das rochas básicas;

3-Grupo das rochas calcioalcalinas;

P - Correlação Polinominal;

\% sign - nivel de significância da correlação.

Com base nas resultados alcançados no item anterior, foram somente calculadas as correlações polinominais, a partir das quais verifica-se que:

a) Para toda a população de amostras do CM (caso 1), a correlação é significante acima de $99,9 \%$ para $\mathrm{Ni}$ e V; entre 99 e $99,9 \%$ para $\mathrm{Sr}$; entre 95 e $99 \%$ para $\mathrm{Ba}$; e entre 90 e $95 \%$ para Hf e Zr.

b) Para o grupo calcioalcalino (caso 3), a correlação é significante acima de $99,9 \%$ para $\mathrm{Ni}$ e $\mathrm{V}$; entre 95 e $99 \%$ para Hf e $\mathrm{Zr}$; e entre $90 \%$ e $95 \%$ para $\mathrm{Ba}$ e $\mathrm{Sr}$.

c) Para o grupo de rochas básicas, a correlação é significante entre 80 e $90 \%$ para V e Sr e abaixo de $80 \%$ para os demais elementos.

Com base no exposto, conclui-we que:

1) É improvável que as rochas básicas constituam uma única suite, o que está de acordo com os resultados obtidos para os elementos maiores.

2) Diferentemente do que ocorreu com os elementos maiores, o nível de significância da correlação obtido para os casos 1 e 3 foi consideravelmente baixo. 

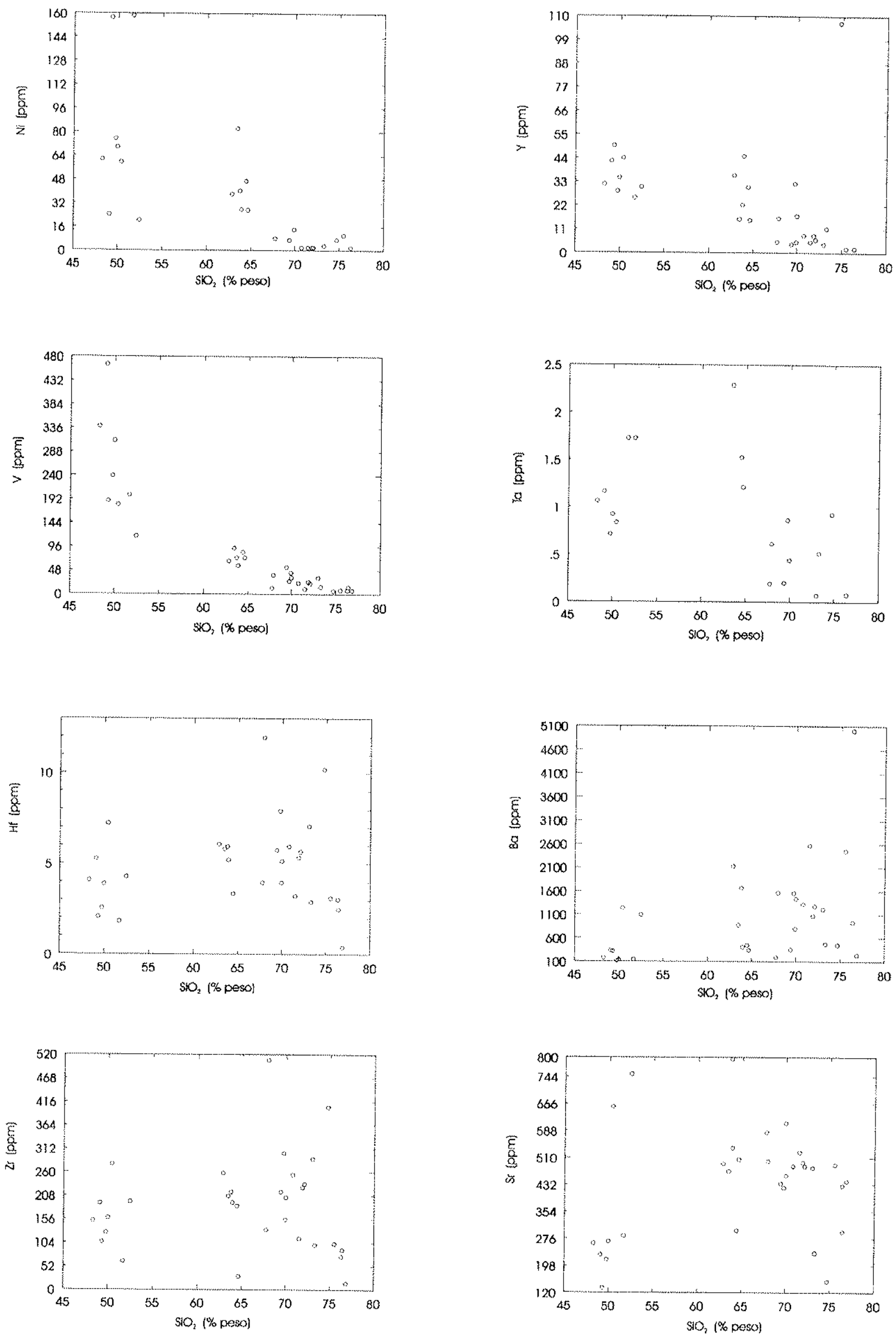

Figura 94 - Diagramas de Harker (elementos traços) para todo o conjunto das amostras do CM. 
3) O critério utilizado para os elementos traços não é capaz de discriminar, estatisticamente, os casos 1 e 3, como foi também observado na abordagem dos elementos maiores. No entanto, comparando-se os valores de $\mathrm{r}^{2}$, e não o nivel de significância, verificamse que o caso 1 tem resultados melhores para $\mathrm{V}, \mathrm{Ba}$ e $\mathrm{Sr}$, enquanto que o caso 3 tem resultados melhores para $\mathrm{Ni}$, $\mathrm{Zr}$ e Hf. Nem os valores de $\mathrm{r}^{2}$ nem o nivel de significância são cristérios discriminatórios para os casos 1 e 3. No entanto, à semelhança do que foi observado para os elementos maiores, os níveis de significância das rochas básicas isoladamente são muito baixos, implicando na inexistência de uma única suite. Isto, por sua vez, não suporta o caso 1; ou seja, para as rochas básicas constituírem uma única suite com as intermediárias e ácidas (caso 1), elas deveriam antes constituir uma sub-suite (caso 2), o que não é indicado pelas correlações apresentadas nas tabelas 1 e 2. Sendo assim, a hipótese mais provável é que as rochas calcioalcalinas (intermediárias e ácidas) constituem uma única suite (caso 3) cujos membros básicos não estão representados.

\section{\# Discussão e Conclusões}

Os critérios estatísticos utilizados mostram que os casos 1 e 3 constituem hipóteses possíveis. No entanto, a análise qualitativa do diagrama $\mathrm{SiO}_{2} \times$ Álcalis mostra a existência de um gap relativamente extenso entre as rochas básicas e as demais, além de um trend transicional para as primeiras. Além disso, o diagrama AFM aponta para a existência de, pelo menos, dois trends distintos, um toleítico e outro calcioalcalino. Estes dois aspectos tornam pouco provável que o caso 1 (toda a população de amostras) seja uma hipótese plausível. Por outro lado, considerando-se que o caso 2 (rochas básicas isoladas) certamente engloba rochas não cogenéticas, abre-se a possibilidade de que algumas destas rochas sejam parentais para o grupo calcioalcalino, cujo comportamento resulta em bom nível de significância.

O grupo das rochas básicas, que inclui os magmas parentais potenciais, atravessa o limite dos campos alcalino/subalcalino (Fig. 91), constituindo, portanto, um trend transicional. Isto implica na possibilidade de, pelo menos, alguns magmas parentais serem transicionais, $i$. e., plotarem perto dos divisores termais (Yoder \& Tilley, 1962). A figura 95 mostra que várias das amostras básicas do CM plotam nas proximidades do divisor termal entre basaltos alcalinos (insaturados em $\mathrm{SiO}_{2}$ ) e basaltos subalcalinos (saturados ou supersaturados em $\mathrm{SiO}_{2}$ ), ou seja, perto da aresta $\mathrm{Di}$ - Ol dos diagramas triangulares. Teoricamente, os magmas transicionais podem atravessar os divisores termais, desde que sob certas condições. Por exemplo, magmas 


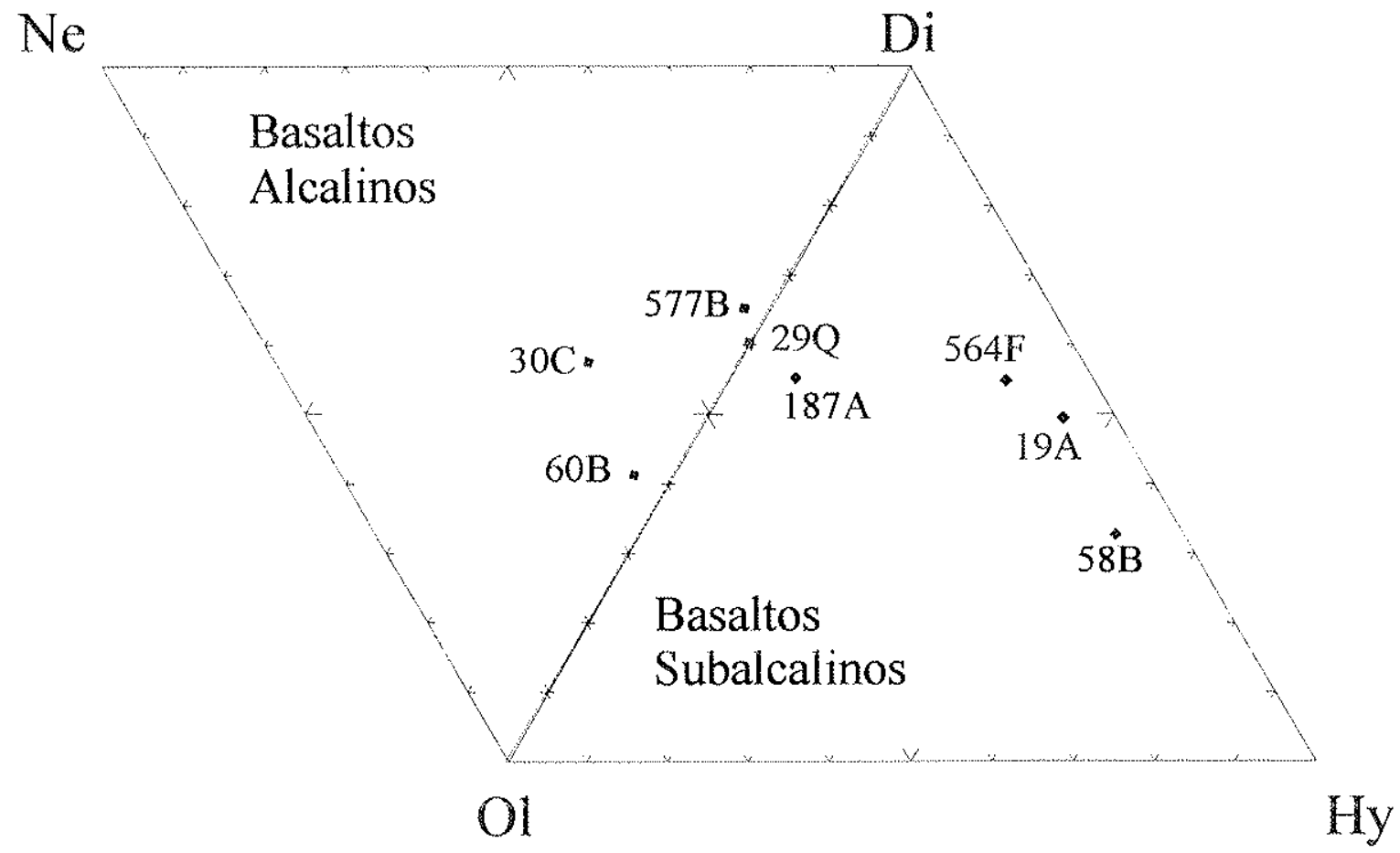

Figura 95 - Plote das amostras básicas em diagrama normativo Ne-Di-Hy-Ol 
parentais transicionais com afinidade alcalina (i. e., pouca nefelina normativa) são potencialmente capazes de evoluir para termos subalcalinos (quartzo e/ou hyperstênio normativos) pelo fracionamento cristalino de fases fortemente insaturadas em $\mathrm{SiO}_{2}$, como hornblenda ou flogopita. Isto requer pressões intermediárias (entre 5 e 20-25 $\mathrm{Kb}$ para a hornblenda e entre 5 e $35 \mathrm{~Kb}$ para a flogopita) e cristalização sob condições de alta $P_{\mathrm{H} 2 \mathrm{O}}$ (Cox et al., 1979). Normalmente, este processo leva à transição de magmas basálticos fracamente insaturados para trends evolutivos toleíticos. Entretanto, dependendo do teor em $\mathrm{Al}_{2} \mathrm{O}_{3}$ da fase fracionante, pode ser possível que a evolução se dê segundo um trend calcioalcalino. Ou seja, o fracionamento de anfibólio relativamente mais rico em $\mathrm{Al}_{2} \mathrm{O}_{3}$ tenderá a originar um trend toleíitico. Em oposição, o fracionamento de um anfibólio relativamente menos rico em $\mathrm{Al}_{2} \mathrm{O}_{3}$ tenderá a gerar líquidos derivativos relativamente mais ricos em $\mathrm{Al}_{2} \mathrm{O}_{3}$ (i.e., calcioalcalinos).

A transição toleiítico-calcioalcalino dentro do campo subalcalino parece ser mais complexa. Um magma parental toleítico (i.e., com hyperstênio normativo) requer o fracionamento de uma fase muito pobre ou destituída de $\mathrm{Al}_{2} \mathrm{O}_{3}$ (possivelmente $<\approx 3 \%$ peso) para ser capaz de gerar líquidos derivativos com os teores de $\mathrm{Al}_{2} \mathrm{O}_{3}$ característicos das suites calcioalcalinas (i.e., 16 - 20\% peso). Um candidato óbvio à fase fracionante é um óxido, cuja entrada no processo de cristalização fracionada deve depender de mudanças complexas de parâmetros de estado, possivelmente $\mathrm{fO}_{2}$.

\section{b.3) Abordagem com base nos Elementos Terras Raras}

Esta abordagem é baseada em critério petrológico que afirma que razões entre elementos incompatíveis são quase constantes dentro de um conjunto de rochas cogenéticas, i.e., dentro de uma suite magmática. A pequena variação esperada é de, no máximo 1,5 vezes o valor da razão. Foi então selecionada a razão $[\mathrm{La} / \mathrm{Yb}]_{N}$ como parâmetro de discriminação entre conjuntos de rochas cogenéticas e não cogenéticas.

Em função do grande número de amostras, a apresentação dos padrões de distribuição dos ETR foi definida em quatro diagramas (Fig. 96): a) para as rochas básicas; b) para as rochas intermediárias; c) e d) para as rochas ácidas. Acompanhando cada um destes diagrmas, estão os teores de $\mathrm{SiO}_{2}$ e $\mathrm{MgO}$ e os valores das razões $[\mathrm{La} / \mathrm{Yb}]_{\mathrm{N}}$ para cada amostra. A partir da análise dos diagramas e dos números apresentados, conclui-se que: 


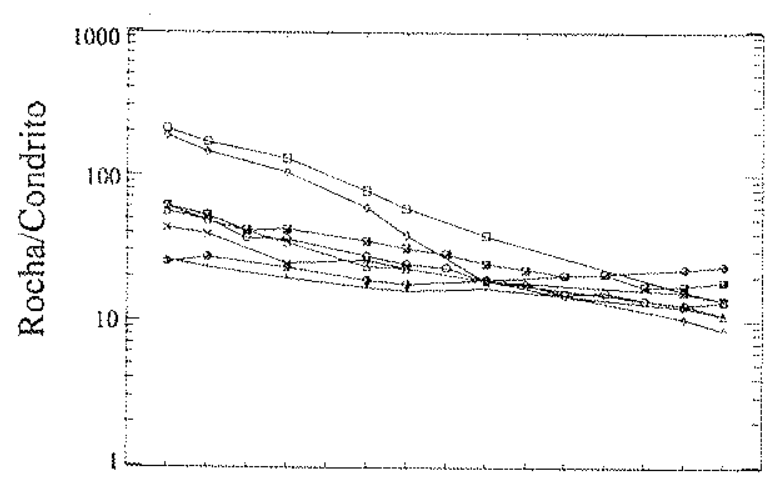

La Ce Pr Nd Pm Sm Eu Ca Tb Dy Ho Kr Tm Yb Lu

A

\begin{tabular}{|cccc|} 
Amosira & \multicolumn{1}{c}{$\mathrm{SO}_{3}$} & $\mathrm{MgO}$ & {$[\mathrm{La} / \mathrm{Yb}]_{\mathrm{N}}$} \\
$0 \mathrm{JF}-56$ & 61,02 & 3,56 & 25,45 \\
$\mathrm{JF}-25$ & 61,04 & 2,95 & 16,78 \\
$\mathrm{JF}-31$ & 62,58 & 2,03 & 30,17 \\
$\mathrm{JH}-30 \mathrm{~A}$ & 63,40 & 3.12 & 38,26 \\
$\mathrm{JF}-29$ & 63,48 & 2,99 & 6,19 \\
$\times \mathrm{JF}-29 \mathrm{~A}$ & 64,03 & 2,66 & 9,28 \\
\hline
\end{tabular}

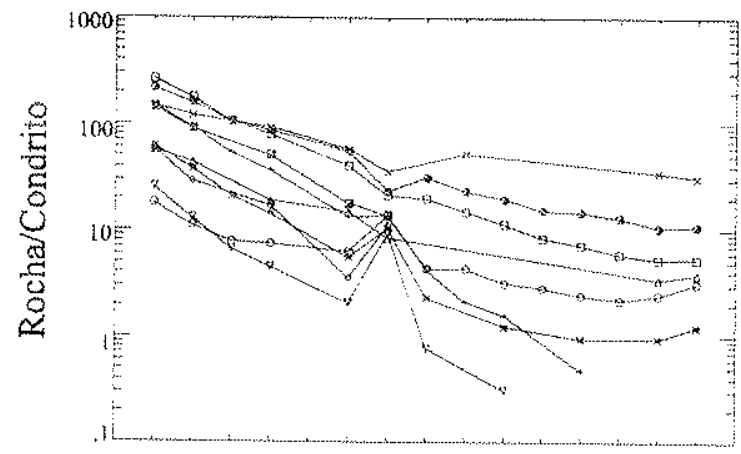

La Ce Pr No Pra Sm tu Ga to Dy Ho ter lm Yo Lu

$\mathrm{C}$

\begin{tabular}{|c|c|c|c|c|}
\hline & Amostra & $\mathrm{SiO}_{2}$ & $\mathrm{MgO}$ & $\{\text { l.a } \mathrm{Xb}]_{\mathrm{V}}$ \\
\hline 0 & $\mathrm{MB}-577 \mathrm{C}$ & 67.67 & 1.00 & 150,52 \\
\hline 7 & $H:-564 \lambda$ & 68,80 & 1,01 & 139,56 \\
\hline$\therefore$ & $J F-190 \mathrm{Al}$ & 70,29 & 0,73 & 113,10 \\
\hline$x$ & $J *-190 \mathrm{~A} 2$ & 70,10 & 0.33 & 114,28 \\
\hline$\therefore$. & $J[-190 D$ & 71,31 & 0,73 & 116,15 \\
\hline$\because$ & $J F-18913$ & 71.34 & 0,64 & \\
\hline 0 & J: -56413 & 73.30 & 0.73 & 103,15 \\
\hline
\end{tabular}

\begin{tabular}{|c|c|c|c|}
\hline Amostra & $\mathrm{SiO}$ & $\mathrm{MgO}$ & {$[1 . a / Y b]_{m}$} \\
\hline $\mathrm{MB}-577 \mathrm{~B}$ & 47.11 & 5,96 & 4.72 \\
\hline a $J F+30 C$ & 47,66 & 6.87 & 1,11 \\
\hline$\therefore$ IF - $58 \mathrm{~B}$ & 48,25 & 4.56 & 13,10 \\
\hline$\Delta \mathrm{H}-564 \mathrm{~F}$ & 48,47 & 4,76 & 3,53 \\
\hline$\therefore F-290$ & 48,77 & 6,57 & 4,37 \\
\hline$\times J F-190 C$ & $\$ 8,82$ & 5,42 & 2,78 \\
\hline * JF - 187A & 50,84 & 6,90 & 2,13 \\
\hline $\begin{array}{l}\text { JF - } 60 \mathrm{~B} \\
\text { N-Morb } \\
\text { E-Morb } \\
\text { OIB }\end{array}$ & 51,60 & 4,23 & 17,99 \\
\hline
\end{tabular}

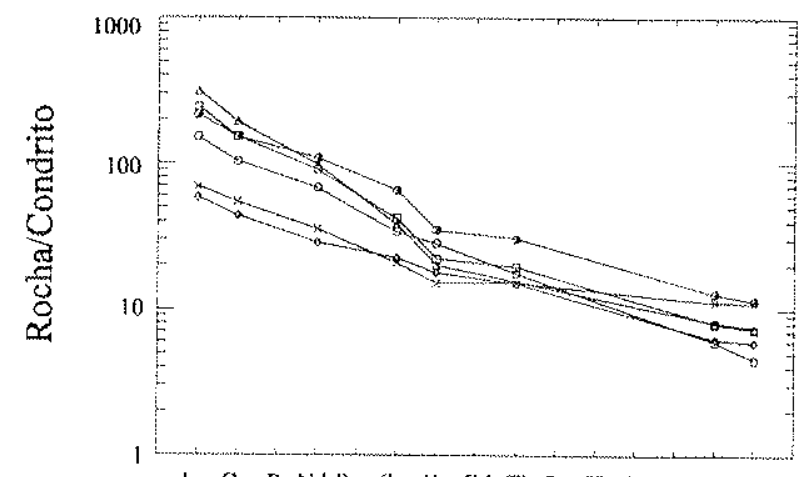

B

\begin{tabular}{|c|c|c|c|c|}
\hline & Amostra & $\mathrm{SiO}$ & $\mathrm{MgO}$ & {$[1, a / \mathrm{Yb}]_{n}$} \\
\hline 0 & $J F-j 641$ & 66.55 & 0,33 & 7,42 \\
\hline ; & $3 F+58 A$ & 68,99 & 1,43 & \\
\hline$A$ & $M B-\$ 775$ & 69,59 & 1,00 & 20,47 \\
\hline 0 & $\mathrm{MB}-577 \mathrm{E}$ & 69,63 & 0,90 & 49,83 \\
\hline$\therefore$ & $J E$ - 29P & 71.25 & 0,81 & 16,57 \\
\hline$x$ & $3 F-30 B$ & 72.60 & 0.29 & 4.35 \\
\hline - & JF $-564 t:$ & 75,23 & 6,21 & \\
\hline 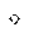 & $\mathrm{JF}-85 \mathrm{D}$ & 75,28 & 0,23 & \\
\hline$\%$ & $\mathrm{MB}-577 \mathrm{H}$ & 76,91 & 0,27 & 65,06 \\
\hline 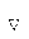 & $3 F-564 \mathrm{D}$ & 76,99 & 0,25 & \\
\hline
\end{tabular}

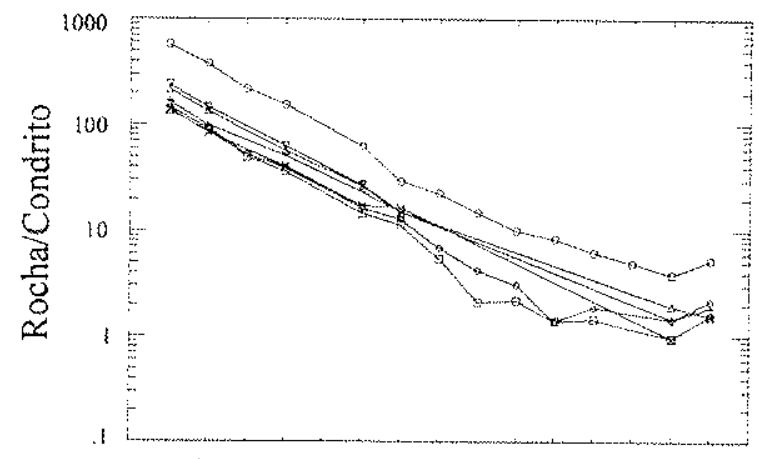

la Ce Pr Na Pm Sm ta Gd Th Dy Ho I's Tm Yb lat

D

Figura 96 - Diagramas de ETR normalizados pelo condrito de Boynton (1984) para rochas do CM.

A) Rochas Básicas; B) Rochas intermediárias; C e D) Rochas ácidas. 
a) Há grande variação nos valores de $[\mathrm{La} / \mathrm{Yb}]_{\mathrm{N}}$, tanto no conjunto das rochas básicas, quanto no das intermediárias e das ácidas. Isto mostra que é improvável que cada um destes grupos forme uma suite de rochas cogenéticas e, consequentemente, que todo o conjunto constitua uma única suite magmática. Os resultados aqui apresentados parecem, portanto, não suportar aqueles obtidos por critérios estatísticos para os eiementos maiores que indicavam boa correlação tanto para toda a população de amostras quanto para o grupo calcioalcalino.

b) Com base nas razões [La/Yb $]_{\mathrm{N}}$, foi possível identificar 8 diferentes grupos de rochas dentro do CM (Fig. 97):

b.1- razão de 1,11 - Amostra 30C;

b. 2 - razões de 2,13 e 2,78 - Amostras $187 \mathrm{~A}$ e $190 \mathrm{C}$;

b.3 - razões de 3,53 a 4,72 - Amostras 29Q, 564F e 577B;

b.4 - razões de 6,19 a 9,28 - Amostras 29A, 61A e 564I;

b.5 - razões de 13,10 a 16,78 (ou 20,47) - Amostras 29P, 29T, 58B, 60B (e 577F);

b.6 - razões de 25,45 (ou 20,47) a 38,26 - Amostras 30A, 31, 56 (e 577F);

b. 7 - razões de 49,83 e 65,06 - Amostras 577E e 577H;

b.8 - razões de 113,10 a 150,52 - Amostras 190A1, 190A2, 190D, 564A, 564B e 577C.

Apesar dos dados de ETR sinalizarem para a existência de mais de uma suite magmática, optou-se por exaurir todas as possibilidades de toda a população de amostras formar um único grupo de rochas cogenéticas. Tendo em vista que os resultados obtidos para elementos maiores, i.e., as curvas de correlação polinominais apresentam maior grau de significância do que aquelas lineares, os processos petrogenéticos possíveis são cristalização fracionada e fusão parcial. Assim, formula-se duas hipóteses:

a) Seriam as rochas do $\mathrm{CM}$ relacionadas por processo de cristalização fracionada, com mudanças significativas da assembléia fracionante?

b) Seriam as rochas do CM relacionadas por processo de fusão parcial?

Para testar estas hipóteses foram realizados modelamentos geoquímicos, como mostrado nos itens seguintes. 


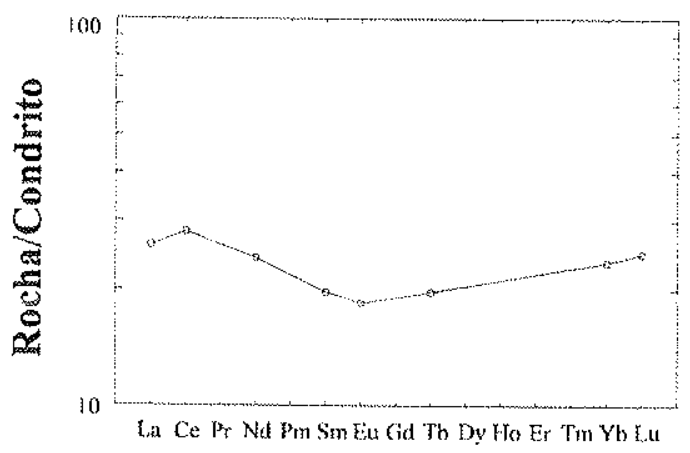

\begin{tabular}{|cccc|}
\hline Amostra & $\mathrm{SiO}_{2}$ & $\mathrm{MgO}$ & {$[\mathrm{La} / \mathrm{Yb}]_{\mathrm{N}}$} \\
$0 \mathrm{JF}-30 \mathrm{C}$ & 47,66 & 6,87 & 1,11 \\
\hline
\end{tabular}

A

\begin{tabular}{|cccc|}
\hline Amostra & $\mathrm{SiO}_{2}$ & $\mathrm{MgO}$ & {$[\mathrm{La} / \mathrm{Yb}]_{\mathrm{N}}$} \\
$\mathrm{JF} \sim 190 \mathrm{C}$ & 48,82 & 5,42 & 2,78 \\
$\square \mathrm{JF}-187 \mathrm{~A}$ & 50,84 & 6,90 & 2,13
\end{tabular}

$\mathbf{B}$
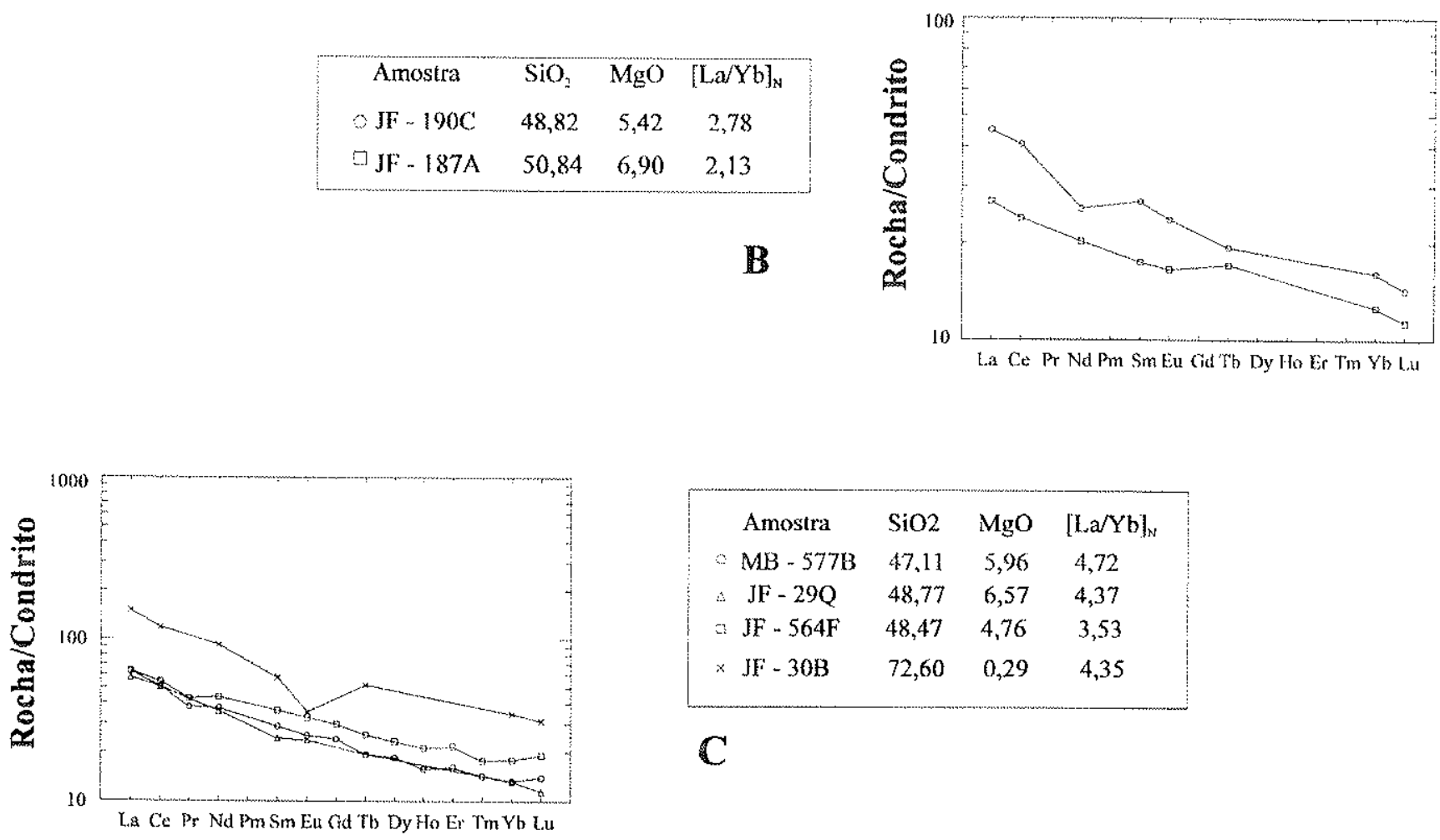

\begin{tabular}{|cccc|}
\hline Amostra & $\mathrm{SiO} 2$ & $\mathrm{MgO}$ & {$[\mathrm{La} / \mathrm{Yb}]_{\mathrm{N}}$} \\
$\mathrm{MB}-577 \mathrm{~B}$ & 47,11 & 5,96 & 4,72 \\
$\mathrm{JF}-29 \mathrm{Q}$ & 48,77 & 6,57 & 4,37 \\
$\mathrm{JF}-564 \mathrm{~F}$ & 48,47 & 4,76 & 3,53 \\
$\times \mathrm{JF}-30 \mathrm{~B}$ & 72,60 & 0,29 & 4,35 \\
\hline
\end{tabular}

C

\begin{tabular}{|cccc} 
Amostra & $\mathrm{SiO}_{2}$ & $\mathrm{MgO}$ & {$[\mathrm{La} / \mathrm{Yb}]_{\mathrm{N}}$} \\
$\mathrm{JF}-58 \mathrm{~B}$ & 48,25 & 4,56 & 13,10 \\
$\mathrm{JF}-60 \mathrm{~B}$ & 51,60 & 4,23 & 17,99 \\
$\therefore \mathrm{JF}-29 \mathrm{~T}$ & 62,58 & 2,03 & 30,17 \\
$\times \mathrm{MB}-577 \mathrm{~F}$ & 69,59 & 1,00 & 20,47 \\
\hline
\end{tabular}

D
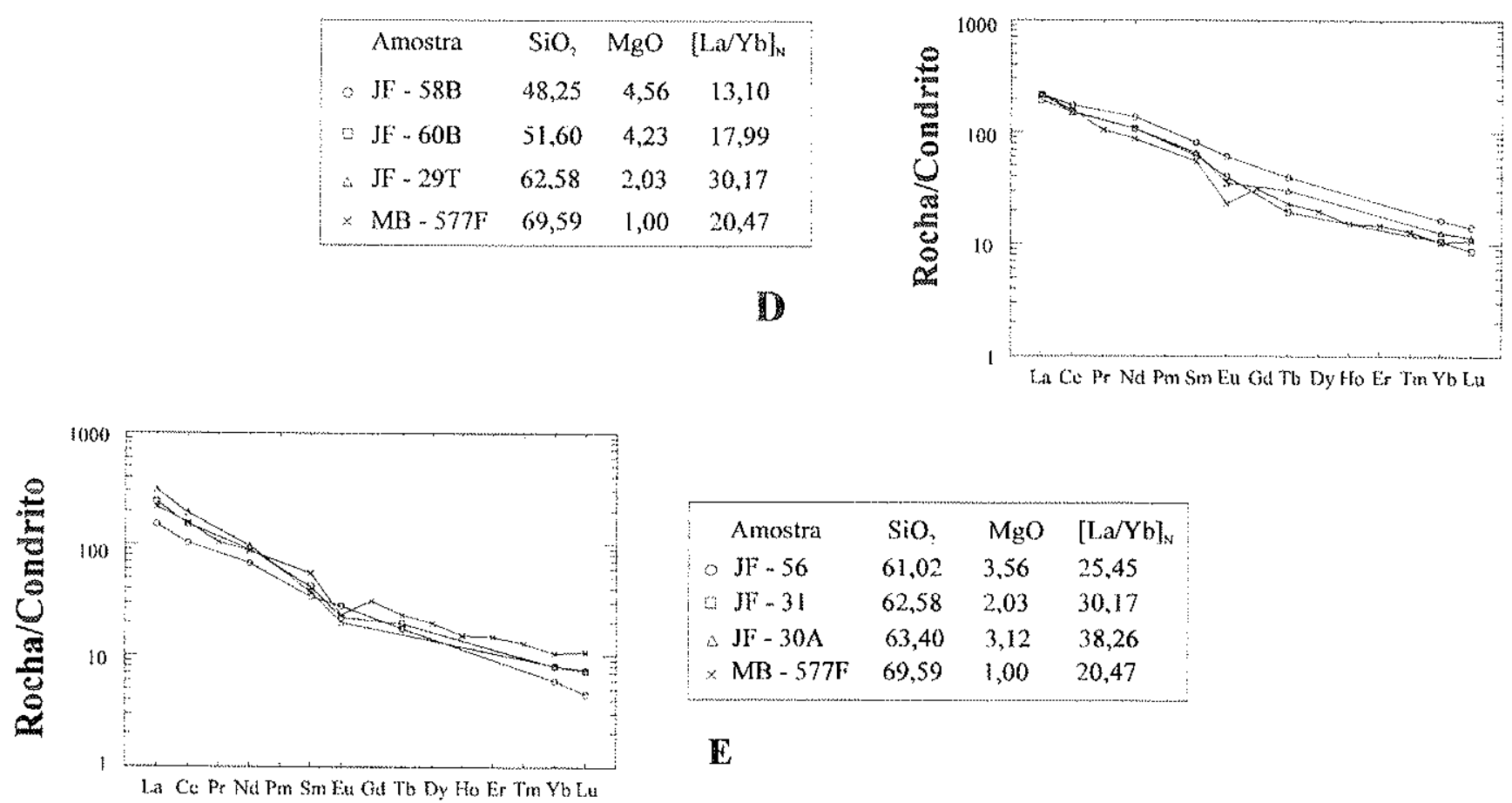

\begin{tabular}{|llll|}
\hline Amostra & $\mathrm{SiO}$, & $\mathrm{MgO}$ & {$[\mathrm{La} / \mathrm{Yb}]_{\mathrm{N}}$} \\
$\mathrm{JF}-56$ & 61,02 & 3,56 & 25,45 \\
$\mathrm{JF}-31$ & 62,58 & 2,03 & 30,17 \\
$\mathrm{JF}-30 \mathrm{~A}$ & 63,40 & 3,12 & 38,26 \\
$\times \mathrm{MB}-577 \mathrm{~F}$ & 69,59 & 1,00 & 20,47 \\
\hline
\end{tabular}

E

Figura 97 - Diagramas de ETR normalizados pelo condrito de Boynton (1984) para as rocha do $\mathrm{CM}$. Agrupamentos segundo as razôes $(\mathrm{La} / \mathrm{Yb})_{\mathrm{N}}$ 


\section{c) Modelamento de Quantitativo do Processo Petrogenético por Cristalização Fracionada.}

A hipótese de que toda a população de amostras do CM possa constituir uma única suite magmática será modelada com base na equação de Rayleigh. O modelamento implica em que cristais são efetivamente separados do líquido. Procedeu-se, assim, ao modelamento petrogenético com base nos ETR de forma a envolver todo o conjunto de rochas do CM. Dada a inconveniência de se trabalhar com todas as amostras, foram selecionadas amostras representativas dos termos básicos, intermediários e ácidos do grupo. Este procedimento vem reforçar a existência de um gap, correspondente a mais de $10 \% \mathrm{SiO} 2$ que será, a princípio, considerado como resultante de problemas na amostragem. A seleção das amostras básicas (577B e 564F), em busca de magmas parentais potenciais (e liquidos derivativos mais evoluídos) se baseou em duas características principais: teores mais baixos e mais altos, respectivamente, em $\mathrm{SiO} 2$ e $\mathrm{MgO}$; e carater transicional da amostra básica (Fig. 95), reportando-se à hipótese e discussão apresentadas nos itens anteriores. A escolha dos termos intermediários e ácidos foi feita com base em suas abundâncias decrescentes de $\mathrm{MgO}$ e, tanto quanto possível, crescentes de ETR (principalmente leves). A figura 98 mostra os padrões de ETR das amostras selecionadas.

Para o modelamento da primeira etapa de fracionamento, do magma parental potencial (577B) para o líquido derivativo potencial (564F), as fases minerais consideradas mais adequadas foram olivina, plagioclásio, clinopiroxênio, ortopiroxênio e magnetita. Esta escolha se deu com base na composição normativa das amostras envolvidas (Apêndice 5), o que permite classificá-las como olivina toleítos. O modelamento obteve sucesso com $27 \%$ de fracionamento de uma assembléia constituída de: olivina $(70 \%)$; plagioclásio (15\%); e magnetita (15\%) (tabela 46).

Tabela 46 - Percentual em volume das fases fracionadas utilizado no modelamento do processo de cristalização fracionada - 27\% de Fracionamento - Modelo 1 (5778 564F).

\begin{tabular}{|l|c|}
\hline Fases Minerais Fracionadas & Percentual em Volume \\
\hline Olivina & $70 \%$ \\
\hline Plagioclásio & $15 \%$ \\
\hline Magnetita & $15 \%$ \\
\hline
\end{tabular}




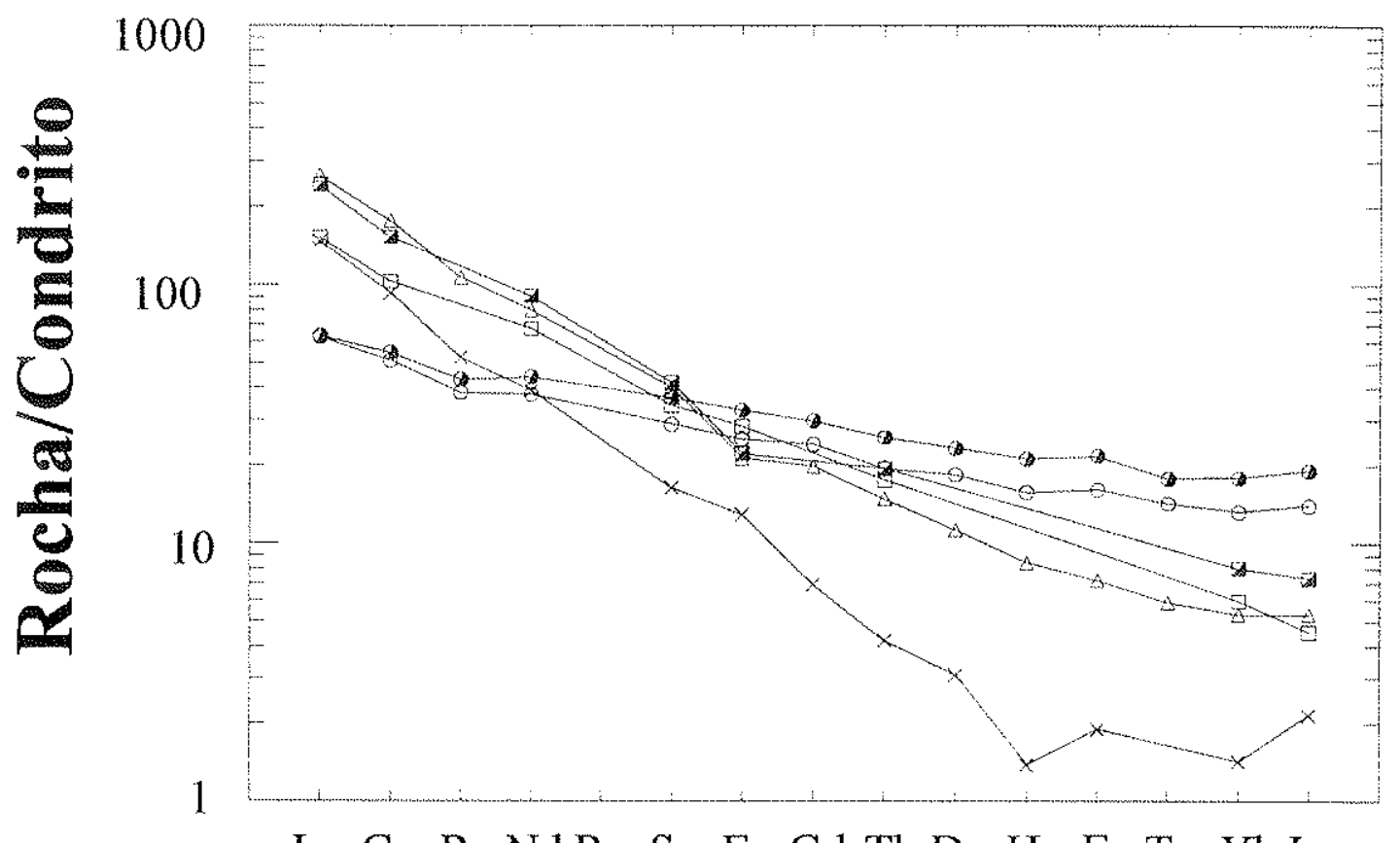

La Ce Pr Nd Pm Sm Eu Gd Tb Dy Ho Er Tm Yb Lu

\begin{tabular}{|cccc|} 
Amostra & $\mathrm{SiO}_{2}$ & $\mathrm{MgO}$ & {$[\mathrm{La} / \mathrm{Yb}]_{\mathrm{N}}$} \\
$\mathrm{MB}-577 \mathrm{~B}$ & 47,11 & 5,96 & 4,72 \\
$\mathrm{JF}-564 \mathrm{~F}$ & 48,47 & 4,76 & 3,53 \\
$-\mathrm{JF}-56$ & 61,02 & 3,56 & 25,45 \\
$\mathrm{JF}-31$ & 62,58 & 2,03 & 30,17 \\
$\mathrm{AB}-577 \mathrm{E}$ & 69,63 & 0,90 & 49,83 \\
$\times \mathrm{JF}-564 \mathrm{~B}$ & 73,30 & 0,73 & 103,15 \\
\hline
\end{tabular}

Figura 98 - Padrões de ETR para as amostras do CM selecionadas para o modelamento de cristalização fracionada. 
Os coeficientes de partição mineral/líquido utilizados são apresentados na tabela 47 . $O$ diagrama da figura 99 mostra os padrões de ETR para os três termos do modelamento: magma parental potencial, líquido derivativo potencial e líquido derivativo modelado. Podewse verificar a boa semelhança existente entre os dois últimos termos.

\section{Tabela 47 - Coeficientes de partição mineral/líquido $\left(K_{d}\right)$ utilizados no modelamento do processo de cristalização fracionada - Modelo $1(577 \mathrm{~B}-564 \mathrm{~F})$.}

\begin{tabular}{|l|c|c|c|c|c|c|c|}
\hline $\mathrm{K}_{\mathrm{d}}$ & $\mathrm{La}$ & $\mathrm{Ce}$ & $\mathrm{Nd}$ & $\mathrm{Sm}$ & $\mathrm{Eu}$ & $\mathrm{Yb}$ & $\mathrm{Lu}$ \\
\hline $\mathrm{Ol}$ & $0,0067^{1}$ & $0,0069^{2}$ & $0,0066^{2}$ & $0,0066^{2}$ & $0,0068^{2}$ & $0,0014^{2}$ & $0,0016^{2}$ \\
\hline $\mathrm{Plg}$ & $0,1900^{1}$ & $0,1200^{2}$ & $0,0810^{2}$ & $0,0670^{2}$ & $0,3400^{2}$ & $0,0670^{2}$ & $0,0600^{2}$ \\
\hline $\mathrm{Mgt}$ & $3,0000^{3}$ & $3,0000^{3}$ & $2,5000^{3}$ & $1,1000^{3}$ & $0,6000^{3}$ & $0,9000^{3}$ & $0,9000^{3}$ \\
\hline
\end{tabular}

1 - líquido basáltico (Fujikami et al. 1984);

2 - liqudo basáltico, compilação de Arth (1976);

3 - líquido basáltico; Lu assume o mesmo valor que Yb (Schock 1979).

A segunda etapa no modelamento da cristalização fracionada, do líquido $564 \mathrm{~F}$ para o derivativo 56, deve levar em consideração os parâmetros que permitem um magma de carater transicional e afinidade alcalina gerar líquidos calcioalcalinos. A condição para que isso ocorra é o fracionamento de uma ou mais fases minerais insaturadas em $\mathrm{SiO}_{2}$ e também relativamente pobres em $\mathrm{Al}_{2} \mathrm{O}_{3}$. $\mathrm{O}$ mineral que mais se adequa a estas características é o anfibólio, particularmente uma hornblenda. Além disso, comparando-se os padrões de distribuição dos ETR das amostras 577B, 564F e 56 (Fig. 98), faz-se necessário considerar uma mudança na assembléia fracionante, já que o valor da razão $[\mathrm{La} / \mathrm{Yb}]_{N}$ varia de $\approx 4$ (amostras 577B e 564F) para 25,45 (amostra 56). Esta variação indica que a nova assembléia fracionante deve ser capaz de retirar muito mais os ETR pesados do que os leves, o que é uma característica da hornblenda e, portanto, qualitativamente, suporta a hipótese considerada. Assim, o procedimento realizado levou em conta combinações entre as fases da assembléia considerada na primeira etapa (olivina, plagioclásio e magnetita) adicionada de hornblenda. Os resultados obtidos não foram satisfatórios para qualquer assembléia em qualquer quantidade de cristalização fracionada (desde $5 \%$ a $>70 \%$ ). Nem mesmo para uma assembléia constituída de $100 \%$ de hornblenda foi possivel atingir-se o elevado grau de fracionamento observado para a amostra 56 (Fig. 100 e tab. 48). Portanto, além da hornblenda, cujo $[\mathrm{La} / \mathrm{Yb}]_{\mathrm{N}} \approx 0,124$, era necessário considerar uma fase que tivesse a razão $[\mathrm{La} / \mathrm{Yb}]_{\mathrm{N}}$ ainda mais baixa. A granada $\left([\mathrm{La} / \mathrm{Yb}]_{\mathrm{N}} \approx 0.017\right)$ seria, então, a fase mineral mais adequada nesta abordagem. Cabe lembrar que a hipótese em teste requer o fracionamento de hornblenda. Entretanto, para quaisquer 
percentuais de fracionamento considerados, uma assembléia constituída de hornblenda e granada, em qualquer proporção, não é capaz de explicar a variação nos padrões ETR das amostras em questão. Nem mesmo uma assembléia constituída de $100 \%$ de granada teria uma razão $[\mathrm{La} / \mathrm{Yb}]_{\mathrm{N}}$ satisfatória (Fig. 101 e Tab.48).

Tabela 48 - Coeficientes de partição mineral/liquido $\left(K_{d}\right)$ utilizados no modelamento do processo de cristalização fracionada - Modelo 1 (564F - 56)

\begin{tabular}{|l|c|c|c|c|c|c|c|}
\hline $\mathrm{K}_{\mathrm{d}}$ & $\mathrm{La}$ & $\mathrm{Ce}$ & $\mathrm{Nd}$ & $\mathrm{Sm}$ & $\mathrm{Eu}$ & $\mathrm{Yb}$ & $\mathrm{Lu}$ \\
\hline $\mathrm{Hbl}^{1}$ & 0,2000 & 0,2000 & 0,3300 & 0,1020 & 0,4000 & 0,4900 & 0,4300 \\
\hline $\mathrm{Grt}^{2}$ & 0,0010 & 0,0070 & 0,0260 & 0,1020 & 0,2430 & 6,1670 & 6,9500 \\
\hline
\end{tabular}

1 - líquido basáltico (Arth, 1976);

2 - média de líquidos basálticos (Irving \& Frey, 1978).

A partir das figuras 91 e 95, verifica-se que a amostra 60B, de afinidade alcalina, tem carater transicional e pode ser também avaliada como possível magma parental para a sequência de rochas calcioalcalinas. Assim, para testar esta hipótese, realizou-se modelamento por cristalização fracionada, tendo ainda como líquido derivativo potencial a amostra 56 . A figura 102 mostra os padrões de ETR destas duas amostras, juntamente com os valores de $[\mathrm{La} / \mathrm{Yb}]_{\mathrm{N}}(17,99$ para a amostra $60 \mathrm{~B}$ e 25,45 para a amostra 56$)$. Verifica-se, a partir deste diagrama, que a assembléia fracionante deve ser capaz de retirar mais ETR pesados do que leves. Como a possibilidade de um magma transicional de afinidade alcalina atravessar o divisor termal está atrelada à participação de hornblenda no fracionamento, qualquer assembléia fracionante considerada deve envolver a presença deste mineral. Foram então empreendidos testes com diversas assembléias, constituídas de um ou mais das fases seguintes: hornblenda, olivina, clinopiroxênio, ortopiroxênio, plagioclásio, granada e magnetita. Entretanto, os resultados obtidos neste modelamento não são adequados, tendo em vista os coeficientes de partição mineral/líquido disponíveis na literatura.

A partir do que foi apresentado, pode-se concluir que:

a) Os basaltos transicionais 577B e 60B não podem ser considerados magmas parentais para as rochas calcioalcalinas mais evoluídas do $\mathrm{CM}$;

b) A hipótese de que todo a população de amostras constitua uma única série magmática relacionada por cristalização fracionada é extremamente desfavorecida pelos modelamentos realizados. 


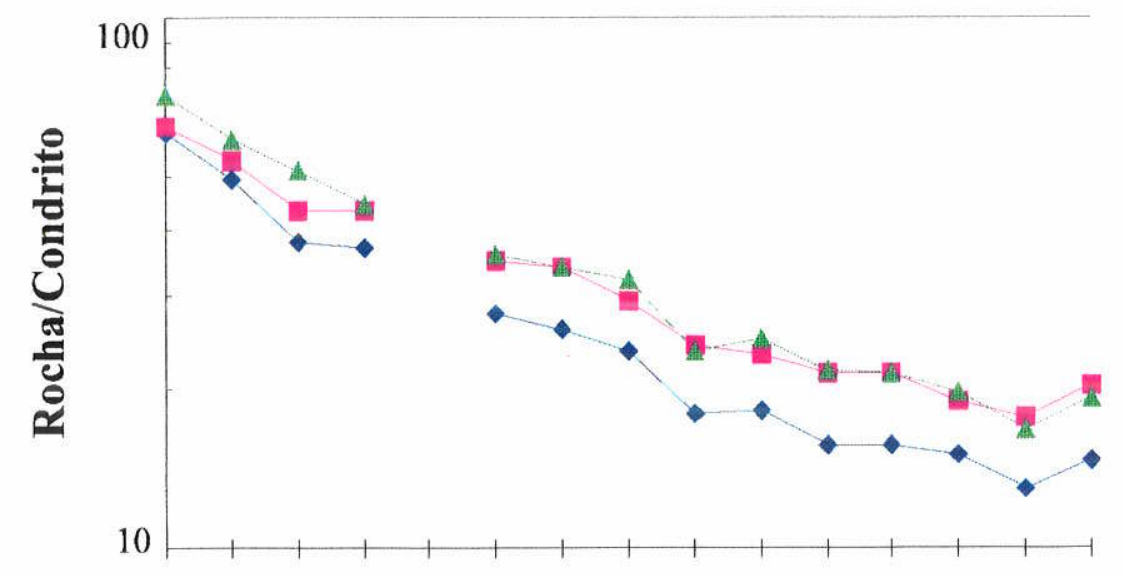

- Magma parental potencial (MB - 577B)

- Líquido derivativo potencial (JF - 564F)

A Líquido derivativo modelado

La Ce Pr Nd Pm Sm Eu Gd Tb Dy Ho Er Tm Yb Lu

Figura 99 - Padrões de ETR para os três termos do modelamento de cristalização fracionada.

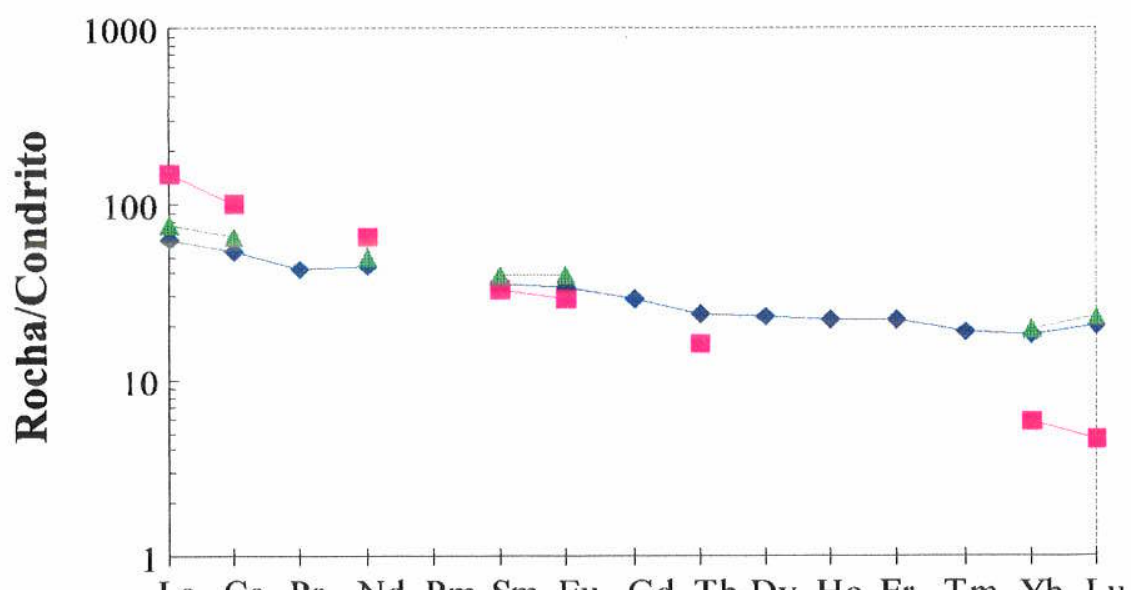

- Magma parental potencial (JF - 564F)

- Líquido derivativo potencial (JF - 56)

« Líquido derivativo modelado (para $100 \% \mathrm{Hbl}$ )

La Ce Pr Nd Pm Sm Eu Gd Tb Dy Ho Er Tm Yb Lu

Figura 100 - Padrões de ETR para os três termos do modelamento de cristalização fracionada considerando um fracionamento de $100 \%$ de hornblenda.

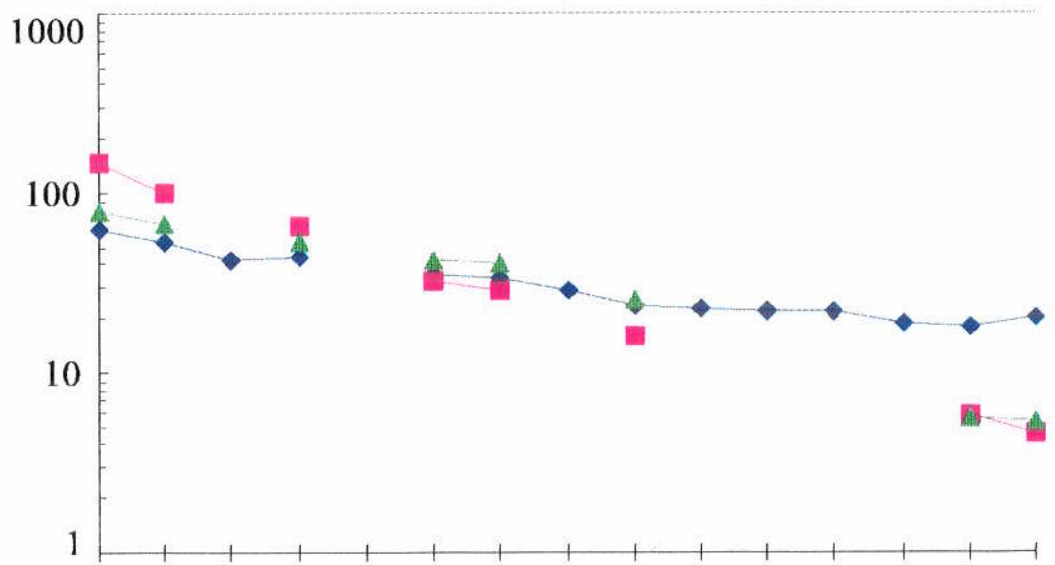

- Magma parental potencial (JF - 564F)

- Líquido derivativo potencial (JF - 56)

4. Líquido derivativo modelado (para $100 \%$ Grt)

La $\mathrm{Ce} P$ Pr Nd Pm Sm Eu Gd Tb Dy Ho Er Tm Yb Lu

Figura 101 - Padrões de ETR para os três termos do modelamento de cristalização fracionada considerando um fracionamento de $100 \%$ de granada. 


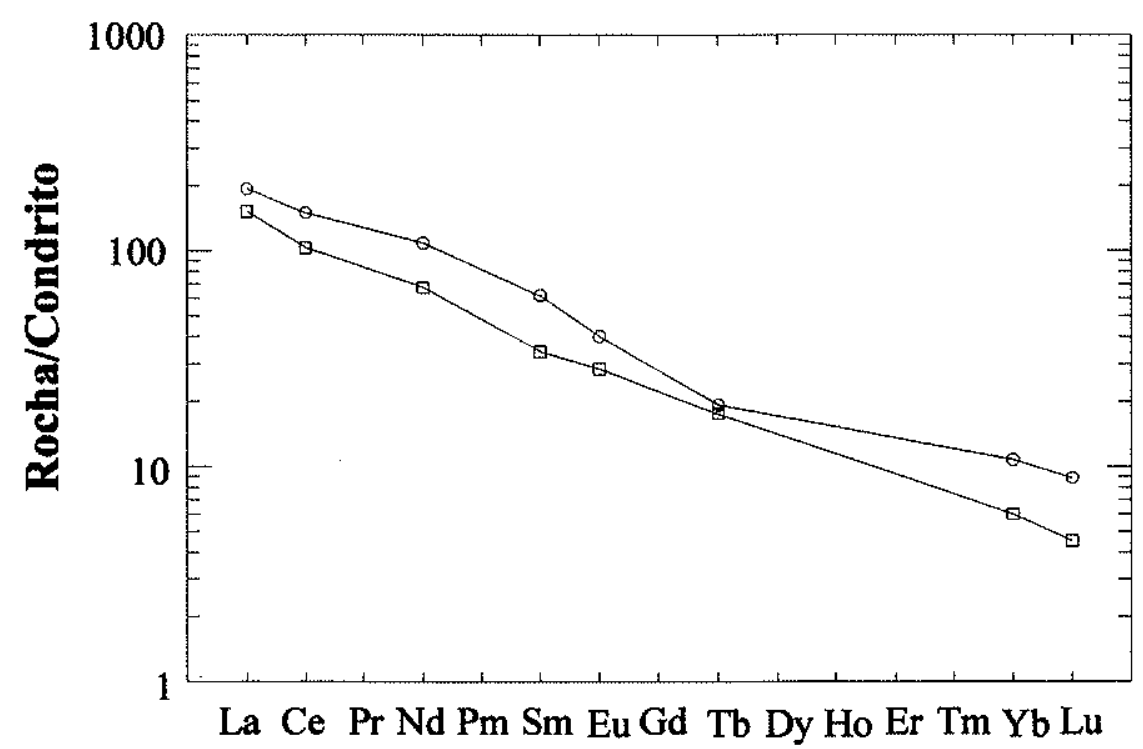

\begin{tabular}{|cccc|}
\hline Amostra & $\mathrm{SiO}_{2}$ & $\mathrm{MgO}$ & {$[\mathrm{La} / \mathrm{Yb}]_{\mathrm{N}}$} \\
$\mathrm{JF}-60 \mathrm{~B}$ & 51,60 & 4,23 & 17,99 \\
$\square \mathrm{JF}-56$ & 61,02 & 3,56 & 25,45 \\
\hline
\end{tabular}

Figura 102 - Padrões de ETR para amostra de afinidade alcalina transicional e de possível líquido derivativo potencial por cristalização fracionada. 
Assim, é possível que processo mais complexo tenha atuado na petrogênese destas rochas, como, por exemplo, aqueles que envolvem a geração de líquidos derivativos calcioalcalinos a partir de.magmas parentais básicos toleiíticos. Entretanto, o teste desta hipótese mais complexa depende de dados da petrologia experimental envolvendo parâmetros como $\mathrm{fO}_{2}$, ainda não amplamente disponíveis na literatura, estando, portanto, fora do escopo da tese.

Retomando os resultados produzidos a partir do tratamento estatístico para os elementos maiores e traços (item b.2), verifica-se que o grau de significância obtido para o grupo calcioalcalino é igual àquele obtido para toda a população de amostras do CM (Tabs. 44 e 45). Torna-se, então, importante testar a hipótese do grupo calcioalcalino constituir uma única suite magmática. Considerando que este grupo não tem rochas básicas que pudessem representar magmas parentais potenciais, o processo petrogenético mais adequado parece ser o de fusão parcial crustal. Sendo assim, o item seguinte abordará o teste desta hipótese.

\section{d) Modelamento de Fusão Parcial}

\section{d.1) Modelamento da Fonte para as Rochas Ácidas}

Existem dois modelos ideais principais (ou dois modelos extremos) que traduzem o processo de fusão parcial:

a) Fusão parcial em equilíbrio (Batch Melting): neste modelo, a fusão formada reage continuamente e equilibra com o resíduo cristalino até o momento da segregação. Até este momento, a composição total do sistema permanece constante.

b) Fusão parcial fracionada (Fusão de Rayleigh): neste modelo, a fusão é continuamente removida do sistema assim que é formada, de forma a não ocorrer reação com o resíduo cristalino. Para este tipo de fusão parcial, a composição total do sistema se modifica continuamente.

Estes modelos foram idealizados para a fusão do manto, a partir de petrologia experimental com o uso de amostras naturais (p. ex.: xenólitos ultramáficos) e/ou de sólidos sintéticos (p. ex.: Green \& Ringwood, 1967; Kushiro, 1972). Os xenólitos ultramáficos indicam que o manto tem composição lherzolítica, ou seja, é constituído, idealmente, de quatro 
fases: olivina, ortopiroxênio, clinopiroxênio e uma fase aluminosa que, dependendo da pressão, pode ser plagioclásio, espinélio ou granada. Na natureza, o parâmetro de mais dificil controle é o que se refere à abilidade da fusão recém-fromada separar dos cristais residuais. Isto irá depender da permeabilidade do manto parcialmente fundido, parâmetro este que varia com o ambiente tectônico e com o grau de fusão parcial. Assim, parece que na natureza, o processo inicial é o de fusão em equilíbrio até que o manto adquira um grau de permeabilidade suficiente para que a fusão possa ser continuamente segregada do resíduo. Isto mostra o caso destes dois modelos representarem termos extremos no processo de fusão parcial que ocorre na natureza.

A maioria dos experimentos foi realizada sob condições de $P=1$ atm e $P_{\mathrm{H} 20}=0$. Poucos experimentos consideraram condições mais altas de $\mathrm{P}$ e $\mathrm{P}_{\mathrm{H} 20}$, já que existem evidências de que o manto tem porções (presença de flogopita ou anfibólio em kimberlitos e xenólitos ultramáficos, dados de geofísica e também dados advindos da petrologia experimental).

Experimentos realizados também para o manto mostraram que a composição de elementos maiores da fusão é insensível ao tipo de processo de fusão parcial considerado (Wilson, 1989; p. 59-63). No entanto, as concentrações de elementos traços podem variar consideravelmente durante o processo de fusão parcial Modelos simples foram desenvolvidos para quantificar as mudanças nas concentrações dos elementos traços durante a fusão parcial. Deve ser ressaltado que estes modelos basearam-se em premissas ideais e que os resultados devem ser interpretados como uma aproximação grosseira do que realmente ocorre na natureza. Por outro lado, este modelos ilustram bem os princípios básicos e as limitações em se considrar processos igneos simples.

No caso de fusão parcial em equilíbrio, a concentração de um elemento traço no líquido, $C_{\mathrm{L}}$, é relacionada àquela no sólido original, $C_{0}$, pela seguinte equação:

$$
C_{L}=\frac{1}{C_{\theta} F+D-F D}
$$

onde $\mathrm{D}=\Sigma_{\alpha} X_{\alpha} D_{\alpha}$ e $X_{\alpha}$ é a fração em peso da fase $\alpha$ na assembléia mineral e $D_{\alpha}$ é seu coeficiente de partição mineral/líquido. $F$ é a fração em peso da fusão formada e $D$ é o coeficiente de partição total para os sólidos residuais no momento em que a fusão é removida 
do sistema. Com o aumento do grau de fusão parcial, minerais distintos podem ser progressivamente consumidos, causando mudanças descontínuas no valor de $D$.

Tanto para fusão parcial em equilibrio quanto para a fusão de Rayleigh, as proporções das fases que entram na fusão podem ser iguais ou diferentes daquelas da rocha original. Estes dois casos são denominados, respectivamente, fusão modal e fusão não modal. Entretanto, para elementos altamente icompatíveis como, por exemplo, os ETR, as equações modais e não modais (ver Wilson, 1989, p. 63) fornecem essencialmente resultados iguais e, para simplificar, as equações modais podem ser usadas mesmo que o processo tenha sido não modal, como determinado pelos experimentos em sistemas ternários e quaternários (Wilson, 1989)

Processo de fusão fracionada perfeito é fisicamente irreal e, então, as equações para fusão modal em equilíbrio são provavelmente as mais úteis para fins de cálculos.

O modelamento ora proposto requer a geração de magmas mais intermediários e ácidos e, portanto, deve envolver maior participação de fusão crustal e não mantélica. Entretanto, os mesmos modelos de fusão parcial aplicados para a fusão do manto têm sido utilizados para a fusão crustal. Obviamente, grandes diferenças serão observadas na composição do resíduo e da fusão.

Com base no que foi exposto, decidui-se utilizar as equações do processo de fusão parcial modal em equilíbrio para modelar a fusão parcial de magmas parentais às rochas intermediárias e ácidas do $\mathrm{CM}$.

Para este procedimento, foram, primeiramente, selecionadas possíveis fontes para as rochas calcioalcalinas. Além de estimativas da composição da crosta continetal disponíveis na literatura, as rochas intermediárias do $\mathrm{CM}$ foram também testadas como possíveis fontes para as rochas ácidas. A composição de todas as fontes potencias está apresentada na tabela 49. 
Tabela 49 - Composição de ETR de fontes potenciais para as rochas ácidas do Complexo Mantiqueira.

\begin{tabular}{|l|c|c|c|c|c|c|c|c|c|}
\hline ETR & $\begin{array}{l}\text { Crosta Cont. } \\
\text { Tayior \& } \\
\text { Mc Leman } \\
(1981)\end{array}$ & $\begin{array}{l}\text { Crosta Sup. } \\
\text { Taylor \& } \\
\text { Mc Lennan } \\
(1981)\end{array}$ & $\begin{array}{l}\text { Crosta Inf. } \\
\text { Taylor \& } \\
\text { Mc Lennan } \\
(1981)\end{array}$ & $\begin{array}{l}\text { Crosta Cont. } \\
\text { Weaver } \\
\text { Tamey } \\
(1984)\end{array}$ & $\begin{array}{l}\text { Crosta Sup. } \\
\text { Weaver \& } \\
\text { Tamney } \\
(1984)\end{array}$ & $\begin{array}{l}\text { Crosta Inf } \\
\text { Weaver \& } \\
\text { Tamey } \\
(1984)\end{array}$ & $\begin{array}{l}\text { Crosta } \\
\text { Cont } \\
\text { Rudnick } \\
(1995)\end{array}$ & $\begin{array}{l}\text { Int1 } 1_{M} \\
\text { Int2 }\end{array}$ & \\
\hline $\mathrm{La}$ & 16,00 & 30,00 & 11,00 & 28,00 & 36,00 & 22,00 & 18,00 & 19,50 & 69,83 \\
\hline $\mathrm{Ce}$ & 33,00 & 64,00 & 23,00 & 57,00 & 69,00 & 44,00 & 42,00 & 39,00 & 118,25 \\
\hline $\mathrm{Pr}$ & 3,90 & 7,10 & 2,80 & & & & 5,00 & & \\
\hline $\mathrm{Nd}$ & 16,00 & 26,00 & 12,70 & 23,00 & 30,00 & 18,50 & 20,00 & 19,00 & 53,25 \\
\hline $\mathrm{Sm}$ & 3,50 & 4,50 & 3,17 & 4,10 & 4,40 & 3,30 & 3,90 & 4,18 & 8,55 \\
\hline $\mathrm{Eu}$ & 1,10 & 0,88 & 1,17 & & 1,09 & & 1,20 & 1,20 & 1,89 \\
\hline $\mathrm{Gd}$ & 3,30 & 3,80 & 3,13 & & & & 3,60 & & \\
\hline $\mathrm{Tb}$ & 0,60 & 0,64 & 0,59 & 0,24 & 0,41 & 0,43 & 0,56 & 0,70 & \\
\hline $\mathrm{Dy}$ & 3,70 & 3,50 & 3,60 & & & & 3,50 & & \\
\hline $\mathrm{Ho}$ & 0,78 & 0,80 & 0,77 & & & & 0,76 & & \\
\hline $\mathrm{Er}$ & 2,20 & 2,30 & 2,20 & & & & 2,20 & & \\
\hline $\mathrm{Tm}$ & 0,32 & 0,33 & 0,32 & 0,24 & 0,14 & 0,19 & & & \\
\hline $\mathrm{Yb}$ & 2,20 & 2,20 & 2,20 & 1,53 & 0,76 & 1,20 & 2,00 & 1,80 & 1,78 \\
\hline $\mathrm{Lu}$ & 0,30 & 0,32 & 0,29 & & & & 0,33 & 0,27 & 0,24 \\
\hline
\end{tabular}

Como exposto anteriormente, parecem existir dois conjuntos distintos de rochas intermediárias e de rochas ácidas:

a) Rochas intermediárias com $[\mathrm{La} / \mathrm{Yb}]_{N}$ entre $\approx 6$ e 9;

b) Rochas intermediárias com $[\mathrm{La} / \mathrm{Yb}]_{\mathrm{N}}$ entre $\approx 20$ e 38 ;

c) Rochas ácidas com $[\mathrm{La} / \mathrm{Yb}]_{\mathrm{N}}$ entre $\approx 4$ e 65 ; e

d) Rochas ácidas com $[\mathrm{La} / \mathrm{Yb}]_{\mathrm{N}}>100$.

Sendo assim, foi formulada as seguintes hipóteses:

1) Seriam as rochas intermediárias menos fracionadas fontes para aquelas ácidas também menos fracionadas?;

2) Seriam as rochas intermediárias mais fracionadas fontes para aquelas ácidas também mais fracionadas?

Para testar estas hipóteses foram, primeiramente, calculadas as médias da composição de ETR de cada um destes quatro conjuntos, como mostra a tabela 50. Além disso, para cada conjunto de rocha fonte potencial é apresentada a composição mineralógica (tab. 51), para direcionar a procura da composição modal do resíduo e, consequentemente, dos coeficientes de partição mineral/líquido. 
Tabela 50 - Composição média de ETR dos seguintes conjuntos de rochas do Complexo Mantiqueira: rochas intermediárias com $[\mathrm{La} / \mathrm{Yb}]_{N} \approx 6-9$; rochas intermediárias com $[\mathrm{La} / \mathrm{Yb}]_{N} \approx 20$ - 38; rochas ácidas com $[\mathrm{La} / \mathrm{Yb}]_{N} \approx 4$ - 65; e rochas ácidas com $[\mathrm{La} / \mathrm{Yb}]_{N}>100$.

\begin{tabular}{|l|c|c|c|c|}
\hline ETR & $\begin{array}{c}\text { Int } 1_{\mathrm{M}} \\
{[\mathrm{La} / \mathrm{Yb}]_{\mathrm{N}} \approx 6-9}\end{array}$ & $\begin{array}{c}\text { Int } 2_{\mathrm{M}} \\
{[\mathrm{La} / \mathrm{Yb}]_{\mathrm{N}} \approx 20-38}\end{array}$ & $\begin{array}{c}\text { Ácidas } 1_{\mathrm{M}} \\
{[\mathrm{La} / \mathrm{Yb}]_{\mathrm{N}} \approx 4-65}\end{array}$ & $\begin{array}{c}\text { Ácidas } 2_{\mathrm{M}} \\
{[\mathrm{La} / \mathrm{Yb}]_{\mathrm{N}}>100}\end{array}$ \\
\hline $\mathrm{La}$ & 19,50 & 69,83 & 39,84 & 71,63 \\
\hline $\mathrm{Ce}$ & 39,00 & 118,25 & 72,41 & 117,29 \\
\hline $\mathrm{Nd}$ & 19,00 & 53,25 & 29,66 & 37,51 \\
\hline $\mathrm{Sm}$ & 4,18 & 8,55 & 5,44 & 5,21 \\
\hline $\mathrm{Eu}$ & 1,20 & 1,89 & 1,30 & 1,20 \\
\hline $\mathrm{Yb}$ & 1,80 & 1,78 & 1,67 & 0,31 \\
\hline $\mathrm{Lu}$ & 0,27 & 0,24 & 0,25 & 0,06 \\
\hline
\end{tabular}

Tabela 51 - Composição mineralógica das rochas fontes potenciais (rochas intermediárias do Complexo Mantiqueira).

\begin{tabular}{|l|c|c|}
\hline Minerais (\% volume) & Int $1_{M}$ & Int $2_{M}$ \\
\hline Plagioclásio & $30-50$ & $50-60$ \\
\hline K-feldspato & $<1-2$ & $1-6$ \\
\hline Quartzo & $5-6$ & $5-16$ \\
\hline Homblenda & $40-60$ & $2-25$ \\
\hline Biotita & $5-8$ & $7-18$ \\
\hline Clinopiroxênio & $2-4$ & \\
\hline Ortopiroxênio & $\approx 4$ & \\
\hline Mineral Opaco & $2-7$ & $<1$ \\
\hline Apatita & $<1$ & $<1$ \\
\hline Titanita & $<1$ & $<1$ \\
\hline
\end{tabular}

Os resultados obtidos com o modelamento da hipótese 1, i.e., das rochas intermediárias com $[\mathrm{La} / \mathrm{Yb}]_{\mathrm{N}}$ entre 6 e 9 serem fontes para as rochas ácidas com $[\mathrm{La} / \mathrm{Yb}]_{\mathrm{N}}$ entre 4 e 65 , são apresentados no diagrama da figura 103. Cabe aqui ressaltar algumas características do teste realizado e, consequentemente, do diagrama então gerado. Ao contrário de se modelar a fusão $\left(\mathrm{C}_{\mathrm{L}}\right)$, optou-se por fixar a composição da fase líquida e modelar possíveis fontes $\left(\mathrm{C}_{0}\right) \mathrm{em}$ determinados percentuais de fusão parcial. Sendo assim, o gráfico da figura 103 apresenta várias curvas para variados graus de fusão. Ao invés destas curvas representarem a composição da fusão, elas representam composições de fontes potenciais para o conjunto ácido, também representado no diagrama por sua média. Assim, cada curva deve ser traduzida da seguinte maneira: por exemplo, a curva de $0,5 \%$ representa a composição de uma fonte que, por processo de fusão parcial a $0,5 \%$, irá gerar a média do conjunto ácido considerado. 
Voltando, então, ao resultado do primeiro modelamento realizado, a figura 103 mostra que dentro do universo de composições potenciais para a fonte destas rochas está a média das rochas intermediárias com $[\mathrm{La} / \mathrm{Yb}]_{\mathrm{N}}$ de 6 a 9, que, por sua vez, coincide com a curva de $30 \%$. Isto significa que a fusão de $30 \%$ de uma fonte com a composição média das rochas intermediárias pode gerar o padrão de distribuição de ETR das rochas ácidas com $[\mathrm{La} / \mathrm{Yb}]_{N}$ entre 4 e 65 . A composição de ETR da fonte modelada é apresentada na tabela 52, juntamente com a composição média das rochas fontes potenciais. Verifica-se que há uma boa ou ótima concordância para a maioria dos elementos, com erro em um intervalo de $<1$ a $7 \%$. A única exceção refere-se ao Eu, cujo teor na fonte modelada é bem mais alto (cerca de $73 \%$ mais alto) do que na rocha fonte potencial. Cabe lembrar que esta mesma dificuldade foi enfrentada quando do modelamento por cristalização fracionada efetuado para as rochas calcioalcalinas do CJF. Este aspecto será discutido mais adiante, após a apresentação dos resultados do modelamento da segunda hipótese.

Tabela 52 - Composição de ETR da fonte modelada em comparação com a média das fontes potenciais $\left(\right.$ Int $\left.1_{M}-[\mathrm{La} / \mathrm{Yb}]_{N} \approx 6-9\right)$.

\begin{tabular}{|l|c|c|}
\hline ETR & Modelo (20\% de fusão parcial) & Int $_{M}$ \\
\hline $\mathrm{La}$ & 20,94 & 19,50 \\
\hline $\mathrm{Ce}$ & 40,09 & 39,00 \\
\hline $\mathrm{Nd}$ & 19,98 & 19,00 \\
\hline $\mathrm{Sm}$ & 4,39 & 4,18 \\
\hline $\mathrm{Eu}$ & 2,07 & 1,20 \\
\hline $\mathrm{Yb}$ & 1,80 & 1,80 \\
\hline $\mathrm{Lu}$ & 0,26 & 0,27 \\
\hline
\end{tabular}

A segunda hipótese considera a possibilidade das rochas ácidas com $[\mathrm{La} / \mathrm{Yb}]_{\mathrm{N}}>100$ serem geradas a partir da fusão parcial das rochas intermediárias com $[\mathrm{La} / \mathrm{Yb}]_{\mathrm{N}}$ entre 20 e 38 . A composição média destes dois conjuntos e a composição mineralógica da média das rochas intermediárias são apresentadas na tabela 53. Os resultados obtidos estão mostrados no diagrama da figura 104, cuja leitura deve ser feita de maneira idêntica ao explicado para o diagrama da figura 103. Assim, a figura 104 mostra a distribuição de ETR para várias rochas fontes potenciais: desde aquelas que por $0,5 \%$ de fusão parcial poderiam gerar o conjunto das rochas ácidas em questão; até aquelas que por $90 \%$ seriam capazes de gerar estas rochas. Verifica-se que a composição média das rochas intermediárias coincide com a curva para uma fonte que por $20 \%$ de fusão parcial é capaz de gerar magma parental das rochas ácidas. Isto 


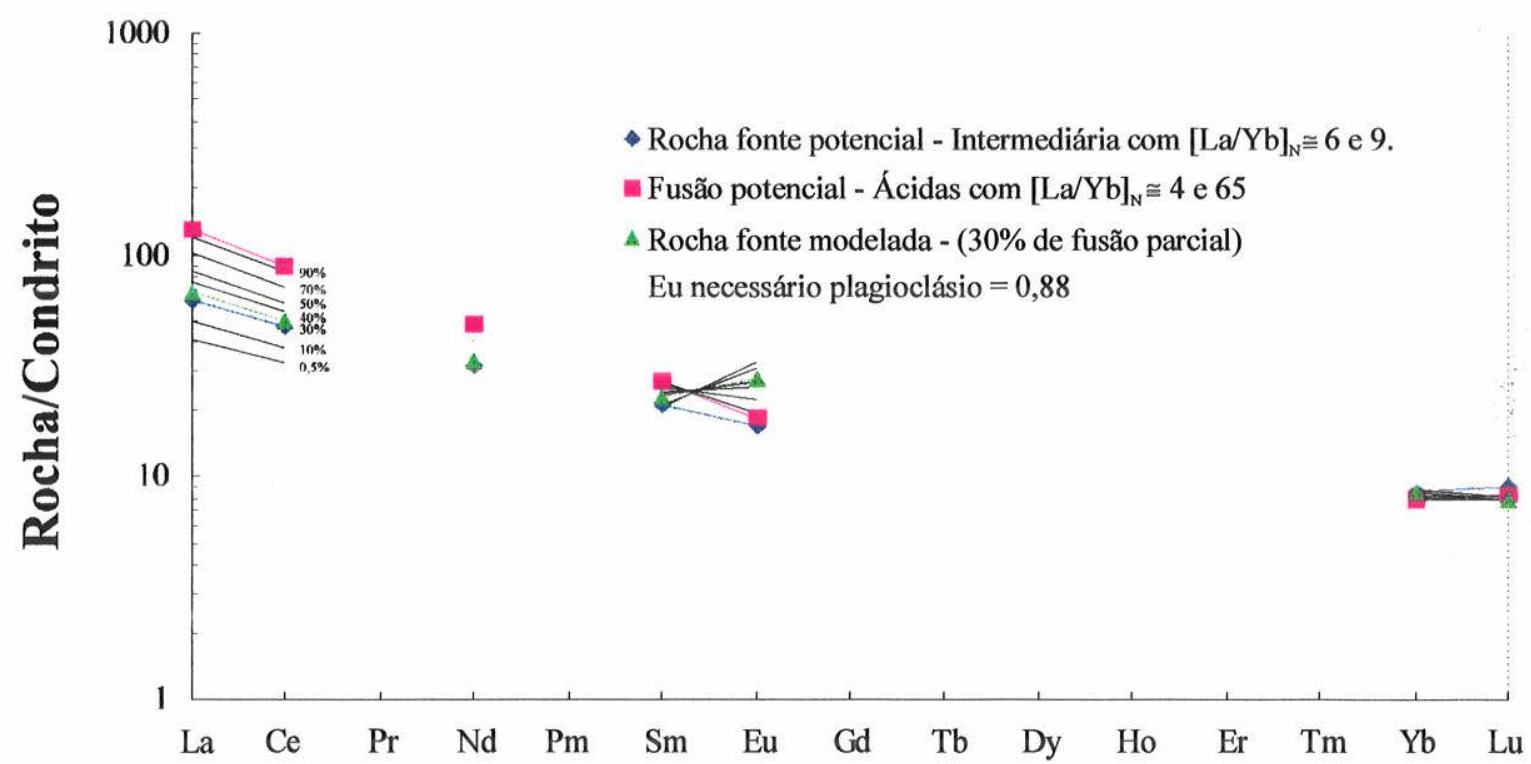

Figura 103 - Resultados obtidos para o modelamento de fusão parcial: de rochas intermediárias do $\mathrm{CM}$ com $[\mathrm{La} / \mathrm{Yb}]_{\mathrm{N}}$ entre 6 e 9 para rochas ácidas com $[\mathrm{La} / \mathrm{Yb}]_{\mathrm{N}}$ entre 20 e 38 .

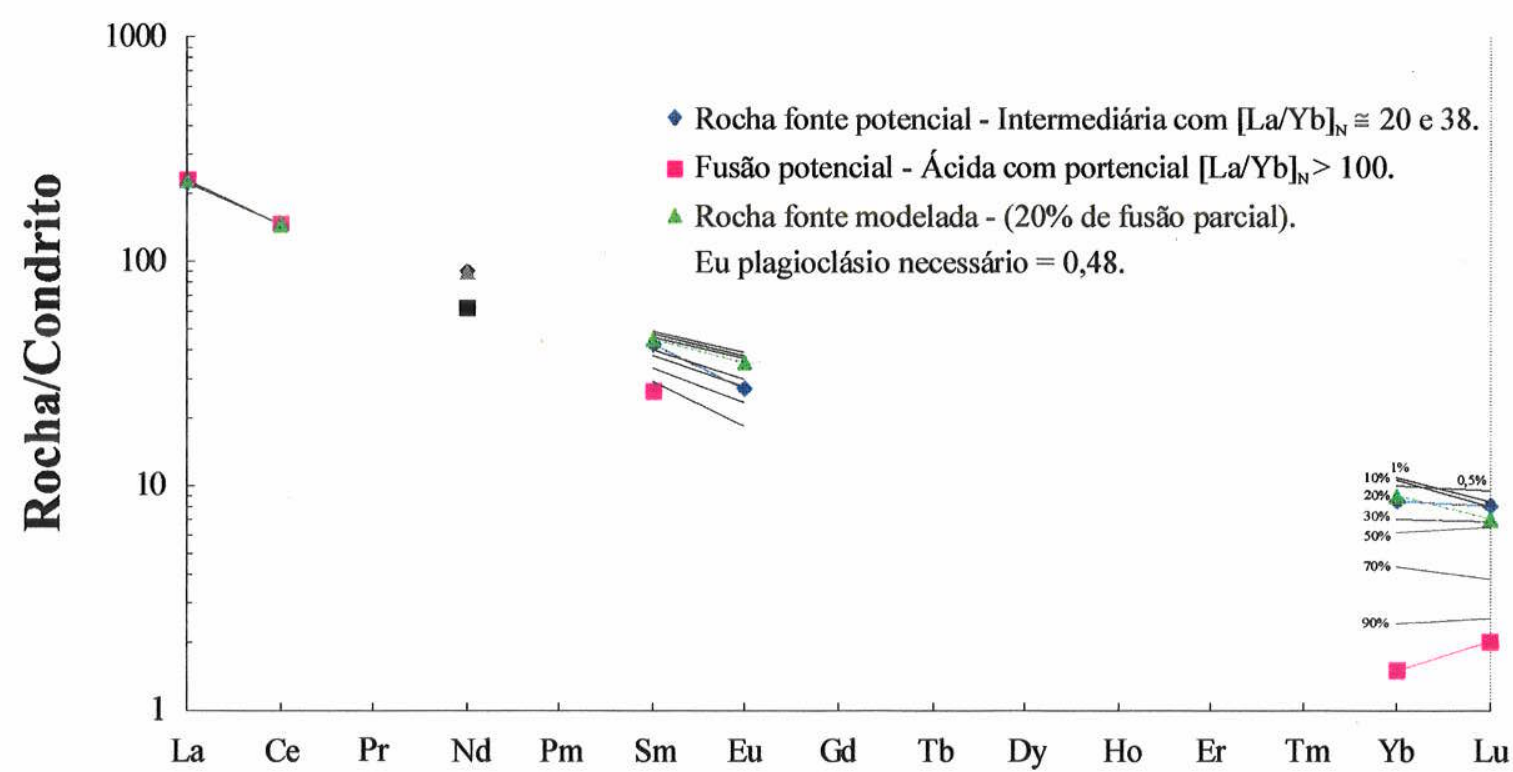

Figura 104 - Resultados obtidos para o modelamento de fusão parcial: de rochas intermediárias do $\mathrm{CM}$ com $[\mathrm{La} / \mathrm{Yb}]_{\mathrm{N}}$ entre 20 e 38 para rochas ácidas com $[\mathrm{La} / \mathrm{Yb}]_{\mathrm{N}}>100$. 
significa que dentro do universo de possíveis composições para rochas fontes potenciais existe uma que é representativa na área estudada. A tabela 53 apresenta os valores obtidos para os ETR para a composição da fonte modelada para $20 \%$ de fusão parcial em comparação com a composição de ETR da média das rochas intermediárias. Pode-se verificar que para quase todos os elementos, o erro é baixo, entre 0 e $5 \%$, com exceção do Eu, cujo erro está na faixa de $35 \%$; i.e., o Eu modelado é $35 \%$ maior do que aquele da fonte potencial.

Tabela 53 - Composição de ETR da fonte modelada em comparação com a média das fontes potenciais $\left(\operatorname{Int} 2_{M}-[L a / Y b]_{N} \approx 20-38\right)$.

\begin{tabular}{|l|c|c|}
\hline ETR & Modelo (20\% de fusão parcial) & Int $2_{M}$ \\
\hline La & 70,17 & 69,83 \\
\hline $\mathrm{Ce}$ & 118,14 & 118,25 \\
\hline $\mathrm{Nd}$ & 53,27 & 53,35 \\
\hline $\mathrm{Sm}$ & 8,64 & 8,55 \\
\hline $\mathrm{Eu}$ & 2,56 & 1,89 \\
\hline $\mathrm{Yb}$ & 1,88 & 1,79 \\
\hline $\mathrm{Lu}$ & 0,23 & 0,24 \\
\hline
\end{tabular}

Foram realizados outros modelamentos, a fim de avaliar a possibilidade de composições médias da crosta disponíveis na literatura (Tab. 49) poderem representar fontes potenciais para o conjunto ácido com $[\mathrm{La} / \mathrm{Yb}]_{\mathrm{N}}>100$. Os resultados obtidos foram bons para a crosta superior, porém muito ruins para a crosta inferior e para a média da crosta. $\mathrm{Na}$ procura de uma possível composição mineralógica para a fração residual, pode-se verificar que uma fonte sem zircão e sem clinopiroxênio, porém com granada, pode explicar a geração das rochas com $[\mathrm{La} / \mathrm{Yb}]_{\mathrm{N}}>100$ com $40 \%$ de fusão parcial. Os problemas associados a este modelamento estão no maior percentual de fusão parcial necessário e na inexistência de granada nas rochas intermediárias do $\mathrm{CM}$.

\section{d.2) Modelamento da Fonte das Rochas Intermediárias}

Resta ainda entender a petrogênese das rochas intermediárias do CM que, como demostrado anteriormente, está disassociada da evolução dos magmas que geraram o conjunto de rochas básicas. A partir das composiçõe de ETR estimadas para a crosta e disponíveis na literatura (Tab. 49), procedeu-se ao modelamento de uma possivel fonte para cada um dos dois conjuntos de rochas intermediárias. Os resultados são apresentados nos diagramas das figuras 
105 e 106. A análise dos resultados permite concluir que as rochas intermediárias com $[\mathrm{La} / \mathrm{Yb}]_{\mathrm{N}}$ entre 6 e 9 podem ser geradas por $30 \%$ de fusão parcial de uma fonte com composição muito semelhante àquela da crosta inferior estimada por Taylor \& McLennan (1981), como mostra a tabela 54. Os minerais considerados na composição modal do resíduo são plagioclásio, clinopiroxênio, ilmenita e granada, nas proporções apresentadas na tabela 55. Por outro lado, as rochas intermediárias com $[\mathrm{La} / \mathrm{Yb}]_{\mathrm{N}}$ entre 20 e 38 foram possivelmente geradas a partir de $20 \%$ de fusão parcial de uma fonte com composição semelhante àquela da crosta superior estimada por Taylor \& McLennan (1981), cuja composição mineralógica do resíduo é dada por plagioclásio, biotita, ilmenita, zircão e K-feldspato (Tab. 56). Assim como ocorreu para todas os modelamentos efetuados até então para rochas calcioalcalinas, os resultados obtidos para o Eu são extremamente discrepantes, sempre superiores no modelo do que no equivalente potencial. Este aspecto será abordado em maior detalhe no item seguinte.

Tabela 54 - Composição em ETR das rochas fontes modeladas em comparação com as composições da crosta de Taylor \& McLennan (1981).

\begin{tabular}{|l|c|c|c|c|}
\hline ETR & $\begin{array}{c}\text { Fonte Modelada para } \\
\text { Int } \mathrm{I}_{\mathrm{M}} \\
\left.(\mathrm{La} / \mathrm{Yb}]_{\mathrm{N}} \approx 6-9\right)\end{array}$ & $\begin{array}{c}\text { Crosta Inferior } \\
\text { Taylor \& Mc Lennan } \\
(1981)\end{array}$ & $\begin{array}{c}\text { Fonte Modelada para } \\
\text { Int } 2_{\mathrm{M}} \\
\left([\mathrm{La} / \mathrm{Yb}]_{\mathrm{N}} \approx 20-38\right)\end{array}$ & $\begin{array}{c}\text { Crosta Superior } \\
\text { Taylor \& Mc Lennan } \\
(1981)\end{array}$ \\
\hline $\mathrm{La}$ & 10,98 & 11,00 & 30,68 & 30,00 \\
\hline $\mathrm{Ce}$ & 24,46 & 23,00 & 55,97 & 64,00 \\
\hline $\mathrm{Nd}$ & 13,62 & 12,70 & 26,13 & 26,00 \\
\hline $\mathrm{Sm}$ & 3,63 & 3,17 & 4,46 & 4,50 \\
\hline $\mathrm{Eu}$ & 1,52 & 1,17 & 2,58 & 0,88 \\
\hline $\mathrm{Yb}$ & 2,19 & 2,20 & 2,06 & 2,20 \\
\hline $\mathrm{Lu}$ & 0,28 & 0,29 & 0,34 & 0,32 \\
\hline
\end{tabular}

Tabela 13 - Composição mineralógica modal do resíduo considerado no modelamento do processo de fusão parcial para a gênese do conjunto de rochas intermediárias com $[\mathrm{L} / \mathrm{Yb}]_{N}$ entre 6 e 9.

\begin{tabular}{|l|c|}
\hline Mineral & \% em Peso \\
\hline Plagioclásio & 50 \\
\hline Clinopiroxênio & 28 \\
\hline Ilmenita & 20 \\
\hline Granada & 2 \\
\hline
\end{tabular}




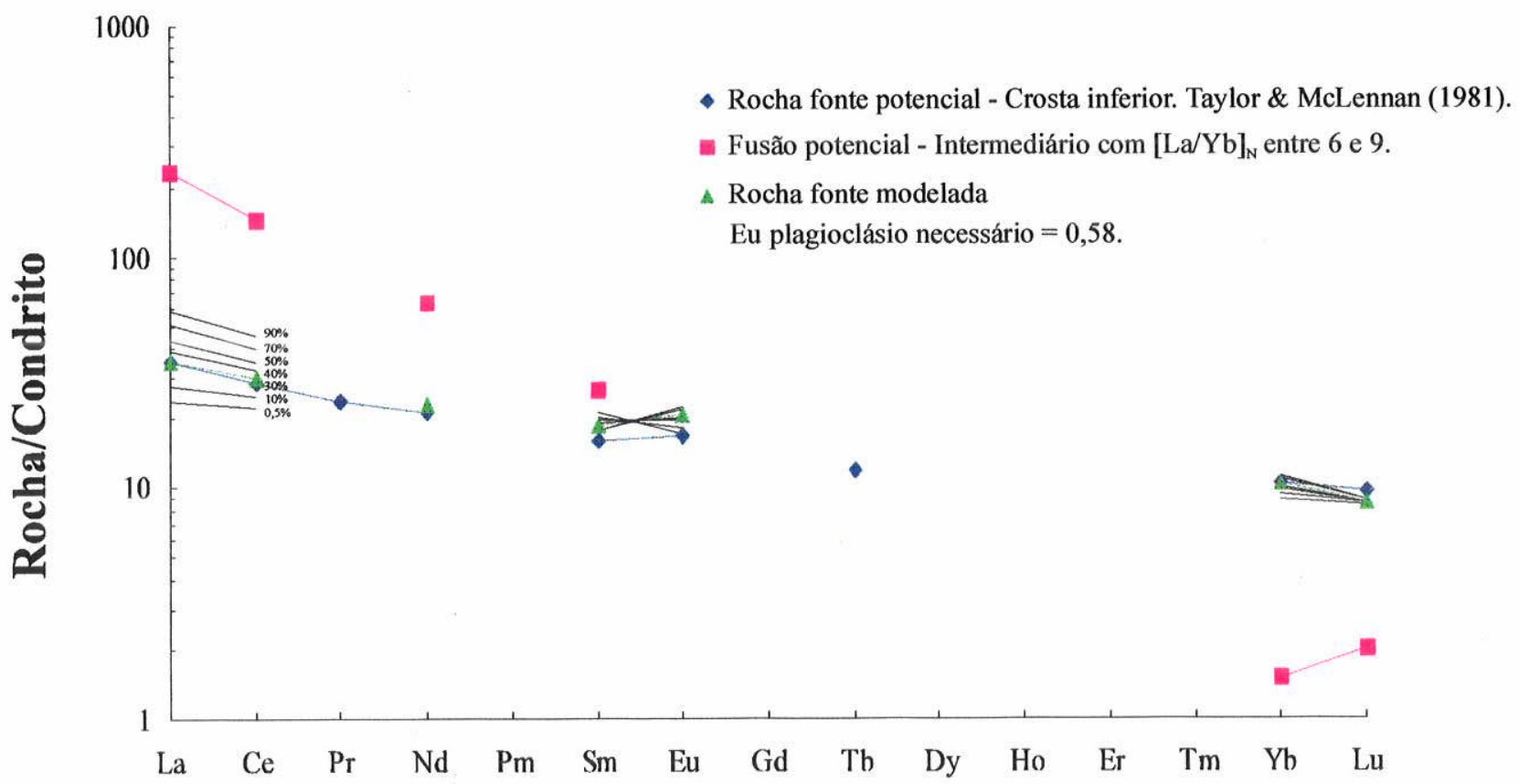

Figura 105 - Padrões de ETR para modelamento da fonte das rochas intermediárias com $[\mathrm{La} / \mathrm{Yb}]_{\mathrm{N}}$ entre 6 e 9, por processo de fusão parcial.

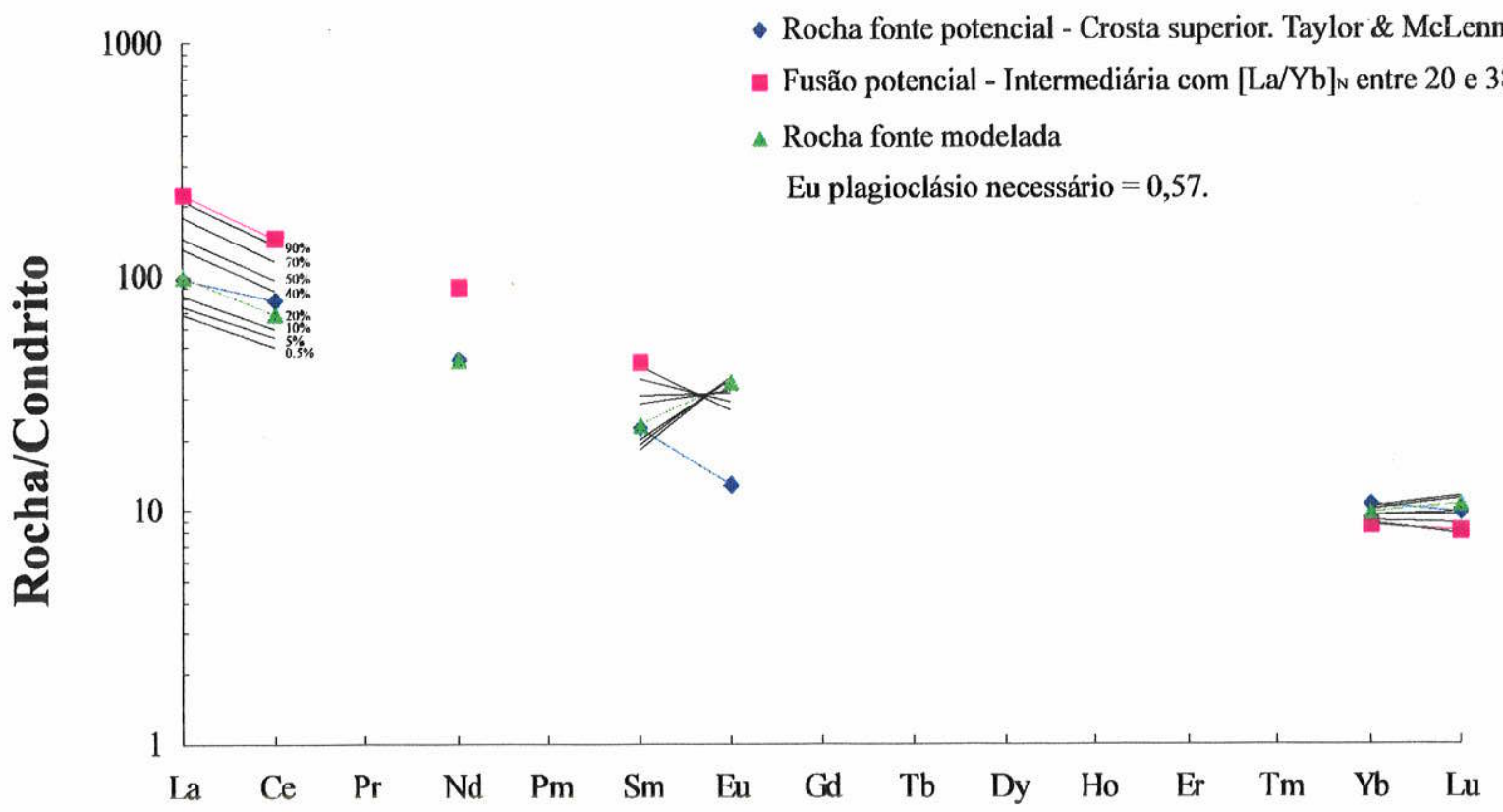

Figura 106 - Padrões de ETR para modelamento da fonte das rochas intermediárias com $[\mathrm{La} / \mathrm{Yb}]_{\mathrm{N}}$ entre 20 e 38 , por processo de fusão parcial. 
Tabela 56 - Composição mineralógica modal do resíduo considerado no modelamento do processo de fusão parcial para a gênese do conjunto de rochas intermediárias com $[\mathrm{L} / \mathrm{Yb}]_{\mathrm{N}}$ entre 20 e 38.

\begin{tabular}{|l|c|}
\hline Mineral & $\%$ em Peso \\
\hline Plagioclásio & 60,5 \\
\hline Biotita & 27 \\
\hline Ilmenita & 10 \\
\hline K-feldspato & 2 \\
\hline Zircão & 0,5 \\
\hline
\end{tabular}

A análise mais geral mostra que a média das rochas com $[\mathrm{La} / \mathrm{Yb}]_{\mathrm{N}}$ entre 6 e 9 tem boa coincidência com os valores estimados para a crosta continental de Rudnick (1995). Por outro lado, as rochas intermediárias com $[\mathrm{La} / \mathrm{Yb}]_{\mathrm{N}}$ entre 20 e 38 são bem mais enriquecidas do que, inclusive, as médias estimadas para a crosta superior (Taylor \& McLennan, 1981; Weaver \& Tarney, 1984).

\section{e) As Condições Oxidantes do Processo de Fusăo Parcial}

Os modelamentos realizados foram capazes de explicar de maneira satisfatória a petrogênese das rochas calcioalcalinas do $\mathrm{CM}$. Os resultados numéircos obtidos mostram-se, na grande maioria, bastante razoáveis. A única exceção, observada em qualquer dos modelamentos realizados, refere-se aos valores obtidos para $\mathrm{Eu}$, os quais foram sermpre superiores aos desejados. Para abordar este problema é necessário reforçar que o Eu tem características específicas, distintas dos demais ETR. Ou seja, enquanto que todos os demais ETR são trivalentes, o Eu pode ser bivalente ou trivalente. Isto significa que o comportamento do Eu, diferentemente dos outros ETR, depende fortemente das condições de fugacidade de oxigêncio $\left(\mathrm{O}_{2}\right)$ do sistema. Consequentemente, o estado de valência do Eu reflete diretamente no valor do $\mathrm{Kd}$ mineral/líquido deste elemento. Sob condições de baixa $\mathrm{fO}_{2}$, o Eu é bivalente e irá preferencialmente substituir o $\mathrm{Ca}$ no plagioclásio, sendo rejeitado pelos minerais ferromagnesianos, principalmente o clinopiroxênio. Nestas condições o coeficiente de partição entre plagioclásio e líquido basáltico será alto (geralmente $>1.0$ ) e anômalo para os demais ETR. Por outro lado, sob altas condições de $f \mathrm{O}_{2}$, este coeficiente de partição é baixo e o Eu comporta-se de maneira semelhante aos demais ETR. Entretanto, este parâmetro $\left(f \mathrm{O}_{2}\right)$ é dificil 
de ser controlado em experimentos realizados na busaca dos valores de $\mathrm{Kd}$ mineral/líquido. Em função desta dificuldade, a grande maioria dos experimentos envolve a utilização de um buffer a fim de bloquear o efeito da $\mathrm{fO}_{2}$. Como a maior parte destes ensaios é feita para líquidos basálticos, cuja fonte é o manto superior, é até interessante considerar condições não oxidantes, já que grande parte do manto superior é tida como um sistema caracterizado por baixa $\mathrm{fO}_{2}$. Somente Drake e Weill (1975) realizaram experimentos sob altas condições de $\mathrm{fO}_{2}$, a fim de determinar o Kd mineral líquido para o Eu trivalente. Entretanto, estes estudos foram realizados para líquidos básicos (basálticos e andesito-basálticos), diferentemente do caso ora em discussão. Assim, os valores dos coeficientes de partição disponíveis na literatura são, em grande maioria, para baixas condições de $\mathrm{fO}_{2}$. As rochas aqui consideradas, tanto as intermediárias quanto as ácidas, são calcioalcalinas e, portanto, representam sistemas de alta $f \mathrm{O}_{2}$.

Devido à restrição de coeficientes de partição disponíveis na literatura, partiu-se para o cálculo do Kd mineral/líquido para Eu que seria necessário aos modelamentos realizados (Tab. 57). A partir destes valores a condição de $\mathrm{fO}_{2}$ foi grosseiramente estimada, com base no diagrama da figura 107 (Drake \& Weill, 1975). Com a finalidade de se buscar uma avaliação qualitativa da $\mathrm{fO}_{2}$ (se oxidante ou não), os valores de $\mathrm{fO}_{2}$ obtidos (Tab. 57) foram plotados no diagrama da figura 108. Considerando valores de $\mathrm{T}$ compatíveis com fusões crustais (entre 600 e $900^{\circ} \mathrm{C}$ ), verifica-se que os valores para $\log f \mathrm{O}_{2}$ são plotados acima da curva magnetitahematita e, portanto, sob condições altamente oxidantes. Como já exposto, o fato das rochas em questão serem calcioalcalinas reforça os altos valores encontrados para $\mathrm{fO}_{2}$.

Tabela 57 - Valores calculados de $K_{d}$ plagioclásio/líquido para $E u$, para cada modelamento de fusão parcial realizado para as rochas calcioalcalinas do Complexo Mantiqueira.

\begin{tabular}{|l|c|c|c|c|}
\hline Modelos & Modelo 1 & Modelo 2 & Modelo 3 & Modelo 4 \\
\hline Valores de $\mathrm{K}_{\mathbf{d}}$ & 0,88 & 0,48 & 0,58 & 0,57 \\
\hline
\end{tabular}

Modelo 1 - fonte potencial para as rochas ácidas com $[\mathrm{La} / \mathrm{Yb}]_{\mathrm{N}}$ entre $\approx 4$ e 65 ;

Modelo 2 - fonte potencial para as rochas ácidas com $[\mathrm{La} / \mathrm{Yb}]_{\mathrm{N}}$ entre $>100$;

Modelo 3 - fonte potencial para as rochas intermediárias com $[\mathrm{La} / \mathrm{Yb}]_{\mathrm{N}}$ entre $\approx 6$ e 9 ;

Modelo 4 - fonte potencial para as rochas intermediárias com $[\mathrm{La} / \mathrm{Yb}]_{\mathrm{N}}$ entre $\approx 20$ e 38 . 


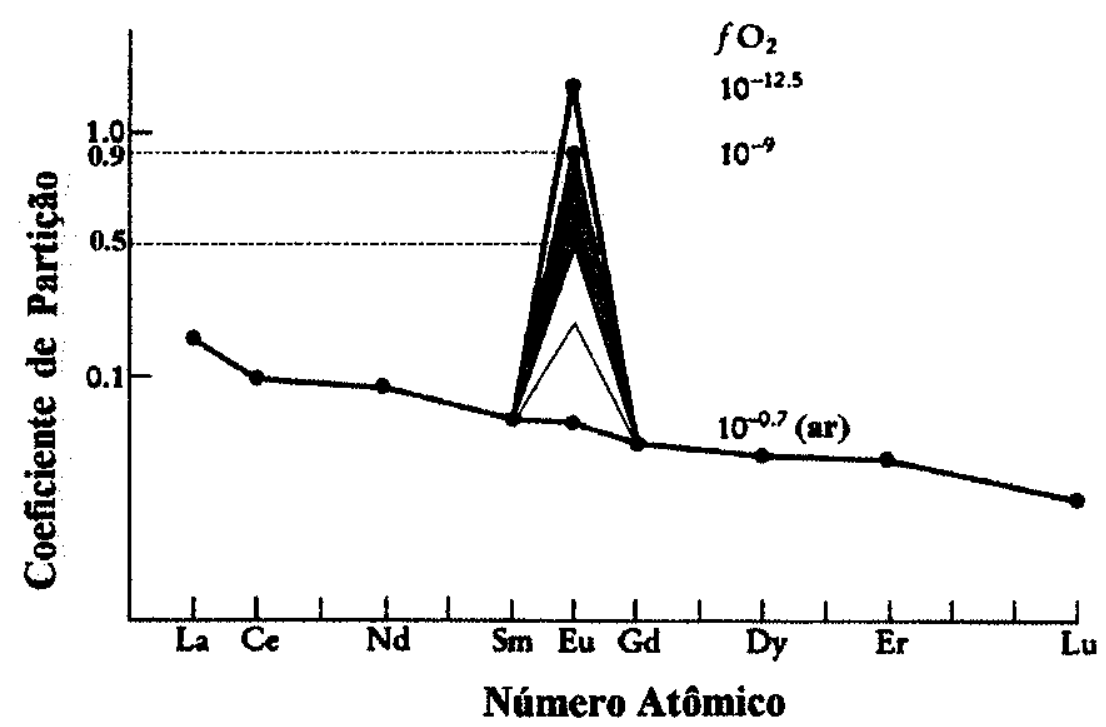

Figura 107 - Diagrama de valores do coeficiente de partição do Eu para diferentes condições de fugacidade de oxigênio (Drake \& Weill, 1975). Área marcada: intervalo de valores de coeficiente de partição de Eu estimados para as rochas do Complexo Mantiqueira.

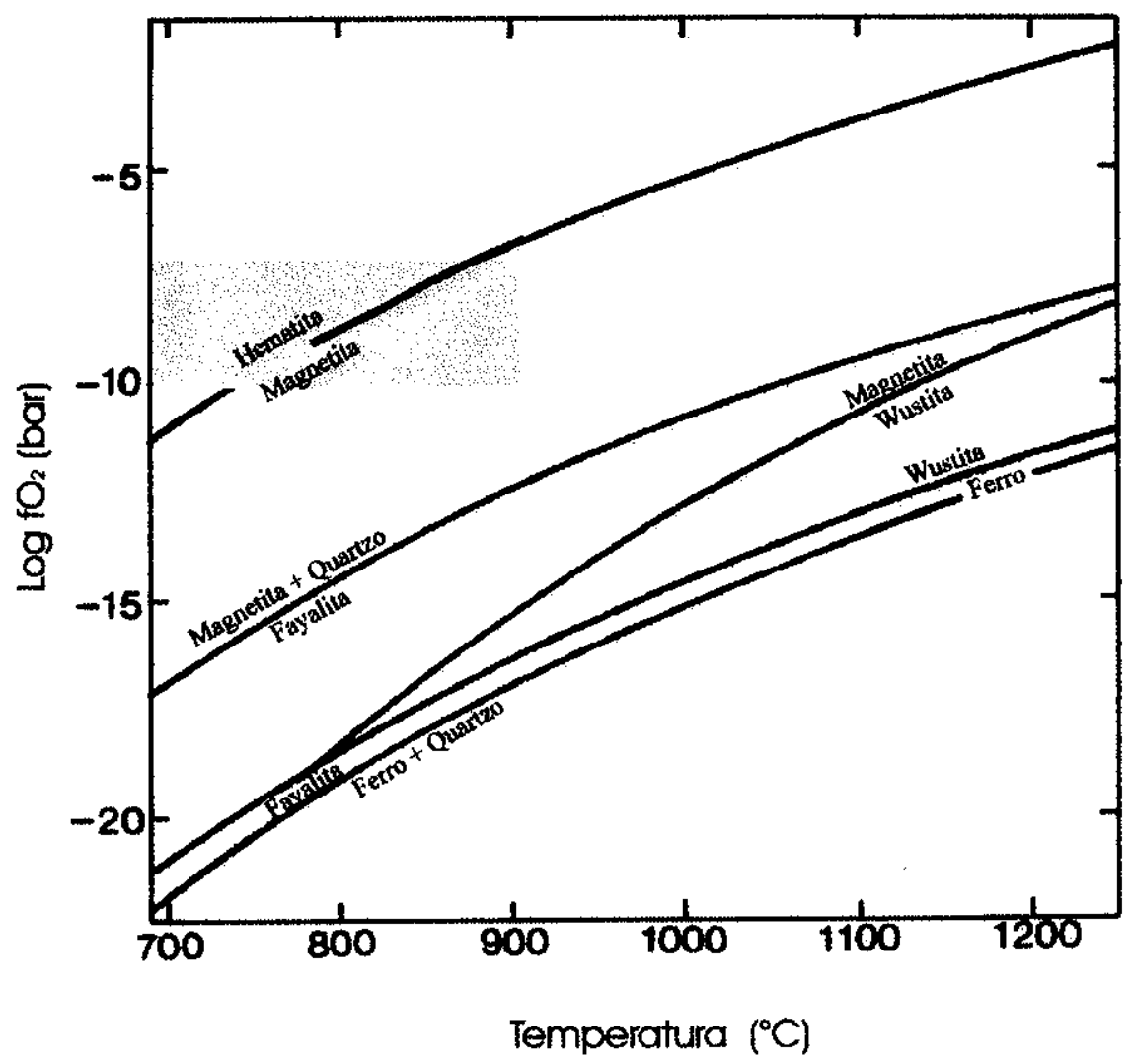

Figura 108 - Diagrama para assembléias usadas como buffers (Myers \& Eugster, 1983). Área marcada: valores estimados para as rochas do Complexo Mantiqueira. 


\section{f) Conclusões}

Com base no modelamento geoquímico das rochas do Complexo Mantiqueira, concluise que:

a) As rochas do CM distribuem-se ao longo de dois trends: transicional, dado pelas rochas básicas; e outro subalcalino-calcioalcalino (rochas intermediárias a ácidas);

b) Com base na análise estatística para os elementos maiores e traços, verificou-se um baixo grau de correlação dentre as rochas básicas, o que sugere que dentro deste grupo existem rochas de origens distintas;

c) Para o grupo de rochas calcioalcalinas, as correlações foram boas e tanto melhores para as correlações polinominais. Isto elimina processos de mistura magmática na gênese destas rochas e suporta processos de cristalização fracionada e/ou fusão parcial;

d) O grupo das rochas básicas é petrogeneticamente heterogêneo. Pelo menos três subgrupos puderam ser identificados: 1) rochas de afinidade toleítica; 2) rochas de afinidade toleítica e carater transicional; e 3) rochas de afinidade alcalina;

e) O modelamento mostrou que nenhum dos subgrupos de rochas básicas continha magmas parentais para as rochas mais evoluidas do trend calcioalcalino;

f) A partir de critérios petrogenéticos tendo como base a distribuição dos ETR, verificou-se que o grupo de rochas calcioalcalinas (intermediárias a ácidas) é também heterogêneo, sendo constituído de quatro subgrupos: 1) rochas intermediárias com $[\mathrm{La} / \mathrm{Yb}]_{\mathrm{N}} \approx 6-9 ; 2$ ) rochas intermediárias com $\left.[\mathrm{La} / \mathrm{Yb}]_{\mathrm{N}} \approx 20-38 ; 3\right)$ rochas ácidas com $[\mathrm{La} / \mathrm{Yb}]_{\mathrm{N}} \approx 4-65 ;$ e 4) rochas ácidas com $[\mathrm{La} / \mathrm{Yb}]_{\mathrm{N}}>100$;

g) $\mathrm{O}$ modelamento geoquímico mostrou que as rochas ácidas com $[\mathrm{La} / \mathrm{Yb}]_{\mathrm{N}} \approx 4-65$ podem ser resultado de $30 \%$ de fusão parcial de uma fonte cuja abundância de ETR é muito semelhante àquela da média das rochas intermediárias com $[\mathrm{La} / \mathrm{Yb}]_{\mathrm{N}} \approx 6-9$; 
h) Para o caso das rochas ácidas com $[\mathrm{La} / \mathrm{Yb}]_{\mathrm{N}}>100$, o modelamento geoquímico mostrou que as mesmas podem ser resultado de $20 \%$ de fusão parcial de uma fonte cuja abundância de ETR é muito semelhante àquela da média das rochas intermediárias com $[\mathrm{La} / \mathrm{Yb}]_{\mathrm{N}} \approx 20-38$;

i) $\mathrm{O}$ modelamento geoquímico mostrou que as rochas intermediárias com $[\mathrm{La} / \mathrm{Yb}]_{\mathrm{N}} \approx 6-9$ podem ser resultado de $30 \%$ de fusão parcial de uma fonte cuja abundância de ETR é muito semelhante àquela da crosta inferior de Taylor \& McLennan (1981);

j) Com relação às rochas intermediárias com $[\mathrm{La} / \mathrm{Yb}]_{\mathrm{N}} \approx 20-38$, o modelamento mostrou que estas foram geradas a partir de processo de fusão parcial de $20 \%$ de uma fonte com abundância em ETR muito semelhante àquela da crosta superior de Taylor \& McLennan (1981); e

k) Para o bom ajuste dos modelos obtidos, é necessário que todos os processos de fusão parcial envolvidos tenham ocorrido sob condições de alta $\mathrm{fO}_{2}$, o que é esperado, já que tratamse de suites calcioalcalinas. 


\section{II.8) Comparação Entre os Complexos Mantiqueira e Juiz de Fora}

\section{II.8.1) Introdução}

Nos dois capítulos precedentes foi efetuado o modelamento geoquímico para as rochas do CM (Seção II.7.3) e do CJF (Seção II.7.4), tendo como base a análise quantitativa por critérios estatísticos e/ou petrológicos. A partir deste procedimento analítico, vários resultados importantes foram alcançados e monitoraram o processo petrogenético a ser modelado. Por exemplo, a existência de uma suíte calcioalcalina expandida $\left(\mathrm{SiO}_{2}\right.$ entre $57 \%$ e $\left.72 \%\right)$ dentro do CJF sugeriu que as rochas deste grupo poderiam estar relacionadas por processo de cristalização fracionada. Por outro lado, os grupos coerentes encontrados no CM sugeriam processos de fusão parcial já que, em todos os casos, a variação de $\mathrm{SiO}_{2}$ é restrita. Os modelamentos foram efetuados apenas para as rochas com afinidade calcioalcalina, por estas serem em número suficiente para o procedimento adotado. $\mathrm{O}$ grupo de rochas básicas, tanto do $\mathrm{CJF}$ quanto do $\mathrm{CM}$, apresenta padrões de ETR indicativos de grande heterogeneidade petrogenética. Isto, associado ao reduzido número de amostras, eliminou a possibilidade de realizar o modelamento geoquímico.

Através da análise quantitativa e do modelamento, testou-se a possibilidade das rochas básicas serem parentais para as intermediárias e ácidas. Tanto para o $\mathrm{CM}$ quanto para o $\mathrm{CJF}$, os resultados foram negativos. Desta forma, concluiu-se que é improvável que qualquer uma das rochas básicas, represente um magma parental para as rochas mais evoluídas de afinidades calcioalcalinas.

A comparação entre estas duas unidades lito-estratigráficas (CM e CJF) será feita com base nos resultados quantitativos já apresentados anteriormente nas seções II.7.3 e II.7.4 e que serão aqui confrontados. Será também apresentada uma análise comparativa dos agrupamentos identificados nestes dois complexos com suítes Arqueanas-Proterozóicas consagradas na literatura. 


\section{II.8.2) Comparação entre os Complexo Mantiqueira e Juiz de Fora}

A comparação entre estas duas unidades será feita com base em dois principais aspectos: 1) aqueles referentes às características de campo e petrográficas; e 2) aqueles referentes às características litoquímicas, petrológicas e petrogenéticas.

\section{a) Aspectos de campo e petrográficos}

Os dados referentes aos aspectos de campo e petrográficos foram apresentados nas Seções II.2.1 e II.3. Na presente seção, pretende-se enumerar as semelhanças e as diferenças verificadas entre o $\mathrm{CJF}$ e o $\mathrm{CM}$, a fim de traçar um quadro comparativo completo entre as duas unidades.

As semelhanças encontradas entre o CJF e o $\mathrm{CM}$ podem ser assim resumidas:

a) Predomínio de rochas de composição tonalítica a granítica, com enclaves, bandas e/ou boudins de rochas metabásicas; $\mathrm{e}$

b) Ocorrência de uma alternância entre rocha de composição básica (CM e CJF) a quartzo diorítica (CJF) e rocha félsica leuco- a hololeucocrática, de composição tonalítica (CM) ou granítica (CJF).

As diferenças mais marcantes encontradas entre as duas unidades são:

a) Ortognaisses de composição quartzo monzonitica a quartzo monzodiorítica estão ausentes no CM, porém presentes no CJF (Fig. 109);

b) Ortognaisses de composição granítica e com augens de K-feldspato são volumetricamente importantes no CM, mas não são observados no CJF;

c) Rocha charnockítica félsica com enclaves de norito representam uma pequena porção do CJF e não foram encontrados no CM;

d) Leucossomas félsicos com restitos de rocha básica ocorrem com frequência no $\mathrm{CM}$, mas não foram encontrados no CJF; e

e) Corpos tabulares discordantes de rochas metabásicas só foram observados no CM, o que, talvez, possa ser atribuido à menor intensidade de deformação que afetou esta uniddde.

f) Os estilos estruturais apresentados pelo CJF e pelo CM são bastante distintos. Enquanto que o primeiro ocorre ao longo de escamas tectônicas, cuja principal característica é ưm 
bandamento entre zonas dobradas e zonas milonitizadas, o segundo tem como principal feição estrutural a presença de dobras e de uma foliação grossa. As evidências de contatos tectônicos entre o $\mathrm{CM}$ e as rochas supracrustais são raras;

g) Em termos de evolução metamórfica, estas unidades apresentam diferenças marcantes. Enquanto que o $\mathrm{CM}$ tem paragêneses que indicam condições metamórficas da facies anfibolito superior e uma grande quantidade de rochas migmatizadas, o CJF tem paragêneses diagnósticas para a facies granulito e as feições de migmatização ocorrem de maneira restrita; $\mathrm{e}$ h) Os dados apresentados nos dois itens anteriores expressam processos atuantes em níveis crustais distintos (ver Seções II.5 e II.6). Sendo assim, verifica-se que, pelo menos durante um certo período de tempo, o CJF e o CM tiveram residências em diferentes níveis crustais.

\section{b) Aspectos geoquímicos, petrológicos e petrogenéticos}

\section{b.1) Análise qualitativa}

A análise comparativa dos dados químicos mostra que tanto o $\mathrm{CJF}$ quanto o $\mathrm{CM}$ são constituídos de rochas que podem ser agrupadas segundo 3 tipos distintos (Fig. 110 e 111): 1) rochas intermediárias a ácidas distribuídas ao longo de um trend calcioalcalino; 2) rochas básicas dispostas ao longo de um trend toleítico; e 3) rochas básicas com afinidade alcalina. Embora este último grupo não tenha sido amostrado para o CJF na área alvo, em área próxima (a W e SW), rochas básicas de afinidade alcalina foram encontradas (Heilbron, 1993) e encontram-se também plotadas nas figuras 110 e 111.

Comparando-se cada grupo composicional (básicas, intermediárias e ácidas) em termos de padrões de distribuição de ETR, verifica-se que:

a) A grande maioria dos padrões encontrados para as rochas básicas toléticas é comum para o CJF e para o CM (Fig. 112). Para ambas as unidades, o conjunto de rochas básicas de afinidade toleitica é bastante heterogêneo em termos de padrões de ETR.

b) As rochas básicas de afinidade alcalina têm padrões de ETR distintos quando compara-se as duas unidades (Fig. 112);

c) Tanto o CJF quanto o $\mathrm{CM}$ apresentam dois conjuntos de rochas intermediárias quando considera-se a distribuição dos ETR: um de padrões pouco fracionados e outro de padrões mais fracionados, que podem ser considerados bastante semelhantes (Fig. 113 e 114); 


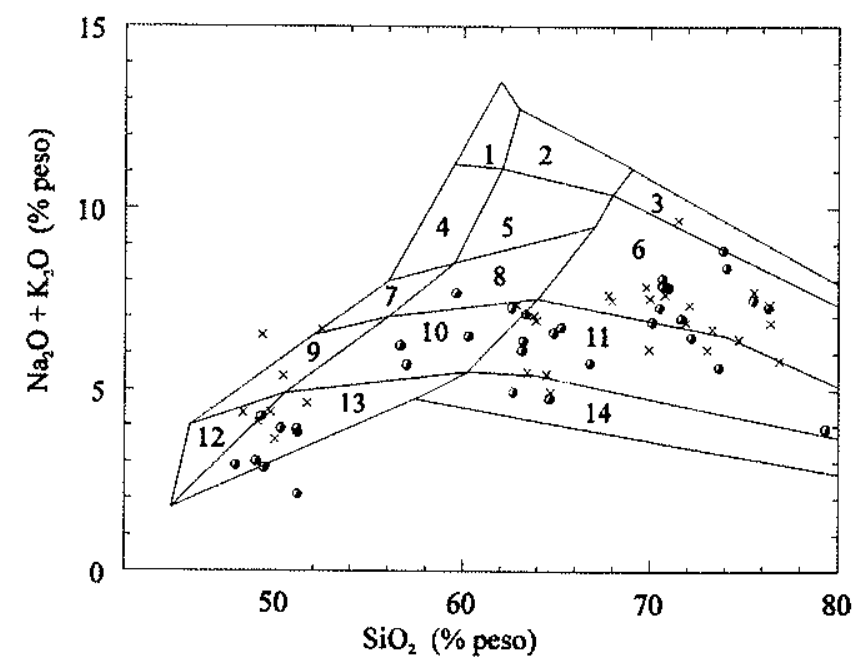

$\times$ Complexo Mantiqueira

- Complexo Juiz de Fora

1 Alcalifeldspato sienito

2 Alcalifeldspato quartzo sienito

3 Alcalifeldspato granito

4 Sienito

5 Quartzo sienito

6 Granito

7 Monzonito

8 Quartzo monzonito

9 Monzodiorito

10 Quartzo monzodiorito

11 Granodiorito

12 Diorito e gabro

13 Quartzo diorito

14 Tonalito

Figura 109 - Diagrama de classificação das rochas dos Complexos Juiz de Fora e Mantiqueira (Middlemost, 1985).

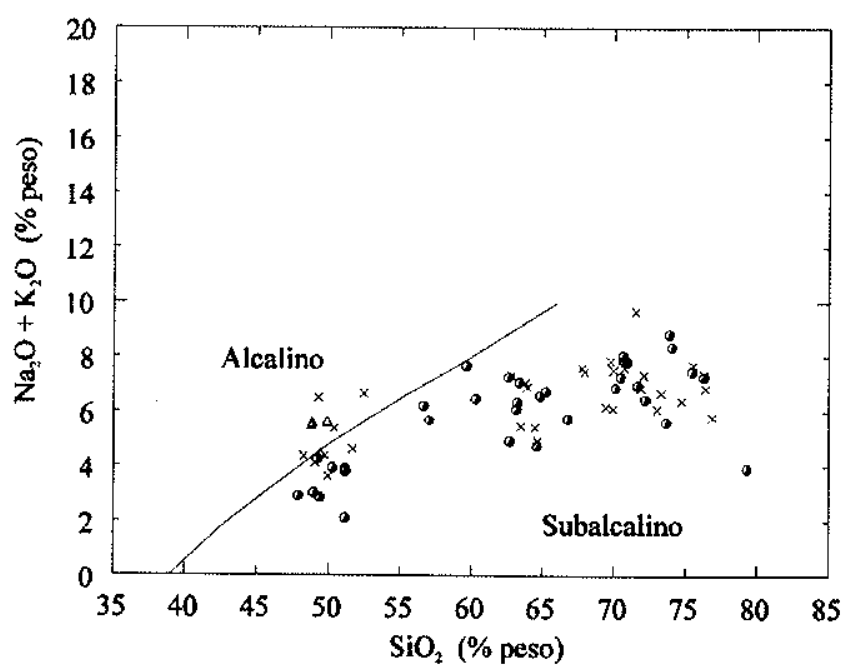

$\times$ Complexo Mantiqueira

- Complexo Juiz de Fora

$\triangle$ Metabásica de afinidade alcalina

do Complexo Juiz de Fora

Figura 110 - Diagrama $\mathrm{SiO}_{2} \times \mathrm{Na}_{2} \mathrm{O}+\mathrm{K}_{2} \mathrm{O}$ para as rochas dos Complexos Juiz de Fora e Mantiqueira. Encontram-se também plotadas as rochas metabásicas de afinidade alcalina do Complexo Juiz de Fora da região entre Bom Jardim de Minas e Barra do Piraí (Heilbron, 1993). O limite dos campos alcalino e subalcalino segundo Irvine \& Baragar (1971).

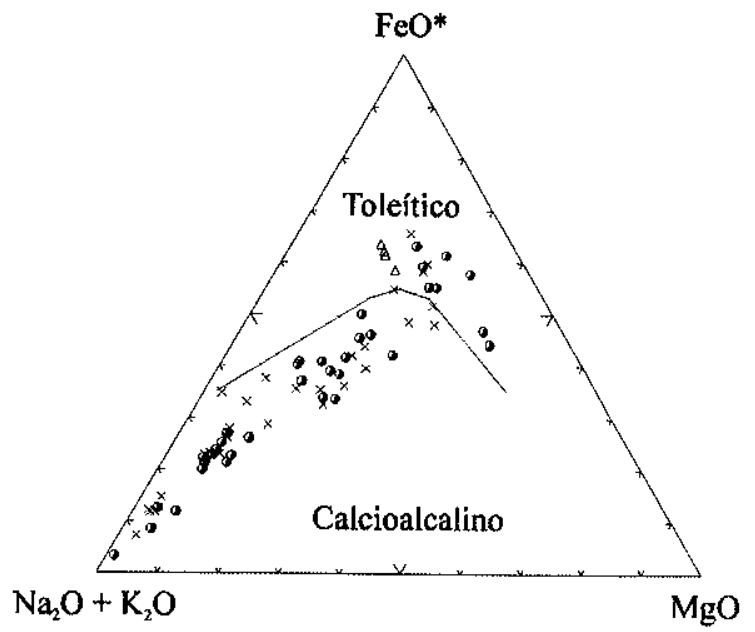

$\times$ Complexo Mantiqueira

- Complexo Juiz de Fora

$\triangle$ Metabásica de afinidade alcalina

do Complexo Juiz de Fora

Figura 111 - Diagrama AFM para as rochas dos Complexos Juiz de Fora e Mantiqueira.

Encontram-se também plotadas as rochas metabásicas de afinidade alcalina do Complexo Juiz de Fora da regiăo entre Bom Jardim de Minas e Barra do Piraí (Heilbron, 1993). O limite dos campos tolético e subalcalino segundo Irvine \& Baragar (1971). 


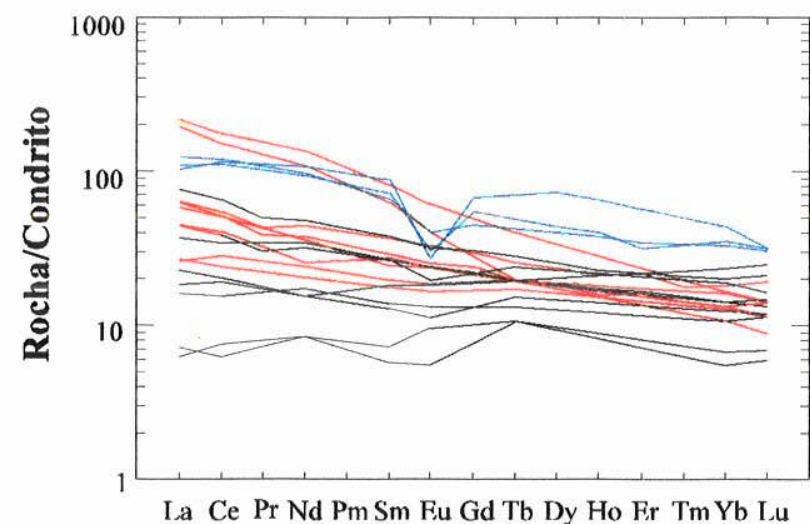

Complexo Mantiqueira

Complexo Juiz de Fora

Rochas Metabásicas do Complexo Juiz de Fora

Figura 112 - Diagrama ETR, normalizadas pelo condrito de Boynton (1984), para as rochas metabásicas dos Complexos Juiz de Fora e Mantiqueira. Estão também plotadas as amostras de rochas metabásicas do Complexo Juiz de Fora da região entre Bom Jardim de Minas e Barra do Piraí (Heilbron, 1993).

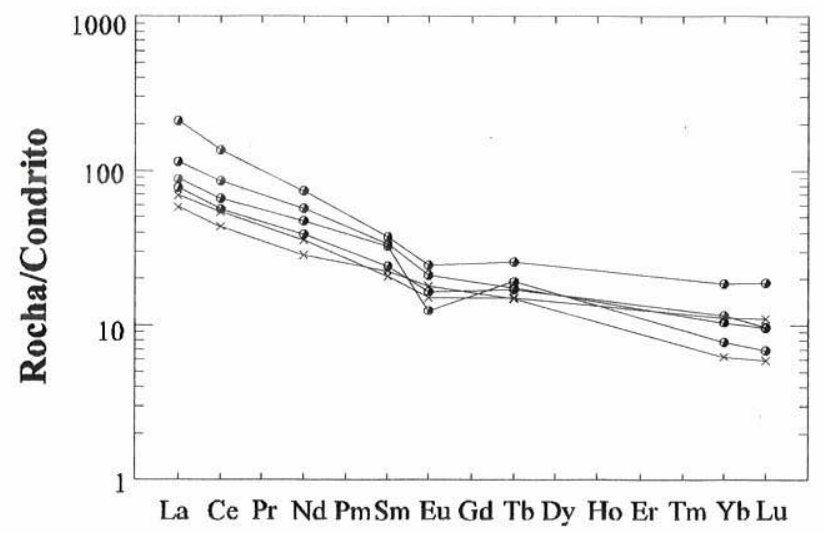

- Complexo Juiz de Fora

$\times$ Complexo Mantiqueira

Figura 113 - Diagrama ETR, normalizadas pelo condrito de Boynton (1984), para as rochas intermediárias dos Complexos Juiz de Fora e Mantiqueira.

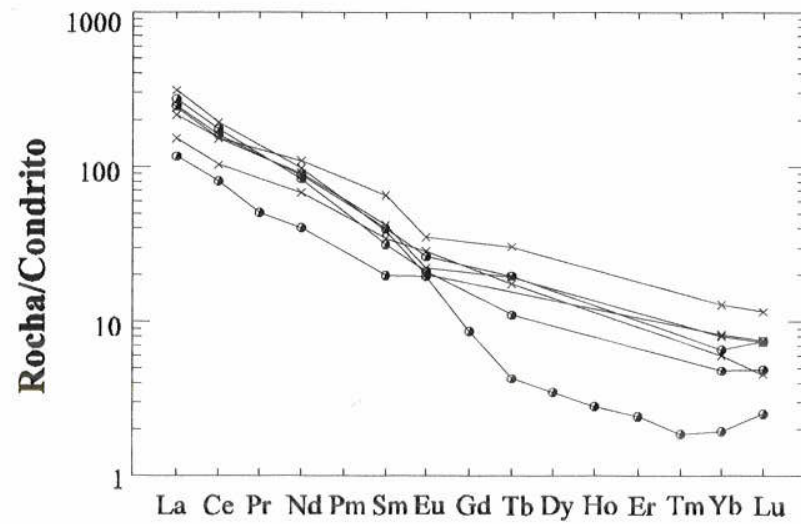

Figura 114 - Diagrama ETR, normalizadas pelo condrito de Boynton (1984), para as rochas intermediárias dos Complexos Juiz de Fora e Mantiqueira. 
d) Ambas as unidades apresentam três grupos de rochas ácidas que são distintos em termos de distribuição de ETR. As figuras 115, 116 e 117 apresenta cada uma destes grupos para o CJF e o $\mathrm{CM}$, permitindo verificar que: 1) o conjunto de rochas ácidas com forte fracionamento de ETR mostra-se semelhantes para as duas unidades (Fig. 116); 2) o mesmo pode ser comentado para as rochas ácidas com anomalias positivas de Eu (Fig. 115 e 117); e 3) por outro lado, o conjunto de rochas ácidas com anomalias negativas de Eu só foi verificado para o $\mathrm{CM}$ (Fig. 115).

\section{b.2) Análise quantitativa}

Embora a análise visual, tanto em termos de elementos maiores quanto traços, mostre uma razoável semelhança entre os dois complexos, a individualização de grupos e/ou suítes dentro do CJF e do CM teve como base critérios quantitativos, sejam estatísticos e/ou petrológicos. A coerência ou não de agrupamentos previamente definidos a partir da análise qualitativa foi testada pela aplicação de parâmetros estatísticos capazes de quantificar o grau de correlação do grupo potencial. A análise petrológica em base numérica, fundamentada na abundância e distribuição dos ETR, propiciou um ótimo refinamento dos resultados. Apesar do modelamento petrogenético com base em todos os componentes químicos das rochas não ter sido um objetivo desta tese, buscou-se o melhor tratamento possível para os ETR, já que existe uma boa concordância entre os vários estudiosos de que estes elementos comportam-se com razoável imobilidade durante os processos de metamorfismo regional.

Assim, com base na procedimento analítico adotado (análise quantitativa e modelamento petrogenético), pode-se listar as seguintes semelhanças entre os dois complexos:

a) Presença de rochas básicas toleíticas com padrões de ETR relativamente bem fracionados $\left([\mathrm{La} / \mathrm{Yb}]_{\mathrm{N}} \approx 3,0\right.$ a 4,7$)$;

b) Presença de rochas intermediárias com $[\mathrm{La} / \mathrm{Yb}]_{\mathrm{N}} \approx 6-13$.

As diferenças existentes entre o CM e o CJF podem ser assim resumidas:

a) Rochas básicas toleiticas com padrões de ETR do tipo N-MORB, i.e., ([La/Yb $\left.]_{\mathfrak{n}} \leq 1\right)$, só foram encontradas no CJF; 


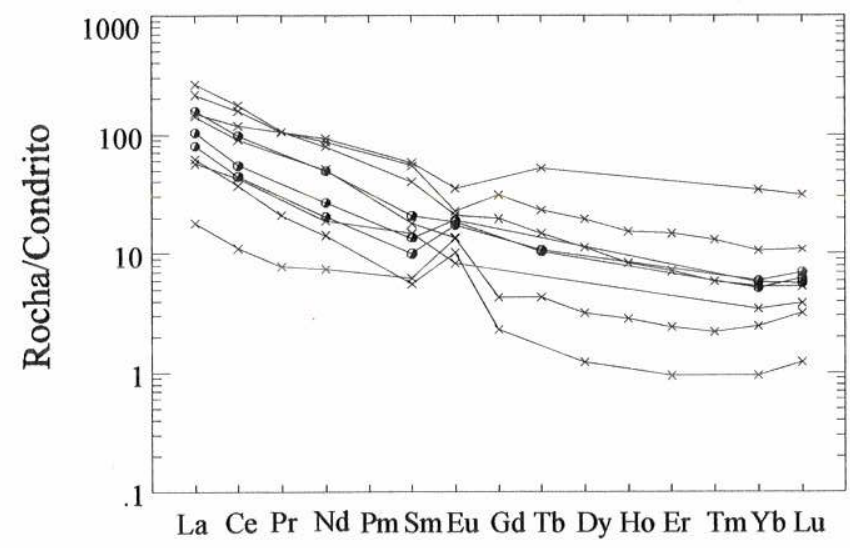

Complexo Mantiqueira

- Complexo Juiz de Fora

Figura 115 - Diagrama de ETR, normalizados pelo condrito de Boynton (1984), para as rochas ácidas dos Complexos Juiz de Fora e Mantiqueira.

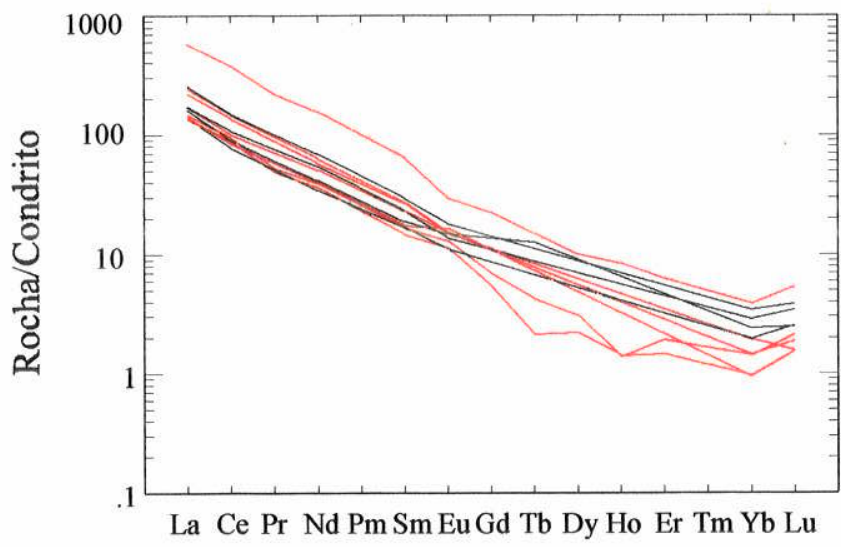

Complexo Mantiqueira

Complexo Juiz de Fora

Figura 116 - Diagrama de ETR, normalizados pelo condrito de Boynton (1984), para as rochas ácidas dos Complexos Juiz de Fora e Mantiqueira.

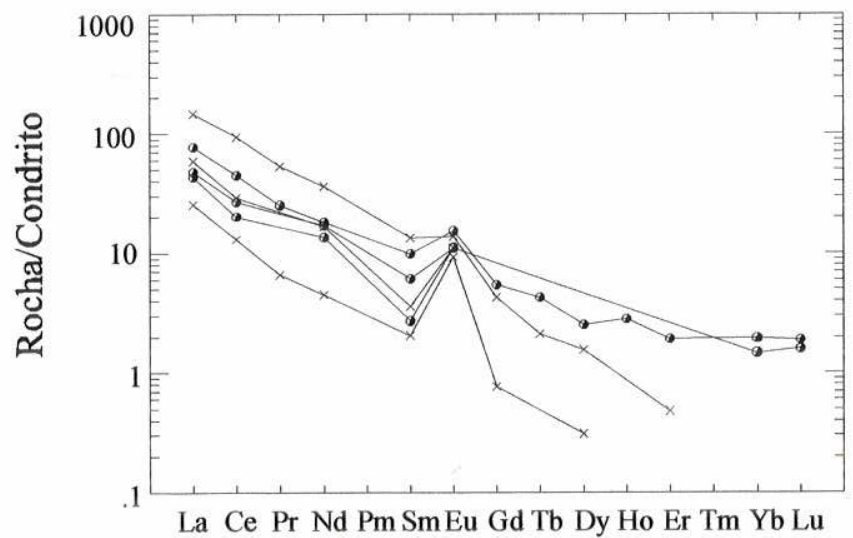

$\times$ Complexo Mantiqueira

- Complexo Juiz de Fora

Figura 117 - Diagrama de ETR, normalizados pelo condrito de Boynton (1984), para as rochas ácidas dos Complexos Juiz de Fora e Mantiqueira. 
b) Rochas básicas com padrões de ETR pouco fracionados e sem anomalia negativa de Eu ocorrem no CM e no CJF. Entretanto, aquelas do $\mathrm{CM}$ são mais fracionadas $\left([\mathrm{La} / \mathrm{Yb}]_{\mathrm{N}} \approx 2,1\right.$ $2,8)$, enquanto que as do $\mathrm{CJF}$ tem $[\mathrm{La} / \mathrm{Yb}]_{\mathrm{N}} \approx 1,3-1,5$;

c) Rochas básicas com padrões de ETR pouco fracionados $\left([\mathrm{La} / \mathrm{Yb}]_{\mathrm{N}} \approx 1,8-2,0\right)$ e anomalias negativas de $\mathrm{Eu}\left(\mathrm{Eu} / \mathrm{Eu}^{*}<1\right)$ foram detectadas somente no CJF;

d) As rochas metabásicas alcalinas do CJF tem relativamente fraco fracionamento $\left([\mathrm{La} / \mathrm{Yb}]_{\mathrm{N}} \approx\right.$ 3 - 4), enquanto que aqueles do $\mathrm{CM}$ têm $\left([\mathrm{La} / \mathrm{Yb}]_{\mathrm{N}} \approx 13-18\right.$;

e) Rochas intermediárias com padrões de ETR mais fracionados têm fracionamentos distintos quando se compara quantitativamente o CJF $\left([\mathrm{La} / \mathrm{Yb}]_{\mathrm{N}} \approx 57-60\right)$ e o $\mathrm{CM}\left([\mathrm{La} / \mathrm{Yb}]_{\mathrm{N}} \approx 16-\right.$ $40)$;

e) Rochas ácidas com padrões de ETR relativamente menos fracionados ([La/Yb $\left.]_{\mathrm{N}} \approx 4-50\right)$ e com anomalia negativa de $\mathrm{Eu}\left(\mathrm{Eu} / \mathrm{Eu}^{*}<1\right)$ só foram verificadas no $\mathrm{CM}$; e

f) Enquanto que em ambos os complexos ocorrem rochas ácidas relativamente bem fracionadas, no CJF a razão $[\mathrm{La} / \mathrm{Yb}]_{\mathrm{N}}$ varia de $60-75$, enquanto que para o $\mathrm{CM}$ esta razão é maior do que $100\left([\mathrm{La} / \mathrm{Yb}]_{\mathrm{N}} \approx 100-150\right)$.

Sendo assim, pode-se concluir que, enquanto a análise apenas qualitativa (visual) leva a um maior número de semelhanças do que de diferenças entre o $\mathrm{CJF}$ e o $\mathrm{CM}$, a análise quantitativa revela diferenças importantes, porém não obvias sob análise menos detalhada. A análise quantitativa, certamente mais adequada, fornece resultados muito diferentes que levam a conclusões contrárias àquelas advindas da análise puramente qualitativa.

\section{b.3) Comparação com base no modelamento petrogenético}

O modelamento petrogenético de cada um dos agrupamentos identificados no CM e no CJF foi extensivamente descrito e discutido nos capítulos precedentes (Cap. II.7.3 e II.7.4). A presente seção tem como objetivo comparar de uma maneira mais geral os resultados obtidos para cada um destes complexos, a fim de agregar mais dados para a discussão de sua origem e evoluções.

A partir do procedimento analítico adotado, foi possível verificar que tanto para o CJF quanto para o CM, as rochas básicas, de um lado, e as intermediárias a ácidas, de outro, têm origens distintas. Ou seja, o modelamento mostrou que é improvável que alguma das rochas 
básicas, do $\mathrm{CJF}$ ou do $\mathrm{CM}$, representem magmas parentais para as rochas intermediárias à ácidas. Como anteriormente relatado, não foi possível modelar os processos genéticos associados às rochas básicas de ambos os complexos, dado o reduzido número de amostras. No entanto, o modelamento quantitativo discutido sugere que cristalização fracionada e assimilação simples são os processos petrogenéticos mais prováveis associados as rochas mais evoluídas do CJF. Dados de campo suportam, também a existência de rochas encaixantes e rochas intrusivas, identificadas como representantes, respectivamente, de materiais contaminantes e contaminados, nos modelos de assimilação simples efetuados. Em conjunto, estes resultados sugerem que durante um período de tempo relativamente longo, um magma ocupou uma câmara magmática em alguma porção da crosta continental. Durante este tempo, a evolução deste magma se deu através de um mecanismo que envolvia, principalmente, cristalização fracionada e, subordinadamente, talvez nas paredes desta câmara, processos de assimilação e contaminação crustal.

Os agrupamentos identificados para o $\mathrm{CM}$ apresentavam características distintas daqueles do CJF, o que forçou a opção pelo modelamento de outros processos petrogenéticos. Sendo assim, cada um dos grupos do CM foi abordado isoladamente. Em função das restrita variação de $\mathrm{SiO}_{2}$ existente dentro de cada grupo e da ausência de magmas parentais potenciais, optou-se pelo modelamento de processos de fusão parcial. Os resultados obtidos foram bons e distintos quando comparando-se estes vários grupos. O modelamento apontou para processos de 20 a 30\% de fusão crustal; ora uma crosta mais enriquecida, semelhante à crosta superior de Taylor \& McLennan (1981); ora uma crosta menos enriquecida, semelhante à crosta inferior destes mesmos autores. No caso dos agrupamentos ácidos, os resultados foram muito bons quando se considera a fusão de 20 ou $30 \%$ de uma fonte com composição semelhante àquela dos agrupamentos intermediários.

Assim, em função do que foi discutido, conclui-se que o sucesso do modelamento dos processos petrogenéticos (cristalização fracionada e assimilação simples para o CJF e fusão parcial para o $\mathrm{CM}$ ) reforça as muitas diferenças e, talvez as pequenas semelhanças, existentes entre o CJF e o CM. 


\section{b.4) Discussão}

Os resultados advindos do modelamento petrogenético indicam diferenças substanciais na origem e evolução dos protólitos das rochas que constituem o CJF quando comparadas àquelas do CM. Entretanto, não são capazes de explicar, mas apenas de sugerir, possíveis causas para estas diferenças.

A evolução por cristalização fracionada associada a processo de assimilação simples, que foi sugerida para o CJF, implica em um tempo de residência de um magma em uma câmara magmática na crosta continental. Este tempo de residência deve ser longo o suficiente para promover a diferenciação desde termos quartzo monzodioríticos até termos graníticos de alta $\mathrm{SiO}_{2}$. Esta câmara magmática tinha necessariamente uma dinâmica própria e eficiente, capaz de acolher uma evolução relativamente complexa. As características deste ambiente de evolução do CJF parecem ser dominantes, sem influências externas, sejam de câmaras vizinhas ou de processos tectônicos. Assim, o CJF parece ter evoluído em uma porção crustal que passava por relativa calmaria em termos de processos tectônicos. Em outras palavras, a crosta que acolheu o "magma CJF" era capaz de desenvolver e manter atuantes processos petrogenéticos típicos de ambientes de câmara magmática.

Por outro lado, a evolução do CM sugere uma crosta incapaz de gerar, ou pelo menos manter, câmaras magmáticas ativas por longo tempo. O processo de fusão crustal leva à geração de magmas, cujos pontos de fusão são bem próximos ao mínimo granítico. Estas duas características associadas apontam para uma evolução relativamente rápida; ou seja, pouco tempo teria transcorrido entre a fusão e a cristalização dos magmas gerados. Isto sugere uma crosta relativamente mais dinâmica, provavelmente sob grande influência de processos tectônicos. 


\section{PARTE III = DISCUSSÕES E EONCLUSÕES}

\section{III.1) Discussão dos Resultados Isotópicos Disponíveis Para os Complexos Juiz de Fora e Mantiqueira}

Dados de campo, petrográficos e, principalmente, a análise quantitativa dos dados químicos realizada na presente tese sugerem diferenças petrogenéticas importantes entre os Complexos Juiz de Fora e Mantiqueira. A análise integrada destes resultados com os dados geocronológicos disponíveis na literatura se faz necessária à luz do conhecimento geológico e petrológico atual para a região de Juiz de Fora.

Delhal et al. (1969) obtiveram idades $\mathrm{Rb} / \mathrm{Sr}$ de $\approx 2000$ Ma. para o metamorfismo de alto grau de granulitos bandados, paraderivados, da Série Paríba (denominação que agrupava as antigas Séries Paraíba-Desengano e Juiz de Fora). Outras quatro amostras de rochas granulíticas, um charnockito e um leptinito forneceram idade $\mathrm{Rb} / \mathrm{Sr}$ de $1923 \pm 60 \mathrm{Ma}$., com $\mathrm{Ri}$ $=0,7115 \pm 0,0016$. Estes altos valores de $\mathrm{Ri}$ foram interpretados pelos autores como coerentes, uma vez que o material tem origem detrítica. Análises para U/Pb em zircão destas mesmas amostras geraram dispersão de pontos, tendo a melhor curva fornecido idade de 2200 Ma. que foi interpretada como a época de cristalização do zircão. Segunda os autores, tal dispersão de pontos era esperada dado que estas rochas são detríticas e, portanto, devem ter zircões herdados e zircões neoformados (ou rehomogeneizados). Idades $\mathrm{Rb} / \mathrm{Sr}$ sistemáticas de $\approx 600 \mathrm{Ma}$. indicam rejuvenescimeto durante a Orogênese Brasiliana.

Após mais de trinta anos, os resultados da investigação isotópica realizada por Cordani et al. (1973) são ainda significantes para o entendimento da evolução da crosta Precambriana do sudeste brasileiro. A partir da localização dos pontos de coleta das amostras utilizadas pelos autores em mapas geológicos mais recentes e da descrição petrográfica destas amostras, Tupinambá et al. (1997) situaram os resultados daqueles autores no contexto atual do conhecimento geológico. Com base nesta pesquisa, Tupinambá et al. (op.cit.) identificaram 
que, dentre as amostras coletadas na região de Juiz de Fora, três amostras analisadas são de paragnaisses granulíticos (englobados na Unidade Jardim Glória no presente trabalho), uma quarta é de granada charnockito e uma quinta é de ortognaisse enderbítico. Somente este último litotipo é englobado no CJF na presente tese. Segundo Cordani et al. (op.cit.), idades $\mathrm{Rb} / \mathrm{Sr}$ destas amostras variam de 2,33 $(\mathrm{Ri}=0,7142)$ a 2,42 $(\mathrm{Ri}=0,7109)$. Para metagrauvacas e kinzigitos desta mesma região, os autores encontraram idade $\mathrm{Rb} / \mathrm{Sr}$ (rocha total) de 2000 Ma. Assim, interpretaram a então Série Juiz de Fora como formada parcialmente por material juvenil do Transamazônico e também por material crustal Arqueano retrabalhado. Análises $\mathrm{Rb} / \mathrm{Sr}$ em plagioclásio e ortoclásio de um charnockito granoblástico forneceram idade de 493 $\pm 9 \mathrm{Ma}$. e Ri de 0,7538 , o que mostra que esta rocha sofreu os efeitos da Orogênese Brasiliana.

Para o Complexo Mantiqueira, os resultados isotópicos de Cordani et al. (1973) foram recalculados por Figueiredo \& Teixeira (1996) que encontraram idade de 2,88 $\mathrm{Ga}$. e $\mathrm{Ri}=$ 0,708. Esta idade foi interpretada como herança Arqueana do protólito dos gnaisses do CM. Tal interpretação não difere muito daquela de Cordani et al. (op.cit.) que sugeriram, para o Complexo Mantiqueira, idade Arqueana com migmatização no Evento Termo-Tectônico Transamazônico e rejuvenescimento na Orogênese Brasiliana.

Machado et al. (1996) analisaram uma amostra de ortogranulito charnockítico do CJF de uma área adjacente a SSW (região de Conservatória, RJ). Este litotipo, um charnockito leuco a hololeucocrático, também ocorre na área alvo, onde mostra contatos intrusivos com os ortogranulitos quartzo monzodioríticos a charnoenderbíticos. Os autores supracitados encontraram, para esta rocha, idade $\mathrm{U} / \mathrm{Pb}$ em zircão de $2,1 \mathrm{Ga}$. Considerando que este litotipo é provavelmente uma das mais novas manifestações magmáticas do $\mathrm{CJF}$, a idade de $2,1 \mathrm{Ga}$. pode ser entendida como uma idade mínima para esta unidade litológica. Entretanto, é possível que o zircão analisado tenha se cristalizado durante o metamorfismo na facies granulito. Assim, 2,1 Ga. corresponderia à idade do pulso metamórfico denominado $\mathrm{M}_{0}$ no presente trabalho.

A partir de novos resultados analíticos para rochas do Complexo Mantiqueira, Figueiredo \& Teixeira (1996) obtiveram isócronas $\mathrm{Rb} / \mathrm{Sr}$ entre 2,2 e 2,1 Ga. Em termos de $\mathrm{Ri}$, dois grupos foram identificados: 1) Ri entre 0,705 e 0,703 ; e 2) Ri entre 0,713 e 0,712. A 
existência de dois grupos indica a participação de diferentes fontes crustais na evolução Paleoproterozóica destas rochas. Integrando outros dados da literatura $(\mathrm{Rb} / \mathrm{Sr} ; \mathrm{Pb}-\mathrm{Pb}$ e U-Pb), os autores encontraram uma concentração no intervalo de 2,1 a $1,9 \mathrm{Ga}$. que foi interpretado como a época do pico do metamorfismo regional de médio a alto grau. Outras idades, $\mathrm{Pb} / \mathrm{Pb}$ e $\mathrm{U} / \mathrm{Pb}$ em zircão, foram interpretadas como herança Arqueana dos protólitos. $\mathrm{O}$ fato dos altos valores de $\mathrm{Ri}$ serem mais numerosos do que os baixos, os autores concluíram que, embora exista material juvenil, a maior parte é derivada de retrabalhamento de crosta pré-existente, com rehomogeinização isotópica completa. Diferenças na assinatura isotópica do $\mathrm{Sr}$ também levaram à identificação de dois agrupamentos: 1) amostras com razão $\mathrm{Rb} / \mathrm{Sr}$ média apresentam baixa $\mathrm{Ri}$ e fornecem idades de 2,2 a 2,00 Ga. (interpretado; e 2) amostras com razão $\mathrm{Rb} / \mathrm{Sr}$ alta têm alta $\mathrm{Ri}$ e fornecem idade de 2,2 a 2,1 Ga. O primeiro grupo é interpretado como como material Paleoproterozóico ortoderivado, enquanto o segundo, como retrabalhamento de crosta superior. Análises K/Ar forneceram idades mais jovens: 550 - 500 Ma. em biotitas (interpretadas como resultantes de rejuvenescimento completo na Orogênese Rio Doce); 535 Ma. em hornblendas (indicam $\mathrm{T}$ superiores a $450^{\circ} \mathrm{C}$ para o último metamorfismo regional; e $640 \mathrm{Ma}$. em biotitas (sugerem outro episódio metamórfico anterior à Orogênese Rio Doce. Com base em análises químicas e nos resultados apresentados, os autores interpretaram o Complexo Mantiqueira como um arco magmático maduro desenvolvido em margem continental ativa durante o Evento Termo-Tectônico Transamazônico, envolvendo retrabalhamento de crosta Arqueana e rejuvenescimento na Orogênse Rio Doce (550 - 500 Ma.). A partir de semelhanças químicas, os autores sugeriram a mesma origem para o complexo Juiz de Fora.

Fischel et al. (1998) obtiveram dados isotópicos $\mathrm{Sm}-\mathrm{Nd}$ para rochas dos Complexos Mantiqueira e Juiz de Fora ocorrentes na região de Abre Campo-Manhuaçu (MG). Para o Complexo Mantiqueira foram encontradas idades modelo $\mathrm{T}_{\mathrm{DM}}$ do Arqueano (entre 3,02 - 3,26 Ga.) e Neoarqueano (entre 2,53 - 2,64 Ga.). Em oposição, o Complexo Juiz de Fora fornece idades modelo $\mathrm{T}_{\mathrm{DM}}(\mathrm{Sm}-\mathrm{Nd})$ correspondentes ao Paleoproterozóico $(2,22-2,13 \mathrm{Ga}$.) ou mais novas $(\approx 1,5-1,4 \mathrm{Ga}$. $)$. 
Com base no exposto, verifica-se que integrando os dados apresentados na presente pesquisa aos resultados isotópicos expostos nesta seção, verifica-se que as diferenças já levantadas entre os Complexos Mantiqueira e Juiz de Fora são reforçadas. Enquanto que todas as análises para rochas do CM indicam a presença de material Arqueano e Paleoproterozóico, os resultados para o CJF indicam idade de formação e/ou metamorfismo granulítico Paleoproterozóica. Em geral, os autores afirmam que existem sugestões para a presença de porções Arqueanas. Métodos mais retentivos (U/Pb, $\mathrm{Pb} / \mathrm{Pb}$ em zircão) e idades modelo $\mathrm{Sm}-\mathrm{Nd}$ para o CJF confirmam o intervalo de 2,2 a 2,1 para sua formação e/ou metamorfismo. referente a partir de métodos mais retentivos para o CJF. Estes mesmos métodos aplicados para o CM indicam idades Arqueanas-Neoarqueanas. Com exceção de Figueiredo \& Teixeira, os demais autores interpretam as idades Paleoproterozóicas obtidas para o CM como resultantes de retrabalhamento de material Arqueano.

Idades de rejuvenescimento isotópico referentes às Orogêneses Brasiliana e Rio Doce foram encontradas pelos vários autores, tanto em amostras do CM quanto do CJF.

Estas diferenças em termos de assinaturas isotópicas vêm reafirmar as diferenças petrogenéticas encontradas entre o CM e o CJF no pesente trabalho. 


\section{III.2) Ambiente Geotectônico de Formação e Evolução dos Litotipos dos Complexos Mantiqueira e Juiz de Fora}

\section{III.2.1) Introdução}

Este capítulo se dedica à comparação das assinaturas geoquímicas dos Complexos Mantiqueira e Juiz de Fora com assinaturas geoquímicas de rochas formadas em ambientes geotectônicos modernos. Tal comparação vem agregar dados ao conhecimento da formação e evolução tectônica destes Complexos, além de abrir discussões referentes ao tipo de processo tectônico atuante no Arqueano e no Paleoproterozóico.

Uma das mais acirradas discussões em Geologia/Geotectônica envolve a questão da aplicação dos conceitos e mecanismos da Tectônica de Placas Moderna aos tempos Arqueano e Proterozóico. Modelos geotectônicos baseados na visão atualística da Tectônica de Placas estão em disputa com modelos não convencionais de orogênse aplicados a esses tempos remotos. Diante deste tema, os autores se dividem em: 1) aqueles que aplicam a Tectônica de Placas Moderna à evolução de rochas precambrianas (atualistas); e 2) aqueles que aplicam para o precambriano modelos não convencionais de orogênese (p.ex: subduç̧ão $A$ ). Os autores do primeiro grupo (p. ex: Windley, 1995; Ellis, 1992) defendem que os oceanos formados pela fragmentação continental eram pequenos, uma vez que o alto fluxo de calor promovia uma movimentação mais rápida do que a observada atualmente. A este modelo associa-se obviamente a acreção continental e formação de suturas. Os autores do segundo grupo (p. ex: Kroner, 1983; Etheridge et al., 1987), com base na ausência de evidências para o fechamento de oceanos precambrianos, aplicam o conceito de subducção A (deslaminação da crosta continental como motor propulsor de convergência e colisão continental) para explicar o desenvolvimento de orogêneses ensiálicas. Segundo este modelo, faixas móveis precambrianas evoluíram em um ambiente ensiálico por retrabalhamento de material antigo, o que requer que um grande percentual de crosta continental tenha formado em tempos relativamente precoces da história da Terra.

Esta polêmica ocorre principalmente no que se refere ao Arqueano, uma vez que a grande produção de calor a partir do decaimento de isótopos radiogênicos (esta produção era 
três vezes maior no Arqueano em comparação ao que é hoje; Ritcher, 1985) promovia pequenas diferenças físicas entre litosfera continental e oceânica. Este aspecto demonstra a dificuldade existente em se aplicar mecanismos da Tectônica de Placas moderna ao Arqueano. Por outro lado, evidências indicam que no Paleoproterozóico formaram-se os primeiros supercontinentes (Piper, 1987), o que demostra diminuição no fluxo térmico e o estabelecimento de litosfera continental e oceânica. Em função das diferenças de fluxo térmico entre Arqueano e Proterozóico, Durrheim e Mooney (1991) propuseram os seguintes modelos: 1) No Arqueano, as correntes de conveç̧ão mantélicas tinham um padrão turbulento e as zonas de espalhamento do assoalho oceânico e de subducção tinham vida curta. Os processos de underplating eram ligados à acreção de magmas ultramáficos que, portanto, não eram distintos do manto superior. Assim, a crosta mantinha-se pouco espessa $(\approx 35 \mathrm{Km}) ; 2)$ No Proterozóico, as correntes de convecção apresentavam um padrão mais estável, sendo as zonas de formação de assoalho oceânico e de subducção de duração mais prolongada. $O$ underplating já era de magmas básicos, o que promovia o espessamento crustal $(\approx 45 \mathrm{Km})$.

\section{III.2.2) Ambiente Geotectônico de Formação das Rochas do Complexo Mantiqueira}

Este tema será discutido com base nas assinaturas geoquímicas dos litotipos do $\mathrm{CM}$, uma vez que a deformação policíclica destas rochas obliterou estruturas e texturas originais.

\section{a) Ambiente Geotectônico dos Anfibolitos de Afinidade Toleiítica}

Em diagrama de variação multi-elementar como os da figura 118, os anfibolitos toleíticos mostram enriquecimento seletivo nos elementos $\mathrm{LIL}, \mathrm{Th}, \mathrm{Ta}, \mathrm{Nb}$ e $\mathrm{Ce}$ e teores semelhantes ao N-MORB no que diz respeito aos HFSE e ao Yb. Esta assinatura é semelhante tanto às de E-MORB quanto às de basaltos de bacias de retro-arco e às de basaltos intracontinentais. A figura 118 apresenta a assinatura destes anfibolitos em comparação a basaltos toleíticos de vários ambientes tectônicos. Analisando-se todos estes diagramas, verifica-se que, os anfibolitos mais empobrecidos têm assinaturas semelhantes a E-MORB, enquanto que os mais enriquecidos têm padrões que mais se aproximam de basaltos intra-continentais modernos (Fig. 118a e c). Esta semelhança geoquímica é reforçada pelos dados de campo que sugerem 
que parte destes metabasitos sejam antigos diques deformados e rompidos (Fig. 12c). A semelhança química entre alguns metabasitos do CM e basaltos toleíticos do tipo E-MORB pode sugerir ambiente de fundo oceânico. Entretanto, assinaturas geoquímicas típicas ou semelhantes às de E-MORB podem ser encontradas em ambientes tectônicos extensionais intra-continentais (Wilson, 1989). Dados de campo associados à ausência de padrões de ETR do tipo N-MORB dentre os anfibolitos do $\mathrm{CM}$ e à semelhança de todo o conjunto destas rochas com basaltos toléticos de platô sugerem que estes anfibolitos representem diques instalados em ambiente tectônico intra-continental, sob regime distensivo.

\section{b) Ambiente Geotectônico dos Anfibolitos de Afinidade Alcalina}

Em diagramas de variação multi-elementar, verifica-se que estes anfibolitos têm um padrão "corcovado", com empobrecimento geral no sentido dos elementos mais imóveis (Fig. 119). Este é um padrão típico de basaltos alcalinos e transicionais de ambientes intra-placa, como, por exemplo, o apresentado na figura 119. Assim, estes anfibolitos são interpretados como basaltos de ambientes distensivos intra-continentais ou intra-oceânicos. Dados de campo e de litogeoquímica apontam mais fortemente para o ambiente intra-continental. Basaltos toleiticos com estas características químicas são típicos de ambientes de riftes continentais.

\section{c) Ambiente Geotectônico dos Gnaisses Intermediários a Ácidos, de Afinidade Calcioalcalina}

Nos regimes tectônicos atuais, a química característica de magmas calcioalcalinos está fortemente relacionada a ambientes tectônicos compressivos desenvolvidos em margens ativas. O membro félsico (vulcânicas félsicas e/ou sequências do tipo TTG) das associações bimodais comuns em terrenos Arqueanos tem assinatura geoquímica semelhante àquela das rochas calcioalcalinas modernas. A ausência de rochas de composição andesítica no $\mathrm{CM}$ faz com que esta unidade tenha um caráter bimodal. Entretanto, dados isotópicos sugerem que o CM é constituído de material formado tanto no Arqueano quanto no Paleoproterozóico. A obliteração das estruturas e texturas originais dificulta a identificação da cronologia relativa dos eventos magmáticos, o que torna dificil uma comparação mais refinada. Assim, sugere-se apenas que as rochas intermediárias a ácidas do $\mathrm{C} M$ tenham sido geradas em ambiente tectônico compressivo, semelhantes àqueles de arcos magmáticos modernos. 

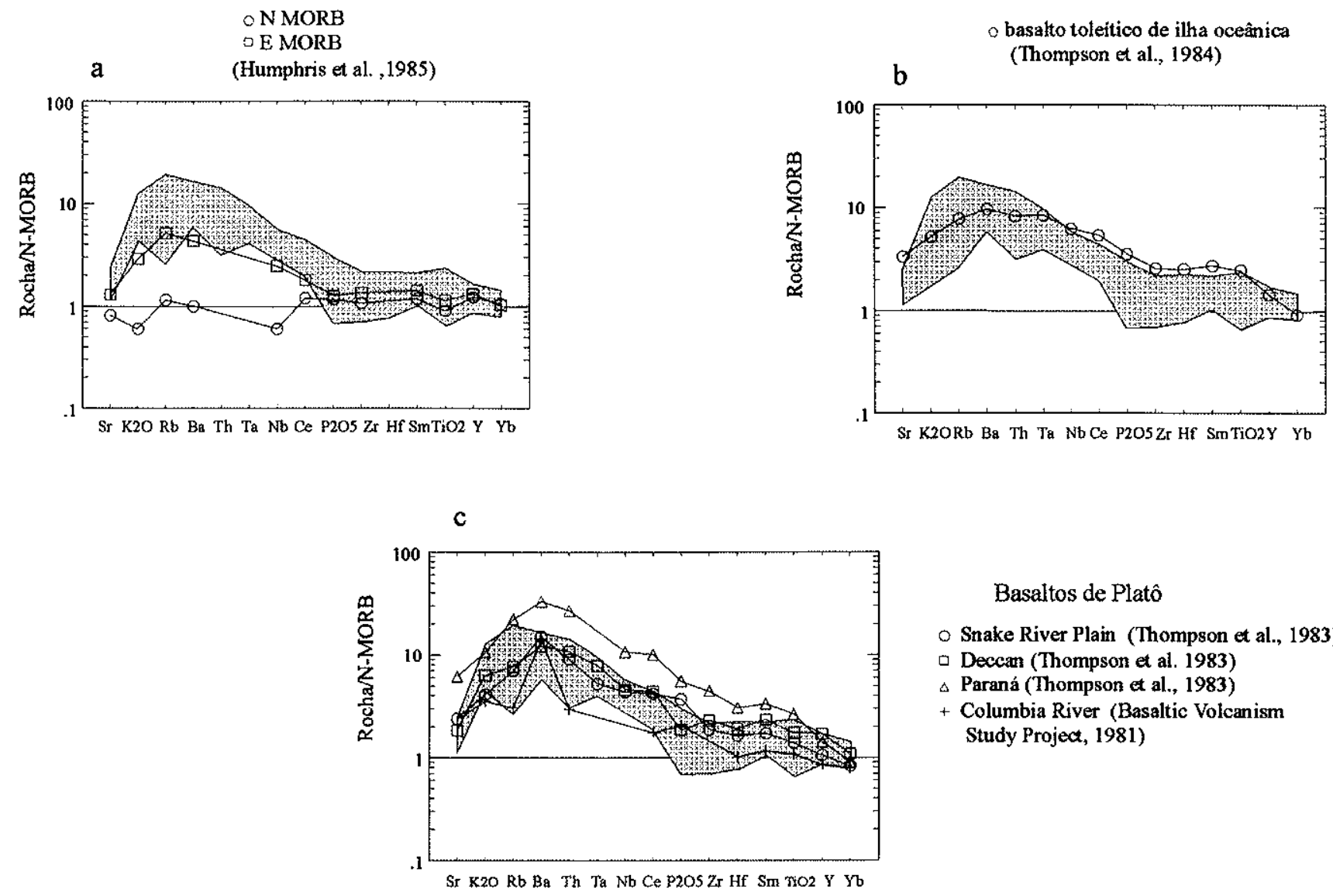

Basaltos de Platô

o Snake River Plain (Thompson et al., 1983)

- Deccan (Thompson et al. 1983)

$\triangle$ Paraná (Thompson et al., 1983)

+ Columbia River (Basaltic Volcanism Study Project, 1981)

Figura 118 - Diagamas de variação multi-elementar para os anfibolitos toleíticos do Complexo Mantiqueira (envelope preenchido) comparados a basaltos toleíticos modernos de ambientes geotectônicos distintos. Dados normalizados por N-MORB (Pearce, 1983).

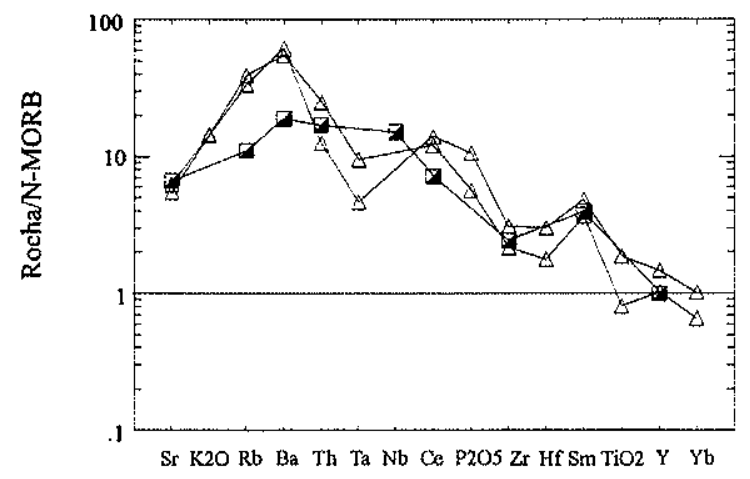

a Basalto alcalino intraplaca (Pearce, 1982)

$\triangle$ Amostas JF - $58 \mathrm{~B}$ e JF $-60 \mathrm{~B}$

Figura 119 - Diagama de variação multi-elementar para os anfibolitos de afinidade alcalina do Complexo Mantiqueira comparados a basalto alcalino moderno de ambiente intra-placa. Dados normalizados por N-MORB (Pearce, 1983). 


\section{III.2.3) Ambientação Geotectônica das Rochas do Complexo Juiz de Fora}

Os ortogranulitos do CJF estão inseridos em um contexto de evolução geológica complexa, policíclica, com o envolvimento de eventos deformacionais e metamórficos de alto grau recorrentes, que se desenvolveram, pelo menos desde o Paleoproterozóico ao Neoproterozóico-Paleozóico Inferior. História tectônica tão complexa levou à obliteração generalizada de texturas, estruturas e paleogeografia originais. Assim, com base nos dados litoquímicos, apresenta-se uma comparação entre assinaturas geoquímicas destas rochas e aquelas de associações litológicas modernas.

\section{a) Ambiente Geotectônico dos Noritos}

A comparação entre as rochas noríticas do CJF e padrões de ambientes geotectônicos modernos é apresentada nas figuras 120 e 121. Como já mostrado na seção II.7.3, os metabasitos do CJF formam um grupo petrogeneticamente heterogêneo. As amostras 17A e 17B (?) têm padrão de distribuição de ETR e razão $[\mathrm{La} / \mathrm{Yb}]_{\mathrm{N}}$ característicos de basaltos toleíticos tipo N-MORB. A figura 120 apresenta diagrama ETR para estas amostras em comparação a um basalto toleítico moderno de cadeias meso-oceânicas. Embora os noritos do CJF sejam mais empobrecidos em ETR total, seus padrões são bastante semelhantes àqueles da amostra de basalto tipo N-MORB.

As amostras $42,15 \mathrm{C}$ e $46 \mathrm{P}$ têm padrões ETR e razões $[\mathrm{La} / \mathrm{Yb}]_{\mathrm{N}}$ semelhantes àquelas de basaltos toleíticos de fonte mantélica tipo E-MORB (seção II.7.3). Em diagramas de variação multi-elementar, normalizados por N-MORB (Fig. 121a), verifica-se a semelhança existente entre as amostras do CJF e estes basaltos toleíticos. Assinaturas geoquímicas típicas ou semelhantes às de E-MORB podem ser encontradas em vários ambientes tectônicos extensionais como cadeias meso-oceânicas, bacias de retro-arco e também em ambientes intracontinentais (Wilson, 1989).

Em diagrama multi-elementar, os noritos de razões $[\mathrm{La} / \mathrm{Yb}]_{\mathrm{N}}$ mais altas $(183 \mathrm{~A}, 514 \mathrm{~B}$ e 514C) apresentam padrão característico de toleítos intra-placa. As figuras 121b e 121c apresentam estas rochas em comparação com basaltos de vários ambientes intra-placa modernos. A partir da análise dos diagramas destas figuras, reforça-se a grande semelhança 


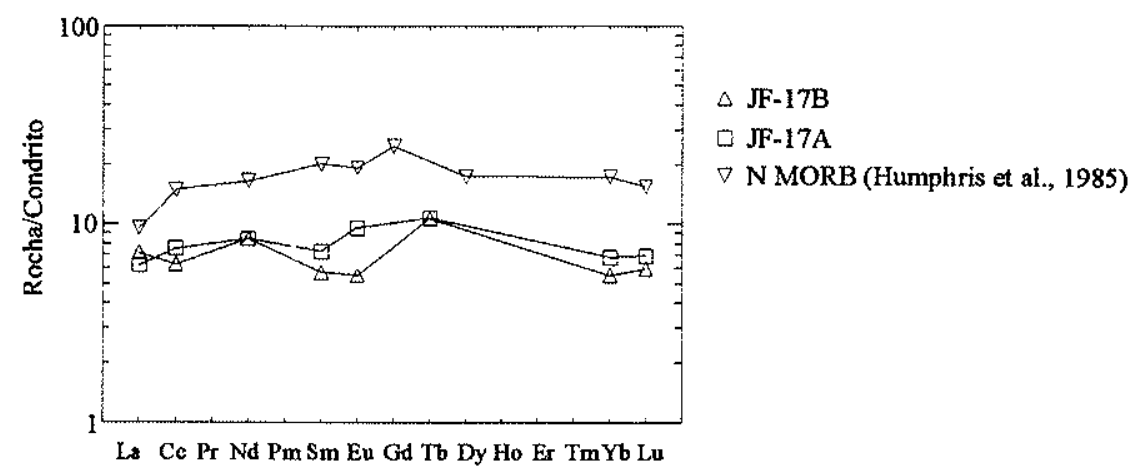

Figura 120 - Diagrama de distribuição de ETR para as amostras 17A e 17B em comparação com basaltos tipo N-MORB. Normalização pelo condrito de Boynton (1984).

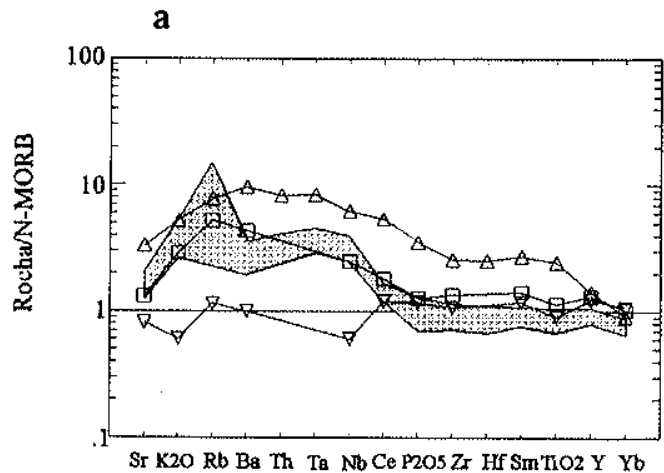

basalto de ilha oceânica

(Thompson et al., 1984)

E MORB (Humphris at al., 1985)

$\nabla$ N MORB (Humphris a al., 1985)

basalto de ilha oceânica

(Thompson et al., 1984)

E MORB (Humphris et al., 1985)

$\nabla$ N MORB (Humphris et al., 1985)

C

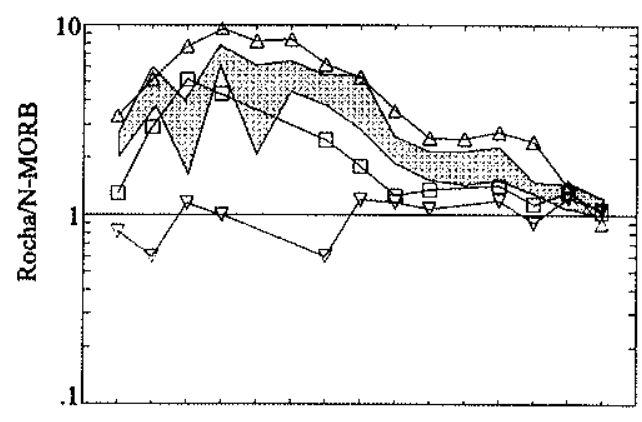

$\mathrm{Sr} \mathrm{K} 2 \mathrm{O} \mathrm{Rb} \mathrm{Ba}$ Th $\mathrm{Ta} \mathrm{NbCe}$ P2Os $\mathrm{Zr}$ HF Sm TrO2Y Yb

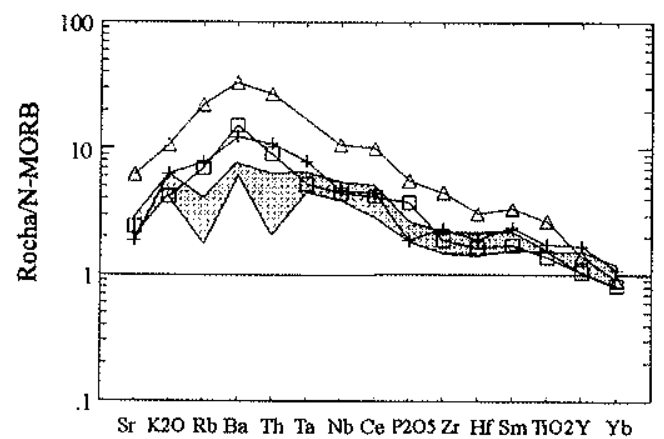

Basaltos de Platô

$\square$ Shake River Plain

$\triangle$ Parand

+ Deccon

(Thompson et a., (983)

Figura 121 - Diagramas de variação multi-elementar para os noritos toleíticos do Complexo Juiz de Fora comparados a basaltos toleíticos $\mathrm{d}$ e vários ambientes modernos. a - amostras 15C, 42 e 46 P; b e c - amostras 183A, 514B e 514C.Normalização segundo N-MORB de Pearce (1983). 
existente entre estas amostras e basaltos intra-placa, principalmente aqueles de ambiente intracontinental do tipo platô.

Assim, em termos de ambientes tectônicos, os metabasitos toléticos do CJF podem ser subdivididos em três grupos: 1) basaltos de assoalhos oceânicos (tipo N-MORB: amostras 17A e 17B (?)); e tipo E-MORB:); 2) basaltos de ambiente intra-placa continental (amostras 183A, 514B e514C); e basaltos tipo E-MORB (amostras 15C, 42 (?) e 46P), cuja química é encontrada em ambientes de fundo oceânico e intra-continental.

\section{b) Ambiente Geotectônica dos Granulitos Enderbíticos a Charnockíticos}

Os granulitos enderbíticos a charnockíticos, quando plotados em aranhogramas normalizados pelo Granito de Crista Oceânica, mostram características semelhantes às rochas calcioalcalinas de arcos magmáticos e/ou de ambientes sin-colisionais modernos (Fig. 122).

Sugere-se, então, que estes granulitos são produtos magmáticos de ambientes tectônicos convergentes e que, portanto, devem representar diferentes estágios e/ou diferentes arcos magmáticos calcioalcalinos Paleoproterozóicos. A ausência de associações com rochas metassedimentares aponta, mais especificamente, para um ambiente de raiz de arco. 


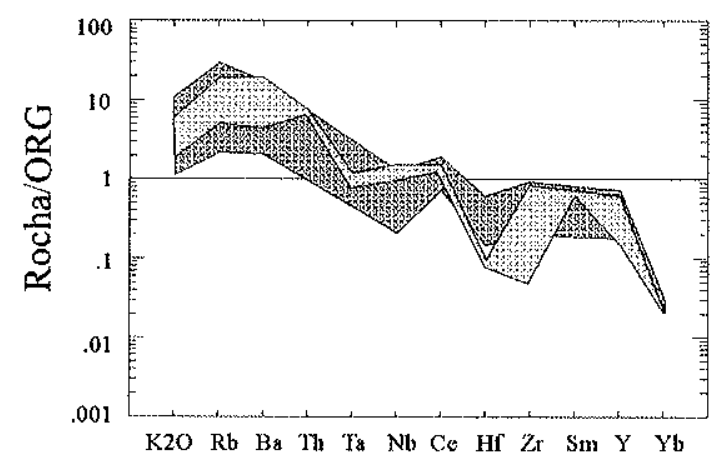

T2 Enderbitos do C.JF com $[\mathrm{La} / \mathrm{Yb}]_{\mathrm{N}}=11$

67. Rochas Graníticas de ArcosVulcânicos e Colisionais (Pearce et al., 1984)

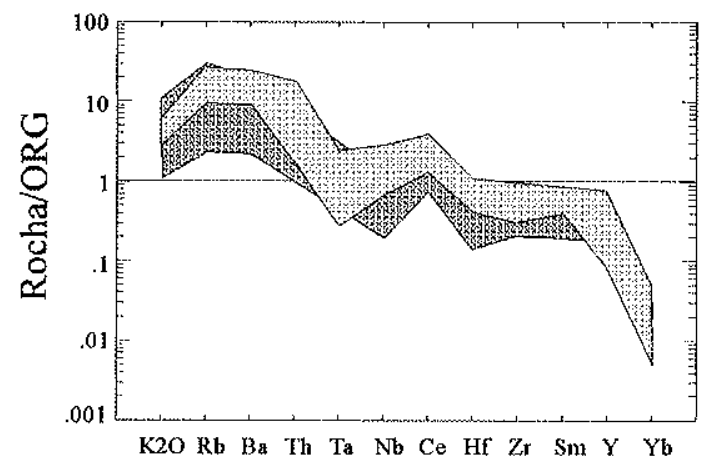

Enderbitos a charno-enderbitos do C.F com $[\mathrm{La} / \mathrm{Yb}]_{\mathrm{N}}$ entre 57 e 60

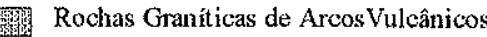
e Colisionais (Pearce et al., 1984)

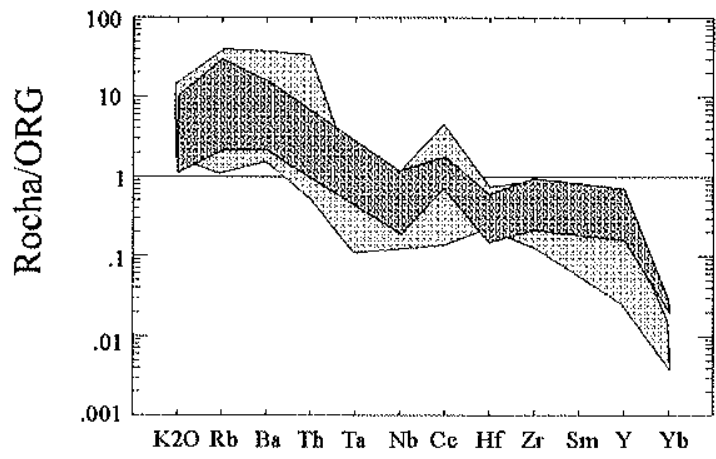

Chamockitos do CJF

Rochas Graníticas de ArcosVulcânicos e Colisionais (Pearce et al., 1984)

Figura 122 - Plote das rochas enderbíticas a charnockíticas do CJF em comparação com rochas graníticas de arcos vulcânicos e ambientes colisionais modernos. Normalização:ORG de Pearce et al.(1984). 


\section{III.3) Integração dos Resultados, Discussões e Modelos Geotectônicos para a Formação e Evolução das Rochas dos Complexos Mantiqueira e Juiz de Fora}

\section{III.3.1) Processos Relacionados à Geração e Evolução dos Protólitos}

A partir da análise quantitativa dos dados litoquímicos e do modelamento petrogenético realizado (seção II.7), foi possível verificar importantes diferenças entre os Complexos Mantiqueira e Juiz de Fora. Enquanto que as rochas de afinidade calcioalcalina do $\mathrm{CM}$ formam quatro agrupamentos não expandidos (em termos de $\mathrm{SiO}_{2}$ ), porém petrogeneticamente distintos, dentre as rochas do CJF pode ser verificada a existência de uma suite relativamente expandida de rochas cogenéticas. Como já discutido anteriormente (seção II.8), esta diferença indica que o ambiente tectônico de formação das rochas do CM não era capaz de gerar câmaras magmáticas e permitir o desenvolvimento de um processo mais complexo de diferenciação magmática. Os processos tectônicos então atuantes tinham, provavelmente, uma dinâmica muito conturbada e rápida, gerando ambientes e processos de vida curta. Por outro lado, o regime tectônico reinante quando da formação das rochas do CJF era relativamente mais calmo, sendo capaz de estabilizar ambientes e gerar e manter câmaras magmáticas.

As diferenças encontradas para o CM e CJF com base nos dados desta tese são suportadas por resultados de investigações isotópicas realizadas para estas unidades (seção III.1). Para o CM, a análise isotópica indica formação, em parte, no Arqueano e, em parte, no Paleoproterozóico. No caso das rochas do CJF, os resultados apontam mais fortemente para formação (e talvez também granulitização) Paleoproterozóca. Em alguns casos, os autores afirmam que no CJF os dados apenas sugerem a existência de porções Arqueanas. Assim, é provável que, enquanto $\circ \mathrm{CM}$ represente uma unidade que evoluiu do Arqueano ao Paleoproterozóico, o CJF parece representar material Paleoproterozóico juvenil.

Outro aspecto que vem suportar os resultdos deste trabalho é o fato de que no $\mathrm{CM}$ foi encontrado um grande número de valores altos de $\mathrm{Ri}$ (razão inicial $\mathrm{Rb} / \mathrm{Sr}$ ) para isócronas Arqueanas. Isto indica que houve intenso retrabalhamento crustal nesta época, o que é 
sugerido pela opção da fusão parcial crustal como processo petrogenético de formação das rochas do $\mathrm{CM}$.

As assinaturas geoquímicas encontradas para as rochas do CM e do CJF mostram-se análogas àquelas de ambientes tectônicos modernos. Ambas as unidades apresentam características químicas de ambientes extensionais para algumas rochas básicas e compressivos para as intermediárias a ácidas. Entretanto, embora os ambientes tectônicos possam ser semelhantes, a análise mais detalhada (seções II.7 e II.8) permitiu a identificação de importantes diferenças entre as duas unidades (p. ex.: basaltos do tipo N-MORB só foram encontrados no CJF e rochas graníticas de razão $[\mathrm{La} / \mathrm{Yb}]_{\mathrm{N}}>100$ ocorrem somente no $\mathrm{CM}$ ).

No entanto, a grande diferença ou a causa das diferenças encontradas entre o CM e o CJF parece estar relacionada à estabilidade do ambiente que gerou cada uma detas unidades. Os resultados da análise quantitativa e do modelamento petrogenético indicam que o ambiente de formação do CM era caracterizado por grande instabilidade e um regime tectônico rápido. Em oposição, o contexto tectônico gerador das rochas do CJF apresentava relativa estabilidade, sugerindo a ocorrência de processos mais lentos. Considerando que o CM e o CJF representem, respectivamente, associações Arqueana e Paleoproterozóica, as diferenças encontradas refletem diferenças entre estas duas épocas da história da Terra. Como exposto anteriormente, vários estudos mostram que o fluxo térmico no Arqueano era superior àquele de todos os períodos mais jovens. Em função deste alto fluxo térmico, o regime tectônico Arqueano era provavelmente mais rápido. Isto tornava dificil o resfriamento da crosta oceânica que, portanto, não apresentava a mesma capacidade de afundar que é observada para a crosta oceânica atual. A ausência do movimento de subducção (pelo menos como ocorre hoje) faz com que não se formem ofiolitos obductados (Windley, 1995; Davies, 1992). Isto pode explicar a ausência de sequências ofilíticas em terrenos Arqueanos. É importante frisar que no $\mathrm{CM}$, cujas idades são, pelo menos em parte, Arqueanas, não foram encontradas rochas de composição basáltica com assinaturas de N-MORB.

No caso do CJF, o tectonismo, provavelmente mais lento, era capaz de gerar ambientes mais estáveis. O fluxo térmico era também mais baixo, o que promovia movimentação mais lenta e um resfriamento mais efetivo da crosta oceânica, possibilitando sua subducção. A identificação de supercontinentes Paleoproterozóicos (Piper, 1987) sugere que a partir desta 
época, o processo de Tectônica de Placas moderno pode ter se instalado. A existência de rochas de composição basáltica tipo N-MORB no CJF indica a possível ocorrência de obduç̧ão de crosta oceânica.

Como resultado das diferenças de fluxo térmico, a força propulsora dos processos tectônicos tinha características distintas no Arqueano e no Proterozóico. Durrheim e Mooney (1991) sugeriram que no Arqueano as correntes de convecção eram turbulentas, promovendo instabilidade de ambientes e processos rápidos de geração e retrabalhamento crustal. Para os autores, no Proterzóico as correntes de conveç̧ão já tinham um padrão mais definido, não turbulento, possibilitando a formação de ambientes mais estáveis.

Estes modelos de distintos padrões de correntes de convecção entre Arqueano e Proterozóico podem explicar as diferenças verificadas entre os processos de formação do CM e do CJF. A demonstrada instabilidade do ambiente de formação do CM pode ser explicada por tectonismo promovido por correntes de convecção turbulentas, como as defendidas para o Arqueano (Durrheim \& Mooney, op.cit.). Por outro lado, o CJF expressa condições mais calmas, sendo provavelmente o reflexo de um padrão mais regular de correntes de convecção.

Sugere-se então que o conjunto de rochas calcioalcalinas do CM tenha se formado em ambientes equivalentes a arcos vulcânicos/magmáticos e ambientes colisionais. As manifestações magmáticas de composição basáltica mostram padrões semelhantes àqueles de basaltos de ambientes distensivos modernos e, com base em dados de campo, conclui-se que aquelas de ambiente intraplaca representam um período tardio na evolução do CM.

A integração dos dados apresentados sugere que as rochas calcioalcalinas do CJF formaram-se em ambiente tipo arco magmático. A ausência de associações com rochas metassedimentares indica que estas rochas evoluíram em ambiente plutônico. Isto corrobora a complexidade do processo petrogenético sugerido para sua formação que, naturalmente, necessitava de condições que acolhessem processos lentos de diferenciação magmática. A associação com rochas basálticas tipo N-MORB sugere proximidade à crosta oceânica, o que reforça a existência de ambiente de margem ativa. 
Magmatismo toleítico tipo platô e alcalino representam provavelmente estágios tardios na evolução do CJF.

Conclui-se então que além das diferenças no grau metamórfico, o $\mathrm{CM}$ e o CJF representam associações litológicas petrogeneticamente distintas, formadas em ambientes e, provavelmente, em épocas também distintas. O cavalgamento do DTJF (onde ocorre o CJF) sobre o DTAND (onde ocorre o CM) ocorreu durante a Orogênese Brasiliana (590 - 495 Ma., Machado et al., 1996). Entretanto, ainda são poucos os dados que permitissem uma conclusão acerca de suas posições relativas em períodos anteriores à Orogênese Brasiliana. Ou seja, a amalgamação destes terrenos pode ter ocorrido no Paleoproterozóico ou no Neoproterozóico/Paleozóico Inferior.

\section{III.3.2) Processos Relacionados ao Metamorfismo Granulítico das Rochas do Complexo Juiz de Fora}

Dados de campo mostram que todos os litotipos do CJF, independente da composição e estrutura, são esverdeados ou cor de caramelo e contém paragêneses com ortopiroxênio. Apenas efeitos parciais de metamorfismo retrogressivo são observados. Embora tanto processos magmáticos quanto metamórficos possam ser os agentes causadores de desidratação nestas rochas, os dados apresentados (campo, petrografia e química mineral e rocha total) sugerem que a granulitização foi promovida por um evento metamórfico. De qualquer forma, é possível que magmatismo anídrico também tenha ocorrido, uma vez que em vários ambientes tectônicos (extensionais ou compressionais) processos magmáticos e metamórficos ocorrem simultaneamente. Duas principais hipóteses petrogenéticas têm sido defendidas para explicar o mecanismo de granulitização: fusão parcial (Fyfe, 1973); e metamorfismo carbônico Newton et al., 1980). A primeira hipótese implica na existência produtos magmáticos ácidos (anatéticos) e de termos intermediários a básicos que representam o resíduo do processo de fusão parcial. Este, portanto, é um processo extremamente ativo que leva à diferenciação entre uma crosta superior ácida de baixa razão $\mathrm{K} / \mathrm{Rb}$ e uma crosta inferior residual, intermediária à básica, de alta razão $\mathrm{K} / \mathrm{Rb}$. Por outro lado, a segunda hipótese implica em um processo metamórfico passivo, resultante de reações de desidratação e expulsão de $\mathrm{H}_{2} \mathrm{O}$ promovidas pela entrada de um front de $\mathrm{CO}_{2}$. 
A elaboração de um modelo petrogenético para o metamorfismo na facies granulito das rochas do CJF deve levar em consideração os seguintes aspectos:

a) Dados de campo e petrográficos mostram que todos os litotipos do CJF, independente de composição, textura e estrutura, são rochas de cor esverdeada ou caramelada, com ortopiroxênio e, sobre as quais o processo retrometamórfico teve um efeito apenas parcial;

b) Os litotipos migmatíticos têm tanto leucossomas quanto paleossomas esverdeados, com ortopiroxênio, sugerindo que a migmatização, processo obviamente dinâmico, foi anterior à granulitização;

c) Se as amostras analisadas são quantitativa e qualitativamente representativas do CJF na área alvo, como presumido pelo presente trabalho, pode-se verificar que a composição média deste terreno é granodiorítica e, portanto, similar à crosta superior (Taylor \& McLennan, 1981; Weaver \& Tarney, 1984). Como a hipótese de fusão parcial considera uma diferença composicional entre a crosta superior (granodiorítica) e a inferior (intermediária), o terreno CJF não se adequa a este modelo;

d) O CJF encerra um grande volume de granulitos ácidos que não podem ser considerados resíduos de processo de fusão crustal;

e) Dados isotópicos sugerem que a granulitização se desenvolveu no Ett Transamazônico (Delhal et al., 1969; Machado et al., 1996), enquanto que a retrogressão ocorreu há $580 \mathrm{Ma}$., durante a Orogênese Brasiliana (Machado et al., op.cit.);

f) $\mathrm{O}$ metamorfismo na facies granulito ocorreu sob condições de $\mathrm{T}>850^{\circ} \mathrm{C}$ e $\mathrm{P}$ baixa (provavelmente entre 4 e $6 \mathrm{~Kb}$; dados deste trabalho e de Nogueira, 1994); e

g) $O$ estudo de inclusões fluidas em fases minerais da paragênese granulítca destas rochas mostrou a predominância de fluidos carbônicos e a evolução deste metamorfismo ao longo de um caminho do tipo resfriamento isobárico (IBC) (Nogueira, 1994). 
Em conclusão, os dados apresentados neste estudo sugerem que o processo de desidratação, que causou o metamorfismo na facies granulito das rochas do CJF, esteve relacionado à infiltração de um fluido, provavelmente rico em $\mathrm{CO}_{2}$, que expulsou e substituiu a $\mathrm{H}_{2} \mathrm{O}$, levando ao consumo de paragêneses hidratadas e formação de fases anidras. $O$ fato deste metamorfismo ter se desenvolvido sob condições de alta temperatura e baixa pressão implica necessariamente na elevação do gradiente geotérmico normal promovida por processo de acreção magmática na base da crosta (underplating). Assim, sugere-se que a fonte de calor e do fluido carbônico necessários ao metamorfismo em questão tenha sido o magma básico acrescido à base da crosta por ocasião de um evento distensivo.

Sugere-se então que o CJF tenha evoluído desde um ambiente compressivo de raiz de arco magmático, quando da formação dos protólitos, até um ambiente distensivo que acolheu o metamorfismo granulítico destas rochas, promovido provavelmente por underplating magmático.

\section{III.3.3) Correlação Regional das Unidades Metassedimentares}

No Domínio Tectônico Andrelândia, as sequências de rochas supracrustais descritas correspondem ao Ciclo Deposicional Andrelândia (Andreis et al., 1989a e 1989b). Três unidades lito-estratigráficas foram identificadas as quais podem ser correlacionadas àquelas informais descritas por Trouw et al. (1986) e às litofácies definidas por Paciullo (1997). A seguir é apresentada esta correlação.

a) Biotita gnaisse bandado (este trabalho) - Biotita gnaisse bandado (Trouw et al., op.cit.) Litofácies 1 (Paciullo, op.cit.);

b) Biotita gnaisse bandado, biotita-granada-(sillimanita) gnaisse e quartzito (este trabalho) Biotita gnaisse bandado e granada gnaisse (Trouw et al., op.cit.) - Litofácies 1 e 2 (Paciullo, 1997); e

c) Quartzito, biotita gnaisse quartzoso e biotita gnaisse fino porfiroclástico (este trabalho) Unidade Quartzítica (Trouw et al., op.cit.).

Ortoanfibolitos com contatos bruscos e, por vezes, claramente discordantes com as rochas do Ciclo Deposicional Andrelândia foram interpretados como diques intrusivos. 
Análises isotópicas $\mathrm{Sm} / \mathrm{Nd}$ forneceram idades modelo entre 1184 e $1053 \mathrm{Ma}$., que representam idades mínimas para as rochas metassedimentares do Ciclo Deposicional Andrelândia (CDA). Resultados de idades ${ }^{207} \mathrm{~Pb} /{ }^{206} \mathrm{~Pb}$ em zircões detríticos de quartzitos do $\mathrm{CDA}$ forneceram valores entre 2886 e $1957 \mathrm{Ma}$., com concentração no intervalo de 2,1 - 2,4 Ga. (Valladares et al., 1997). Estes resultados indicam fonte Arqueana e Paleoproterozóica para estas rochas.

No Domínio Tectônico Juiz de Fora, as rochas metassedimentares ocorrem tectonicamente interdigitadas com os ortogranulitos do Complexo Juiz de Fora. Entretanto, dados de campo e ptrográficos associados a dados isotópicos e à integração com dados de Trouw et al. (1996), e Paciullo (1997) permitem que se faça algumas considerações. A seguinte sequência lito-estrutural foi identificada para as rochas metassedimentares deste domínio:

a) Biotita-granada-(sillimanita)-(ortopiroxênio) gnaisse (predomínio de meta-semipelitos) informalmente denominado de Unidade Jardim Glória;

b) Biotita gnaisse bandado e quartzito (predomínio de litotipos quartzosos);

c) Biotita-granada-sillimanita gnaisse biotita gnaisse homogêneo, quartzito, rochas calcissilicáticas e granada quartzito (predomínio de metapelitos).

Análises isotópicas foram também realizadas em rochas metassedimentares deste domínio. Cordani et al. (1973) encontraram idades $\mathrm{Rb} / \mathrm{Sr}$ de 2,33 a 2,42 Ga.. para as rochas meta-semipelíticas englobadas na Unidade Jardim Glória no presente trabalho. Entretanto, dados de campo mostram que esta unidade sofreu intensos efeitos da Orogênese Brasiliana, quando então foi cavalgada por espessa escama de ortogranulitos do Complexo Juiz de Fora e metamorfisada sob condições correspondentes à fácies granulito. Condições tão intensas em termos de deformação e metamorfismo promoveriam a rehomogeneização do sistema isotópico. Uma possível explicação para esta incoerência seria se estas rochas, de idade Arqueana, já estivessem sob as condições de pressão e temperatura a que foram submetidas durante a Orogênese Brasiliana.

Outros dois importantes aspectos devem ser considerados. O primeiro é que não existem registros da ocorrência de rochas metassedimentares Arqueanas em áreas adjacentes. É possível que as rochas metassedimentares do Grupo Paraíba do Sul (Almeida et al., 1991) sejam Arqueanas, entretanto, não existem dados isotópicos disponíveis. Além disso, este 
paragnaisse da Unidade Jardim Glória não se assemelha, em termos de associações litológicas, a nenhuma das unidades lito-estratigráficas definidas para aquele Grupo. Por outro lado, este predomínio de rochas meta-semipelíticas associadas a poucas lentes de rochas calcissilicáticas e metabasitos se assemelha bastante ao biotita-granada-(sillimanita) gnaisse descrito, neste trabalho, para o Domínio Tectônico Andrelândia. Desta forma, esta unidade poderia se correlacionar ao granada gnaisse de Trouw et al. (1986) e á litofácies 2 de Paciullo (1997). Com base no exposto, identifica-se a correlação regional da Unidade Jardim Glória como uma questão ainda não definida.

A associação entre biotita gnaisse bandado e quartzito, que ocorre estruturalmente acima dos gnaisses da Unidade Jardim Glória, foi datada por Valladares et al. (1997). Em região adjacente (região entre Santa Rita do Jacutinga e Rio Preto), foram obtidos resultados de idades ${ }^{207} \mathrm{~Pb} /{ }^{208} \mathrm{~Pb}$ em zircões detríticos em quartzitos. Idades similares àquelas do Domínio Tectônico Juiz de Fora foram encontradas, entretanto com concemtração no intervalo $2,0-2,1$ Ga.. Valores mais antigos, entre 3065 e $2614 \mathrm{Ga}$., foram também encontrados. Os autores concluíram que tanto as rochas metassedimentares do Domínio Tectônico Andrelândia quanto aquelas do Domínio Tectônico Juiz de Fora são produto da erosão de uma crosta predominantemente Transamazônica com contribuição Arqueana subordinada.

Dados de campo e petrográficos permitem verificar a grande semelhança existente entre esta associação de rochas quartzosas e àquela descrita para a sequência de topo do Dominio Tectônico Andrelândia (este trabalho) e, portanto, também em relação à Unidade Quartzítica de Trotw et al. (1986) definida informalmente como um dos níveis litoestratigráficos do Ciclo Deposicional Andrelândia de idade Mesoproterozóica. Desta forma, no presente trabalho, propõe-se a correlação da associação biotita gnaisse bandado e quartzito à Unidade Quartzitica de Tromw et al. (1996).

A sequência metassedimentar estruturalmente superior do Domínio Tectônico Juiz de Fora corresponde a um conjunto de rochas de várias naturezas, porém com largo predomínio de rochas metapelíticas. Além de biotita-granada-sillimanita gnaisses, ocorrem biotita gnaisses homogêneos e bandados, quartzitos, granada quartzitos e rochas calcissilicáticas. Diferentemente da Unidade Jardim Glória, este conjunto além de ser caracteristicamente metapelítico, apresenta maior volume dos demais litotipos em sua associação. Esta unidade 
lito-estrutural ainda não foi contemplada com análises isotópicas, entretanto, dados de campo e petrográficos sugerem fortemente que seja correlacionável à sequência estratificada e à litofácies 6 definidas, respectivamente, por Trouw et al. (1986) e Paciullo (1997) como a unidade de topo do Ciclo Deposicional Andrelândia. 


\section{REFERÊNCIAS BIBLIOGRÁFICAS}

AB'SABER, A. N. 1972. Participação de superficies periféricas e superficies aplainadas na compartimentação do planalto brasileiro: considerações finais e conclusões. Geomorfologia. São Paulo, 28: 01-38.

ALMEIDA, F.F.M. 1967. Origem e Evolução da Plataforma Brasileira. Boletim da Divisão de Geologia Mineral. DNPM, Rio de Janeiro, 241:1-36.

ALMEIDA, F.F.M. 1969. Diferenciação Tectônica da Plataforma Brasileira In: Cong. Bras. Geol., 23, Salvador, 1969, Anais... SBG, p.29-46.

ALMEIDA, F.F.M. 1971. Geochronological Division of the Precambrian of South America. Rev. Bras. Geoc., São Paulo, 1(1): 13-21.

ALMEIDA, F.F.M. 1977. O Cráton de São Francisco. Rev. Bras. Geoc., 7:349-364.

ALMEIDA, F.F.M. 1981. O Cráton de Paramirim e suas relações com o Cráton do São Francisco e suas Faixas Marginais. In: Simpósio sobre o Cráton do São Francisco e suas Faixas Marginais, 1,Anais... 1981, Salvador, CBPM-SBG, p. 1-10.

ALMEIDA, F.F.M; AMARAL, G.; CORDANI, U.G.; KAWASHITA, K. 1973. The Precambrian evolution of the South American Cratonic Margin South of Amazonas River. In: The Ocean Basin and Margins (Nairn \& Stille, Eds.), 1:411-446, Plenum, New York.

ALMEIDA, F.F.M. , HASUI, Y. \& Brito Neves, B.B. 1976. The Upper Precambrian os South America. Boletim IG-USP, São Paulo 7:45-80.

ALMEIDA, F.F.M.; HASUI, Y.; DAVINO, A. \& HARALYI, N.L.E. 1980. Informações geofísicas sobre o oeste mineiro e sua significado geotectônico. An. Acad. Bras. Cienc. 52: 49-60.

ALMEIDA, F.F.M. \& HASUI, Y. 1984. O Pré-Cambriano do Brasil. São Paulo, Editora Edgard Blucher, 378p.

ALMEIDA, J.C.H. 1992. Mapeamento Litoetsrutural da folha Luminárias, MG. 1:50.000, com ênfase nos metasedimentos do ciclo deposicional Andrelândia. Dissertação de Mestrado. 116p. IG/UFRJ. Inédita.

ANDREIS, R.R., RIBEIRO, A. \& PACIULLO, F.V.P. 1989a. Ciclos deposicionais no proterozóico das folhas Barbacena e Divinópolis (setor sul), 1:250.000. In Simp. Geol. Sudeste, I, Rio de Janeiro, 1989, Bol. Res., p. 97-98.

ANDREIS, R.R., RIBEIRO, A. \& PACIULLO, F.V.P. 1989b. Observações preliminares em sequências silicoclásticasda Formação Tiradentes (Grupo São João del Rei) nas áreas da Serra do Lenheiro e são José. In: Simp. Geol. de Minas Gerais, 4, Anais... B. Horizonte, $\mathrm{SBg} / \mathrm{Núcleo} \mathrm{MG}$. 
ARTH, J.G. 1976. Behaviour of trace elements during magmatic process - a summary of theoretical models and their aplications. Jorn. Res. U. S. Geol. Survey. 4:41-47

ARTH, J.G. \& HANSON, G.N. 1975. Geochemistry and origin of the early precambrian crust of northeastern Minessota, Geochim Cosmochim. Acta 38: 757-775.

BACKER A. J. 1990. Introduction to Metamorphic Textures and Microstructures. Blackie, Ney York. 162p.

BARBOSA, A.L. \& SAD, J.H.G. 1983a . Reinterpretação Das Séries Juiz de Fora e Paraíba, em Minas Gerais e no Rio de Janeiro. IN: Simp. Geol. MG., 2, Belo Horizonte, 1983. Anais... Belo Horizonte, SBG. P. 1-15.

BARBOSA, A.L. \& SAD, J.H.G. 1983b. Petrografia dos Charnockitos e Rochas Afins ao Longo da Divisa RJ/MG. IN: Simp. Geol. MG., 2, Belo Horizonte, 1983. Anais... Belo Horizonte SBG. P. 63-74.

BARBOSA, A.L. \& SAD, J.H.G. 1983c. Geoquímica e Petrologia dos Charnockitos e Rochas Afins do Complexo Juiz de Fora. RJ/MG. IN: Simp. Geol. Mg., 2, Belo Horizonte, 1983. Anais... Belo Horizonte SBG. P. 75-84.

BARBOSA, O. 1954. Evolution du Geossinclinal Espinhaço. Comptes. Rendus, Section xiii, 19e session: 1-37. Intern. Geol. Congr. 1952, Argélia.

BARD, J. P. 1985. Microtexturas de Rocas Magmáticas y Metamorficas. Masson Ed. 181p.

BASALTIC VOLCANISM STUDY PROJECT. 1981. Basaltic Volcanism on teh Terrestial Planets. New York, Pergamon Press. 1286 pp.

BITAR, S.M. 1990. Mapa geológico-estrutural da folha Caxambu e de parte sul da folha Luminárias, MG. In: Congr. Bras. Geol. 36, Natal, 1990. Anais... Natal, SBG. V.6: 2798-2807.

BLUNDY, J.D. \& HOLLAND, J.B. 1990. Calcic amphibole equilibria and a new amphiboleplagioclase geothermometer. Contr. Miner. Petrol. 104: 208-224.

BOHLEN, S.R. 1987. Pressure-temperature-time paths and a tectonic model for the evolution of granulites. Journ. Geol. 95: 617-633.

BOHLEN, S.R.; WALL, V.J. \& BOETTEHER, A.L. 1983. Experimental investigation and application of garnet granulite equilibria. Contr. Miner. Petrol. 83: 52-61.

BOYNTON, W.R. 1984. Cosmochemistry of the rare earth elements meteorite studies. In: HENDERSON, P. (ed). Rare Earth Element Geochemistry, pp.63-114. Elsevier, Amsterdan.

CAVAlCANTI, J.C. 1979. Projeto Sapucai. Serv. Geol. Bras. DGM/DNPM, Brasília V(2): $299 \mathrm{p}$. 
CHRISPIM, S. J. 1990. Mapeamento geológico de uma área na Folha Carmo da Cachoeira (MG) com ênfase nas Serras da Bocaina e Faria (Rio de Janeiro), Rio de Janeiro. Dissertação de Mestrado. IG/UFRJ. 197p. Inédita.

CAMPBELL, I.H. 1985. The diffrence between oceanic and continental tholeiites: a fluid dynamic explanation. Contr. Mineral. Petrol. 91: 37-43.

CAMPOS NETO, M.C. 1990. A porção ocidental da Faixa Alto Rio Grande - Ensaio de Evolução Tectônica. Tese de Doutoramento. IG-USP. 210p.

CAMPOS NETO, M.C. \& FIGUEIREDO, M.C.H. 1990. Evolução geológica dos terrenos Costeiro, Paraíba do Sul e Juiz de Fora (RJ-MG-ES). In: Cong. Bras. Geol., 36, Natal, 1990. Anais... SBG, 6:2631-2648.

CAMPOS NETO, M.C. \& FIGUEIREDO, M.C.H. 1992. A Orogênese Rio Doce. In: CONGRESSO BRASILEIRO DE GEOLOGIA, 37, São Paulo, 1992. Boletim de Resumos Expandidos... SBG, 1:276-277.

CAMPOS NETO, M.C. \& FIGUEIREDO, M.C.H. 1995, The Rio Doce Orogeny, Southeastern Brazil. Journal of South American Earth Sciences, 8(2): 143-162.

CASTRO, H.O; QUEIROZ, M.A.; BARBOSA, A.L. \& SAD, J.H.G. 1984. Geologia das folhas Rio Preto, Valença, Barra do Piraí e Vassouras. In: Congr. Bras. Geol., 33, Rio de Janeiro, Anais... Rio de Janeiro, p: 2346-2354.

CLEMENS, J. \& VIELZEUF, D. 1987. Constraints on melting and magma production in the crust. Earth Plan. Sci. Lett. 86: 287-306.

CLARK, S.P. 1962. Temperatures in the continental crust. In: Temperature, its Measurement and Control in Science and Industry. Vol 3/1 (Ed. C.M.Herzfeld). Reinhold.

CONDIE, K. 1981. Archean Greenstone Belt. Elsevier. Amsterdan. 434 p.

CORDANI, U.G.; MELCHER, G.C. \& ALMEIDA, F.F.M. de . 1967. Outline of Precambrian Geochronology of South America. Canadian Journal of Earth Science, 5:629-632.

CORDANI, U.G.; DELHAL, J.; LEDENT, O. 1973. Orogeneses superposeés dans le Précambrien du Brésil sud-oriental (États du Rio de Janeiro et de Minas Gerais). Rev. Bras. Geoc., 3(1):1-22.

CORDANI, U.G. \& BRITO NEVES, B.B. 1982. The geologic evolution of south America during the Archean and Early Proterozoic. Rev. Bras. Geoc. V.12:78-88.

COX, K.G.; BELL, J.D. \& PANKHURST, R.T. 1979. The interpretation of the igneous rocks. Univ. Chicago Press. 450p.

DELHAL, J.; LEDENT, D. \& CORDANI, U. 1969. Ages Pb/U, Sr/Rb et Ar/K de formations métamorphiques et granitique du Sud-Est du Brésil (États de Rio de Janeiro et de Minas Gerais). Annales de la Société Géologique de Belgique,T.92: 271-283. 
De PAOLO, D.J. 1981. Trace element and isotopic effects of combined wallrock assimilation and fractional cristallisation. Earth Planet Sciec. Lett. Vol 53: 189-202.

DIOS, F.R.B. 1995. Geologia, Petrologia e metamorfismo dos terrenos de alto grau da porção norte da folha Mangaratiba, RJ - 1:50.000. Dissertação de Mestrado. IG/UFRJ. 119p.

DOSTAL, J.; DUPUY, C.; CARRON, J.P.; Le GUEN de KERNEIZON, M. \& MAURY, R.C. 1983. Partition coefficients of trace elements: application to volcanic rocks of St Vicent, West Indies. Geochim. Cosmochim. Acta. 47: 525-533.

DRAKE, M.J. 1975. The oxidation stage of europium as an indicator of oxigen fugacity. Geochim. Cosmochim. Acta, 39: 55-64.

DRAKE, M.J. \& WEILL, D.F. 1975. Partition of Sr, Ba, Ca, Y, $\mathrm{Eu}^{+2}, \mathrm{Eu}^{+3}$ and other REE between plagioclase feldspar and magmatic liquids: an experimental study. Geochemi. Cosmochim Acta, 39: 686-712.

DRURY, S.A. 1979. Distributions in a high grade archean gneiss complex in Scotland: implications for the genesis of ancient sialic crust. Precambrian Reserch, 7: 237-257.

DUARTE, B.P.; FIGUEIREDO, M.C.H.; CAMPOS NETO, M.C \& HEILBRON, M. 1997. Geochemistry of granulitefacies orthogneisses of the Juiz de Fora Complex, central segment of the Ribeira Belt, southern Brazil. Rev. Bras. Geoc. V 27(1): 67-83.

DUARTE, B. P. ; NOGUEIRA, J. R.; HEILBRON, M. \& FIGUEIREDO, M. C. H. 1994. Geologia da Região Juiz de Fora e Matias Barbosa (MG). In: Cong. Bras. Geol., 38. Balneário de Camboriú, 1994. Boletim de Resumos... Balneário de Camboriú, SBG V2, p: $88-90$.

DURRHEIM, R. J. \& MOONEY, W. D. 1991. Archean and proterozoic crustal evolution: evidences from crustal seismology. Geology. 19: 606-609.

EBERT, H. 1955. Pesquisas na parte sudeste do Estado de Minas Gerais. Relatório Anual do Diretor. DNPM, DGM, p. 62-81, Rio de Janeiro.

EBERT, H. 1956a. Relatório de Atividades. Relatório Amual do Diretor da Div. Geol. Min.,DNPM, Rio de Janeiro, Ano 1955: 62-81.

EBERT, H. 1956b. Relatório de atividades. Relatório Anual do Diretor da Div. Geol. Min., Rio de Janeiro, p. 97-107.

EBERT, H. 1957. A Tectônica do sul do Estado de Minas Gerais e regiões adjacentes. Relatório Anual do Diretor. DNPM, DGM, 97-107, Rio de Janeiro.

EBERT, H. 1968. Ocorrência de fácies granulítica no sul de Minas Gerais e regiões adjacentes, em dependência da estrutura orogênica: hipóteses sobre sua origem. Anais da Acad. Bras. Ciênc., 40(Supl.):215-229. 
EBERT, H. 1971. Os Paraíbides entre São João del Rei, Minas Gerais e Itapira, São Paulo, e a bifurcação entre Paraíbides e Araxaídes. In: Cong. Bras. de Geol., 25, São Paulo, 1971. Boletim Especial, 1:177-178.

EDGAR, A.D. 1973. Experimental petrology. Oxford: Clarendon Press.

EKERT, J.O; NEWTON, R.C. \& KLEPPA, O. J. 1989. Recalibration of the garnet-anorthitediopside-quartz (GADS) geobarometry oxide-melt solution calorimetryof stoichiometric mineral mixes. EOS 70: 1392.

EKERT, J.O; NEWTON, R.C. \& KLEPPA, O. J. 1990. The $\triangle H$ of reaction and recalibration of garnet-pyroxene-plagioclase-quartz geobarometers in the CMAS system by solution calorimetry. Amer. Mineral. 76: 148-160.

ELLIS, D.J. \& GREEN, D.H. 1979. An Experimental Study of the Effect of Ca Upon GarnetClinopyroxene Fe - Mg Exchange Equilibria. Contr. Miner. Petrol., 71: 13 - 22.

ELLIS, D. J. 1992. Precambrian tectonics in the physicalchemical evolution of continental crust. II Lithospheric delamination and ensialic orogeny. Precamb. Res. 55: 507-524.

ETHERIDGE, M. A.; RUTLAND, R. W. \& WYBORN, L. A. I. 1987. Orogenesis and tectonic processes in the early to middle proterozoic of northern Australia. In: A. KRONER (Ed.). Proterozoic Lithospheric Evolution. P: 121-147.

FERNANDES, P.E.C.A. 1982. Levantamento de recursos naturais. Projeto Radambrasil (29). Folha SD 23 Brasília.

FERRY, J. M. \& SPEAR, F. S. 1978. Experimental calibration of the partitioning of $\mathrm{Fe}$ and $\mathrm{Mg}$ between biotite and garnet. Contrib. Mineral. Petrol. 66: 113-117.

FIGUEIREDO, M.C.H.; CAMPOS NETO, M.C. \& RÊGO, I.T.S.F. 1989. Geoquímica dos terrenos Juiz de Fora, Paraíba do Sul e Costeiro nos estados do Rio de Janeiro e Espírito Santo. In: Workshop de Geoquímica Isotópica, Geocronologia e Litogeoquímica das Regiões Sul E Sudeste do Brasil, São Paulo, 1989. Boletim de Resumos... SBGqIG/USP, p.41-45.

FIGUEIREDO, M.C.H.; CAMPOS NETO, M.C. \& BARROS, E.J. 1992. Geoquímica dos charnockitóides Serra do Valentim (ES). In: Congr. Bras. de Geol., 37, São Paulo, 1992. Boletim de Resumos Expandidos.., São Paulo, SBG/SP, V1:383-384.

FIGUEIREDO, M.C.H. \& CAMPOS NETO, M.C. 1993. Geochemistry of the Rio Doce Magmatic Arc, Southeastern Brazil. Anais da Acad. Bras. Cienc., 65 (supl. 1):63-81.

FIGUEIREDO, M.C.H (in memorian) \& TEIXEIRA (1996). The Mantiqueira Metamorphic Complex, eastern Minas Gerais State: preliminary geochronologal and geochemical results. Anais Acad. Bras. Ciênc. (no prelo). 
FISCHEL, D. P.; PIMENTEL, M. M.; FUCK, R. A.; COSTA, A. G. \& ROSIERE, C. A. 1998. Geology and Sm-Nd Isotopic Data for the Mantiqueira and Juiz de Fora Complexes (Ribeira Belt) in the Abrecampo-Manhuaçú Region, Minas Gerais, Brazil. 14th. Intern. Conf. Basement Tect. Ouro Preto, Brazil. Abstracts. p: 21-23

FONSECA, M.J.G.; SILVA, Z.C.G.; CAMPOS D.A. \& TOSATO, P. 1979. Mapa e texto explicativo das folhas Rio de Janeiro, Vitória e Iguape, na escala de 1:1.000.000 (SF23, SF24 e SG230). DNPM. Brasília.

FUJIMAKI, H; TATSUMOTO, M. \& AOKI, K. 1984. Partition coefficients of Hf, Zr, and REE between phenocrysts and groundmass. Proccedings of fourteenth lunar and planetary science conference, Part 2. Jour. Geophys. Res. Vol 89. Suppl. B662-B672.

GILL, J.B. 1981. Orogenic Andesite and Plate Tectonics. Springer-Verlag. Berlim. 208p.

GONÇALVES. M.L. 1987. Geologia da área de Santana do Garambéu, MG. Tese de Mestrado, IG/UFRJ, 113 p. (inédita).

GREEN, D.H. \& RINGWOOD, A.E. 1967. The genesis of basaltic magmas. Cont. Miner. Petrol. 15: 103-190.

GREEN, T.H. \& PEARSON, N. J. 1985. Experimental determination of REE partition coefficients between amphiboles and basaltic liquids at high pressure. Geochim. Cosmochim. Acta. 49: 1465-1468.

GROSSI SAD, J. H. \& BARBOSA, L. M. 1985. A origem dos charnockitos e rochas afins da região do médio Paraíba do Sul, Estado do Rio de Janeiro. Contribuições à Petrologia e à Mineralogia, SBG-Núcleo de Minas Gerais, 1985 p. 15-27

GUIMARÃES, D. 1956. Os charnockitos do Espírito Santo. Bol. Inst. Técnico Ind. B. Horizonte. 23: 3-30.

GUIMARÃES, D. 1961. A origiem dos charnockitos. Bol. Soc. Bras. Geol. 10(2): 3-38.

FYFE, W.S. \& LEONARDOS JR., O.H. 1974. Ancient metamorphic migmatite belts of the Brazilian Atlantic coast : the African connection. Rev. Bras. Geoc., 4(4):247-251.

HAGGERTY, S. E. \& TOMPKINS, L.O. 1983. Redox state of the Earth's upper mantle from kimbrlitic ilmenites. Nature. 303: 295-300.

HALL, A. 1987. Igneous Petrology. Longman Scientifical \& Technical. London 573p.

HARALYI, N.L.E. \& HASUI,Y. 1982a. The gravimetric information and the ArcheanProterozoic structural framework of Eastern Brazil. Int. Symp. Archean and Early Prot. Geol. Evol. and Metall. Salvador, Abstracts... BA, p:

HARALYI, N.L.E. \& HASUI,Y. 1982b. Compartimentação geotectônica do Brasil oriental com base na informação geofisica. In: 32 Cong. Bras. Geol. Anais... Salvador, BA, V: 
HARLEY, S.L.1984. An experimental study of the partitioning of $\mathrm{Fe}$ and $\mathrm{Mg}$ between garnet and orthopyroxene. Contr. Miner. Petrol. 86:359-373.

HASUI, Y. 1982. The Mantiqueira Province: Archean Structure and Proterozoic Evolution. In: Int. Symp. Archean and Early Proterozoic Evolution and Metallogenesis, Salvador, BA.

HASUI, Y; CARNEIRO, C.D.R. \& COIMBRA, A.M. 1975. The Ribeira Fold Belt. Rev. Bras. Geoc. 5(4): 257-266.

HASUI, Y.; ALMEIDA, F. F. \& BRITO NEVES, B. B. 1978. As estruturas Brasilianas. 30 Cong. Bras. Geol., Recife, PE, Anais... p: 2423-2437.

HASUI, Y. \& OLIVEIRA, M.A.F. 1984. A Província Mantiqueira: Setor Central. In: Almeida \& Hasui. O Precambriano do Brasil. Edgard Blucher, 344p.

HEIER, K.S. \& ADAMS, J.A.S. 1964. The geochemistry of alkali metals. Phys. Chem. Earth, 5: 253-381.

HEILBRON, M. 1984. A geologia e o metamorfismo da área entre Itutinga e Madre de Deus de Minas, MG. Dissertação de Mestrado. (IG/UFRJ). 151 p. Inédita.

HEILBRON, M. 1990. O limite entre as faixas de dobramento Alto Rio Grande e Ribeira na seção geotransversal Bom Jardim de Minas (MG) -Barra do Piraí (RJ). In: Cong. Bras. de Geol. 36, Natal, 1990. Anais...Natal, SBG/RN, v.6:2813-2826.

HEILBRON, M. 1993. Evolução tectono-metamórfica da seção Bom Jardim de Minas-MG Barra do Piraí-RJ, setor central da Faixa Ribeira. Tese de Doutoramento, IG/USP. 268p.

HEILBRON, M. 1995. O Segmento Central da Faixa Ribeira: Síntese Geológica e Ensaio de Evolução Geotectônica. Tese de Livre Docência, UERJ. 115p.

HEILBRON, M.; GONÇALVES, M.L.; TEIXEIRA, W.; TROUW, R.A.J.; KAWASHITA, K. \& PADILHA, A. 1989. Geocronologia da área entre Lavras, São João del Rei, Lima Duarte e Caxambu. An. Acad. Bras. Cienc. 61(2): 177-199.

HEILBRON, M; VALERIANO, C.M; ALMEIDA, J.C.H \& TUPINAMBÁ, M.. 1991. A Megassinforma do Rio Paraíba do Sul e sua implicação na compartimentação tectônica do setor central da Faixa Ribeira. In: Simp. Geol. Sudeste, 2, São Paulo, 1991. Atas... São Paulo, SBG:SP, p. 519-527.

HEILBRON, M.; SANTOS, R.O; VALLADARES, C. \& VALERIANO, C.M. 1992. Geologia e lito-geoquímica do leucogranito Serra do Ipiranga. In: Cong. Bras. Geol. 37. S. Paulo, Bol. Res. Exp. S. Paulo, SBG, p:375-376.

HEILBRON, M; VALERIANO, C.M; TUPINAMBÁ, M; ALMEIDA, J.C.H.; \& VALLADARES, C. S.; EIRADO SILVA, L. G.; NAVA, D.B. \& DIOS. F.B. 1993. Compartimentação Tectônica e Evolução Geológica do Segmento Central da Faixa Ribeira, a sul do Cráton de São Francisco: uma interpretação. In : Simpósio Sobre o Cráton do São Francisco, 2, Salvador, 1993. Anais... Salvador, SBG/SGM, p. 263-265. 
HEILBRON, M.; VALERIANO, C.M; ALMEIDA, J.C.H.; VALLADARES, C.S. \& TUPINAMBÁ, M. 1994. Segmento Central da Faixa Ribeira, exemplo de colisão continental oblíqua no evento termo-tectônico Brasiliano. In: Congr. Bras. De Geol., 38, Balneário de Camboriú, 1994. Boletim de Resumos Expandidos... SBG, vol 1: 263-265.

HEILBRON, M.; ROCHA A.D.; SILVA, L.G.E.; NOGUEIRA, J.R.; TROUW, R.A.J.; POLÔNIA, J.A.L. 1994. Compartimentação Tectônica da seção Conceição do IbitipocaValença (RJ), segmento central da Faixa Ribeira. 38, Cong. Bras. Geol. SBG, Bol. Res. Exp. Camboriú, SC, V2:55-56.

HEILBRON, M. \& MACHADO, R. 1995. O magmatismo tardi- a pós-colisional Brasiliano na seção entre Bom Jardim de Minas e Barra do Piraí, Segmento Central da Faixa Ribeira. In: Simp. de Geol. Sudeste, 4, Águas de São Pedro, 1995. Boletim de Resumos... São Paulo, SBG:SP/RJ/ES, p. 140.

HEILBRON, M; VALERIANO, C.M; VALLADARES, C.S. \& MACHADO, N. 1995. A orogênese Brasiliana no segmento central da Faixa Ribeira, Brasil. Rev. Bras. Geoc. 25(4): 245-266.

HEILBRON, M; VALERIANO, C.M.; VALLADARES, C.S; ALMEIDA, J.C.H.; TUPINAMBÁ, M. \& DUARTE, B.P. 1996. The Brasiliano Orogeny (590-520 Ma.) at the Central Segment of Ribeira Belt, SE Brazil. In: Cong. Bras. Geol., 39, Salvador, Ba. Bol. Res. Exp. V 6: 107-109.

HEILBRON, M. FIGUEIREDO, M.C.H. \& MACHADO, R. 1997. Lithogeochemistry of paleoprotezoic orthogranulites from Rio Preto (MG) - Vassouras (RJ) region, centarl Ribeira Belt. Rev Bras. Geoc. V27(1): 83-99.

HOINKES, G. 1986. Effect of grossular - content in garnet on the partitioning of Fe and $\mathrm{Mg}$ between garnet and biotite. Contibuitions to Mineralogy and Petrology . 92: 393-239.

HOPPE, A. KLEIN, H. CHOUDURI, A. SCHIMIDT, W. 1985. Eclogitos Precambrianos no SW de Minas Gerais. Anais Simp. Geol. Minas Gerais, 3, p: 180-192.

HUMPHRIS, S. E.; THOMPSON, G.; SHILLING, G. \& KINGSLEY, R. A. 1985. Petrological and Geochimical variations along the Mid-Atlantic Ridge between $46^{\circ} \mathrm{S}$ and $32^{\circ} \mathrm{S}$ : influence of the Tristan da Cunha mantle plume. Geochim. Cosmochim. Act. 49: 1445-1464.

HUPPERT, H. E. \& SPARKS, S.J. 1985. Cooling and contamination of mafic and ultramafic magmas during ascent through the continental crust. Earth Planet. Science Lett. 74: 371-386.

INDARES, A. \& MARTIGNOLE, J. 1985. Biotite-garnet geothermometry in the granulite facies: the influences of Ti and $\mathrm{Al}$ in biotite. Amer. Mineral. 70: 272-278.

IRVINE, T. N. \& BARAGAR, W.R.A. 1971. A guide to the chemical classification of the common volcanicà rocks. Can. Jour. Earth Science. Vol 8: 523-548. 
IRVING, A.J. \& FREY, F.A. 1978. Distribution of trace elements between garnet megacrysts and host volcanic liquids of kimberlitic to thyolitic composition. Geochim. Cosmochim. Acta, 42: 771-787.

KING, L.C. 1956. A geomorfologia do Brasil oriental. Separata da Rev. Bras, de Geografia, Rio de Janeiro, v18 (2): 265 p.

KRONER, A. 1984. Evolution, growth and stabilization of the Precambrian lithosphere. Phys. Chem. Earth. 15: 69-106.

KUSHIRO, I. 1972. Effect of water on the compostion of magmas formed at high pressure. $J$. Petrol. 13: 314-334.

LAIRD, H. \& ALBEE, T. 1981. Pressure-temperature and time indicators in mafic schis: their application to reconstructing the polymetamorphic history of Vermont. Amer. Journ. Sci. 281: $127-175$

LAMBERT, I.B. \& HEIER, K.S. 1968. Geochemical investigation of deep seated rocks in the Australian Shield. Lithos, 1: 30-53.

LE MAITRE, R. W. 1989. The chemical variability of sun common igneous rocks. J. Petrol. 17: $589-537$.

LESQUER, A.; ALMEIDA, F.F.M; DAVINO, A; LACHAUD, J.C. \& MAILLARD, P. 1981. Signification structurale des anomalies gravimétrics de la partie sud du craton de São Francisco (Brésil). Tectonophysics, 76: 273-292.

LINDSLEY, D. H. 1991. Experimental studies of oxide minerals. Rev. Mineral. 25: 69-106

MAAL $\varnothing \mathrm{E}$, S. 1982. Geochemical aspects of permeability-controlled partial melting and fractional crystallisation. Geochemi. Cosmochemi Acta, 46: 43-57.

MACHADO FILHO, L; RIBEIRO, M.W; GONZALEZ, S.R.; SCHENINI, C.A.; SANTOS NETO, A.; PALMEIRA, R.G.B.; PIRES J.L.; TEIXEIRA, W. \& CASTRO, H.E.F. de. 1983. In: Projeto RADAMBRASIL. Folhas SF-23/24, Rio de Janeiro/Vitória, 1.Geologia, Rio de Janeiro, MME, 27-304.

MACHADO, N; VALLADARES, C; HEILBRON, M. \& VALERIANO, C. 1996. U-Pb geochronology of the central Ribeira Belt (Brazil) and implications for the evolution of the Brazilian Orogeny. Precambrian Research, 79: 347-361.

MACHADO, R. 1984. Evolução Geológica, Análise Estrutural e Metamórfica da Região de Vassouras e Paracambí, Rio de Janeiro. RJ. Tese de Doutoramento. IG-USP. 196p.

MACHADO, R. 1986. Evolução Geológica do Complexo Paraíba do Sul na Porção Ocidental do Estado do Rio de Janeiro. RJ. 34 Cong. Bras. Geol., Goiânia, GO, Anais... V2: 10881095. 
MACIEL, R. R. 1986. Geologia Estrutural da Serra das Três Pontas, MG. Dissertação de Mestrado. IG/UFRJ. $114 \mathrm{p}$. inédita.

MAGALHÃES, A.C. 1985. Geologia de corpos ultramáficos da região entre São João del Rei e Liberdade, com ênfase especial na área de Carrancas, MG. Dissertação de Mestrado. IG/UFRJ. 120p. inédita.

MAHOOD, G. \& HILDRETH W. 1983. Large partition coefficients for trace elements in high silica ryolites. Geochim. Cosmochim. Acta. 47: 11-30.

MIDDLEMOST, E.A.K. 1985. Magmas and magmatic rocks. Longoman Press, London. $266 \mathrm{p}$.

MOORBATH, S. 1975. The geological significance of early precambrian rocks. Proc. Geol. Assoc. 86: 259-279.

MOORBATH, S.; POWELL, J.L. \& TAYLOR, P.N. 1975a. Isotopic evidence for the age and origin of the "Grey Gneiss" Complex of the southern Outer Hebrides, Scotland. Joxr. Geol. Soc. London, 131: 213-222.

MOORBATH, S.; O'NIONS, R.K. \& PANKHURST, R.J. 1975b. Eaeth Sci. Lett. 27: 229 241.

MYERS, J. \& EUGSTER, H. P. 1983. The system Fe-Si-O: oxygen buffer calibrations to 1500k. Contr. Mineral. Petrol. 82: 75-90.

NASH, W.P. \& CRECRAFT, H.R. 1985. Partition coefficients for trace elements in silicic magmas. Geochim. Cosmochim. Acta. 49: 2309-2322.

NEWTON, R.C. 1978. Experimental and thermodynamic evidence for the operation of high pressures in Archean metamorphism. In: Windley, B.F. \& Naqvi, S.M. (Eds.) Archean Geochemistry. Elsevier. P. 221-240.

NEWTON, R. C \& PERKINS, D . 1982. Thermodynamic calibration of geobarometers based on the assemblages garnet-plagioclase-orthopyroxene (clinopyroxene)-quartz. Amer. Mineral. 67: 203-222.

NOGUEIRA, J.R 1994. Relações tectonoestruturais e metamórficas entre metasedimentos e ortognaisses em facies granulito na região à sudoeste de Juiz de Fora, MG. IG/UFRJ. Dissertaçâo de Mestrado. $151 \mathrm{p}$. Inédita.

NOGUEIRA, J.R; TROUW, R.A.J. 1993. Mapeamento geológico, escala 1:50.000, estruturas e metamorfismo de uma região a sudoeste de Juiz de Fora, MG. 7 Simp. Geolog. de Minas Gerais. p: 180-186.

NUMMER, A. R. 1992. Análise Estrutural e Estratigráfica do Grupo Andrelândia na região de Santa Rita do Ibitipoca- Lima Duarte, sul de Minas gerais. Dissertação de MestradoIG/UFRJ (inédito). $191 \mathrm{p}$. 
OLIVEIRA, M. A F F 1980. Petrologia das rochas granuliticas da Faixa Paraíba do Sul, Estados do Rio de Janeiro e Minas Gerais. Tese de Livre Docência, IGCE-UNESP, $116 \mathrm{p}$ (inédito).

OLIVEIRA M A F 1981. Granulitos da Faixa Paraíba do Sul: caracteres geoquímicos dos piroxênios e valores geotermométricos. Rev. Bras. Geoc., 11(4):222-226.

OLIVEIRA, M A F . 1982. Bulk geochemistry of the Paraiba do Sul Granulitic Belt. Rev. Bras: Geoc, $12(1-3): 369-374$

OLIVEIRA, M. A. F. 1983. As rochas granulíticas da Faixa Paraiba do Sul Rev. Bras. Geoc., $13(2): 84-902$.

PACIULLO, F. V. P. 1980. Mapeamento geológico estrutural da área de Minduri, MG. Tese de Mestrado IG-UFRJ, 151 p. (inédito).

PACIUllo, F. V. P.. 1997. A sequência deposicional Andrelândia. Tese de Doutoramento, IGEO - UFRJ. 263 p.

PACIULLO, F. V. P.; RIBEIRO, A. \& ANDREIS, R. 1993. Reconstrução de uma bacia fragmentada: o caso do ciclo deposicional Andrelândia. In: Simp. Sobre o Craton do São Francisco, II, Salvador, Anais... Salvador, BA, SBG, p:224-226.

PARKISER, L. S. \& ROBINSON, R. 1967. Composition of the continental crust as estimated from seismic observations. In: The Earth Beneath the Continents. J.S. Steinhardt and T.J. Smith, Eds). Amer. Geophys. Union. Monographn. 10.

PEARCE, J. A. 1982. Trace element characteristics of lavas from destructive plate bounderies. In: Andesites: Orogenic andesites and related rocks. R. S. Thorpe (Ed.) 525 548. Willey.

PEARCE, J. A. 1983. The role of subcontinental lithosphere in magma genesis at destructive plate margins. In: Continental Basalts and Mantle Xenoliths. C. J. Hawkesworth \& M. J. Norry (Eds.), 230-249. Shiva.

PEARCE, J. A.; HARRIS, B.W. \& TINDLE, A. G. 1984. Trace element discrimination diagrams for the tectonic interpretation of granitic rocks. J. Petrol. 25:956-983.

PERCHUK L. L. \& LAVRENT'EVA, I. V. 1981. Experimental Investigation of exchange equilibria in the system cordierite-garnet-biotite. In: Saxena Sk (Ed) Kinetics and Equilium in mineral reactions. Springer-Verlag. New York. p: 199-240

PINTO, C. P.. 1991. Programa de levantamentos geológicos básicos do Brasil: Folha Lima Duarte. CPRM/MG. Texto Explicativo. $212 \mathrm{p}$.

PIPER, J. D. A 1987. Paleomagnetism and the continental crust. Milton Keynes: Open University Press. 
POWELL, R. 1985. Regression diagnostics and robust regresion in geothermometer / geobarometer calibration: the garnet - clinopyroxene geothermometer revisited. Journ. Met. Geol. 3: 231-243.

RAMSAY, J. G. 1967. Folding and Fracturing of Rocks, McGraw-Hill, New York, 568p.

RIBEIRO, A. 1980. Mapeamento geológico estrutural da área de Itumirim, MG. Tese de Mestrado IG-UFRJ (inédito), 57p.

RIBEIRO, A. 1992. Diques Máficos Proterozóicos em São João Del Rei. 37 Cong. Bras. Geol., São Paulo, SP. Bol. Res. Expand. V1: 508-509.

RIBEIRO, A. 1997. Estratigrafia e paleoambiente nas sucessões metassedimentares proterozóicas das Serras do Lenheiro e São José, São João del Rei. Tese de Doutoramento. IGEO - UFRJ. 167 p.

RIBEIRO, A. \& HEILBRON, M. 1982. Estratigrafia e metamorfismo dos Grupos Carrancas e Andrelândia. Sul de Minas Gerais. In: Cong. Bras. Geol., 32, Salvador, Ba. Anais...V 1: 177-186.

RIBEIRO, A.; PACIULLO, F.V.P.; ANDREIS, R.R.; TROUW, R.A.J. \& HEILBRON, M. 1990. Evolução policíclica proterozóica no sul do Cráton do São Francisco: análise da região de São João del Rei e Andrelândia, MG. In: Cong. Bras. de Geol., 36, Natal, 1990. Anais... Natal, SBG/RN, v.6:2605-2614.

RIBEIRO, A.; ANDREIS, R.R.; TROUW, R.A.J.; PACIULLO, F.V.P. \& VALENÇA, J.G. 1995. Evolução das bacias proterozóicas e o termotectonismo brasiliano na margem sul do craton do São Francisco. Rev. Bras. Geoc. 25(4) 235-248.

RICHTER, F. M. 1985. Models for the Archean thermal regime. Earth Planet Sci. Lett. 68 : 471-484.

RIETMEIJER, F.J.M. 1983. Chemical distinction between igneous and metamorphic orthopyroxenes especially those coexisting with Ca-rich clinopyroxenes: a re-evaluation. Mineralogical Magazine. 47:143-151.

RINGWOOD, A.E. \& GREEN, D.H. 1966. An experimental investigation of gabro - eclogite transformation and some geophysical implications. Tectonophysics, 3: 383-427.

ROLLINSON, H. R. \& WINDLEY, B.F. 1980. An archean granulite grade tonalitetrondhjemite-granite suite from Scourie, NW Scotland: geochemistry and origin. Contr. Mineral. Petrol. 72: 265-281.

ROSIER, G. F. 1957. A Geologia da Serra do Mar, entre os picos de Maria Comprida e do Desengano (Estado do Rio de Janeiro). DNPM, GGM, Boletim 166, 58p.

ROSIER, G. F. 1965. Pesquisa geológica na parte oriental do Estado do Rio de Janeiro e a parte vizinha do Estado de Minas Gerais. DNPM, DGM, Boletim 222, 41p.

RUDNICK, R.L. 1995. Making continental crust. Nature, 378: 571-577. 


\section{Apêndice 1 - Abreviaturas Utilizadas para minerais}

$\begin{array}{ll}\text { all - allanita } & \text { mi - microclina } \\ \text { and - andalusita } & \text { mon - monazita } \\ \text { ap - apatita } & \text { mu - muscovita } \\ \text { bt - biotita } & \text { op - mineral opaco } \\ \text { cb - carbonato } & \text { opx - ortopiroxênio } \\ \text { cl - clorita } & \text { ort - ortoclásio } \\ \text { cpx - clinopiroxênio } & \text { plg - plagioclásio } \\ \text { crd - cordierita } & \text { qz - quartzo } \\ \text { di - diopsídio } & \text { rt - rutilo } \\ \text { fbr - fibrolita } & \text { scp - escapolita } \\ \text { gf - grafita } & \text { sf - sulfeto } \\ \text { gr e grt - granada } & \text { sil e sill - sillimanita } \\ \text { hb e hbl - hornblenda } & \text { tit e ti - titanita } \\ \text { hm - hematita } & \text { tm - tremolita } \\ \text { ilm - ilmenita } & \text { tur - turmalina } \\ \text { Kf - feldspato potássico } & \text { zc - zircão } \\ \text { ky - cianita } & \end{array}$




\section{Apêndice 2 - Terminologia Petrográfica}

Para as rochas ortoderivadas utilizou-se a nomenclatura proposta por Streckeisen (1976). No caso das rochas metamórficas, foram empregados os termos usuais (xisto, gnaisse, quartzito, calcissilicática, anfibolito), acrescidos do nome de minerais índices usados na identificação das diversas unidades litológicas (p. ex: biotita-granada-sillimanita gnaisse ou biotita-hornblenda gnaisse). Nas rochas em que o bandamento foi utilizado como uma feição importante para identificação, o termo foi incorporado ao nome da rocha (p. ex: biotita gnaisse bandado).

O termo granulito foi empregado com uma conotação genética, para indicar rochas formadas ou reequilibradas sob condições de tempertaura e pressão de fluidos características para a fácies granulito. Para a classificação das rochas granulíticas ortoderivadas utilizou-se a nomenclatura proposta por Streckeisen (1974).

Para classificação granulométrica, foram definidos e utilizados os seguintes intervalos:

fina - grãos $<1,0 \mathrm{~mm}$

média - grãos entre 1,0 e 3,0 mm

grossa - grãos $>3,0 \mathrm{~mm}$

muito grossa - grãos $>5,0 \mathrm{~mm}$

A classificação textural foi utilizada segundo Bard (1985) 


\section{Apêndice 3 - Composição Modal das Amostras Selecionadas para Análise Química}

Composição Modal das Amostras Selecionadas para Análise Química de rocha total: Complexo Juiz de Fora.

1 - minerais de alteração

\begin{tabular}{|c|c|}
\hline Amostra & $\begin{array}{l}\text { Composição Modal: } \\
\text { mineral (\% volume.) }\end{array}$ \\
\hline$M B-17 A$ & $\begin{array}{l}\text { hbl (43), plg (36), cpx (10), opx } \\
\text { (9), op, ap, bt, cb }\end{array}$ \\
\hline MB - 42 & $\begin{array}{l}\text { plg (33), hbl (29), opx (16), cpx } \\
\text { (10), op (4), gr, qz, ap, bt }\end{array}$ \\
\hline $\mathrm{MB}-514 \mathrm{C}$ & $\begin{array}{l}\text { plg (45), hbl (31), cpx (6), opx, } \\
\text { op, bt, ap, tit }\end{array}$ \\
\hline $\mathrm{MB}-46 \mathrm{P}$ & $\begin{array}{l}\text { plg (48), cpx (19), hbl (17), bt } \\
\text { (8), opx (5), op, qz, }\end{array}$ \\
\hline $\mathrm{MB}-17 \mathrm{~B}$ & $\begin{array}{l}\text { plg (42), hbl (28), cpx (14), opx } \\
\text { (13), op, ap }\end{array}$ \\
\hline$M B-15 C$ & $\begin{array}{l}\text { plg (52), bt (34), qz (5), gr (5), } \\
\text { opx, ort, hbl, zc, op, ap }\end{array}$ \\
\hline$M B-183 A$ & $\begin{array}{l}\text { plg (66), opx (18), hbl (7), cpx } \\
\text { (4), bt, qz, ort, op, }\end{array}$ \\
\hline $\mathrm{MB}-514 \mathrm{~B}$ & $\begin{array}{l}\text { hbl (43), plg (39), cpx (8), opx } \\
\text { (3), op, ap, tit }\end{array}$ \\
\hline MB - 99D & $\begin{array}{l}\text { plg (71), opx (10), hbl (5), qz } \\
\text { (5), bt, cpx, op, zc }\end{array}$ \\
\hline $\mathrm{MB}-43 \mathrm{C}$ & $\begin{array}{l}\text { plg (63), opx (19), ort (10), op, } \\
\text { qz, bt, ap, hbl, zc, cb }\end{array}$ \\
\hline$M B-15 B$ & $\begin{array}{l}\text { plg (48), hbl (26), opx (16), cpx } \\
\text { (4), qz (4), gr, op, bt, ap, cb }\end{array}$ \\
\hline $\mathrm{MB}-46 \mathrm{C}$ & $\begin{array}{l}\text { plg (61), opx (18), ort (11), op, } \\
\text { qz, bt, ap, hbl, zc, cb }\end{array}$ \\
\hline MB - 19 & $\begin{array}{l}\text { plg (63), bt (13), ort (9), opx } \\
\text { (7), qz (4), op, hbl, ap, zc }\end{array}$ \\
\hline $\mathrm{MB}-46 \mathrm{~A}$ & $\begin{array}{l}\text { plg (66), qz (17), opx (12), bt } \\
\text { (4), op, ap }\end{array}$ \\
\hline$M B-32 A$ & $\begin{array}{l}\text { plg (70), bt (12), qz (8), opx (5), } \\
\text { ort (3), hbl, op, ap, zc, mu }{ }^{1}, \mathrm{cb}^{1}\end{array}$ \\
\hline $\mathrm{MB}-46 \mathrm{~T}$ & $\begin{array}{l}\text { plg (69), opx (14), qz (7), cpx } \\
\text { (3), bt (3), ort, op, ap, cb }\end{array}$ \\
\hline $\mathrm{MB}-32 \mathrm{D}$ & $\begin{array}{l}\text { plg (68), bt (13), qz (8), opx (6), } \\
\text { ort (3), hbl, op, ap, zc, mu }{ }^{1}, \mathrm{cb}^{1}\end{array}$ \\
\hline$M B-145 B$ & $\begin{array}{l}\text { plg (68), qz (12), bt (11), ort } \\
\text { (5), opx (3), op, ap, } \mathrm{cb}^{1}, \mathrm{cl}^{1}\end{array}$ \\
\hline
\end{tabular}

\begin{tabular}{|c|c|}
\hline Amostra & $\begin{array}{l}\text { Composição Modal: } \\
\text { mineral (\% volume) }\end{array}$ \\
\hline MB - 297D & $\begin{array}{l}\text { plg (70), qz (13), bt (12), opx } \\
\text { (4), op, ap, zc, hbl }\end{array}$ \\
\hline MB - 297B & $\begin{array}{l}\text { plg (65), qz (14), bt (10), ort } \\
\text { (4), hbl (4), opx, op, ap, zc }\end{array}$ \\
\hline$M B-115 B$ & $\begin{array}{l}\text { plg (76), bt (9), qz (7), opx (6), } \\
\text { ort, cpx, ap, op, zc, hbl }\end{array}$ \\
\hline$M B-32 C$ & $\begin{array}{l}\text { plg (48), ort (26), qz (21), bt, } \\
\text { opx, hbl, gr, op, ap, zc, mu }{ }^{1}, \mathrm{cb}^{1}\end{array}$ \\
\hline $\mathrm{MB}-241 \mathrm{~A}$ & $\begin{array}{l}\text { plg (39), ort (32), qz (18), bt } \\
\text { (7), opx, op, hbl, ap, cb }{ }^{1}\end{array}$ \\
\hline$M B-48 A$ & $\begin{array}{l}\text { plg (41), ort (32), qz (19), bt } \\
\text { (7), op, opx, hbl, ap, zc }\end{array}$ \\
\hline $\mathrm{MB}-514 \mathrm{E}$ & $\begin{array}{l}\text { plg (46), ort (24), qz (12), opx } \\
\text { (3), bt (3), op, zc, ap, hbl }\end{array}$ \\
\hline $\mathrm{MB}-151 \mathrm{~B}$ & $\begin{array}{l}\text { plg (44), ort (34), qz (14), bt } \\
\text { (7), op, opx, gr, ap, zc }\end{array}$ \\
\hline$M B-514 A$ & $\begin{array}{l}\mathrm{Kf}(62), \mathrm{plg}(23), \mathrm{qz}(22), \mathrm{bt} \\
\text { (4), tit, op, hbl, ap, zc }\end{array}$ \\
\hline$M B-32 B$ & $\begin{array}{l}\text { plg (50), ort (24), qz (22), bt, } \\
\text { opx, hbl, op, ap, zc, mu }{ }^{1}, \mathrm{cb}^{1}\end{array}$ \\
\hline $\mathrm{MB}-37(1)$ & $\begin{array}{l}\text { plg (46), ort (27), qz (23), bt, } \\
\text { opx, hbl, op, ap, zc, mu', cb }\end{array}$ \\
\hline$M B-46 R$ & $\begin{array}{l}\text { plg (67), qz (15), opx (11), ort } \\
\text { (3), bt (3), op, ap, zc, cb }\end{array}$ \\
\hline $\mathrm{MB}-151 \mathrm{~A}$ & $\begin{array}{l}\text { plg (37), ort (37), qz (16), bt } \\
\text { (7), op (3), ap, zc, opx, gr }\end{array}$ \\
\hline$M B-43 B$ & $\begin{array}{l}\text { plg (48), qz (35), ort (13), op, } \\
\text { opx, mu }{ }^{1}, \mathrm{cb}^{1}\end{array}$ \\
\hline $\mathrm{MB}-46 \mathrm{~B}$ & $\begin{array}{l}\text { plg (47), qz (38), ort (11), op, } \\
\text { opx }, \mathrm{mu}^{1}, \mathrm{cb}^{1}\end{array}$ \\
\hline $\mathrm{MB}-46 \mathrm{U}$ & $\begin{array}{l}\text { ort (57), plg (29), qz (15), opx, } \\
\text { op, cb }\end{array}$ \\
\hline $\mathrm{MB}-43 \mathrm{~A}$ & $\begin{array}{l}\text { plg (57), bt (15), opx (13), hbl } \\
\text { (7), qz (4), op, cpx, ort, ap }\end{array}$ \\
\hline$M B-17 H$ & $\begin{array}{l}\text { qz (85), opx (5), bt, ap, zc, ort, } \\
\text { plg, mu }{ }^{1}, \mathrm{cb}^{1}\end{array}$ \\
\hline
\end{tabular}


Composição Modal das Amostras Selecionadas para Análise Química de rocha total: Complexo Mantiqueira.

1. mineral de alteraçầo

\begin{tabular}{|c|c|}
\hline Amostra & $\begin{array}{l}\text { Composição Modal } \\
\text { mineral (\% vol) }\end{array}$ \\
\hline $\mathrm{MB}-577 \mathrm{~B}$ & $\begin{array}{l}\text { hbl (48), plg (38), tit (5), bt (5), } \\
\text { op, qz, ort, ap, zc }\end{array}$ \\
\hline$J F-30 C$ & $\begin{array}{l}\text { hbl (43), plg (35), bt (16), qz (4), } \\
\text { tit, op, ort }\end{array}$ \\
\hline $\mathrm{JF}-58 \mathrm{~B}$ & $\begin{array}{l}\text { plg (44), hbl (40), bt (12), qz, op, } \\
\text { tit }\end{array}$ \\
\hline$J F-564 F$ & $\begin{array}{l}\text { hbl (42), plg (37), op (8), bt (7), } \\
\text { tit, ap, qz }\end{array}$ \\
\hline$J F-29 Q$ & $\begin{array}{l}\text { hbl (58), plg (34), cpx (4), op, tit, } \\
\text { bt }\end{array}$ \\
\hline$J F-190 \mathrm{C}$ & $\begin{array}{l}\text { plg (60), cpx (18), hbl (17), op, } \\
\text { ap }\end{array}$ \\
\hline$J F-187 \mathrm{~A}$ & $\begin{array}{l}\mathrm{plg}(47), \mathrm{hbl}(38), \mathrm{bt}(11), \mathrm{tit}, \\
\mathrm{cpx}, \mathrm{qL}, \text { op }\end{array}$ \\
\hline$J F-60 B$ & $\begin{array}{l}\text { plg (50), hbl (27), bt (13) qz (4), } \\
\text { cpx, op, tit, zc ap }\end{array}$ \\
\hline $\mathrm{JF}-56$ & $\begin{array}{l}\text { plg (55), hbl (23), bi (9) qz (8), } \\
\text { cpx, op, tit, zc ap }\end{array}$ \\
\hline$J F-29 T$ & $\begin{array}{l}\text { plg }(6.3), h b l(22), b t(8), q(7) \\
\text { op }\end{array}$ \\
\hline $\mathrm{JF}-31$ & $\begin{array}{l}\text { plg }(60), \text { bt (18), qz (17), hbl, orl, } \\
\text { op, cb }\end{array}$ \\
\hline $\mathrm{JF}-30 \mathrm{~A}$ & $\begin{array}{l}\text { plg (58), hbl (23), bt (7). } \mathrm{Kf}(6) \\
q .(5), \mathrm{op}, \mathrm{cb}^{\prime}\end{array}$ \\
\hline$J F-29 A$ & $\begin{array}{l}\text { pig (63), hbl (22), bt (8), qz (7), } \\
\text { op }\end{array}$ \\
\hline$J F-61 A$ & $\begin{array}{l}\text { plg (46), hbl (31), qz (12), bt (6), } \\
\text { ort, cpx, opx, ap, zc, op }\end{array}$ \\
\hline $\mathrm{JF}-5641$ & $\begin{array}{l}\text { plg (49), ort (18), c) (18), hbl } \\
(6), \text { bt (4), tit, mi, op }\end{array}$ \\
\hline $\mathrm{MB}-577 \mathrm{C}$ & $\begin{array}{l}\text { plg (42), mi (23), qz (21), bt (10), } \\
\text { tit, op, zc, ap }\end{array}$ \\
\hline
\end{tabular}

\begin{tabular}{|c|c|}
\hline Amostra & $\begin{array}{l}\text { Composição Modal } \\
\text { mineral (\% vol) }\end{array}$ \\
\hline$J F-564 A$ & $\begin{array}{l}\text { plg (47), ort }(20) \text {, qz (20), mi (5), } \\
\text { bt (3), op, ap }\end{array}$ \\
\hline $\mathrm{JF}-58 \mathrm{~A}$ & $\begin{array}{l}\text { plg (48), ort (18), qz (23), bt (6), } \\
\text { hbl, op, ap, zc, } \mathrm{mu}^{1}, \mathrm{cl}^{1}, \mathrm{cb}^{1}\end{array}$ \\
\hline $\mathrm{MB}-577 \mathrm{~F}$ & $\begin{array}{l}\operatorname{mi}(36), \operatorname{plg}(35), q z(21), \text { hbl } \\
\text { (4), bt, ap, op, zc, tit }\end{array}$ \\
\hline $\mathrm{MB}-577 \mathrm{E}$ & $\begin{array}{l}\text { mi (37), plg (34), qz (22), bt (3), } \\
\text { op, zc }\end{array}$ \\
\hline $\mathrm{JF}-19 \mathrm{Al}$ & $\begin{array}{l}\mathrm{plg}(46), \mathrm{Kf}(29), \mathrm{qz}(20), \mathrm{bt}(4) \\
\mathrm{op}, \mathrm{cb}^{1}, \mathrm{mu}^{\mathrm{l}}\end{array}$ \\
\hline $\mathrm{JF}-190 \mathrm{~A} 2$ & $\begin{array}{l}\mathrm{Kf}(40), \mathrm{plg}(32), \mathrm{qz}(23), \mathrm{bt}, \mathrm{op}, \\
\mathrm{cb}^{\prime}, \mathrm{mu}^{\mathrm{l}}\end{array}$ \\
\hline$J F-29 P$ & $\begin{array}{l}\text { plg (48), qz (23), ort (18), bt (6), } \\
\text { hbl, op, ap, zc, mu', } \mathrm{cl}^{\prime}, \mathrm{cb}^{l}\end{array}$ \\
\hline $\mathrm{JF}-190 \mathrm{D}$ & $\begin{array}{l}\operatorname{plg}(50), q z(30), b t(11), K f(9), \\
\text { op }\end{array}$ \\
\hline$J F-189 B$ & $\begin{array}{l}\text { mi (39), plg (31), qz. (22), on (4), } \\
\text { bt, op, ap, zc }\end{array}$ \\
\hline $\mathrm{JF}-30 \mathrm{~B}$ & $\begin{array}{l}\text { plg (50), ort (31), qz (13), bt (3), } \\
\text { hbl, op, cb }\end{array}$ \\
\hline$J F-564 B$ & $\begin{array}{l}\text { ort (37), plg (36), q\% (16), mi (4), } \\
\text { bt (3), op, zc ap }\end{array}$ \\
\hline $\mathrm{JF}-564 \mathrm{E}$ & $\begin{array}{l}\operatorname{mi~(47),~plg~(35),~qp.~(15),~bl,~op,~} \\
\mathrm{zc}\end{array}$ \\
\hline$J F-85 D$ & $\mathrm{plg}(70)$, qz $(16)$, ort $(10), \mathrm{bt}(4)$ \\
\hline $\mathrm{MB}-577 \mathrm{H}$ & $\begin{array}{l}\mathrm{mi}(48), \operatorname{plg}(32), \mathrm{qz}(15), \mathrm{bt}, \mathrm{op}, \\
\text { tit, ap, zc }\end{array}$ \\
\hline$J F-564 \mathrm{D}$ & $\begin{array}{l}\mathrm{Kf}(48), \operatorname{plg}(29), \mathrm{q},(16), \mathrm{bt}(3) \\
\text { ap, op, tit, } z \mathrm{c}\end{array}$ \\
\hline $\mathrm{JF}-58 \mathrm{~A}$ & $\begin{array}{l}\text { plg (48), ort (18), qz (23), bt (6), } \\
\text { hbl, op, ap, zc, } \mathrm{mu}^{1}, \mathrm{cl}^{1}, \mathrm{cb}^{\prime}\end{array}$ \\
\hline
\end{tabular}




\section{Apêndice 4 - Especificações das Condições de Análise por Microssonda Eletrônica Utilizado, Método Utilizado e Composição Química dos Mimerais Analisados}

A análise química mineral foi realizada no Laboratório de Microssonda do Instituto de Geociências da Universidade de São Paulo. O equipamento utilizado tem as seguintes especificações:

Microssonda Eletrônica JEOL - Modelo JXA - 8600, com as seguintes características:

a) Cinco espectrômetros acoplados;

b) Operação em Sistema EDS (Energy Dispersive System) e WDS (Wavelength Dispersive System).

Sistema de análise automatizada, Tracor Northern/Noran Instrument 1990, operou ao longo deste trabalho sob as seguintes condições de rotina:

a) Corrente do Feixe: $20,10 \mathrm{nA}$;

b) Diâmetro do Feixe: $5 \mu \mathrm{m}$;

c) Voltagem de Aceleração: 15 qV.

\section{Método de Trabalho}

A partir da análise petrográfica de lâminas delgadas, foram selecionadas as amostras para a análise química de minerais. Por apresentarem paragêneses ou pares minerais sensíveis às variações de temperatura ou pressão, amostras de dois diferentes litotipos foram eleitas para esta abordagem: 1) 5 amostras de metabasito granulítico do Complexo Juiz de Fora; e 2) 3 amostras de bt-gr-(opx) gnaisse da Unidade Jardim Glória. Grãos visivelmente zonados não foram identificados nesta etapa. Assim, o método empregado consistiu na sondagem de 3 pontos nas bordas e 3 no núcleo de cada grão de interesse, tendo sido analisada uma média de 4 grãos de um mesmo mineral por lâmina. Este número aparentemente excessivo de análises se deve à necessidade de um rigoroso controle das composições minerais, já que se pretende usálas como padrões para o estudo geotermobarométrico. 
Foi sondado um total de 740 pontos, tendo sido analisados ortopiroxênio, clinopiroxênio, granada, hornblenda, biotita e plagioclásio. Destes 740 pontos, apenas aqueles que tiveram fechamento satisfatónio (ver a seguir) foram considerados, tendo sido os demais descartados. Os dados analíticos não descartados foram então trabalhados da seguinte maneira: 1) cálculo da média aritmética dos pontos obtidos para cada núcleo, para cada borda $e$, finalmente, para cada amostra; b) projeção dos valores destas médias em diagramas de classificação mineral e em outros diagramas apropriados; e c) cálculo das temperaturas ou pressões dos pulsos metamórfiscos (fácies granulito e fácies anfibolito superior) a partir das análises obtidas, utilizando-se calibrações apropriadas.

Os seguintes intervalos de fechamento das análises foram considerados satisfatórios:

a) ortopiroxênio, clinopiroxênio, granada e plagioclásio: 99 - 101;

b) hornblenda: $>97$;

c) biotita: $>94$

A correção para $\mathrm{Fe} 2 \mathrm{O} 3$ e o cálculo das fórmulas estruturais foram efetuados através das opções inseridas no software Minpet (versão 2,02). A opção realizada foi, a princípio, guiada pelas modelos de atividade e calibrações que seriam utilizados para o cálculo dos parâmetros temperatura e pressão.

Em função da grande quantidade de dados analíticos obtidos para química mineral e frisando que apenas dados de boa qualidade foram considerados, a seguir serão apresentadas apenas as médias das composições químicas dos minerais analisados 


\section{Composição Química Média dos Ortopiroxênios dos Ortogranulitos do Complexo Juiz de Fora e suas Fórmulas Estruturais}

$\begin{array}{ccccccccccccccc}\text { AMOSTRA } & \begin{array}{l}\text { LOCAL } \\ \text { ANALISADO }\end{array} & \text { MINERAL } & \text { SIO2 } & \text { TIO2 } & \text { AL2O3 } & \text { CR2O3 } & \text { FEO } & \text { MNO } & \text { MGO } & \text { NIO } & \text { CAO } & \text { NA2O } & \text { K2O } & \text { TOTAL } \\ 17 a & n & o p x & 52.490 & 0.050 & 1.010 & 0.040 & 24.760 & 0.560 & 21.250 & 0.050 & 0.460 & 0.040 & 0.010 & 100.720 \\ 17 a & b & o p x & 52.430 & 0.030 & 1.000 & 0.020 & 24.800 & 0.570 & 21.170 & 0.050 & 0.420 & 0.020 & 0.020 & 100.530 \\ 42 & n & o p x & 50.580 & 0.030 & 0.830 & 0.050 & 32.940 & 0.640 & 14.470 & 0.050 & 0.810 & 0.050 & 0.020 & 100.470 \\ 42 & b & o p x & 50.720 & 0.060 & 0.710 & 0.020 & 33.620 & 0.670 & 14.430 & 0.060 & 0.470 & 0.060 & 0.020 & 100.840 \\ 15 b & n & o p x & 50.810 & 0.060 & 0.670 & 0.040 & 31.270 & 0.640 & 15.960 & 0.030 & 0.620 & 0.050 & 0.010 & 100.160 \\ 15 b & b & o p x & 50.860 & 0.050 & 0.610 & 0.010 & 31.180 & 0.660 & 15.780 & 0.030 & 0.590 & 0.040 & 0.020 & 99.810 \\ 99 d & n & o p x & 51.090 & 0.050 & 1.030 & 0.030 & 29.750 & 0.700 & 17.270 & 0.030 & 0.610 & 0.030 & 0.010 & 100.600 \\ 99 d & b & o p x & 50.990 & 0.050 & 1.010 & 0.020 & 29.590 & 0.710 & 17.390 & 0.040 & 0.630 & 0.060 & 0.010 & 100.500 \\ 183 a & n & o p x & 49.760 & 0.080 & 0.560 & 0.030 & 36.260 & 0.490 & 12.200 & 0.050 & 0.920 & 0.050 & 0.010 & 100.410 \\ 183 a & b & o p x & 49.510 & 0.110 & 0.540 & 0.030 & 36.350 & 0.500 & 12.190 & 0.030 & 0.780 & 0.040 & 0.010 & 100.090\end{array}$

AMOSTRA TS!

TFE3 M1AL M1TI M1FE3 M1FE2 M1CR M1MG M1NI M2MG M2FE2 M2MN M2CA M2NA M2K SUM_CAT

$\begin{array}{cc}17 a & 1.958 \\ 17 a & 1.960 \\ 42 & 1.977 \\ 42 & 1.979 \\ 15 b & 1.974 \\ 15 b & 1.984 \\ 99 d & 1.959 \\ 99 d & 1.955 \\ 183 a & 1.979 \\ 183 a & 1.976\end{array}$

\subsection{2} $\begin{array}{llllllllllllllllll}0.023 & 0.000 & 0.016 & 0.001 & 0.008 & 0.129 & 0.002 & 0.843 & 0.002 & 0.000 & 0.940 & 0.021 & 0.034 & 0.004 & 0.001 & 3.999\end{array}$ $\begin{array}{llllllllllllllll}0.021 & 0.000 & 0.012 & 0.002 & 0.010 & 0.134 & 0.001 & 0.839 & 0.002 & 0.000 & 0.953 & 0.022 & 0.020 & 0.005 & 0.001 & 3.999 \\ 0 & 0.000 & 0.005 & 0.002 & 0.021 & 0.046 & 0.001 & 0.924 & 0.001 & 0.000 & 0.949 & 0.021 & 0.026 & 0.004 & 0.000 & 4.000\end{array}$ $\begin{array}{llllllllllllllllll}0.016 & 0.000 & 0.012 & 0.001 & 0.004 & 0.063 & 0.000 & 0.918 & 0.001 & 0.000 & 0.950 & 0.022 & 0.025 & 0.003 & 0.001 & 3.999\end{array}$ $\begin{array}{llllllllllllllllll}0.016 & 0.000 & 0.012 & 0.001 & 0.004 & 0.063 & 0.000 & 0.918 & 0.001 & 0.000 & 0.950 & 0.022 & 0.025 & 0.003 & 0.001 & 3.999 \\ 0.041 & 0.000 & 0.005 & 0.001 & 0.035 & 0.000 & 0.001 & 0.957 & 0.001 & 0.030 & 0.919 & 0.023 & 0.025 & 0.002 & 0.000 & 4.000\end{array}$ $\begin{array}{llllllllllllllll}0.041 & 0.000 & 0.005 & 0.001 & 0.035 & 0.000 & 0.001 & 0.957 & 0.001 & 0.030 & 0.919 & 0.023 & 0.025 & 0.002 & 0.000 & 4.000 \\ 0.045 & 0.000 & 0.000 & 0.001 & 0.046 & 0.000 & 0.001 & 0.950 & 0.001 & 0.044 & 0.902 & 0.023 & 0.026 & 0.004 & 0.000 & 4.000\end{array}$ $\begin{array}{llllllllllllllll}0.045 & 0.000 & 0.000 & 0.001 & 0.046 & 0.000 & 0.001 & 0.950 & 0.001 & 0.044 & 0.902 & 0.023 & 0.026 & 0.004 & 0.000 & 4.000 \\ 0.021 & 0.000 & 0.005 & 0.002 & 0.014 & 0.252 & 0.001 & 0.723 & 0.002 & 0.000 & 0.940 & 0.017 & 0.039 & 0.004 & 0.001 & 3.999\end{array}$ $\begin{array}{llllllllllllllll}0.024 & 0.000 & 0.002 & 0.003 & 0.018 & 0.250 & 0.001 & 0.725 & 0.001 & 0.000 & 0.946 & 0.017 & 0.033 & 0.003 & 0.001 & 3.999\end{array}$

bes Borda

n= núcleo 


\section{Composição Química dos Agregados de Ortopiroxênio dos Ortogranulitos do Complexo Juiz de Fora e suas Fórmulas Estruturais}

$\begin{array}{cccccccccccccc}\text { AMOSTRA } & \text { NINERAL } & \text { SIO2 } & \text { TIO2 } & \text { AL2O3 } & \text { CR2O3 } & \text { FEO } & \text { MNO } & \text { MGO } & \text { NIO } & \text { CAO } & \text { NA2O } & \text { K2O } & \text { TOTAL } \\ 42 & \text { pyr } & 50.550 & 0.000 & 0.770 & 0.010 & 32.820 & 0.660 & 14.360 & 0.050 & 0.590 & 0.000 & 0.000 & 99.910 \\ 42 & \text { pyr } & 50.490 & 0.020 & 0.780 & 0.060 & 33.610 & 0.090 & 14.430 & 0.000 & 0.460 & 0.020 & 0.000 & 100.560 \\ 42 & \text { pyr } & 50.750 & 0.110 & 0.820 & 0.000 & 33.390 & 0.000 & 14.030 & 0.030 & 0.440 & 0.080 & 0.000 & 100.250 \\ 42 & \text { pyr } & 49.350 & 0.020 & 0.650 & 0.000 & 33.490 & 0.670 & 15.010 & 0.000 & 0.400 & 0.030 & 0.040 & 100.150 \\ 42 & \text { pyr } & 50.440 & 0.040 & 0.760 & 0.020 & 33.330 & 0.630 & 14.460 & 0.020 & 0.470 & 0.030 & 0.010 & 100.240 \\ 99 d & \text { pyr } & 50.740 & 0.110 & 0.880 & 0.030 & 29.160 & 0.770 & 17.280 & 0.030 & 0.470 & 0.100 & 0.020 & 99.590 \\ 99 d & \text { pyr } & 50.740 & 0.110 & 0.880 & 0.030 & 29.160 & 0.770 & 17.280 & 0.030 & 0.470 & 0.100 & 0.020 & 99.590\end{array}$

AMOSTRA TSI TAL TFE3 M1AL M1TI MIFE3 MIFE2 M1CR M1MG M1NI M2MG M2FE2 M2MN M2CA M2NA M2K SUM_CAT

\begin{tabular}{|c|c|c|c|c|c|c|c|c|c|c|c|c|c|c|c|c|c|}
\hline 42 & 1.960 & 0.007 & 0.000 & 0.029 & 0.000 & 0.000 & 0.127 & 0.000 & 0.842 & 0.002 & 0.000 & 0.953 & 0.022 & 0.025 & 0.000 & 0.000 & 4000 \\
\hline 42 & 1.976 & 0.024 & 0.000 & 0.012 & 0.004 & 0.010 & 0.133 & 0.002 & 0.842 & 0.000 & 0.000 & 0.956 & 0.023 & 0.019 & 0.002 & 0.000 & 0 \\
\hline 42 & 904 & 0.006 & 0.000 & 0.032 & 0.003 & 0.000 & 0.142 & 0.000 & 0.822 & 0.001 & 0.000 & 0.955 & 0.020 & 0.019 & 0.006 & 0.000 & $\infty 00$ \\
\hline 42 & 953 & 0.030 & 0.017 & 0.000 & 0.001 & 0.050 & 0.073 & 0.000 & 0.876 & 0.000 & 0.000 & 0.967 & 0.022 & 0.017 & 0.002 & 0.002 & 3.998 \\
\hline 42 & 1.979 & 0.021 & 0.000 & 0.014 & 0.001 & 0.007 & 0.131 & 0.00 & 0.846 & 0.001 & 0.000 & 0.956 & 0.022 & 0.020 & 0.002 & 0.001 & 3.909 \\
\hline 90 & 1.962 & 0.038 & 0.000 & 0.002 & 0.003 & 0.036 & & 0.00 & 0.956 & 0.001 & 0.040 & 0.907 & 0.025 & 0.019 & 0.007 & 0.001 & 3.909 \\
\hline$\theta d$ & 1.962 & 0.038 & 0.000 & 0.002 & 0.003 & 0.036 & 0.000 & 0.001 & 0.956 & 0.001 & 0.040 & 0.907 & 0.025 & 0.019 & 0.007 & 0.001 & 3.90 \\
\hline
\end{tabular}


Composição Química Média dos Climopiroxênios dos Ortogranulitos do Complexo Juiz de Fora e suas Fórmulas Estruturais

\begin{tabular}{|c|c|c|c|c|c|c|c|c|c|c|c|c|c|c|c|c|c|}
\hline AMOSTRA & $\begin{array}{l}\text { LOCAL } \\
\text { ANALISADO }\end{array}$ & MINERAL & $\mathrm{SiO} 2$ & T102 & A $\{203$ & $\mathrm{CR} 203$ & FEO & MNO & MGO & NO & CAO & NA2O & $\mathrm{K} 2 \mathrm{O}$ & TOTAL & & & \\
\hline $17 a$ & ก & $\operatorname{cpx}$ & 52.46 & 0.13 & 1.84 & 0.02 & 8.62 & 0.22 & 13.70 & 0.04 & 22.91 & 0.38 & 0.01 & 100.33 & & & \\
\hline $17 a$ & b & $\operatorname{cpx}$ & 52.63 & 0.13 & 1.61 & 0.02 & 8.38 & 0.21 & 13.98 & 0.04 & 23.30 & 0.36 & 0.01 & 100.67 & & & \\
\hline 42 & $\mathrm{n}$ & $\operatorname{cpx}$ & 50.84 & 0.24 & 2.16 & 0.04 & 14.42 & 0.27 & 10.96 & 0.04 & 20.98 & 0.44 & 0.01 & 100.40 & & & \\
\hline 42 & b & $c p x$ & 51.69 & 0.14 & 1.56 & 0.03 & 12.84 & 0.24 & 10.98 & 0.06 & 22.52 & 0.40 & 0.01 & 100.47 & & & \\
\hline $99 d$ & $n$ & $\operatorname{cpx}$ & 51.68 & 0.13 & 1.92 & 0.03 & 11.27 & 0.26 & 12.10 & 0.02 & 22.49 & 0.47 & 0.02 & 100.39 & & & \\
\hline $99 \mathrm{~d}$ & b & $\operatorname{cpx}$ & 51.97 & 0.07 & 1.61 & 0.04 & 10.96 & 0.26 & 12.46 & 0.05 & 22.74 & 0.40 & 0.01 & 100.57 & & & \\
\hline $183 a$ & $n$ & $\operatorname{cpx}$ & 50.73 & 0.16 & 1.51 & 0.04 & 16.30 & 0.22 & 9.48 & 0.02 & 21.43 & 0.35 & 0.02 & 100.26 & & & \\
\hline $183 a$ & b & $\operatorname{cpx}$ & 51.18 & 0.12 & 1.31 & 0.02 & 15.48 & 0.20 & 9.74 & 0.03 & 22.10 & 0.33 & 0.01 & 100.52 & & & \\
\hline AMOSTRA & TSI & $T A L$ & TFE3 & MIAL & MTT & MIFE3 & M1FE2 & M1CR & M1MG & $M T N \mid$ & M2MG & $\mathrm{M} 2 \mathrm{FE} 2$ & $M 2 M N$ & $\mathrm{M} 2 \mathrm{CA}$ & $M 2 \mathrm{NA}$ & $\mathrm{M} 2 \mathrm{~K}$ & SUM_CAT \\
\hline $17 a$ & 1.95 & 0.06 & 0.00 & 0.03 & 0.00 & 0.05 & 0.16 & 0.00 & 0.76 & 0.00 & 0.00 & 0.06 & 0.01 & 0.91 & 0.03 & 0.00 & 4.00 \\
\hline $17 a$ & 1.94 & 0.06 & 0.00 & 0.01 & 0.00 & 0.06 & 0.15 & 0.00 & 0.77 & 0.00 & 0.00 & 0.05 & 0.01 & 0.92 & 0.03 & 0.00 & 4.00 \\
\hline 42 & 1.93 & 0.07 & 0.00 & 0.02 & 0.01 & 0.07 & 0.28 & 0.00 & 0.62 & 0.00 & 0.00 & 0.11 & 0.01 & 0.85 & 0.03 & 0.00 & 4.00 \\
\hline 42 & 1.95 & 0.05 & 0.00 & 0.02 & 0.00 & 0.05 & 0.31 & 0.00 & 0.62 & 0.00 & 0.00 & 0.05 & 0.01 & 0.91 & 0.03 & 0.00 & 4.00 \\
\hline $99 d$ & 1.94 & 0.06 & 0.00 & 0.02 & 0.00 & 0.07 & 0.23 & 0.00 & 0.68 & 0.00 & 0.00 & 0.05 & 0.01 & 0.90 & 0.03 & 0.00 & 4.00 \\
\hline $99 d$ & 1.94 & 0.06 & 0.00 & 0.01 & 0.00 & 0.07 & 0.22 & 0.00 & 0.69 & 0.00 & 0.00 & 0.05 & 0.01 & 0.91 & 0.03 & 0.00 & 4.00 \\
\hline $183 a$ & 1.95 & 0.05 & 0.00 & 0.01 & 0.01 & 0.06 & 0.38 & 0.00 & 0.54 & 0.00 & 0.00 & 0.09 & 0.01 & 0.88 & 0.03 & 0.00 & 4.00 \\
\hline $183 a$ & 1.95 & 0.05 & 0.00 & 0.01 & 0.00 & 0.05 & 0.38 & 0.00 & 0.55 & 0.00 & 0.00 & 0.07 & 0.01 & 0.90 & 0.02 & 0.00 & 4.00 \\
\hline
\end{tabular}

$n=$ núcleo

$s=$ borda 


\section{Composição Química dos Agregados de Ortopiroxênio dos Ortogranulitos do Complexo Juiz de Fora e suas Fórmulas Estruturais}

$\begin{array}{cccccccccccccc}\text { AMOSTRA } & \text { MINERAL } & S 102 & \text { TIO2 } & \text { AL2O3 } & \text { CR2O3 } & \text { FEO } & \text { MNO } & \text { MGO } & \text { NIO } & \text { CAO } & \text { NA2O } & \text { K2O } & \text { TOTAL } \\ 42 & \text { pyr } & 50.650 & 0.000 & 0.770 & 0.010 & 32.820 & 0.660 & 14.360 & 0.050 & 0.590 & 0.000 & 0.000 & 99.910 \\ 42 & \text { pyr } & 50.490 & 0.020 & 0.780 & 0.080 & 33.610 & 0.690 & 14.430 & 0.000 & 0.460 & 0.020 & 0.000 & 100.560 \\ 42 & \text { pyr } & 50.750 & 0.110 & 0.820 & 0.000 & 33.390 & 0.600 & 14.030 & 0.030 & 0.440 & 0.080 & 0.000 & 100.250 \\ 42 & \text { pyr } & 49.850 & 0.020 & 0.650 & 0.000 & 33.490 & 0.670 & 15.010 & 0.000 & 0.400 & 0.030 & 0.040 & 100.160 \\ 42 & \text { pyr } & 50.440 & 0.040 & 0.760 & 0.020 & 33.330 & 0.660 & 14.460 & 0.020 & 0.470 & 0.030 & 0.010 & 100.240 \\ 99 d & \text { pyr } & 50.740 & 0.110 & 0.880 & 0.030 & 29.160 & 0.770 & 17.280 & 0.030 & 0.470 & 0.100 & 0.020 & 99.590 \\ 99 d & \text { pyr } & 50.740 & 0.110 & 0.880 & 0.030 & 29.160 & 0.770 & 17.280 & 0.030 & 0.470 & 0.100 & 0.020 & 99.590\end{array}$

AMOSTRA TSI TAL TFE3 M1AL M1TI MIFE3 M1FE2 M1CR M1MG M1NI M2MG M2FE2 M2MN M2CA M2NA M2K SUM_CAT

$$
\begin{aligned}
& 42 \\
& 42 \\
& 42 \\
& 42 \\
& 42 \\
& 99 d \\
& 99 d
\end{aligned}
$$$$
\begin{aligned}
& 1.993 \\
& 1.976 \\
& 1.994 \\
& 1.953 \\
& 1.979 \\
& 1.962 \\
& 1.962
\end{aligned}
$$$$
\begin{array}{lllllllllll}
0.007 & 0.000 & 0.029 & 0.000 & 0.000 & 0.127 & 0.000 & 0.842 & 0.002 & 0.000 & 0.953
\end{array}
$$$$
\begin{array}{lll}
0.024 & 0.000 & 0.012
\end{array}
$$$$
\begin{array}{lll}
0.006 & 0.000 & 0.032
\end{array}
$$$$
\begin{array}{ll}
0.001 & 0.010
\end{array}
$$$$
0.0010 .010
$$$$
\begin{array}{llllll}
0.133 & 0.002 & 0.842 & 0.000 & 0.000 & 0.956
\end{array}
$$$$
\begin{array}{llll}
0.030 & 0.017 & 0.000
\end{array}
$$

$\begin{array}{llllll}0.021 & 0.000 & 0.014 & 0.001 & 0.007\end{array}$

$\begin{array}{llllll}0.142 & 0.000 & 0.822 & 0.001 & 0.000 & 0.955\end{array}$

$\begin{array}{llllll}0.073 & 0.000 & 0.876 & 0.000 & 0.000 & 0.957 \\ 0.131 & 0.001 & 0.846 & 0.001 & 0.000 & 0.956\end{array}$

$\begin{array}{llll}0.038 & 0.000 & 0.002\end{array}$

$0.001 \quad 0.007$

$\begin{array}{llllll}0.000 & 0.001 & 0.846 & 0.001 & 0.000\end{array}$

0.956

0.022

0.020

$\begin{array}{lll}0.025 & 0.000 & 0.000\end{array}$

$\begin{array}{lll}0.019 & 0.002 & 0.000\end{array}$

$\begin{array}{llll}0.017 & 0.002 & 0.002\end{array}$

$0.020 \quad 0.002 \quad 0.001$

$\begin{array}{llllllllll}0.038 & 0.000 & 0.002 & 0.003 & 0.036 & 0.000 & 0.001 & 0.956 & 0.001 & 0.040\end{array}$

$0.907 \quad 0.025$

$\begin{array}{llll}0.019 & 0.007 & 0.001 & 3.999\end{array}$

$\begin{array}{llll}0.007 & 0.001 & 3.999\end{array}$




\section{Composição Química dos Anfibólios dos Ortogranulitos do Complexo Juiz de Fora e suas Fórmulas Estruturais}

\begin{tabular}{|c|c|c|c|c|c|c|c|c|c|c|c|c|c|c|}
\hline AMOSTRA & $\begin{array}{l}\text { LOCAL } \\
\text { ANALISADO }\end{array}$ & MNNERAL & $\mathrm{S1O} 2$ & $\mathrm{~T} 102$ & $A \leq 203$ & $\mathrm{CR} 2 \mathrm{O} 3$ & FEO & MNO & MGO & NIO & CAO & $\mathrm{NA} 2 \mathrm{O}$ & 100 & TOTAL \\
\hline $17 a$ & $n$ & amp & 43.500 & 1.790 & 11.110 & 0.050 & 13.990 & 0.100 & 12.250 & 0.050 & 11.960 & 1.320 & +320 & 97.440 \\
\hline $17 a$ & $b$ & amp & 43.970 & 1.640 & 10.850 & 0.070 & 13.660 & 0.120 & 12.660 & 0.030 & 12.000 & 1.260 & 1.200 & 97.550 \\
\hline 42 & $n$ & $a m p$ & 41.160 & 2.040 & 12.200 & 0.070 & 19.200 & 0.130 & 8.480 & 0.010 & 11.640 & 9.450 & 1,30 & 97.810 \\
\hline 42 & b & amp & 41.350 & 1.860 & 12.250 & 0.060 & 18.970 & 0.150 & 8.510 & 0.110 & 11.690 & 1.470 & 3.450 & 97.870 \\
\hline $15 b$ & $n$ & amp & 45.650 & 0.920 & 9.770 & 0.070 & 16.380 & 0.120 & 11.640 & 0.060 & 11.870 & 1.140 & 0.030 & 98.250 \\
\hline $15 b$ & $b$ & amo & 40.330 & 0.830 & 3.270 & 0.040 & 16.230 & 0.120 & 11.820 & 0.030 & 11.650 & 1,030 & 0.580 & 97.930 \\
\hline $99 d$ & $n$ & amp & 41.650 & 1.990 & 11,210 & 0.060 & 17.140 & 0.160 & 10.080 & 0.050 & 11.760 & 1,270 & 1.950 & 97.320 \\
\hline $99 d$ & b & $a m p$ & 40.650 & 2.160 & 12.030 & 0.010 & 17.300 & 0.120 & 8.700 & 0.070 & 11.970 & $\$ .230$ & 2.090 & 97.330 \\
\hline $183 a$ & $n$ & amp & 40.250 & 2.750 & 12.010 & 0.040 & 21.090 & 0.050 & 6.660 & 0.020 & 11.560 & 1.400 & 2.060 & 97.890 \\
\hline $183 a$ & $b$ & amp & 39.990 & 2.650 & 2.170 & 0.030 & 21.400 & 0.080 & 6.550 & 0.040 & 11.580 & 1.280 & 2.130 & 97.900 \\
\hline AMOSTRA & TSI & TAL & TFE3 & $\mathrm{TT}$ & SUM $M_{-} T$ & $\mathrm{CAL}$ & $\mathrm{CCR}$ & CFE3 & CTI & CMG & CFE2 & CMN & CCA & SUM_C \\
\hline $17 a$ & 8.448 & 1.552 & 0.000 & 0.000 & 8.000 & 0.388 & 0.006 & 0.238 & 0.200 & 2.707 & 456 & 0.006 & 0.000 & 5.000 \\
\hline $17 a$ & 6.484 & 1.516 & 0.000 & 0.000 & 8.000 & 0.376 & 0.008 & 0.284 & 0.182 & 2.783 & 1.360 & 0.007 & 0.000 & 5.000 \\
\hline 42 & 6.251 & 1.749 & 0.000 & 0.000 & 8.000 & 0.433 & 0.008 & 0.251 & 0.233 & 1.920 & 2.147 & 0.008 & 0.000 & 5.000 \\
\hline 42 & 6.280 & 1.720 & 0.000 & 0.000 & 8.000 & 0.471 & 0.007 & 0.208 & 0.212 & 1.927 & 2.185 & 0.010 & 0.000 & 5.000 \\
\hline $15 b$ & 6.696 & 1.304 & 0.000 & 0.000 & 8.000 & 0.384 & 0.008 & 0.411 & 0.102 & 2.545 & 1.543 & 0,007 & 0.000 & 5.000 \\
\hline $15 b$ & 6.793 & 1.207 & 0.000 & 0.000 & 8.000 & 0.394 & 0.005 & 0.404 & 0.092 & 2.584 & 1.514 & 0.007 & 0.000 & 5.000 \\
\hline $99 d^{\circ}$ & 6.323 & 1.877 & 0.000 & 0.000 & 8.000 & 0.328 & 0.007 & 0.228 & 0.227 & 2.281 & 1.948 & 0.010 & 0.000 & 5.000 \\
\hline $99 d$ & 6.192 & 1.308 & 0.000 & 0.000 & 8.000 & 0.351 & 0.001 & 0.241 & 0.248 & 2.203 & 1.949 & 0.008 & 0.000 & 5.000 \\
\hline $183 a$ & 6.239 & 1.761 & 0.000 & 0.000 & 8.000 & 0.432 & 0.005 & 0.036 & 0.321 & 1.539 & 2.86 .4 & 0.003 & 0.000 & 5.000 \\
\hline $183 a$ & 6.201 & 1.798 & 0.000 & 0.000 & 8.000 & 0.423 & 0.004 & 0.077 & 0.300 & 1.514 & 2.888 & 0.005 & 0.000 & 5.000 \\
\hline AMOSTRA & BMG & BFE2 & BMN & $8 C A$ & BNA & SUM_B & $A C A$ & ANA & AK & SUM_A; & :UM_CA & $\mathrm{CCL}$ & CF : & UUM_OXY \\
\hline $17 a$ & 000 & .041 & 0.006 & 1.899 & 0.054 & 2.000 & 0.000 & 0.32 & 0.250 & 0.575 & 15.575 & 0.000 & 0.000 & 23,000 \\
\hline $17 a$ & 0.000 & .041 & 0.008 & 1.896 & 0.056 & 2.000 & 0.000 & 0.305 & 0.235 & 0.540 & 15.540 & 0.000 & 0.000 & 23.000 \\
\hline 42 & 0.000 & 0.041 & 0.008 & 1.894 & 0.057 & 2.000 & 0.000 & 0.370 & 0.277 & 0.647 & 15.647 & 0.000 & 0.000 & 23.000 \\
\hline 42 & 0.000 & 0.036 & 0.010 & 1,902 & 0.052 & 2.000 & 0.000 & 0.381 & 0.281 & 0.662 & 15.662 & 0.000 & 0.000 & 23.000 \\
\hline $15 b$ & 0.000 & 0.055 & 0.007 & 1.865 & 0.072 & 2.000 & 0.000 & 0.252 & 0.118 & 0.370 & 15.370 & 0.000 & 0.000 & 23.000 \\
\hline $15 b$ & 0.000 & 0.072 & 0.007 & 1.830 & 0.090 & 2.000 & 0.000 & 0.202 & 0.108 & 0.311 & 15.311 & 0.000 & 0.000 & 23.000 \\
\hline $98 \mathrm{~d}$ & 0.000 & 0.030 & 0.010 & 1.913 & 0.046 & 2.000 & 0.000 & 0.327 & 0.378 & 0.705 & 15.705 & 0.000 & 0.000 & 23.000 \\
\hline $99 \mathrm{~d}$ & 0.000 & 0.014 & 0.008 & 1.954 & 0.025 & 2.000 & 0.000 & 0.339 & 0.406 & 0.745 & 15.745 & 0.000 & 0.000 & 23.000 \\
\hline $183 a$ & 0.000 & 0.034 & 0.003 & 1.920 & 0.043 & 2.000 & 0.000 & 0.378 & 0.407 & 3.785 & 15.785 & 0.000 & 0.000 & 23.048 \\
\hline $183 a$ & 0.000 & 0.030 & 0.005 & $1.92 d$ & 0.041 & 2.000 & 0.000 & 0.344 & 0.421 & $\Gamma 765$ & 15.765 & 0.000 & 0.000 & 23.024 \\
\hline
\end{tabular}




\section{Composição Química dos agregados de Anfibólio dos Ortogranulitos do Complexo Juiz de Fora e suas Fórmulas Estruturais}

$\begin{array}{cccccccccccccc}\text { AMOSTRA } & \text { MINERAL } & \text { SIO2 } & \text { TIO2 } & \text { AL2O3 } & \text { CR2O3 } & \text { FEO } & \text { MNO } & \text { MGO } & \text { NIO } & \text { CAO } & \text { NA2O } & \text { K2O } & \text { TOTAL } \\ 42 & \mathrm{amp} & 42.290 & 1.510 & 11.670 & 0.050 & 18.530 & 0.090 & 8.870 & 0.110 & 11.990 & 1.030 & 1.670 & 97.810 \\ 42 & \mathrm{amp} & 41.320 & 1.430 & 12.080 & 0.060 & 19.410 & 0.070 & 8.490 & 0.110 & 11.800 & 1.240 & 1.550 & 97.560 \\ 42 & \mathrm{amp} & 41.690 & 1.680 & 12.100 & 0.030 & 19.080 & 0.190 & 8.670 & 0.030 & 12.000 & 1.430 & 1.470 & 98.370 \\ 42 & \mathrm{amp} & 41.410 & 1.820 & 11.780 & 0.070 & 19.000 & 0.150 & 8.330 & 0.050 & 11.740 & 1.540 & 1.340 & 97.230 \\ 42 & \mathrm{amp} & 41.460 & 1.960 & 12.060 & 0.050 & 18.630 & 0.170 & 8.470 & 0.000 & 11.630 & 1.530 & 1.330 & 97.290 \\ 42 & \mathrm{amp} & 41.130 & 1.810 & 12.030 & 0.070 & 19.790 & 0.130 & 8.280 & 0.100 & 11.740 & 1.510 & 1.400 & 97.990 \\ 42 & \mathrm{amp} & 41.770 & 1.690 & 12.000 & 0.030 & 18.930 & 0.040 & 8.470 & 0.020 & 11.540 & 1.430 & 1.410 & 97.330 \\ 42 & \mathrm{amp} & 41.580 & 1.700 & 12.010 & 0.050 & 19.050 & 0.110 & 8.510 & 0.060 & 11.770 & 1.390 & 1.450 & 97.680 \\ 15 \mathrm{~b} & \mathrm{amp} & 45.940 & 0.880 & 9.370 & 0.000 & 16.060 & 0.180 & 11.950 & 0.030 & 11.690 & 0.710 & 0.650 & 97.460 \\ 99 \mathrm{~d} & \mathrm{amp} & 42.210 & 1.650 & 10.850 & 0.010 & 16.780 & 0.110 & 10.380 & 0.050 & 12.740 & 1.080 & 1.740 & 97.600\end{array}$

$\begin{array}{ccccccccccccccc}\text { AMOSTRA } & \text { TSI } & \text { TAL } & \text { TFE3 } & \text { TTI } & \text { SUM_T } & \text { CAL } & \text { CCR } & \text { CFE3 } & \text { CTI } & \text { CMG } & \text { CFE2 } & \text { CMN } & \text { CCA } & \text { SUM_C } \\ 42 & 6.405 & 1.595 & 0.000 & 0.000 & 8.000 & 0.486 & 0.006 & 0.192 & 0.172 & 2.003 & 2.135 & 0.006 & 0.000 & 5.000 \\ 42 & 6.291 & 1.709 & 0.000 & 0.000 & 8.000 & 0.457 & 0.007 & 0.331 & 0.164 & 1.927 & 2.110 & 0.005 & 0.000 & 5.000 \\ 42 & 6.295 & 1.705 & 0.000 & 0.000 & 8.000 & 0.447 & 0.004 & 0.233 & 0.191 & 1.952 & 2.162 & 0.012 & 0.000 & 5.000 \\ 42 & 6.340 & 1.660 & 0.000 & 0.000 & 8.000 & 0.463 & 0.008 & 0.130 & 0.210 & 1.901 & 2.278 & 0.010 & 0.000 & 5.000 \\ 42 & 6.324 & 1.676 & 0.000 & 0.000 & 8.000 & 0.491 & 0.006 & 0.143 & 0.225 & 1.926 & 2.198 & 0.011 & 0.000 & 5.000 \\ 42 & 6.257 & 1.743 & 0.000 & 0.000 & 8.000 & 0.412 & 0.008 & 0.283 & 0.207 & 1.878 & 2.203 & 0.008 & 0.000 & 5.000 \\ 42 & 6.363 & 1.637 & 0.000 & 0.000 & 8.000 & 0.516 & 0.004 & 0.174 & 0.194 & 1.924 & 2.186 & 0.003 & 0.000 & 5.000 \\ 42 & 6.322 & 1.678 & 0.000 & 0.000 & 8.000 & 0.473 & 0.006 & 0.208 & 0.194 & 1.929 & 2.183 & 0.007 & 0.000 & 5.000 \\ 15 b & 6.746 & 1.254 & 0.000 & 0.000 & 8.000 & 0.367 & 0.000 & 0.539 & 0.097 & 2.616 & 1.369 & 0.011 & 0.000 & 5.000 \\ 99 d & 6.378 & 1.622 & 0.000 & 0.000 & 8.000 & 0.309 & 0.001 & 0.217 & 0.188 & 2.338 & 1.904 & 0.014 & 0.029 & 5.000\end{array}$

$\begin{array}{ccccccccccccccc}\text { AMOSTRA } & \text { BMG } & \text { BFE2 } & \text { BMN } & \text { BCA } & \text { BNA } & \text { SUM_B } & \text { ACA } & \text { ANA } & \text { AK } & \text { SUM_A } & \text { SUM_CAT } & \text { CCL } & \text { CF } & \text { SUM_OXY } \\ 42 & 0.000 & 0.020 & 0.006 & 1.946 & 0.029 & 2.000 & 0.000 & 0.273 & 0.323 & 0.596 & 15.596 & 0.000 & 0.000 & 23.000 \\ 42 & 0.000 & 0.030 & 0.005 & 1.925 & 0.040 & 2.000 & 0.000 & 0.326 & 0.301 & 0.627 & 15.627 & 0.000 & 0.000 & 23.000 \\ 42 & 0.000 & 0.015 & 0.012 & 1.941 & 0.031 & 2.000 & 0.000 & 0.387 & 0.283 & 0.671 & 15.671 & 0.000 & 0.000 & 23.000 \\ 42 & 0.000 & 0.025 & 0.010 & 1.926 & 0.040 & 2.000 & 0.000 & 0.417 & 0.262 & 0.679 & 15.679 & 0.000 & 0.000 & 23.000 \\ 42 & 0.000 & 0.035 & 0.011 & 1.901 & 0.053 & 2.000 & 0.000 & 0.400 & 0.259 & 0.658 & 15.658 & 0.000 & 0.000 & 23.010 \\ 42 & 0.000 & 0.032 & 0.008 & 1.914 & 0.046 & 2.000 & 0.000 & 0.399 & 0.272 & 0.671 & 15.671 & 0.000 & 0.000 & 23.000 \\ 42 & 0.000 & 0.052 & 0.003 & 1.884 & 0.062 & 2.000 & 0.000 & 0.360 & 0.274 & 0.634 & 15.634 & 0.000 & 0.000 & 23.008 \\ 42 & 0.000 & 0.031 & 0.007 & 1.917 & 0.044 & 2.000 & 0.000 & 0.366 & 0.281 & 0.647 & 15.647 & 0.000 & 0.000 & 23.000 \\ 15 b & 0.000 & 0.064 & 0.011 & 1.839 & 0.086 & 2.000 & 0.000 & 0.117 & 0.122 & 0.238 & 15.238 & 0.000 & 0.000 & 23.000 \\ 99 \mathrm{~d} & 0.000 & 0.000 & 0.000 & 2.000 & 0.000 & 2.000 & 0.034 & 0.316 & 0.335 & 0.686 & 15.686 & 0.000 & 0.000 & 23.000\end{array}$




\section{Composição Quínica do Plagioclásio dos Ortogranulitos do Complexo}

Juìz Je For a suas Fómulas Estruturais

$\begin{array}{cccccccccccc}\text { AMOSTRA } & \begin{array}{c}\text { LOCAL } \\ \text { ANALISADO }\end{array} & \text { MINERAL } & \text { SIO2 } & \text { AL.2O3 } & \text { FEG } & \text { CAO } & \text { NA2O } & \text { K2O } & \text { פAO } & \text { SRO } & \text { TOTAL } \\ 15 \mathrm{~b} & \mathrm{n} & \mathrm{plg} & 47.580 & 32.960 & 0.210 & 16.920 & 1.890 & 0.030 & 0.040 & 0.120 & 99.750 \\ 15 \mathrm{~b} & \mathrm{~b} & \mathrm{plg} & 48.310 & 32.590 & 0.120 & 16.460 & 2.240 & 0.050 & 0.040 & 0.070 & 99.880 \\ 17 \mathrm{a} & \mathrm{n} & \mathrm{plg} & 55.080 & 28.310 & 0.140 & 11.220 & 4.990 & 0.270 & 0.070 & 9.000 & 100.080 \\ 17 \mathrm{a} & \mathrm{b} & \mathrm{plg} & 54.810 & 28.490 & 0.190 & 11.350 & 4.930 & 0.250 & 0.060 & 0.080 & 100.160 \\ 183 \mathrm{a} & \mathrm{n} & \mathrm{plg} & 57.470 & 26.610 & 0.070 & 8.910 & 6.140 & 0.240 & 0.050 & 0.050 & 99.540 \\ 1 \mathrm{a} 3 \mathrm{a} & \mathrm{b} & \mathrm{plg} & 56.540 & 27.330 & 0.170 & 9.760 & 5.700 & 0.220 & 0.030 & 0.060 & 99.810 \\ 42 & \mathrm{n} & \mathrm{plg} & 56.830 & 27.190 & 0.070 & 9.860 & 5.760 & 0.210 & 0.040 & 0.010 & 99.970 \\ 42 & \mathrm{~b} & \mathrm{plg} & 56.690 & 27.210 & 0.150 & 9.850 & 5.810 & 0.200 & 0.050 & 0.030 & 99.990 \\ 99 \mathrm{~d} & \mathrm{n} & \mathrm{plg} & 58.900 & 25.790 & 0.100 & 8.220 & 6.270 & 0.440 & 0.050 & 0.090 & 99.800 \\ 29 \mathrm{~d} & \mathrm{~b} & \mathrm{plg} & 58.460 & 25.960 & 0.090 & 8.400 & 6.290 & 0.390 & 0.050 & 0.020 & 99.660\end{array}$

$\begin{array}{cccccccccccc}\text { AMOSTRA } & \mathrm{SI} & \text { AL } & \text { FE2 } & \text { BA } & \text { CA } & \text { NA } & \text { K } & \text { CATIONS } & \text { AB } & \text { AN } & \text { OR } \\ 15 \mathrm{~b} & 8.766 & 7.152 & 0.032 & 0.003 & 3.340 & 0.675 & 0.007 & 4.987 & 16.800 & 83.000 & 0.200 \\ 15 \mathrm{~b} & 8.872 & 7.049 & 0.018 & 0.003 & 3.239 & 0.798 & 0.012 & 4.998 & 19.700 & 80.900 & 0.300 \\ 17 \mathrm{a} & 9.936 & 6.014 & 0.021 & 0.005 & 2.169 & 1.745 & 0.062 & 4.983 & 43.900 & 54.600 & 1.600 \\ 17 \mathrm{a} & 9.891 & 6.055 & 0.029 & 0.004 & 2.194 & 1.725 & 0.058 & 4.982 & 43.400 & 55.200 & 1.500 \\ 183 \mathrm{a} & 10.346 & 5.642 & 0.011 & 0.004 & 1.719 & 2.143 & 0.055 & 4.981 & 54.700 & 43.900 & 1.400 \\ 183 \mathrm{a} & 10.181 & 5.795 & 0.026 & 0.002 & 1.883 & 1.990 & 0.051 & 4.983 & 50.700 & 48.000 & 1.300 \\ 42 & 10.211 & 5.753 & 0.011 & 0.003 & 1.898 & 2.007 & 0.048 & 4.984 & 50.800 & 48.000 & 1.200 \\ 42 & 10.193 & 5.762 & 0.023 & 0.004 & 1.898 & 2.026 & 0.046 & 4.980 & 51.000 & 47.800 & 1.200 \\ 99 \mathrm{~d} & 10.546 & 5.438 & 0.015 & 0.004 & 1.577 & 2.177 & 0.101 & 4.963 & 56.500 & 40.900 & 2.600 \\ 99 \mathrm{~d} & 10.493 & 5.488 & 0.014 & 0.004 & 1.615 & 2.189 & 0.089 & 4.972 & 56.200 & 41.500 & 2.3600\end{array}$

$b=$ borda

n= núcleo 


\section{Composição química Média das Granadas dos Ortogranulitos do Complexo Juiz de Fora e suas Fórmulas Estruturais}

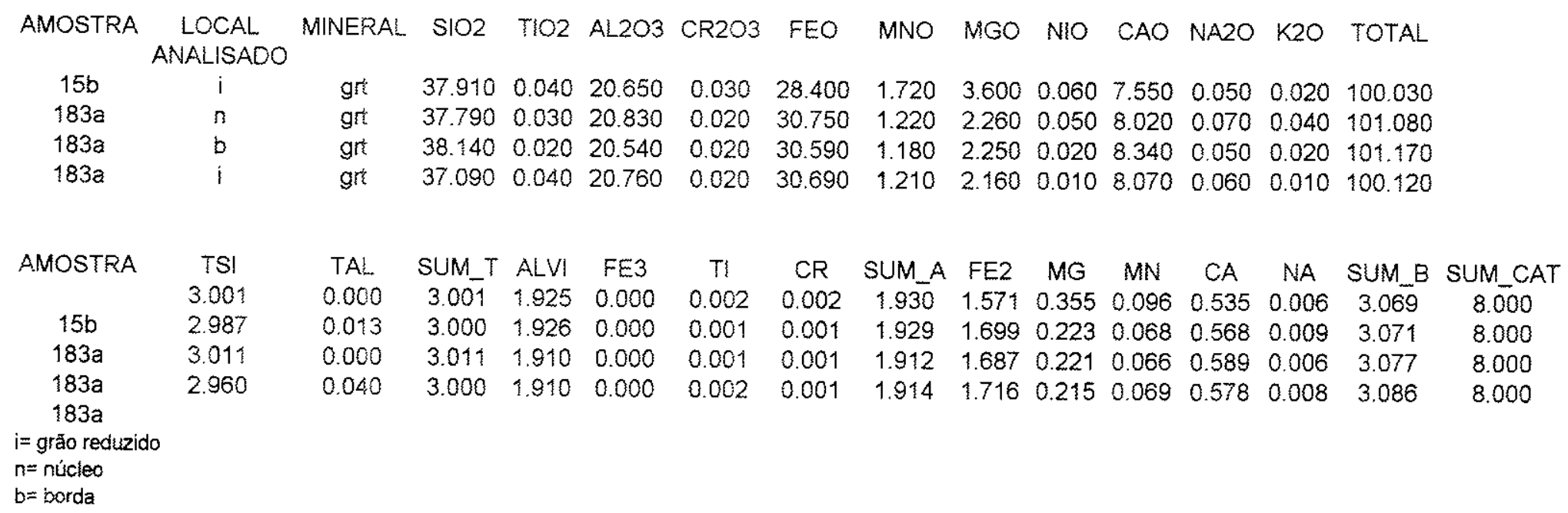




\section{Composição Química Média dos Ortopiroxênios do Biotita-Granada-(Ortopiroxênio) Gnaisse}

da Unidade Jardim Glória

\begin{tabular}{|c|c|c|c|c|c|c|c|c|c|c|c|c|c|c|}
\hline AMOSTRA & $\begin{array}{l}\text { LOCAL } \\
\text { ANALISADO }\end{array}$ & MINERAL & $\mathrm{SIO} 2$ & $\mathrm{TlO} 2$ & $\mathrm{AL} 203$ & CR2O3 & FEO & MNO & MGO & NOO & CAO & $\mathrm{NA} 2 \mathrm{O}$ & $\mathrm{K} 2 \mathrm{O}$ & TOTAL \\
\hline 360 & $n$ & $o p x$ & 50.56 & 0.08 & 1.52 & 0.00 & 30.11 & 0.44 & 16.20 & 0.01 & 0.38 & 0.00 & 0.01 & 99.40 \\
\hline $36 b$ & $b$ & $o p x$ & 50.15 & 0.12 & $1 . \infty$ & 0.06 & 30.01 & 0.33 & 16.80 & 0.04 & 0.41 & 0.01 & $0 . \infty$ & 98.93 \\
\hline jg108 & ก & opx & 50.99 & 0.08 & 2.05 & 0.06 & 28.92 & 0.25 & 17.13 & 0.02 & 0.24 & 0.04 & 0.01 & 99.79 \\
\hline jg108 & $b$ & $o p x$ & 50.80 & 0.16 & 2.01 & 0.02 & 28.76 & 0.26 & 17.25 & 0.04 & 0.20 & 0.07 & 0.02 & 99.59 \\
\hline
\end{tabular}

AMOSTRA TSI TAL TFE3 M1AL M1TI M1FE3 M1FE2 MiCR M1MG MINI M2MG M2FE2 M2MN M2CA M2NA M2K SUM_CAT

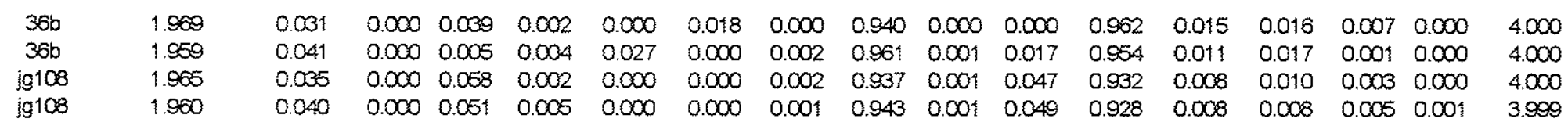

$n=$ núcleo

$b=$ borda 


\section{Composição Química Média dos Plagioclásios do Biotita-Granada-(ortopiroxênio) Gnaisse da Unidade Jardim Glória}

\begin{tabular}{|c|c|c|c|c|c|c|c|c|c|c|c|}
\hline AMOSTRA & $\begin{array}{c}\text { LOCAL } \\
\text { ANALISADO }\end{array}$ & MINERAL & $\mathrm{SIO} 2$ & AL2O3 & FEO & CAO & NA2O & $\mathrm{K} 2 \mathrm{O}$ & $\mathrm{BAO}$ & SRO & TOTAL \\
\hline $35 b$ & $n$ & plg & 59.39 & 25.35 & 0.06 & 7.45 & 6.92 & 0.36 & 0.02 & 0.04 & 99.59 \\
\hline $35 b$ & $b$ & plg & 58.86 & 26.15 & 0.12 & 8.06 & 6.65 & 0.29 & 0.03 & 0.05 & 100.21 \\
\hline $36 b$ & $b$ & plg & 59.04 & 25.62 & 0.05 & 8.02 & 6.79 & 0.25 & 0.08 & 0.07 & 99.92 \\
\hline $36 b$ & $\mathrm{n}$ & $\mathrm{plg}$ & 59.49 & 25.48 & 0.07 & 7.89 & 6.82 & 0.36 & 0.05 & 0.06 & 100.22 \\
\hline jg-108 & $n$ & plg & 61.51 & 24.11 & 0.03 & 6.05 & 7.58 & 0.36 & 0.03 & 0.06 & 99.73 \\
\hline jg-108 & $b$ & $\mathrm{plg}$ & 61.09 & 24.35 & 0.07 & 6.18 & 7.59 & 0.29 & 0.02 & 0.01 & 99.60 \\
\hline SAMPLE & SI & $\mathrm{AL}$ & FE2 & $B A$ & $\mathrm{CA}$ & NA & K & CATIONS & $A B$ & AN & ORTOC \\
\hline $35 b$ & 2.660 & 1.337 & 0.002 & 0.000 & 0.358 & 0.601 & 0.021 & 4.979 & 61.300 & 36.500 & 2.100 \\
\hline $35 b$ & 2.625 & 1.374 & 0.004 & 0.001 & 0.385 & 0.575 & 0.017 & 4.981 & 58.900 & 39.400 & 1.700 \\
\hline $36 \mathrm{~b}$ & 2.641 & 1.350 & 0.002 & 0.001 & 0.384 & 0.589 & 0.014 & 4.981 & 59.700 & 38.900 & 1.400 \\
\hline $36 b$ & 2.652 & 1.338 & 0.003 & 0.001 & 0.377 & 0.590 & 0.020 & 4.981 & 59.800 & 38.200 & 2.000 \\
\hline jg-108 & 2.737 & 1.263 & 0.001 & 0.001 & 0.288 & 0.654 & 0.020 & 4.964 & 68.000 & 29.900 & 2.100 \\
\hline jg-108 & 2.723 & 1.278 & 0.003 & 0.000 & 0.295 & 0.656 & 0.016 & 4.971 & 67.800 & 30.500 & 1.700 \\
\hline
\end{tabular}




\section{Composição Química Média das Granadas do Biotita-Granada-(ortopiroxênio) Gnaisse}

\section{da Unidade Jardim Glória}

\begin{tabular}{|c|c|c|c|c|c|c|c|c|c|c|c|c|c|c|c|c|}
\hline AMOSTRA & $\begin{array}{c}\text { IOCAL } \\
\text { ANALISADO }\end{array}$ & MINERAL & $\mathrm{S} 102$ & $\mathrm{TH}$ & AL2O3 & CR2O3 & FEO & MNO & MGO & CAO & $\mathrm{NA} 2 \mathrm{O}$ & TOTAL & & & & \\
\hline $36 b$ & $n$ & gra & 38.00 & 0.05 & 20.78 & 0.05 & 31.13 & 1.56 & 5.01 & 2.81 & 0.08 & 99.47 & & & & \\
\hline $36 b$ & b & gra & 37.83 & 0.01 & 20.69 & 0.07 & 31.34 & 1.46 & 4.62 & 3.25 & 0.04 & 99.31 & & & & \\
\hline $36 \mathrm{~b} 2$ & b & gra & 37.78 & 0.05 & 20.48 & 0.05 & 29.29 & 0.98 & 3.71 & 7.06 & 0.04 & 99.44 & & & & \\
\hline $36 \mathrm{~b} 2$ & $n$ & gra & 38.18 & 0.11 & 20.37 & 0.01 & 29.81 & 0.68 & 3.44 & 6.84 & 0.06 & 99.50 & & & & \\
\hline jg108 & $n$ & gra & 38.44 & 0.03 & 20.93 & 0.07 & 31.87 & 0.91 & 5.50 & 2.21 & 0.03 & 99.99 & & & & \\
\hline 39108 & $b$ & gra & 38.06 & 0.03 & 20.76 & 0.07 & 31.82 & 0.98 & 5.23 & 2.50 & 0.06 & 99.51 & & & & \\
\hline $35 b$ & $n$ & gra & 38.60 & 0.05 & 21.12 & 0.07 & 31.50 & 0.94 & 5.82 & 2.21 & 0.07 & 100.38 & & & & \\
\hline $35 b$ & b & gra & 38.54 & 0.09 & 21.06 & 0.04 & 31.25 & 0.91 & 5.55 & 2.65 & 0.07 & 100.16 & & & & \\
\hline jg108-2 & $n$ & gra & 38.75 & 0.09 & 21.08 & 0.06 & 31.91 & 0.91 & 5.65 & 2.19 & 0.03 & 100.67 & & & & \\
\hline jg108-2 & b & gra & 38.10 & 0.05 & 20.87 & 0.12 & 31.60 & 0.97 & 5.47 & 2.17 & 0.03 & 99.18 & & & & \\
\hline $35 b$ & $s$ & gra & 38.62 & 0.02 & 21.05 & 0.03 & 30.30 & 0.91 & 5.74 & 3.05 & 0.03 & 99.75 & & & & \\
\hline $36 b$ & $s$ & gra & 38.18 & 0.04 & 21.06 & 0.05 & 28.82 & 1.47 & 3.68 & 6.74 & 0.03 & 100.07 & & & & \\
\hline jg-108 & $\mathrm{s}$ & gra & 38.44 & 0.03 & 21.10 & 0.00 & 29.40 & 0.86 & 5.15 & 4.21 & 0.03 & 99.22 & & & & \\
\hline AMOSTRA & TSI & TAL & SUM_T & AlVI & FE3 & $\mathrm{TI}$ & $C R$ & SUM_A & $F E 2$ & $M G$ & $M N$ & $C A$ & NA & SUM_B & SUM_CAT & 0 \\
\hline $36 \mathrm{~b}$ & 3.024 & 0.000 & 3.024 & $\# \#$ & 0.000 & 0.003 & 0.003 & 1.953 & 2.072 & 0.594 & 0.105 & 0.240 & 0.012 & 3.023 & 8.000 & 12.000 \\
\hline $36 b$ & 3.022 & 0.000 & 3.022 & $\#$ & 0.000 & 0.001 & 0.004 & 1.951 & 2.094 & 0.550 & 0.099 & 0.278 & 0.006 & 3.027 & 8.000 & 12.000 \\
\hline $36 \mathrm{~b} 2$ & 3.008 & 0.000 & 3.008 & \#\# & 0.000 & 0.003 & 0.003 & 1.927 & 1.950 & 0.440 & 0.066 & 0.602 & 0.006 & 3.065 & 8.000 & 12.000 \\
\hline $36 \mathrm{~b} 2$ & 3.044 & 0.000 & 3.044 & $\#$ & 0.000 & 0.007 & 0.001 & 1.920 & 1.988 & 0.409 & 0.046 & 0.584 & 0.009 & 3.036 & 8.000 & 12.000 \\
\hline jg108 & 3.038 & 0.000 & 3.038 & $\# \#$ & 0.000 & 0.002 & 0.004 & 1.954 & 2.107 & 0.648 & 0.061 & 0.187 & 0.005 & 3.007 & 8.000 & 12.000 \\
\hline jg108 & 3.026 & 0.000 & 3.026 & $\#$ & 0.000 & 0.002 & 0.004 & 1.950 & 2.116 & 0.620 & 0.066 & 0.213 & 0.009 & 3.024 & 8.000 & 12.000 \\
\hline $35 b$ & 3.031 & 0.000 & 3.031 & $\#$ & 0.000 & 0.003 & 0.004 & 1.960 & 2.068 & 0.681 & 0.063 & 0.186 & 0.011 & 3.090 & 8.000 & $\{2,000$ \\
\hline $35 \mathrm{~b}$ & 3.035 & 0.000 & 3.035 & $\# \#$ & 0.000 & 0.005 & 0.002 & 1.961 & 2.058 & 0.652 & 0.061 & 0.224 & 0.011 & 3.004 & 8.000 & 12.000 \\
\hline ig108-2 & 3.040 & 0.000 & 3.040 & $\#$ & 0.000 & 0.005 & 0.004 & 1.957 & 2.094 & 0.681 & 0.060 & 0.184 & 0.005 & 3.003 & 8.000 & 12.000 \\
\hline ig108-2 & 3.037 & 0.000 & 3.037 & $\#$ & 0.000 & 0.003 & 0.008 & 1.951 & 2.107 & 0.650 & 0.065 & 0.185 & 0.005 & 3.012 & 8.000 & $\{2.000$ \\
\hline $35 b$ & 3.046 & 0.000 & 3.046 & $\#$ & 0.000 & 0.001 & 0.002 & 1.958 & 1.998 & 0.675 & 0.061 & 0.258 & 0.005 & 2.996 & 8.000 & 12.000 \\
\hline $36 b$ & 3.019 & 0.000 & 3.019 & $\# \#$ & 0.000 & 0.002 & 0.003 & 1.967 & 1.906 & 0.434 & 0.098 & 0.571 & 0.005 & 3.014 & 8.000 & 12.000 \\
\hline$j g-108$ & 3.049 & 0.000 & 3.049 & $\#$ & 0.000 & 0.002 & 0.000 & 1.972 & 1.950 & 0.609 & 0.058 & 0.358 & 0.005 & 2.979 & 8.000 & 12.000 \\
\hline
\end{tabular}




\section{Composição Química Média da Biotita do Biotita-Granada-(Ortopiroxênio) Gnaisse da Unidade Jardim Glória}

\begin{tabular}{|c|c|c|c|c|c|c|c|c|c|c|c|c|c|c|}
\hline AMOSTRA & $\begin{array}{l}\text { LOCAL } \\
\text { VALISADO }\end{array}$ & MINERAL & $\mathrm{SlO} 2$ & $\mathrm{TIO} 2$ & AL2O3 & CR2O3 & FEO & MNO & MGO & $\mathrm{NIO}$ & $\mathrm{NA2O}$ & $\mathrm{K} 2 \mathrm{O}$ & \multicolumn{2}{|l|}{ TOTAL } \\
\hline $35 b$ & $n$ & bio & 36.12 & 5.06 & 14.87 & 0.11 & 16.18 & 0.03 & 12.93 & 0.10 & 0.08 & 9.73 & 95.21 & \\
\hline $35 b$ & b & bio & 36.52 & 5.02 & 15.01 & 0.07 & 15.93 & 0.04 & 12.73 & 0.03 & 0.08 & 9.71 & 95.14 & \\
\hline $36 b$ & $n$ & bio & 36.36 & 4.83 & 14.54 & 0.09 & 18.67 & 0.02 & 11.58 & 0.07 & 0.07 & 9.62 & 95.85 & \\
\hline $36 b$ & $b$ & bio & 36.14 & 4.43 & 14.36 & 0.08 & 18.58 & 0.03 & 11.68 & 0.03 & 0.04 & 9.48 & 94.85 & \\
\hline $36 b$ & i & bio & 36.29 & 5.22 & 14.86 & 0.10 & 16.69 & 0.04 & 12.37 & 0.04 & 0.10 & 9.43 & 95.14 & \\
\hline jg-108 & $n$ & bio & 36.00 & 5.17 & 14.59 & 0.06 & 16.34 & 0.01 & 12.58 & 0.06 & 0.10 & 9.61 & 94.52 & \\
\hline jg-108 & $b$ & bio & 35.98 & 5.10 & 14.69 & 0.09 & 15.87 & 0.05 & 13.00 & 0.03 & 0.03 & 9.68 & 94.52 & \\
\hline AMOSTRA & SI & ALIV & ALVI & $\mathrm{TI}$ & FE2 & CR & MN & $M G$ & NA & K & ATION & 0 & E_FEM N & G_FEMG \\
\hline $35 b$ & 2.142 & 0.858 & 0.180 & 0.226 & 0.802 & 0.005 & 0.002 & 1.143 & 0.009 & 0.736 & 6.103 & 9.000 & 0.410 & 0.590 \\
\hline $35 b$ & 2.160 & 0.840 & 0.205 & 0.223 & 0.788 & 0.003 & 0.002 & 1.122 & 0.009 & 0.733 & 6.085 & 9.000 & 0.410 & 0.590 \\
\hline $36 b$ & 2.163 & 0.837 & 0.182 & 0.216 & 0.929 & 0.004 & 0.001 & 1.027 & 0.008 & 0.730 & 6.097 & 9.000 & 0.470 & 0.530 \\
\hline $36 b$ & 2.172 & 0.828 & 0.188 & 0.200 & 0.934 & 0.004 & 0.002 & 1.046 & 0.005 & 0.727 & 6.106 & 9.000 & 0.470 & 0.530 \\
\hline $36 b$ & 2.153 & 0.847 & 0.191 & 0.233 & 0.828 & 0.005 & 0.002 & 1.094 & 0.012 & 0.714 & 6.079 & 9.000 & 0.430 & 0.570 \\
\hline jg-108 & 2.151 & 0.849 & 0.178 & 0.232 & 0.816 & 0.003 & 0.001 & 1.121 & 0.012 & 0.733 & 6.096 & 9.000 & 0.420 & 0.580 \\
\hline jg-108 & 2.146 & 0.854 & 0.178 & 0.229 & 0.791 & 0.004 & 0.003 & 1.156 & 0.003 & 0.736 & 6.100 & 9.000 & 0.410 & 0.590 \\
\hline
\end{tabular}




\begin{tabular}{|c|c|c|c|c|c|c|c|c|c|c|c|c|c|}
\hline \multirow[b]{2}{*}{ Amostra } & \multicolumn{13}{|c|}{ Composição Química das Rochas do Complexo Juiz de Fora: Elementos Maiores } \\
\hline & $\mathrm{Mg \#}$ & $\mathrm{SiO} 2$ & $\mathrm{TiO} 2$ & $\mathrm{Al} 2 \mathrm{O} 3$ & $\mathrm{Fe} 2 \mathrm{O} 3$ & $\mathrm{MnO}$ & $\mathrm{MgO}$ & $\mathrm{CaO}$ & $\mathrm{Na} 2 \mathrm{O}$ & $\mathrm{K} 2 \mathrm{O}$ & P2O5 & LOI & TOTAL \\
\hline$M B-17 A$ & 60.34 & 47.21 & 0.76 & 15.30 & 10.37 & 0.17 & 8.85 & 13.03 & 2.22 & 0.66 & 0.04 & 0.45 & 99.06 \\
\hline MB - 42 & 43.57 & 47.62 & 1.53 & 13.29 & 14.95 & 0.22 & 6.48 & 10.08 & 2.56 & 0.38 & 0.15 & 0.00 & 97.26 \\
\hline MB - 514C & 46.38 & 47.80 & 2.22 & 13.27 & 12.75 & 0.21 & 6.19 & 10.25 & 3.26 & 0.88 & 0.22 & 2.02 & 99.07 \\
\hline MB - 46P & 47.60 & 48.67 & 0.98 & 13.69 & 12.62 & 0.19 & 6.43 & 10.33 & 2.98 & 0.83 & 0.08 & 0.05 & 96.85 \\
\hline MB -17B & 63.17 & 48.77 & 0.56 & 15.12 & 9.28 & 0.17 & 8.93 & 13.02 & 2.35 & 0.46 & 0.06 & 0.37 & 99.09 \\
\hline MB -15 C & 50.02 & 49.21 & 1.06 & 15.22 & 11.90 & 0.20 & 6.68 & 9.75 & 1.45 & 0.58 & 0.12 & 0.85 & 7.02 \\
\hline$M B-183 A$ & 36.93 & 49.41 & 1.94 & 13.85 & 14.42 & 0.23 & 4.74 & 8.06 & 2.94 & 0.74 & 0.22 & 0.70 & 97.26 \\
\hline MB - 514B & 41.72 & 49.72 & 2.18 & 12.86 & 13.25 & 0.22 & 5.32 & 9.57 & 3.19 & 0.61 & 0.31 & 0.68 & 97.91 \\
\hline MB - 99D & 45.79 & 54.99 & 0.98 & 16.70 & 7.89 & 0.13 & 3.74 & 6.24 & 3.58 & 1.91 & 0.31 & 20 & 0.67 \\
\hline$M B-43 C$ & 39.45 & 55.90 & 1.43 & 16.42 & 9.71 & 0.27 & 3.55 & 4.78 & 4.18 & 1.95 & 0.49 & 0.74 & 99.42 \\
\hline$M B-15 B$ & 45.99 & 57.95 & 0.86 & 16.41 & 6.74 & 0.11 & 3.22 & 4.41 & 3.90 & 2.32 & 0.18 & 0.79 & 96.89 \\
\hline$M B-46 C$ & 54.09 & 58.07 & 0.66 & 17.65 & 5.69 & 0.11 & 3.76 & 3.80 & 5.23 & 2.24 & 0.17 & 0.7 & \\
\hline MB - 19 & 46.00 & 61.12 & 0.92 & 15.37 & 5.67 & 0.10 & 2.71 & 4.34 & 4.24 & 1.90 & 0.34 & 0.26 & 96.97 \\
\hline$M B-46 A$ & 53.64 & 61.59 & 1.13 & 14.51 & 6.73 & 0.12 & 4.37 & 4.64 & 4.10 & 0.76 & 0.31 & 0.08 & 98.34 \\
\hline$M B-32 A$ & 35.91 & 61.80 & 1.03 & 16.42 & 6.14 & 0.11 & 1.93 & 3.69 & 4.08 & 3.10 & 0.40 & 0.21 & 98.91 \\
\hline $\mathrm{MB}-46 \mathrm{~T}$ & 48.74 & 62.40 & 0.38 & 16.25 & 5.64 & 0.13 & 3.01 & 4.49 & 4.99 & 1.02 & 0.48 & 0.40 & 99.19 \\
\hline MB - 32D & 35.83 & 62.82 & 1.13 & 15.76 & 6.19 & 0.12 & 1.94 & 3.77 & 3.72 & 3.31 & 0.39 & 0.30 & 99.45 \\
\hline$M B-145 B$ & 44.27 & 63.79 & 0.78 & 15.15 & 6.24 & 0.09 & 2.78 & 4.97 & 3.05 & 1.66 & 0.20 & 0.50 & 99.21 \\
\hline MB - 297D & 41.60 & 64.35 & 0.70 & 15.60 & 6.25 & 0.12 & 2.50 & 3.01 & 4.34 & 2.20 & 0.19 & 0.51 & 99.77 \\
\hline MB - 297B & 41.98 & 64.44 & 0.63 & 16.39 & 5.15 & 0.07 & 2.09 & 3.24 & 4.65 & 2.00 & 0.12 & 0.32 & 99.10 \\
\hline$M B-115 B$ & 51.41 & 66.24 & 0.52 & 15.41 & 4.21 & 0.07 & 2.50 & 4.34 & 4.51 & 1.19 & 0.22 & 0.30 & 99.51 \\
\hline MB - 32 C & 35.98 & 68.77 & 0.43 & 14.29 & 2.66 & 0.05 & 0.84 & 2.46 & 3.17 & 4.48 & 0.12 & 0.31 & 97.58 \\
\hline$M B-241 A$ & 38.83 & 69.00 & 0.35 & 14.90 & 2.11 & 0.03 & 0.75 & 2.37 & 3.82 & 3.80 & 0.12 & 0.50 & 97.75 \\
\hline$M B-48 A$ & 44.66 & 69.49 & 0.55 & 14.76 & 2.87 & 0.06 & 1.30 & 3.05 & 4.39 & 2.43 & 0.24 & 0.28 & 99.42 \\
\hline $\mathrm{MB}-514 \mathrm{E}$ & 35.29 & 70.17 & 0.40 & 15.22 & 2.74 & 0.03 & 0.84 & 2.71 & 3.76 & 3.49 & 0.17 & 0.31 & 99.84 \\
\hline$M B-151 B$ & 36.69 & 70.18 & 0.51 & 14.80 & 2.58 & 0.04 & 0.84 & 2.39 & 3.70 & 4.14 & 0.16 & 0.35 & 99.69 \\
\hline$M B$ - 514A & 36.58 & 70.79 & 0.34 & 15.08 & 2.07 & 0.03 & 0.67 & 2.81 & 4.00 & 2.89 & 0.11 & 0.31 & 99.10 \\
\hline $\mathrm{MB}-32 \mathrm{~B}$ & 33.27 & 70.82 & 0.36 & 15.06 & 2.54 & 0.05 & 0.71 & 2.46 & 3.38 & 4.72 & 0.16 & 0.39 & 100.65 \\
\hline MB - 37 (1) & 34.15 & 71.50 & 0.53 & 14.02 & 2.65 & 0.04 & 0.77 & 3.00 & 3.22 & 3.18 & 0.15 & 0.00 & 99.06 \\
\hline$M B$ - 46R & 45.47 & 71.92 & 0.19 & 13.98 & 1.88 & 0.03 & 0.88 & 3.18 & 4.22 & 1.28 & 0.07 & 1.15 & 98.78 \\
\hline$M B-151 A$ & 33.60 & 72.05 & 0.21 & 13.75 & 1.23 & 0.02 & 0.35 & 1.47 & 3.30 & 4.85 & 0.05 & 0.20 & 97.48 \\
\hline$M B-43 B$ & 50.93 & 73.61 & 0.19 & 13.59 & 1.30 & 0.02 & 0.76 & 1.30 & 2.56 & 6.26 & 0.04 & 0.32 & 99.95 \\
\hline$M B-46 B$ & 48.50 & 74.55 & 0.08 & 13.66 & 0.74 & 0.02 & 0.39 & 1.92 & 3.70 & 3.68 & 0.03 & 1.19 & 99.96 \\
\hline$M B-46 U$ & 38.90 & 74.97 & 0.02 & 13.81 & 0.25 & 0.00 & 0.09 & 1.98 & 3.71 & 3.44 & 0.00 & 0.35 & 98.62 \\
\hline$M B-43 A$ & 46.86 & 79.43 & 0.19 & 11.63 & 1.23 & 0.02 & 0.61 & 3.05 & 3.22 & 0.72 & 0.02 & 0.62 & 100.74 \\
\hline MB-17H & 77.02 & 87.62 & 0.14 & 1.17 & 3.28 & 0.03 & 6.16 & 0.27 & 0.06 & 0.46 & 0.06 & 0.71 & 99.96 \\
\hline
\end{tabular}

OBS: nd - não detectado

na - não analisado 


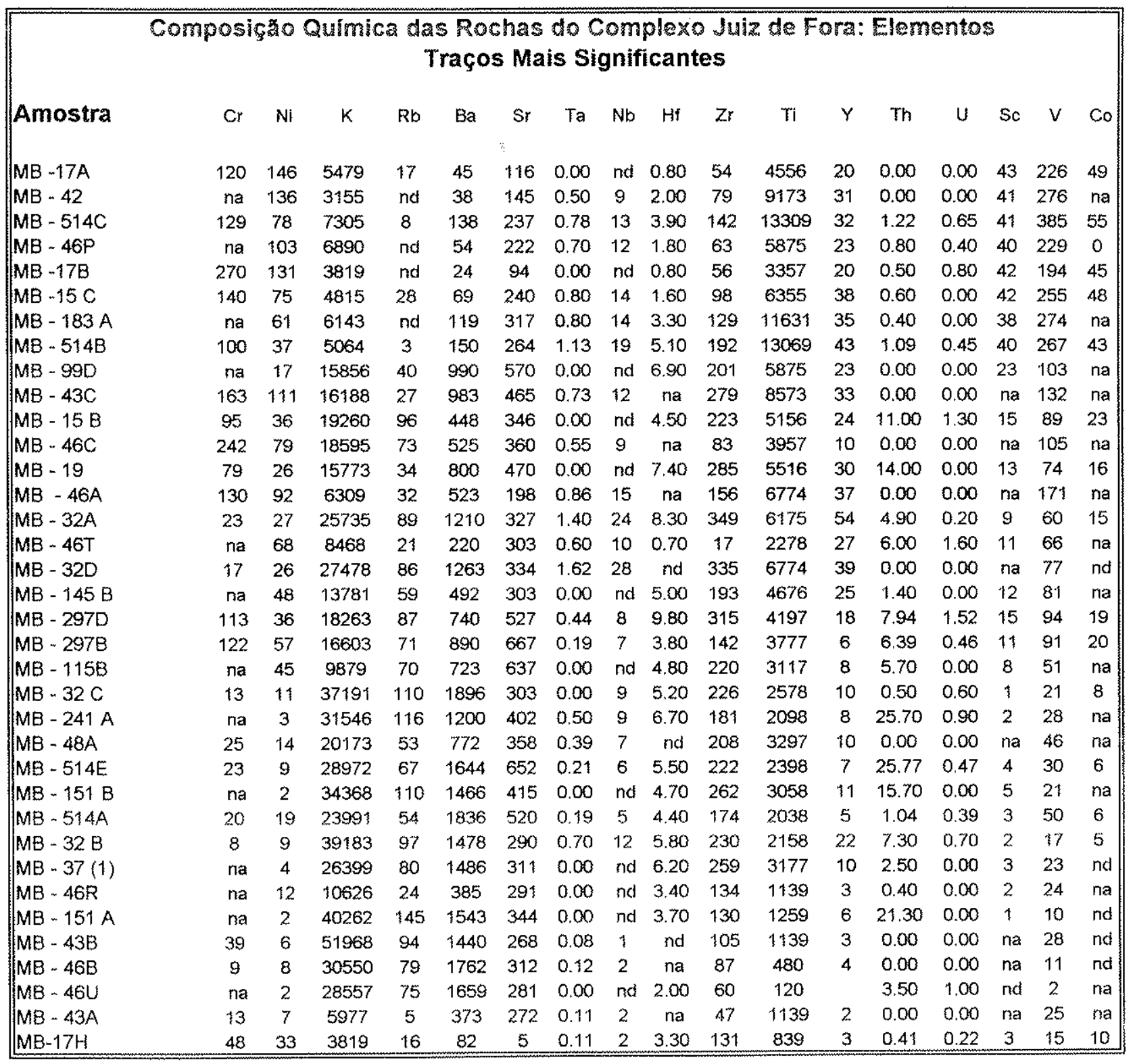




\begin{tabular}{|c|c|c|c|c|c|c|c|c|}
\hline \multicolumn{9}{|c|}{$\begin{array}{c}\text { Composição Quimica das Rochas do Complexo } \\
\text { Juiz de Fora:Outros Elementos Traços }\end{array}$} \\
\hline Amostra & $\mathrm{Cu}$ & $\mathrm{Pb}$ & $\mathrm{Zn}$ & Sn & $w$ & Mo & $\mathrm{Sb}$ & $\mathrm{Ga}$ \\
\hline$M B-17 A$ & 109 & 0 & 60 & 3 & nd & nd & nd & nd \\
\hline$M B-42$ & 103 & 8 & 112 & 3 & 9 & 3.65 & nd & nd \\
\hline$M B-514 C$ & 57 & 12 & 28 & 6 & nd & 1.30 & nd & 23.00 \\
\hline$M B-46 P$ & 69 & 16 & 89 & 3 & 5 & 1.93 & nd & nd \\
\hline$M B-17 B$ & 20 & nd & 48 & 3 & nd & nd & nd & nơ \\
\hline MB -15 C & 37 & nd & 96 & 3 & 16 & 1.76 & nd & nd \\
\hline$M B-183 A$ & 74 & 11 & 115 & 4 & 3 & 9.49 & nd & 0.00 \\
\hline$M B-514 B$ & 78 & 11 & 27 & 5 & nd & 1.20 & 0.20 & 22.00 \\
\hline MB - 99D & 47 & 22 & 83 & 9 & nd & nd & nd & nd \\
\hline$M B-43 C$ & 46 & 18 & 120 & 9 & 2 & 2.64 & nd & nd \\
\hline$M B-15 B$ & 30 & 13 & 82 & 9 & na & nd & nd & nd \\
\hline$M B-46 C$ & 26 & 26 & 97 & 9 & 9 & 1.01 & nd & nd \\
\hline$M B-19$ & 13 & nd & 86 & 10 & na & nd & nd & nd \\
\hline$M B-46 A$ & 28 & 21 & 97 & 4 & 11 & 2.52 & nd & nd \\
\hline$M B-32 A$ & 45 & 19 & 90 & 6 & 15 & 2.27 & nd & nd \\
\hline$M B-46 T$ & 61 & 21 & 78 & 1 & 2 & 2.65 & nd & nd \\
\hline $\mathrm{MB}-32 \mathrm{D}$ & 45 & 20 & 95 & 9 & 12 & 1.41 & nd & nd \\
\hline$M B-145 B$ & 100 & 21 & 69 & 8 & na & nd & nd & nd \\
\hline$M B-297 D$ & 18 & 27 & 77 & 2 & na & 1.10 & 0.90 & 20.00 \\
\hline MB - 297B & 13 & 17 & 76 & 15 & na & 1.40 & 0.70 & 22.00 \\
\hline$M B-115 B$ & 76 & 15 & 71 & 28 & na & nd & nd & nd \\
\hline$M B-32 C$ & 14 & 24 & 36 & 23 & 27 & 1.18 & nd & nd \\
\hline$M B-241 A$ & 5 & 26 & 43 & 23 & 24 & 0.94 & nd & nd \\
\hline$M B-48 A$ & 8 & 23 & 48 & 20 & 31 & 1.58 & nd & nd \\
\hline$M B-514 E$ & 500 & 74 & 26 & 5 & nd & 1.70 & 1.60 & 19.00 \\
\hline$M B-151 B$ & 5 & 23 & 32 & 24 & nd & nd & nd & nd \\
\hline$M B-514 A$ & 19 & 26 & 24 & 3 & nd & 0.80 & 0.50 & 19.00 \\
\hline$M B-32 B$ & 17 & 22 & 37 & 10 & 19 & 1.85 & nd & nd \\
\hline$M B-37(1)$ & 16 & 17 & 35 & 26 & na & nd & nd & nd \\
\hline$M B-46 R$ & 64 & 19 & 19 & 45 & na & nd & nd & nd \\
\hline$M B-151 A$ & 4 & 184 & 17 & 22 & na & nd & no & nd \\
\hline$M B-43 B$ & 5 & 41 & 22 & 39 & 75 & 1.93 & nd & nd \\
\hline$M B \sim 46 B$ & 23 & 28 & 9 & 24 & 44 & 1.80 & nd & nd \\
\hline$M B-46 U$ & 9 & 27 & 4 & 0 & na & nd & nd & nd \\
\hline$M B-43 A$ & 9 & 10 & 11 & 28 & 26 & 0.94 & nd & nd \\
\hline MB-17H & 24 & 8 & 8 & 7 & na & 1.20 & 1.30 & 4.00 \\
\hline
\end{tabular}




\begin{tabular}{|c|c|c|c|c|c|c|c|c|c|c|c|c|c|c|}
\hline \multicolumn{15}{|c|}{$\begin{array}{c}\text { Composição Química das Rochas do Complexo Juiz de Fora: Elementos } \\
\text { Terras Raras }\end{array}$} \\
\hline Amostra & La & $\mathrm{Ce}$ & $\mathrm{Pr}$ & $\mathrm{Nd}$ & $\mathrm{Sm}$ & $\mathrm{Eu}$ & $\mathrm{Gd}$ & Tb & Dy & Ho & $\mathrm{Er}$ & $\mathrm{Tm}$ & $\mathrm{Yb}$ & Lut \\
\hline$M B-17 A$ & 1.90 & 6.00 & na & 5.00 & 1.40 & 0.69 & na & 0.50 & na & na & na & na & 1.40 & 0.22 \\
\hline$M B-42$ & 5.60 & 15.00 & na & 9.00 & 3.46 & 1.30 & na & 0.90 & na & na & na & na & 2.90 & 0.42 \\
\hline$M B-514 C$ & 13.30 & 29.90 & 3.58 & 18.50 & 5.00 & 1.72 & 5.60 & 0.90 & 5.80 & 1.20 & 3.40 & 0.49 & 2.90 & 0.46 \\
\hline$M B-46 P$ & 6.80 & 16.00 & na & 9.00 & 2.43 & 0.80 & na & 0.70 & na & na & na & na & 2.50 & 0.37 \\
\hline$M B-17 B$ & 2.20 & 5.00 & na & 5.00 & 1.10 & 0.40 & na & 0.50 & na & na & na & na & 1.14 & 0.19 \\
\hline$M B-15 C$ & 4.80 & 12.00 & na & 10.00 & 2.60 & 0.93 & na & 0.60 & na & na & na & na & 2.15 & 0.35 \\
\hline$M B-183 A$ & 11.10 & 27.00 & na & 20.00 & 5.03 & 1.40 & na & 1.10 & na & na & na & na & 3.80 & 0.51 \\
\hline$M B-514 B$ & 23.10 & 51.30 & 5.88 & 28.10 & 7.20 & 2.27 & 7.70 & 1.30 & 8.00 & 1.60 & 4.50 & 0.66 & 4.10 & 0.66 \\
\hline$M B-99 D$ & 34.30 & 67.00 & na & 33.00 & 6.33 & 1.50 & na & 0.80 & na & na & na & na & 2.10 & 0.30 \\
\hline$M B-43 C$ & 0.00 & na & na & 0.00 & na & na & na & na & na & na & na & na & na & na \\
\hline$M B-15 B$ & 81.50 & 136.00 & na & 48.00 & 5.90 & 1.49 & na & 0.50 & na & na & na & na & 0.96 & 0.15 \\
\hline$M B-46 C$ & na & na & na & na & na & 0.00 & na & na & na & na & na & na & na & na \\
\hline$M B-19$ & 74.50 & 125.00 & na & 51.00 & 7.50 & 1.86 & na & 0.90 & na & na & na & $\mathrm{na}$ & 1.32 & 0.23 \\
\hline$M B-46 A$ & na & na & na & na & na & na & na & na & na & na & na & na & na & na \\
\hline$M B-32 A$ & 64.30 & 108.00 & na & 44.00 & 7.20 & 1.78 & 0.00 & 1.20 & na & na & na & na & 3.83 & 0.60 \\
\hline$M B-46 T$ & 27.20 & 53.00 & na & 28.00 & 6.23 & 0.90 & 0.00 & 0.90 & na & na & na & na & 1.60 & 0.22 \\
\hline$M B-32 D$ & na & na & na & na & na & na & 0.00 & 0.00 & na & na & na & na & na & na \\
\hline$M B-145 B$ & 23.70 & 45.00 & na & 23.00 & 4.65 & 1.20 & 0.00 & 0.80 & na & na & na & na & 2.40 & 0.31 \\
\hline MB - 297D & 35.30 & 67.60 & 6.62 & 26.70 & 4.60 & 1.17 & 3.40 & 0.50 & 3.00 & 0.60 & 1.90 & 0.28 & 1.80 & 0.30 \\
\hline MB - 297B & 35.70 & 64.60 & 6.08 & 23.90 & 3.80 & 1.42 & 2.20 & 0.20 & 1.10 & 0.20 & 0.50 & 0.06 & 0.40 & 0.08 \\
\hline$M B-115 B$ & 52.70 & 86.00 & na & 33.00 & 4.47 & 1.00 & 0.00 & na & na & na & na & na & 0.60 & 0.11 \\
\hline$M B-32 C$ & 24.20 & 35.00 & na & 12.00 & 1.90 & 1.25 & 0.00 & 0.50 & na & na & na & na & 1.21 & 0.22 \\
\hline$M B-241 \mathrm{~A}$ & 77.90 & 117.00 & na & 41.00 & 5.59 & 1.30 & 0.00 & na & na & na & na & na & 0.70 & 0.12 \\
\hline$M B-48 A$ & na & na & na & na & na & na & 0.00 & na & na & na & na & na & na & na \\
\hline$M B-51 A E$ & 101.20 & 165.60 & 14.19 & 50.20 & 6.50 & 1.36 & 3.20 & 0.30 & na & 0.30 & 0.50 & 0.06 & 0.30 & 0.08 \\
\hline$M B-151 B$ & 49.90 & 73.00 & 0.00 & 25.00 & 3.69 & 1.10 & 0.00 & 0.60 & na & na & na & na & 0.50 & 0.08 \\
\hline$M B=514 A$ & 23.90 & 35.60 & 3.04 & 10.80 & 1.90 & 1.12 & 1.40 & 0.20 & na & 0.20 & 0.40 & na & 0.40 & 0.06 \\
\hline$M B-32 B$ & 49.10 & 79.00 & 0.00 & 30.00 & 4.10 & 1.38 & 0.00 & 0.50 & na & na & na & na & 1.08 & 0.20 \\
\hline$M B-37(1)$ & 32.00 & 44.00 & 0.00 & 16.00 & 2.63 & 1.40 & 0.00 & na & na & na & na & na & 1.20 & 0.18 \\
\hline$M B-46 R$ & 14.50 & 21.00 & 0.00 & 10.00 & 1.16 & 0.80 & 0.00 & na & na & na & na & na & 0.30 & 0.05 \\
\hline$M B-151 A$ & 42.30 & 61.00 & 0.00 & 20.00 & 3.21 & 0.80 & 0.00 & na & na & na & na & na & 0.40 & 0.08 \\
\hline$M B-43 B$ & na & na & 0.00 & na & na & na & 0.00 & na & na & na & na & กา & na & na \\
\hline$M B-46 B$ & na & na & 0.00 & na & na & na & 0.00 & na & na & na & na & na & na & na \\
\hline$M B-46 U$ & 13.30 & 16.00 & 0.00 & 8.00 & 0.52 & 0.80 & 0.00 & na & na & na & na & na & na & na \\
\hline$M B-43 A$ & 0.00 & na & 0.00 & na & na & na & 0.00 & 0.00 & 0.00 & na & na & na & na & na \\
\hline $\mathrm{MB}-17 \mathrm{H}$ & 2.50 & 5.20 & 0.57 & 2.70 & 0.60 & 0.07 & 0.50 & nd & 0.50 & 0.10 & 0.40 & 0.06 & 0.40 & 0.07 \\
\hline
\end{tabular}




\begin{tabular}{|c|c|c|c|c|c|c|c|c|c|c|c|c|c|}
\hline \multirow[b]{2}{*}{ Amostra } & \multicolumn{13}{|c|}{ Composiçâo Quimica das Rochas do Complexo Mantiqueira: Elementos Maiores } \\
\hline & $\mathrm{Mg} \#$ & $\mathrm{SiO}_{2}$ & TiO2 & $\mathrm{Al} 2 \mathrm{O} 3$ & $\mathrm{Fe} 2 \mathrm{O} 3$ & $\mathrm{MnO}$ & $\mathrm{MgO}$ & $\mathrm{CaO}$ & $\mathrm{Na} 2 \mathrm{O}$ & $\mathrm{K} 2 \mathrm{O}$ & $\mathrm{P} 2 \mathrm{O} 5$ & LOI & TOTAL \\
\hline MB-577B & 42.60 & 47.11 & 2.45 & 12.95 & 14.31 & 0.22 & 5.96 & 10.06 & 3.06 & 1.20 & 0.27 & 0.56 & 98.15 \\
\hline $\mathrm{JF}-30 \mathrm{C}$ & 49.70 & 47.66 & 1.26 & 14.60 & 12.39 & 0.27 & 6.87 & 7.16 & 4.48 & 1.80 & 0.16 & 0.43 & 97.08 \\
\hline $\mathrm{JF}-58 \mathrm{~B}$ & 40.73 & 48.25 & 2.69 & 14.28 & 11.82 & 0.19 & 4.56 & 7.55 & 3.10 & 2.05 & 1.22 & 0.55 & 96.26 \\
\hline$J F-564 F$ & 33.58 & 48.47 & 3.44 & 12.21 & 16.78 & 0.25 & 4.76 & 8.46 & 3.03 & 1.02 & 0.35 & 0.08 & 98.85 \\
\hline$J F-29 Q$ & 50.25 & 48.77 & 1.85 & 14.50 & 11.59 & 0.23 & 6.57 & 10.00 & 3.14 & 1.16 & 0.21 & 0.65 & 98.67 \\
\hline$J F-190 \mathrm{C}$ & 42.19 & 48.82 & 2.00 & 14.07 & 13.24 & 0.21 & 5.42 & 10.15 & 2.90 & 0.64 & 0.24 & 0.40 & 98.09 \\
\hline$J F-187 A$ & 53.81 & 50.84 & 0.96 & 14.85 & 10.55 & 0.22 & 6.90 & 9.40 & 3.52 & 1.03 & 0.08 & 0.45 & 98.80 \\
\hline$J F-60 \mathrm{~B}$ & 47.36 & 51.60 & 1.19 & 18.18 & 8.38 & 0.15 & 4.23 & 7.40 & 4.40 & 2.15 & 0.67 & 0.65 & 99.00 \\
\hline $\mathrm{JF}-56$ & 52.34 & 61.02 & 1.45 & 13.39 & 5.78 & 0.11 & 3.56 & 5.28 & 3.34 & 1.93 & 0.30 & 0.80 & 96.96 \\
\hline $\mathrm{JF}-29 \mathrm{~T}$ & 48.80 & 61.04 & 0.67 & 14.53 & 5.52 & 0.12 & 2.95 & 4.62 & 3.76 & 3.37 & 0.56 & 0.55 & 97.69 \\
\hline$J i-31$ & 42.72 & 62.58 & 0.46 & 16.55 & 4.85 & 0.08 & 2.03 & 4.20 & 5.31 & 1.46 & 0.38 & 0.63 & 98.53 \\
\hline $\mathrm{JF}-30 \mathrm{~A}$ & 53.18 & 63.40 & 0.56 & 15.22 & 4.89 & 0.09 & 3.12 & 4.86 & 4.35 & 2.66 & 0.24 & 0.41 & 99.80 \\
\hline$J F-29 A$ & 46.92 & 63.48 & 0.79 & 14.76 & 6.03 & 0.14 & 2.99 & 4.78 & 3.83 & 1.52 & 0.16 & 0.36 & 98.84 \\
\hline$J F-61 \mathrm{~A}$ & 52.53 & 64.03 & 0.42 & 16.36 & 4.28 & 0.07 & 2.66 & 6.17 & 4.30 & 0.59 & 0.15 & 0.45 & 99.48 \\
\hline JF-564I & 34.03 & 66.55 & 0.09 & 18.60 & 1.14 & 0.02 & 0.3 .3 & 4.01 & 6.57 & 0.90 & 0.00 & 0.71 & 98.92 \\
\hline $\mathrm{MB}-577 \mathrm{C}$ & 29.89 & 67.67 & 0.76 & 15.47 & 4.18 & 0.04 & 1.00 & 2.78 & 4.19 & 3.25 & 0.26 & 0.26 & 99.86 \\
\hline $3 \mathrm{~F}-564 \mathrm{~A}$ & 29.41 & 68.80 & 0.48 & 15.17 & 4.32 & 0.03 & 1.01 & 3.08 & 4.76 & 1.37 & 0.12 & 0.65 & 99.79 \\
\hline $\mathrm{JF}-58 \mathrm{~A}$ & 45.81 & 68.99 & 0.53 & 15.01 & 3.01 & 0.03 & 1.43 & 3.45 & 4.39 & 1.65 & 0.17 & 0.95 & 99.61 \\
\hline MB-577F & 36.43 & 69.59 & 0.51 & 14.83 & 3.11 & 0.07 & 1.00 & 2.56 & 3.54 & 4.30 & 0.25 & 0.28 & 100.04 \\
\hline MB-577L & 33.04 & 69.63 & 0.50 & 14.94 & 3.25 & 0.04 & 0.90 & 2.57 & 3.72 & 3.77 & 0.19 & 0.17 & 99.68 \\
\hline $5 F-190 \mathrm{Al}$ & 33.97 & 70.29 & 0.40 & 15.36 & 2.53 & 0.03 & 0.73 & 2.25 & 4.27 & 3.31 & 0.15 & 0.25 & 99.57 \\
\hline$J F=190 \mathrm{~A} 2$ & 30.78 & 71.10 & 0.19 & 15.38 & 1.32 & 0.02 & 0.33 & 1.38 & 3.18 & 6.44 & 0.09 & 0.40 & 99.83 \\
\hline $\mathrm{fF}-29 \mathrm{P}$ & 39.76 & 71.25 & 0.22 & 13.78 & 2.19 & 0.05 & 0.81 & 2.31 & 4.20 & 2.30 & 0.09 & 0.30 & 97.50 \\
\hline$J F-190 D$ & 36.55 & 71.31 & 0.38 & 15.02 & 2.26 & 0.03 & 0.73 & 2.49 & 4.31 & 2.51 & 0.14 & 0.35 & 99.53 \\
\hline $\mathrm{JF}-189 \mathrm{I}$ & 32.77 & 71.34 & 0.38 & 14.64 & 2.34 & 0.03 & 0.64 & 2.19 & 4.14 & 3.13 & 0.13 & 0.35 & 99.31 \\
\hline $\mathrm{JP}-30 \mathrm{~B}$ & 12.92 & 72.60 & 0.25 & 12.50 & 3.48 & 0.05 & 0.29 & 1.71 & 4.84 & 1.38 & 0.06 & 0.21 & 97.37 \\
\hline $\mathrm{SF}-564 \mathrm{~B}$ & 33.61 & 73.30 & 0.30 & 14.56 & 2.57 & 0.03 & 0.73 & 2.65 & 4.24 & 1.89 & 0.10 & 0.21 & 100.58 \\
\hline $\mathrm{J}-564 \mathrm{E}$ & 25.56 & 75.23 & 0.09 & 13.65 & 1.09 & 0.00 & 0.21 & 1.63 & 3.18 & 4.49 & 0.02 & 0.18 & 99.77 \\
\hline $\mathrm{HF}-85 \mathrm{D}$ & 41.20 & 75.28 & 0.08 & 13.47 & 0.58 & 0.00 & 0.23 & 1.64 & 3.43 & 3.81 & 0.06 & 0.25 & 98.83 \\
\hline MB-577H & 28.12 & 76.91 & 0.16 & 13.23 & 1.23 & 0.02 & 0.27 & 1.90 & 3.62 & 3.27 & 0.04 & 0.12 & 100.77 \\
\hline $\mathrm{JF}-564 \mathrm{D}$ & 35.20 & 76.99 & 0.07 & 13.58 & 0.82 & 0.00 & 0.25 & 2.61 & 4.94 & 0.89 & 0.00 & 0.60 & 100.75 \\
\hline
\end{tabular}




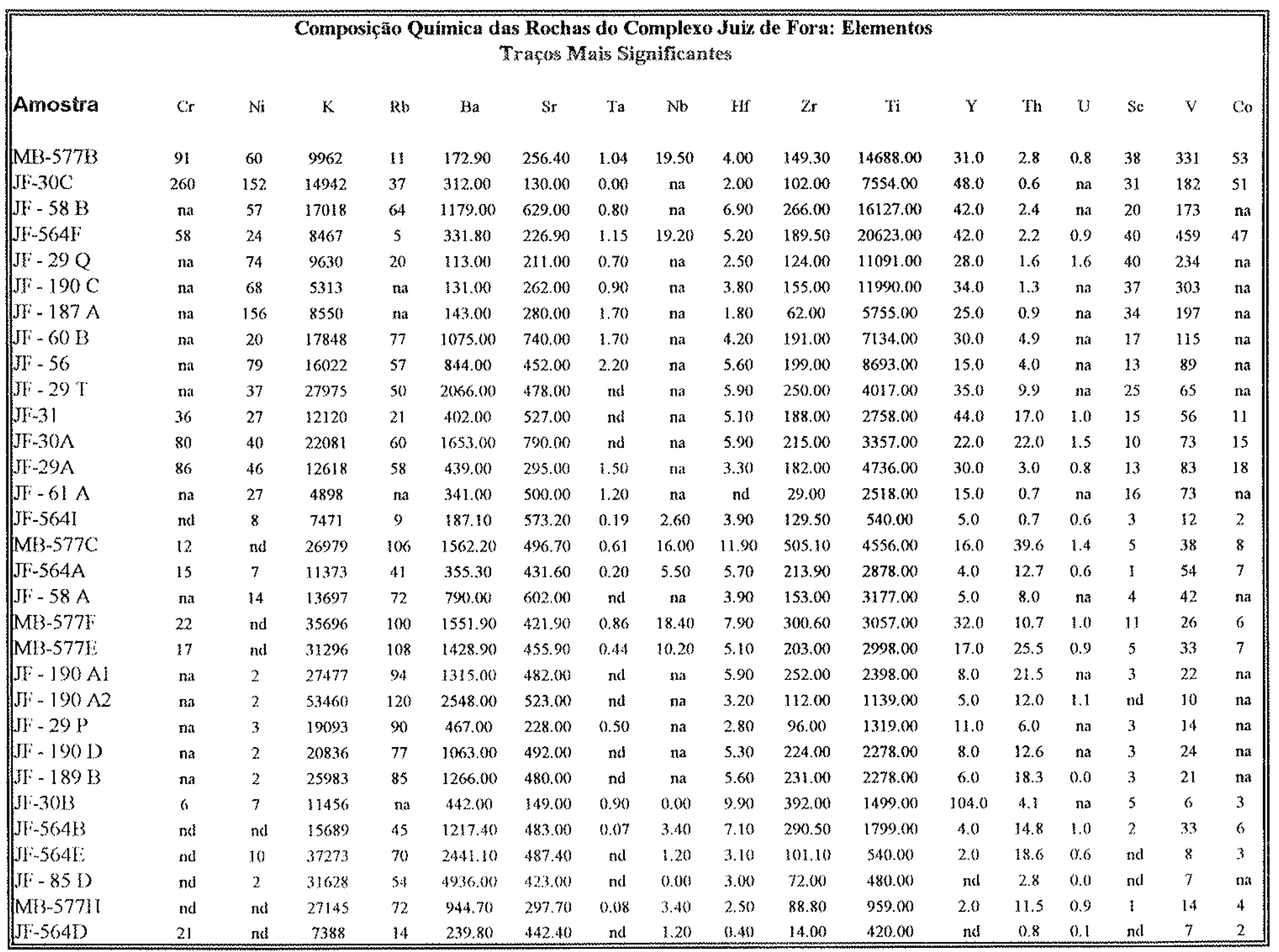




\begin{tabular}{|c|c|c|c|c|c|c|c|c|}
\hline \multirow[b]{2}{*}{ Amostra } & \multicolumn{8}{|c|}{$\begin{array}{l}\text { Composição Química das Rochas do Complexo } \\
\text { Juiz de Fora:Outros Elementos Traços }\end{array}$} \\
\hline & $\mathrm{Cu}$ & $\mathrm{Pb}$ & $\mathrm{Zn}$ & $\mathrm{Sn}$ & $w$ & Mo & Sb & Ga \\
\hline $\mathrm{MB}-577 \mathrm{~B}$ & 52 & 15 & 34 & 13.00 & nd & 1.30 & 0.20 & 22.00 \\
\hline $\mathrm{JF}-30 \mathrm{C}$ & 30 & 5 & 170 & na & na & $\mathrm{ma}$ & na & ma \\
\hline $\mathrm{JF}-58 \mathrm{~B}$ & 39 & 14 & 137 & na & na & $n a$ & na & na \\
\hline$J F-564 F$ & 66 & 13 & 49 & 16.00 & 0.10 & 1.70 & 0.40 & 24.00 \\
\hline$J F-29 Q$ & 105 & 11 & 92 & na & na & na & na & na \\
\hline$J F-190 C$ & 112 & 10 & 97 & na & na & na & na & na \\
\hline$J F-187 \mathrm{~A}$ & 5 & 16 & 106 & na & na & na & na & na \\
\hline $\mathrm{JF}-60 \mathrm{~B}$ & 31 & 23 & 92 & na & na & na & na & na \\
\hline$J F-56$ & 36 & 16 & 71 & na & na & na & na & na \\
\hline$J F-29 T$ & 40 & 22 & 79 & na & na & $\mathrm{na}$ & $\mathrm{na}$ & na \\
\hline$J F-31$ & 15 & 19 & 76 & na & na & na & na & na \\
\hline $\mathrm{JF}-30 \mathrm{~A}$ & 21 & 22 & 68 & na & nd & na & na & $\mathrm{na}$ \\
\hline $\mathrm{JF}-29 \mathrm{~A}$ & 32 & 10 & 78 & na & nd & na & na & na \\
\hline$J F-61 A$ & 19 & 12 & 48 & na & nd & $\mathrm{ma}$ & na & na \\
\hline$J F-564 I$ & nd & 27 & 12 & 3.00 & nis & 0.70 & 0.50 & 21.00 \\
\hline MB-577C & 16 & 30 & 70 & 8.00 & nd & 1.10 & 0.40 & 24.00 \\
\hline$J F-564 A$ & nd & 19 & 49 & 15.00 & 0.10 & 1.00 & 0.50 & 21.00 \\
\hline $\mathrm{JF}-58 \mathrm{~A}$ & 14 & 17 & 42 & $n$ & na & $n a$ & na & na \\
\hline $\mathrm{MB}-5775$ & 9 & 28 & 39) & 18.00 & nd & 1.00 & 0.60 & 19,00 \\
\hline $\mathrm{MB}-577 \mathrm{E}$ & 7 & 29 & 44 & 4.00 & nd & 1.50 & 0.50 & 21.00 \\
\hline $\mathrm{JF}-190 \mathrm{Al}$ & 3 & 27 & 44 & na & na & na & na & na \\
\hline$J F-190 A 2$ & 4 & 42 & 21 & $n a$ & na & na & $\mathrm{ma}$ & na \\
\hline$J F-29 P$ & 5 & 27 & 33 & na & na & na & $\mathrm{ma}$ & na \\
\hline$J F-190 D$ & 4 & 25 & 40 & na & na & $\mathrm{na}$ & na & na \\
\hline$J F-189 B$ & 7 & 27 & 40 & na & no & $n$ & 3as & na \\
\hline$J F_{-30 B}$ & 9 & 12 & 56 & $n a$ & no & $\mathrm{na}$ & na & na \\
\hline$J F-564 B$ & 25 & 24 & 37 & 4.00 & nd & 0.70 & 0.20 & 17.00 \\
\hline$J F-564 E$ & 19 & 50 & 43 & 5.00 & nd & 0.60 & 0.30 & 15.00 \\
\hline$J F-85 D$ & 11 & 25 & 9 & $\mathrm{na}$ & nd & na & na & na \\
\hline MB-577H & 43 & 33 & 14 & 3.00 & nd & 1.30 & 0.40 & 16.00 \\
\hline JF-564D & 10 & 22 & 11 & 6.00 & 0.20 & 1.60 & 0.50 & 16.00 \\
\hline
\end{tabular}




\begin{tabular}{|c|c|c|c|c|c|c|c|c|c|c|c|c|c|c|}
\hline \multirow[b]{2}{*}{ Amostra } & \multicolumn{13}{|c|}{$\begin{array}{c}\text { Composição Química das Rochas do Complexo Mantiqueira: } \\
\text { Elementos Terras Raras }\end{array}$} & \multirow[b]{2}{*}{ Lu } \\
\hline & La & $\mathrm{Ce}$ & $\mathrm{Pr}$ & $\mathrm{Nd}$ & $\mathrm{Sm}$ & Eu & $\mathrm{Gd}$ & $\mathrm{Tb}$ & Dy & Ho & Er & $\mathrm{Tm}$ & $\mathrm{Yb}$ & \\
\hline MB3-577B & 18.90 & 40.20 & 4.54 & 22.00 & 5.50 & 1.81 & 6,10 & 0.90 & 5.80 & 1.10 & 3.30 & 0.45 & 2.70 & 0.44 \\
\hline$\sqrt{12}-30 \mathrm{C}$ & 7.80 & 22.00 & na & 14.00 & 3.70 & 1.31 & na & 0.90 & $\mathbf{n} \mathfrak{a}$ & $n a$ & na & na & 4.75 & 0.77 \\
\hline $\mathrm{JF}-58 \mathrm{~B}$ & 64.10 & 135,00 & na & 78.00 & $\$ 5.10$ & 4.30 & na & 1.80 & na & na & $\mathrm{na}$ & $n a$ & 3.30 & 0.44 \\
\hline $\mathrm{JF}-564 \mathrm{~F}$ & 19.40 & 43.50 & na & 26.00 & 7.00 & 2.37 & 7.60 & 1.20 & 7.40 & 1.50 & 4.50 & 0.57 & $3.70^{\prime}$ & 0.61 \\
\hline$J F-29 Q$ & 17.50 & 40.00 & na & 21.00 & 4.65 & 1.70 & na & 0.90 & na & na & na & na & 2.70 & 0.36 \\
\hline$J F=190 \mathrm{C}$ & 13.60 & 32.00 & na & 15.00 & 5.34 & 1.70 & na & 0.90 & na & na & $\mathrm{na}$ & na & 3.30 & 0.45 \\
\hline$J{ }^{*}-187 \AA$ & 8.20 & 19.00 & $\mathrm{na}$ & 12.00 & 3.36 & 1.20 & nat & 0.80 & ma & na & $\mathrm{na}$ & $\mathrm{nH}$ & 2.60 & 0.36 \\
\hline$J 5:-60 \mathrm{~B}$ & 58.70 & 119.00 & nat & 64.00 & 11.90 & 2.90 & $\mathrm{na}$ & 0.90 & na & na & $\mathrm{na}$ & na & 2.20 & 0.28 \\
\hline Jy: -56 & 45.30 & 80.00 & na & 39.00 & 6.41 & 2.00 & nat & 0.80 & na & na & na & n's & 1.20 & 0.14 \\
\hline$W-29 T$ & 64.70 & 139.00 & na & 63.00 & 12.40 & 2.50 & na & 1.40 & $\mathrm{na}$ & na & na & $\mathrm{nd}$ & 2.60 & 0.36 \\
\hline WF -31 & 73.40 & 120.00 & ma & 53.00 & 8.00 & 1.60 & $\mathrm{na}$ & 0.90 & na & $n a$ & $\mathrm{na}$ & $\mathrm{na}$ & 1.64 & 0.23 \\
\hline $\mathrm{HF}-30 \mathrm{~A}$ & 25.90 & 154.00 & na & 58.00 & 7.40 & 1.47 & 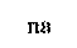 & nat & $\mathrm{ma}$ & $n \&$ & $\mathrm{na}$ & $\mathrm{na}$ & 1.69 & 0.24 \\
\hline $\mathrm{JF}-29 \mathrm{~A}$ & 21.10 & 43.00 & na & 23.00 & 4.00 & 1.09 & na & 0.70 & na & na & na & na & 2.30 & 0.35 \\
\hline$H:-61 \mathrm{~A}$ & 17.90 & 35.00 & $n a$ & 17.00 & 4.36 & 1.30 & $\mathrm{na}$ & 0.70 & $\mathrm{na}$ & na & na & na & 1.30 & 0.19 \\
\hline $31-5641$ & 5.50 & 8.80 & 0.93 & 4.40 & 1.20 & 0.98 & 1.10 & 0.20 & 1.00 & 0.20 & 0.50 & 0.07 & 0.50 & 0.10 \\
\hline $\mathrm{MB}-577 \mathrm{C}$ & 178.60 & 303.90 & 26.55 & 92.80 & 12.20 & 2.14 & 5.80 & 0.70 & 3.20 & 0.60 & 1.30 & 0.16 & 0.80 & 0.17 \\
\hline $37-56,4 A$ & 41.40 & 70.00 & 5.97 & 21.40 & 2.80 & 0.83 & 1.40 & 0.10 & 0.70 & 0.10 & 0.30 & nd & 0.20 & 0.05 \\
\hline$M i-58$ A & 43.60 & 72.00 & na & 30.00 & 3.45 & 1.00 & $n a$ & na & na & na & na & nd & nd & nd \\
\hline MB-577i: & 66.80 & 127.00 & 12.78 & 52.00 & 10.70 & 1.69 & 8.10 & 1.10 & 6.30 & 1.10 & 3.10 & 0.42 & 2.20 & 0.35 \\
\hline MB-577I: & 81.30 & 143.70 & 12.91 & 47.60 & 7.80 & 1.56 & 5.10 & 0.70 & 3.60 & 0.60 & 3.50 & 0.19 & 1.10 & 0.17 \\
\hline$J F-190 \mathrm{~A} 1$ & 67.10 & 108.00 & na & 34.00 & 5.18 & 1.10 & na & na & na & $\mathrm{na}$ & na & na & 0.40 & 0.05 \\
\hline$J F-190 \wedge 2$ & 42.80 & 67.00 & na & 24.00 & 3.34 & 1.20 & nat & na & na & $\mathrm{na}$ & $\mathrm{na}$ & na & 0.20 & 0.05 \\
\hline$J F-29 P$ & 17.20 & 34.00 & na & 11.00 & 2.81 & 0.60 & $\mathrm{n} *$ & ถล & nat & ma & na & $\mathrm{nat}$ & 0.70 & 0.12 \\
\hline $5 F-190 \mathrm{D}$ & 51.70 & 79.00 & na & 30.00 & 4.48 & 3.10 & $\mathrm{na}$ & na & na & $\mathrm{ma}$ & $\mathrm{n} \leftrightarrow$ & nat & 0.30 & 0.06 \\
\hline$J F-189 B$ & 73.90 & 118.00 & $\mathrm{nax}$ & 37.00 & 5.25 & 1.10 & $\mathrm{nd}$ & na & na & $\mathrm{na}$ & $\mathrm{na}$ & $\mathrm{n} 8$ & nd & nd \\
\hline $\mathrm{JE}-30 \mathrm{OB}$ & 45.20 & 93.00 & na & 54.00 & 11.00 & 2.54 & nd & 2.40 & na & 1.10 & $\mathrm{na}$ & $\mathrm{na}$ & 7.00 & 0.98 \\
\hline Jf:-56413 & 45.90 & 75.10 & 6.40 & 23.40 & 3.20 & 0.95 & 1.80 & 0.20 & 3.00 & 0.10 & 0.40 & nd & 0.30 & 0.07 \\
\hline$J \because \div 564 \mathrm{H}$ & 45.60 & 75.30 & 6.47 & 21.70 & 2.60 & 1.01 & 1.10 & 0.10 & 0.50 & nd & 0.10 & nd & nd & nd \\
\hline $\mathrm{r}-85 \mathrm{D}$ & 17.90 & 23.00 & $n a$ & 10.00 & 0.69 & 0.80 & nd & nd & 0.00 & nd & 0.00 & nd & nd & nd \\
\hline $\mathrm{MB} 3-577 \mathrm{H}$ & 19.30 & 30.40 & 2.58 & 8.60 & 1.10 & 0.76 & 0.60 & $\mathrm{nd}$ & 0.40 & $\mathrm{nd}$ & 0.20 & nd & 0.20 & 0.04 \\
\hline $51-5641)$ & 7.90 & 10.60 & 0.81 & 2.77 & 0.40 & 0.68 & 0.20 & $n d$ & 0.10 & nd & nd & $\mathrm{nd}$ & nd & no \\
\hline
\end{tabular}




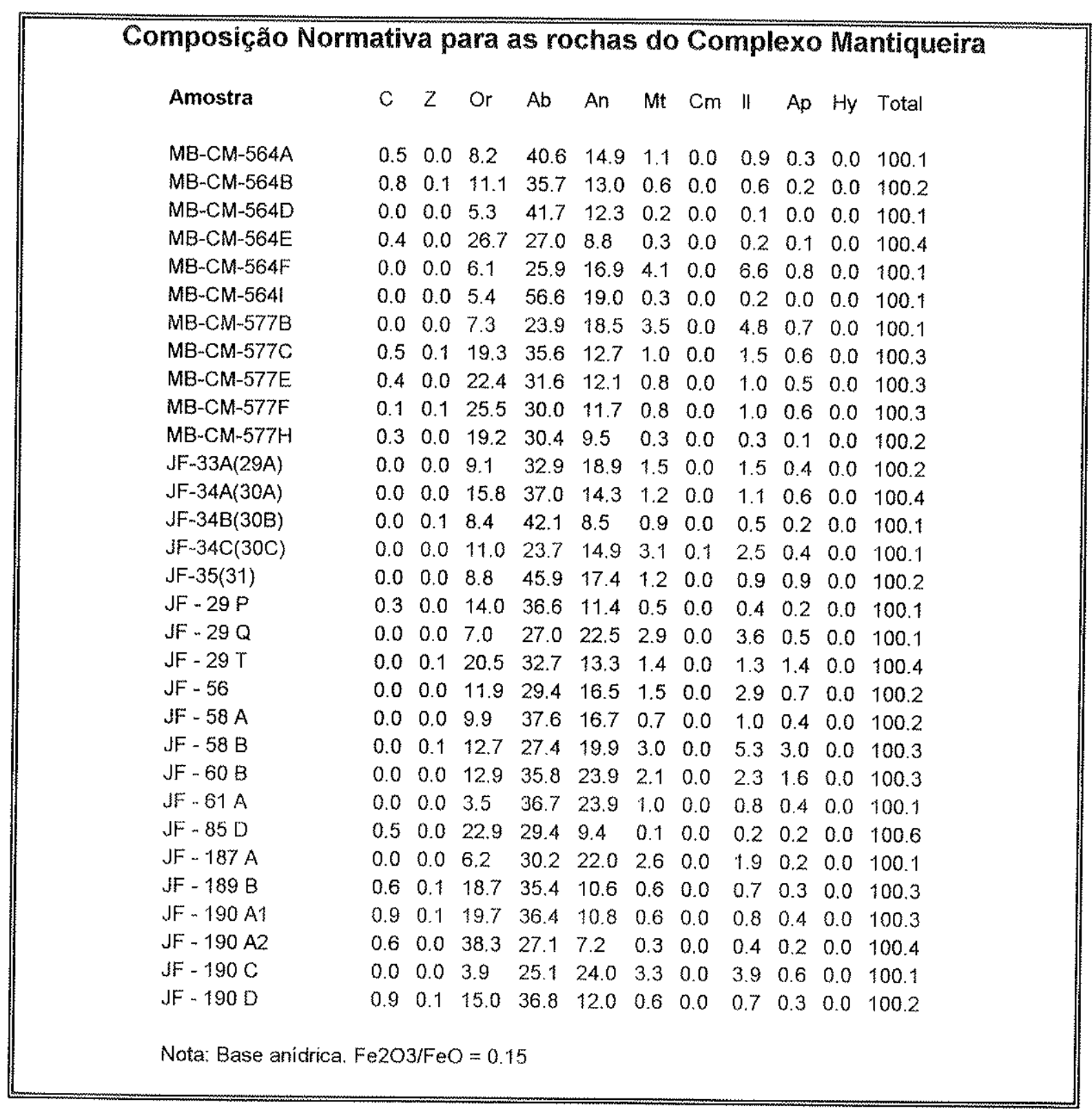




\section{TÉCNICAS ANALÍTICAS}

As amostras selecionadas foram enviadas para análise em quatro lotes. As técnicas de análise empregadas para cada lote são citadas abaixo:

a) 2 Lotes (40 amostras) - enviados ao Activation Laboratories L.td (Canadá), tendo sido realizadas a análise dos seguintes elementos pelas seguintes técnicas:

\# Elementos maiores, $\mathrm{Sc}, \mathrm{Y}, \mathrm{Zr}, \mathrm{Ba}, \mathrm{Sr}, \mathrm{Ag}, \mathrm{Be}, \mathrm{Bi}, \mathrm{Cu}, \mathrm{Ni}, \mathrm{Pb}, \mathrm{V}$ e $\mathrm{Zn}$ - ICP/AES*1; e

\# Elementos Terras Raras (La, Ce, Nd, Sm, Eu, Tb, Yb, Lu) - INAA*2.

b) 1 Lote (20 amostras) - enviado ao Activation Laboratories (Canadá), tendo sido realizadas a análise dos seguintes elementos pelas seguintes técnicas:

\# Elementos maiores, Ba, Sr, Y, Zr, Sc, Be, e V-ICP/AES*1; e

\# Todos os elementos traços, incluindo as Terras Raras - ICP/MS*3.

c) 1 Lote (08 amostras) - enviado ao laboratório de geoquímica da Queen's University Belfast, tendo sido realizada a análise dos seguintes elementos pelas seguintes técnicas:

\# Elementos maiores + $\mathrm{Cr}, \mathrm{Ni}, \mathrm{Rb}, \mathrm{Be}, \mathrm{Sr}, \mathrm{Ta}, \mathrm{Nb}, \mathrm{Zr}, \mathrm{Y}, \mathrm{V}, \mathrm{Co}, \mathrm{Cu}, \mathrm{Pb}, \mathrm{Zn}, \mathrm{Sn}, \mathrm{W}$ e Mo Espectrometria de Fluorescência de Raios $\mathrm{X}$ (WOS-XRF*4 ${ }^{4}$ ).

Em todos os casos foi enviada uma amostra padrão para possibilitar o controle da qualidade da análise.

\footnotetext{
$*^{1}$ Inductively Coupled Plasma - Atomic Emission Spectrometry

$*^{2}$ Instrumental Neutron Activation Analysis

$*^{3}$ Inductively Coupled Plasma - Mass Spectrometry

*4 Wave Disperssive Spectrometry - X Ray Fluorescence
}

AP $-5-10$ 


\section{$\underline{I C P}=\underline{\mathrm{AES}}$}

A técnica de ICP -AES consiste na dissolução da amostra, utilizando-se ácidos puros ou misturados ou técnicas de fusão, através do emprego de fundentes. A solução da amostra é então introduzida em um plasma excitado a uma frequência de rádio $\left(\approx 8000^{\circ} \mathrm{K}\right)$. Cada elemento na solução produz um espectro característico. A intensidade das linhas espectrais é diretamente proporcional à quantidade do elemento presente.

\section{$\underline{\mathrm{ICP}}=\underline{\mathrm{MS}}$}

A tecnologia ICP-MS agrega o material em chamas produzido pela técnica padrão de ICP a um espectrômetro de massa de quatro polos para medir a massa do elemento e não as linhas de emissão.

\section{INAA}

O INAA é uma técnica analítica que depende da medição da radiação gama primária que é emitida por isótopos radioativos. Esta radiação primária é produzida através da irradiação da amostra (sólida) em um rator nuclear. Cada elemento ativado irá emitir um radiação gama própria (tipo impressão digital) que pode ser medida e quantificada.

\section{WDS $=$ XRF}

A técnica XRF consiste no bombardeamento de material sólido com Raios $X$ e na medição das emissões de raio-X geradas. Para a determinação dos elementos maiores por XRF, amostra é diluída e homogeneizada através de um método de fusão. No caso da determinação dos elementos traços, as análises foram feitas em pellets de rocha.

$$
\text { AP - 5-11 }
$$




\section{Métodos De Regressão}

A análise por regressão pode ser utilizada para quantificar o grau de correlação existente em uma associação de rochas. Além disso, em um espaço $x y$, este método pode fornecer o valor de $\mathrm{x}$ em função de y ou vice-versa.

A quantificação de uma associação é efetuada através do ajuste de uma reta aos dados plotados em espaço $x y$ e da definição da equação desta linha. A equação de uma reta que relaciona as variáveis $\mathrm{x}$ e y é:

$$
y=a x+b
$$

Esta relação é ideal e não permite qualquer desvio da reta. No entanto, isto está longe de ser real, já que a maioria das observações envolve algum grau de erro, e os dados formam uma nuvem de pontos, introduzindo incerteza ao procedimento de ajuste da reta.

Várias formas de regressão existem, como por exemplo: 1 - Regressão pelo Método dos Mínimos Quadrados de y em x; 2 - Regressão pelo Método dos Mínimos Quadrados de x em y; 3 - Regressão Proporcional pelo Método dos Mínimos Quadrados; 4 - Regressão Robusta.

Neste trabalho, foi utilizada a regressão de $\mathrm{y}$ em $\mathrm{x}$ pelo método dos mínimos quadrados. Através deste método, a melhor linha (a mais ajustada) é construída de forma a que a soma dos quadrados dos desvios verticais a partir da linha seja mínima.

A regressão de $\mathrm{y}$ em $\mathrm{x}$ pode ser definida por:

$$
b=y-a x
$$

$$
\text { AP }-5-12
$$


onde $\mathrm{x}$ e y são os valores médios para as variáveis $\mathrm{x}$ e y e a quantifica a inclinação da linha. Esta inclinação (a) pode ser definida por:

$$
a=r\left(S_{y} / S_{x}\right)
$$

onde $\mathrm{r}$ é o coeficiente de correlação e $\mathrm{S}_{\mathrm{x}}$ e $\mathrm{S}_{\mathrm{y}}$ são os desvios padrão das amostras em $\mathrm{x}$ e $y$, respectivamente.

O coeficiente de correlação $r$ é calculado como

$$
r=S x y / \sqrt{ }\left(S x^{2} \cdot S y^{2}\right)
$$

onde Sxy é a covariância $\mathrm{x}, \mathrm{y} ; S x y=\Sigma(x-x) \cdot(y-y) /(n-1)$ para uma população $n$.

Os mesmos princípios de correlação linear aplicam-se a regressões polinomiais. Quanto mais $\mathrm{r}$ se aproximar da unidade, melhor a correlação linear ou polinomial.

Nesta tese, deu-se preferência ao quadrado de $r\left(r^{2}\right)$. Por exemplo, se $r=0,9$ e, portanto, $r^{2}=0,81,81 \%$ de variância total da amostragem podem ser explicadas por uma correlação linear ou polinomial.

Os níveis de significância de $r$ são dependentes do número de amostras na regressão, conforma apresentado na tabela a seguir.

AP $-5-13$ 
Niveis de Significância do Quadrado do Coeficiente de Regressão $\left(\mathbb{R}^{2}\right)$

\begin{tabular}{|ccccccc|}
\hline $\mathrm{n}$ & $\mathrm{f}$ & $80 \%$ & $90 \%$ & $95 \%$ & $99 \%$ & $99,9 \%$ \\
3 & 1 & 0,951 & 0,988 & 0,997 & 1,000 & 1,000 \\
4 & 2 & 0,800 & 0,900 & 0,950 & 0,990 & 0,999 \\
5 & 3 & 0,687 & 0,805 & 0,878 & 0,959 & 0,991 \\
6 & 4 & 0,608 & 0,729 & 0,811 & 0,917 & 0,974 \\
7 & 5 & 0,551 & 0,669 & 0,755 & 0,875 & 0,951 \\
8 & 6 & 0,505 & 0,621 & 0,707 & 0,834 & 0,925 \\
9 & 7 & 0,472 & 0,582 & 0,666 & 0,798 & 0,898 \\
10 & 8 & 0,443 & 0,549 & 0,632 & 0,765 & 0,872 \\
11 & 9 & 0,419 & 0,521 & 0,602 & 0,735 & 0,847 \\
12 & 10 & 0,398 & 0,497 & 0,576 & 0,708 & 0,823 \\
13 & 11 & 0,380 & 0,476 & 0,553 & 0,684 & 0,801 \\
14 & 12 & 0,365 & 0,457 & 0,532 & 0,661 & 0,780 \\
15 & 13 & 0,351 & 0,441 & 0,514 & 0,641 & 0,706 \\
16 & 14 & 0,338 & 0,426 & 0,497 & 0,623 & 0,742 \\
17 & 15 & 0,327 & 0,412 & 0,482 & 0,606 & 0,725 \\
18 & 16 & 0,317 & 0,400 & 0,468 & 0,590 & 0,708 \\
19 & 17 & 0,308 & 0,389 & 0,456 & 0,575 & 0,693 \\
20 & 18 & 0,299 & 0,378 & 0,444 & 0,561 & 0,679 \\
21 & 19 & 0,291 & 0,369 & 0,433 & 0,549 & 0,665 \\
22 & 20 & 0,284 & 0,360 & 0,423 & 0,537 & 0,652 \\
23 & 21 & 0,277 & 0,352 & 0,413 & 0,526 & 0,640 \\
24 & 22 & 0,271 & 0,344 & 0,404 & 0,515 & 0,629 \\
25 & 23 & 0,265 & 0,337 & 0,396 & 0,505 & 0,618 \\
26 & 24 & 0,206 & 0,330 & 0,388 & 0,496 & 0,607 \\
27 & 25 & 0,255 & 0,323 & 0,381 & 0,487 & 0,597 \\
28 & 26 & 0,250 & 0,317 & 0,374 & 0,479 & 0,588 \\
29 & 27 & 0,245 & 0,311 & 0,367 & 0,471 & 0,579 \\
30 & 28 & 0,241 & 0,306 & 0,361 & 0,463 & 0,570 \\
31 & 29 & 0,237 & 0,301 & 0,355 & 0,456 & 0,562 \\
32 & 30 & 0,233 & 0,296 & 0,349 & 0,449 & 0,554 \\
42 & 40 & 0,202 & 0,257 & 0,304 & 0,393 & 0,490 \\
62 & 60 & 0,165 & 0,211 & 0,250 & 0,325 & 0,408 \\
122 & 120 & 0,117 & 0,150 & 0,178 & 0,232 & 0,294 \\
\hline & & & & & & \\
\hline
\end{tabular}

$\mathrm{n}=$ número de amostras; $\mathrm{f}=$ grau de liberdade $(\mathrm{f}=\mathrm{n}-2)$.

Exemplo: Para 15 amostras, o coeficiente de correlação $r=0,525$ (ou $\left.r^{2}=0,276\right)$ é considerado significante entre os níveis $95 \%$ e $99 \%$. 

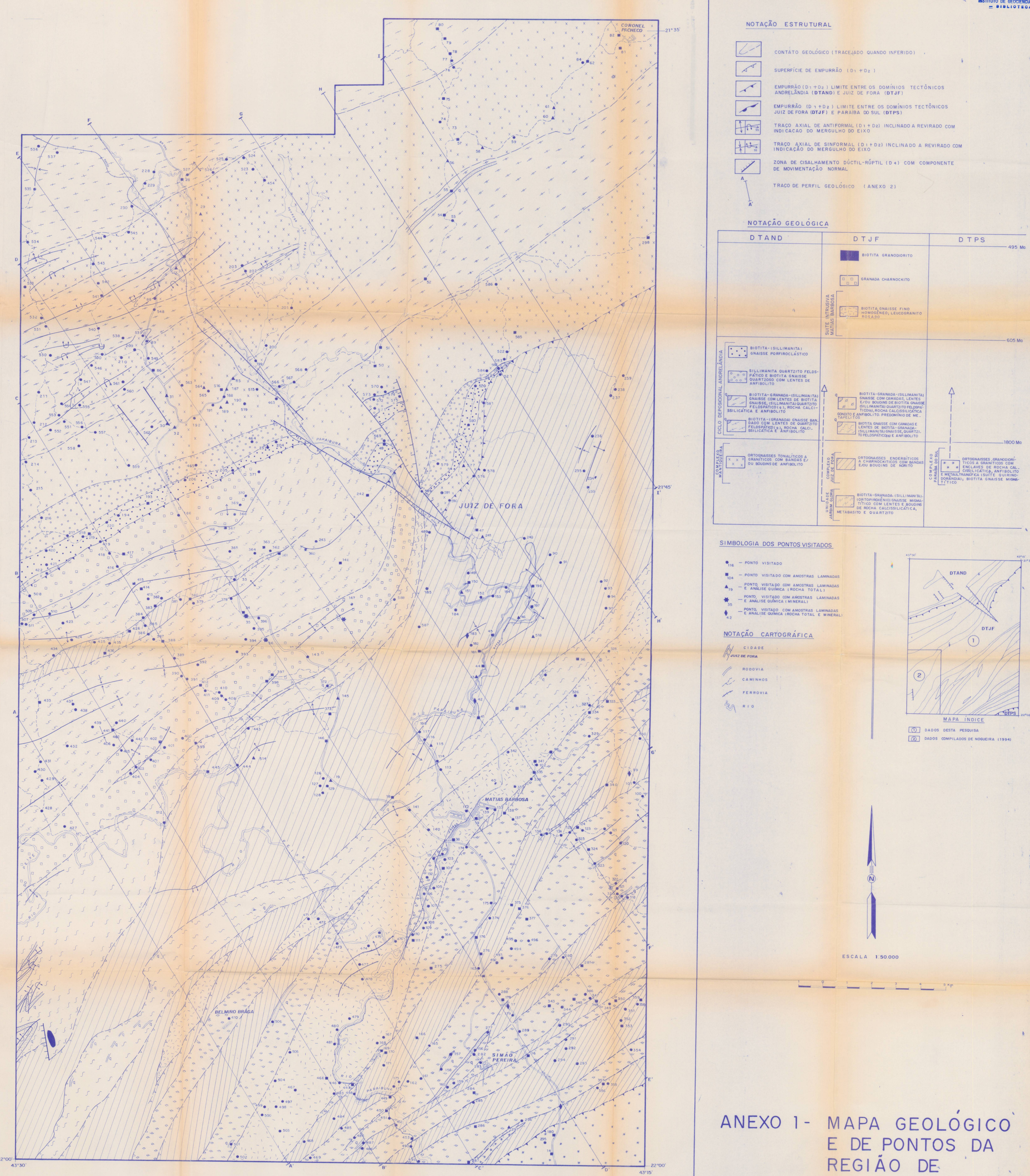

TSU CI OA DE

rodoovia
Li, caminhos

Ferrovia

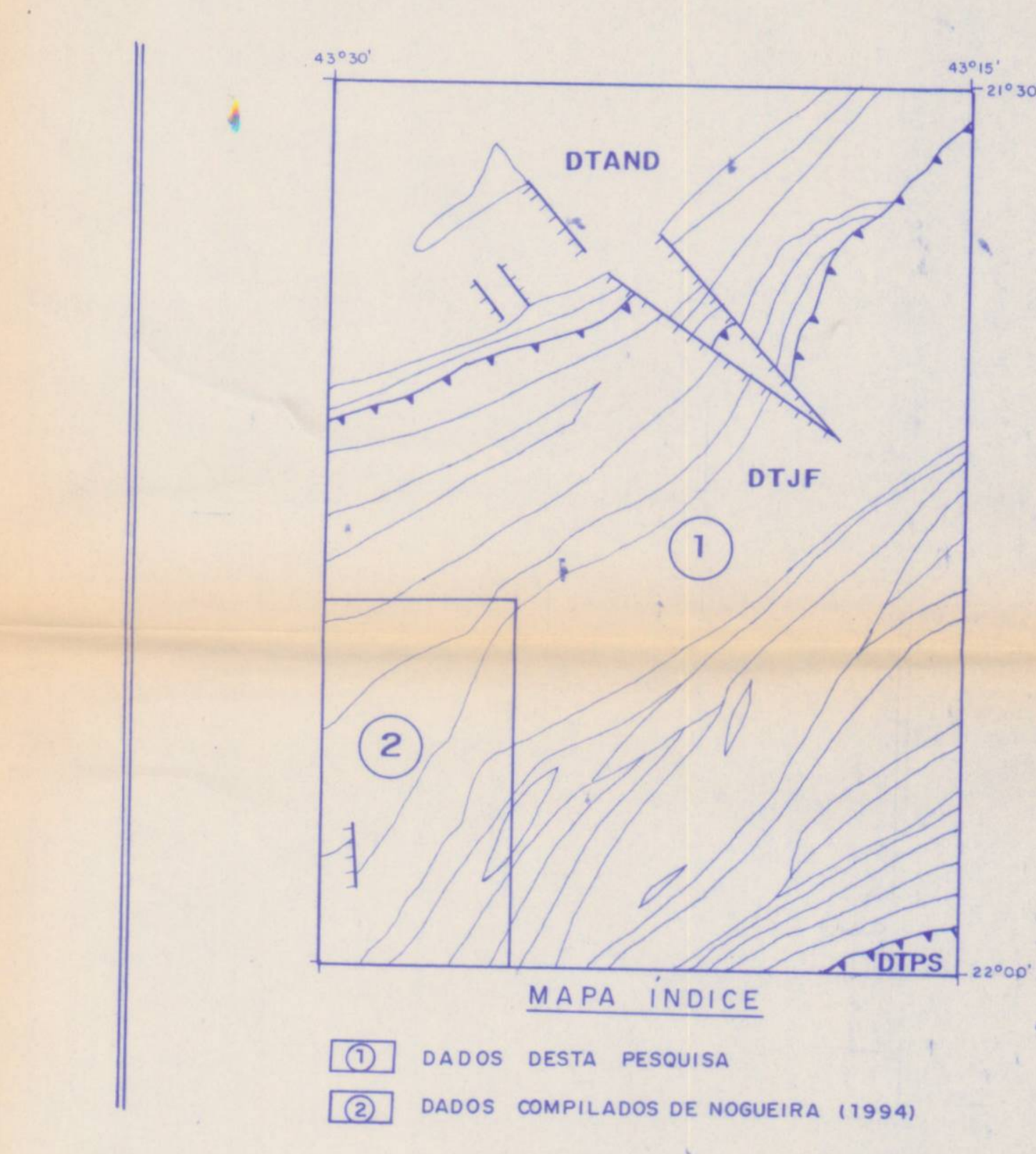

ANEXO 1- MAPA GEOLÓGICO E DE PONTOS DA REGIÄO DE JUIZ DE FORA (MG) 

